
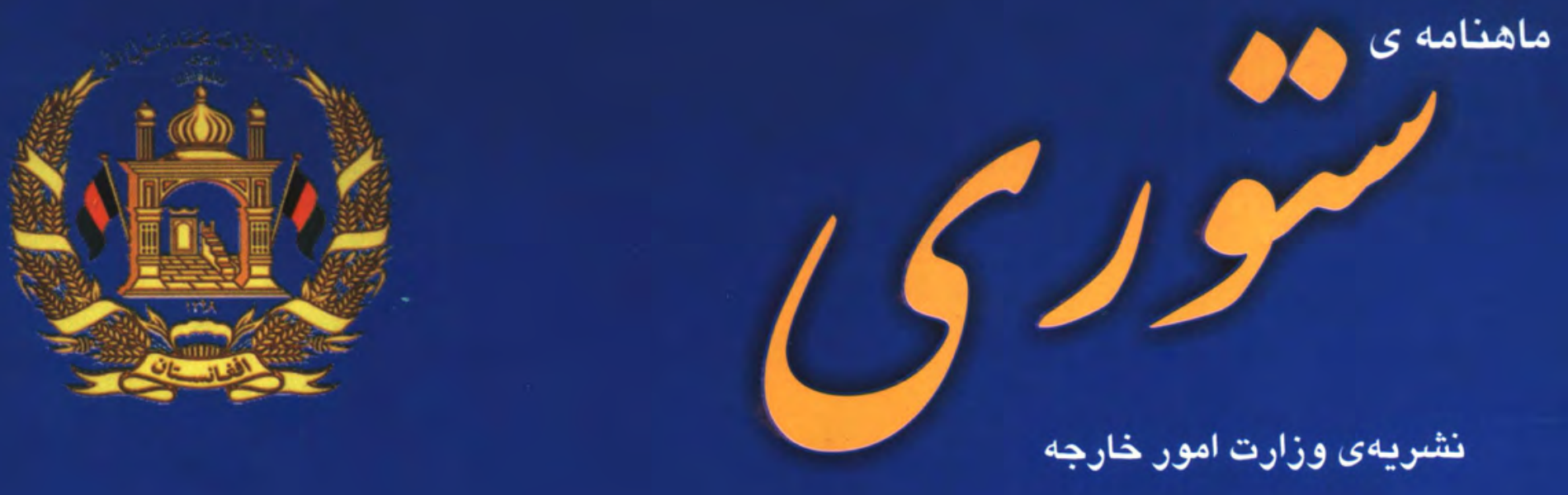

شماره بيست جهارم و بيست و هنجم، دور دوم، ميزان و عقرب، سال rrAY
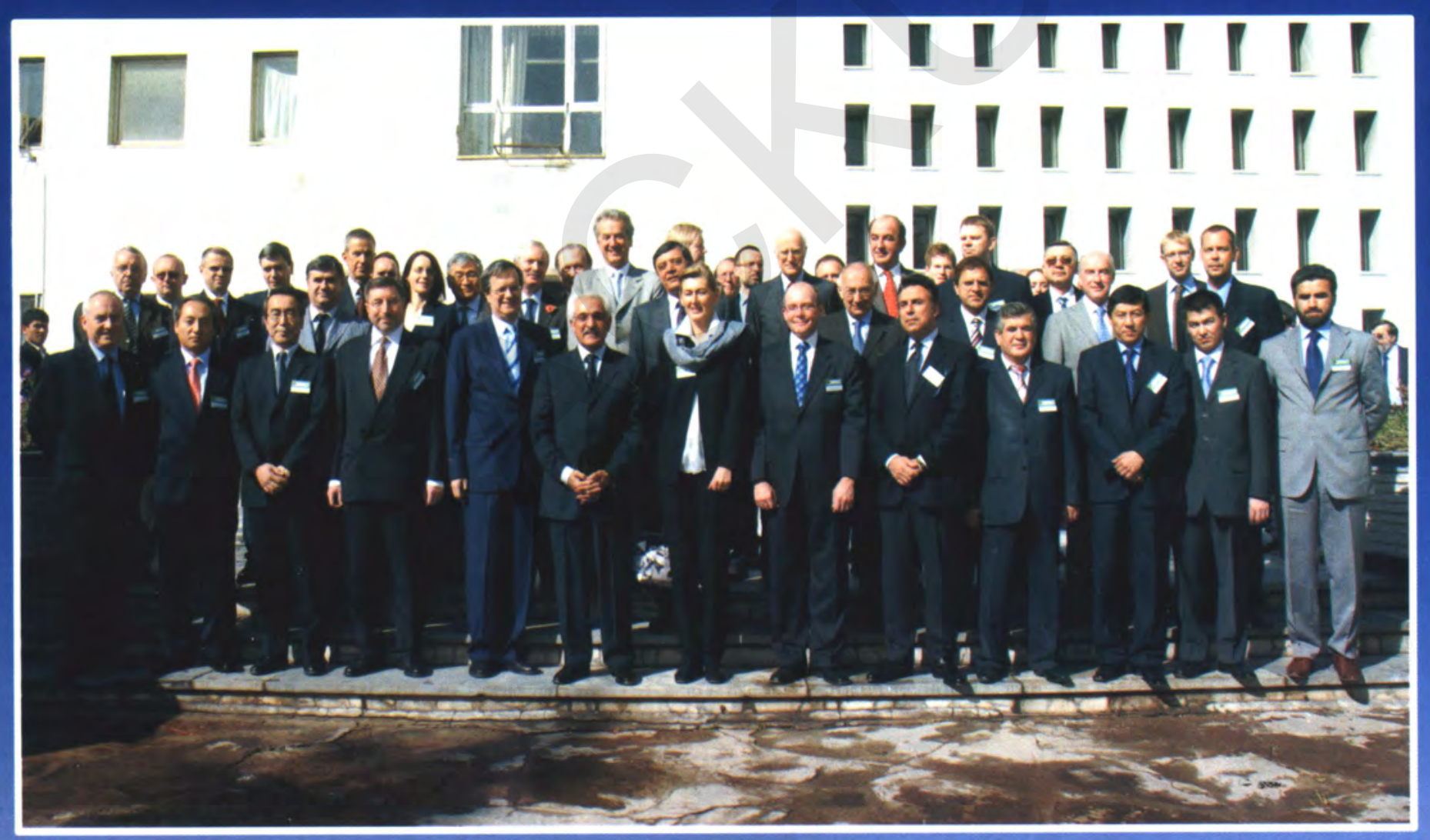

داكتر رنكين دادفر سهنتا وزير امور خارجه جمهورى اسلامى افغانستان با اشتراك كنند كان كنفرانس مشتر كى سازمان امنيت و همكارى ارويا (OSCE) و جمهورى اسلامى افغانستان

$$
\text { 19 و و عقرب IrAV }
$$




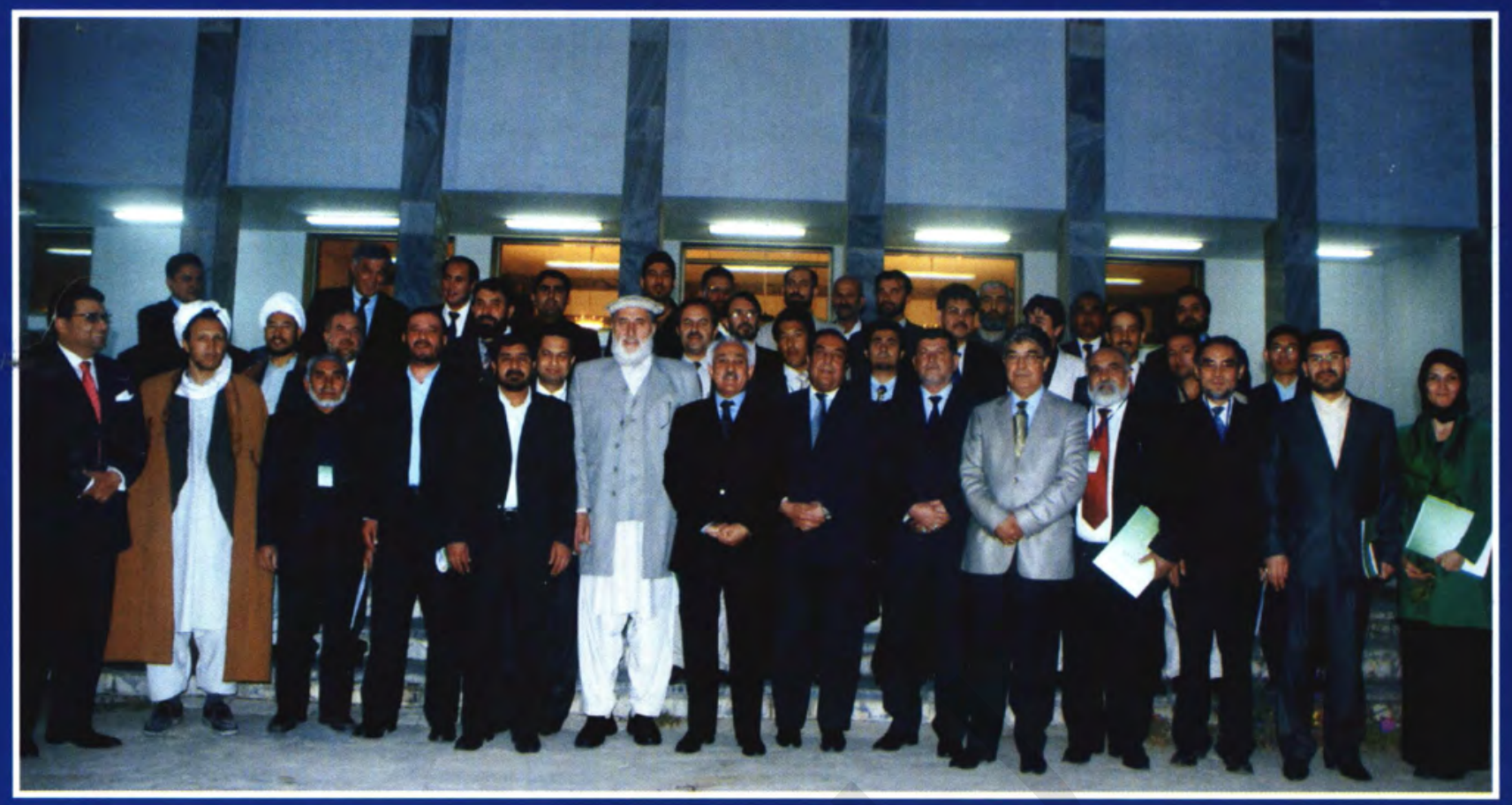

د بهرنيو جارو به وزارت كي "سوله به اسلامي انكيرنه كي "

تر نوم لاندب دكنفر انس كلهورون كورنكي

د تلي P مه، TAV I I لمريز كال

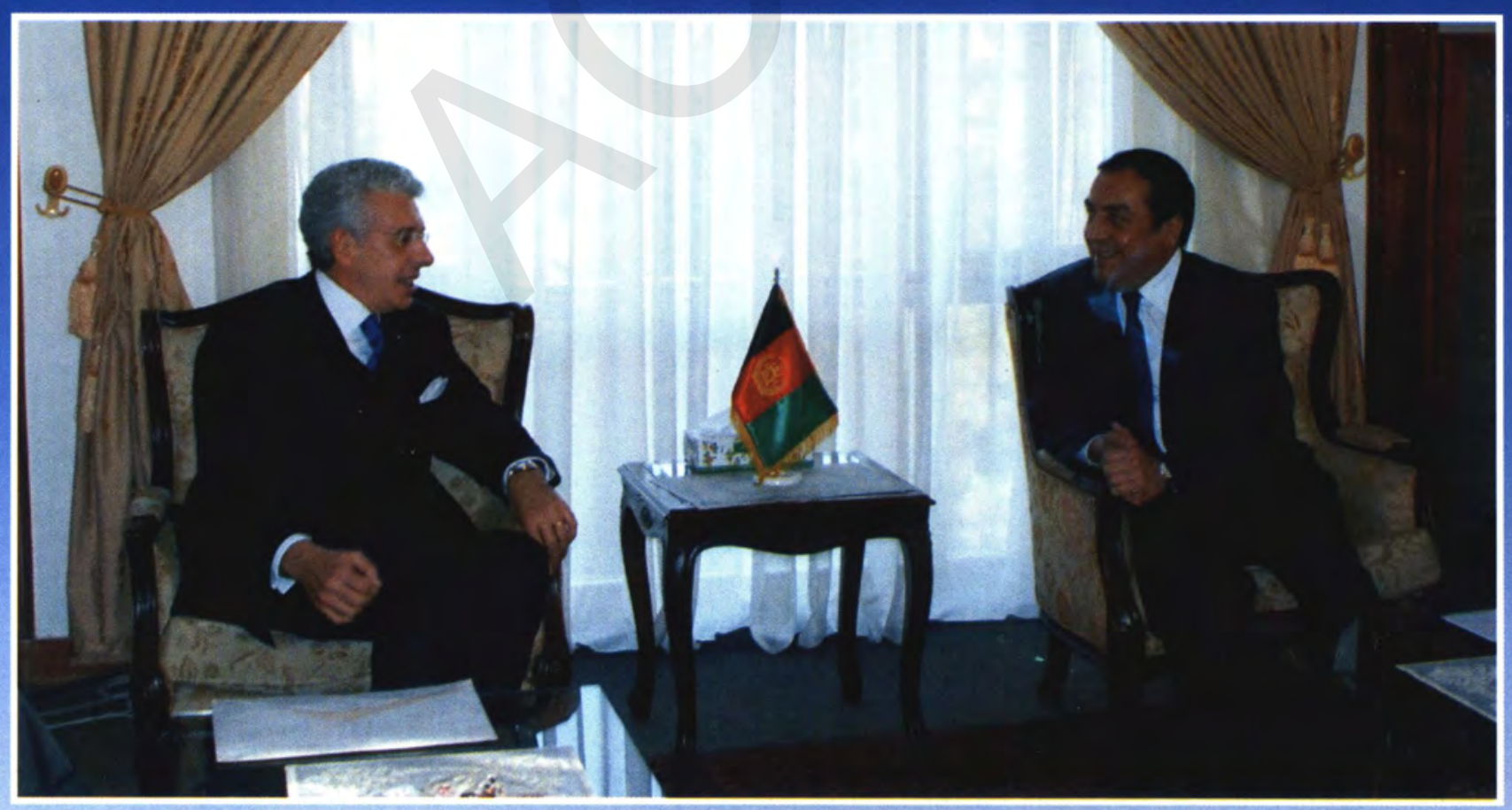

د بهرنيو جارو وزارت سياسي مرستيال؛ بناغلى محمد كبير فراهي د ابتاليا د نوي سفير سره د

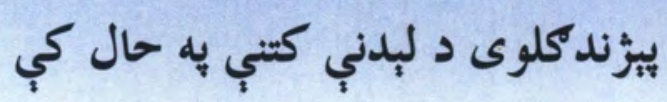



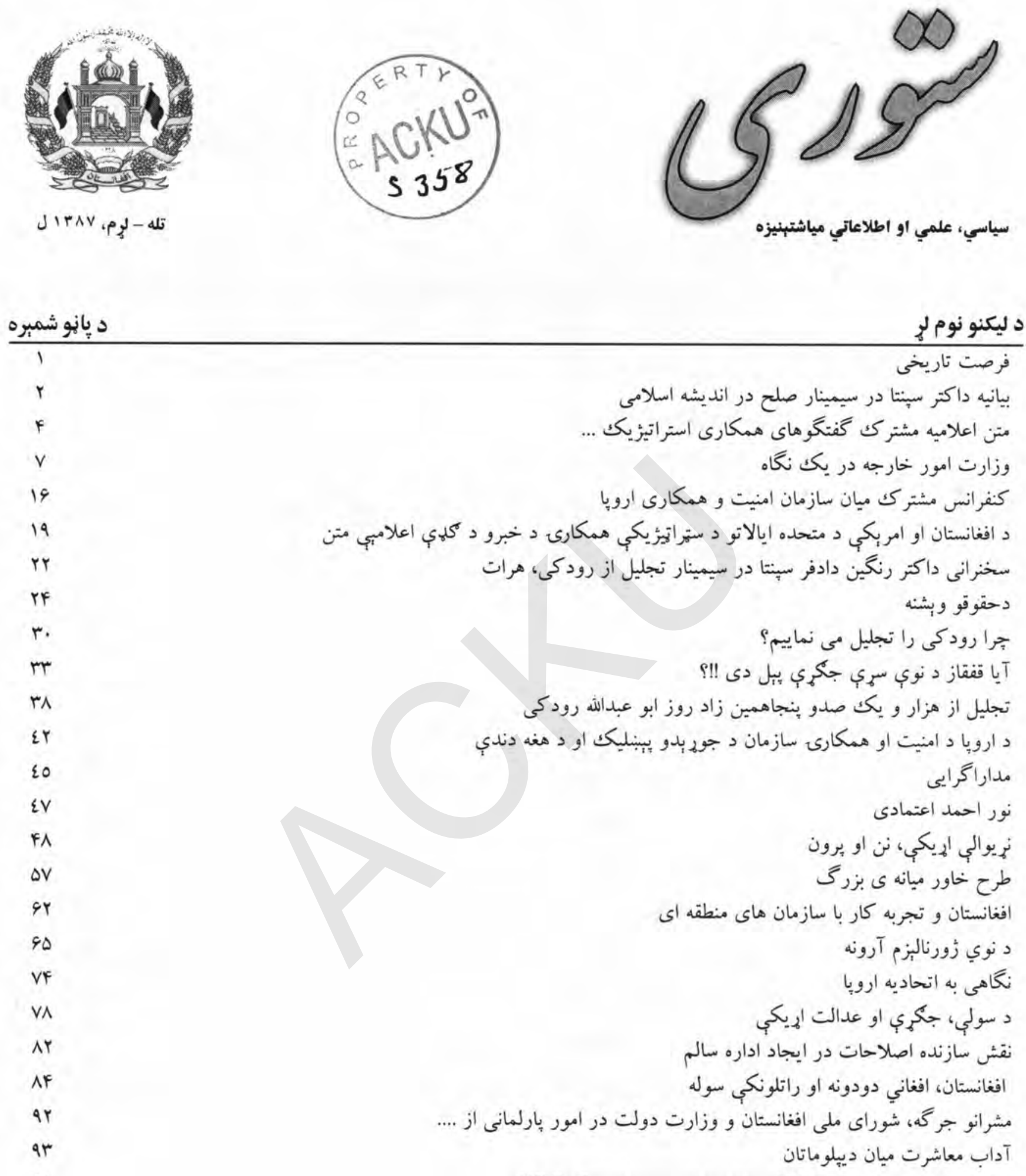

HE.Dr.Spanta speech at the OSCE Conference in Kabul

$$
\text { حته:د اطللاعاتو او خهرونو مديريت، د بهرنيو جارو وزارت }
$$$$
\text { r...rvr_.vaqrqvva० تيليفون: }
$$

برينبنائي : Ipdmfa@gmail.com - noor.foreignministry@gmail.com

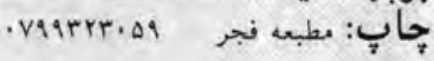

زير نظر هيئت تحرير

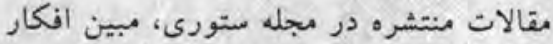

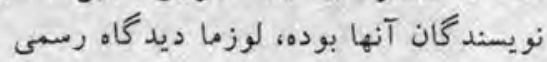

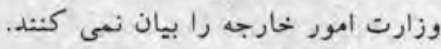

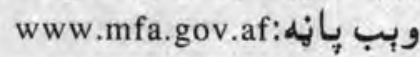




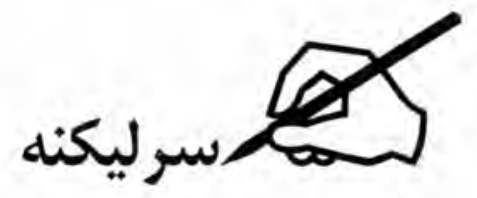

\section{فرصت تاريخى}

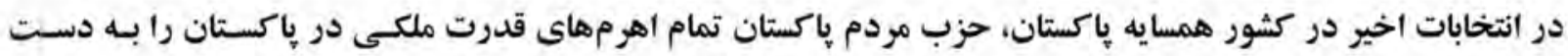
كرفت. تعهد دولت مردان جديد در ياكستان براى ريشه كن ساختن تروريزم و همكارى كسترده با جامعه جهانى و تقويت روابط با همسايكان براى تأمين ثبات در منطقه، اميدوارىهاى زيادى به وجود آورده است. افغانستان كه حتى در روزهاى دشوار روابط دو كشور در دو سال اخير، كه باكستان به وسيله جنرال مشرف اداره مىشد، از هيج تلاش براى جلب آن كشور در مبارزه با تروريزم، روابط نيك ميان دو كشور و توسعه همكارىهاى منطقهاى دريغ نكرد، يِيام اسلام آباد را اميدهاى تازه ميى بندارد. كام شجاعانه رئيس جمهور كرزى جهت شر كت در مراسم سوكند رئيس جمهور زردارى و ديدار كولمبو، بـا صـدراعظم كيلانى، موحله جديدى در روابط دو كشور است. ديدار وزيران خارجه افغانستان و ياكستان در اسلام آباد و توافق براى ايجاد كميسيونهاى كارى به اشتراك متخصصسين عرصه هاى امنيتى، سياسى و اقتصادى و تحت رهبرى وزيران خارجه دو كشور و كار ووى ايجاد "آرمان" مشتر ك بـراى دورنماى روابط دو كشور؛ مى تواند در عمل به روابط دو كشور كان جديد بدهد. اكنون كه رهبران جديد در باكستان اهميت كارمشتر ك در مبارزه با تروريزم را به عنوان قربانيان اين بديده شـوم و بـــ اصطلاح آقاى زردارى "سرطان جهانى" بيش از ييش در ك مى كنند. زمان آن فرا رسيده اسـت كسه در بـاره همكسارى كسترده اقتصادى و تجارى فكر كرد و تصميم كرفت تا مردمان هر دو كشور جنان به هم هيبوند يابند كـه راه بـراى حسل همه مشكلات كنونى و كذشته باز كردد. به عبارهى ديكر: منافع اقتصادى مردمان هر دو كشور جنان كره بخـورد كـه بـر مشكلات كذشته كه اكنون هم به عنوان بديدههاى غير قابل حل بنداشته مىشود، فايق كردند. زمان مى كذرد و مردم و تاريخ قضاوت خواهد كرد كه آيا ما به كفته داكتـر ســنتا وزيـر امسور خارجـه كشـورما از ايسن "فرصت تاريخى " استفاده برده ايم يا نه؟ سياست مداران شجاع بر تابوهاى ناموجه فايق مىى آيند و از انتقـادات و تحـريمهــى روزكـذار مخــالفين خـويش نمسى هراسند. تاريخ حل اين معما را به عهده دولتمردان كنونى كذاشته است. اما دولت مردان نيز به حمايت وسيع مـردم بـهـ ويزه حمايت كسترده از جامعه مدنى و روشنفكران نياز دارند. نبايد كذاشت كه "اين فرصت" هم كه در كشور همسايه ما خيلى شكننده معلوم مىشود، از دست رود. 


\section{بسم الله الرحمن الرحيم. \\ بانيه داكت سينتا در سيمينار صلح فر انفيشه اسلامى}

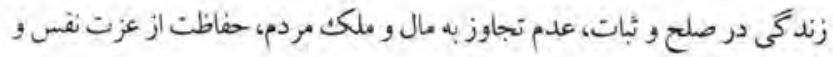

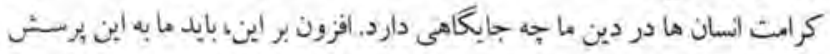

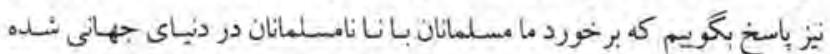

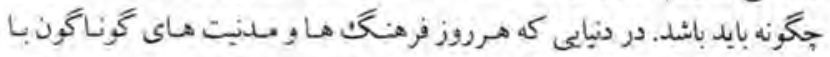

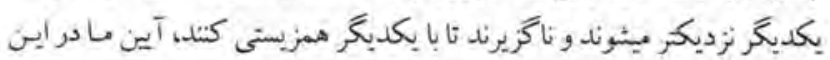

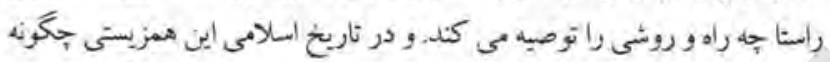

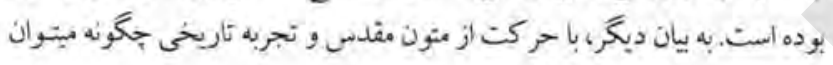

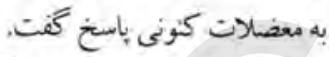
فرهيخته كان، خانم ها و آقايان،

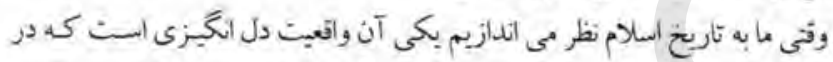

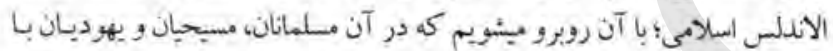

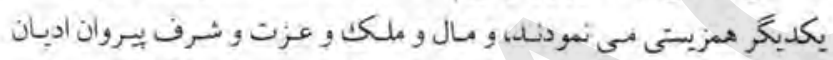

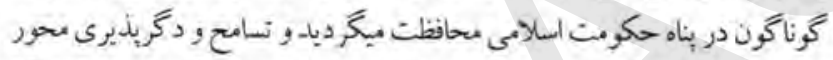

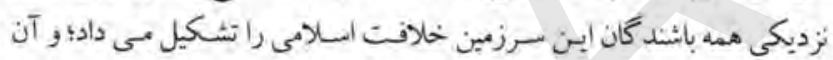

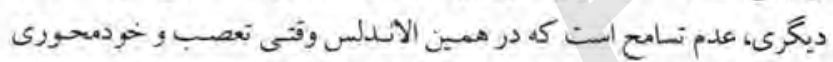

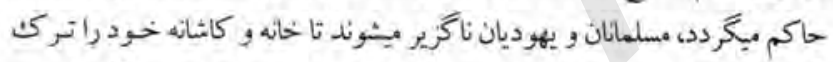

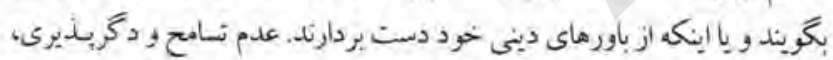

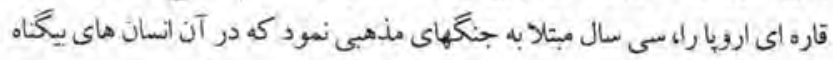

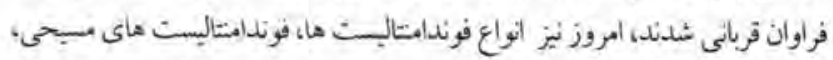

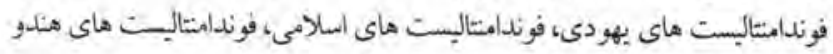

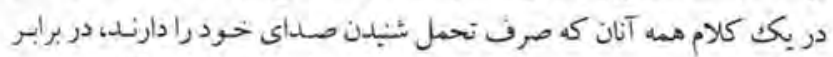

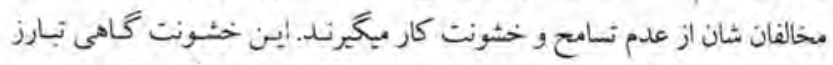

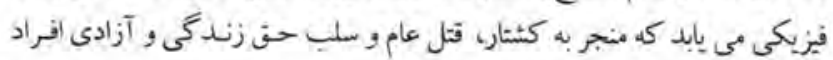

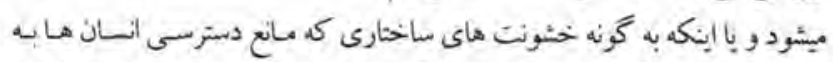

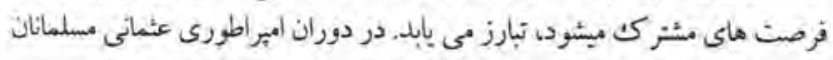

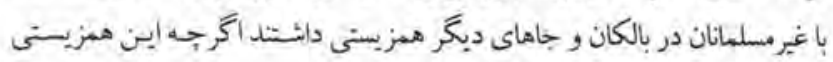

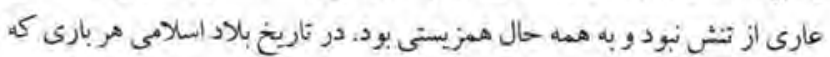

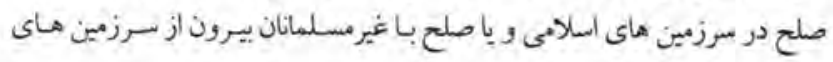

فرزانكان، جلالتمآبان، خانم ها و آقايان.

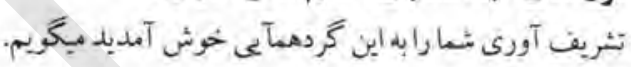

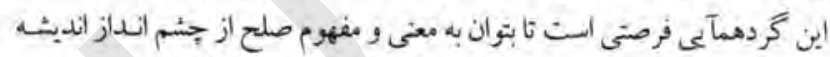

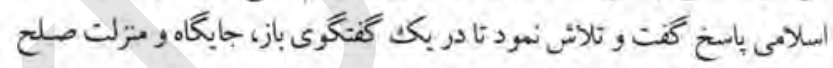

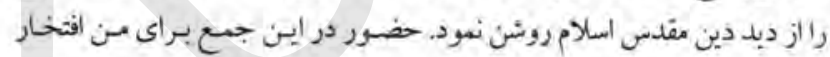

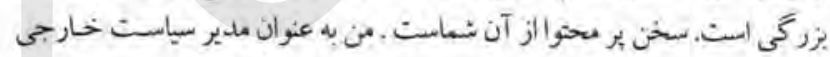

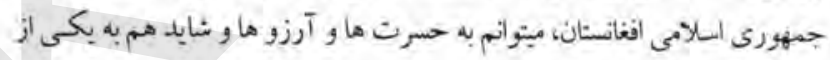

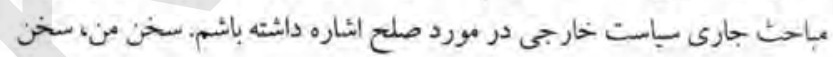

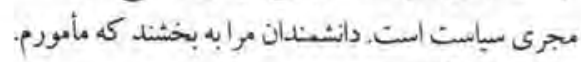
خانم ها و آقايان،

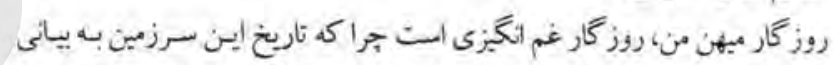

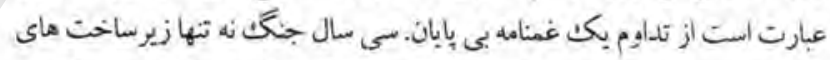

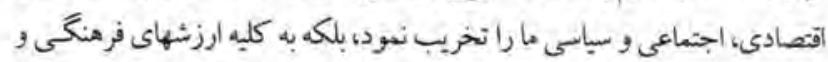

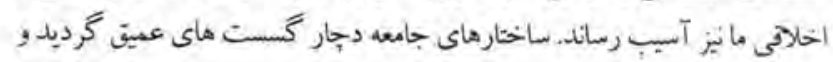

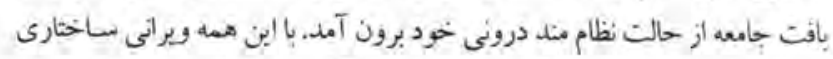

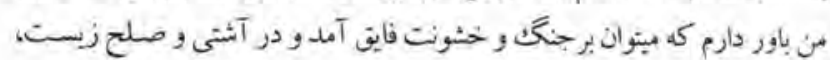

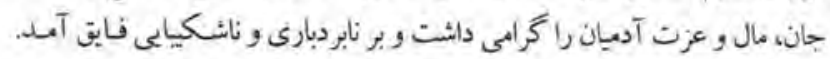

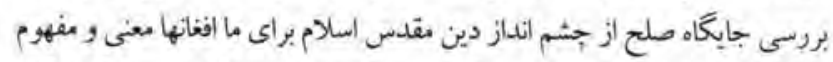

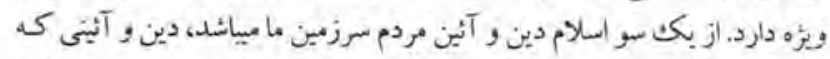

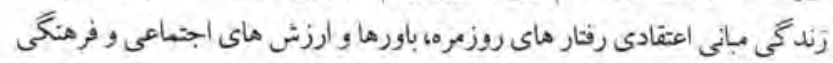

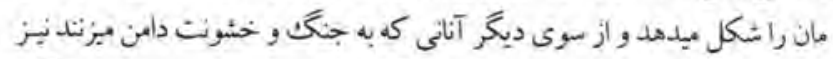

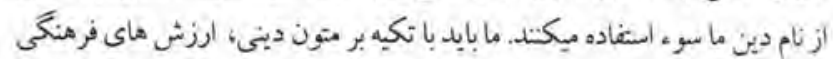

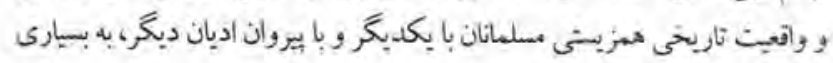

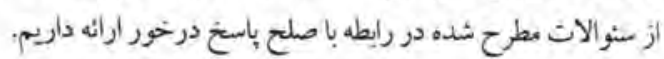

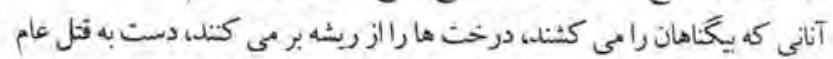

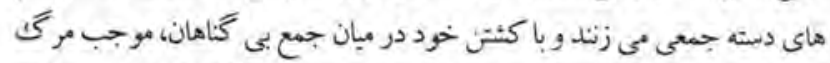

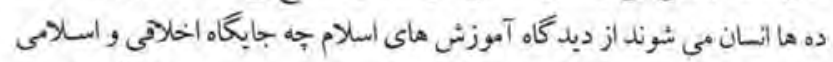

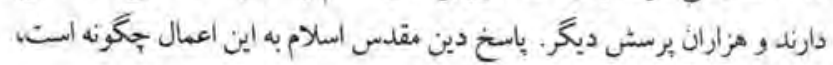


ديخران احترام بخذاريم و براى دفاع از حقوق و آرادى هاى انسان ها، سواى ائكه

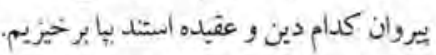
فززاتكان، خانم ها وآقايان.

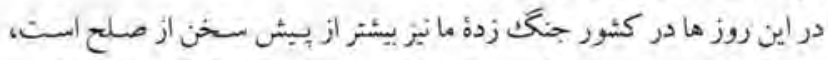

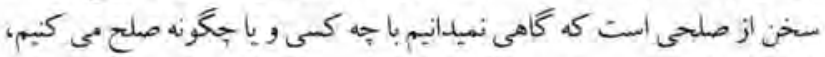

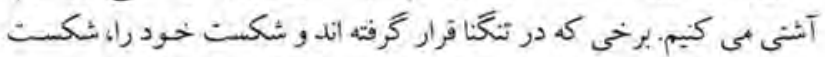

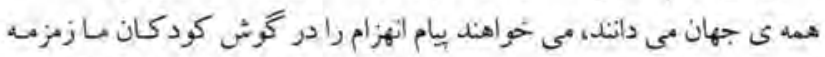

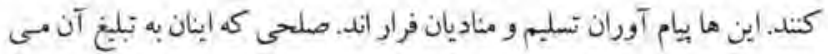

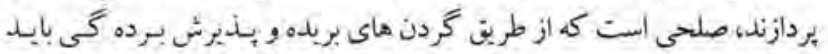

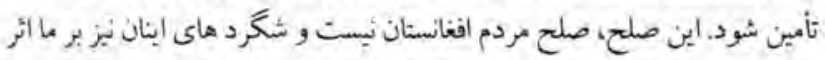

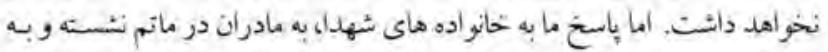

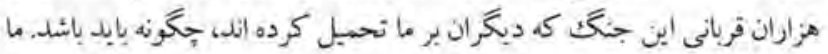

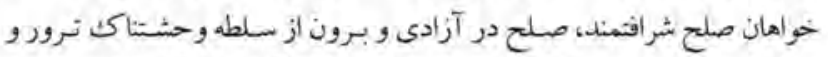

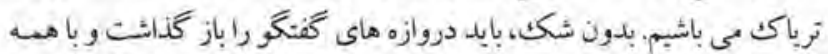

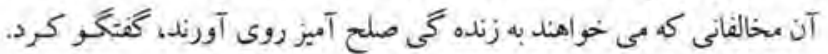

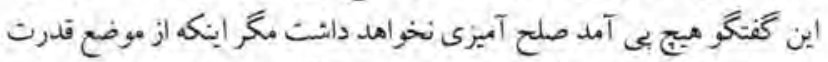

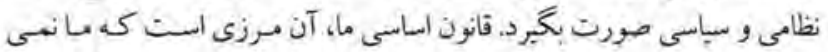

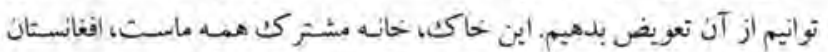

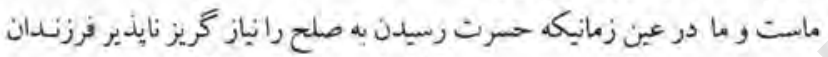

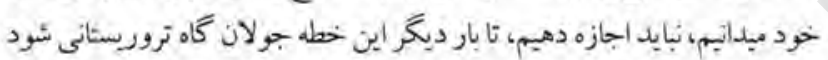

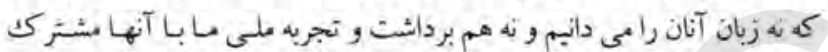

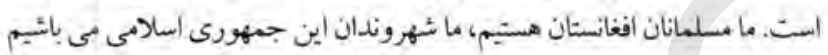

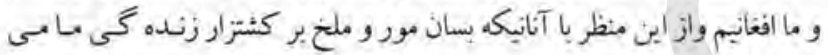

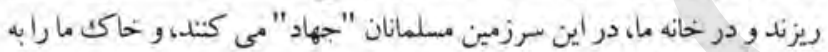

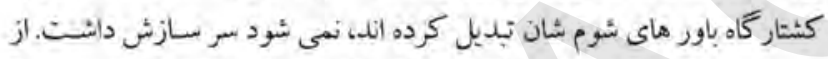

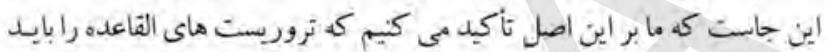

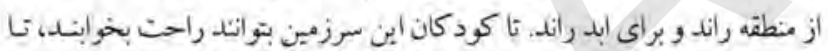

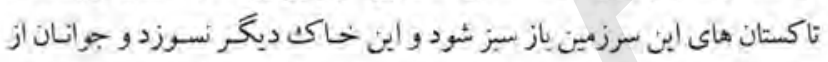

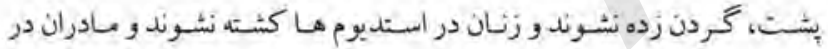

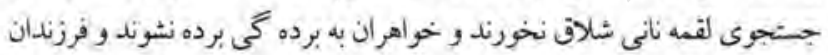

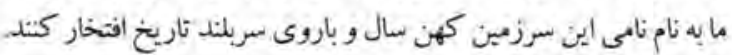

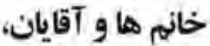

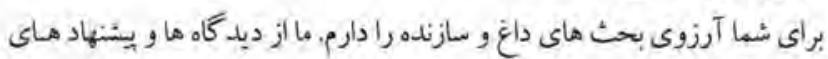
سما در اجراى سياست خارجى بهره خوأهيم برد

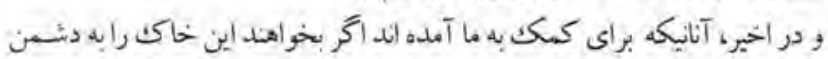

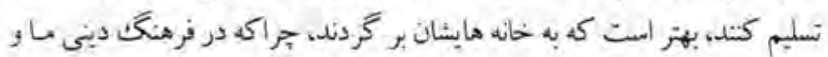

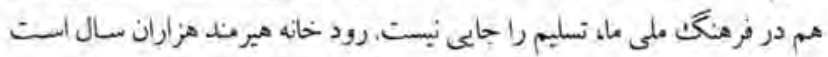

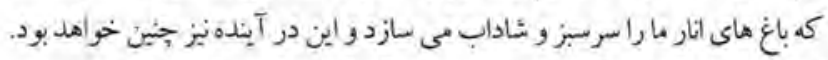

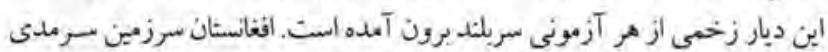

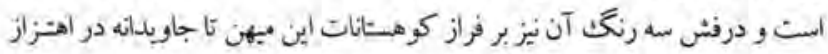

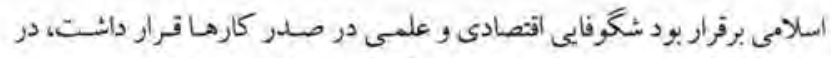

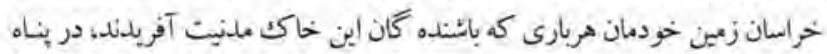

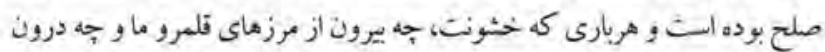

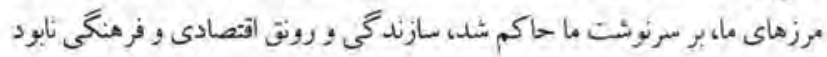

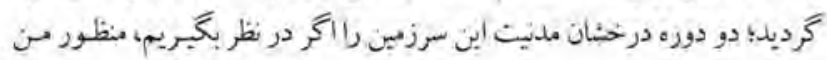

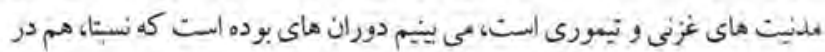

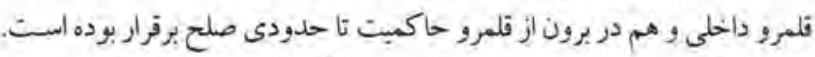

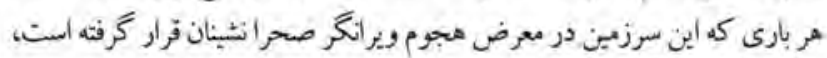

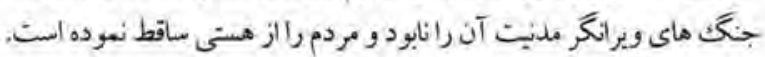
خانم ها و آقايان،

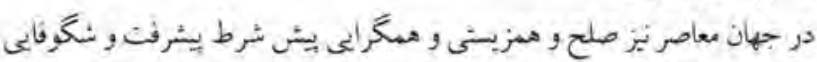

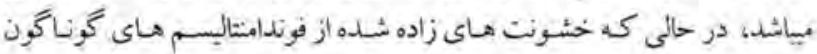

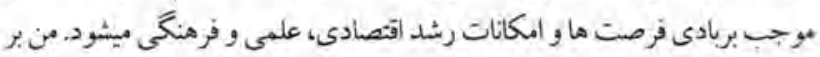

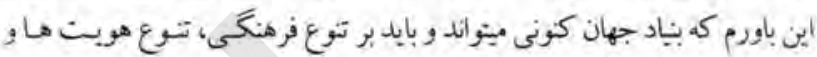

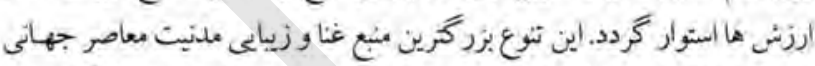

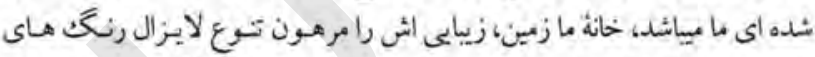

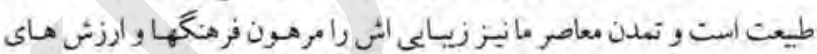

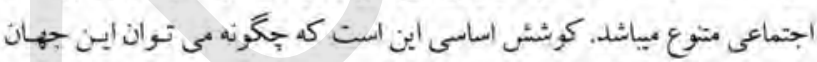

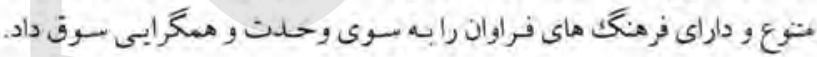

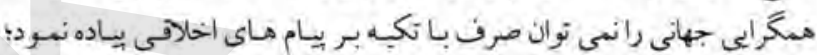

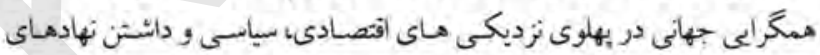

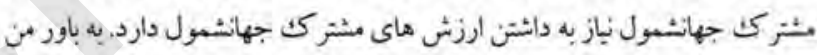

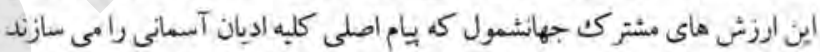

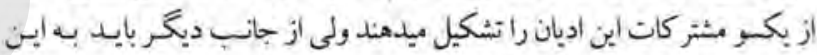

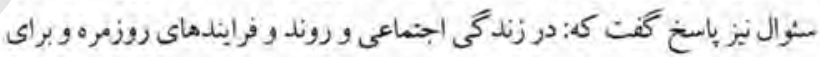

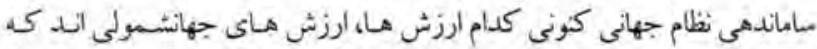

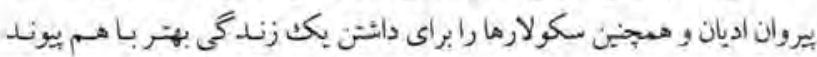

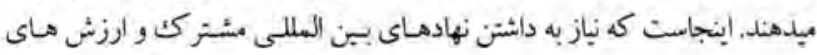

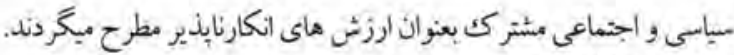
خانم ها و آقايان،

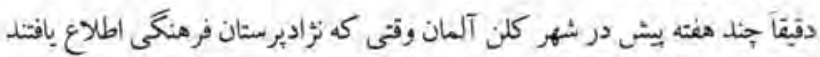

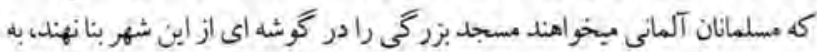

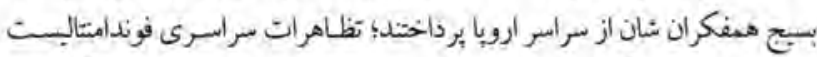

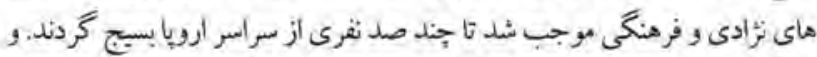

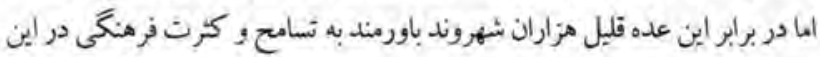

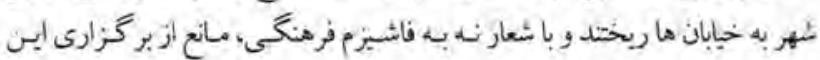

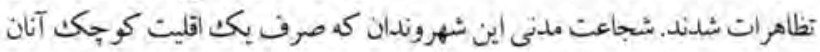

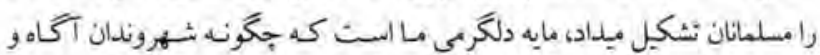

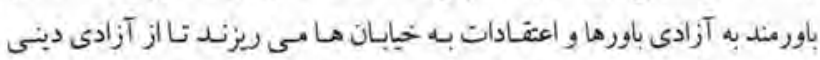

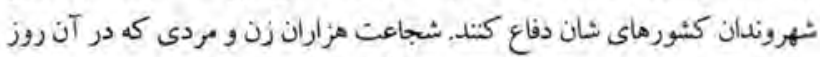

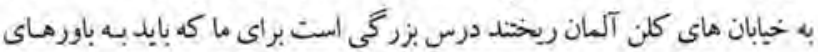




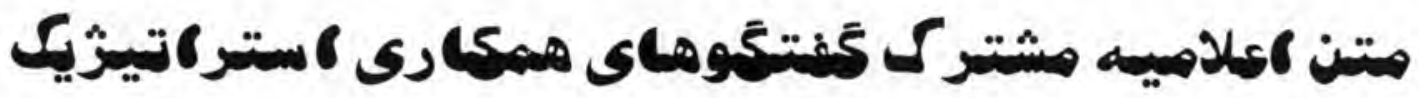 كنفانستان و ايبلات متهد ه اهزيكها
}

\author{
TA
}

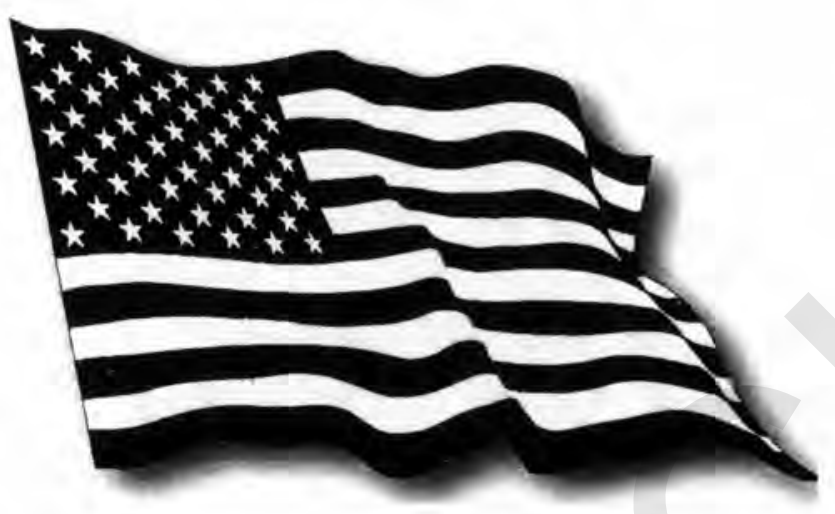

به كار مي گمارد.

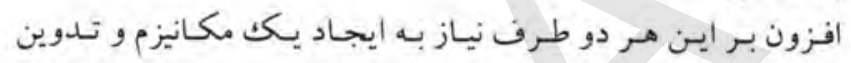

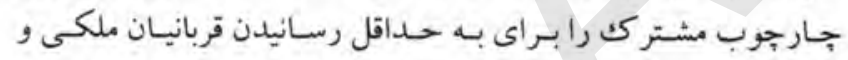

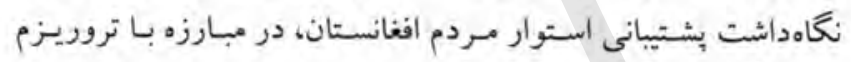
مورد تأييد قرار دادند. در اين كفتخوها، ايالات متحده امريكا تأكيد كرد دور كه تمام تبدابير

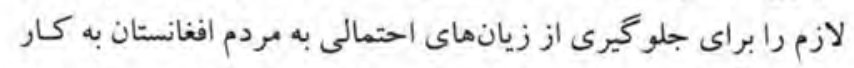

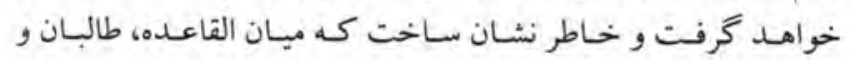

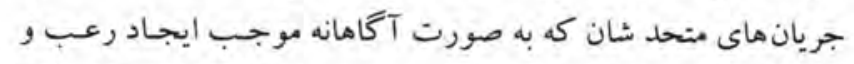

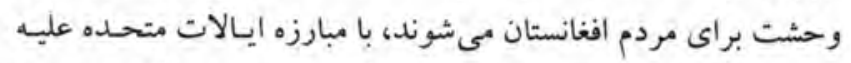

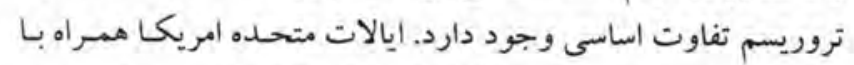

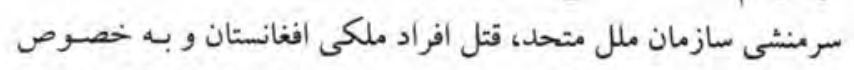

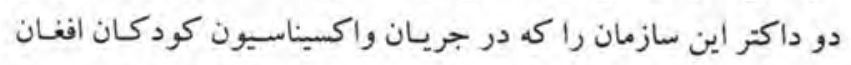
در جنوب اين كشور به وقوع بيوست، محكوم مى كند.

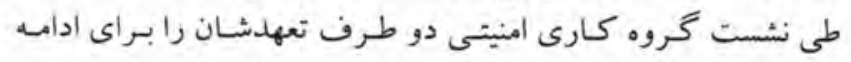

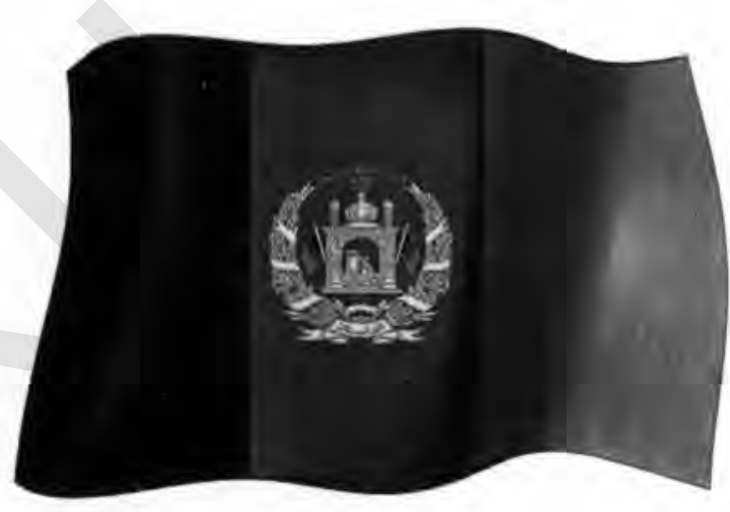

نما يند كان ارشد ايالات متحده امريكا و جمهورى اسـلامى افغانستان

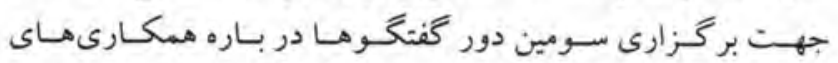
استراتيزيكك افغانستان و ايالات متحده امريكا كرد هم آمدند.

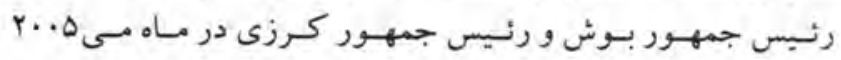

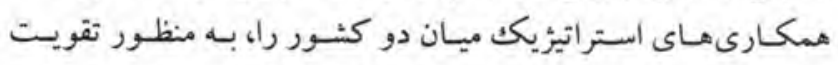

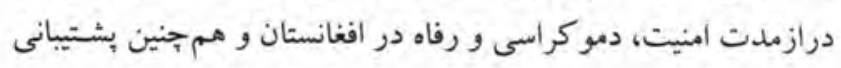

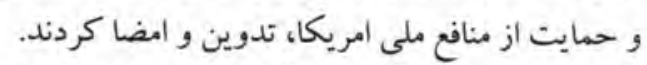

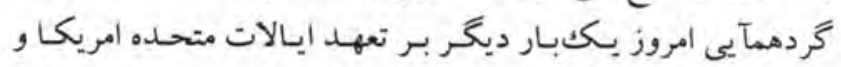

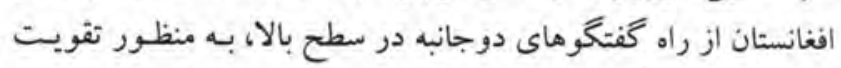

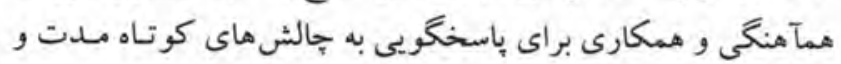
درازمدت، تأكيد مىنمايد.

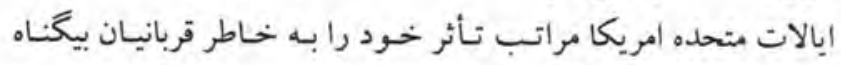

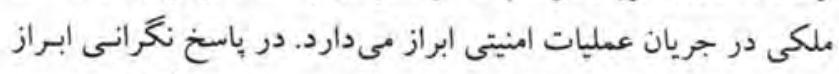

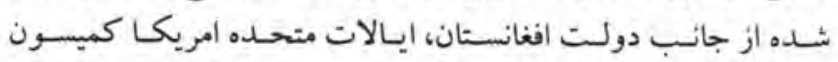

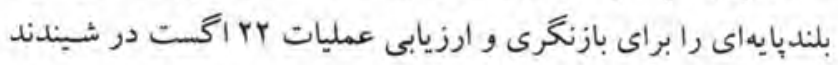




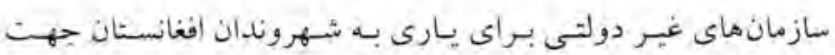

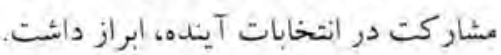

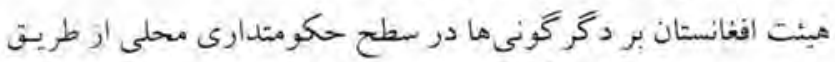

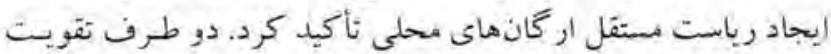

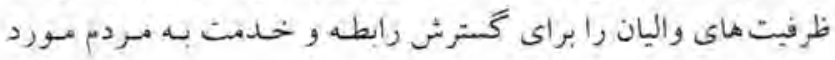

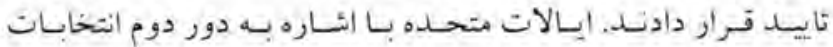

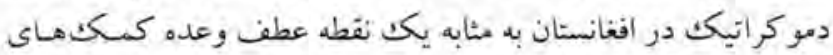

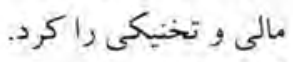

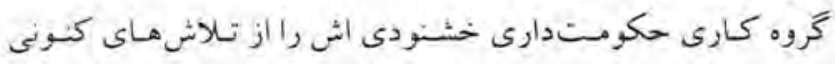

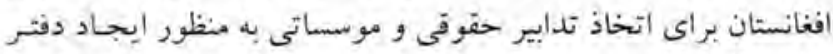

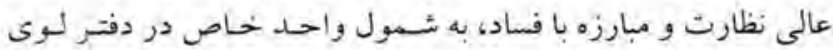

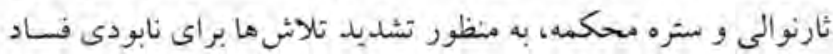

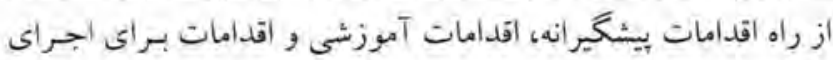

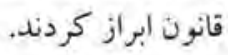
دو طرف تعهد كردند تا در جريان سال آينده در امر مبـارزه بـا فسـاد

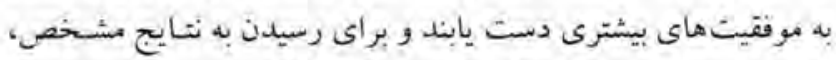

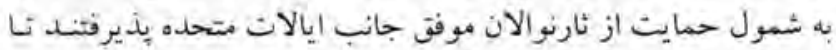

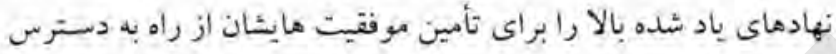

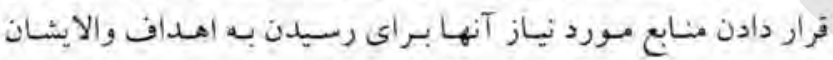

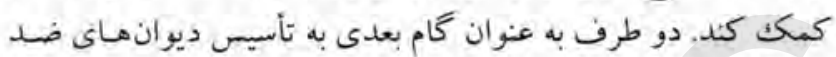
فساد اشاره كردند.

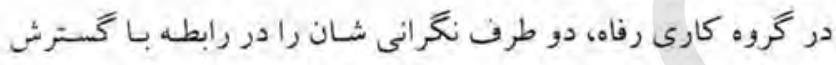

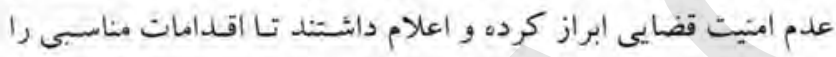

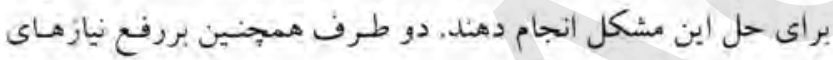

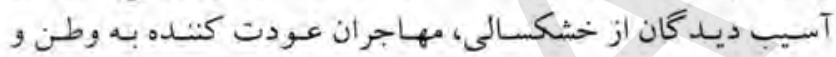

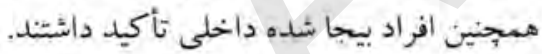

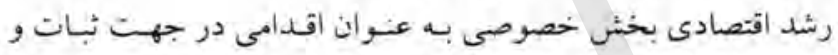

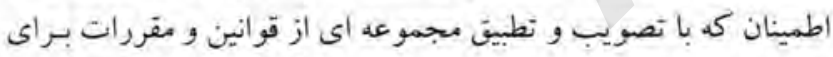

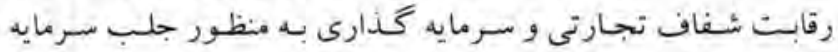

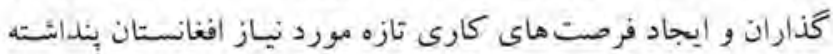

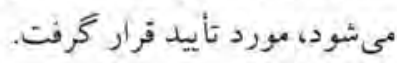

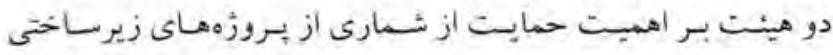

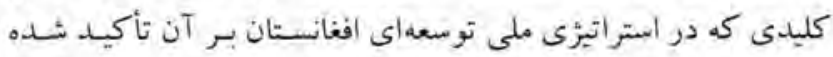

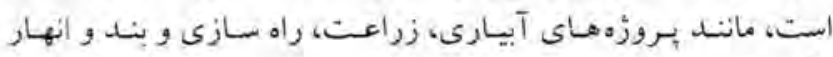
تأكيد كردند. هيئت بر بيسرفتهاي مثبت در زابطه به تو افقات به منظور تأمين بـرق،

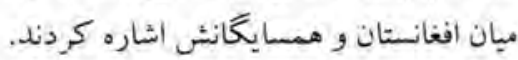

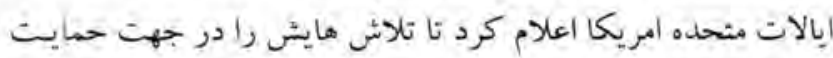

استراتيرّى فر اخِير امنيتى براى مقابله با جالش هاى امنيتى و تهديـات

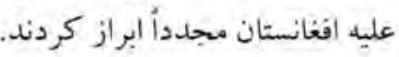

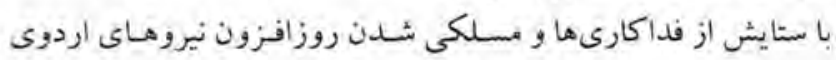

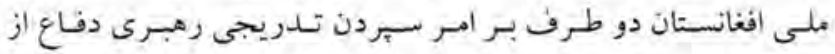

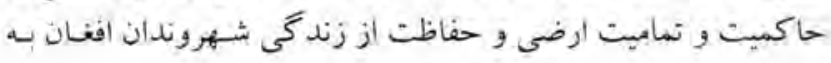

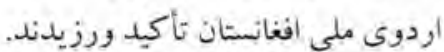

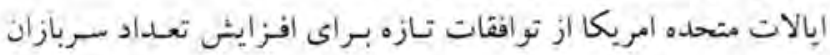
اردوى ملى افغان به آلا هز از نفر استقبال كرد.

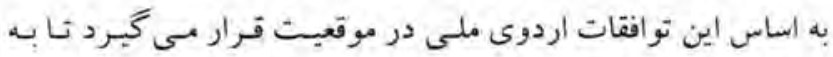

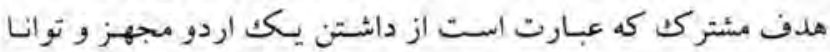

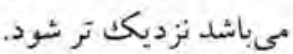

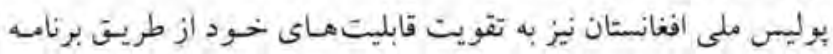

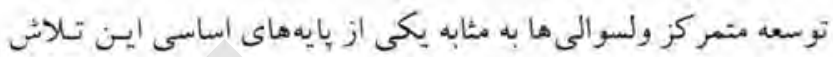

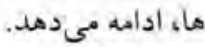

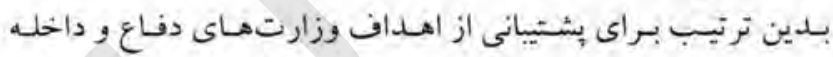

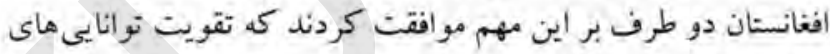

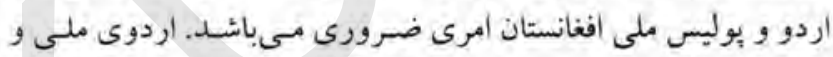

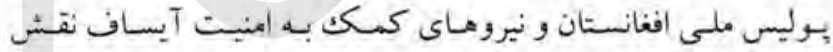

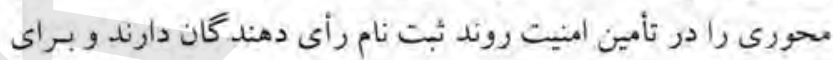

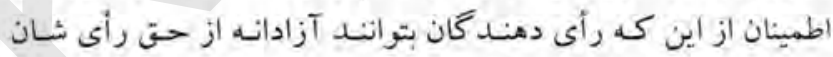

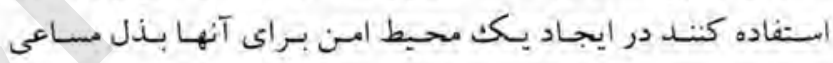
بى بـنمايند.

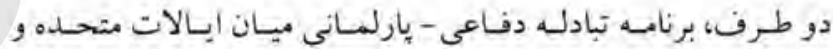

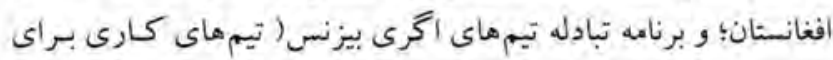

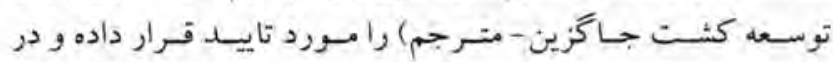

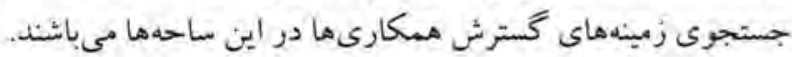

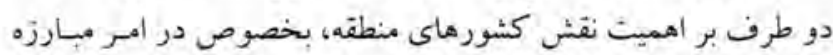

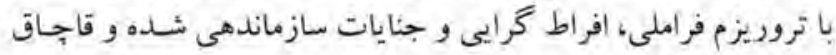
مواد مخدر تأكيد داشتيد.

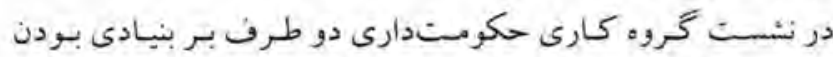

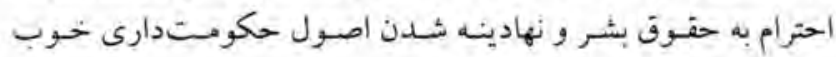
ثأكيد كردند.

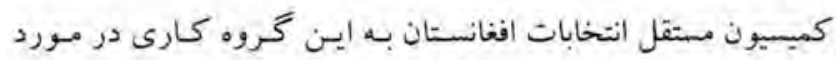

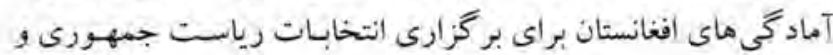

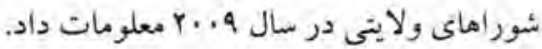

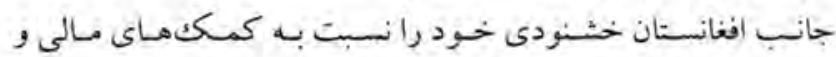

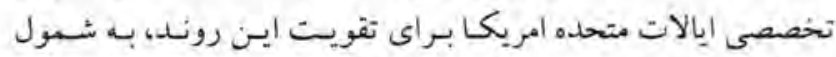

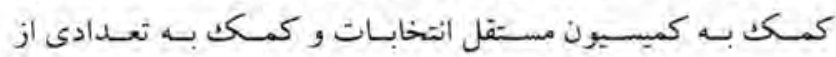




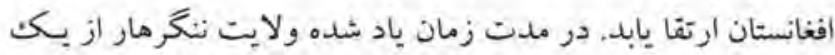

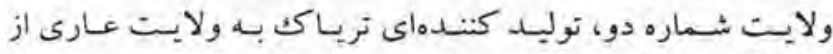

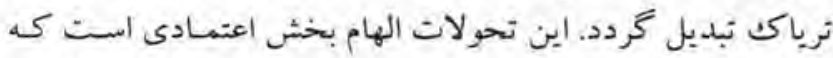

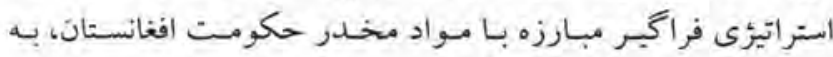

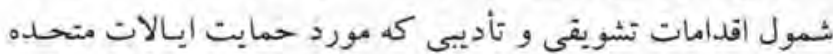

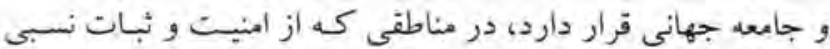
برخوردار است موثر واقع شود وراند

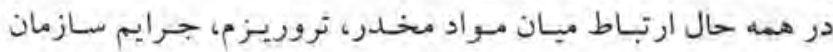

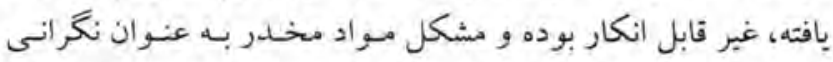

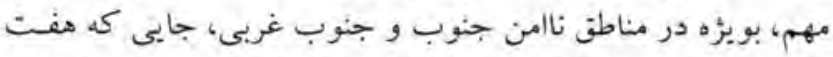

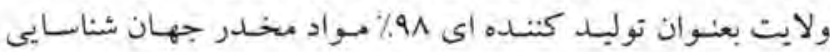

شده اند، باقى مى ماند.

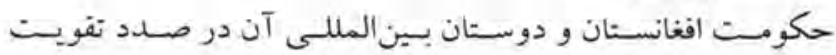

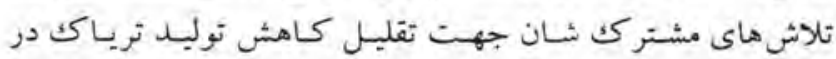
مناطق مورد نظر مى باشند. هر دو هيثت تلاش هاى حكومت افغانستان را در ولايبت هلمنـد در راستاى تقويت امنيت و حكومبتدارى و در نتيجها بـراى بيشـرفت

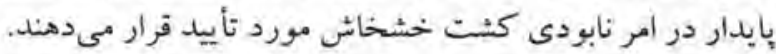

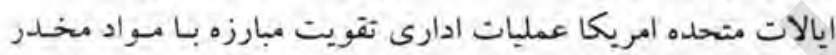

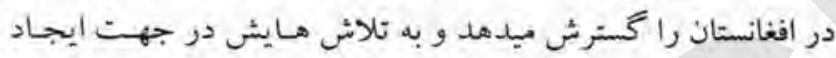

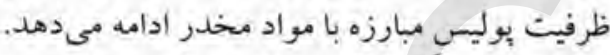

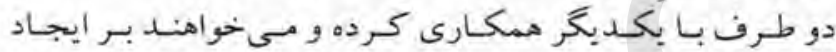

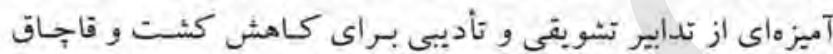

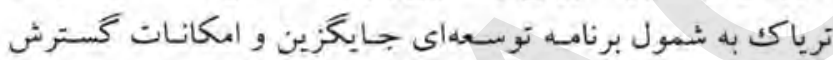

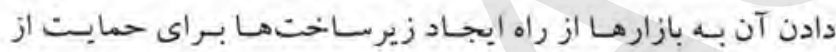

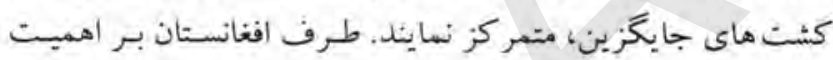

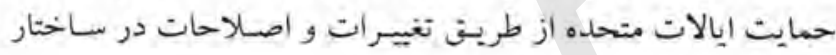
صندوق مبارزه با مواد مخدر اشاره كرد.

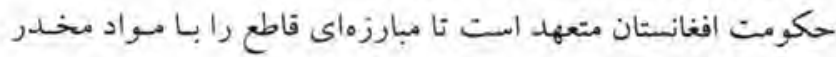

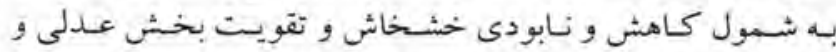

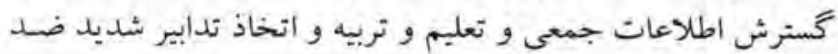

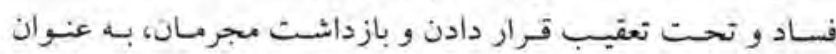

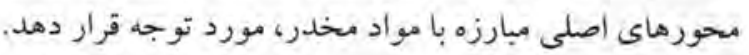

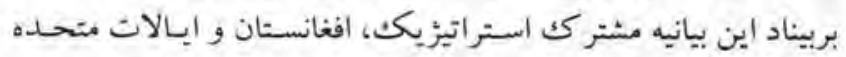

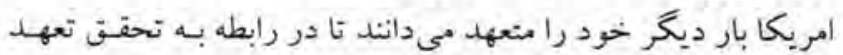

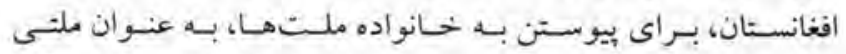

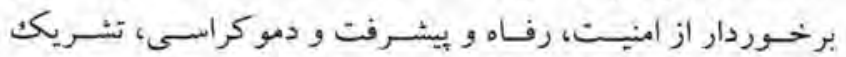

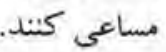

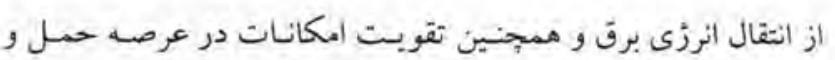
نقل و ارتباطات تقويت نمايد.

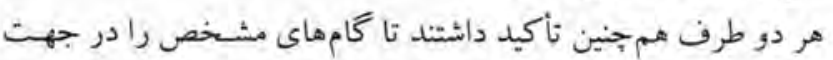

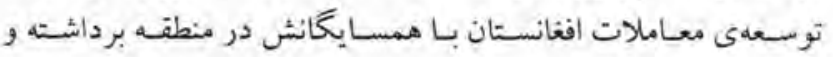

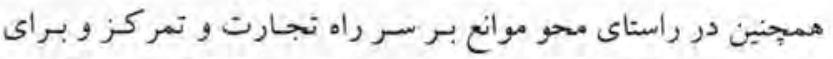

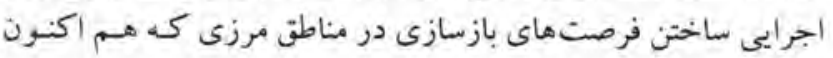

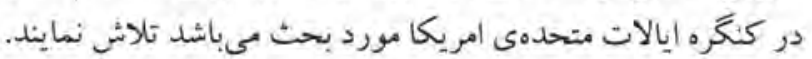

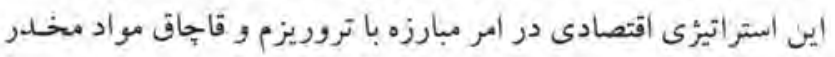

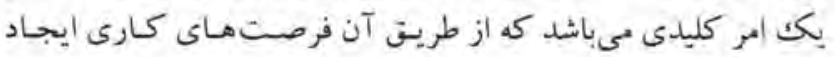

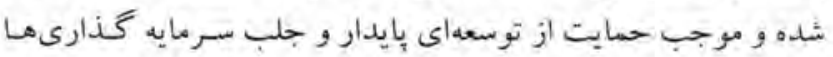

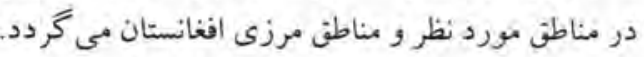

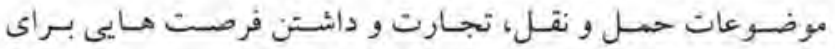

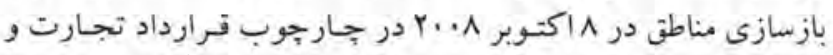

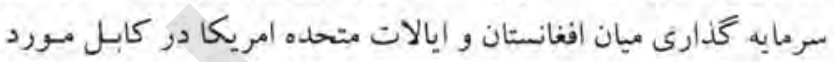

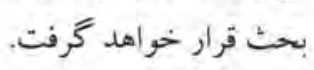
هردو هيثت اهميت تقويت ثبات مالى، به شمول ارتقائ نظام تحصيل

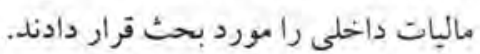

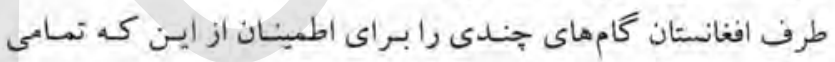

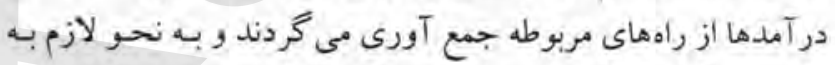

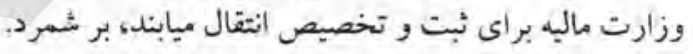

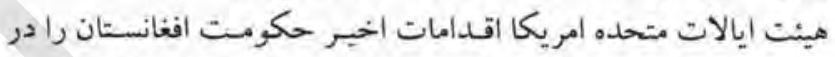

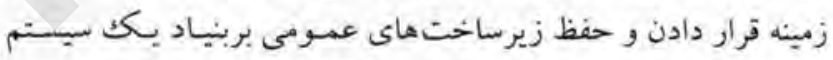
سالم بازيافت هزينه استقبال كرد.

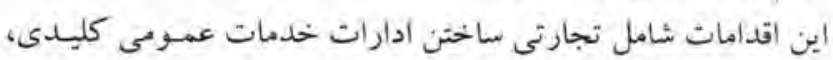

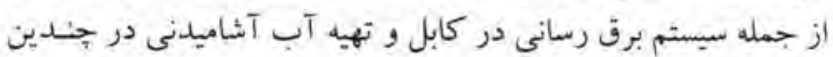

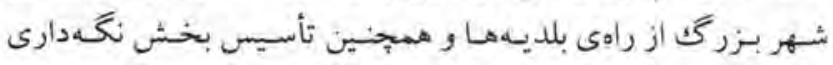

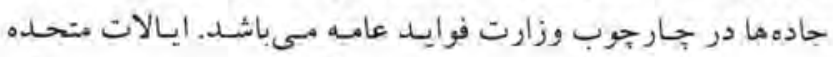

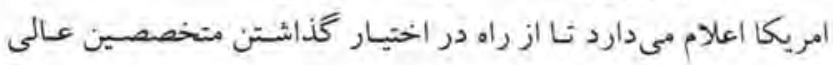
تخبكى از اين مأمول حمايت نمايد.

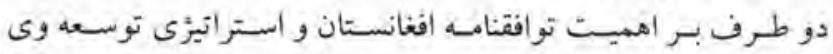

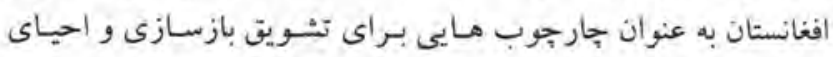
افغانستان تأكيد كردنان.

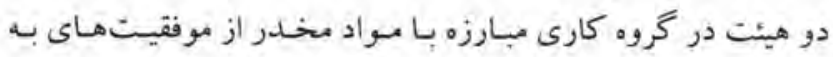

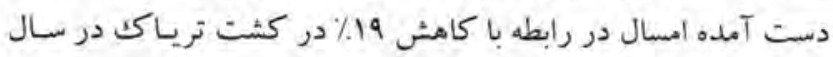

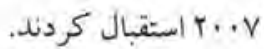

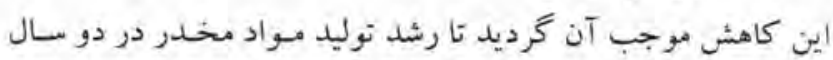

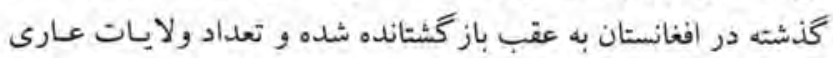

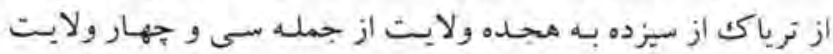



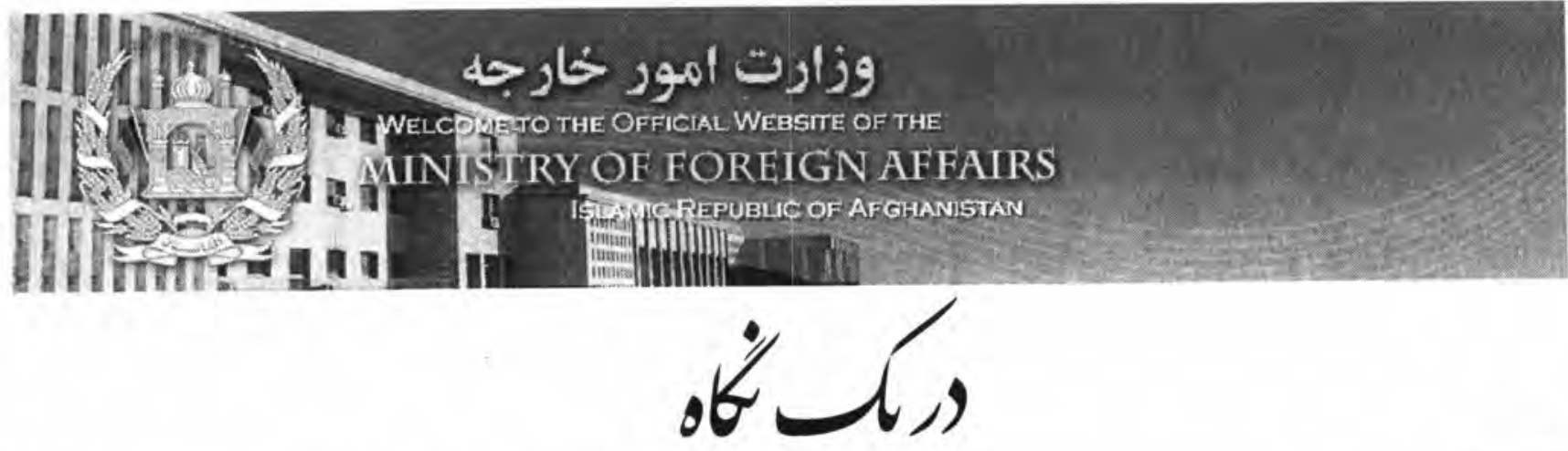

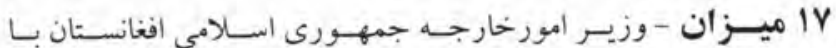

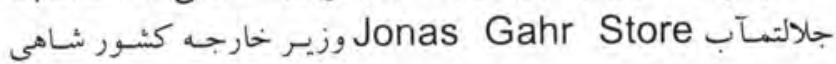

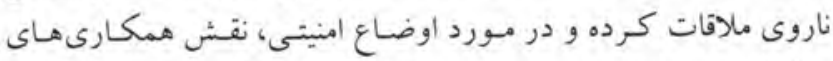

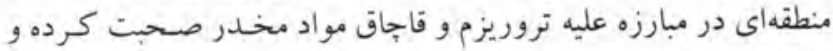

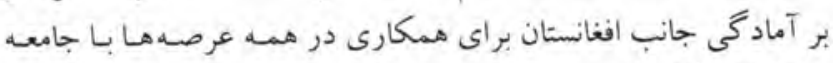
بين المللى تأكيد كرد.

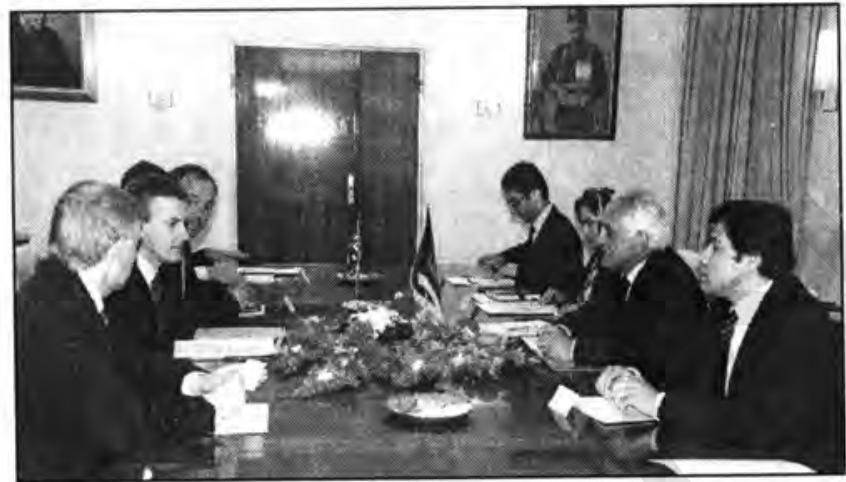

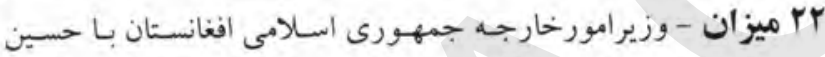

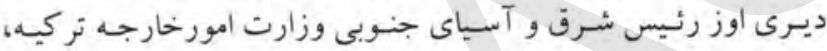

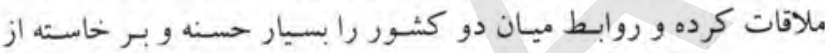

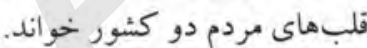

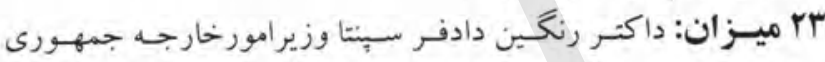

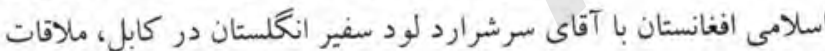

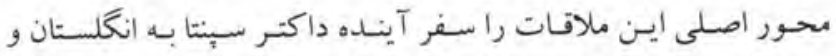

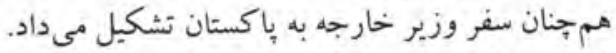

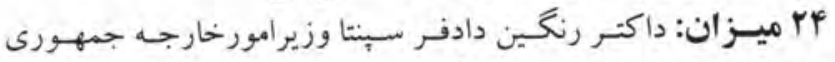

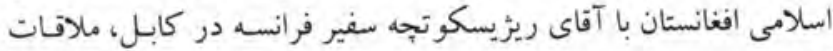
كرد. دراين ملاقات سفير فرانسه گفت: وزير خارجه آن كثـور در نظر دارد

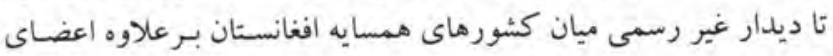

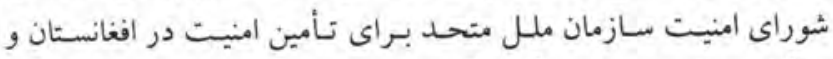
همكارى هاى سرحدى بركزار كند.
4

ملاقاتها؛

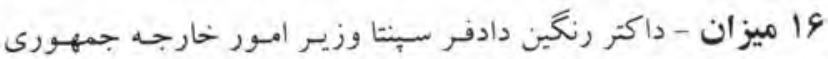

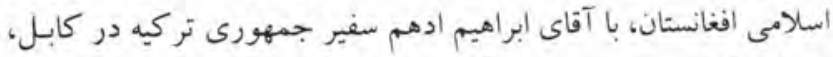

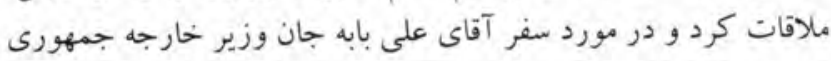

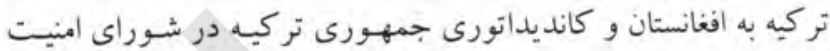
سازمان ملل متحد بحث و تبادل نظر كردئ توند

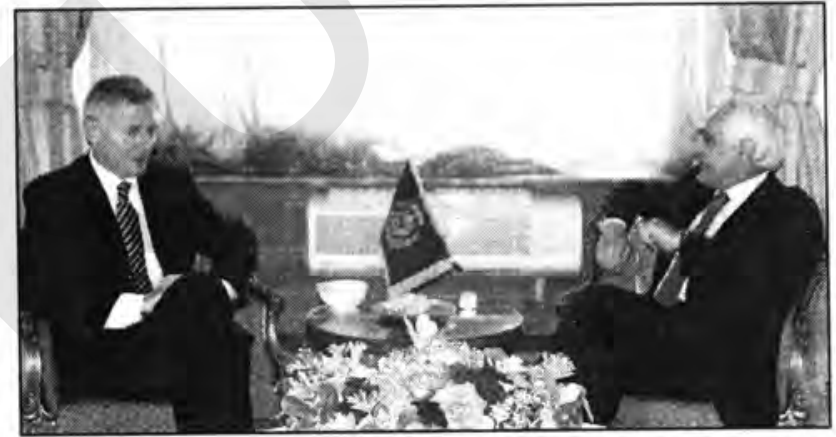

19 ميزان - وزير امور خارجه جمهـورى اسلامى افغانستان، بـا آقاى

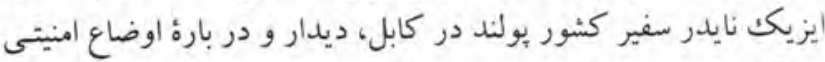

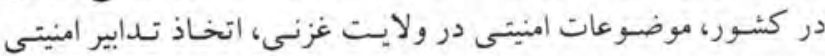

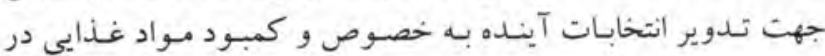
افغانستان صحبت كرد.

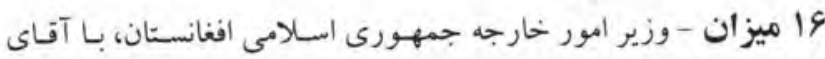
Werner hans louk .25

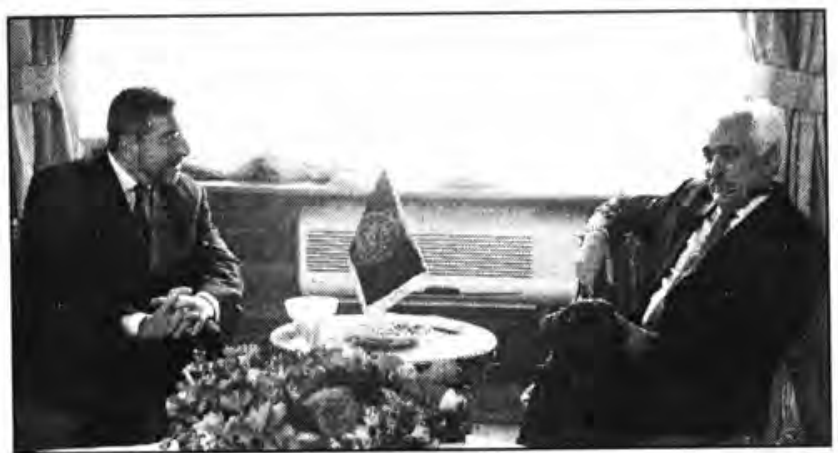




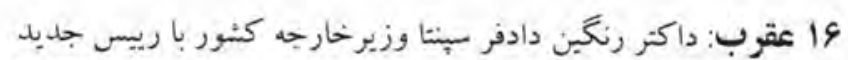

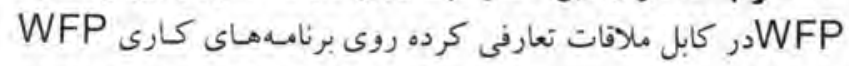

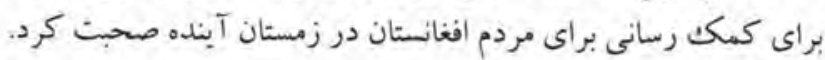

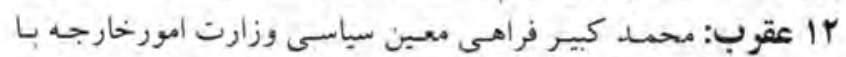
آقاى Claudio Glaentzer سفير جذيد ايتالبا در كابل ملاقلاقدات

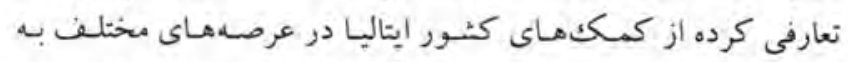

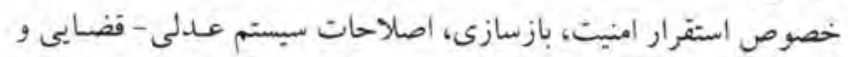

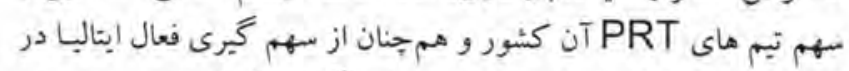

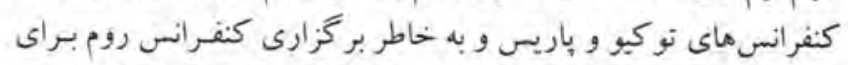

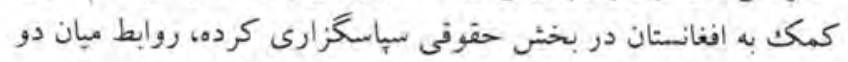
كثور را روابط تاريخى خواندان

اعلاميهها

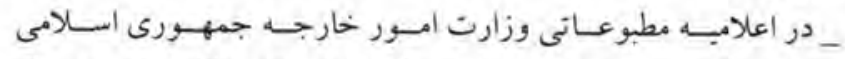

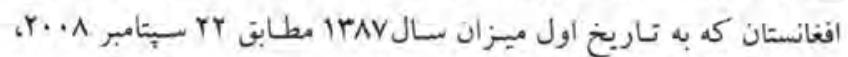

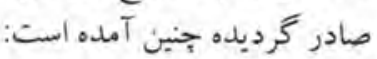

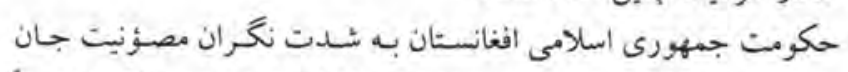

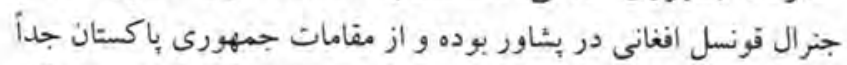

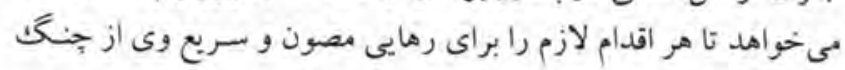

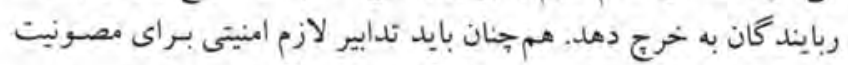

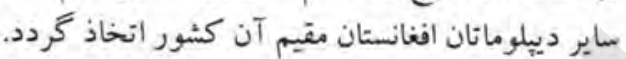

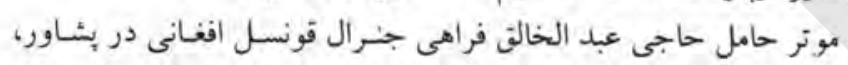

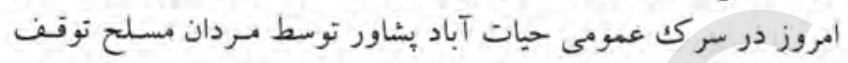

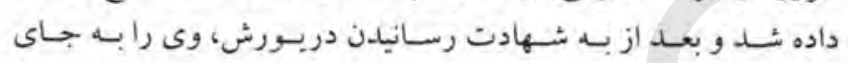
نامعلومى انتقال داده اند.

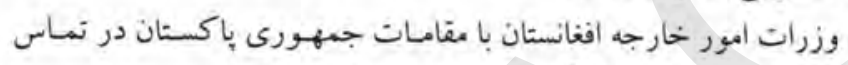

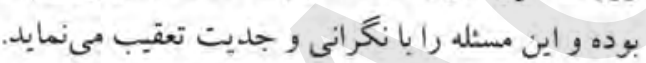

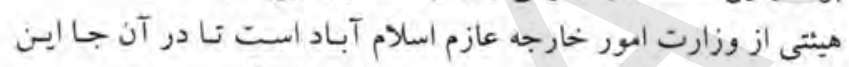

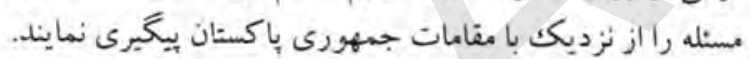

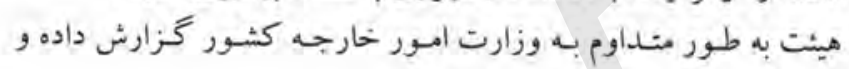

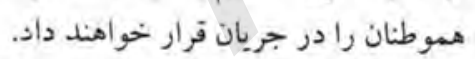

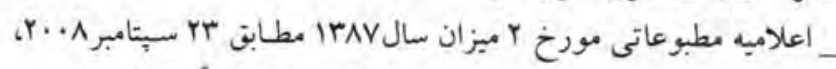

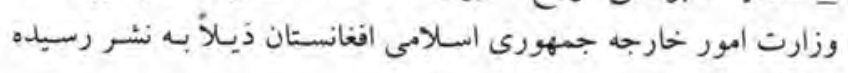

حكومت جمهورى اسلامى افغنانستان از تمديد مأموريت نيروهاى حفظ

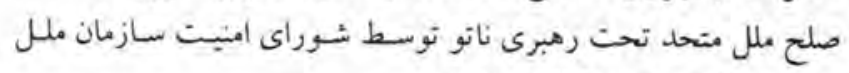
متحلد در افغانستان استقبال مئمايد.

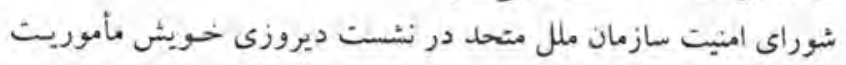

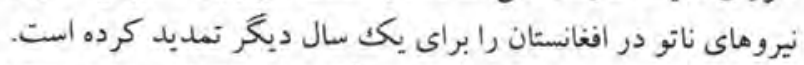

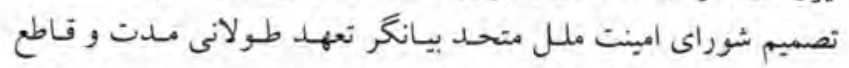

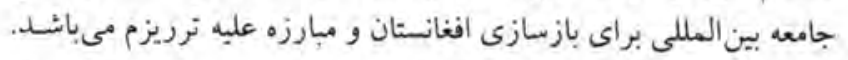

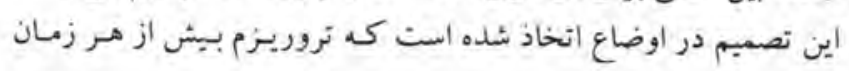

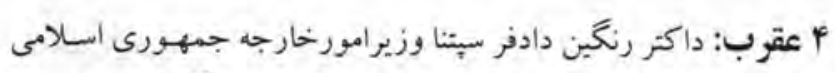

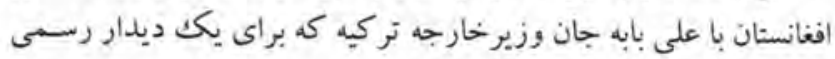

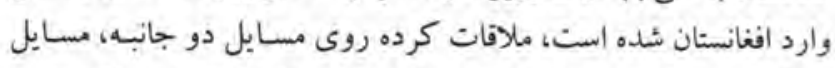

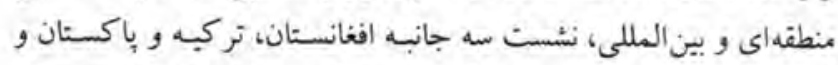

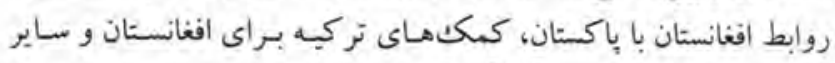
مسايل ذيعلاقه صحبت و گفتخو كرد.

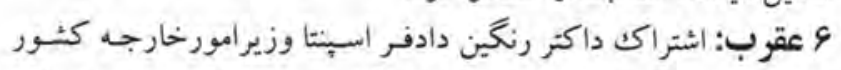

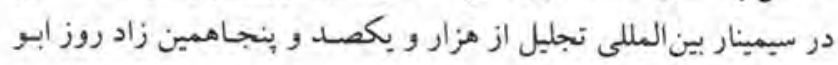

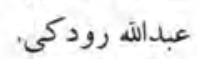

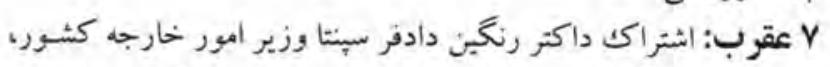

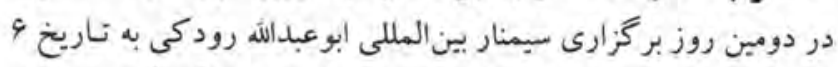

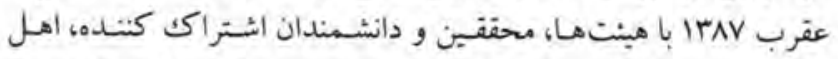

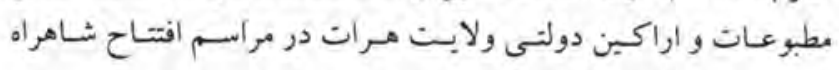
رودكى. A عقرب: داكتر رنكين دادفر سينتا وزير امورخارجه جمهورى اسلامى

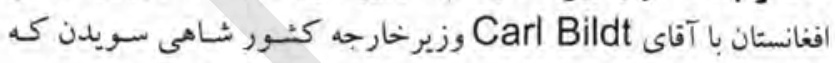

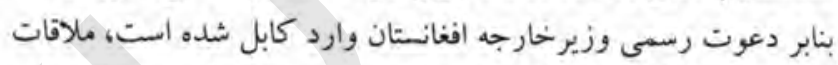

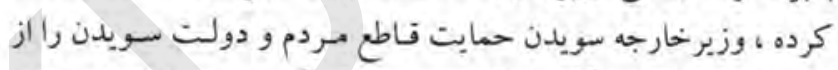

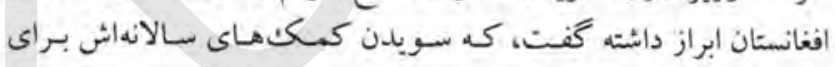

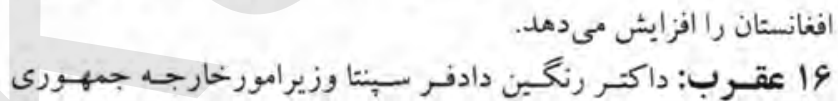

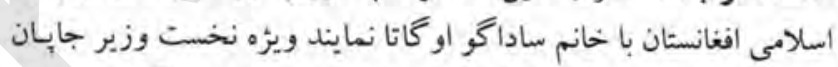

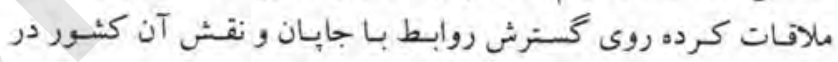

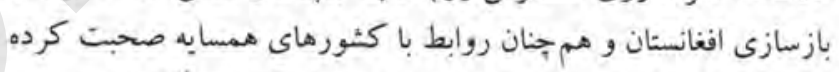

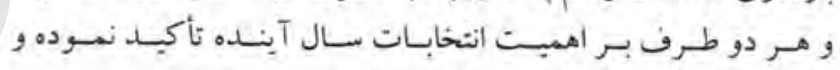

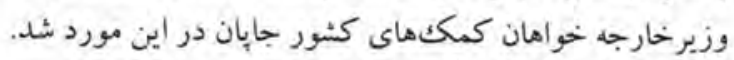

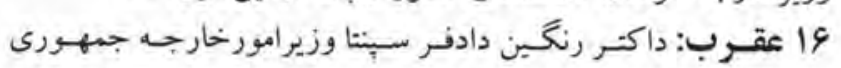

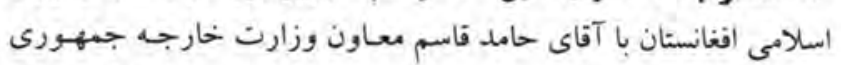

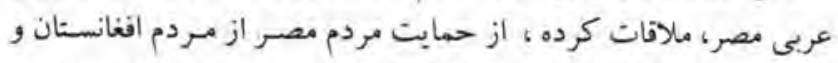

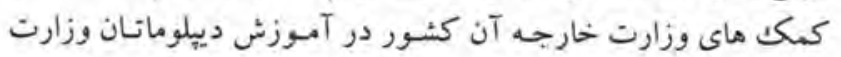

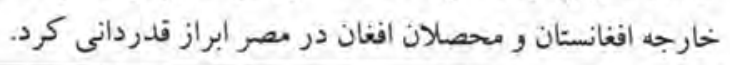

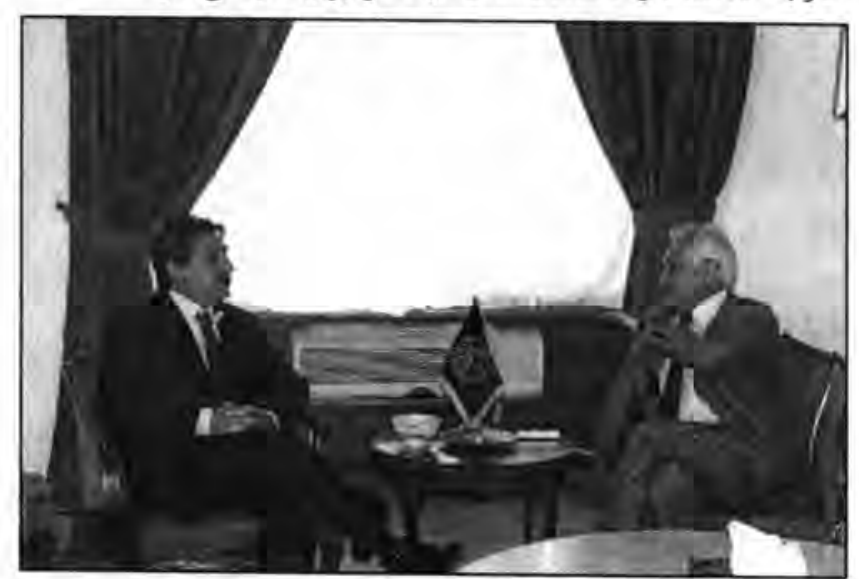

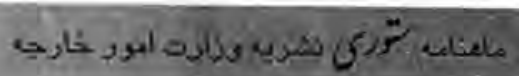


همكارى هاى حتوفى، به امضا مىرسئ.

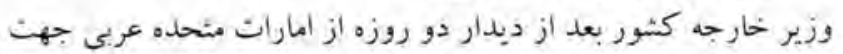

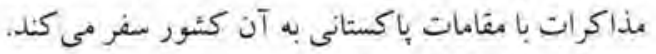

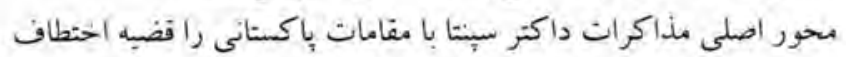

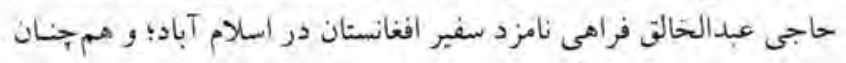

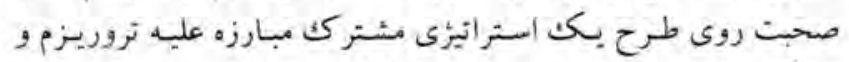

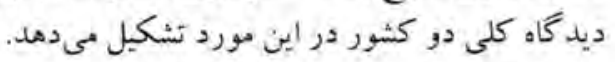

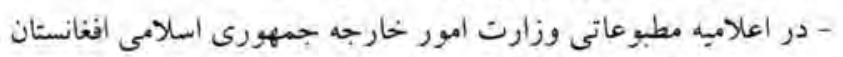

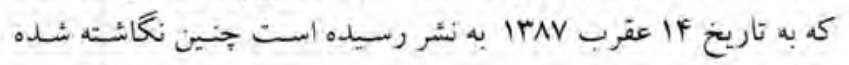

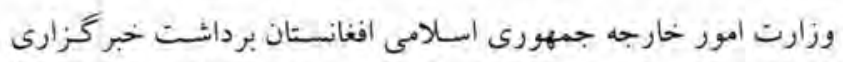

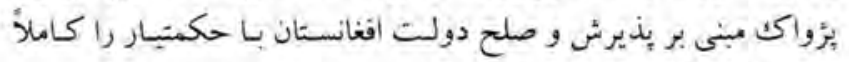
نادرست ميد ماند.

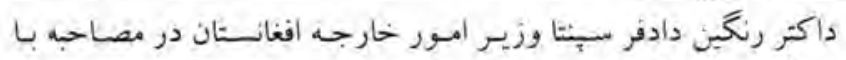

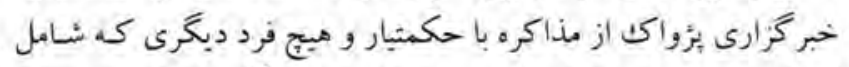

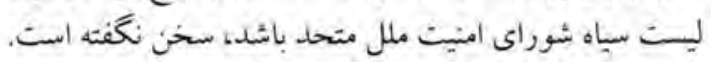

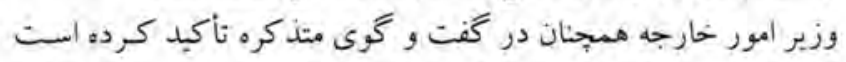

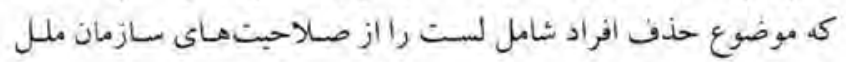

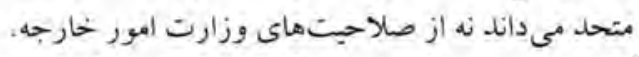

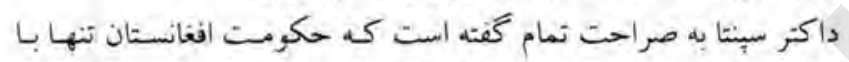

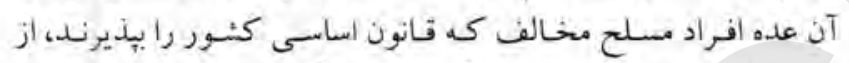

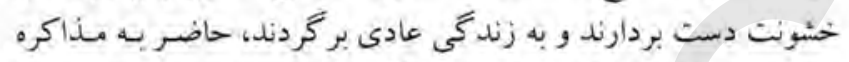

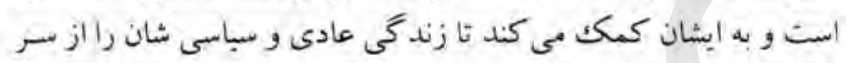
كامبرند.

بيامها ماندان آميزان-از جانب وزير امور خارجه جمهوري اسلامى افغائستان يـام

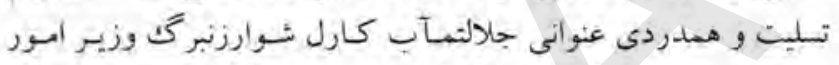

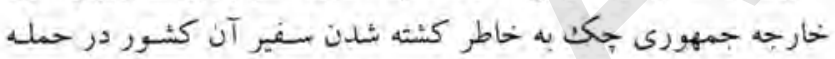

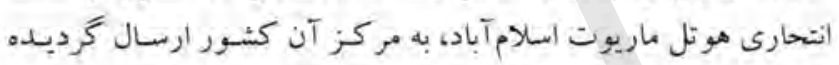

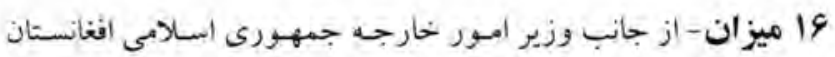

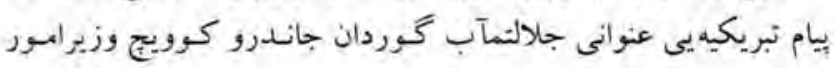

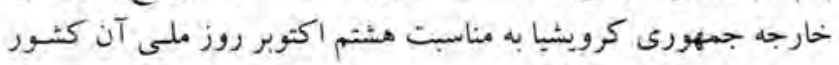

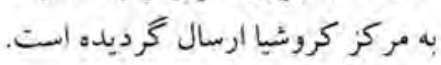

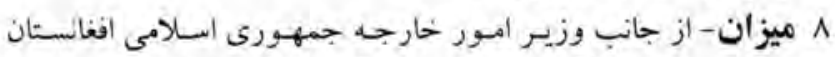

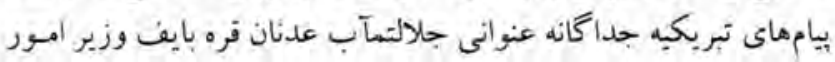

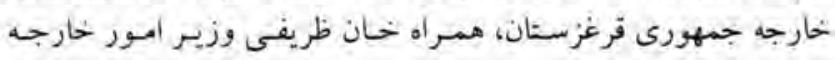

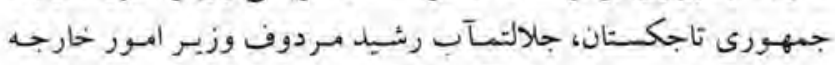

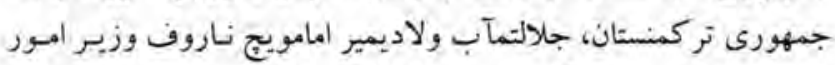

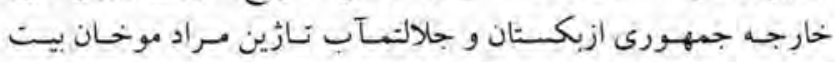

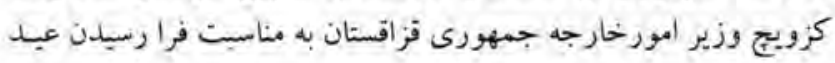

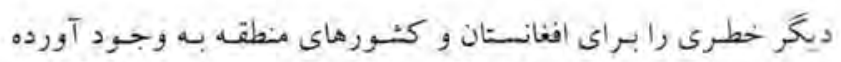

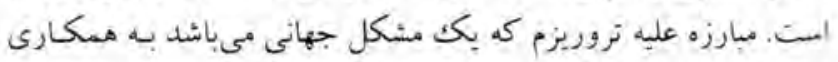

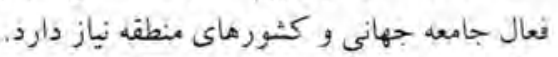

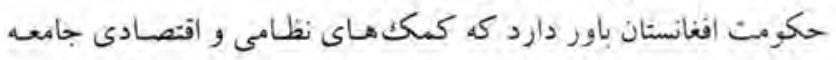

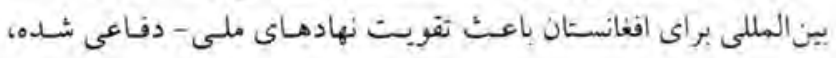

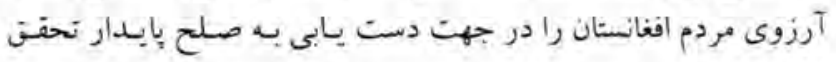

عى بخشد.

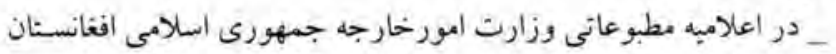

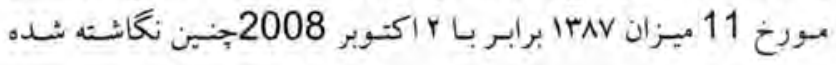

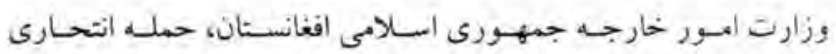

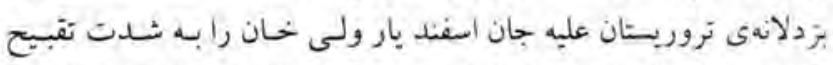

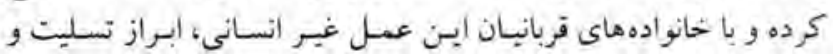
همدردى مى كند.

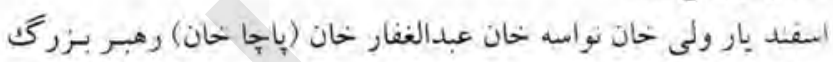

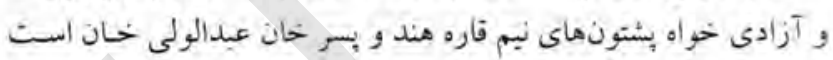

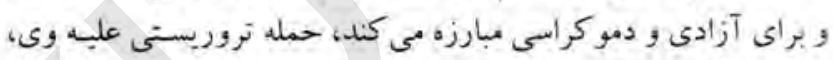

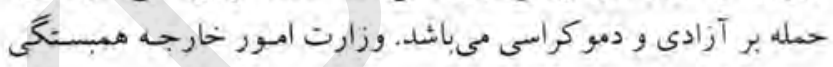

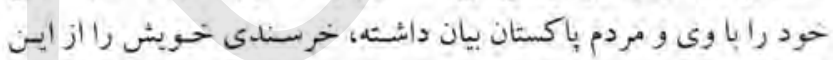
كه بر وى در اين حمله آسيب نرسيده است، ابر إز مئ دارد.

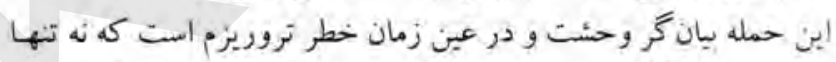

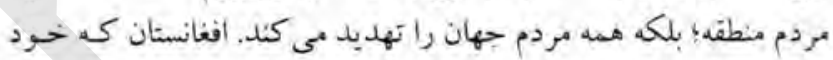

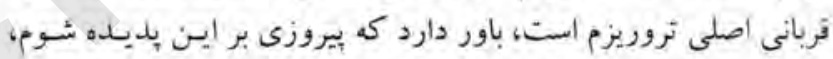

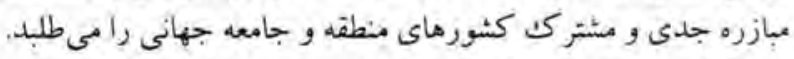

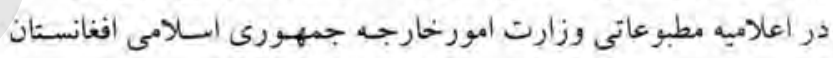

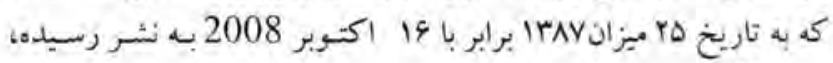
جنين آمده است تارنيخ

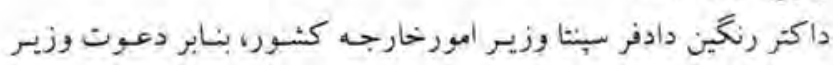

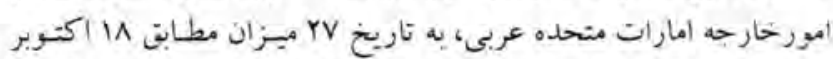

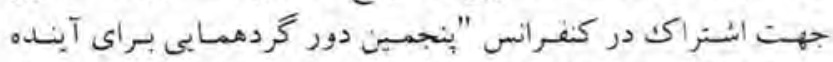

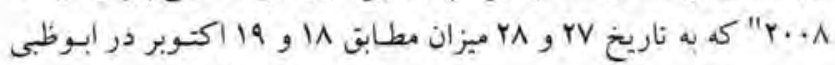

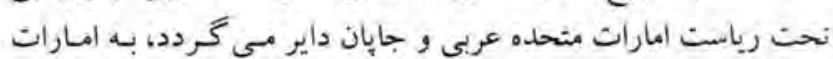
متخده عربى سفر مئمايل.

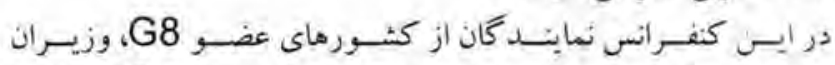

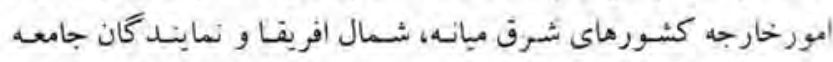

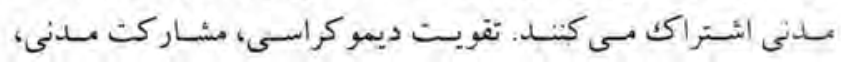

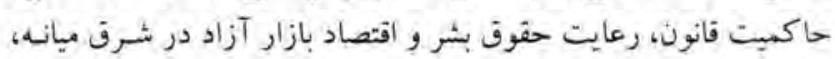

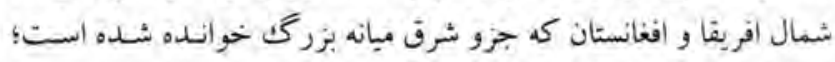
از اهذاف عسده اين كنفر انس مى باشيد.

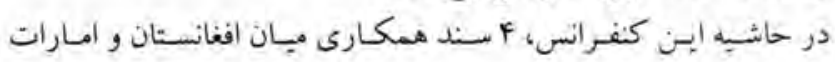

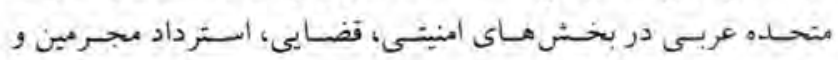


كر ويده انست.

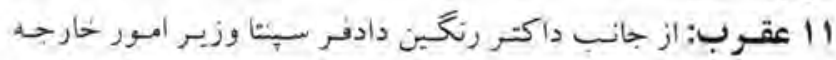

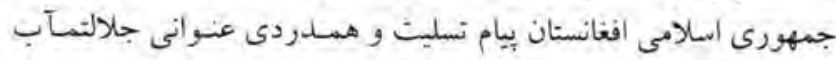

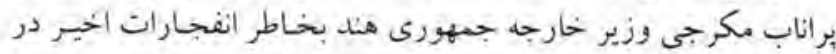

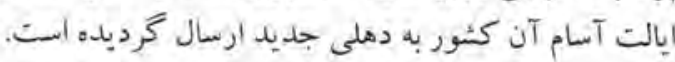
كنف انس هاى مطبوعاتى

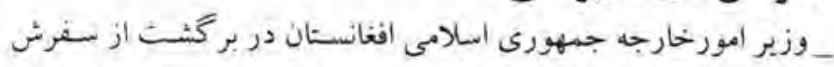

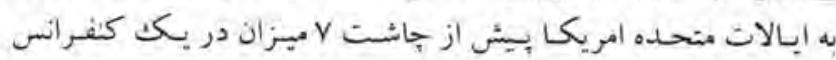
مطبوعاتى انشتراكت و در مورد نتايج سفر هيئت عالى رتبه أفغانستان بـانس

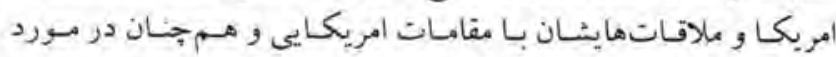

اختطاف آقاى فراهى جنر الل قونسل افغانستان در بيساور صحسث كرد.

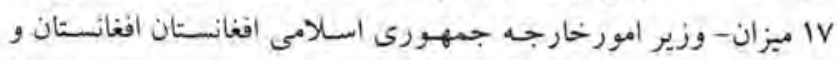

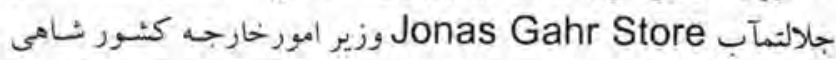

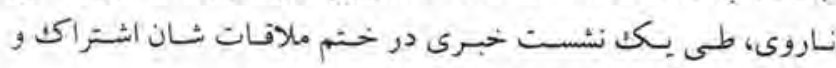

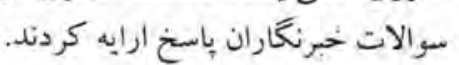

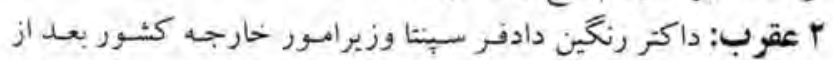

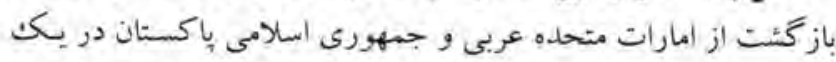

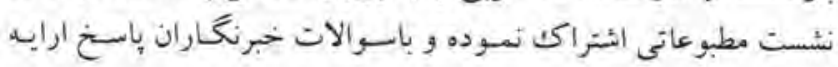

دانتــ

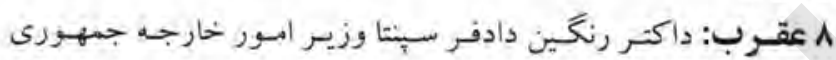

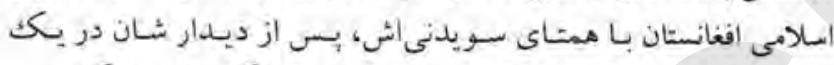

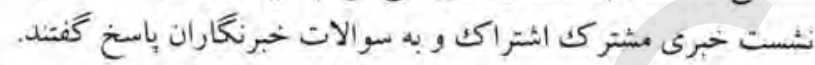

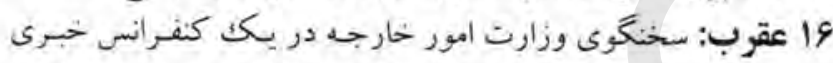

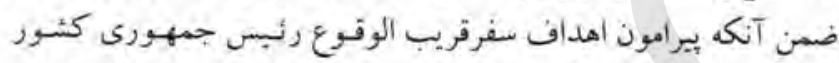

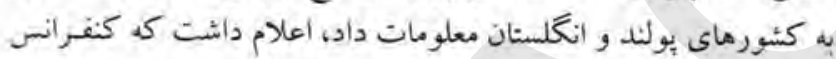

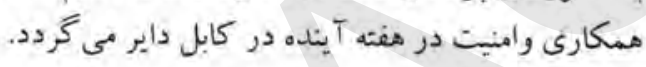

\section{مجموع اجرآت وزارت امور خارجه به خاطر رهايى نسامزد سفير افغانستان در يراكستان}

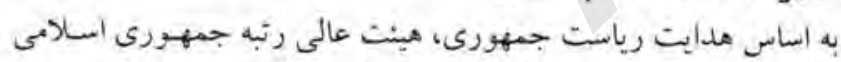

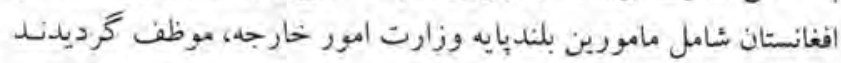

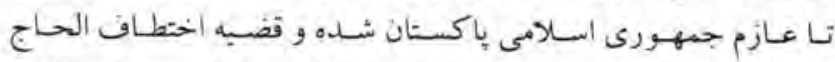

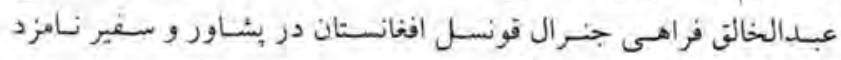

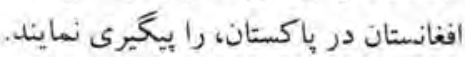

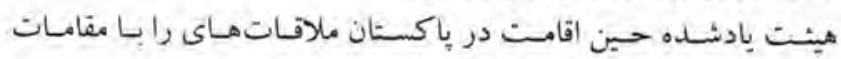

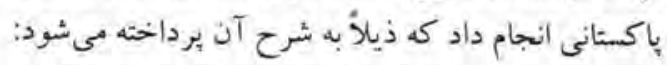

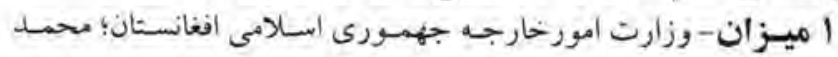

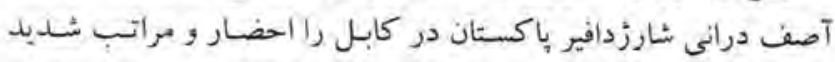

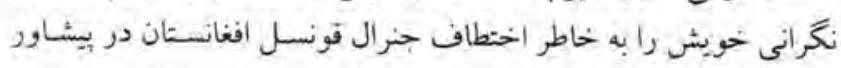
به ورى أبراز دانشت. هحمد كير فراهى معين سياسى وزارت امورخارجه خواست نـا دولت

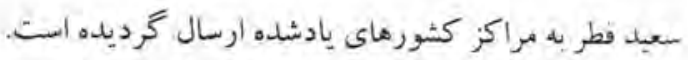

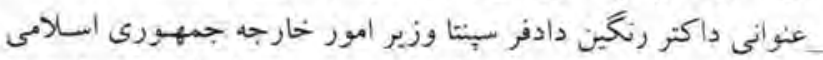

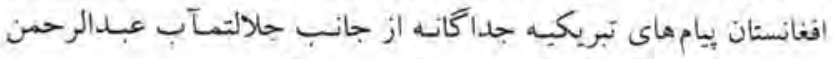

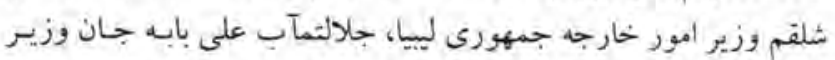

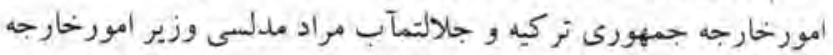

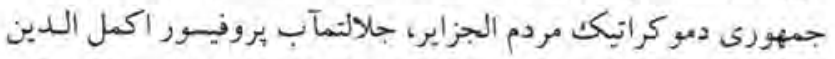

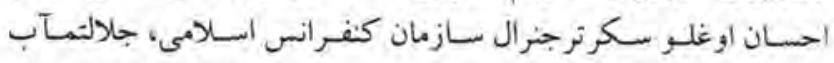

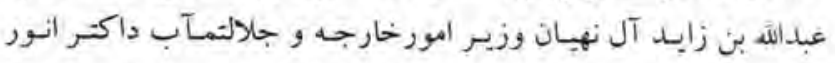

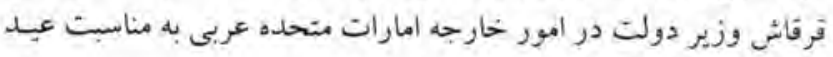

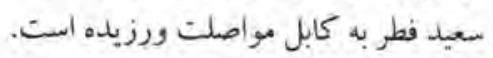
_عنوانى وزير امور حارجه جههورى انسلامى افغانستيان بيامهـاي امتنانيه.

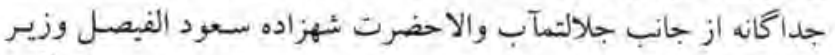
امور خارجه كثور شاهى عربستان سعودى در جواب يبامهاى تبريكيه

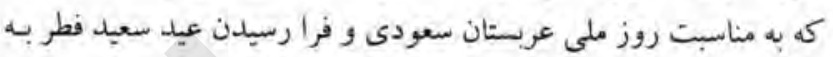

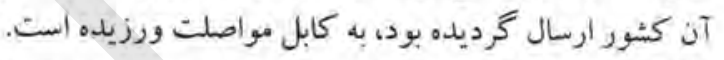

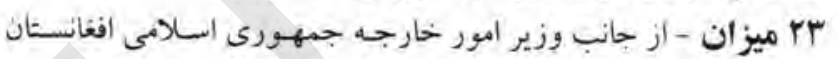

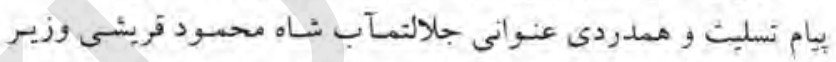

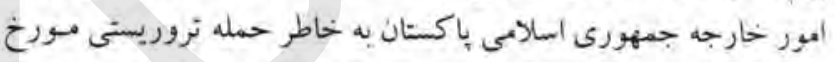

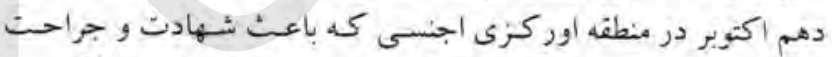

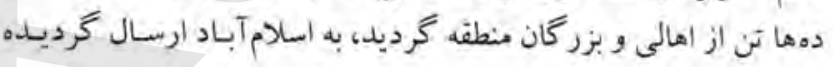

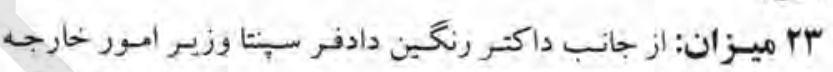

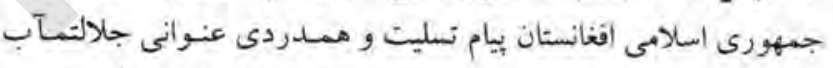

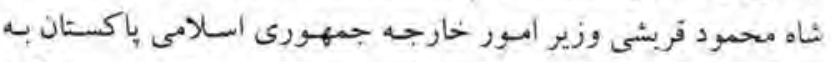

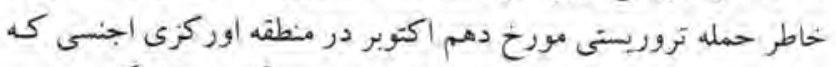

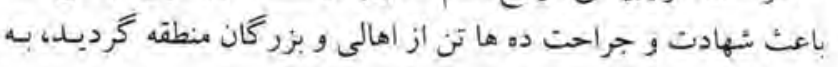

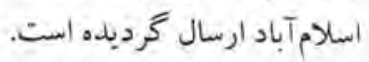

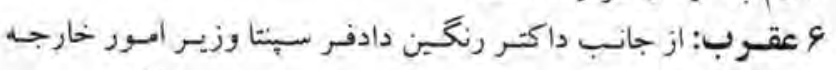

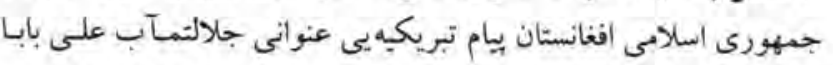

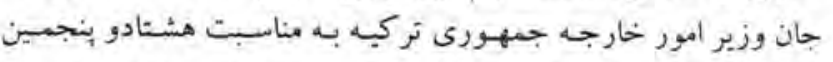

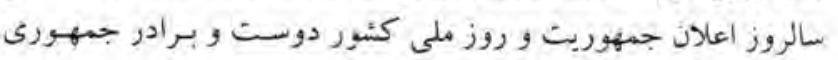

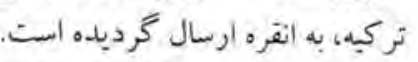

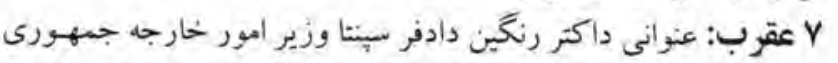

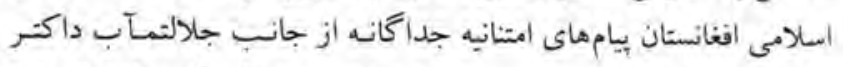

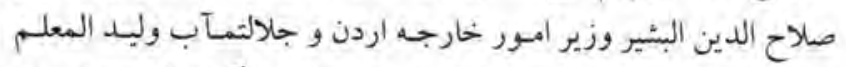

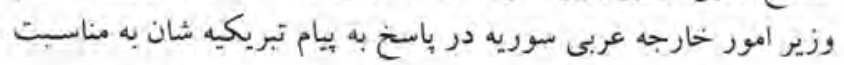

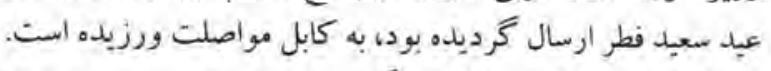

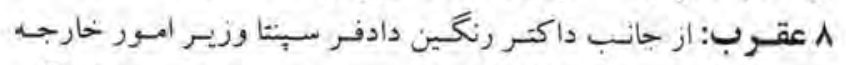

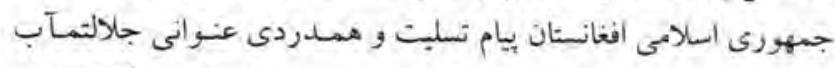

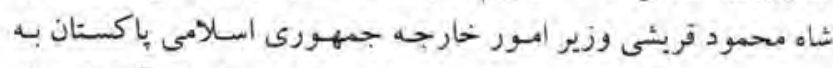

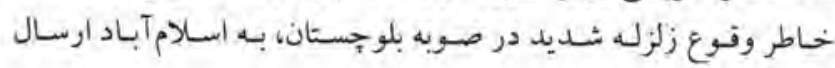




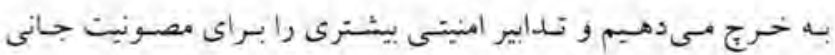

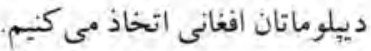

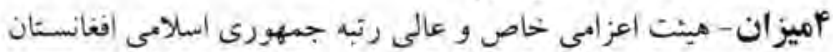

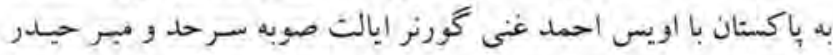

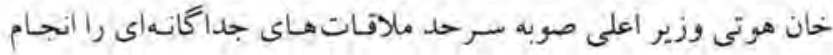

. 21

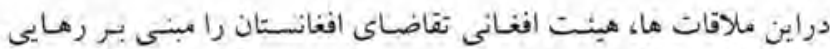

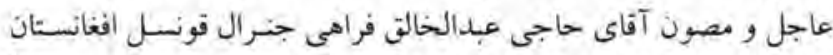

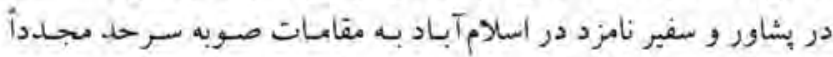

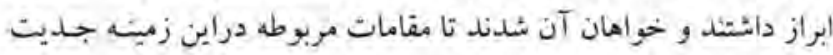
بئتر به خرب دهند.

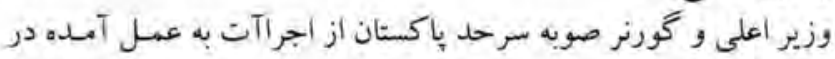

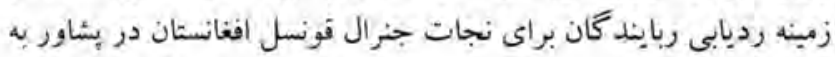

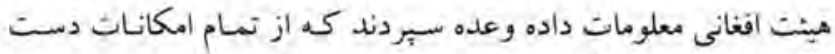

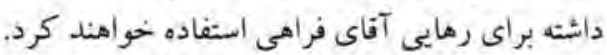

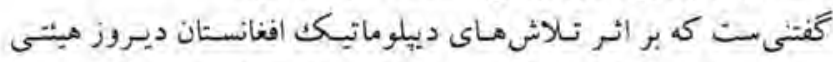

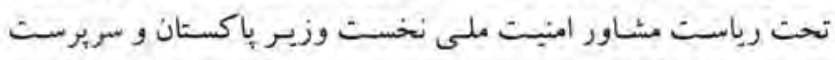

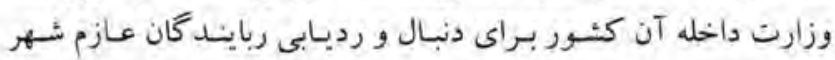
بشاور شدند.

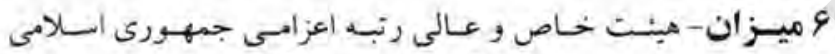

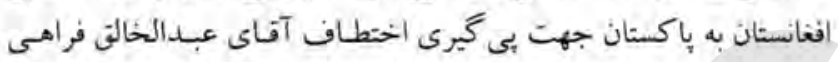

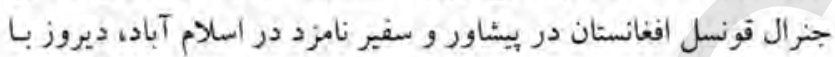

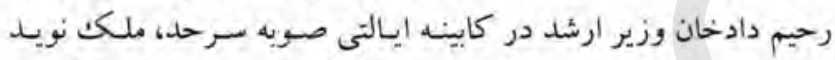

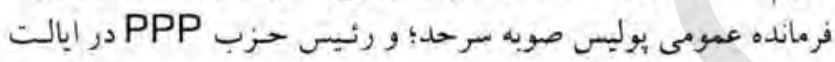
سر حد ملاقات كرد.

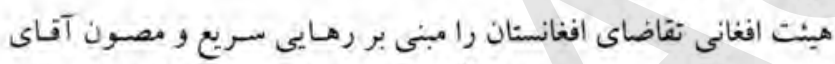

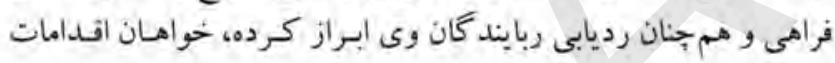

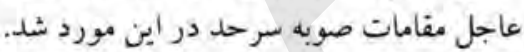

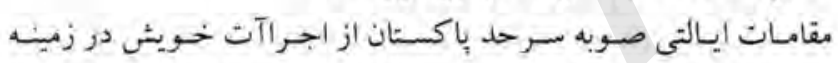

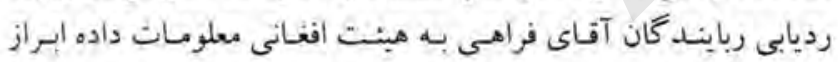

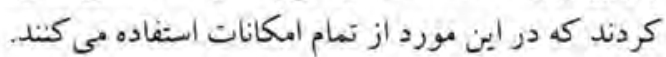

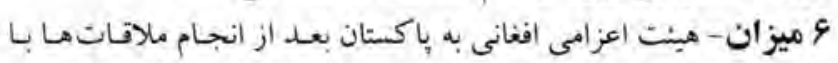

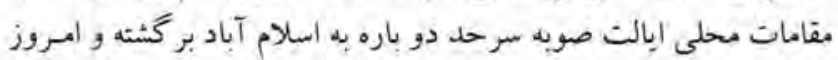

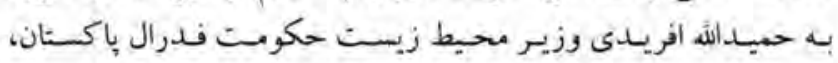
ملاقات كرد.

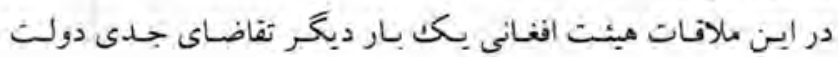

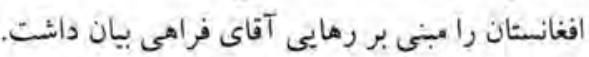

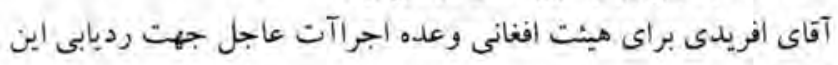
تضيه را سبرح.

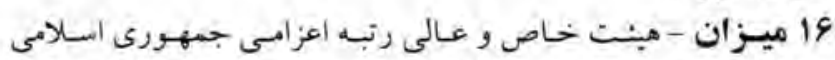

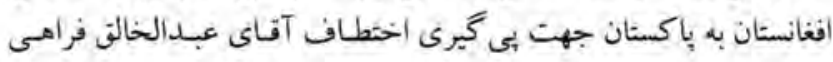

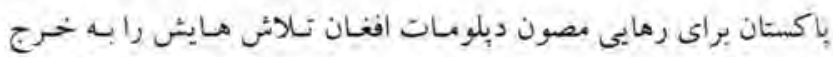

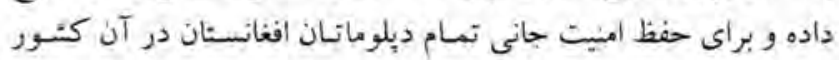
كوشش هائ همه جانبه نمايل.

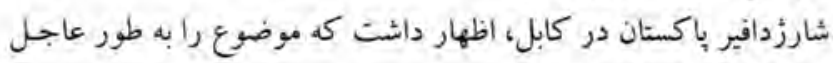

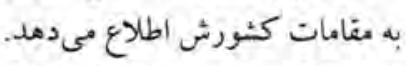

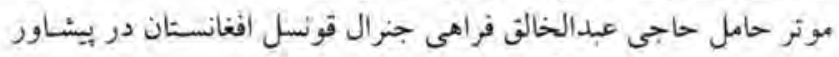

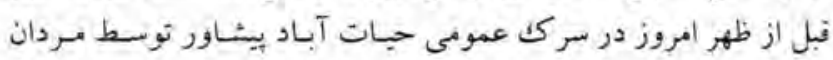

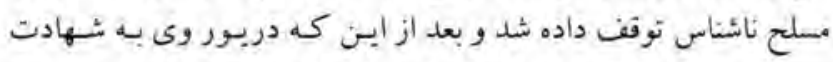
رسبد، هوصوف رابا خود با جائ نامعلوم انتقال دادند.

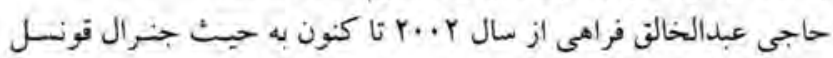

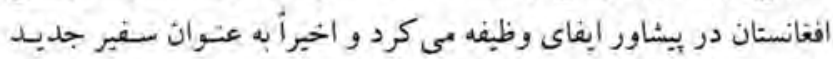

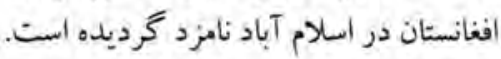

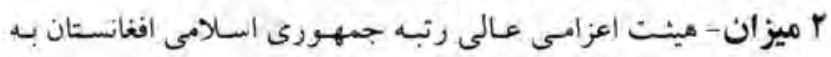

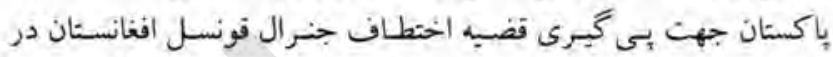

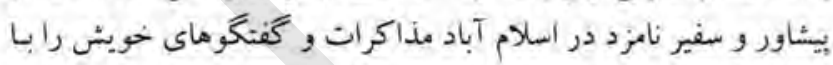

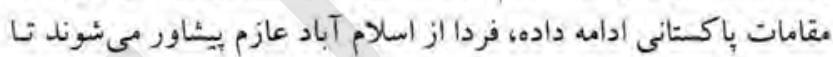

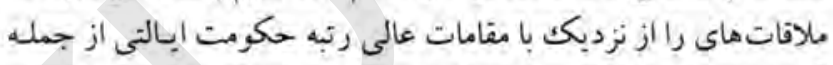
كورنر و وزير اعلى آن جا، انجام دهند.

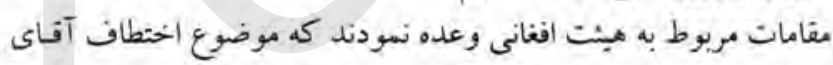

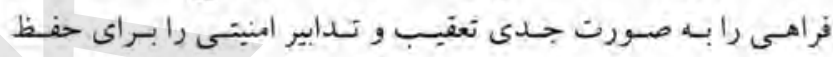

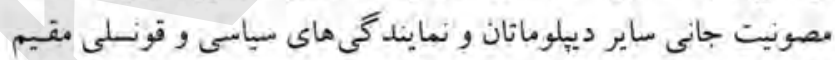

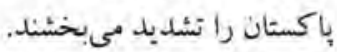

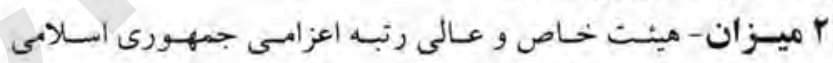

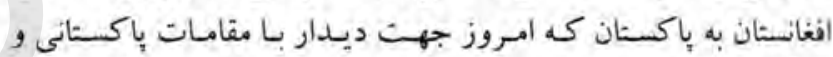

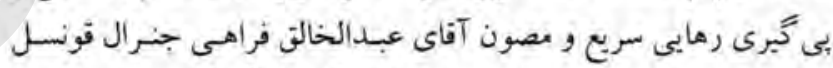

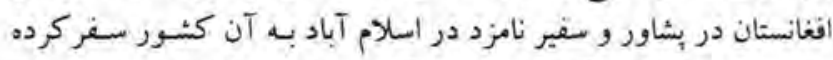

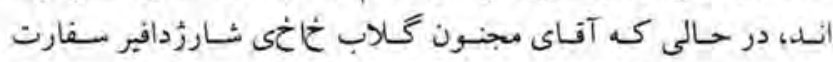

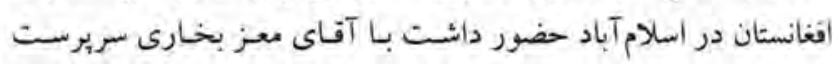

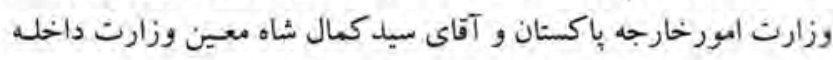

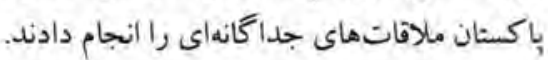

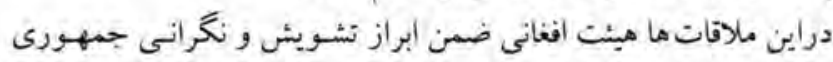

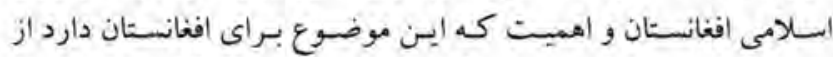

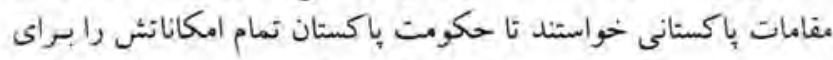

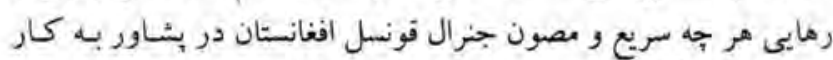

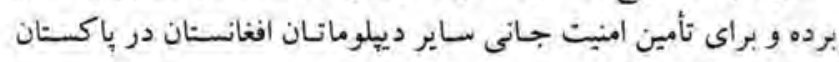
تدابير شديذ اتخاذ كند. ترون.

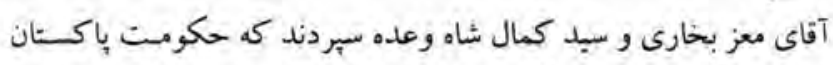

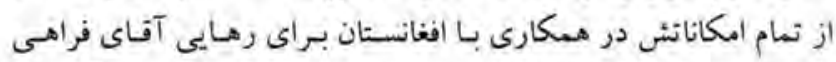

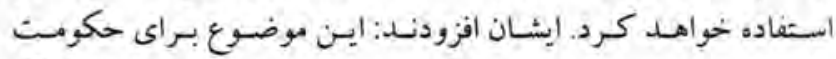

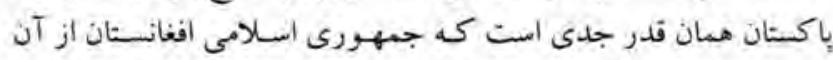

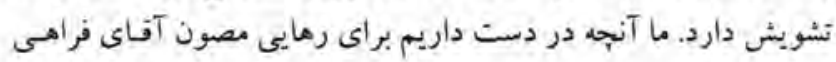


كونشئ مى كند كه اقاى فراهى به زودى رها كرددد و با مقامسات دولت

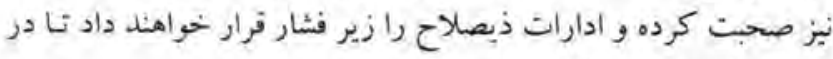

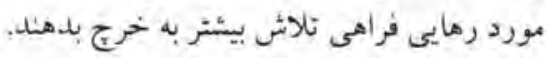

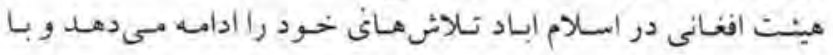

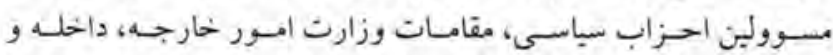

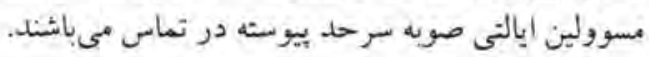

\section{فعاليت هاى عمــده مـديريت هــا و سـفارت هــاى جمهـورى

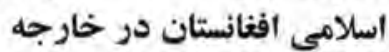

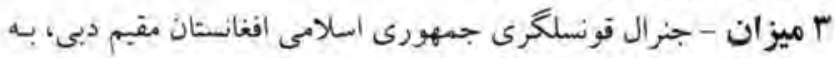

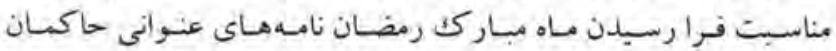

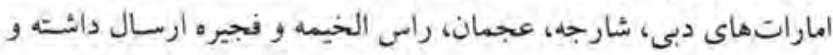

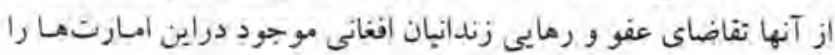
كر.

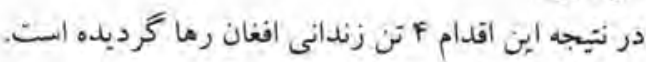

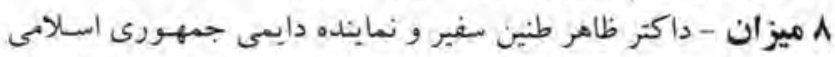

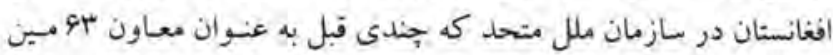

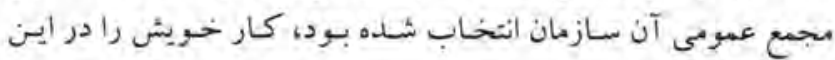

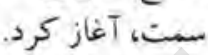
If

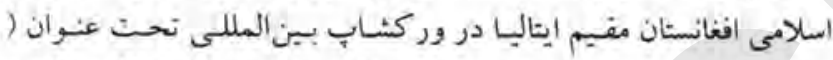

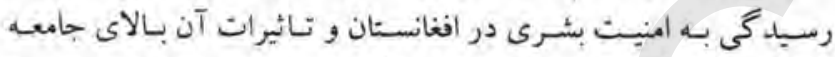

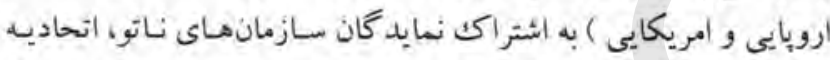

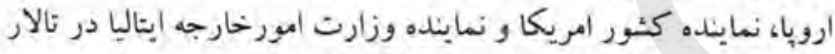

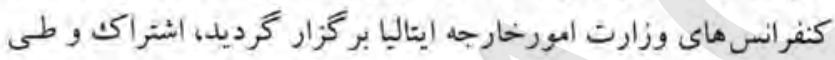

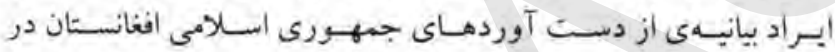

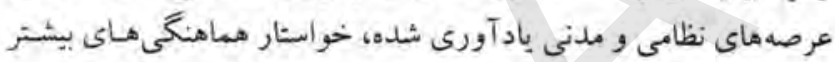

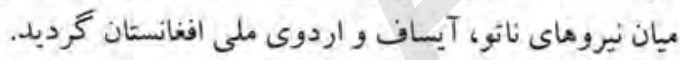

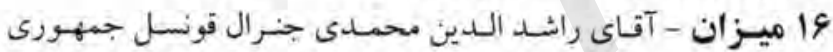

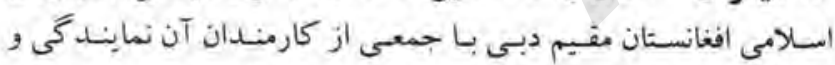

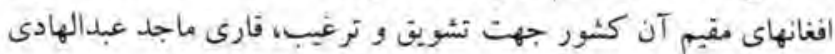

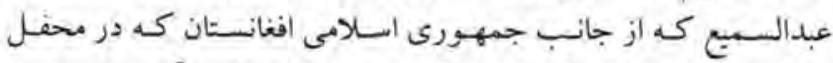

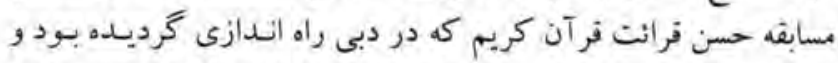

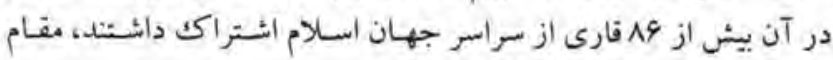

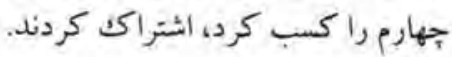

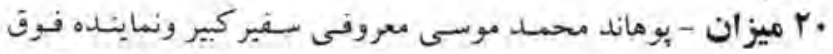

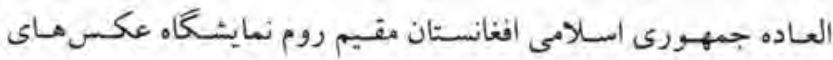

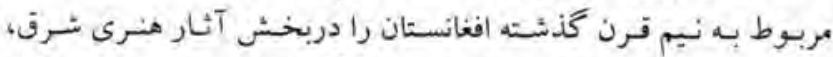

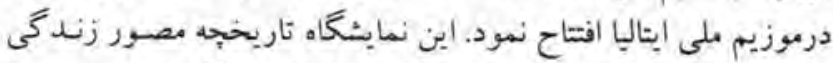

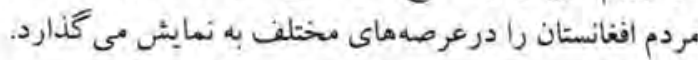

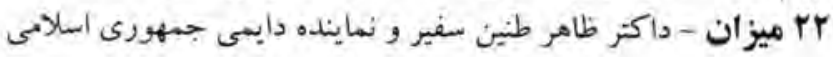

جرز ال قونسل افغائستان در بيئاور و سقير نامزد در اسلام آباد، امسروز بـا

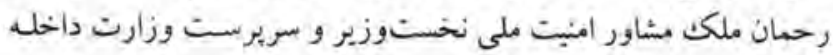
بإكستان ملاقات كرد.

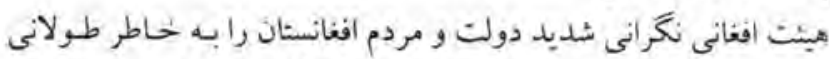

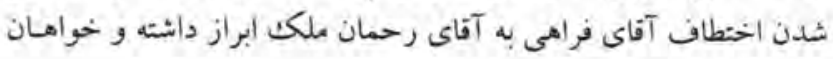

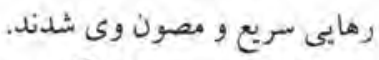

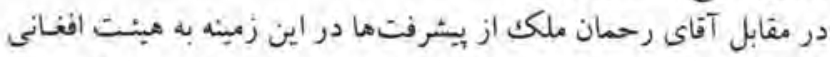

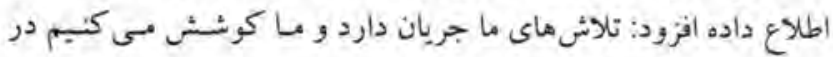

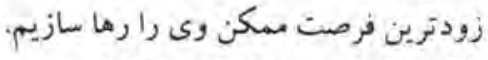

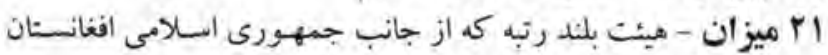

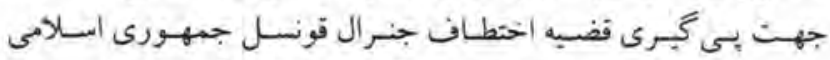

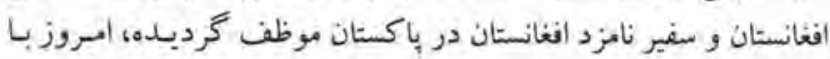

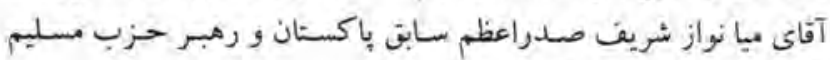
ليخت شاخه نواز ديدار كردند.

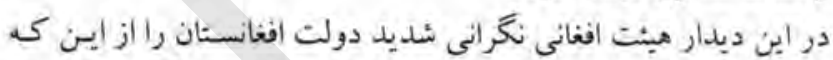

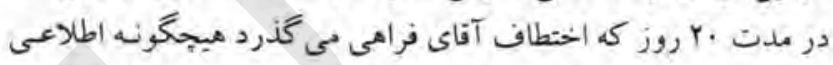

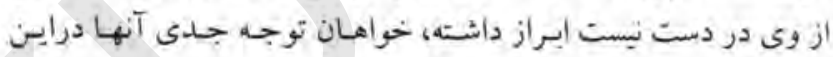
مورد شدند.

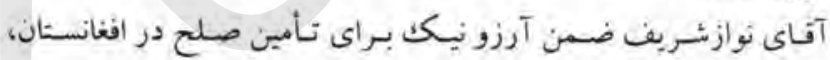

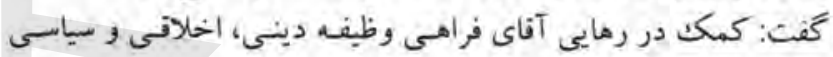

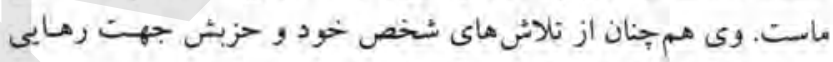

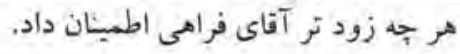

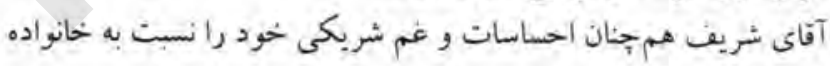

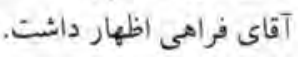

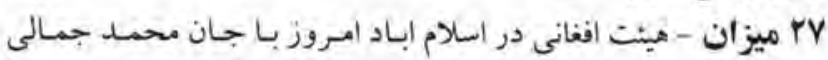

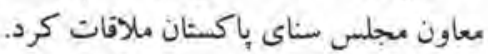

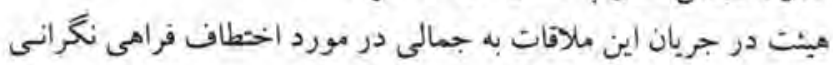

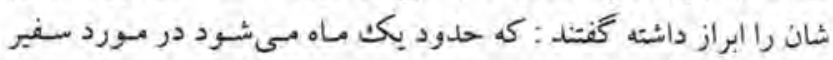

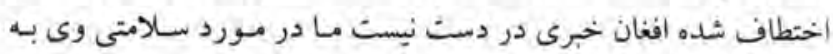

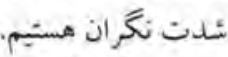

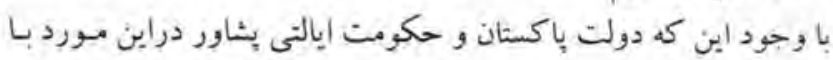

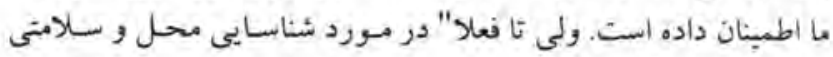

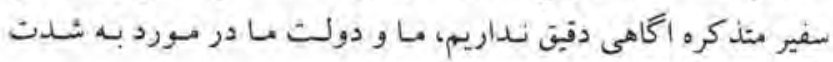
از جمالى تقاضا شد كه با استفاده از تفوذ شخصى به صفت بزركت فترم

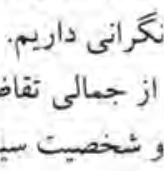

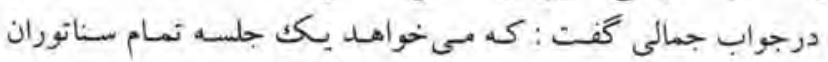

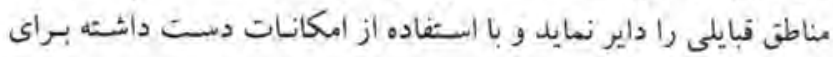

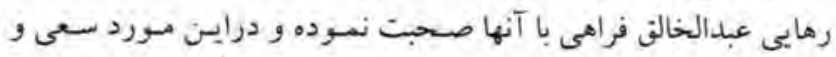

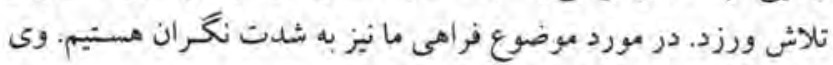

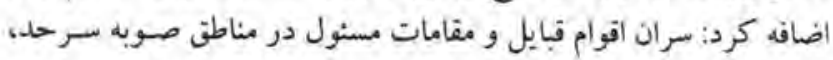


كعيبه صدراعظم و رييس كنخره ملى ليبا تقديم كرد.

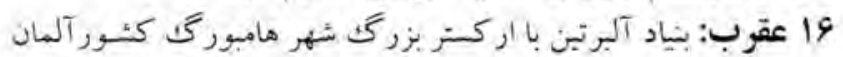

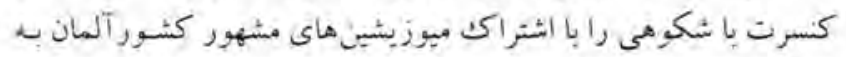

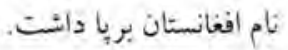

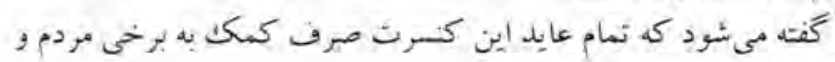

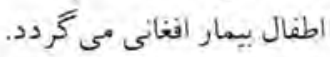

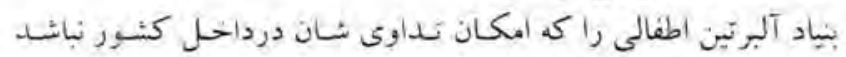
در آلمان تداوى مى كئد.

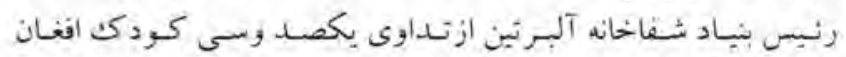

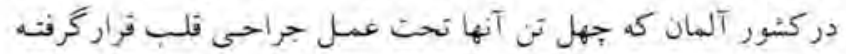

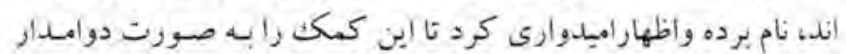

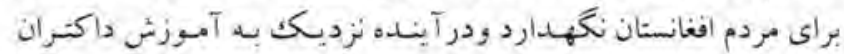

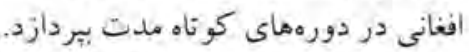

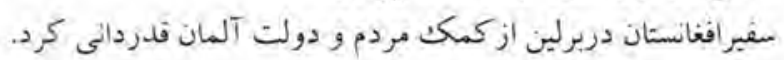
مسافرت ها

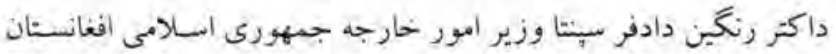

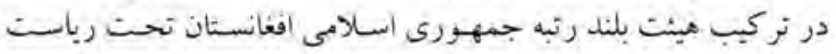

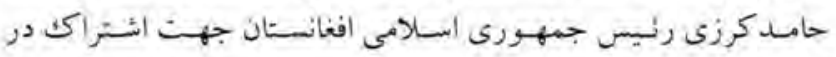

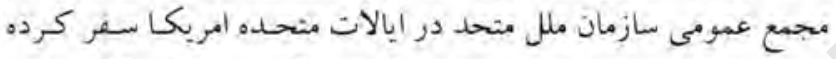

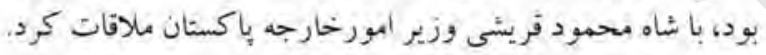

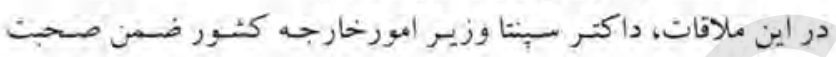

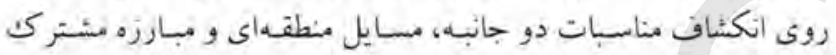

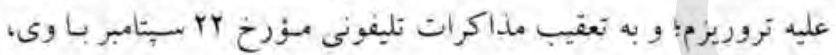

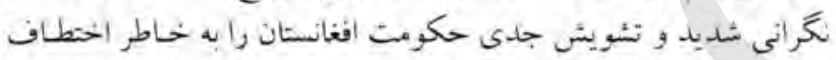

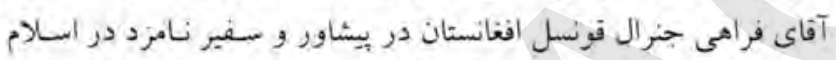

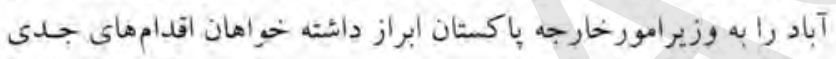

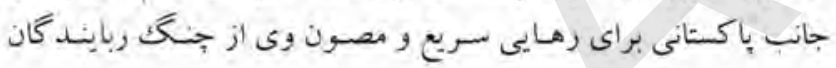

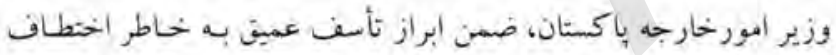

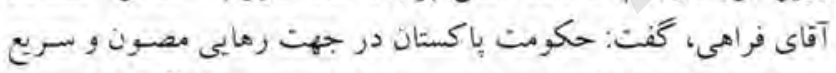

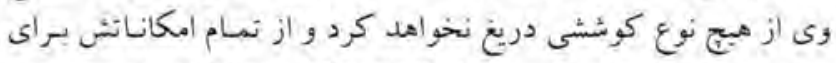

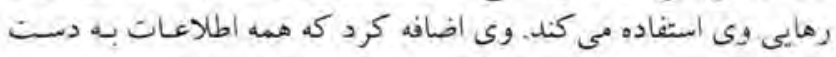

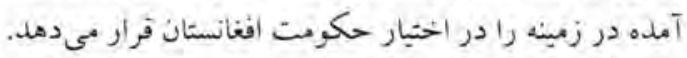

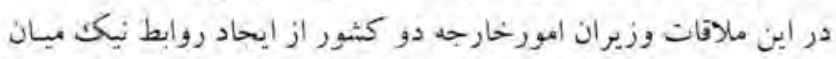

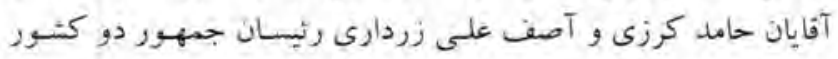
ابر ازز خر سئدى كر دند.

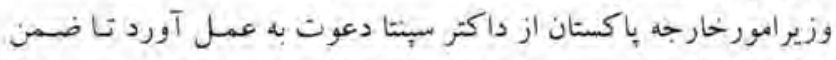

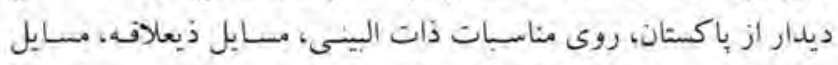

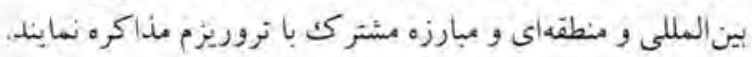

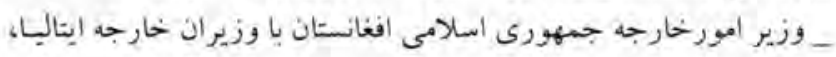

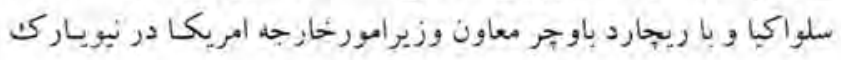

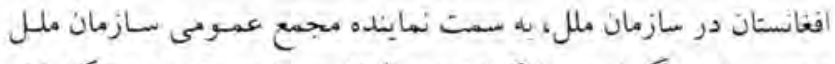

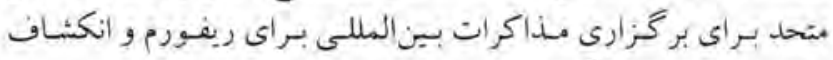

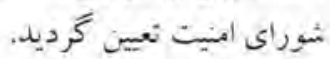

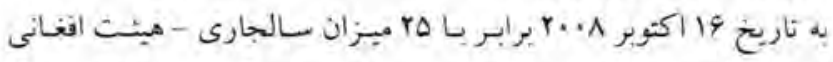

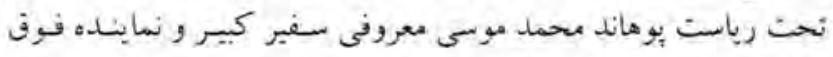

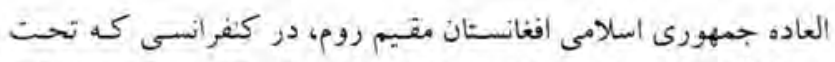

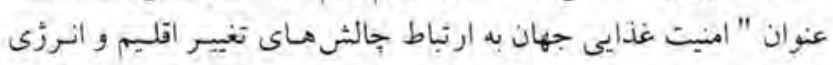

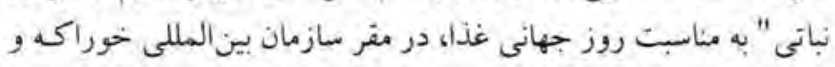

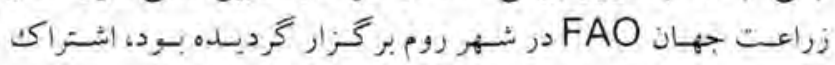
كردند.

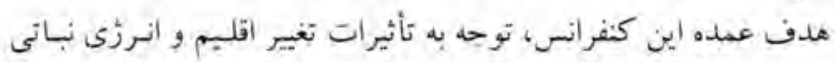

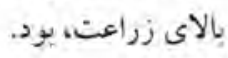

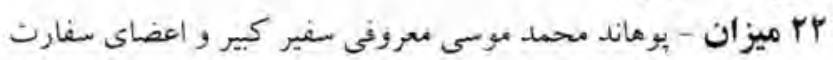

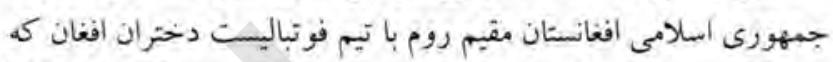

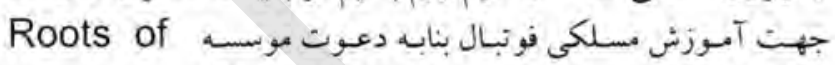

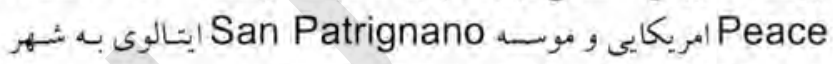

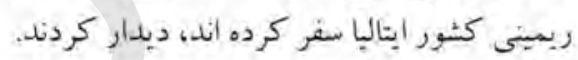

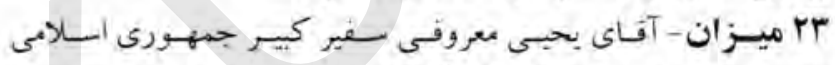

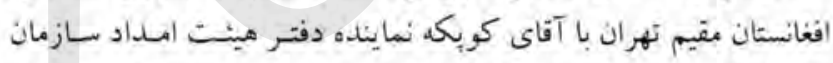

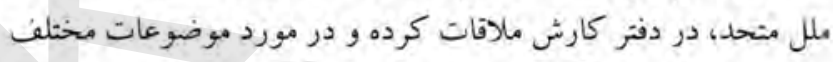

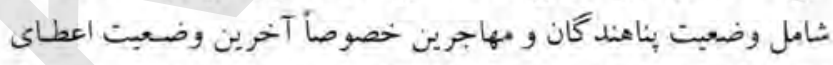

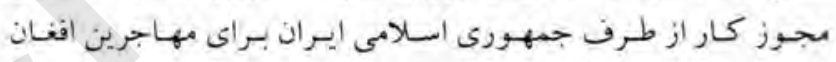

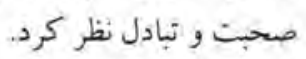

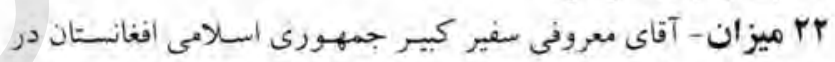

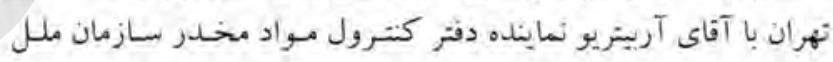

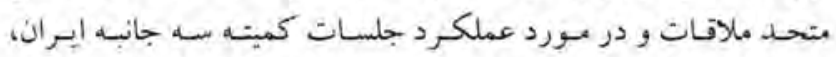

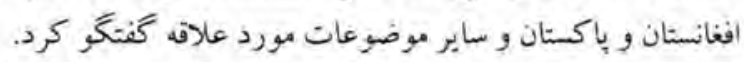

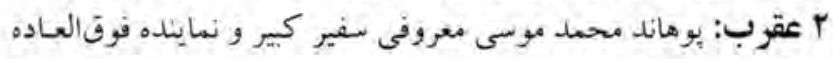

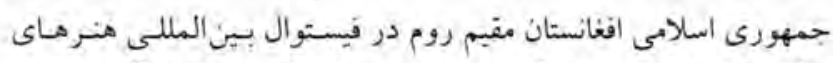

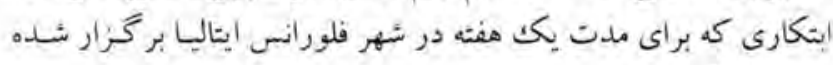
بود، الشتراكت ورزيلد.

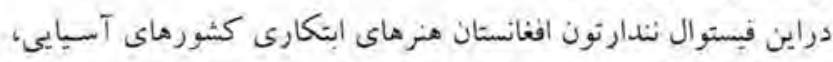

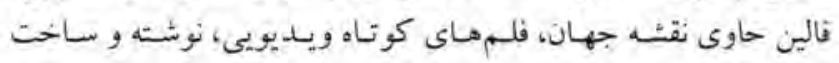

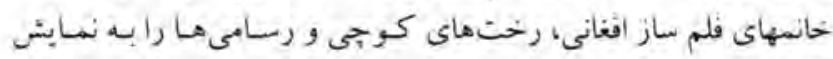
كزاشتها بود.

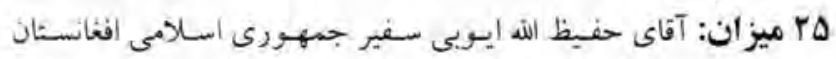

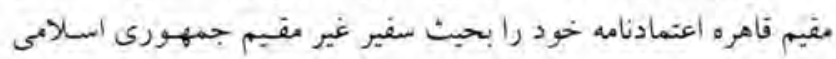

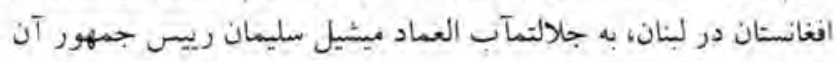

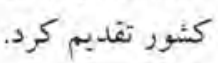

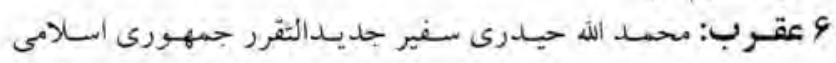

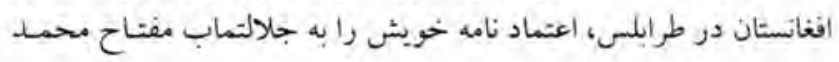




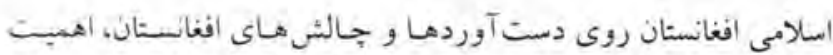

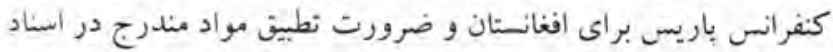

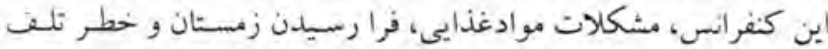

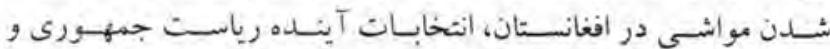

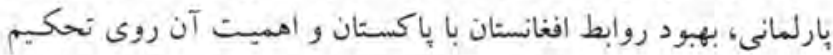

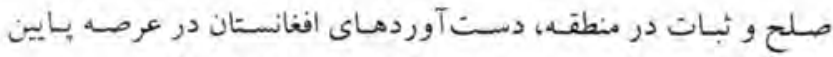
آوردن كئت بواد مخدر تا حدود 19 فيصد، سخنر انى كرد.

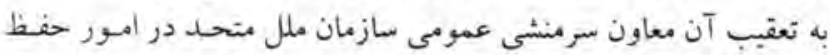

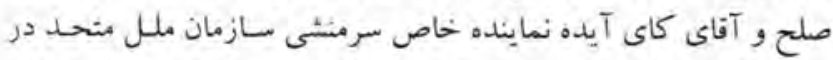

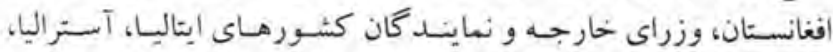

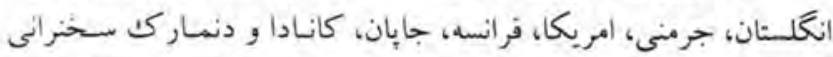

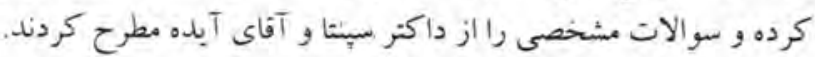

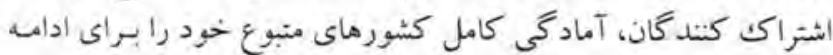

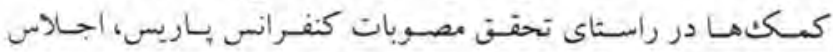

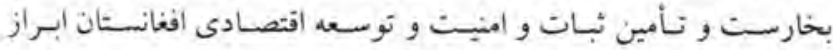
كردند. _ جلسه نوبتى وزراى خارجه كثورهاى سأزمان همكارى هاى افتصادى

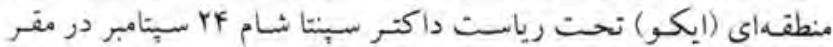

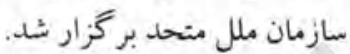

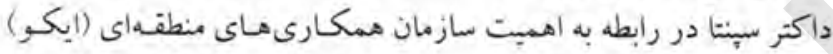

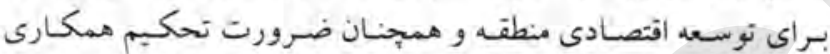

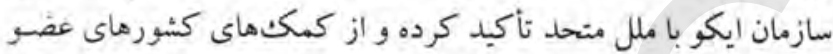

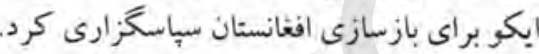

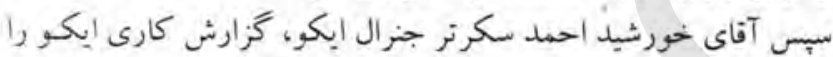
ارايه كرد. در اين نشست وزراى خارجه اير ان و آذربايجان و نمايند أنان عالى رئه

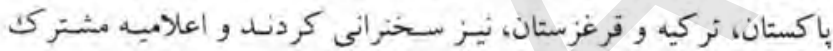

$$
\text { وزراى خارجه ايكو به تصويب رنسيد. }
$$

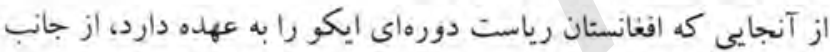

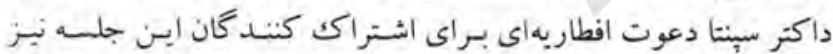

$$
\text { ترتيب گرديد. }
$$

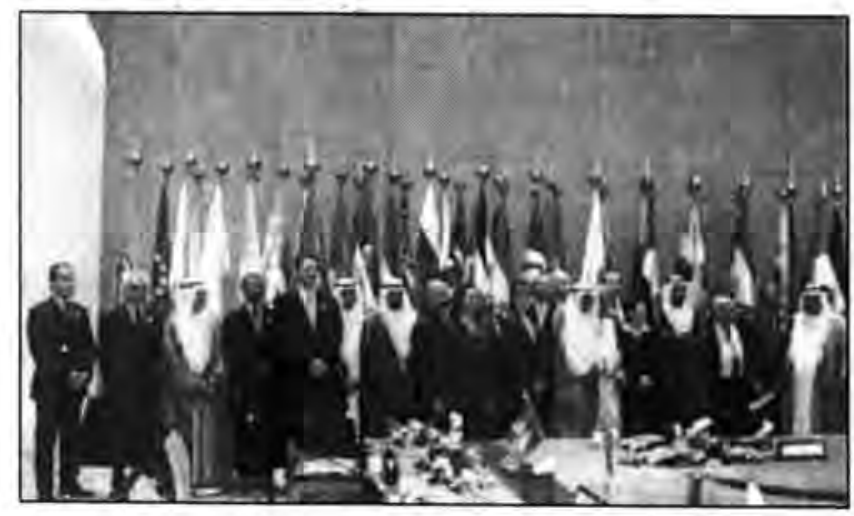

ملاقات هاى جداكانهاى رابه عمل آورد.

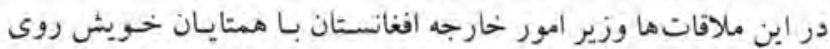

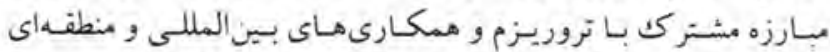

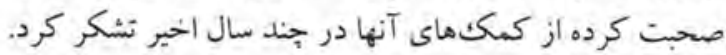

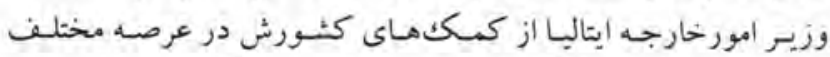

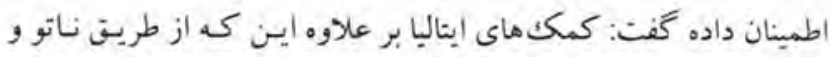

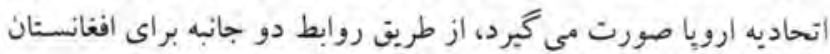

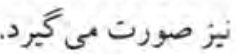

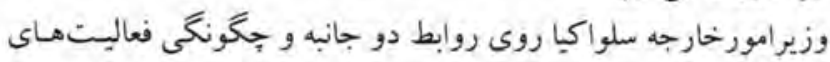

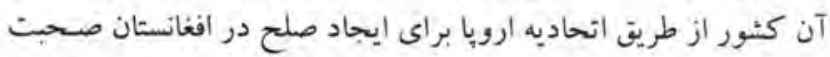

وزير امور خارجه در ملاقات با ريجارد باوجر روى روابط دو جانبه بـه

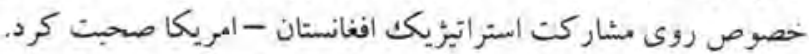

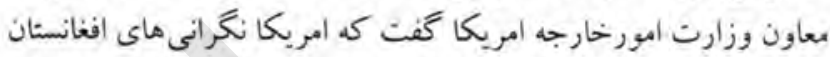

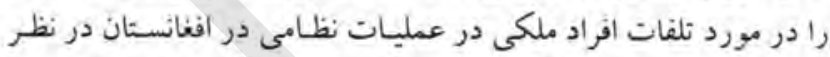

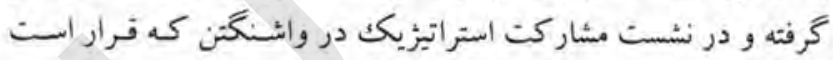

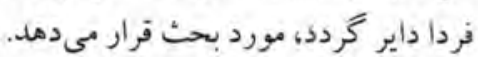

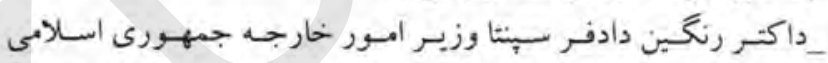

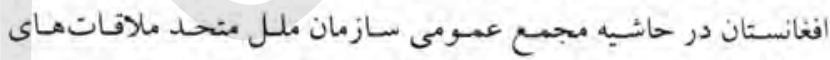

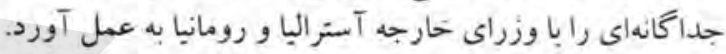

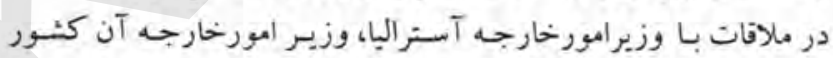

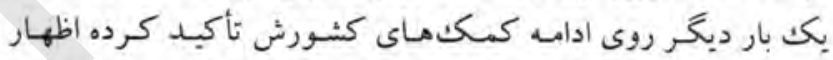

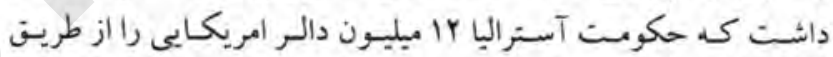

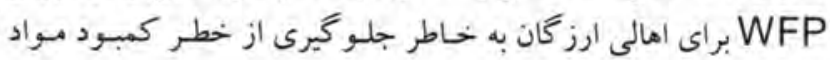
غذاى كمك مئنمائ.

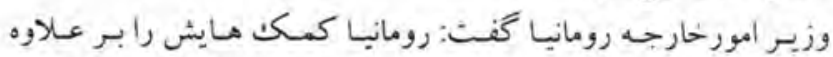

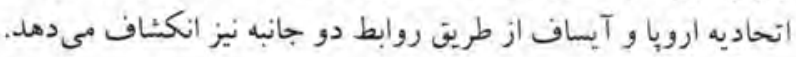

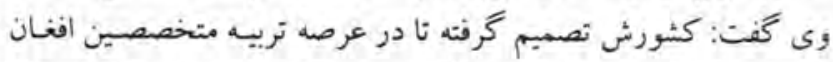

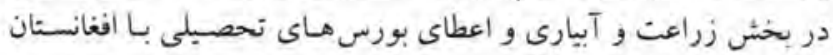

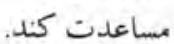

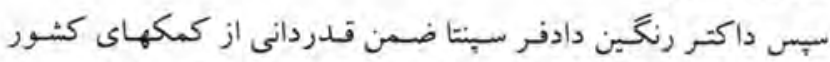

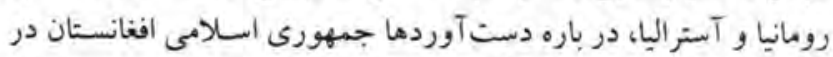

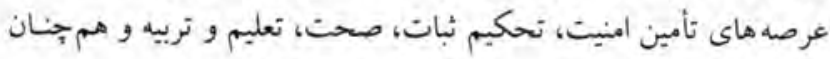

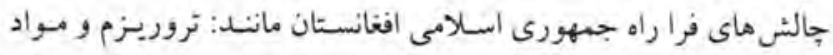

$$
\text { عخدر صحبت كرد. }
$$

طرفين بر مبارزه مشتركت عليه بديده شوم تروريزم و مواد مخدـر تأكيد ورزيلـ. _ جلسهى تحت نام "وزراى خارجه گروه دوستان افغانستان" به تـاريخ

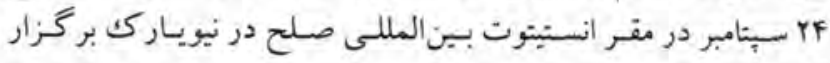
كرديد. - مئد در آغاز جلسه داكتر رنغين دادفر سبنتا وزيبر امسور خارجه جمهورى 


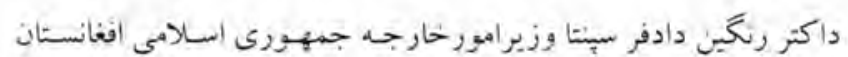

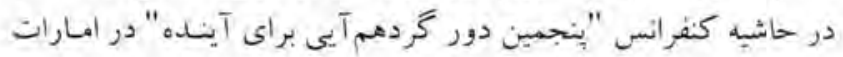

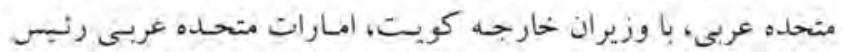

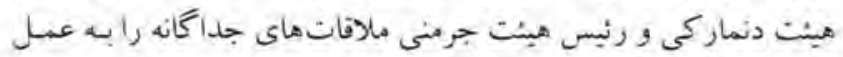
$2,2, T^{\top}$

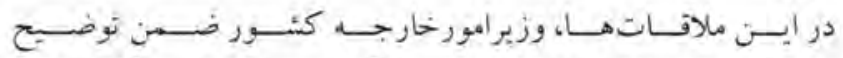

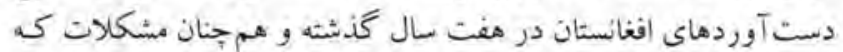

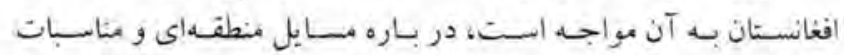

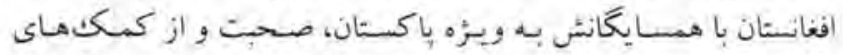

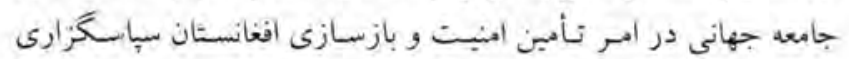

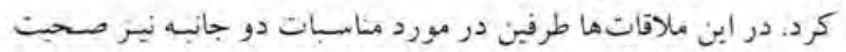

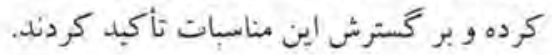

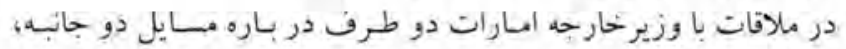

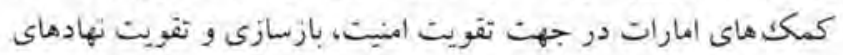

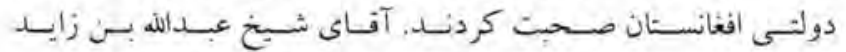

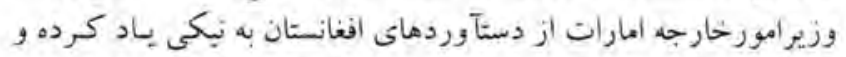

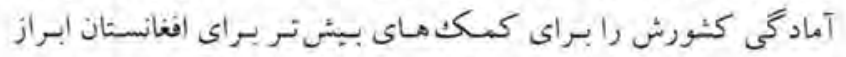

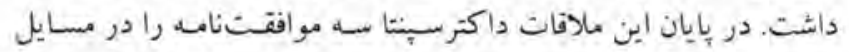

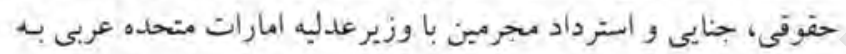
امضا رسلد.

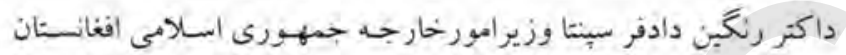

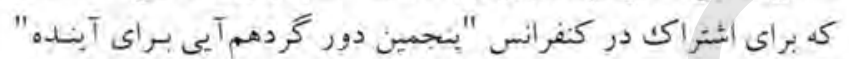

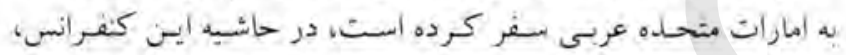

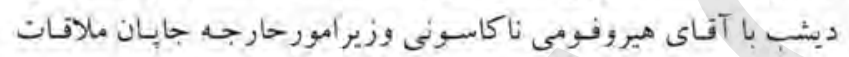

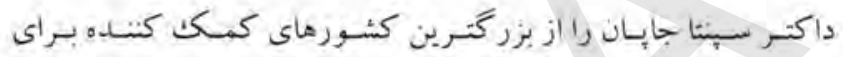

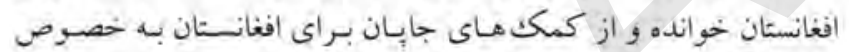

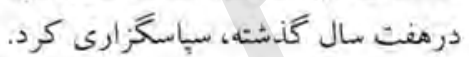

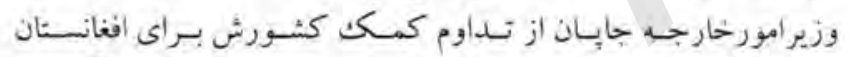

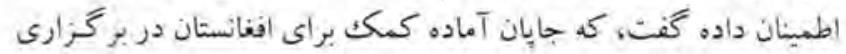

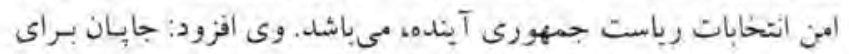

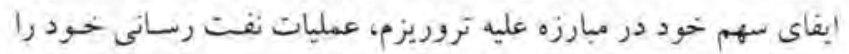

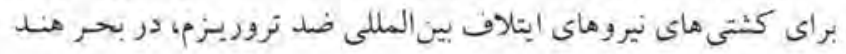

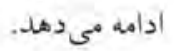

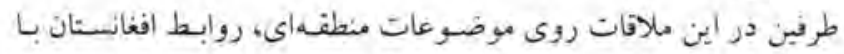

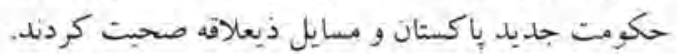

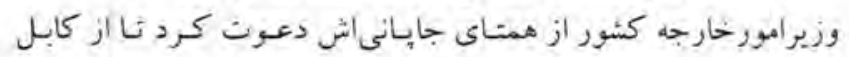

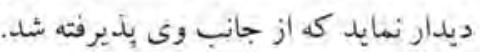

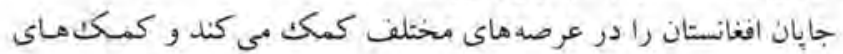

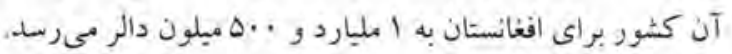

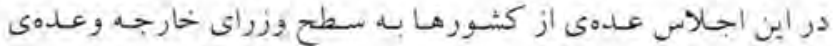

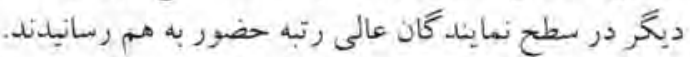

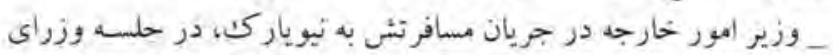

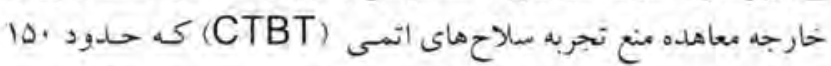

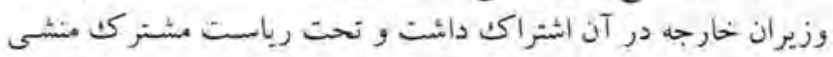

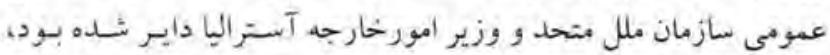
ا اشتراكت كرد.

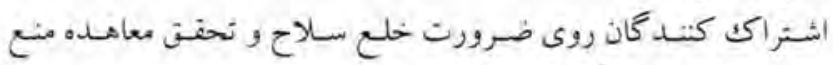

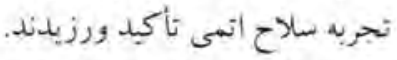

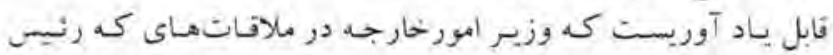

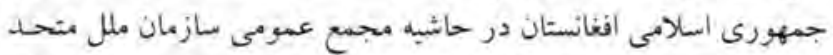

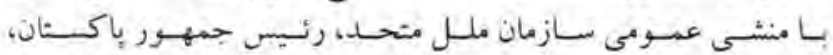

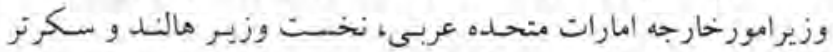

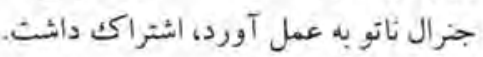

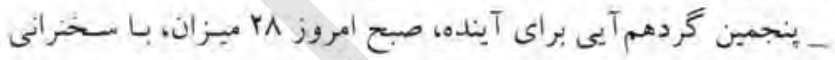

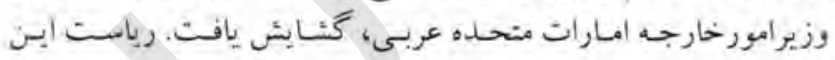

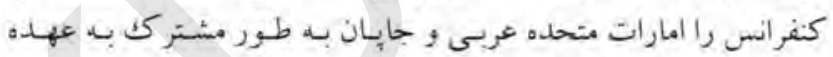
2ارند

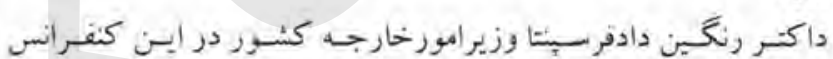
الشتراكك دارد.

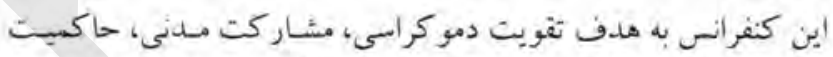

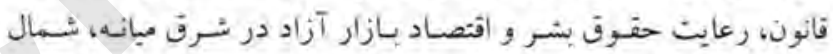

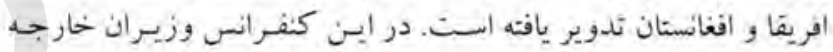

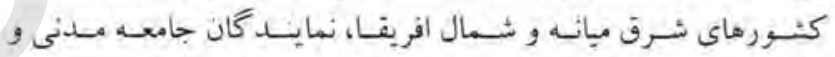

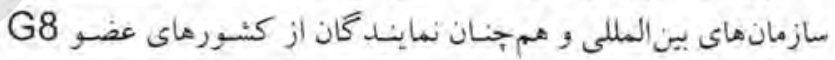
اشتراكت دارئد.

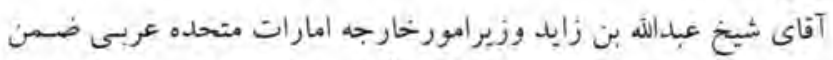

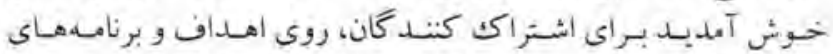

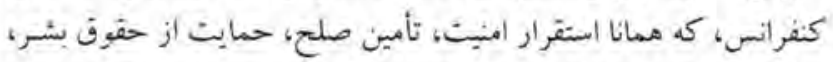

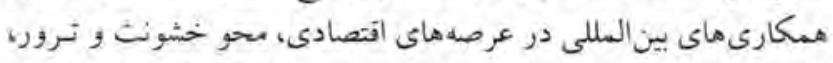

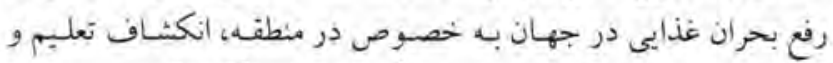

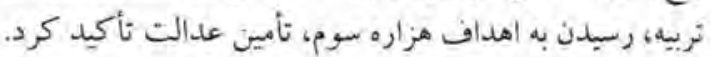

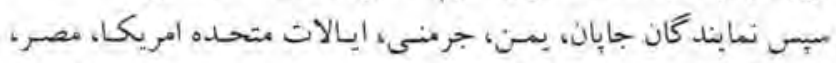

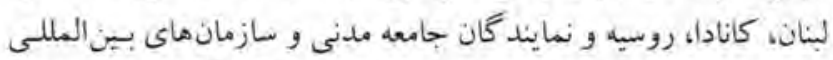

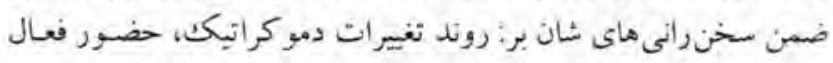

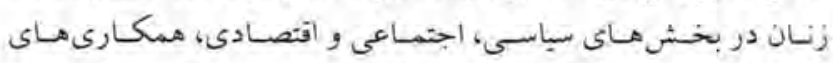

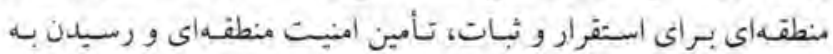

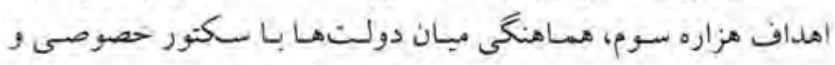

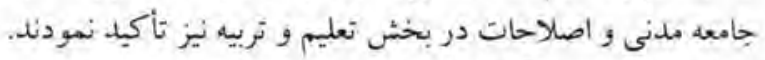

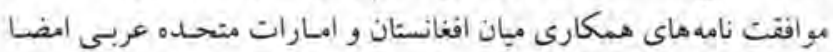




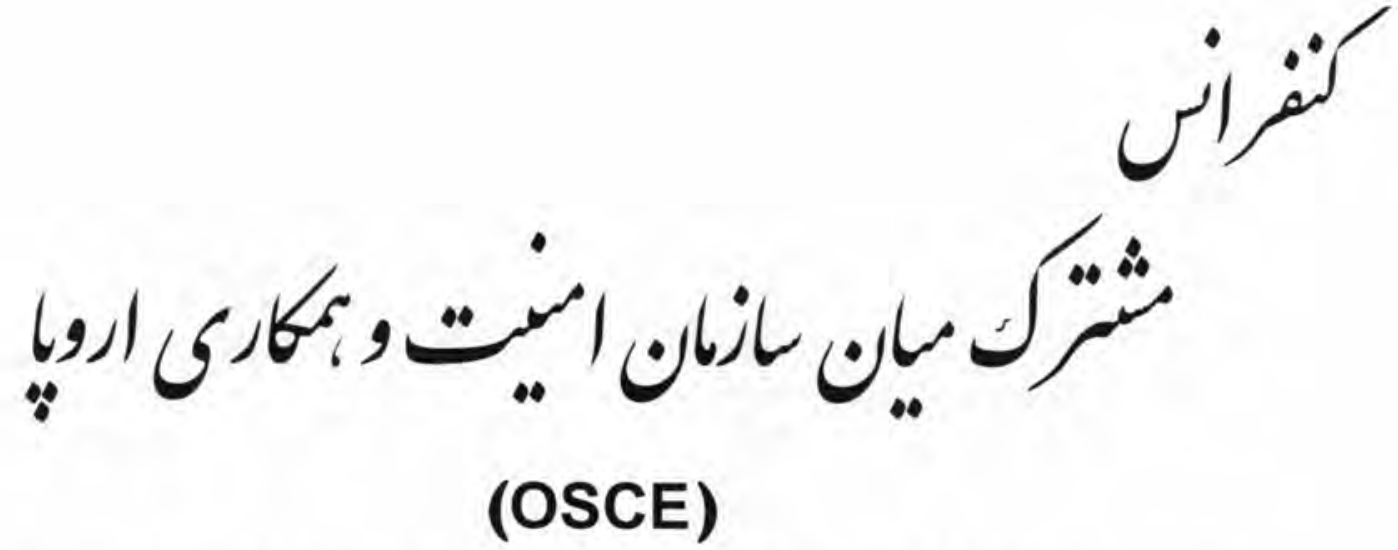

\section{و جمهورى اسلامى افغانستان، به ميزبانى وزارت امورخارجه در تالار محمد ولى خان دروازى بركزار شد}

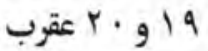

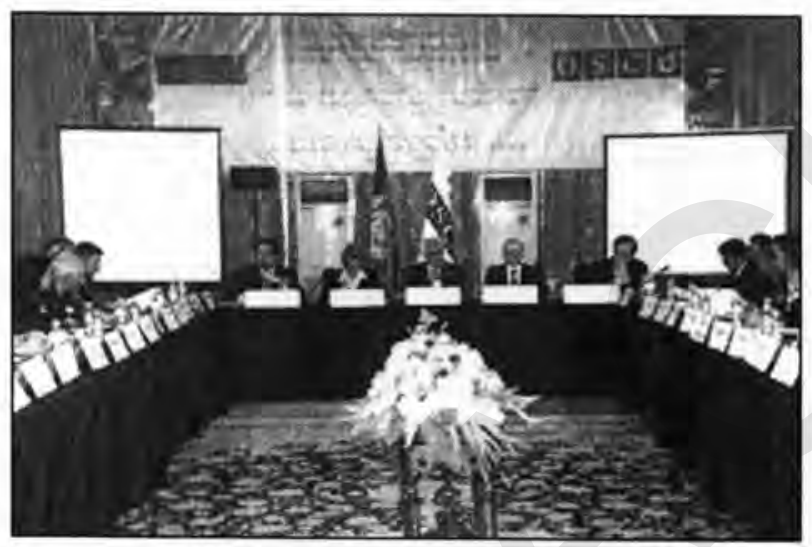

مركزي، آمـوزش بـوليس سـرحدى و بـوليس مبـارزه بـا مـواد

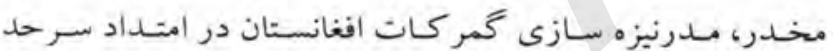

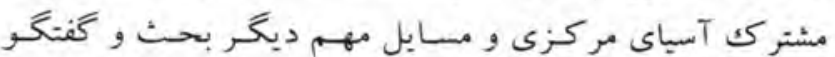

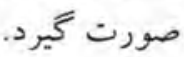
سبِس وزير امور خارجه و سكرتر جنرال سازمان امنيـت أرويـا و

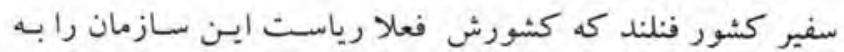
عهده دارد در كنفرانس مطبوعاتى اشتراكت ورزيده و به برسش هاى خبر نغاران باسخ دادند.

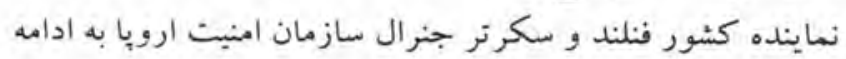
كمكك اين سازمان در همه عرصه ها وبه ويسرة انتخابـات آينـده

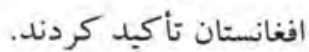

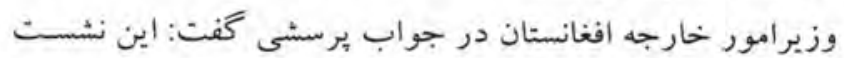

در اين كنفر انس نمابئدگان و سفيران دايمى عضو و بارثينر اين

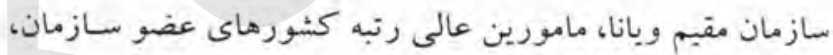

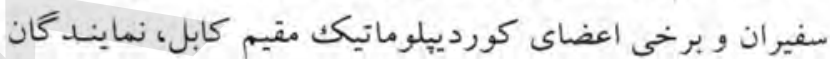

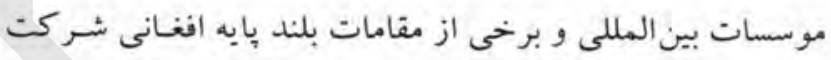

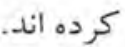
وزيـر امـور خارجـه جمهـورى اسـلامى افغانســان طـى سـخنان

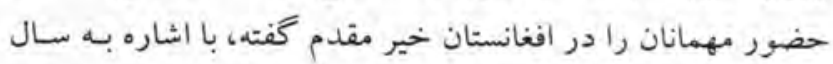

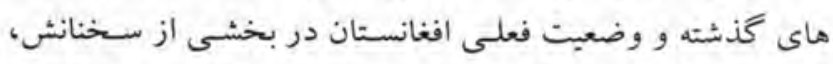

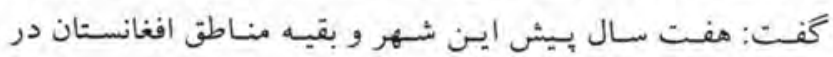

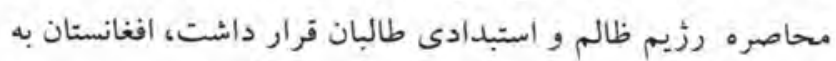

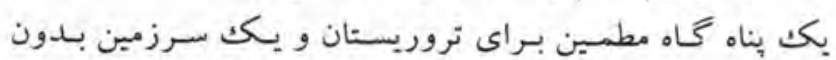

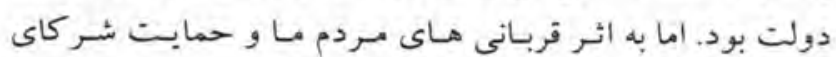

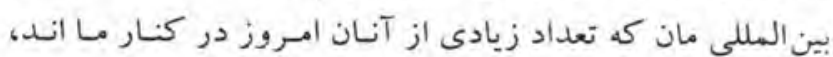
فصل جديدى را باز نموديم. امروز گرجه ما آهسته قدم بر مى داز داريم ولى بـ با اراده قوى و عـزم

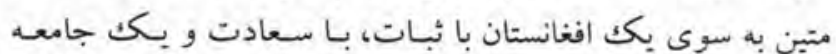

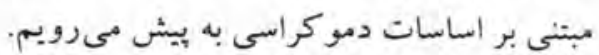

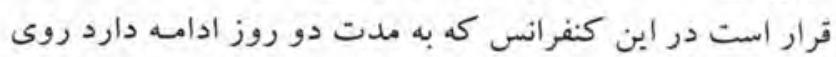

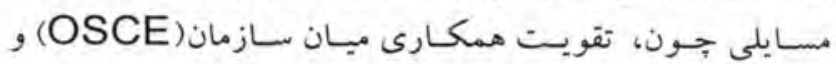

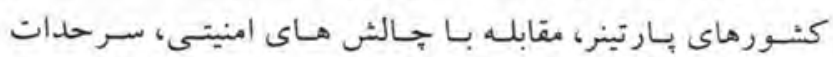

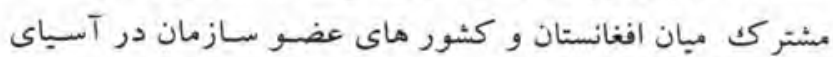


ما حالا بكك قانون اساسى جديد و مترقى داريم هـز اران مكتب

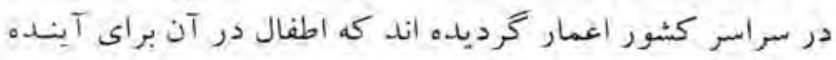

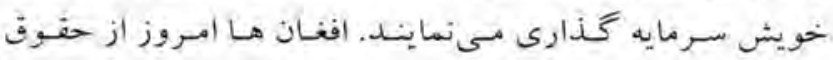

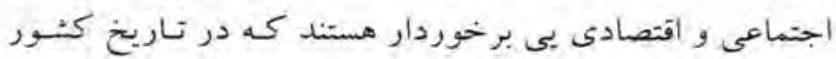

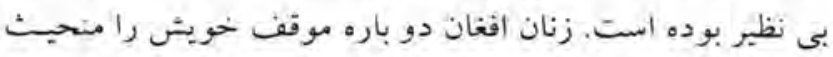

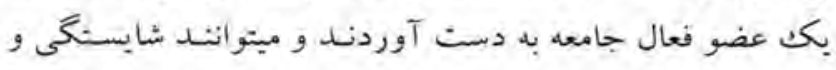

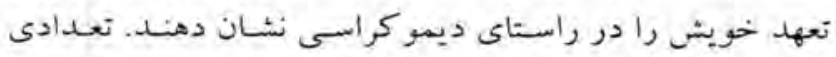

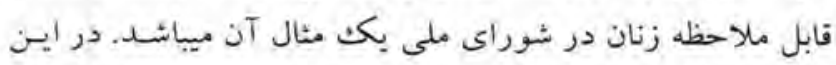

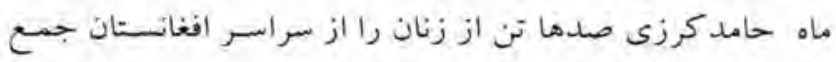

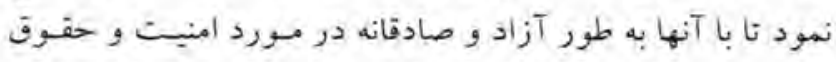

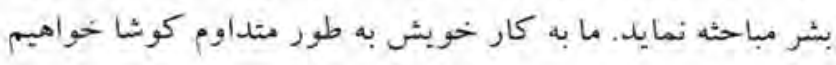

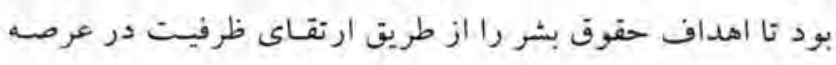

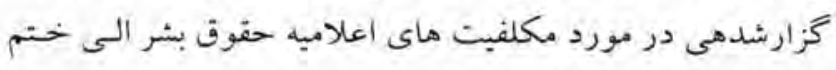

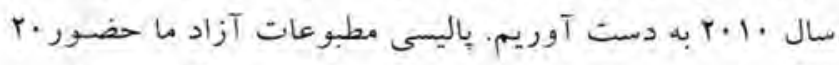

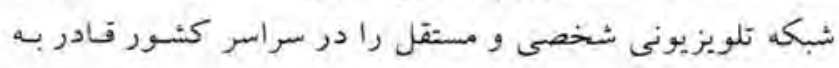

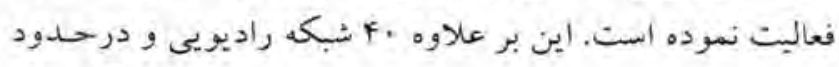

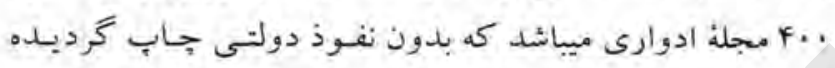

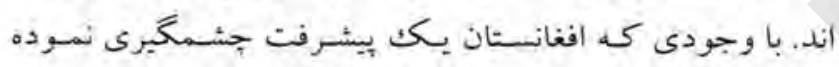

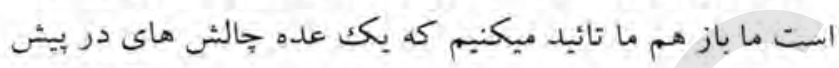

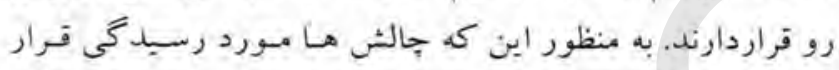

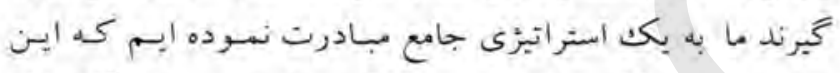

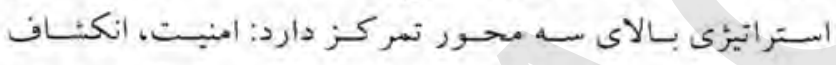

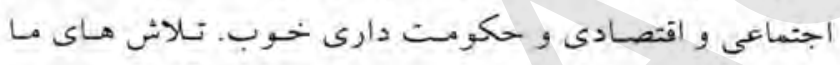

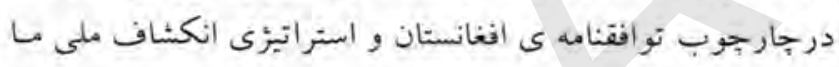
صورت ميخيرِن. تروريزم جالشي است كه در رديف اول قرار دارد. حر جنس مـاه

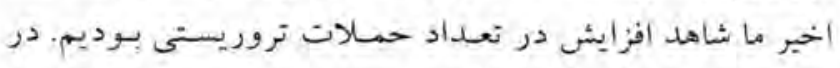

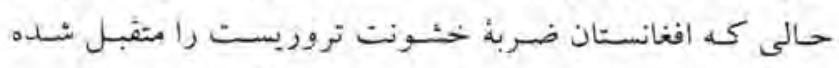

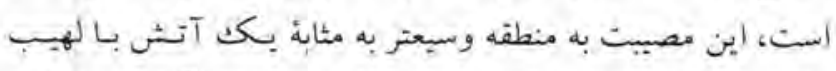

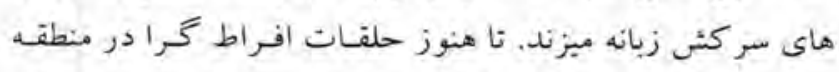

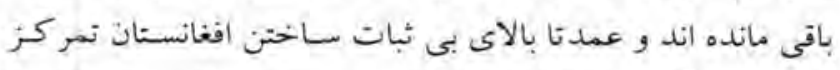
نموده إند.

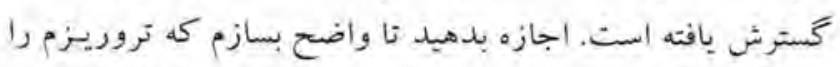

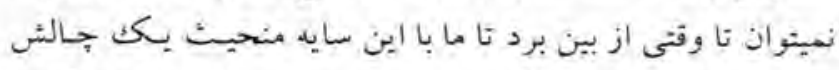

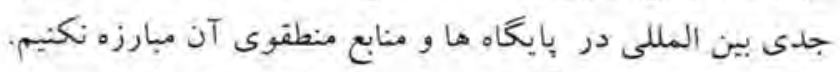

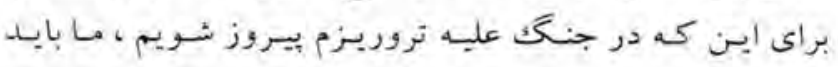

نمايانخر اعتماد جامعه جهانى به سياست خارجى افغانستان بـوده

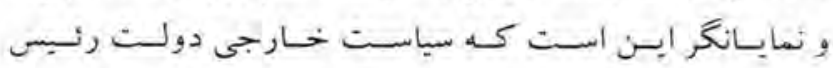
جمهر ركرزى مورد تائيد جامعه جهانى فرار دارد.

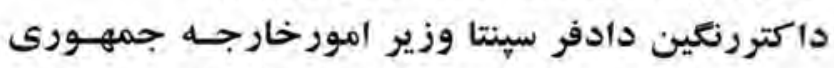
اسلامى افغانستان در اين كنفرانس بيانيه ايراد كردنس وريد

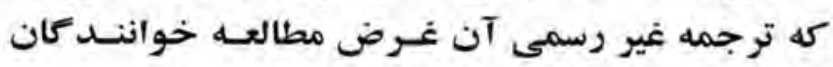
محترم در زير مى آيد. آقاى سر منشى عمومى، جلالتمآبان، خانمان و آقايان،

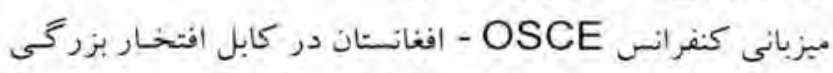

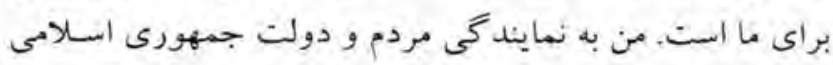

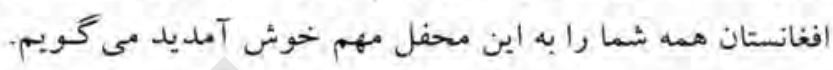

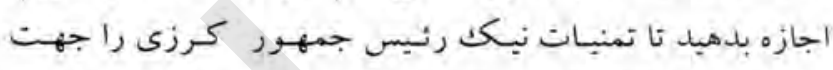

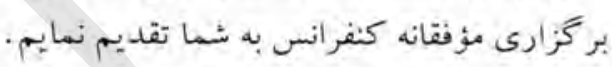

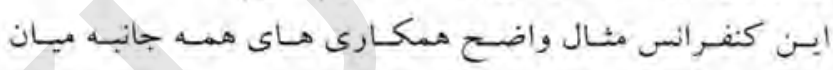

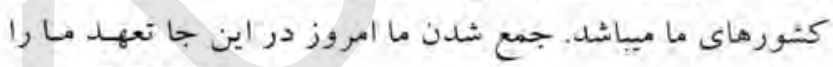

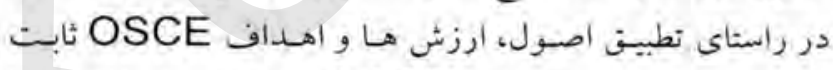

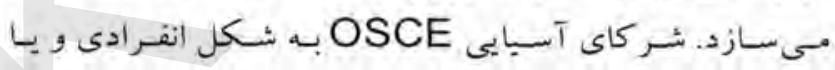

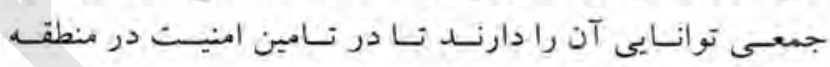
OSCE

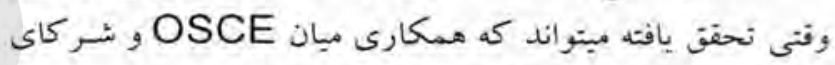

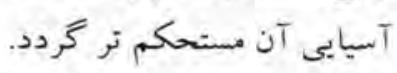

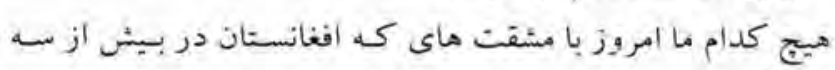

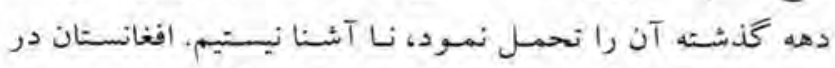

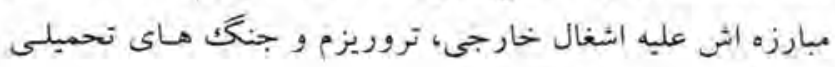

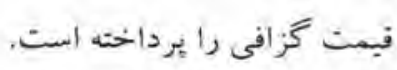

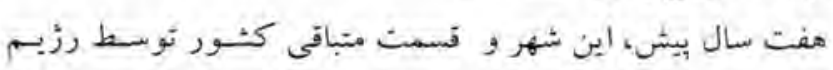

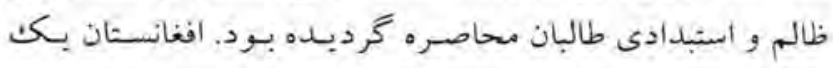

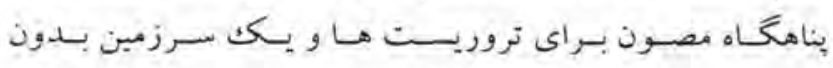

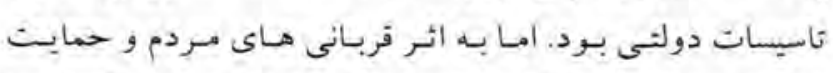

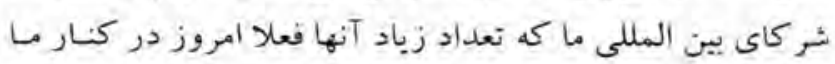

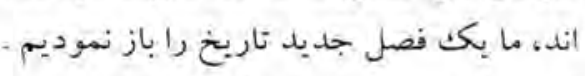

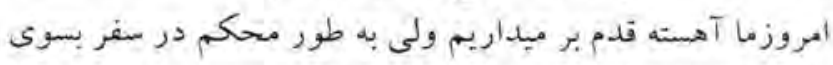

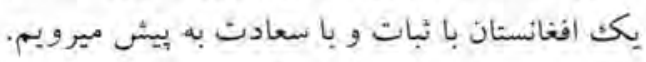

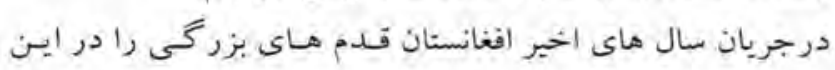

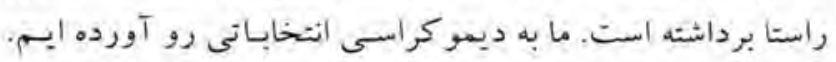


ولايت برسد.

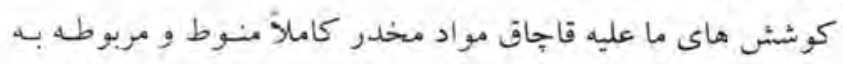

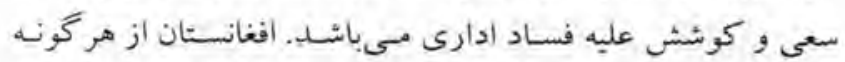

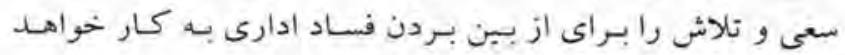

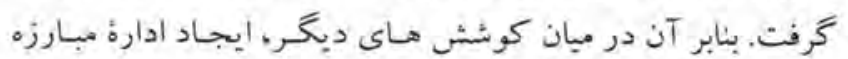

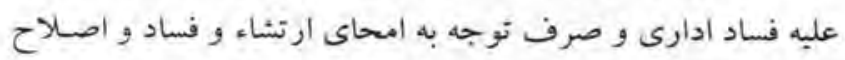
دولت دارى خوب به سطح ملى، كام هاى بسا مثبث مى باشئن.

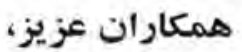

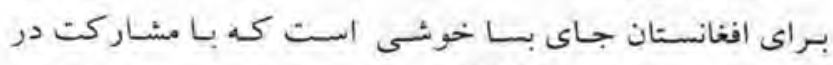

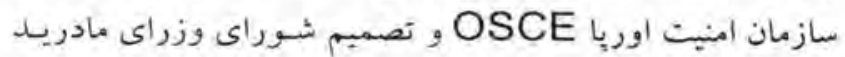

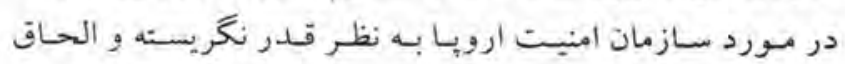

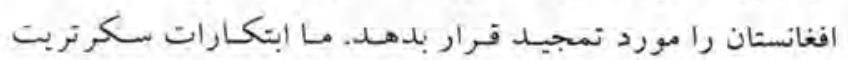

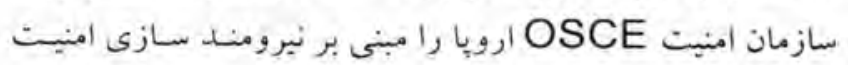

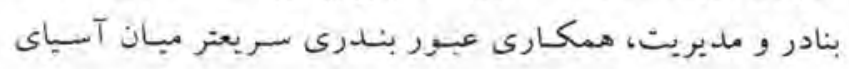

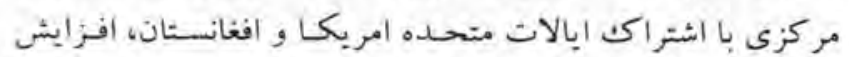

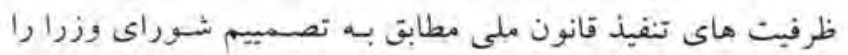

$$
\text { مورد تحسين قرار ميدهيبم. }
$$

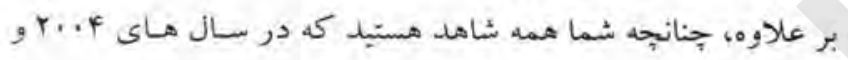

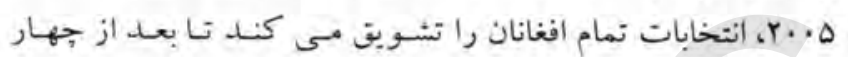

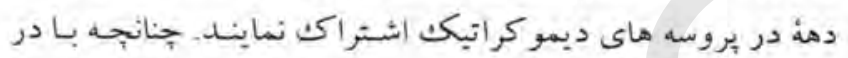

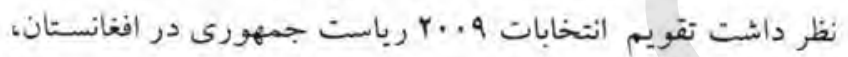

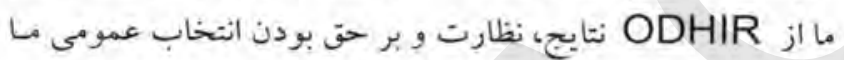

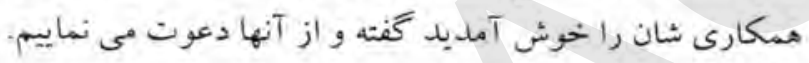

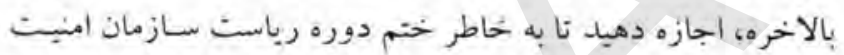

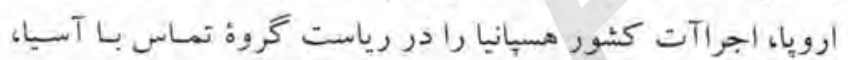

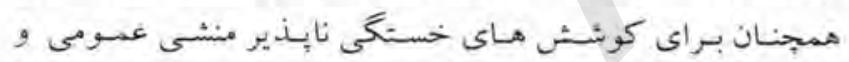

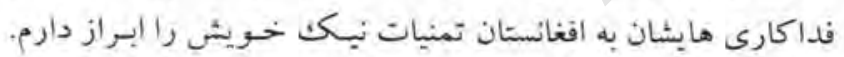

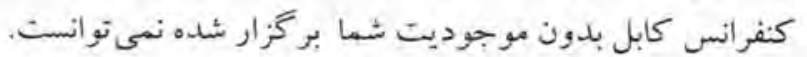

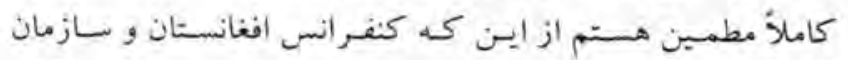

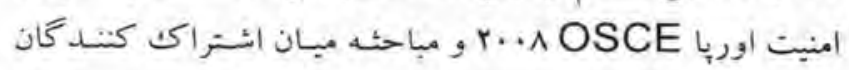

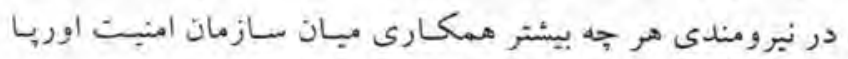
OSCE

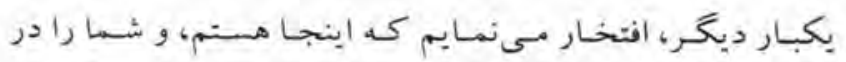

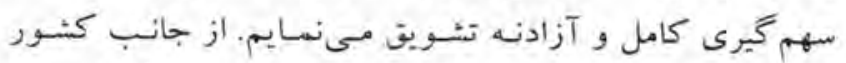
خويش، از تشريف آورى شما در اين محفل أبراز تشكر نهيوده،

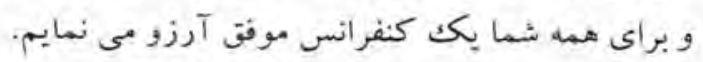

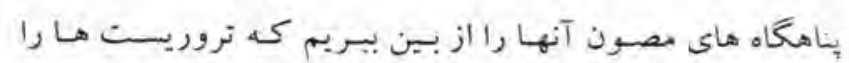

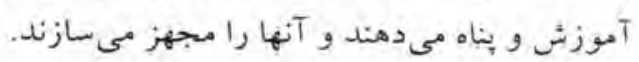

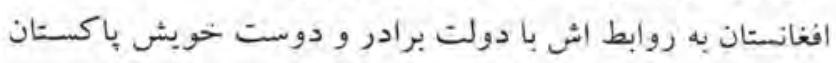

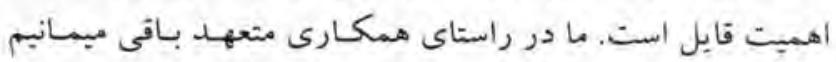

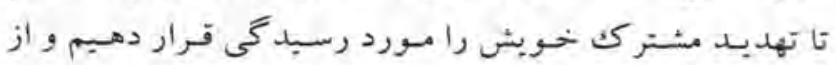

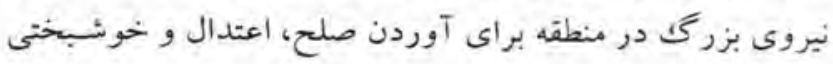
تمام منطقه، استفاده نمايبم. خانمان و آقايان،

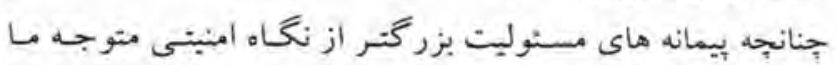

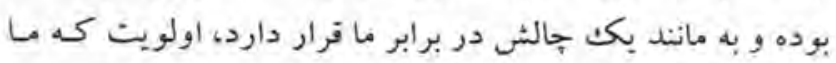

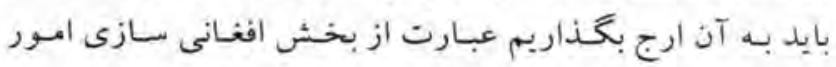

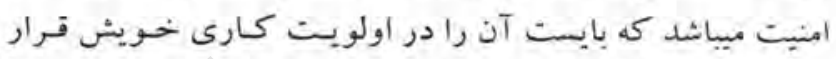
دهيم. سرمايه گذارى روى سكتور امنبتى افغانستان برنامة طويل

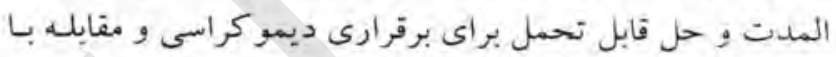

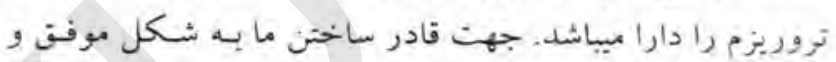

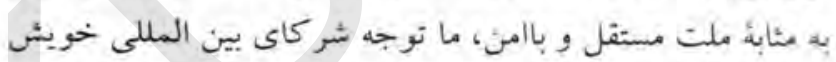

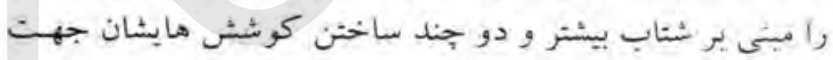

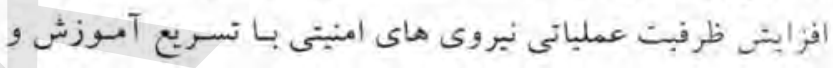

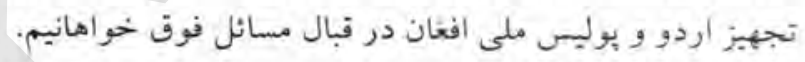

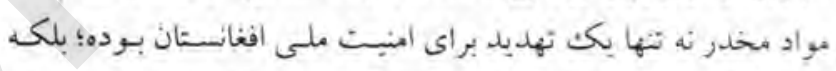

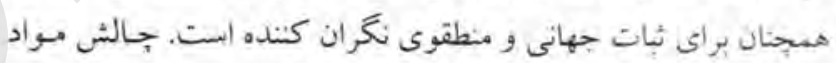

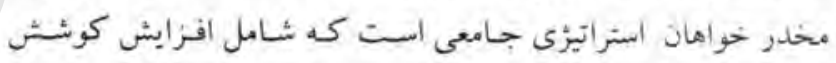

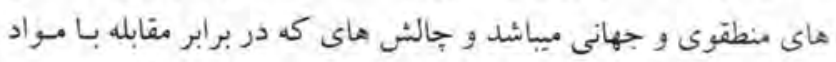

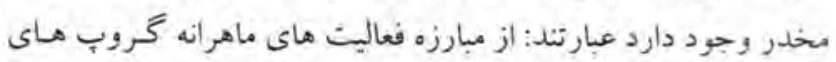

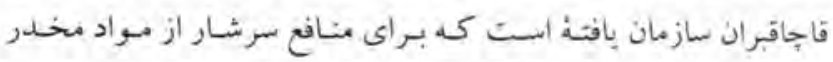

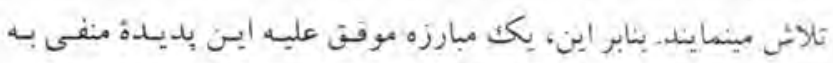

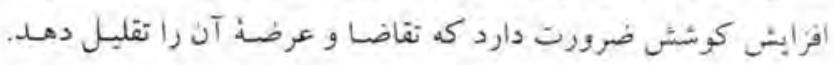

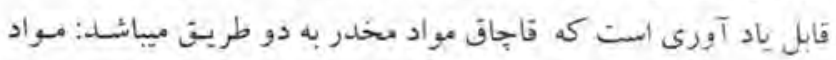

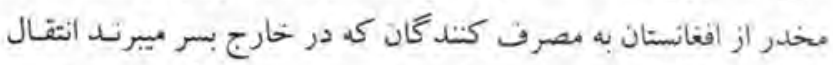

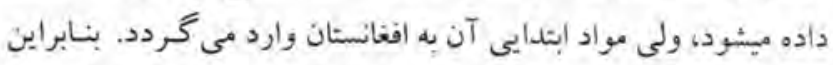

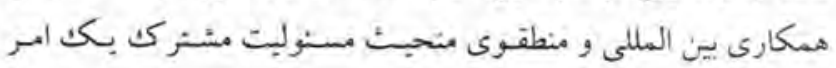

$$
\text { حياتى و جدى به حساب ميرود. }
$$

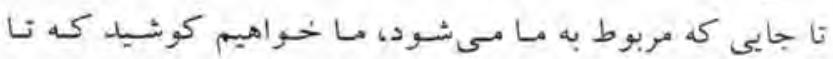

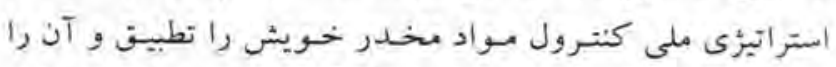

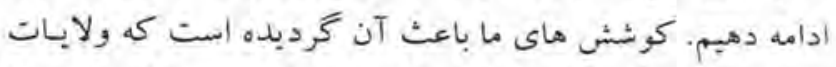

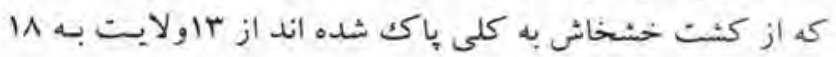


2 ساتلو به خاطر د يو ميكانيزم او جو كاتئ د جورولو إينا ومنله.

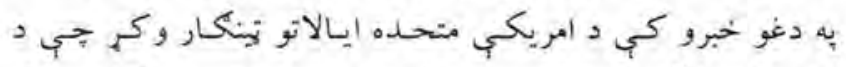

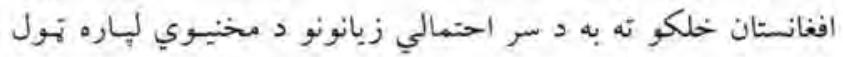

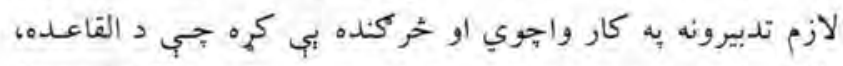

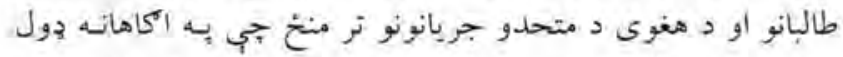

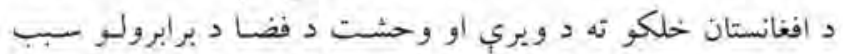

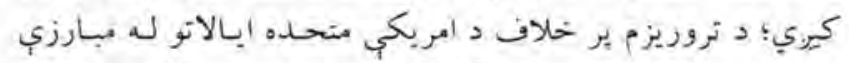

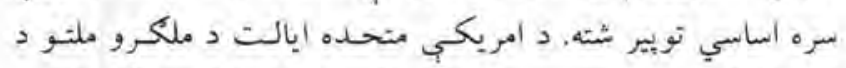

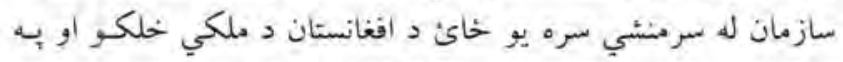

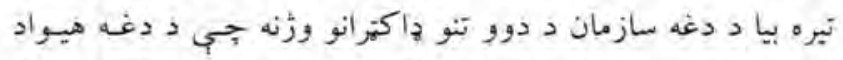

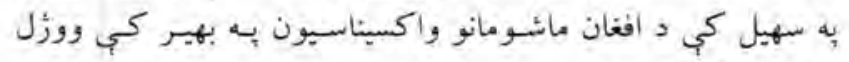
شول، بهه كلكه غندي.

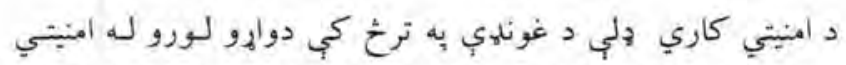

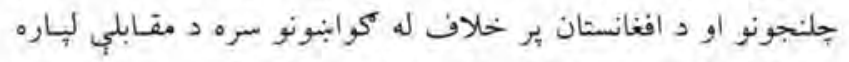

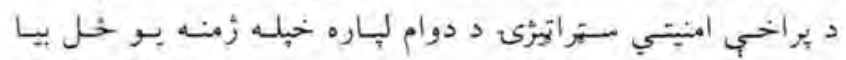
خر كنده كيره

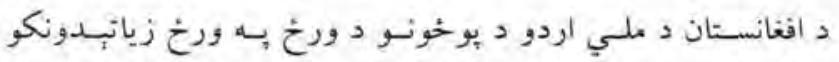

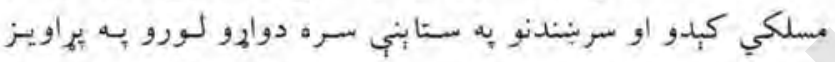

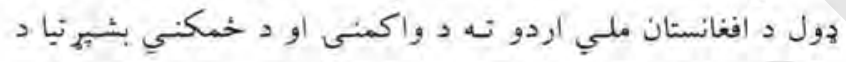

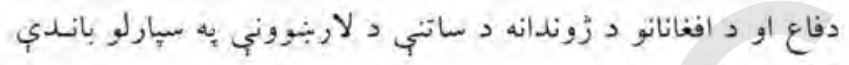

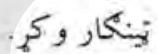
د امريكي متحده أبالاتو د أفغان ملي أردو يـو سلو خلمور ديرشيو

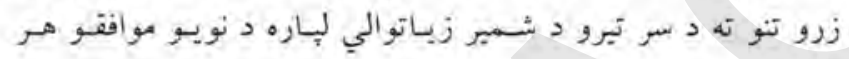
كلي وكر.

د دغو موافقو له مخب ملي أردو به داسي موفقيت كي خباي نيسي

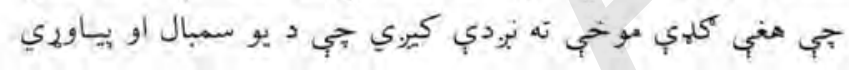
اردو لرل دي.

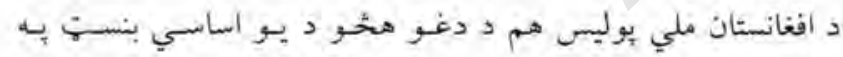

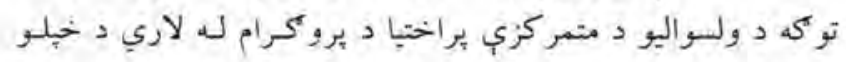

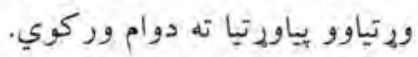

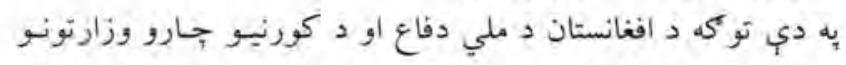

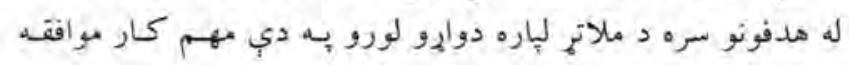

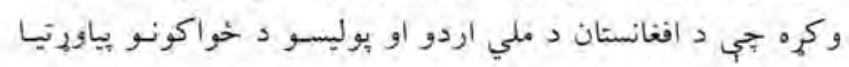
ضروري كار دي.

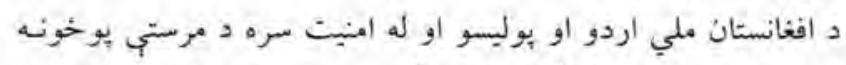

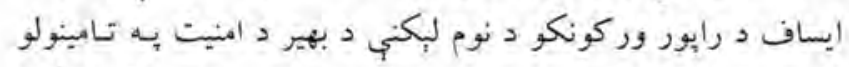

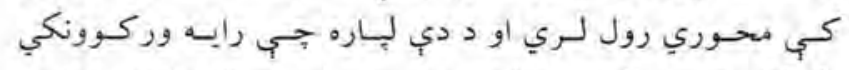

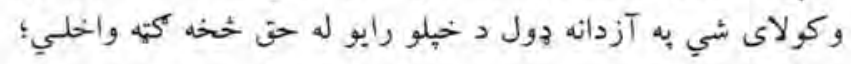

\section{ه افغانستان او اهيكي}

\section{هـ هتمده ايالاتو}

\section{ده ستراتيخيكب همكار ي}

\section{هبرو}

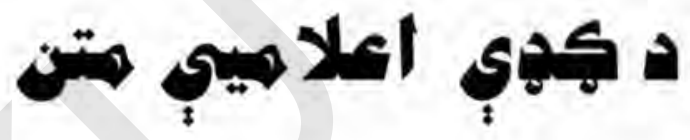

2 امريكي د متحده إيالاتو او ح افغانستان د اسلامي جمهوريبت

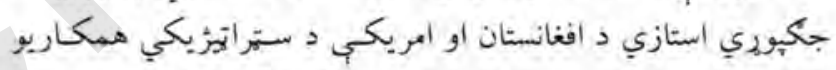

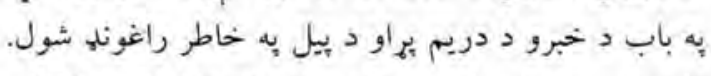

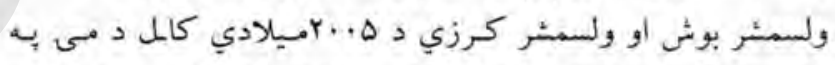

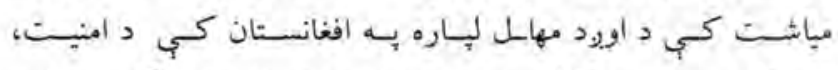

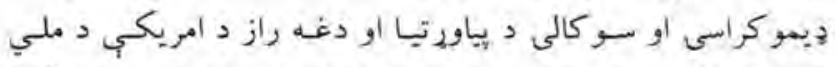

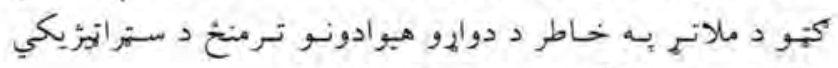
همكارى موافقه لِيكت تدوين او لاسليكت كئ.

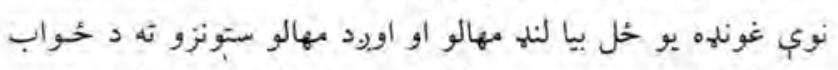

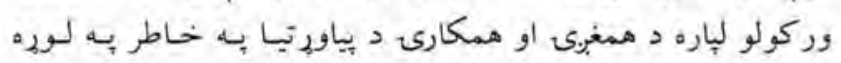

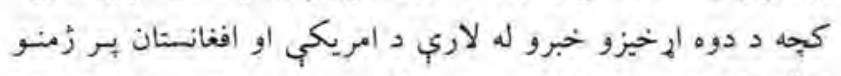

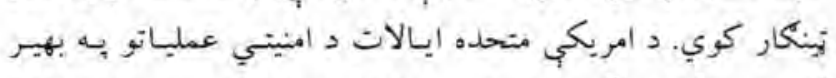

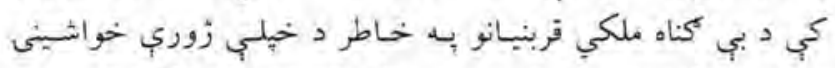

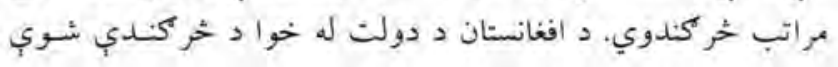

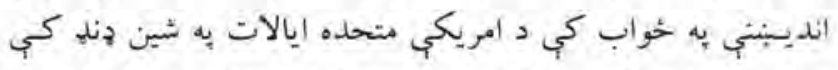

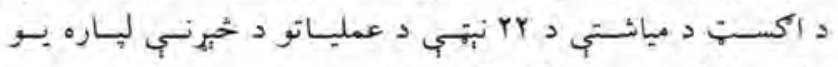
جكيولى كمبسيون به كار كموماري.

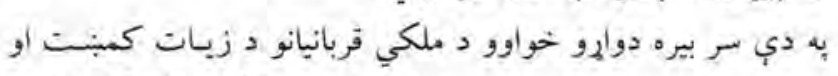

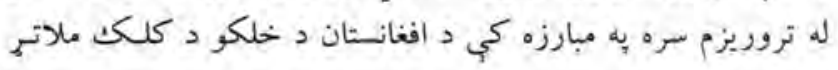


امريكا د متحده ايالاتو له لوري له برياليو خارنوالانو سـره د ملاتم

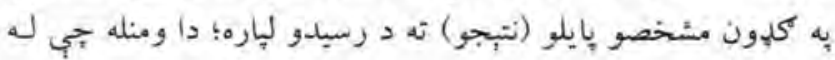

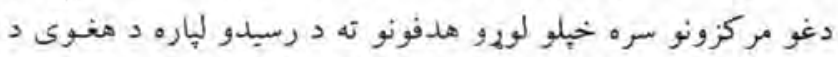

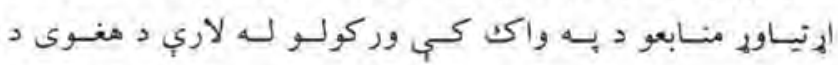

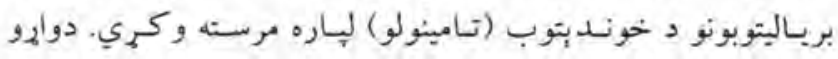

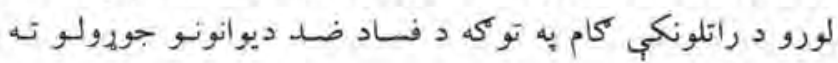

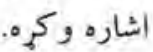

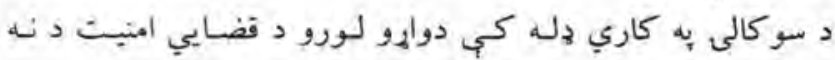

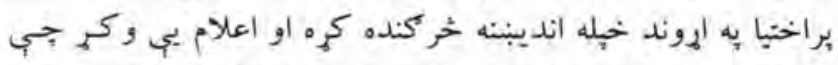

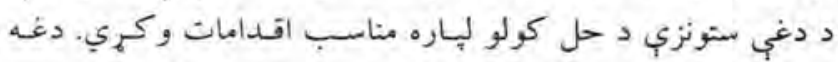

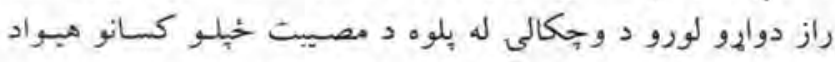

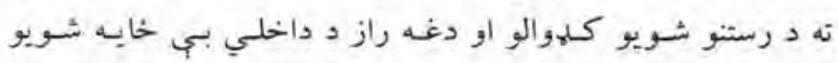

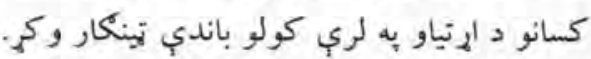

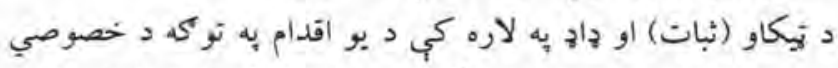

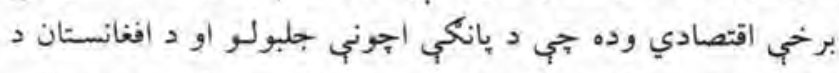

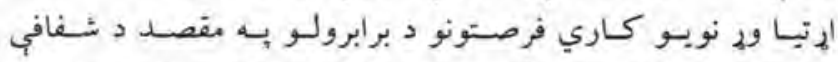

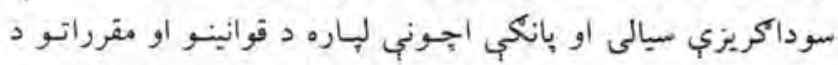

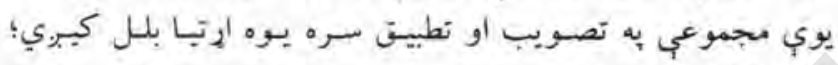

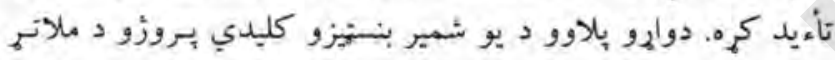

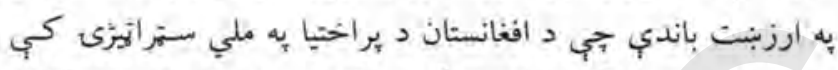

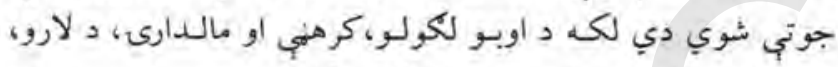

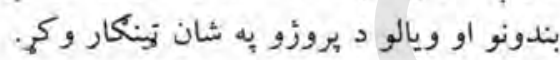

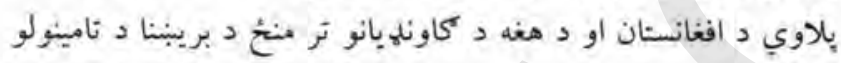

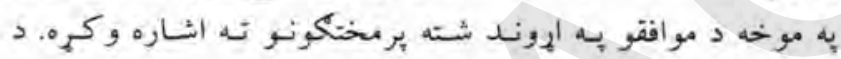

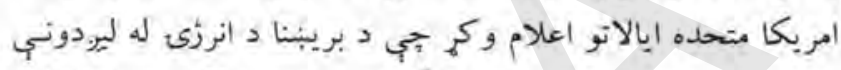

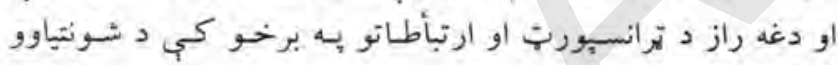

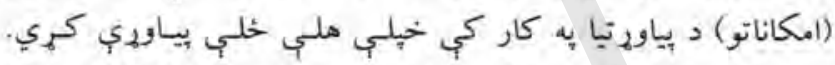

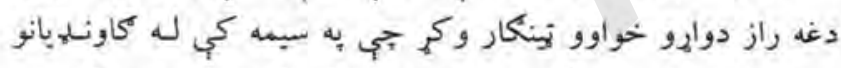

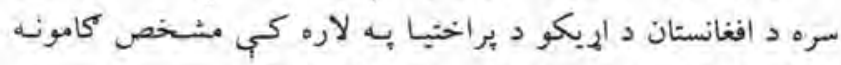

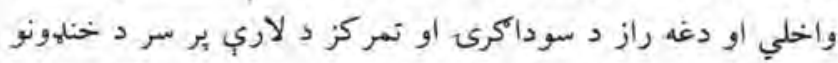

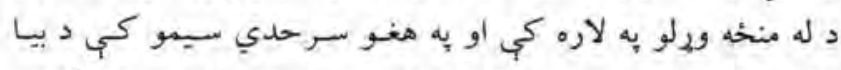

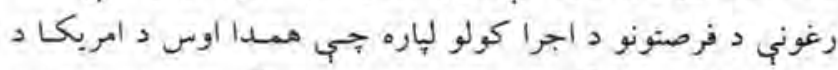

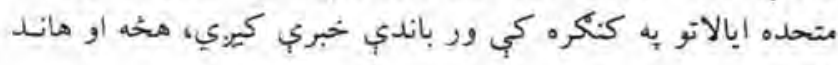

وكمي. دغه اقتصادي ستراتيزي له تروريزم او د نشه يب توكي لـه فاجساقو

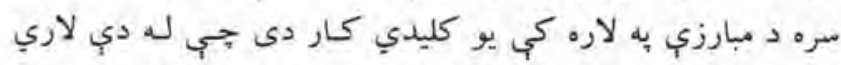

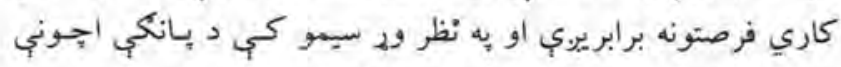

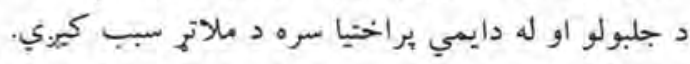

هغوى ته د يو امن جاييريال به برابرولو كي هخه او هاند كوي.

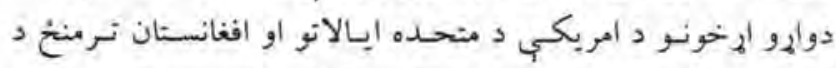

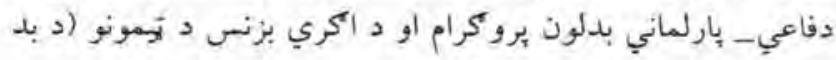

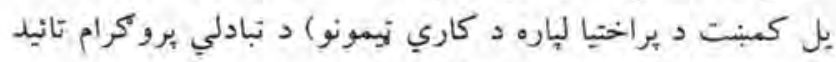

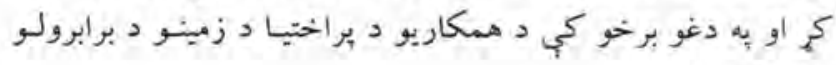
بيه لهه كي دي دئ

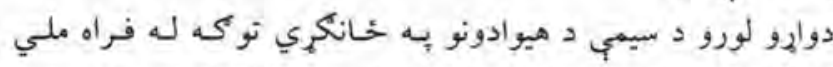

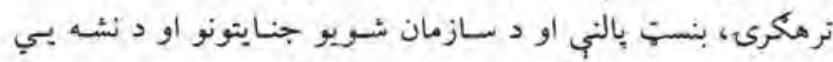

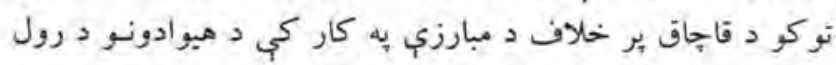
به ارزبنت باندي تونئكار وكرئ.

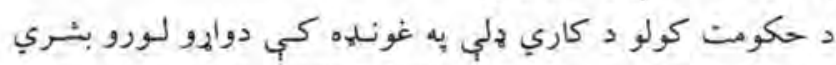

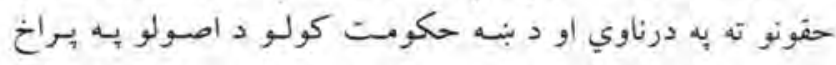
بنسته كبدو باندي تينكار وكرئ.

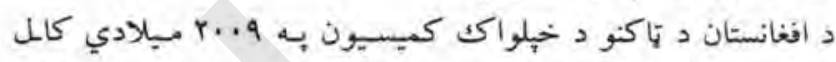

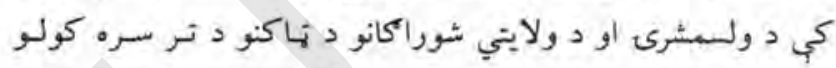

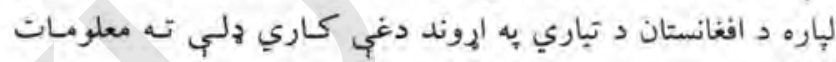

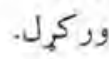

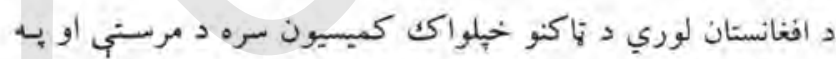

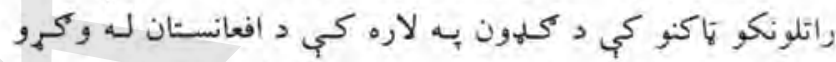

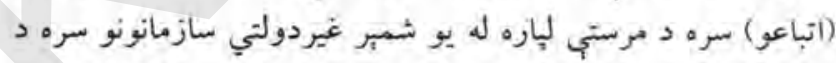

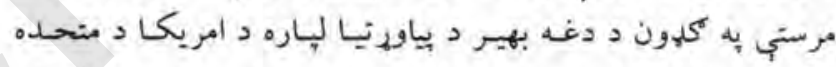

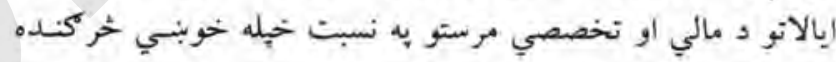
.05

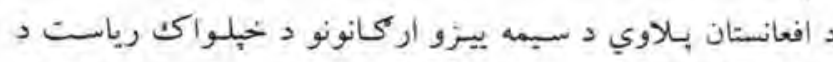

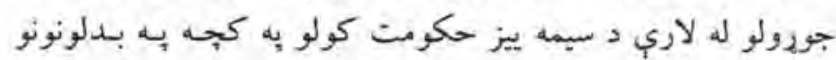

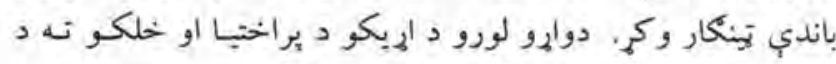

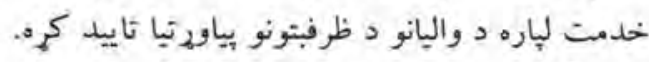

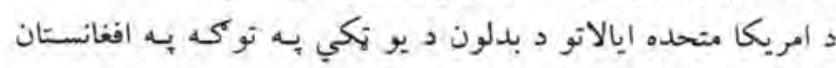

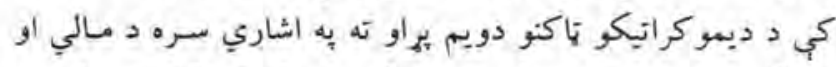

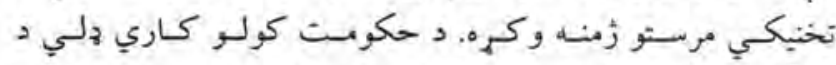

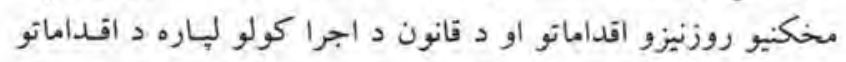

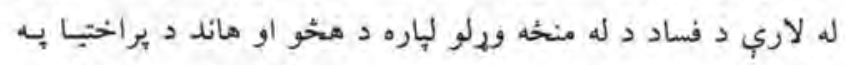

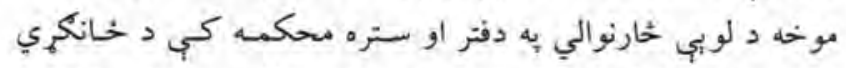

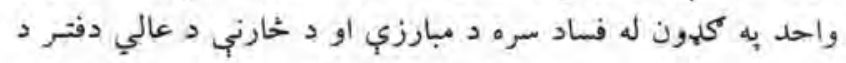

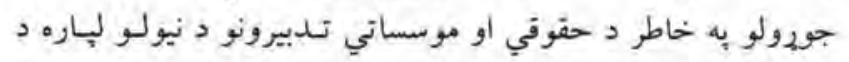

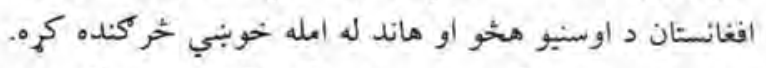

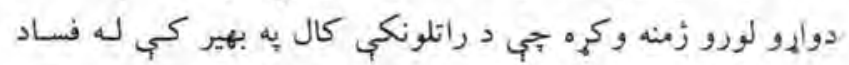

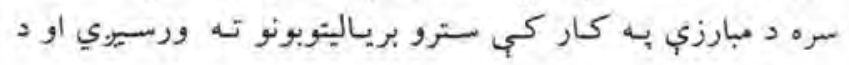




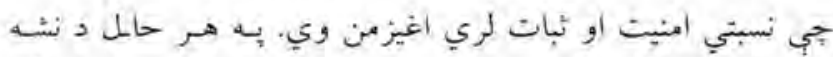

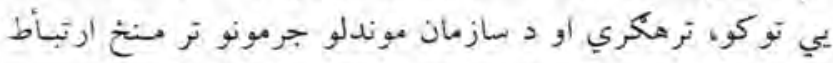

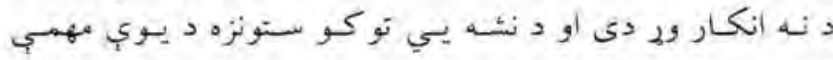

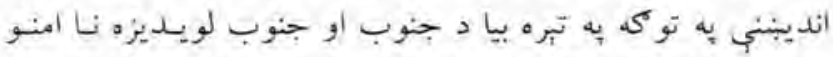

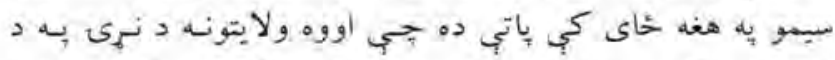

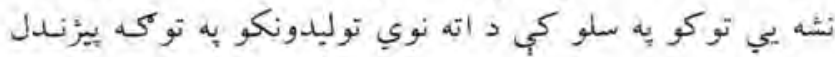
شوي دي.

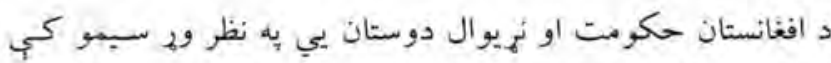

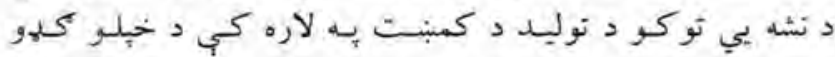

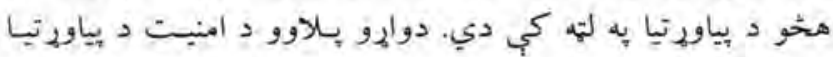

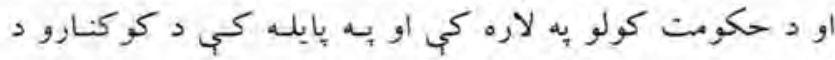

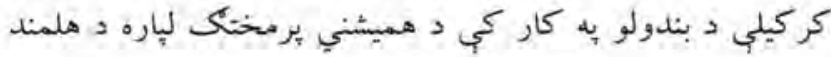

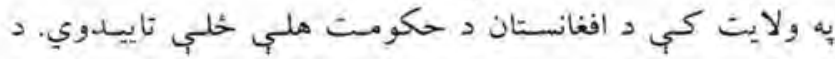

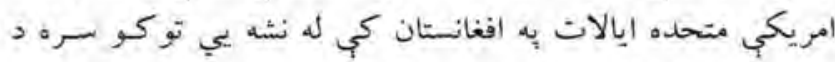

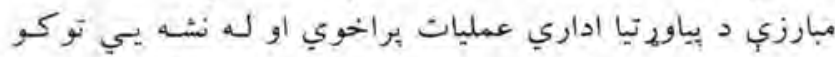

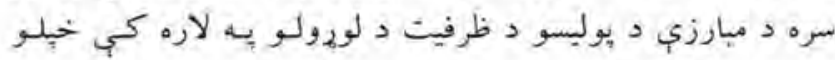
هخو ته دوام وركوي.

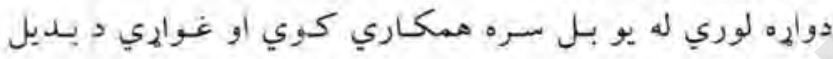

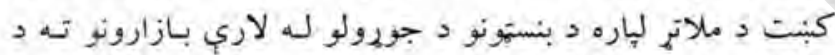

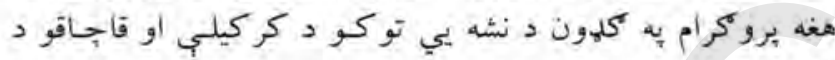

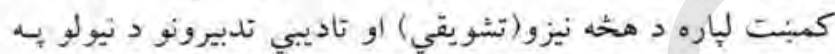
باب متمر كز كمئي.

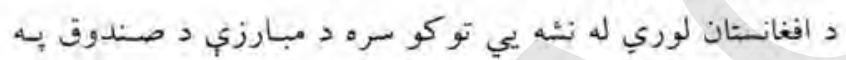

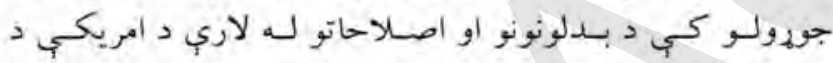

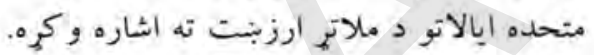

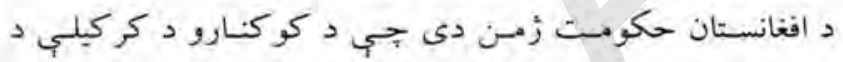

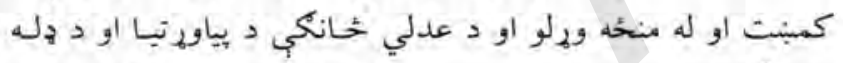
بيزو أطلاعاتو د وسايلو او بنووني او روزني د ديراختيا او د دفياد

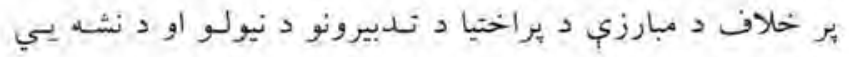

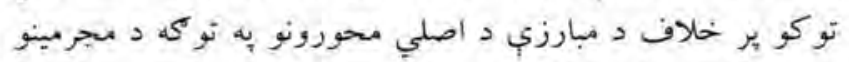

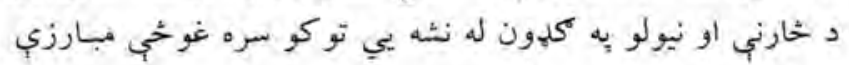
ته بإملرنه وكري.

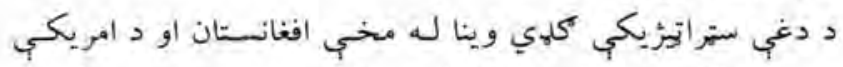

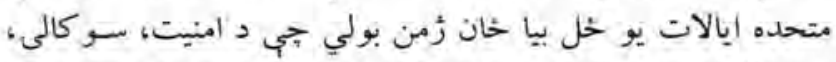

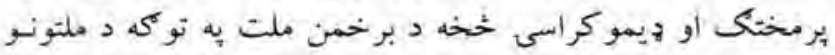

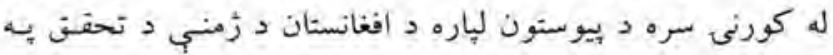

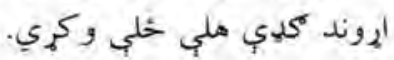

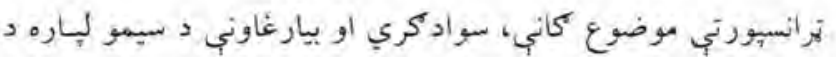

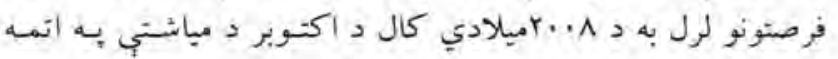

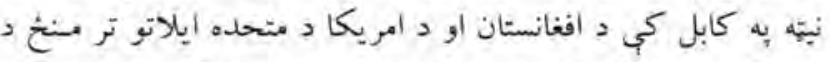

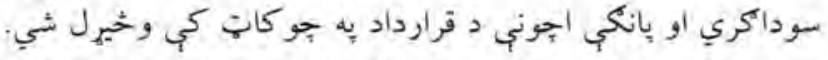

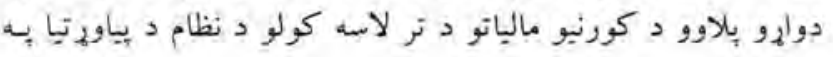

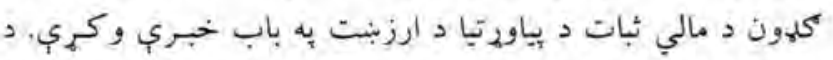

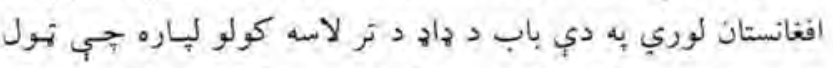

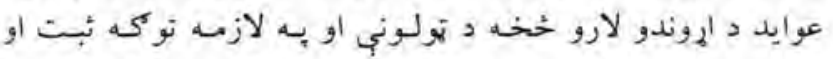

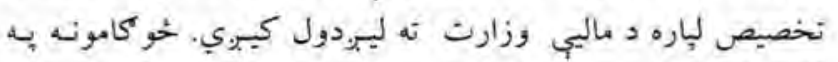
كوته كرل = امريكاد دمتحده ايالاتو هينت د عوايدو د بيا تر لاسه كولو د يـو

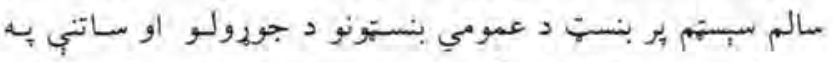

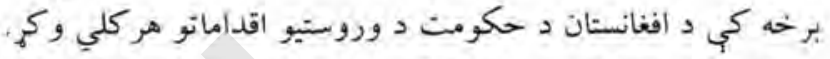

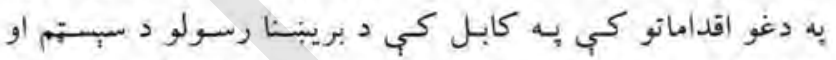

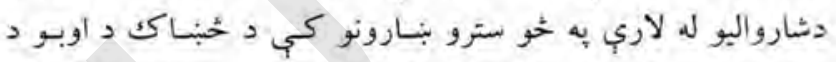

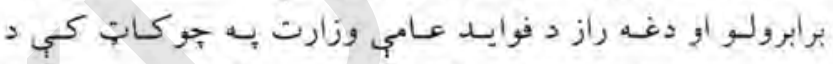

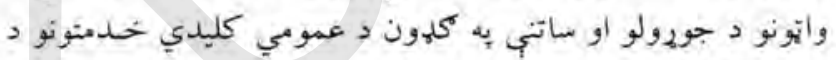

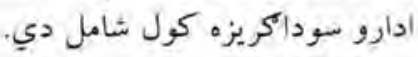

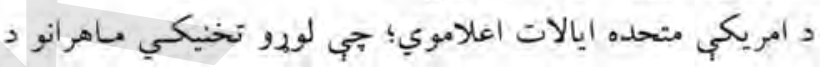

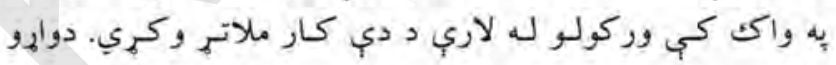

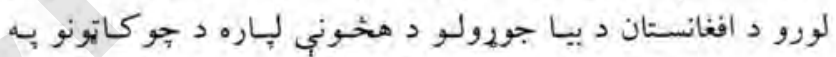

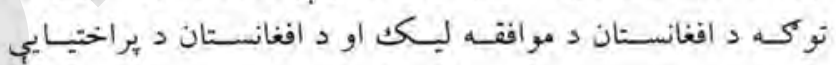

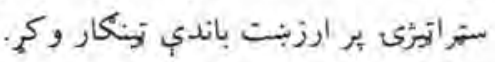

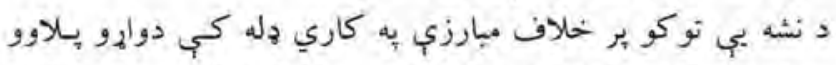

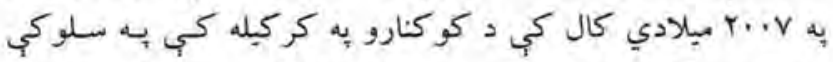

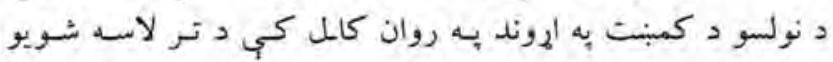
بريالتوبونو هركلي وكري.

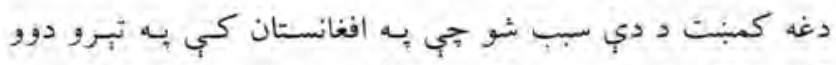

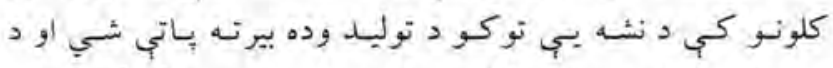

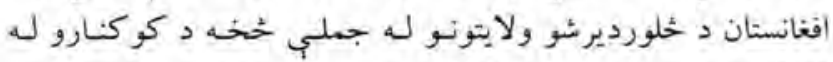

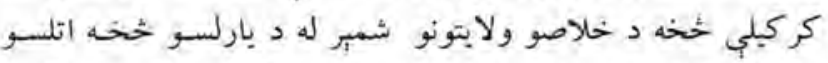

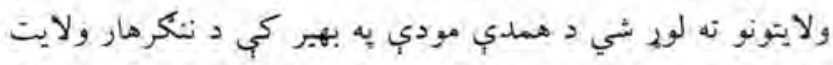

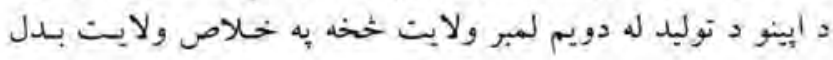

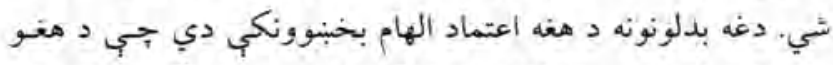

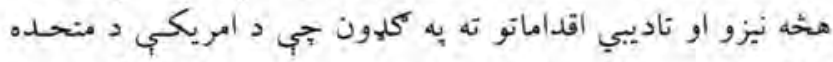

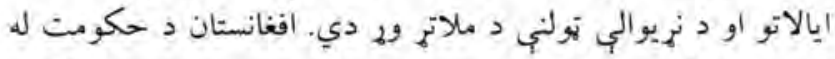

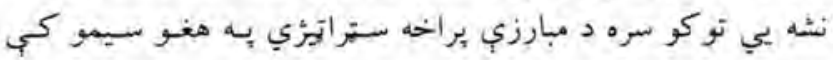




\section{سخرانى}

\section{داكتر رنكين دادفر سبيتا رينا}

\section{در سيمينار تجليل از رودكى، هرات}

$$
\text { رودكى، در حسرت ديارش سرود: }
$$

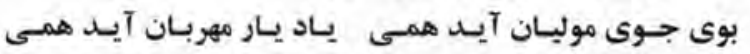

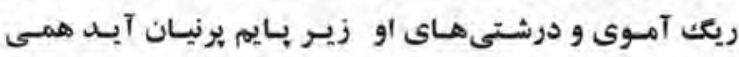

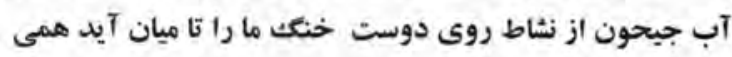

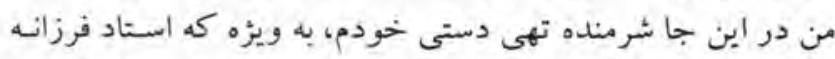

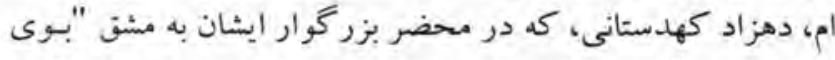

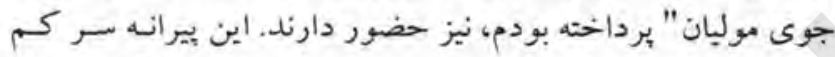

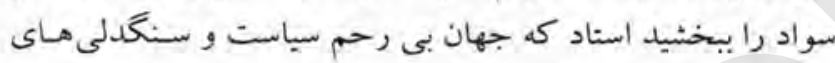

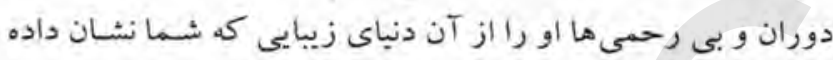

$$
\begin{aligned}
& \text { بوديد، بسيار دور كرده أست. } \\
& \text { خانمها و آقايان، }
\end{aligned}
$$

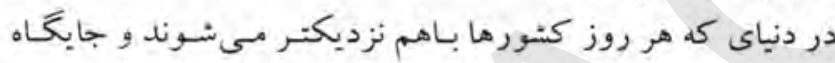

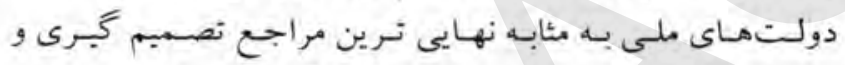

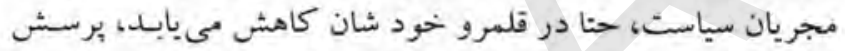

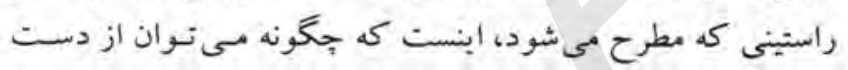

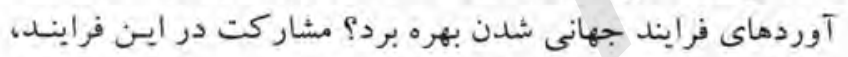

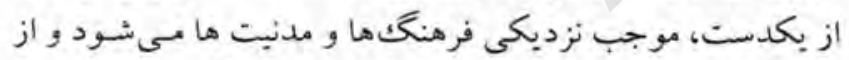

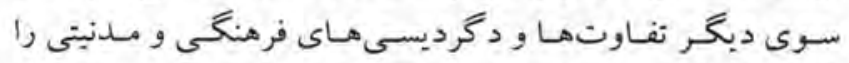

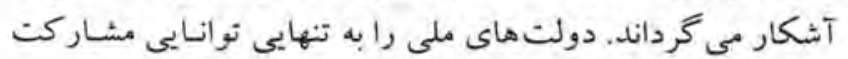

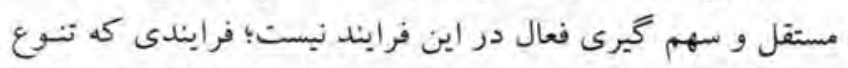

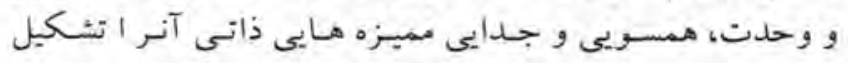

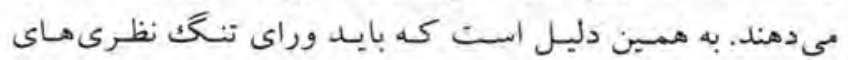

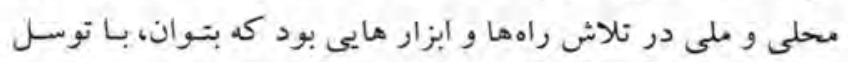

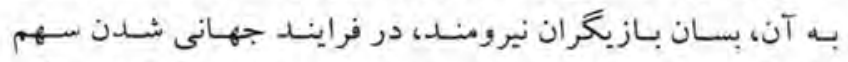

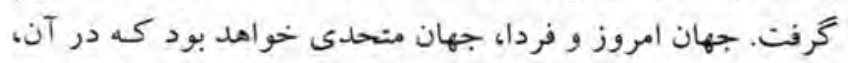

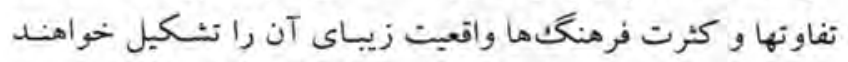

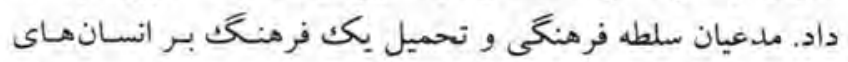

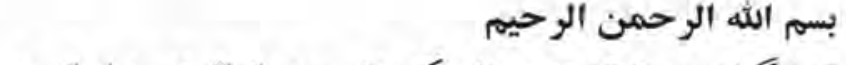

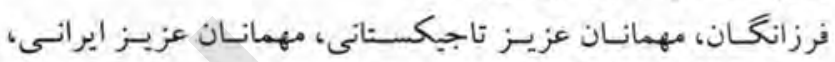

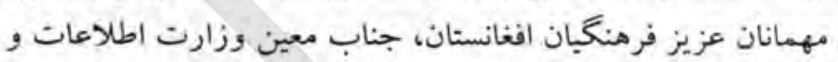

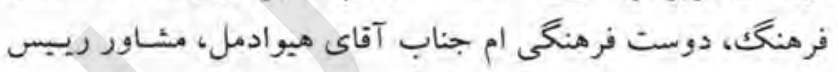

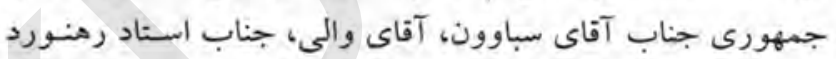
زرياب، خانم ها و آقايان،

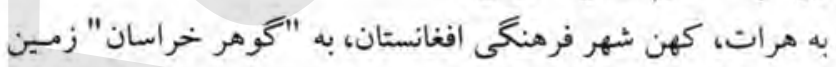

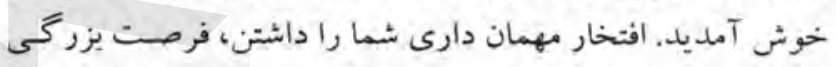

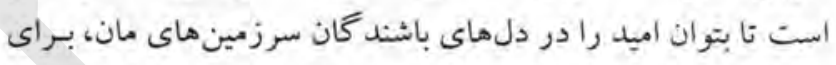

$$
\text { رسيدن به همدلى بيشتر، زنده كرد. }
$$

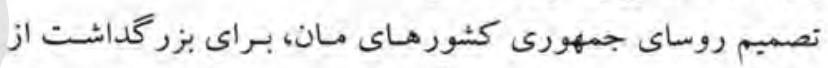

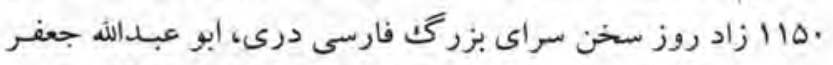

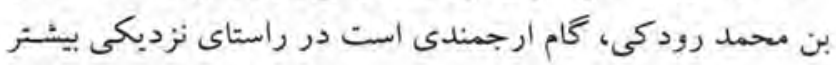
كشور هايمان. فرزانكان عزيز، خانمها و آقايان،

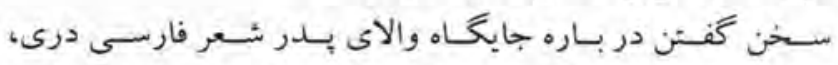

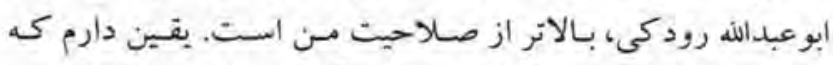

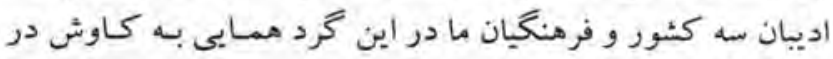

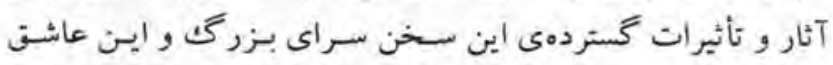

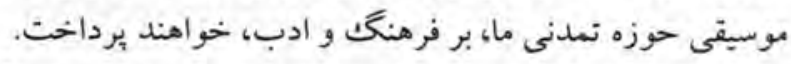

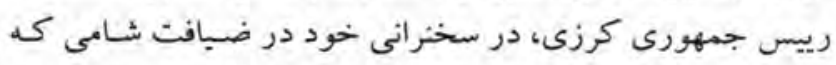

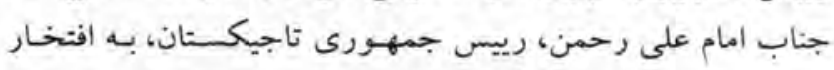

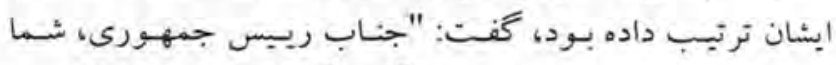

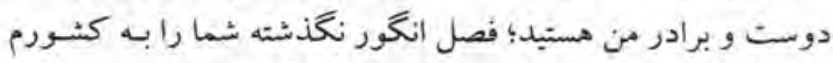

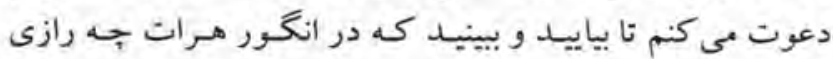

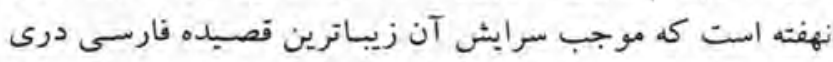

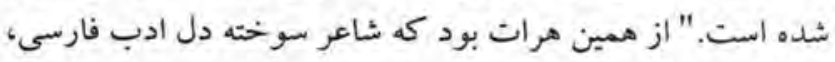




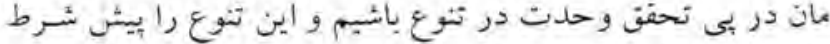

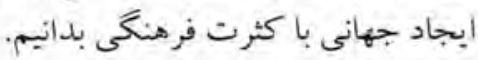
خانمها و آقايان،

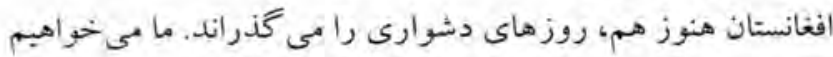

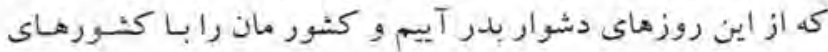

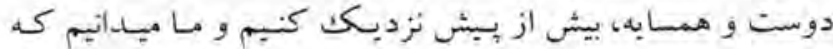
فرداى بهتر، براى فرزندان ما در جارجوب اتحاد منطقةاى بر بنيساد

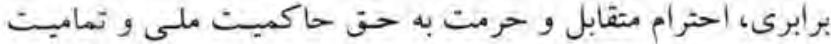

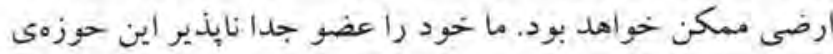

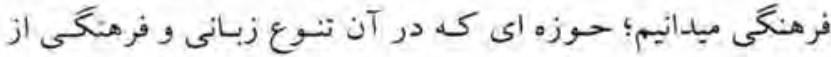

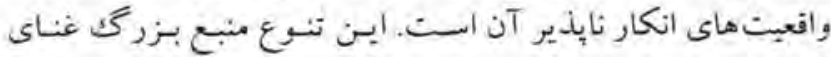

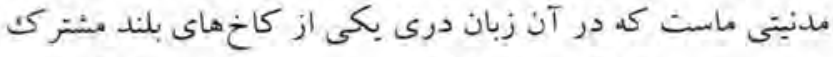

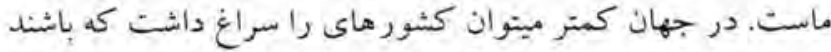

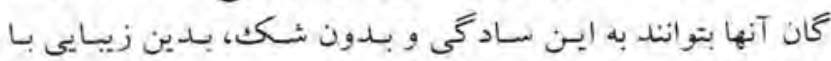
يكديخر كفتخو كنيد. شكر شكن شوند همه طوطيان هند

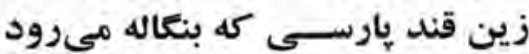

\section{خانم ها و آقايان،}

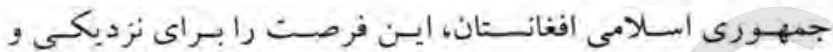

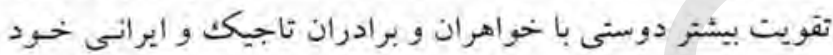

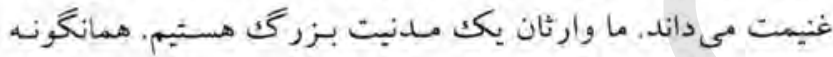

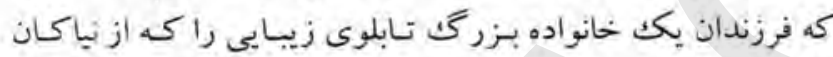

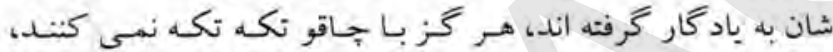

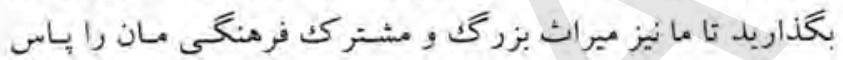

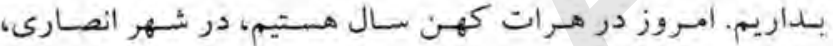

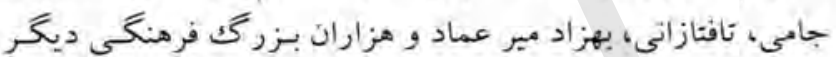

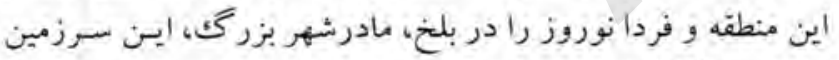

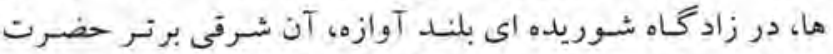

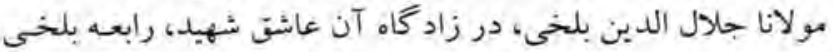

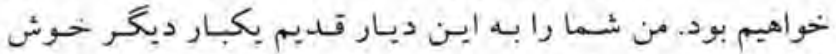

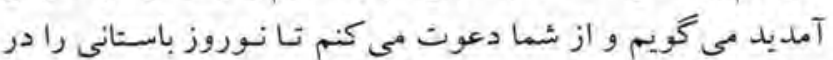

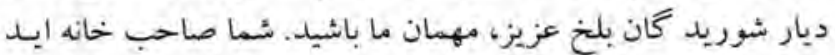

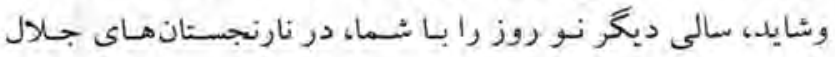

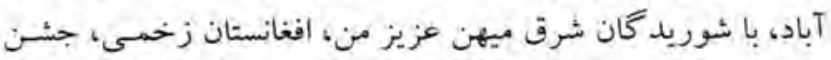

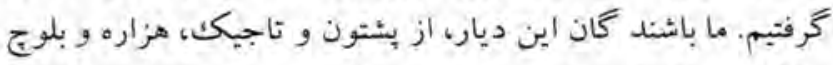

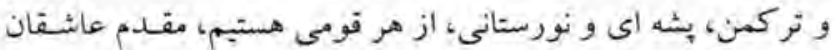

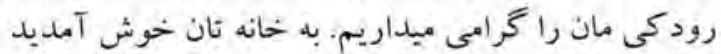

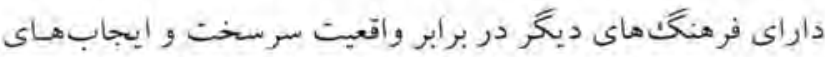

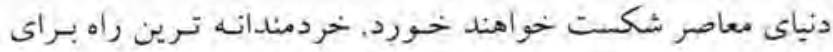

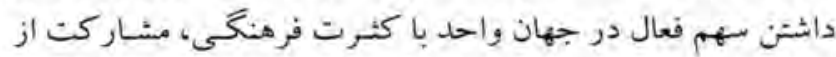

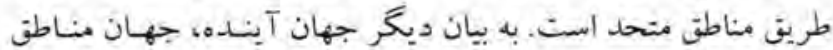
متحد خحواهد بود.

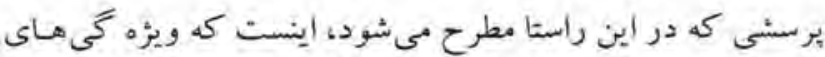

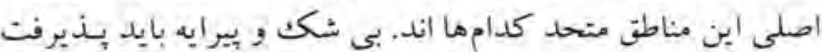

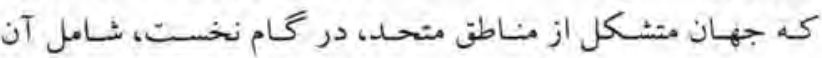

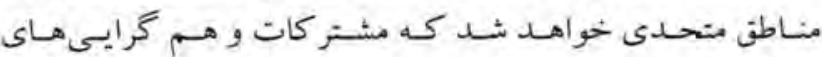
فرهنكَى، مدنيتى و جغر افيابيى بيشترى دارند.

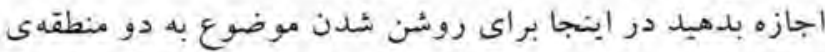

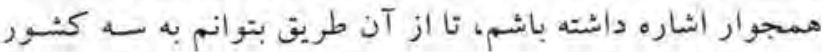

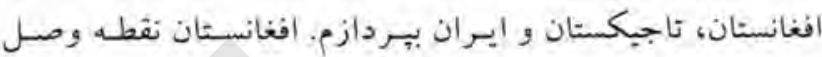

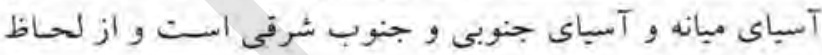

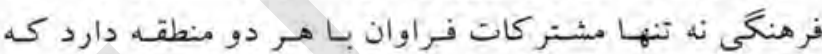

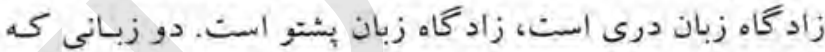

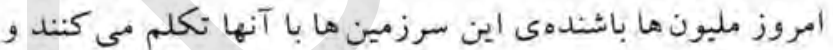

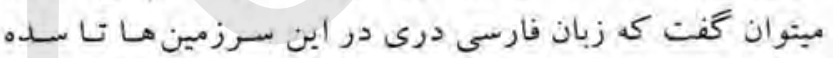

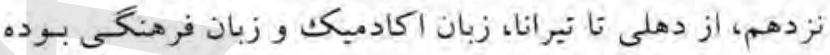

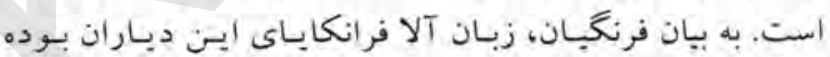

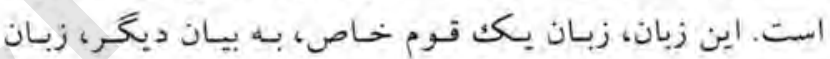

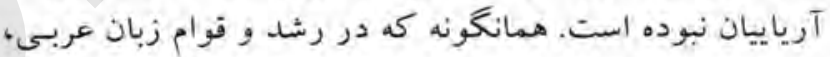

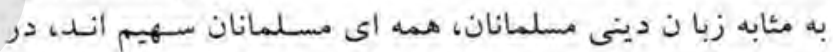

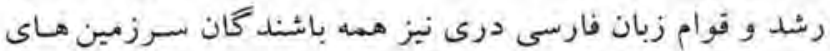

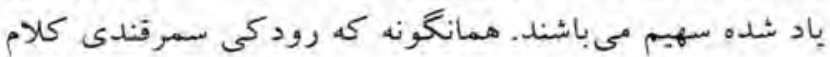

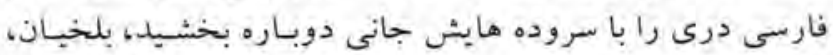

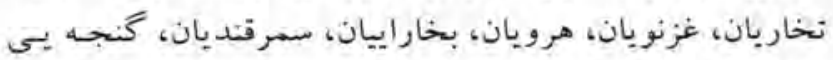

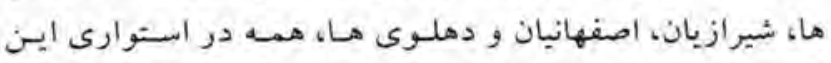

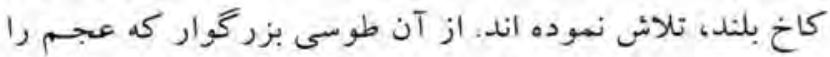

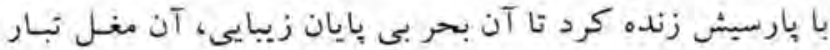

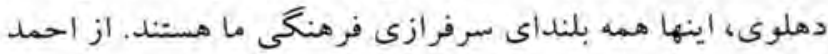

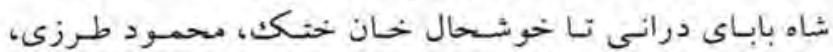

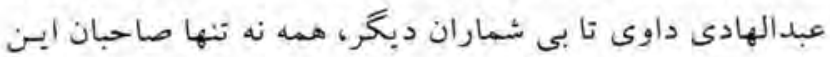

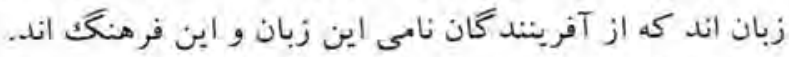

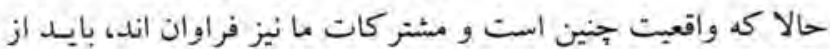

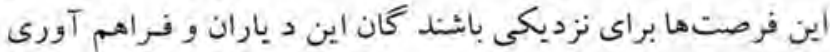

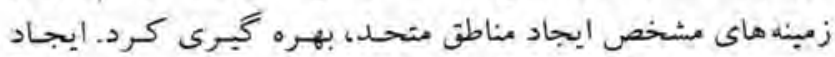

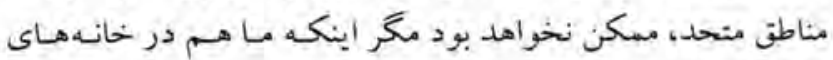




\section{هـ حقوقو وبشُنهـ}

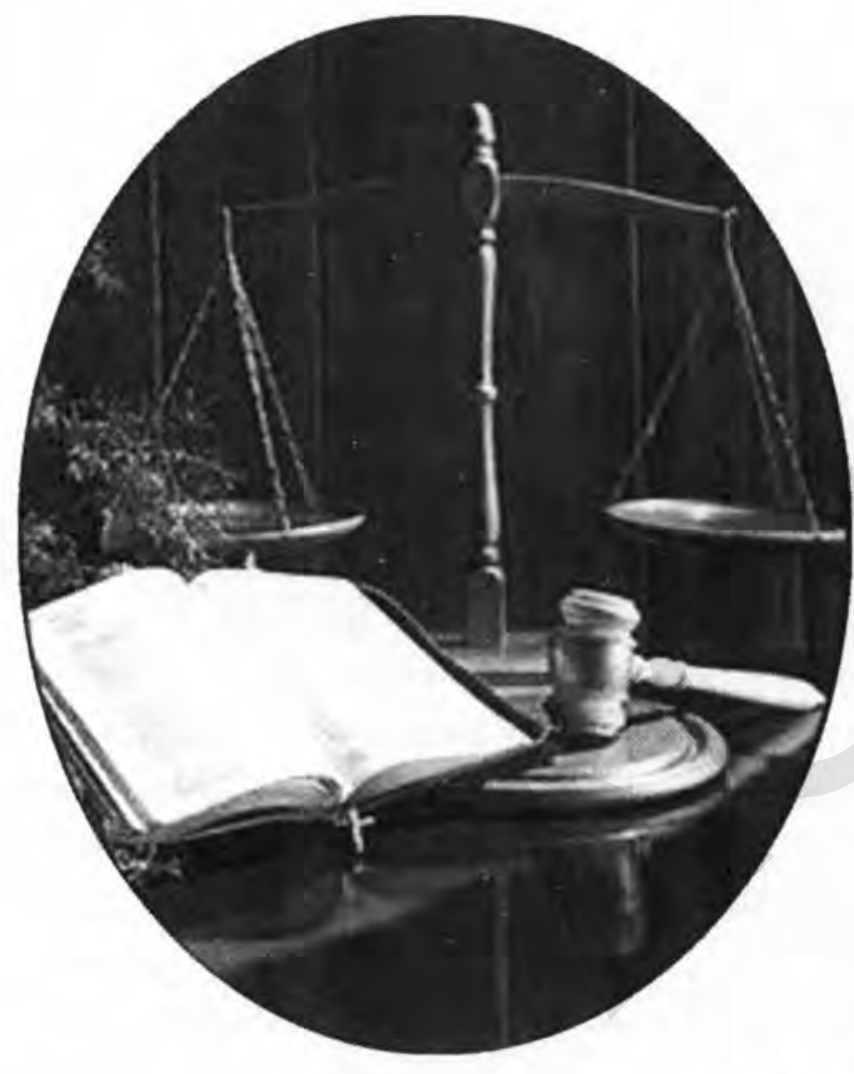

وبشل كيري. ملي يا كورني حقوق هغه قواعد دي جي دي دي يوه هبواد به قلمرو او

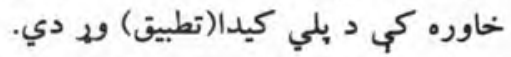

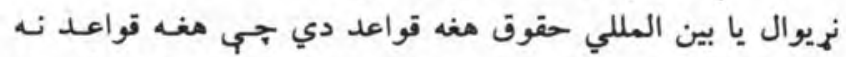

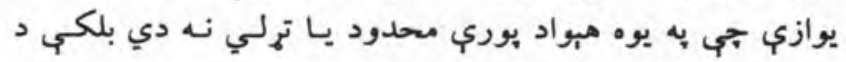

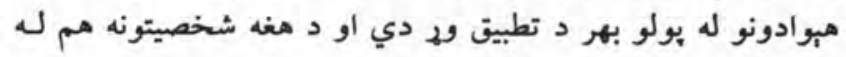
ملي حقوقو خخه توبير لري.

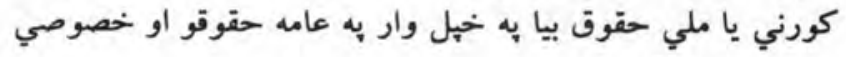
حقوقو وبشل كيري. عامه حقوق هغه قواعد دي جي دي دوكي وكي و او دولت تر منغ الريكي

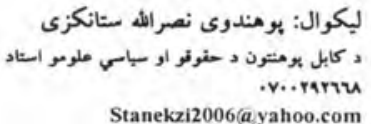

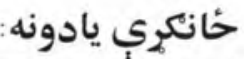

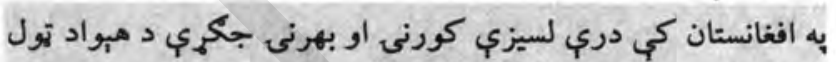

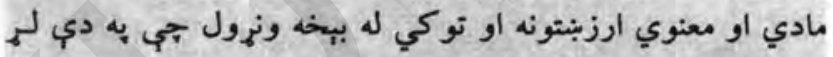

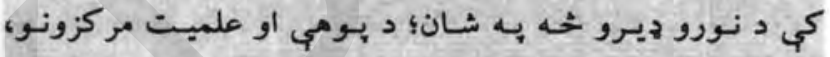

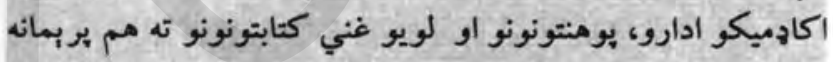

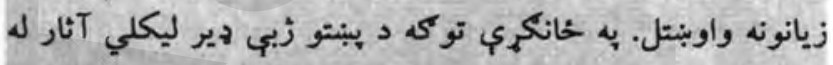

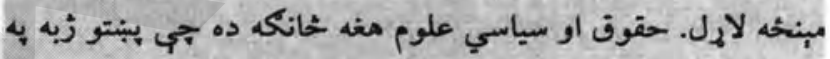

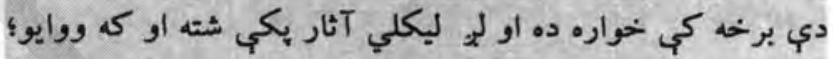

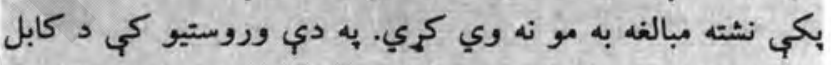

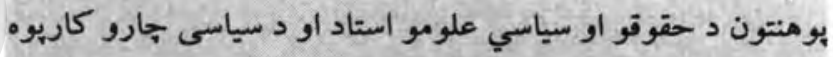

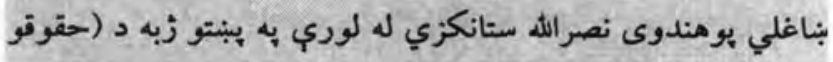

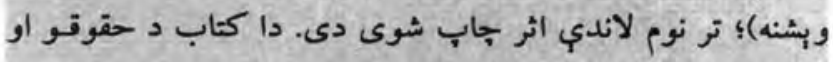

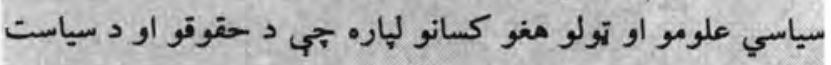

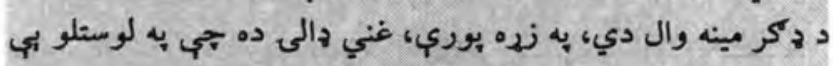

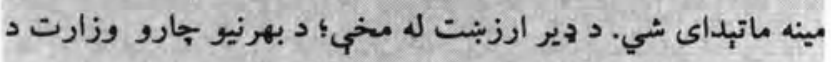

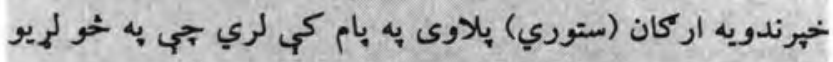

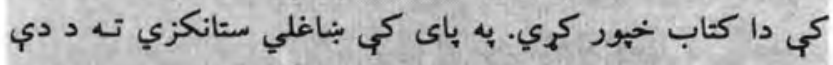

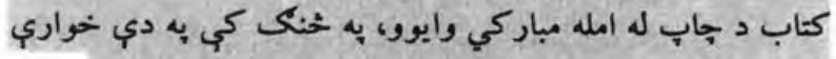

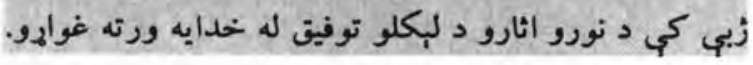
لومرى برخه د افاقي حقوقو جولونه لكه حنكه جي مو مخكي ياده كره، افاقي حقوق جي جي اكثراً

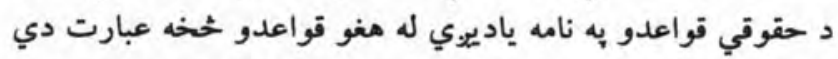

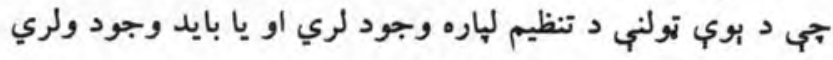

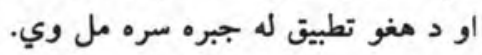
دغه قواعد به لومري سر كي به ملي (كورني) او نهيوالو حقوقـو مل وكي 


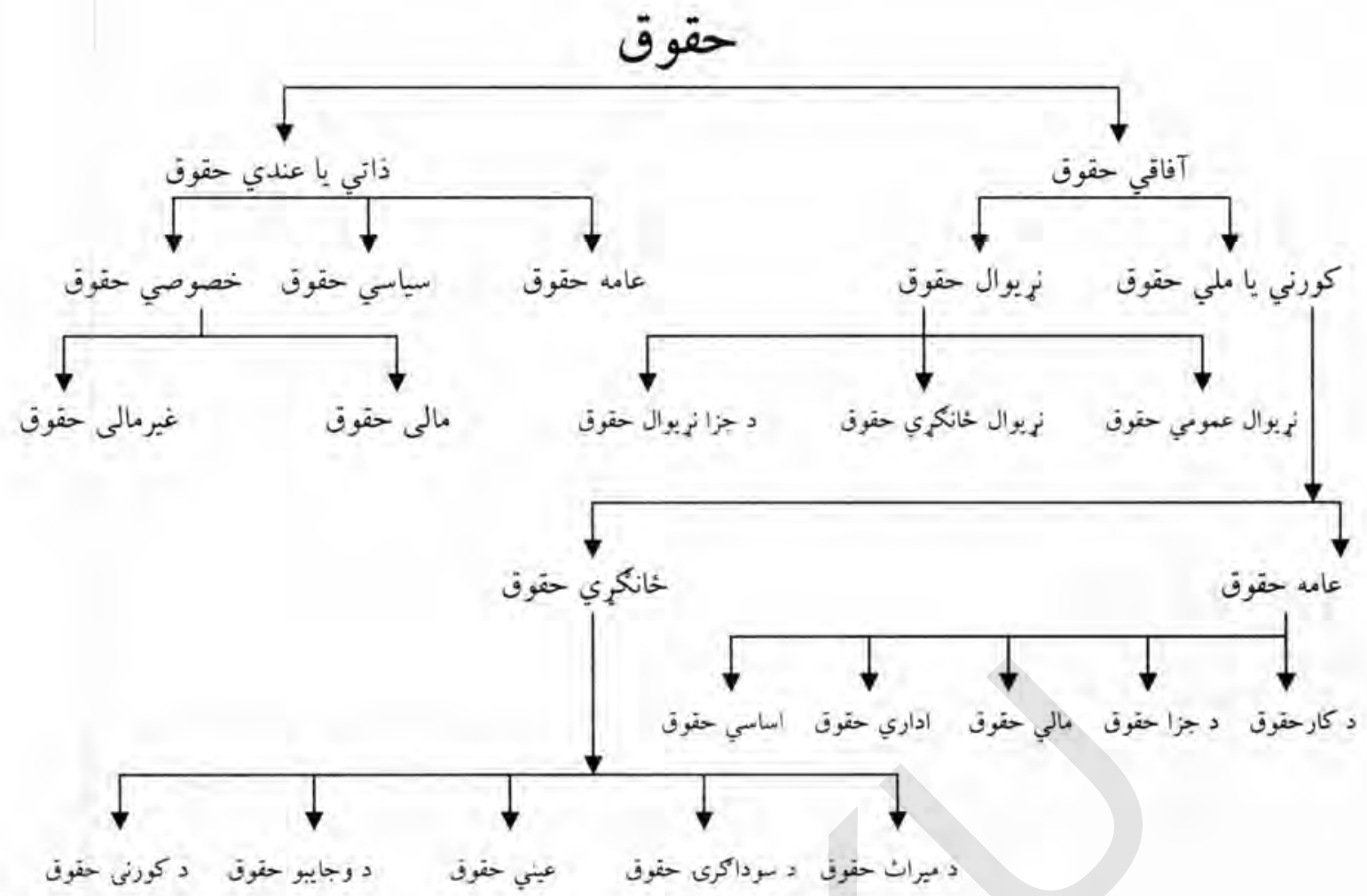

عمومي، با عامه حقوق هغه قواعـد او مفررات دي جيجي د

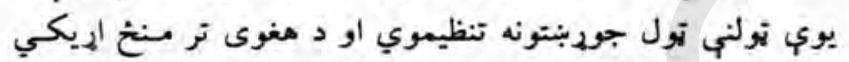

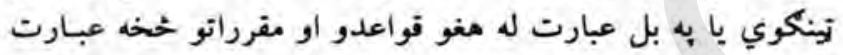

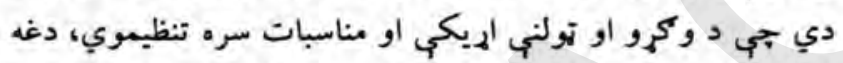

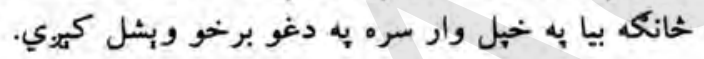

$$
\text { _ اساسي حقوق _ ' }
$$

اساسي حقوف د عمومي حقوقو بنست او اساس تشكيلوي،

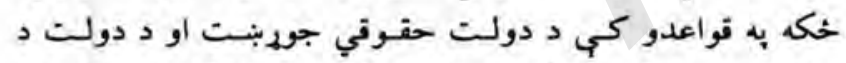

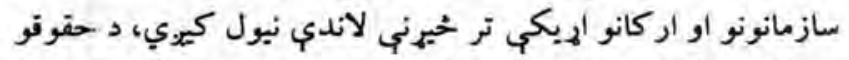

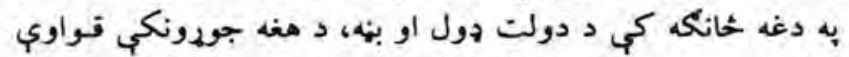

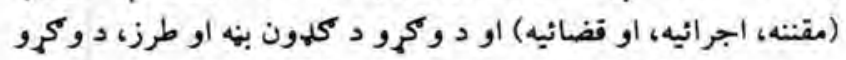

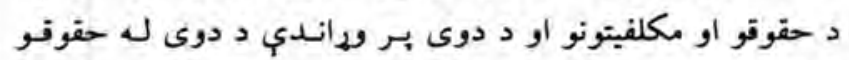

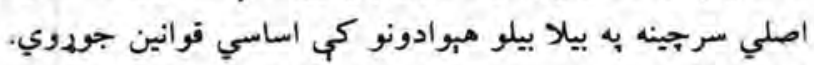

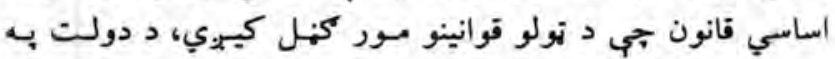

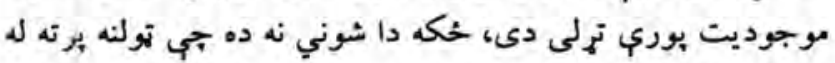

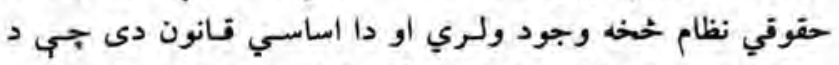

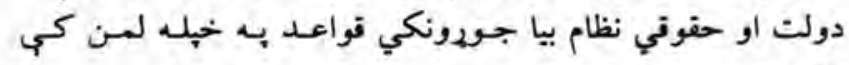
رانغإي. اساسي حقوق به لومري سر كي د دولت بنه او شكل (شـاهي،
تنظيموي، او خصوصي حقوق مغه قواعد دي بجي د وكيرو تر منغ

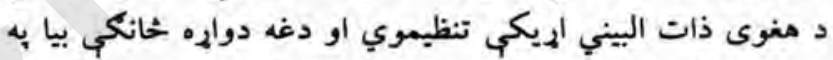

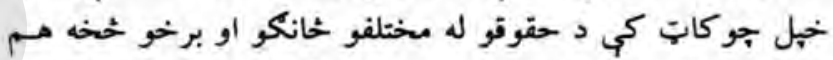

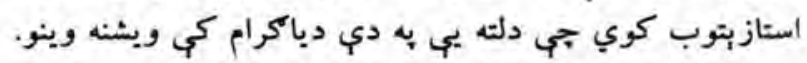

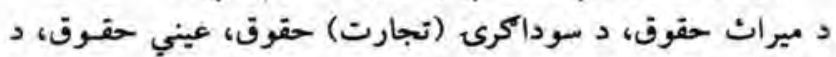
وجايبو حقوق، د كورنى حقوق.

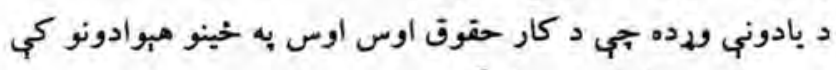
د خصوصي حقوقو يوه خانكه ده.

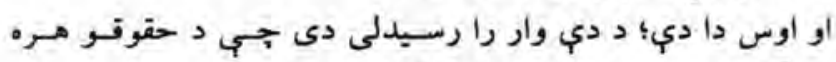

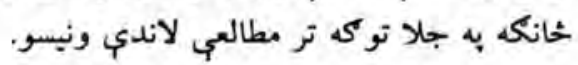

\section{لومئى خيركى}

\section{د ملي حقوقو خانكي}

لكه مخكي مو بجي يادونه وكهم، ملي يا كورني حقوف هغه

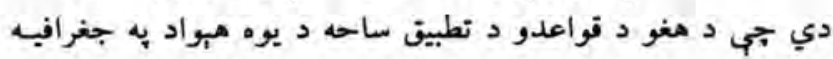

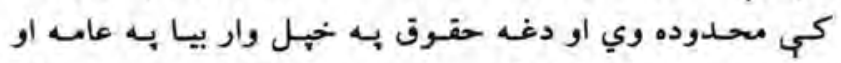

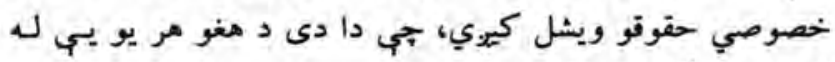
إيوندو خانكو سره خميرو. لومبى : عامه حقوق 
بنستونو او د خلكو ثر منخ له اليكو خهخه بحث كوي. له ممدي

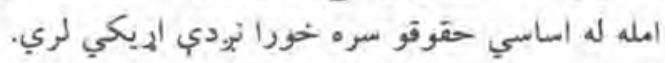

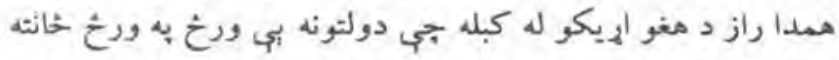

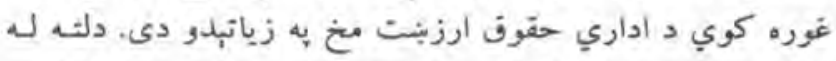

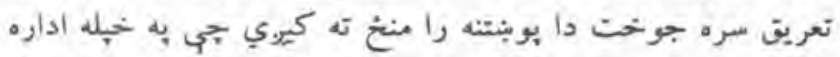

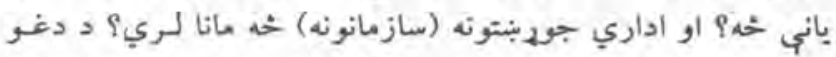

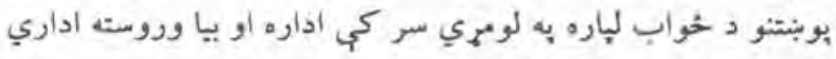
جوينتونه يا سازماتونه تعريفوو.

$$
0,101
$$

اداره له هنو فعاليتونو حخهد عبارت ده جي دولث بي به مستقيمه يا

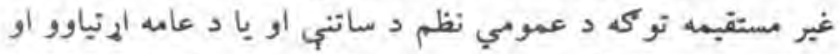

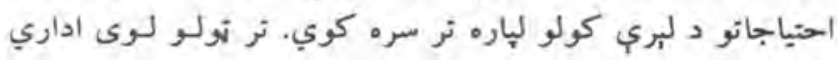

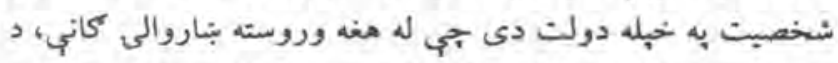

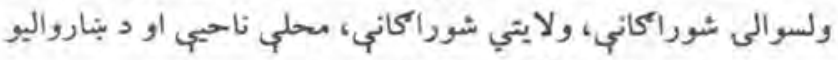

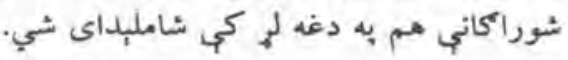

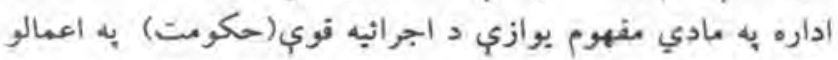

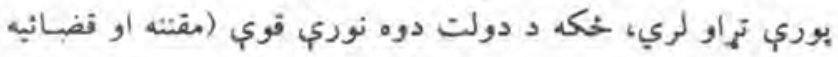

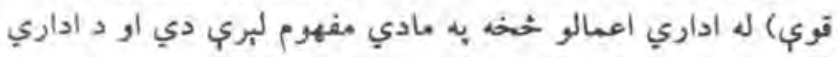

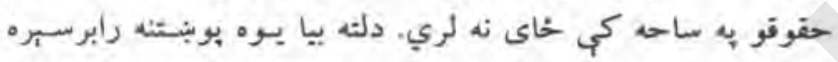

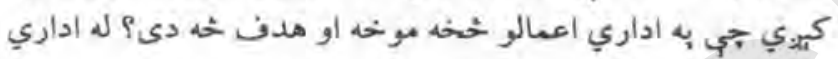

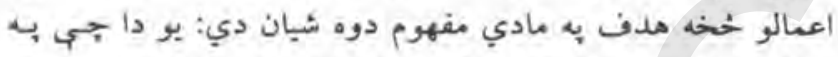

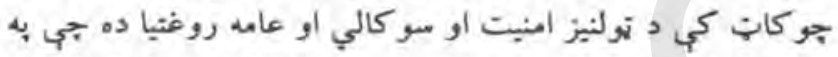

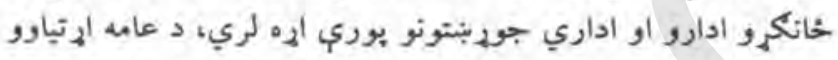

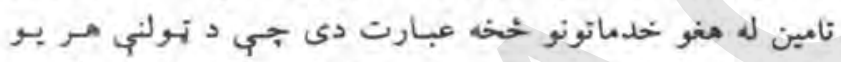

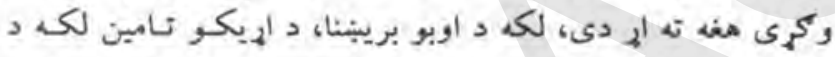

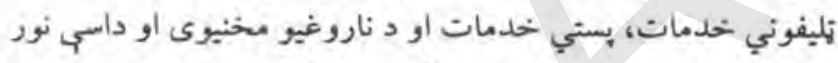

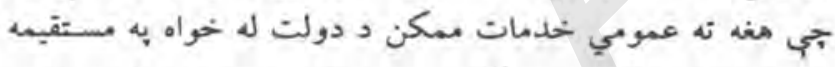

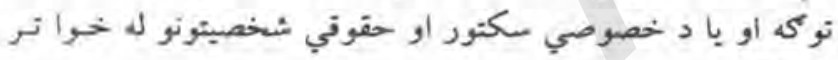
سره كيري.

\section{اداري سازمان (جورنبتَ)}

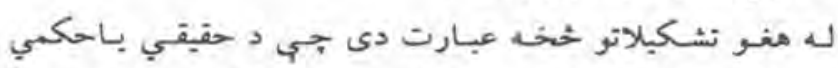

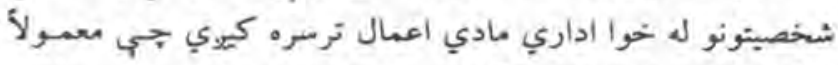

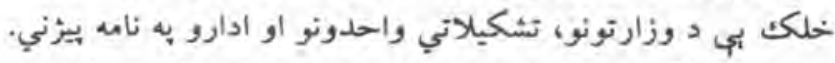

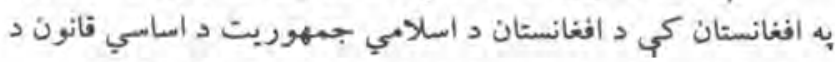

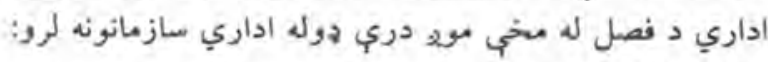

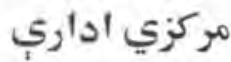

جي د هني د هر اداري واحد به سر كي د ولايت مفام وافع كيري

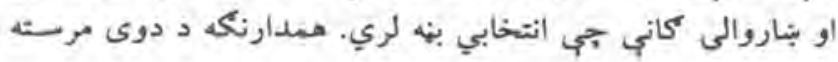

جمهوري، ديموكراتيك، غيرديموكراتبك، مـذهبي، نامـأهبي،

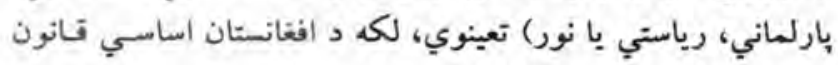

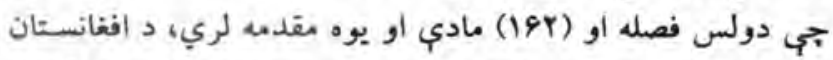

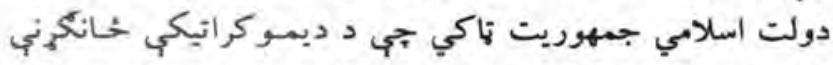

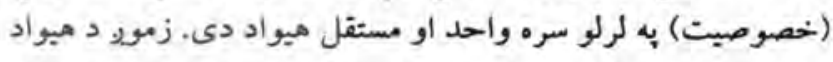

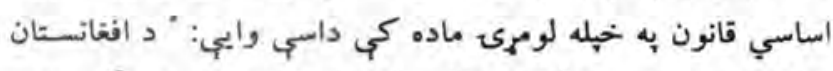

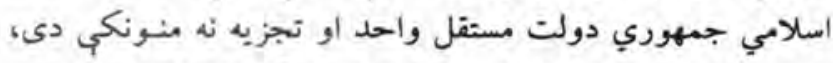

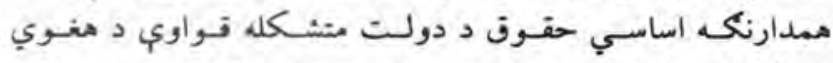

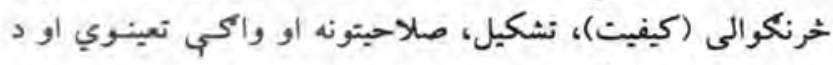

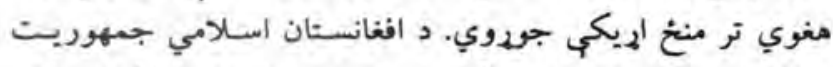

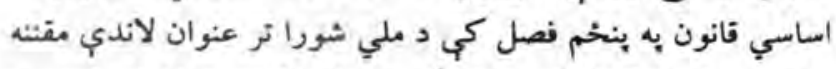

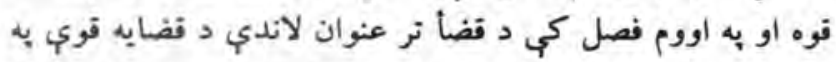

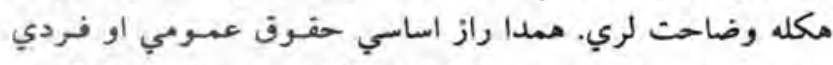

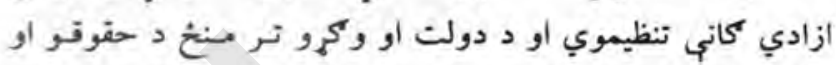

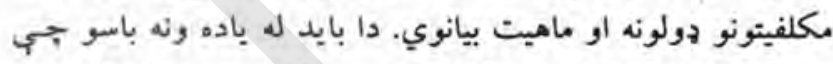

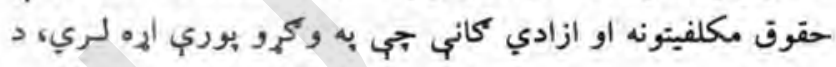

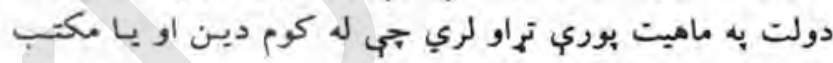

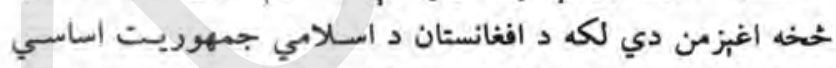

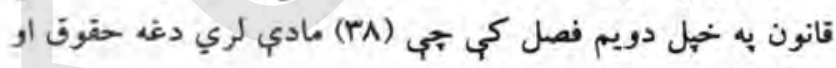
مكلفيتونه تثبيتوي.

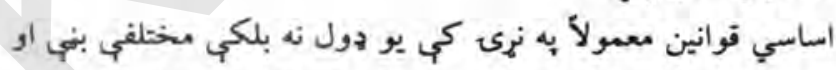

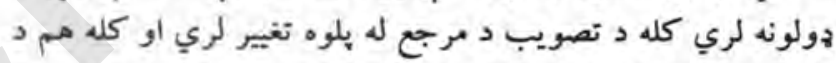

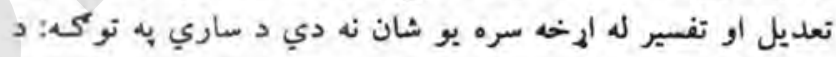

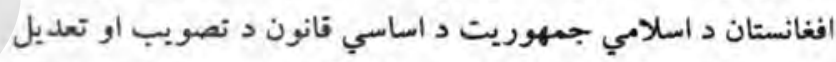

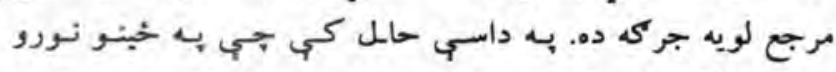

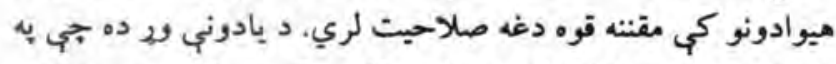

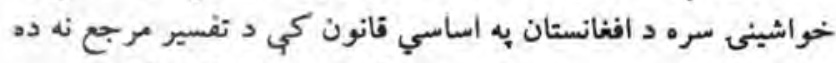

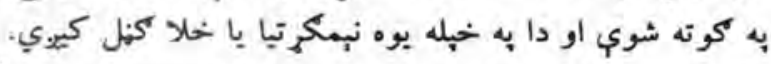

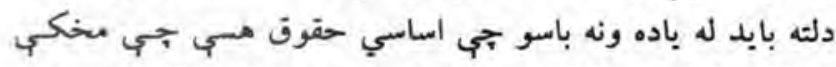

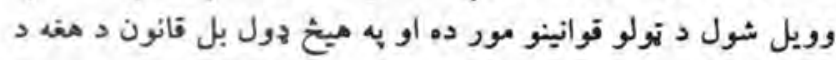

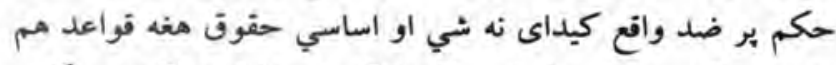

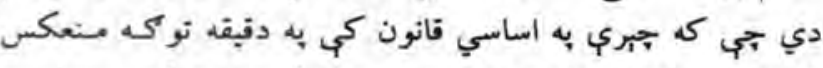

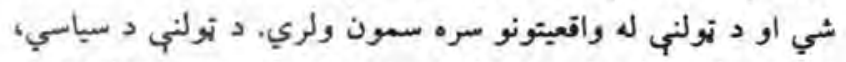

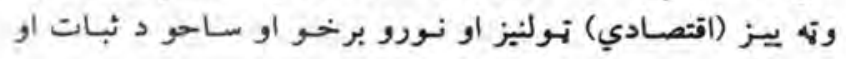
برمختك عوامل برابروي.

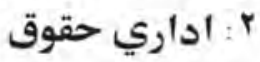
دغه خانكه د هغو حكمي شخصيتونو (كساتو) جي اداري كرئري

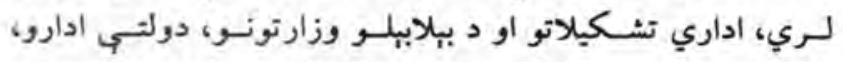

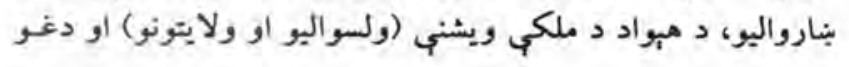


سابقه لري او د تاريخ به اوبدور كي بي بنال بنلي بني او جولونه

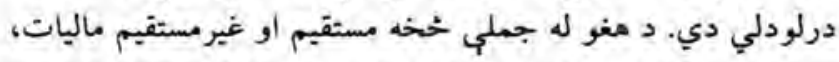

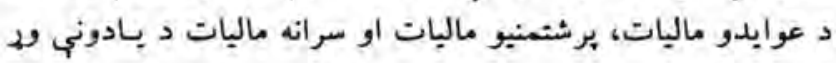

دي.

يورونه له هغو بيسو خخه عبارت دي جيى دولتونه بي د خهيلو

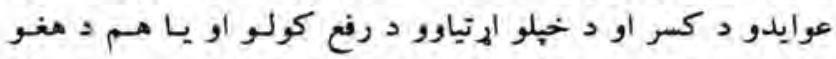

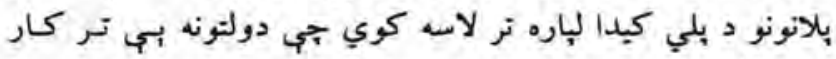

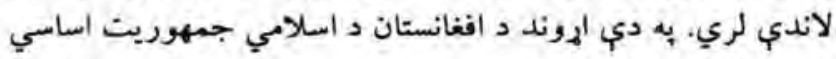

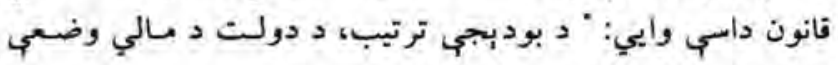

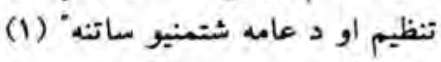

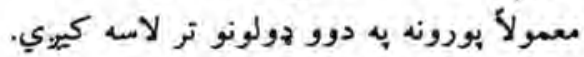

\section{لـ لله كورنيو سرجينو}

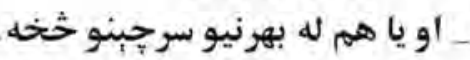

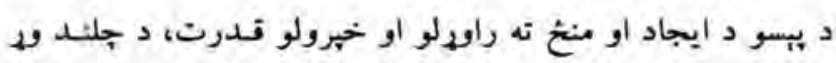

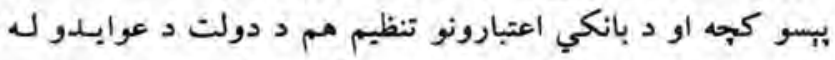

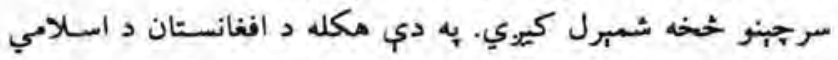

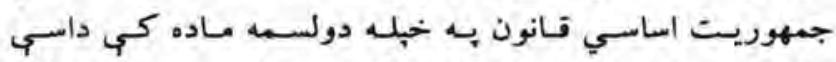

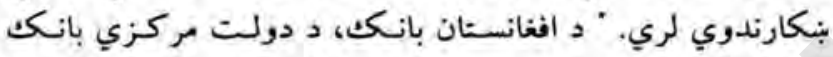

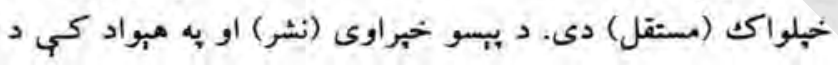

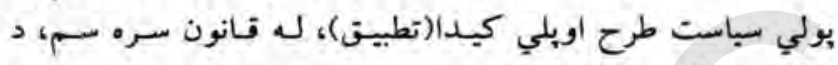
مركزي بانكت صلاحيت دي.

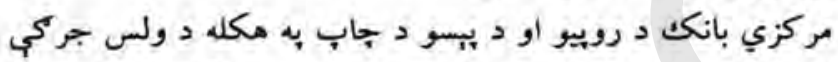

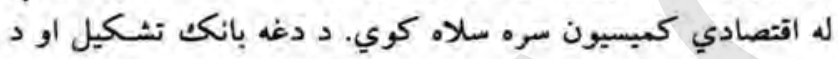

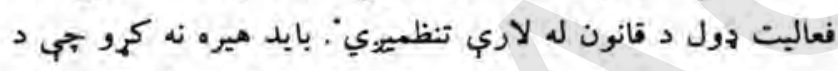

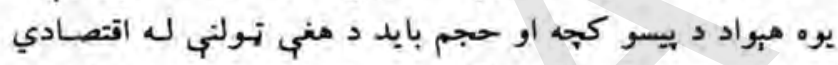

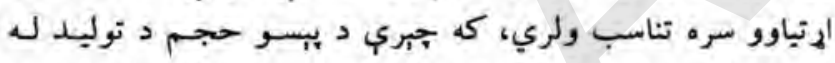

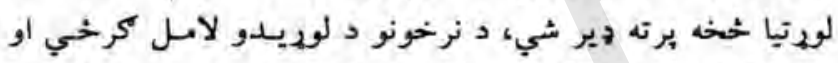

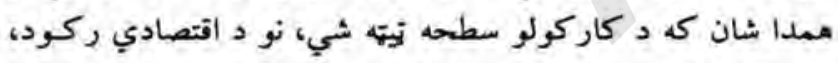

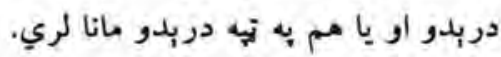

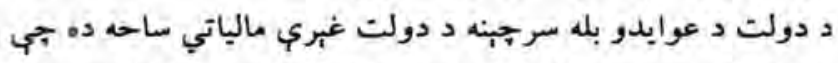

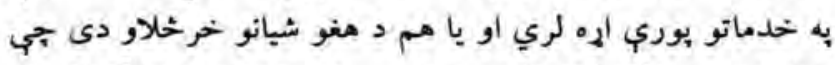

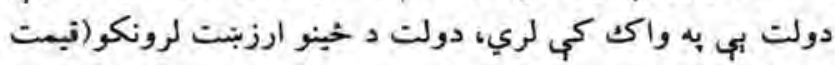

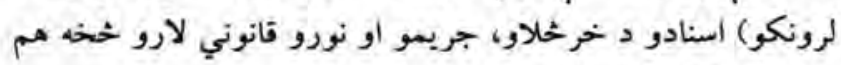

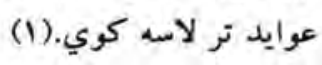$$
\text { ب - د جزا حقوق }
$$

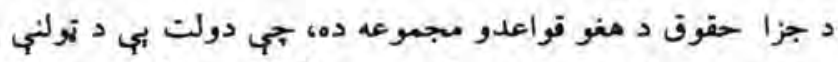

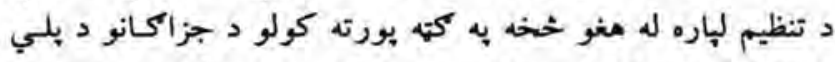

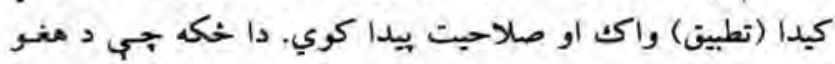

كوونكي اركانونه د ولسواليو، ولايتي او بناروالى شوراكاني كهنلى

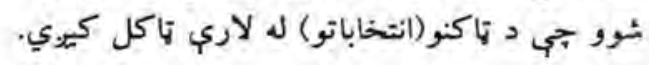

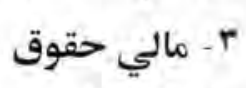

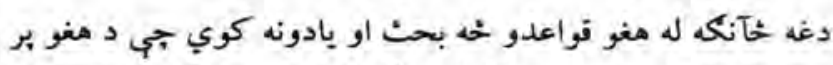

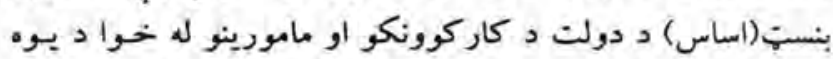

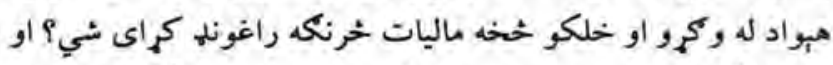

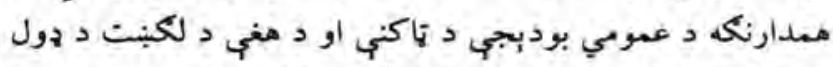

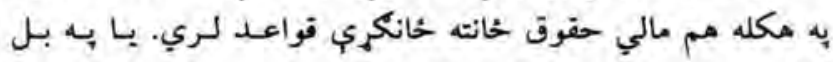

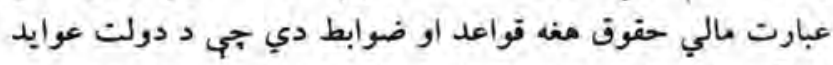

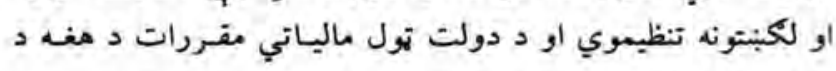

بحث موضوع ده.

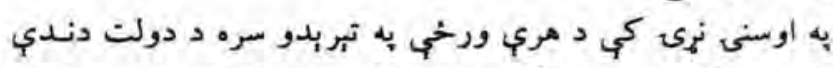

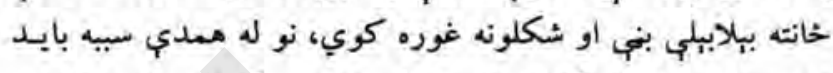

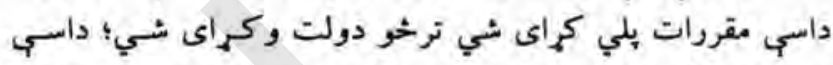

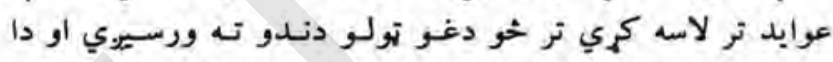

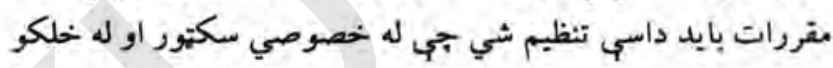

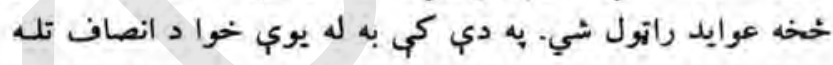

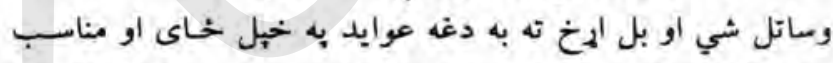

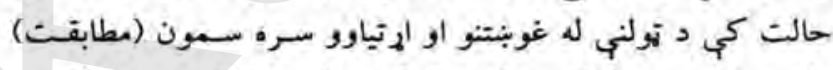

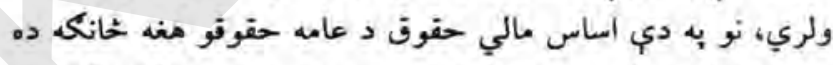

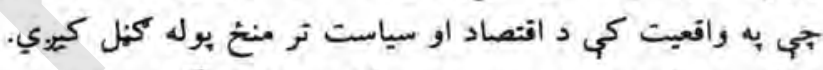

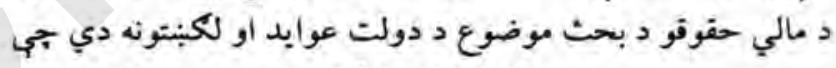

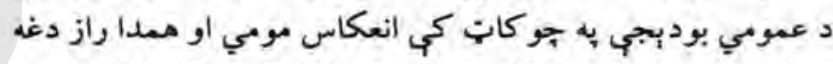

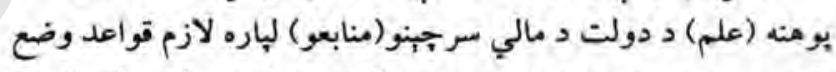

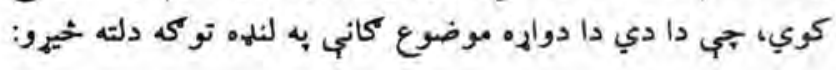

عمومي بوديجه

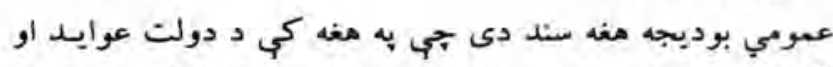

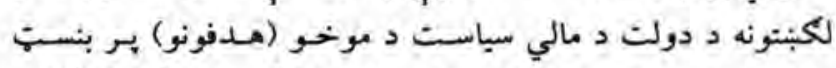

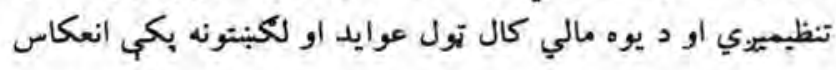

مومي.

د دولت د عوايدو سرجينج دولثونه به عامه توكى د عوايدو خحلور جوله سرجبني (منابع) لري. 1- ماليات ؛

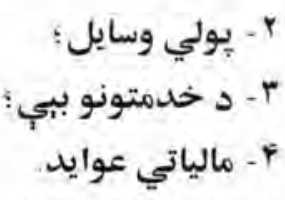
د مالياتو تر لاسه كول د دولتونو له خوا به تاريخ كي خورا اودده 
همدا راز د افغانستان د جزا د قانون له مخي جزايكاني به لاندي

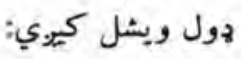

$$
\begin{aligned}
& \text { اصلي جزانكاني } \\
& \text { اصلي جزاكاني عبارت دي له: } \\
& \text { ا- به دار خرئ جزل (اعدام)؛ } \\
& \text { r- دوام لرونكى حبس؛ } \\
& \text { r- اويد حبس؛ }
\end{aligned}
$$

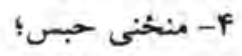

$$
\begin{aligned}
& \text { ه- لليه حبس؛ }
\end{aligned}
$$

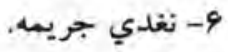

$$
\begin{aligned}
& \text { تبعي جزاكاني }
\end{aligned}
$$

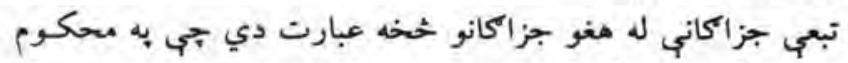

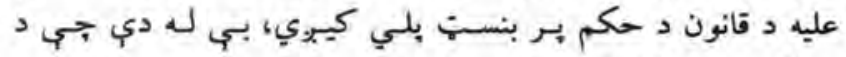
محكبي به حكم كي تصريح شي.

$$
\text { تكميلي جزاكاني }
$$

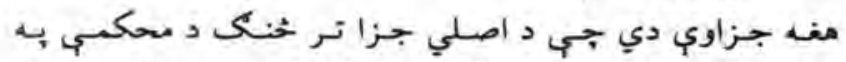

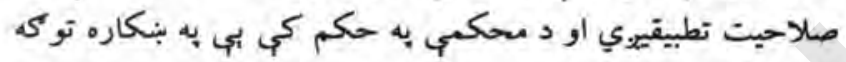
يادونه كيري.

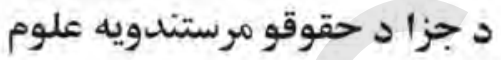

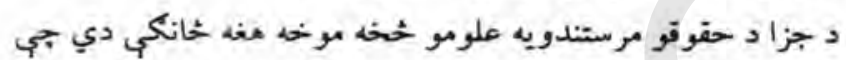

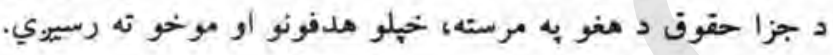

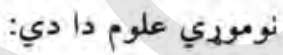

د جزا يرنزنانه د دغه بومي يا علم به مرسته هغه مسايل بحي د مجازاتو اجراء؛

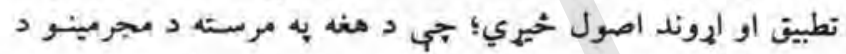

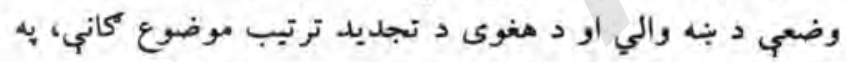

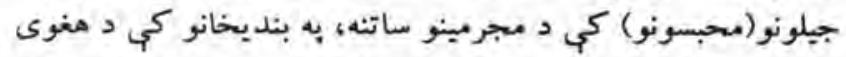

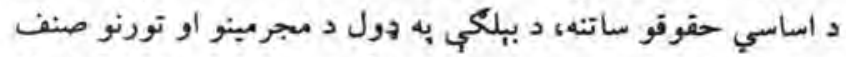

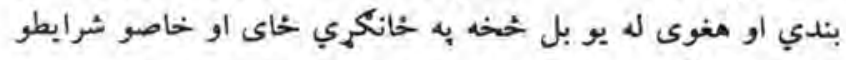

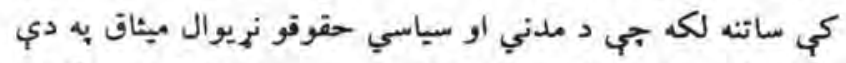

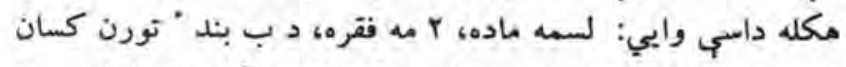

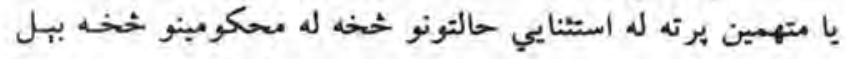

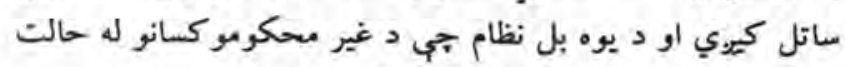

$$
\text { سره وله او مناسب دي، ساتل كيرين: }
$$

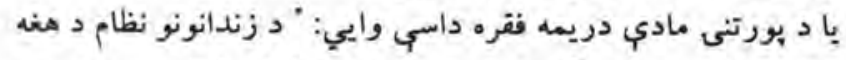

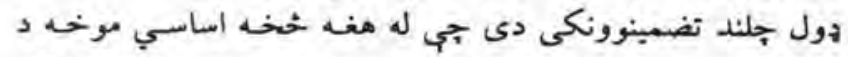

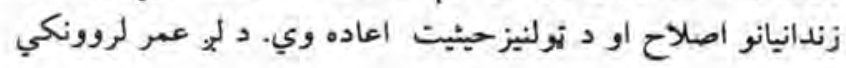

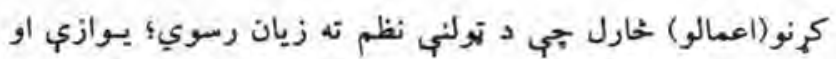

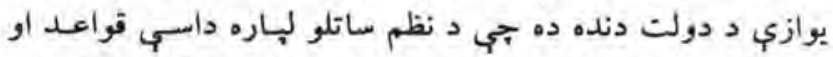

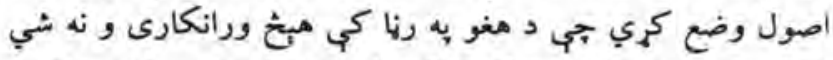

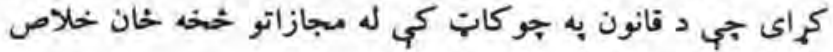
كري. له دي كبله د جزا حقوفو د تطبيق لياره د متني قواعدو ثر خنيك

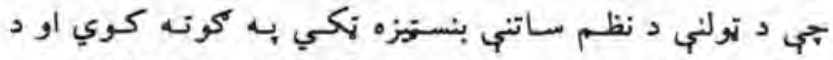

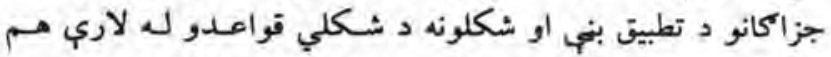
تنظيميري جي د جزايي صحكمو اصول ورته ويل كيري.

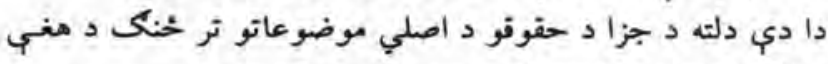

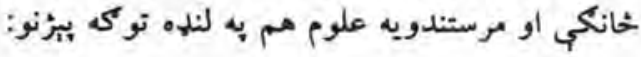

\section{د جزا عومي حقوق}

له هغو قواعدو او مقرراتو خخه عبارت دي جي د د جرمونسو او

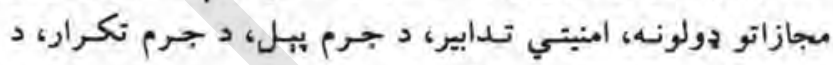

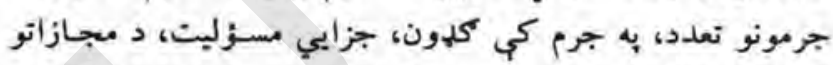

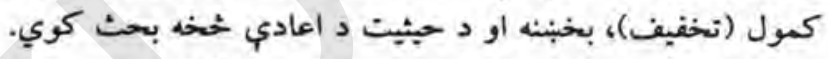

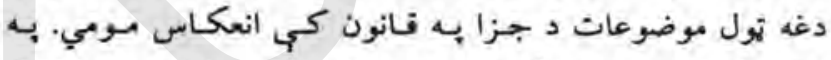

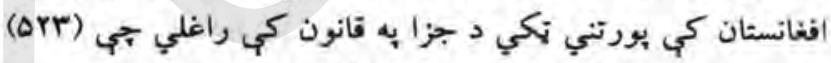

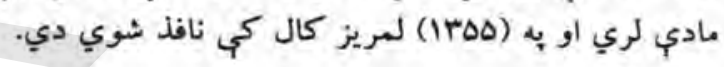
د جزا اختصاصي حقوق

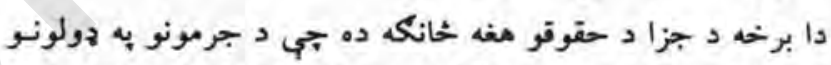

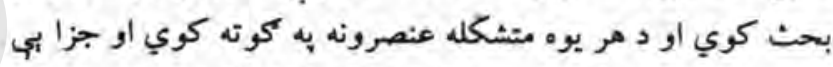

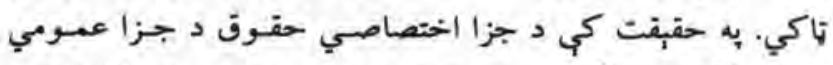

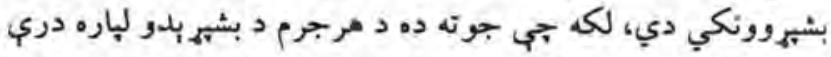

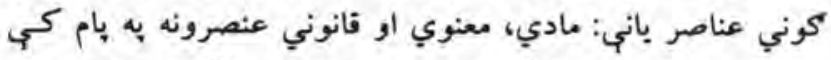

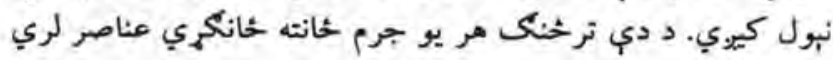

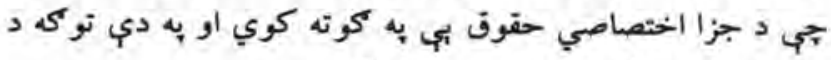

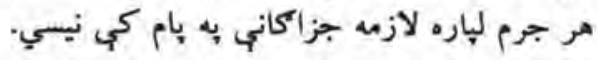

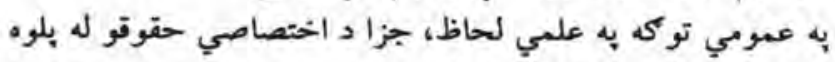

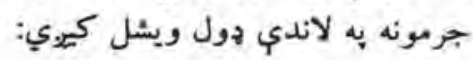

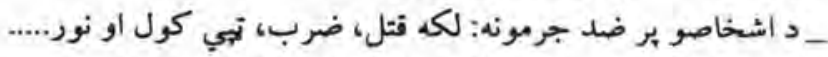

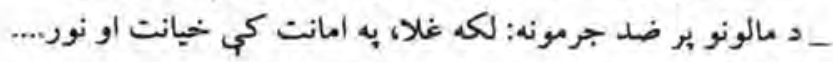

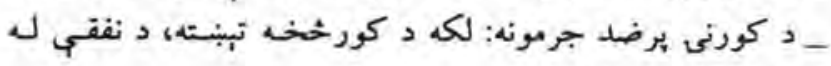

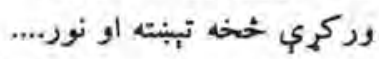

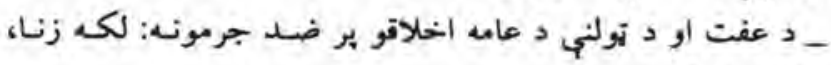
لواطت او نور......

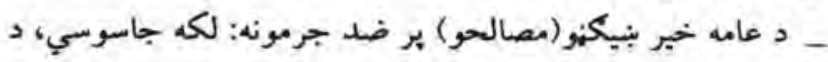

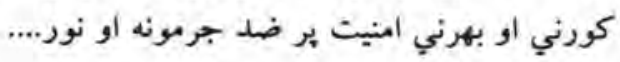


IrAY لمريز كال د كب د مياشتي به F مه نبته نافذ شوى دى.

$$
\text { ه د دكار حقوق }
$$

كه د كار د حقوقو خاكي ثياوو ته خير شـوو، نـو د حقوقو دغه

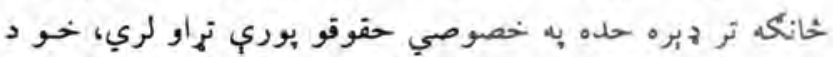

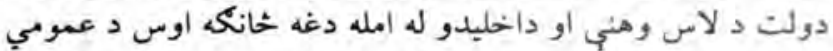

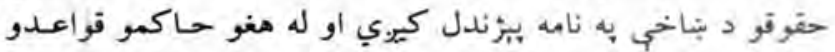

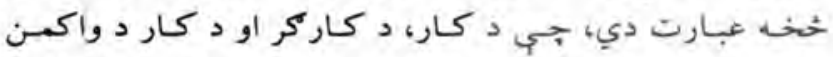

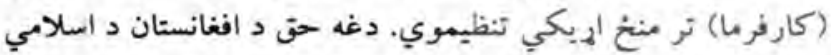

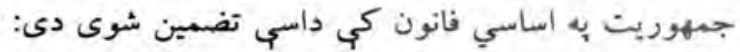

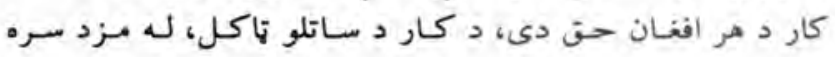
رخصني، دكار او كاركمر حفوق أو د هغه الهوندي جار داري د د قانون له مخي ......... تنظيمبري. د شغل، حرفي أو كسب غوره كول او تاكل د دانون د احكامو به

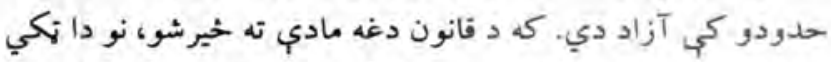

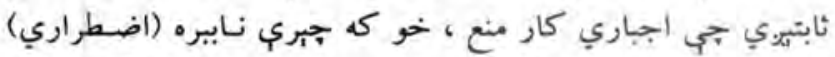

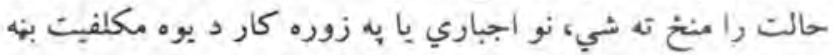

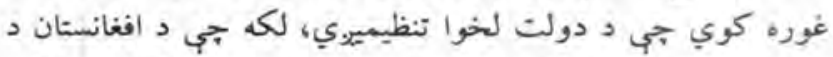

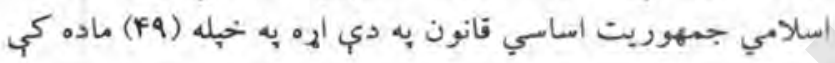

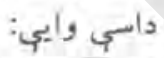

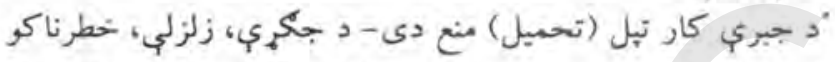

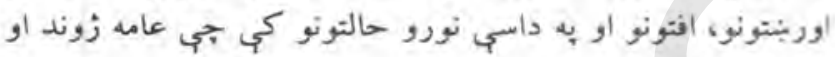

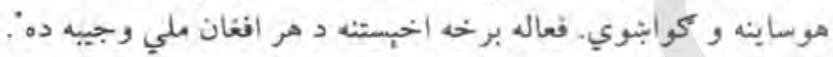

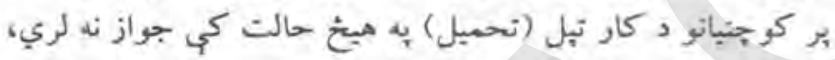

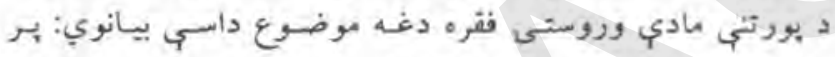

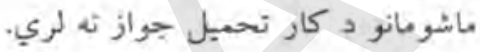

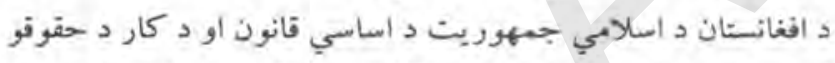

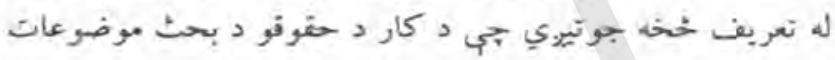

: Is - د كاركمر او د كار د واكمن (كارفرما) ترمنغ أريكي، - مزيد با اجوره،

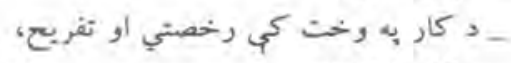
_ د كار ترارداد، _ د كار ساعتونه، ـ ـ كار ساحي،

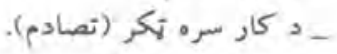

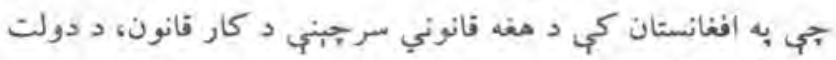

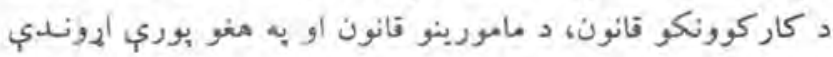

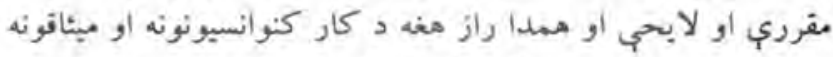

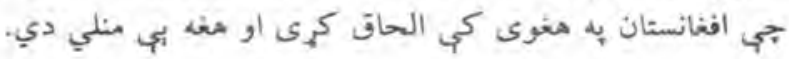
دوام لمك

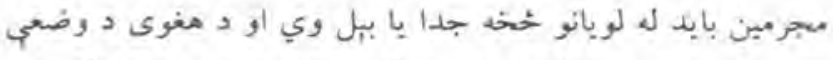

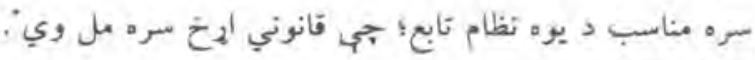

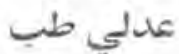

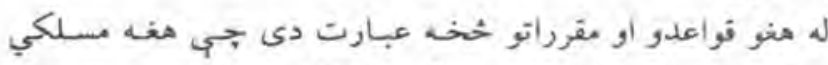

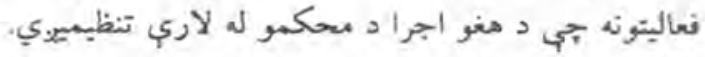

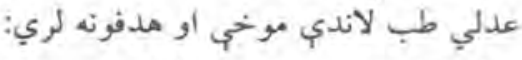

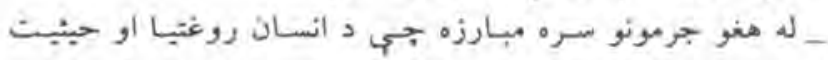
كوابنوي، الهان _ 2 تراوماتيزم، تسموماتو او نابيرو مركونو تثبيتول،

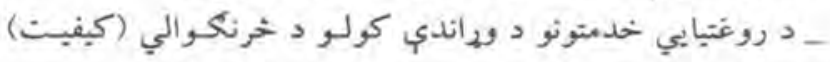
لويدول.

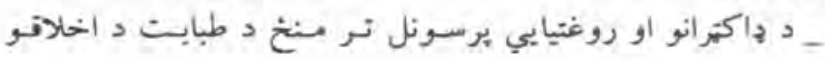
يوهونه او بر اختيا به افغانستان كي دوني عدلي طب قانوني سرجني دا دويث _ د جزايب اجرآنو موقت قانون. د نشه يي توكو بر ضير ضد قانون.

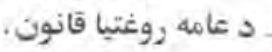
ماني قانون. - مان. ـ د عدلي طب د خدمتونو د مونسي قانون.

\section{جرم يبرّندنه ,كرايمينالوزي، Criminology}

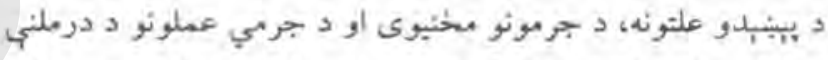

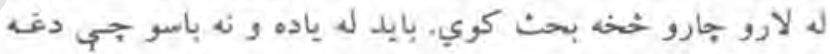

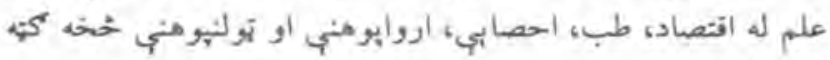

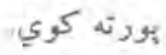

\section{كرايمينالبيتيك}

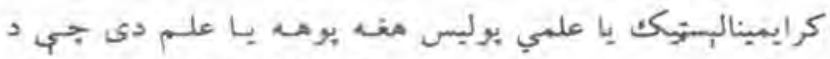

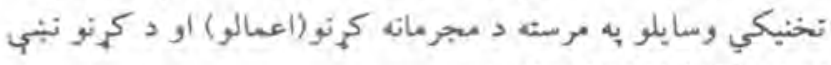

$$
\text { نبنّاني (اثار) او اعلايم تنبيتوي. }
$$

$$
\text { د جزايي محاكماتو اصول }
$$

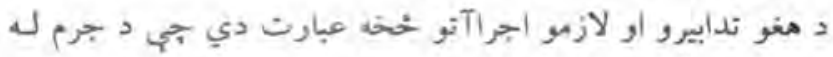

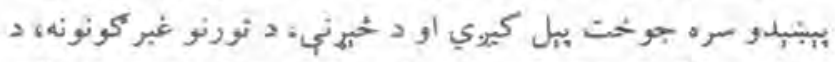

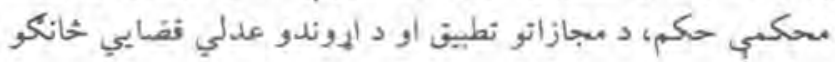

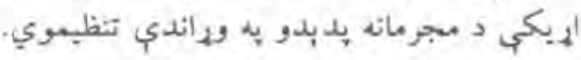

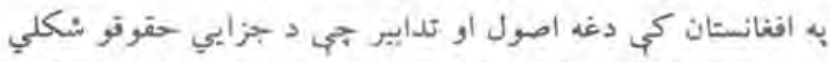

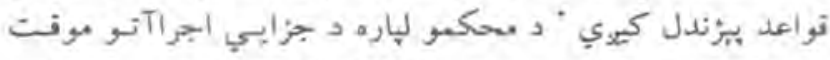

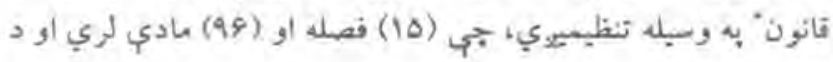




\section{جرا رودكى را}

\section{تجليل مى نماييم؟؟}

\section{هر كه ناموخت از كذشت روز كار نيز ناموزد ز هيج آموز كار كنار روز}

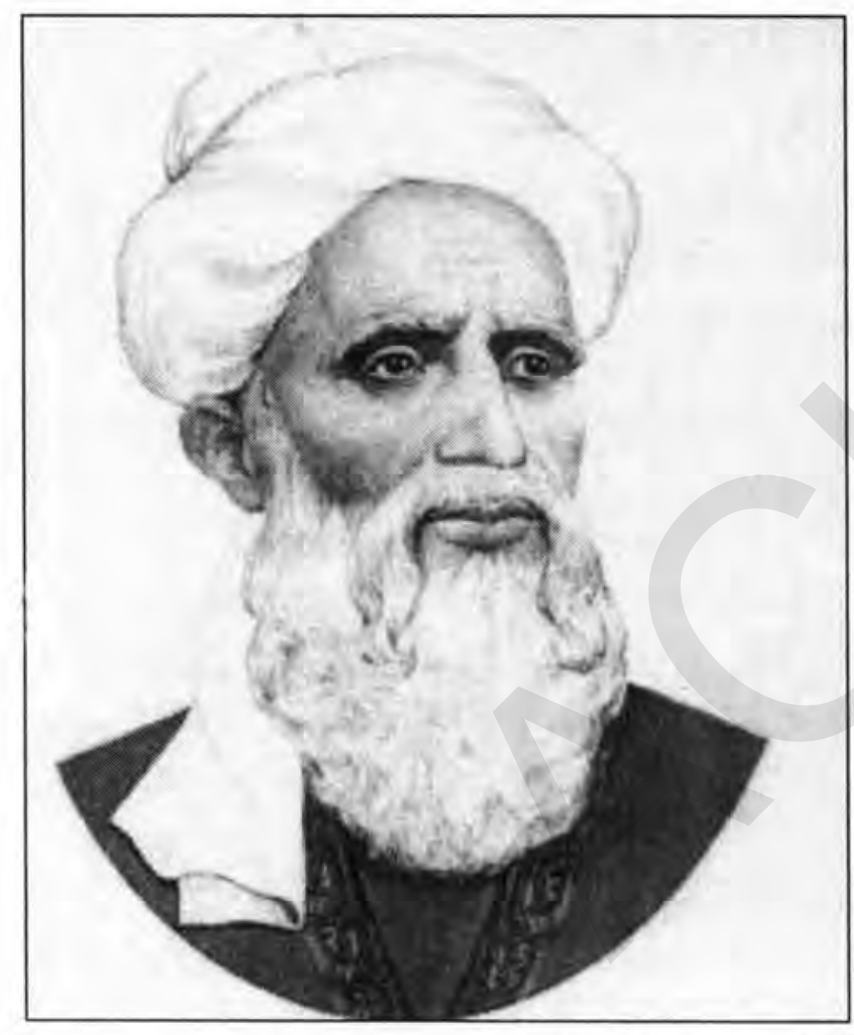

دادن سر موافقت نشان مىدهد.

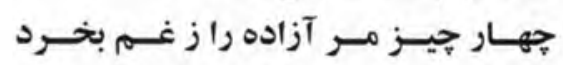

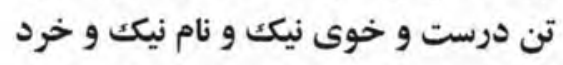

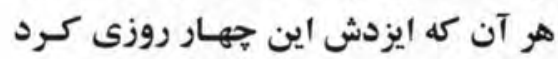

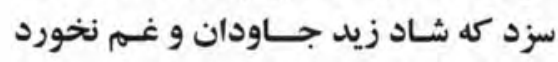

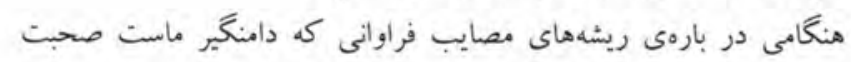

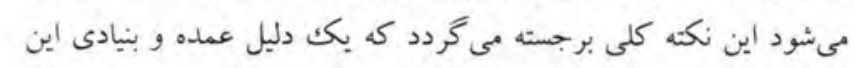

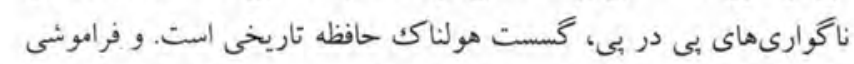

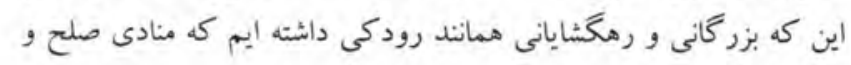

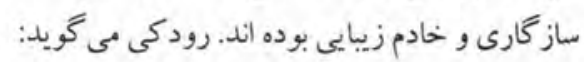

در تمامى ادوار تاريخ بشريت، همهى دانشمندان و صاحب نظران در اين

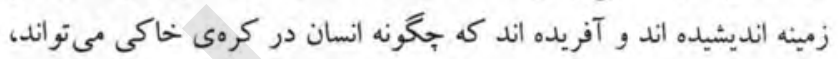

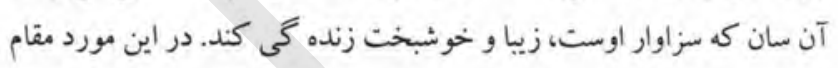
و نقش مهمى راشعراى راستين بر عهده داشته اند و دارند.

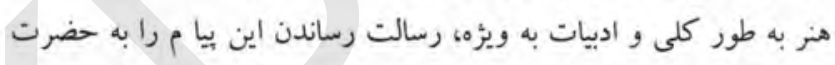

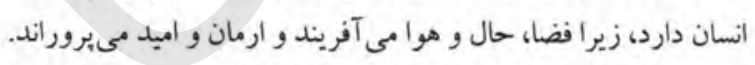

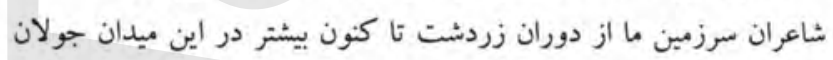

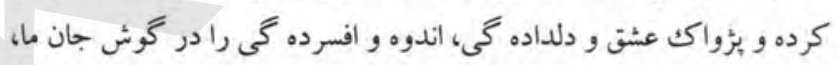

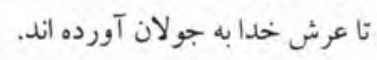

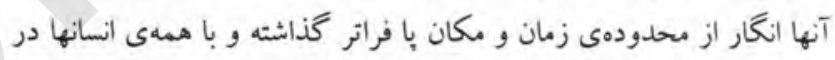

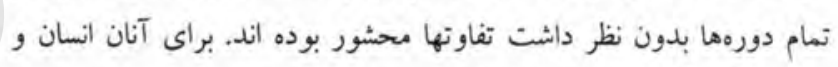

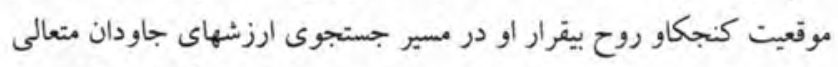

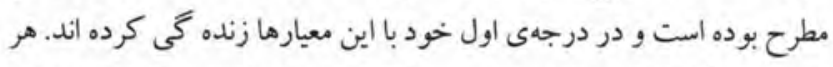

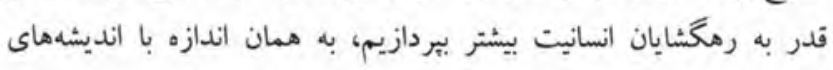

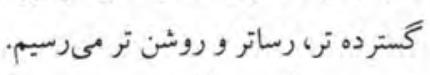

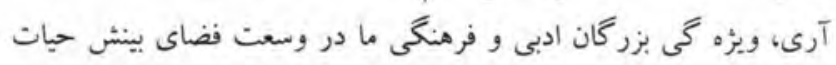

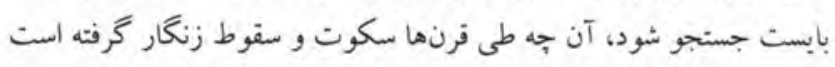
و به شنستوى نغاه نياز دارد. بزركان سرزمين فرهنگى ما، كه بزرختر از وطن جغر افيايى ماست، با جنان

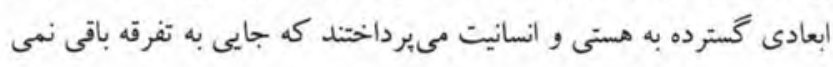

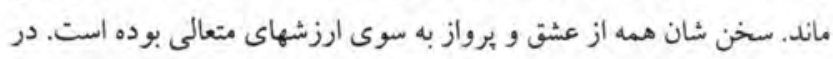

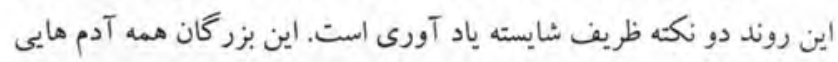

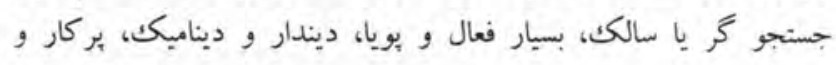

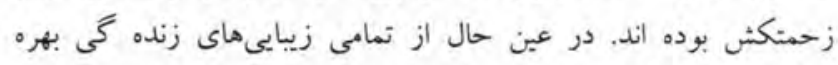

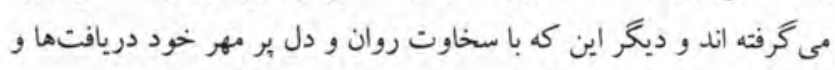

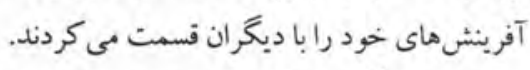

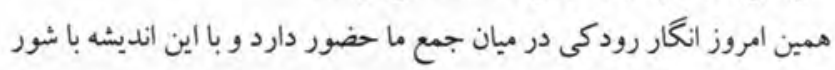




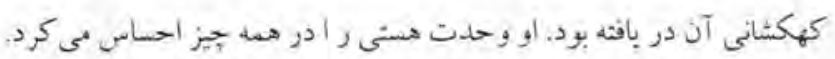

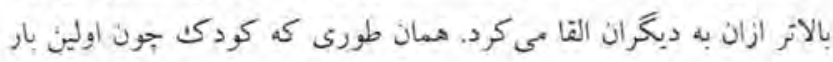

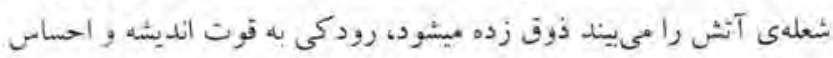

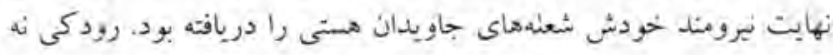

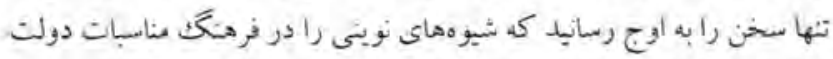

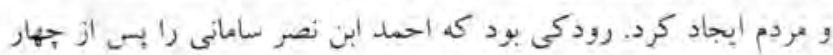

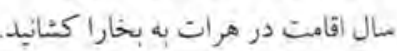

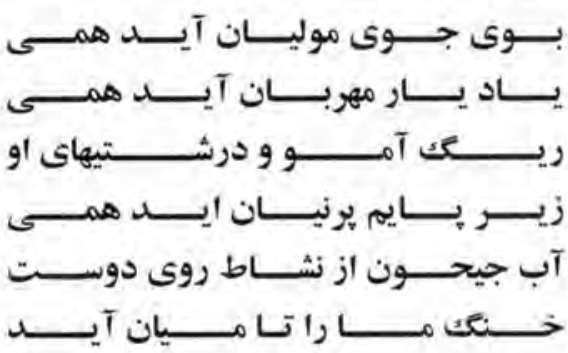

همين دو تصوير - ياد يار و نشاط روى دوست - جيى شيكوهى داردي ياد

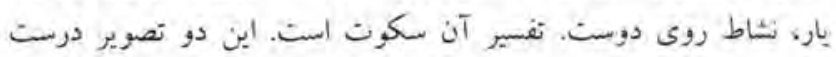

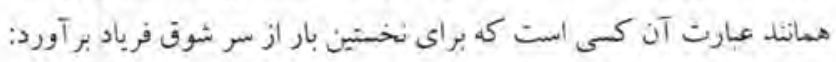

$$
\text { كز سرخ زيباست. }
$$

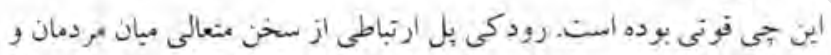

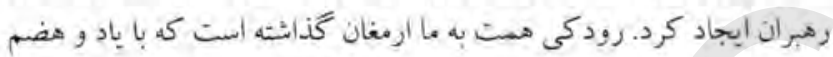

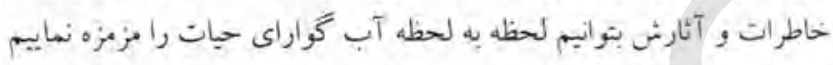
ور به اين حفيت دست يابيم كه هستى سخن است.

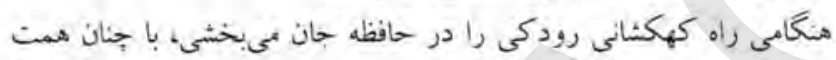

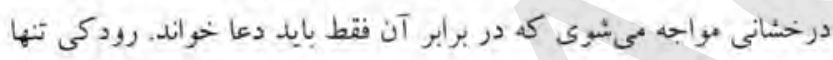

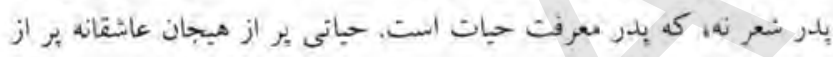

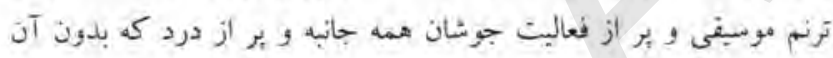

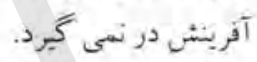

رودكى براي عا روابت شيونهاى عاشقائه زيستن و درد كتَبدن را بيان

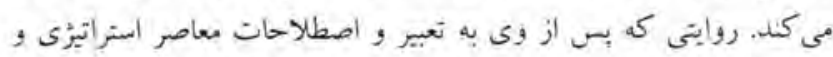

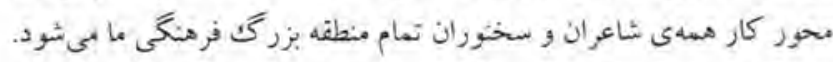

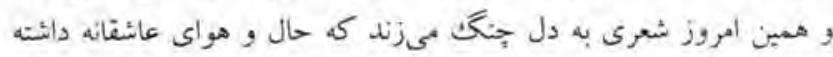

بانَّد.

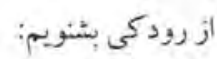

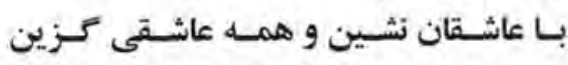

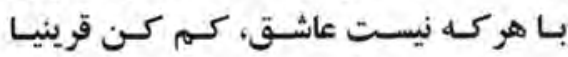

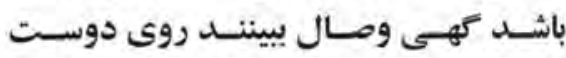

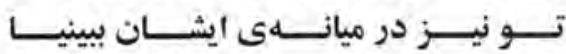

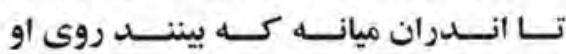

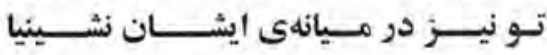

جون تيغ به دست آرى، مودم نتوان كشت

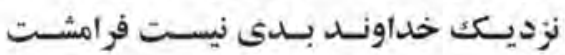

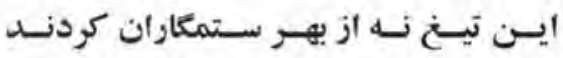

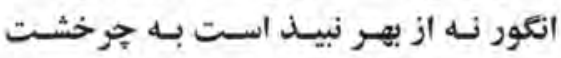
عيسى بسه رهسى ديسد يكسى كثسته فتـاده

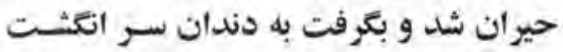

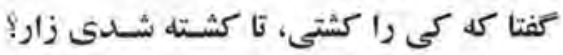

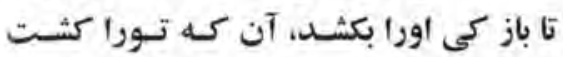

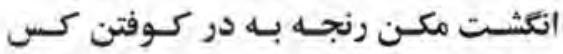

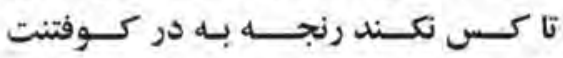

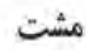

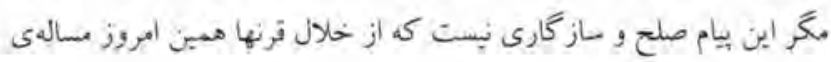
هـنى و بنستى ماسته"

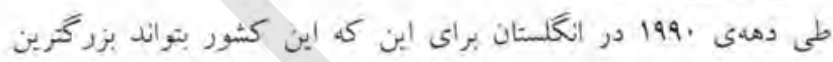

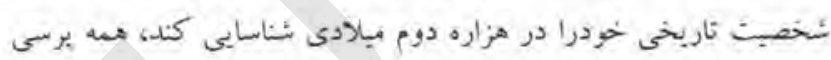

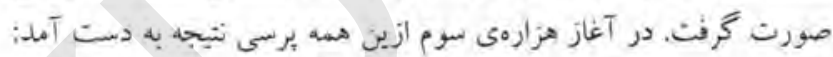

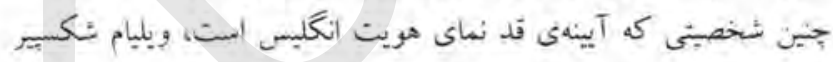

و رودكى براي ما هديه يبست كه از درون دل و غاطعه با ما سخن مي كريد.

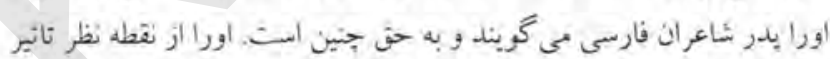

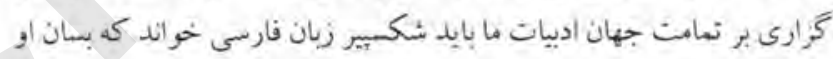
رهكثا و الهام بختش است.

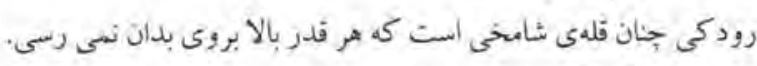

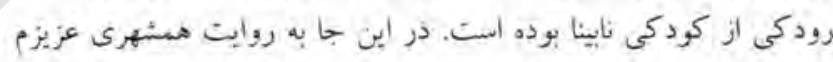

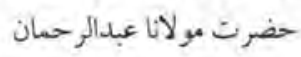

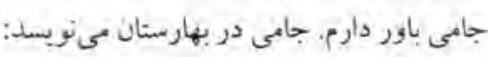

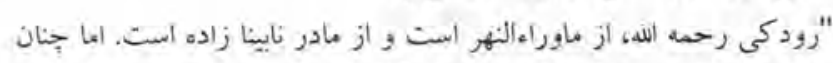

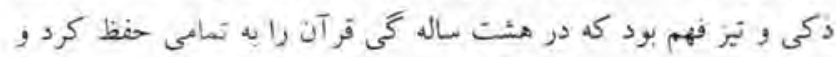

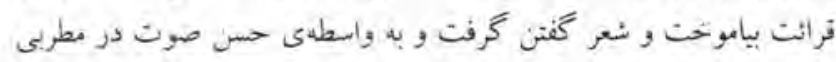

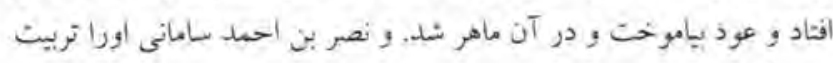

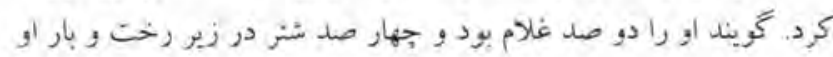

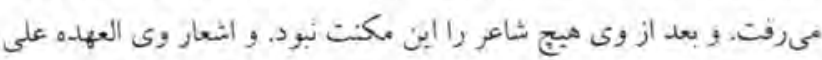

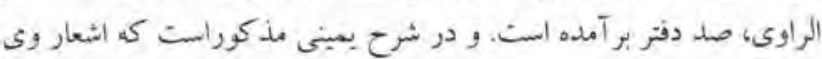

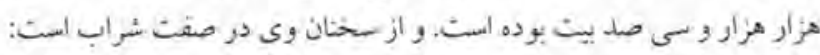

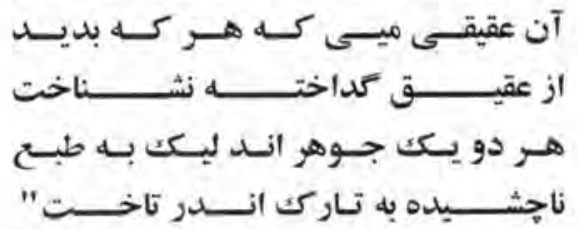

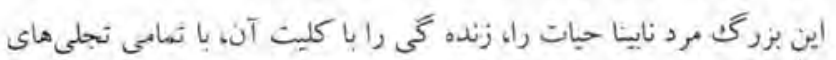

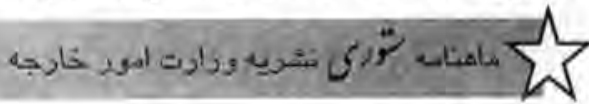


كرختى و كراهت و عطالت كنونى را در ذهن ها، دلها و عمل هاى ما بكيرد.

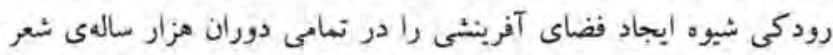

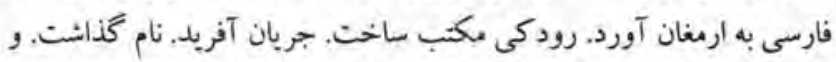

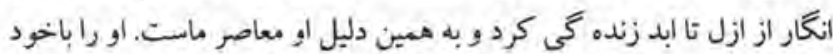

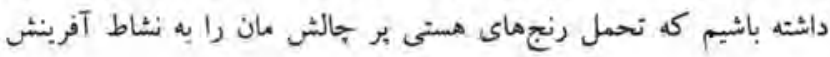

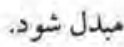

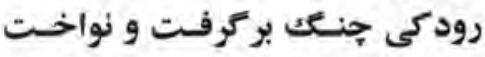

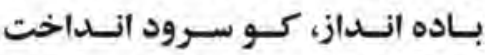
زان عقيقسى ميسى كسه هوركسه بديس

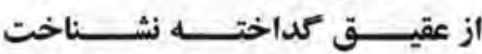
هر دو يكت كوهرند، ليكك بـه طبـع

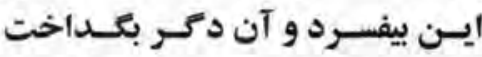

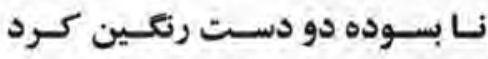
نا جشـيده به تـار كت انسلدر تـاخت

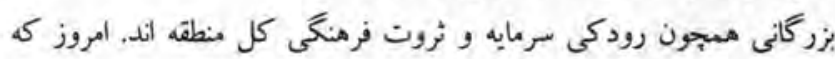

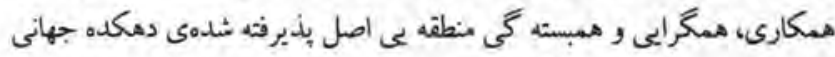

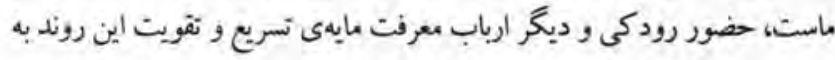
شمار مىروند. آنها سفيران جاودان روابط برادرانه ميان مردمان منطقه ما هستخد.

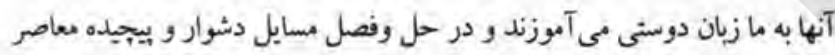

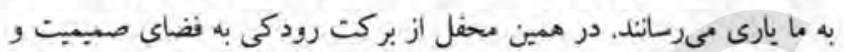

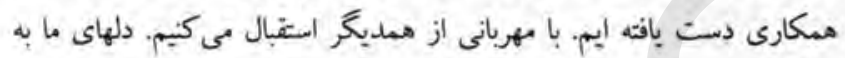

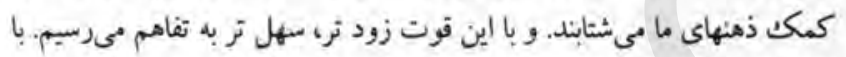

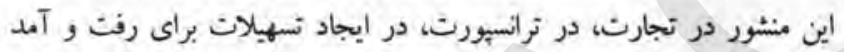
شهروندان كثورهاى مان، با مشاركت در توسعه دانش و فرهنغن، اقتصاد و امور

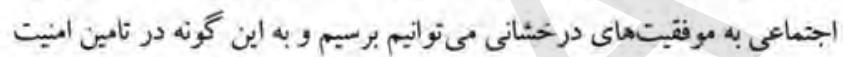
و رفاهيت مهوطنان خود زود تر دست يابيم.

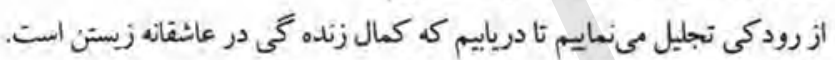

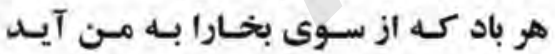
با بوى كـل و مشـك و نسـيم سـمن آيسـ بو هر زن و هر مرد، كجـا بـر وزد آن بـاد

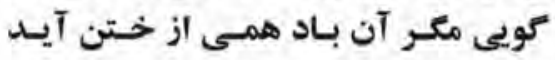

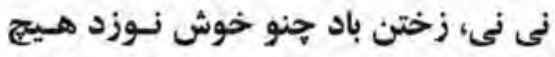

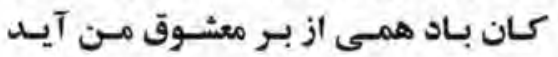

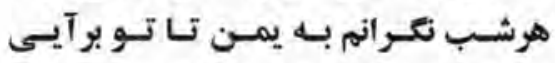

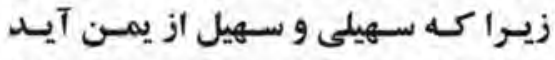

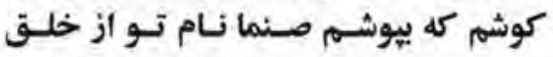

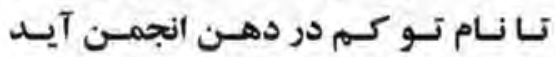

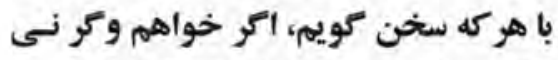

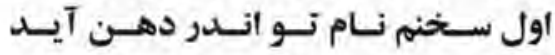

در اوضاع و احوال كنونى كه با درد و فشار زياد ثلاش مىكنيم أز تونل

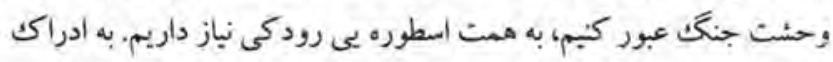

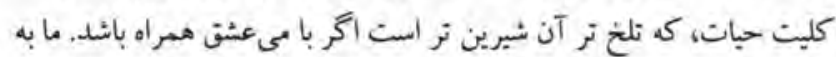

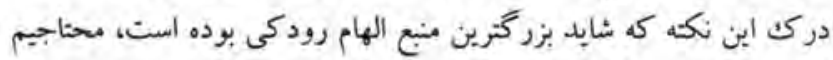

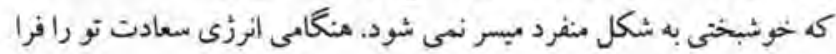

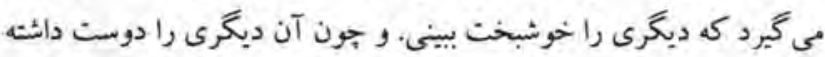

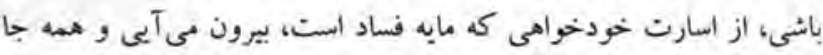

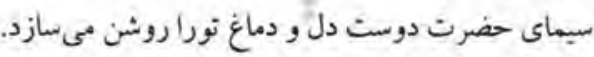
هيج شادى نيست انسدر ايـن جهـان

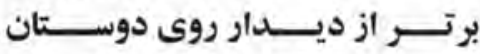
هـيج تلخـى نيست بسردل تلـخ تسر

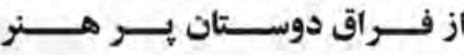
ميراث رودكى تنها غزل نبكو سرودن نيست. ميراث رودكى دريافت كليت

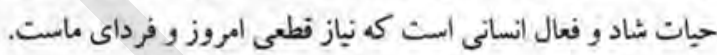

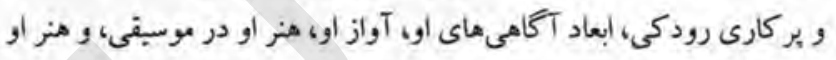

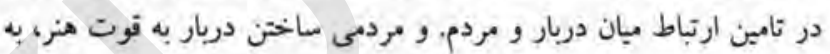

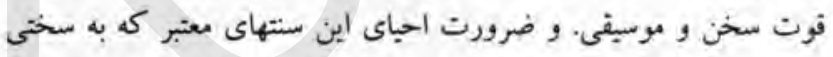

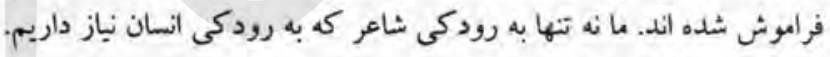

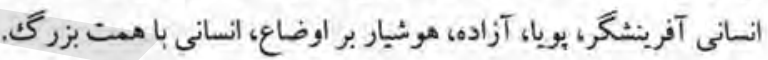

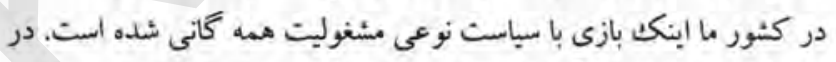

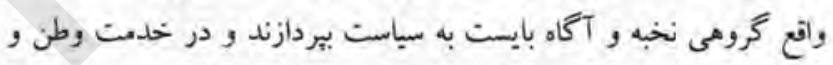

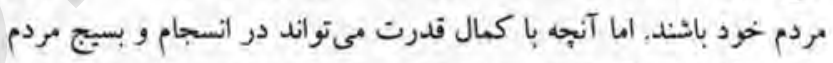

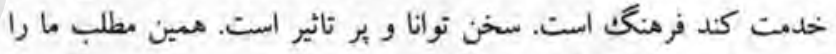

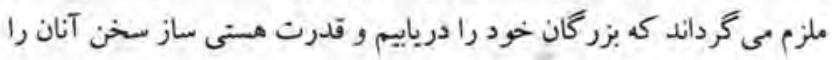

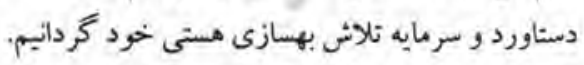

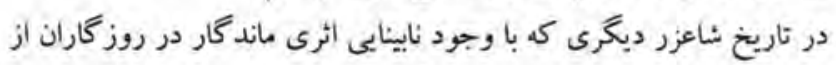

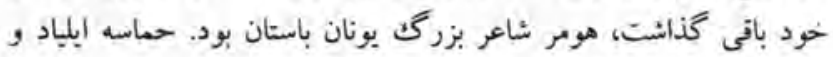

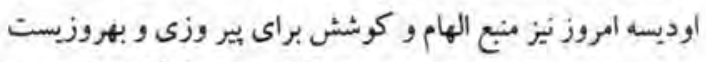

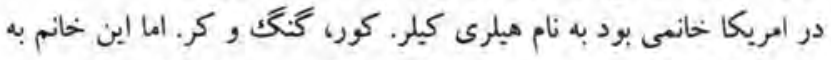

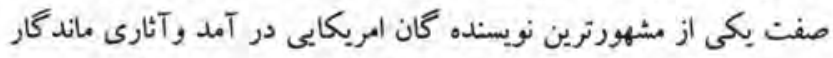

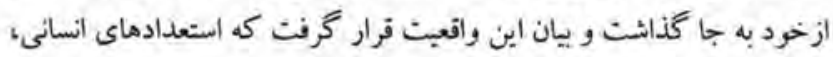
خدايى و بيكران است.

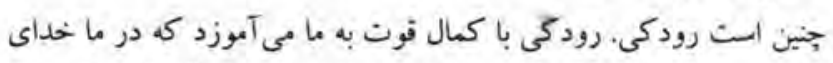

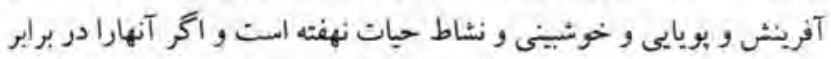

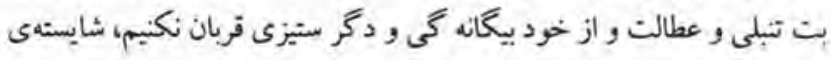

$$
\text { عزت آسمانى نخو اهيم بود. }
$$

رودكى قامثى بر افراشته دارد كه از هزار سال كذشته است ود و أز هزارمهاى

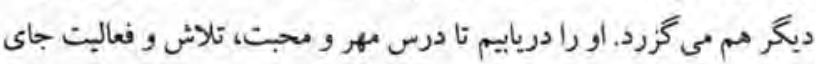




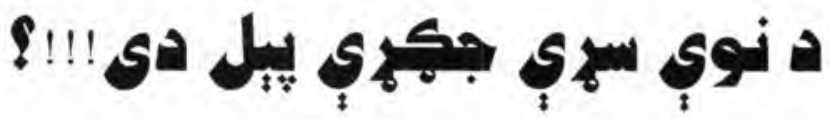

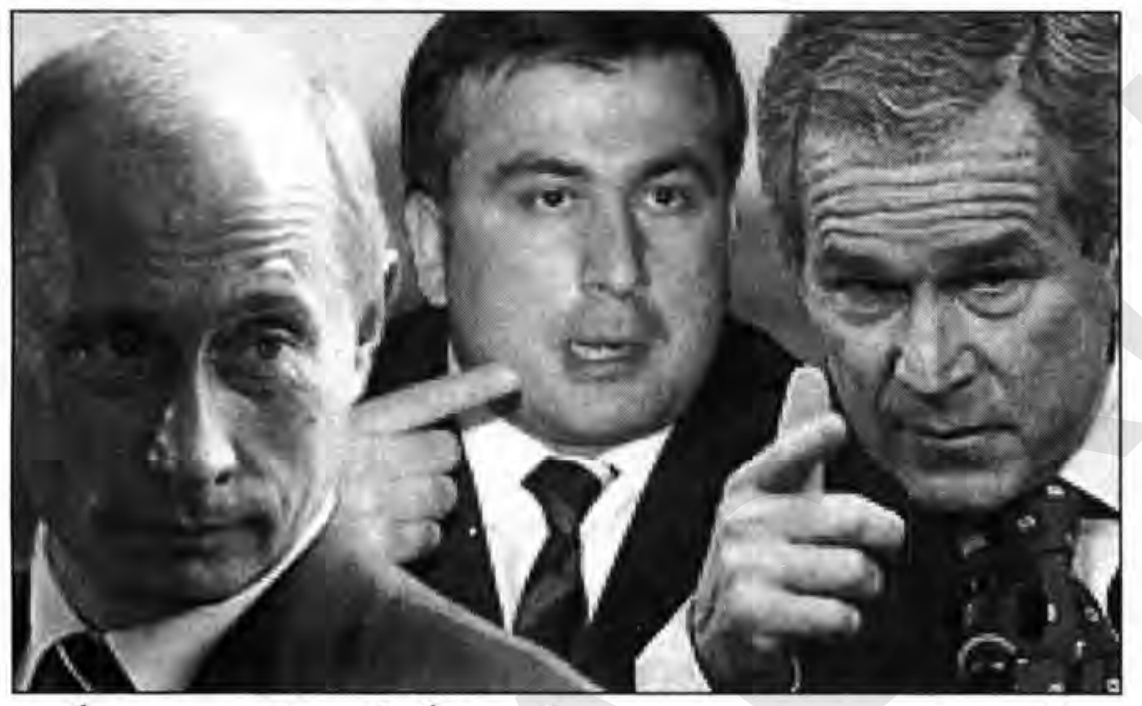

له هني جملي د سهيلي اوستيا استقلال د كوزو

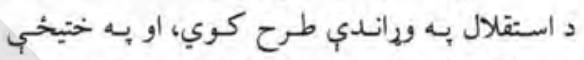

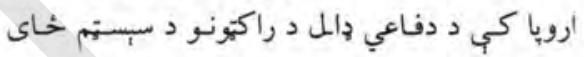

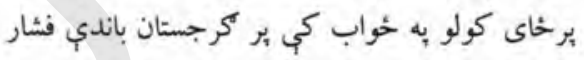

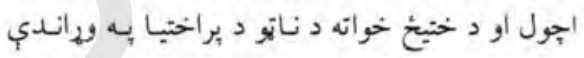

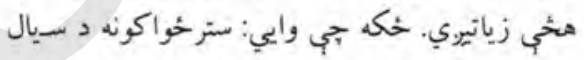

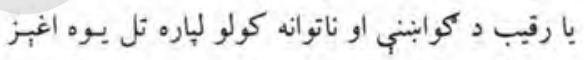

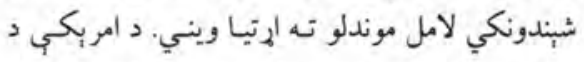

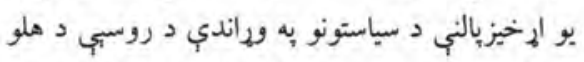

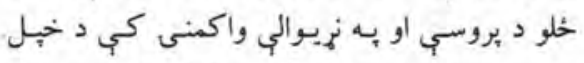

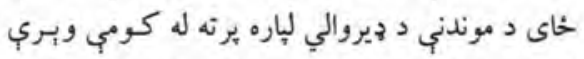

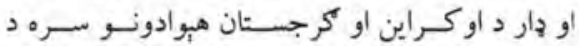

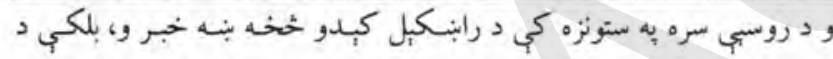

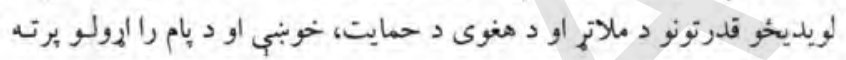

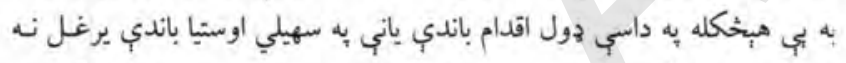

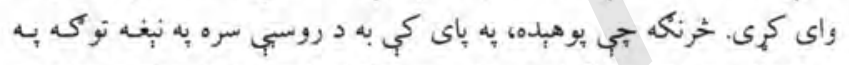

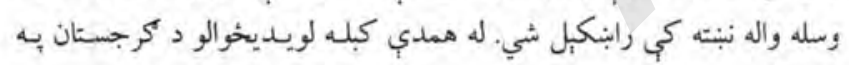

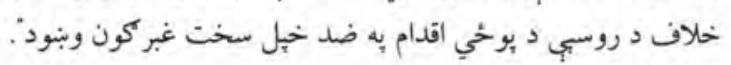

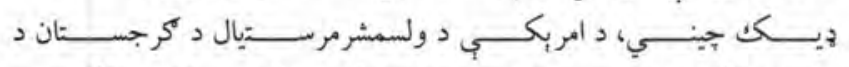

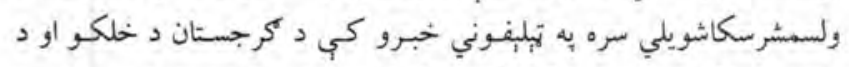

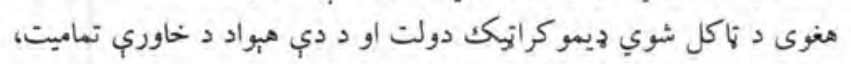

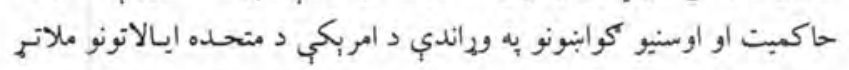

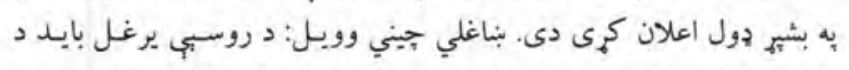

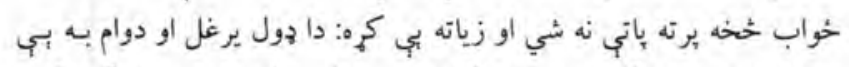

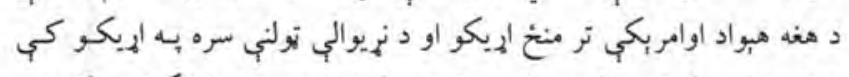

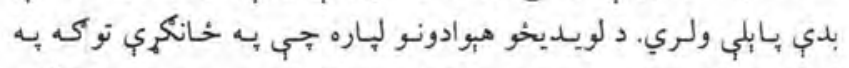

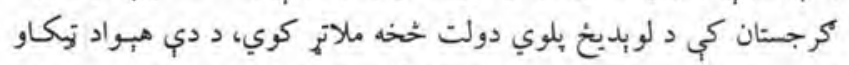

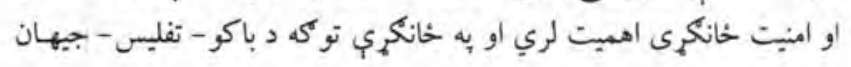

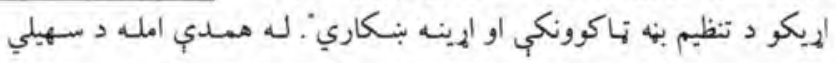

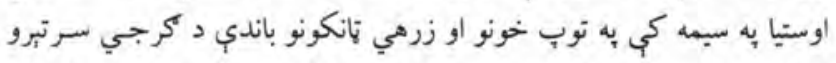

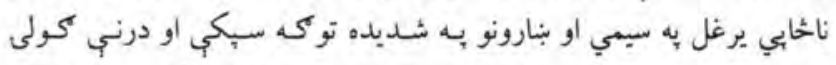

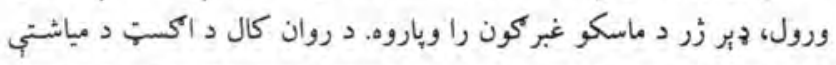

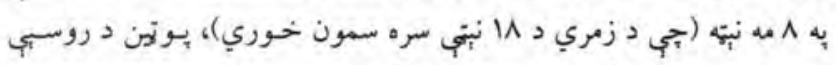

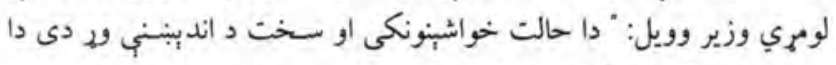

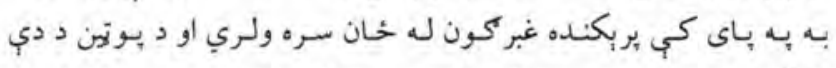

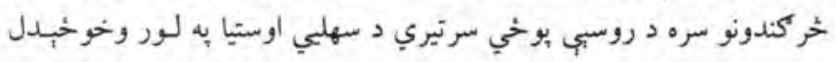

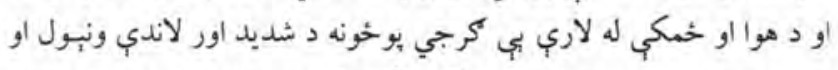

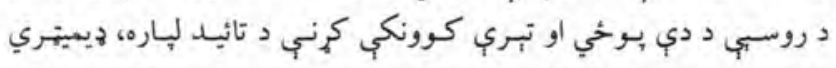

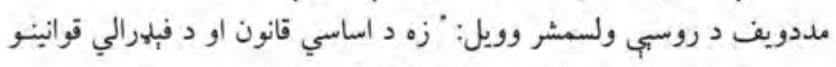

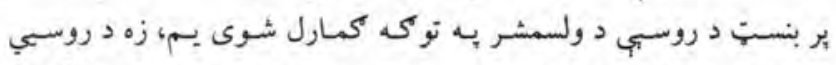

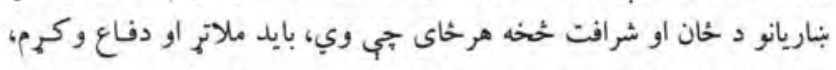

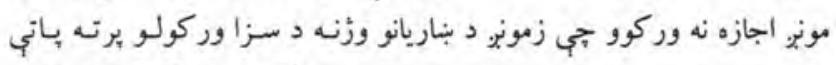

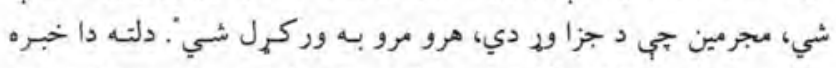

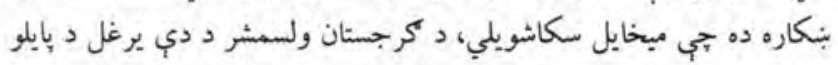




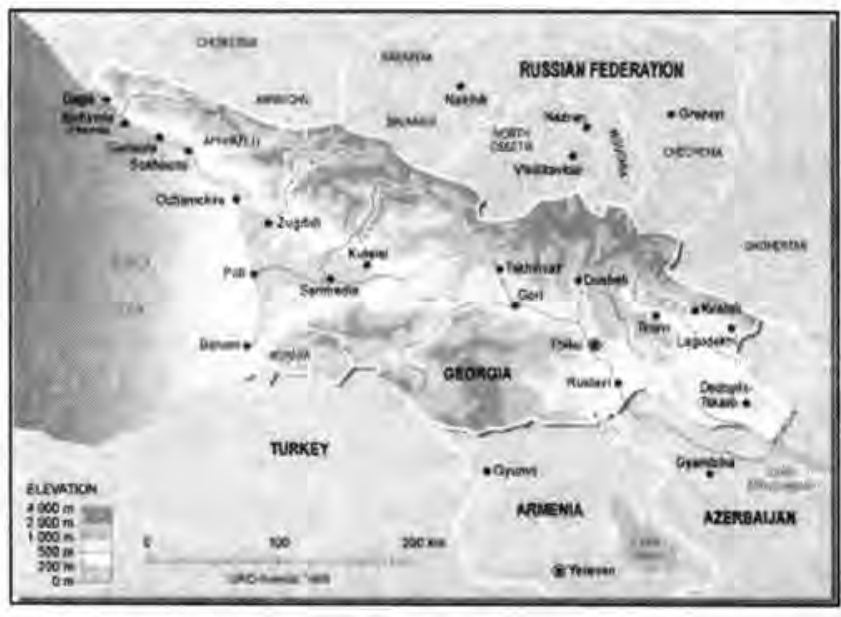

سبيمي لياره ور امنيتي جتر جور كم. له دي أمله د شـانكهاى د ممكاريو

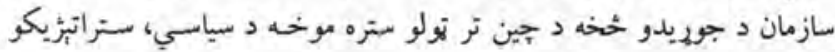

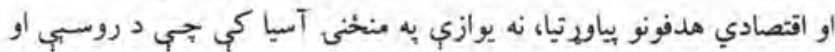

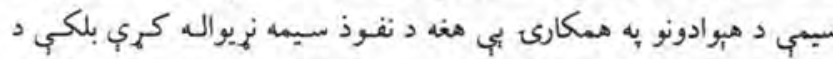

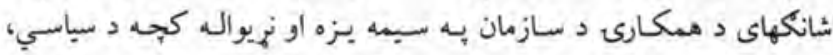

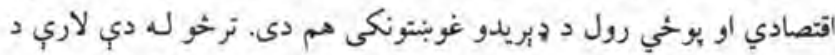

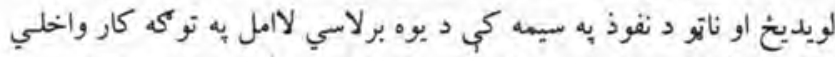

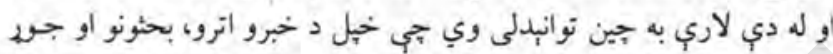

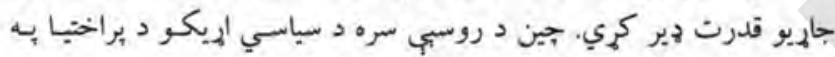

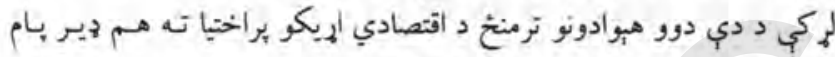

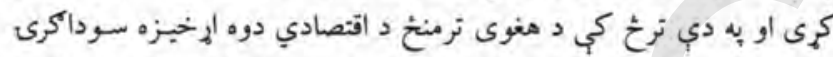

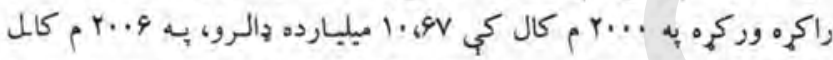

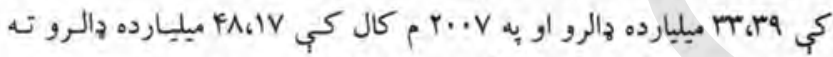

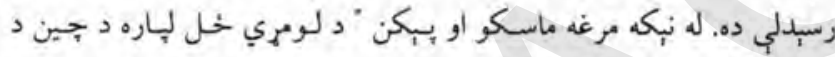

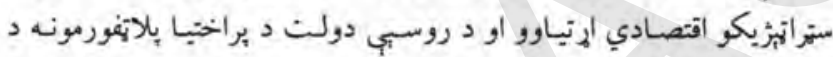

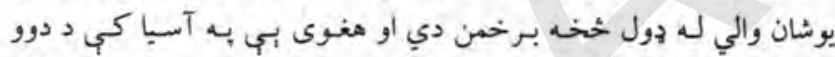

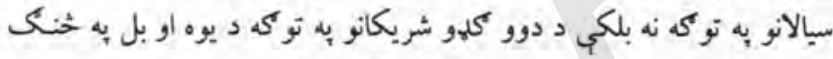

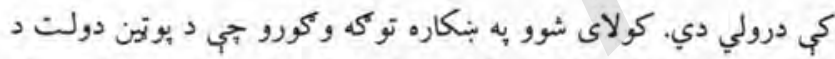

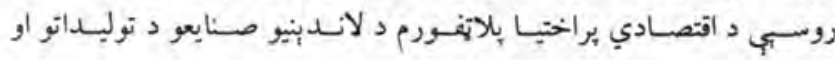

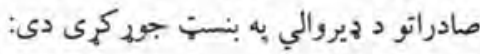
1- نفت أو كاز r - هستوي انرزئ

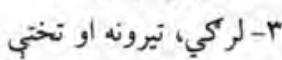

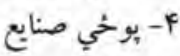

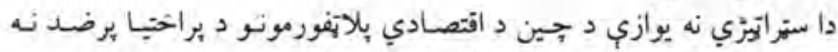

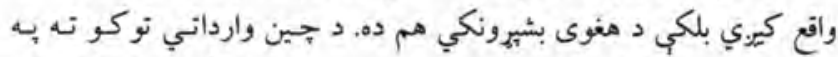

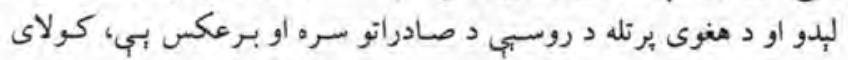

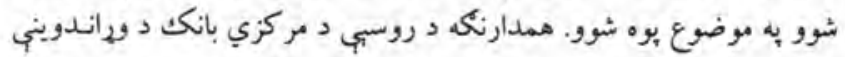

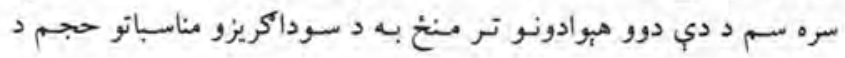

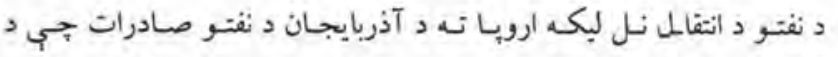

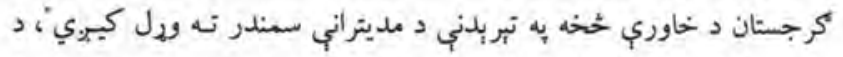

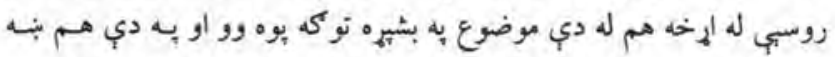

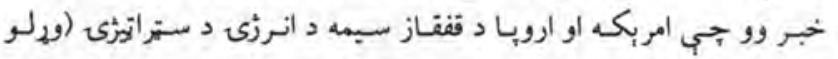

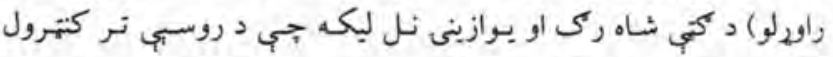

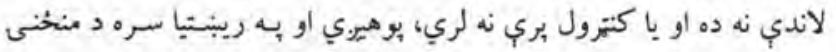

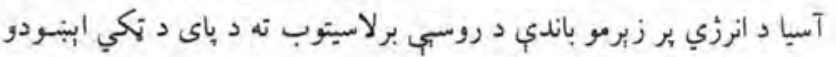

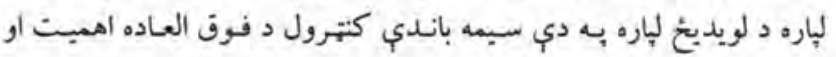

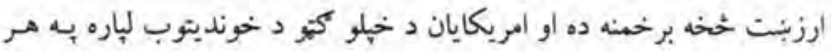

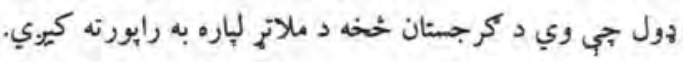

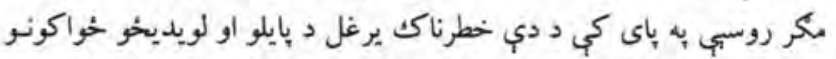

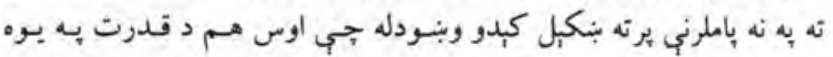

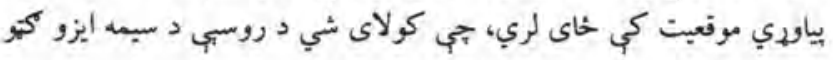

$$
\begin{aligned}
& \text { خخه به ملاتي او دفاع را بورته شي. } \\
& \text { خو جين! هو جين!" }
\end{aligned}
$$

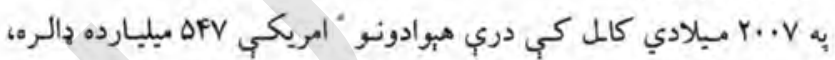

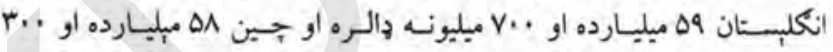

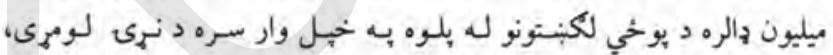

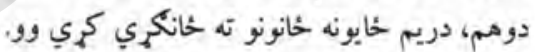

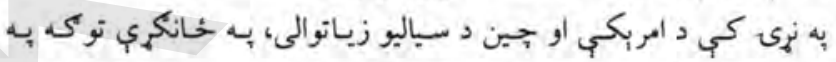

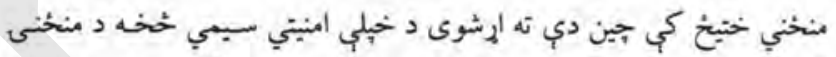

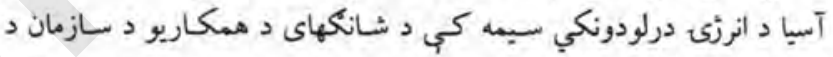

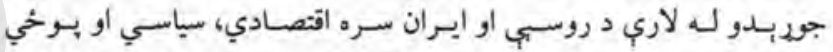

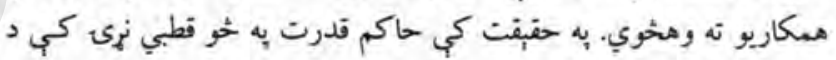

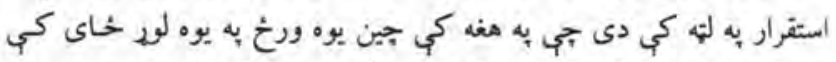

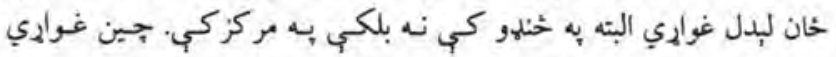

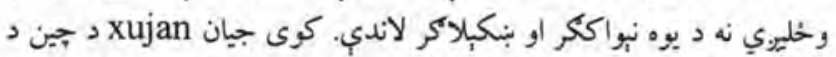

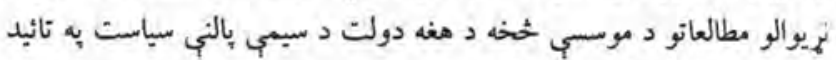

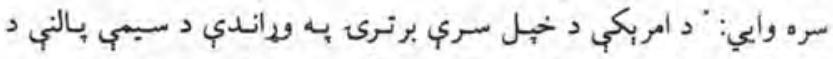

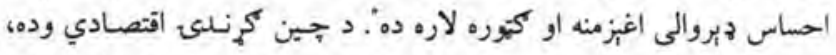

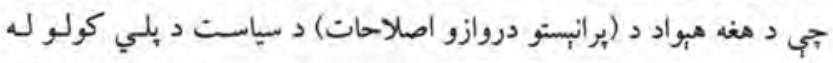

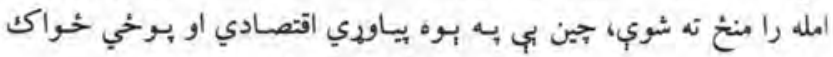

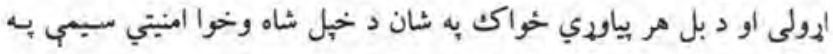

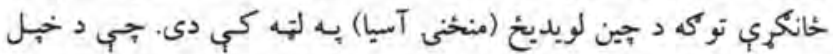

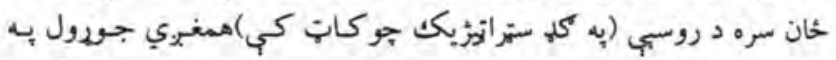

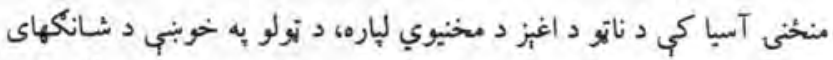

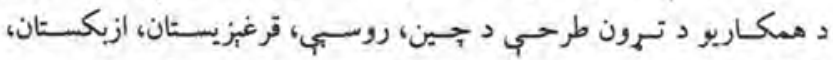

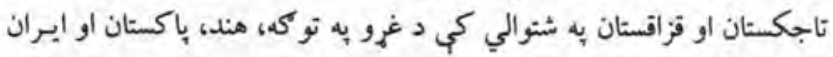

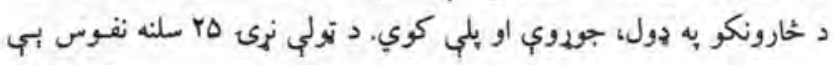

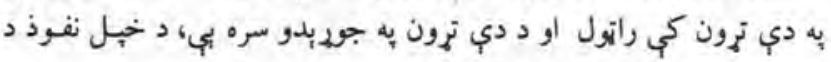


دريم د انرزّي موادو تضمبن.

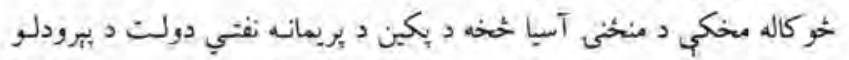

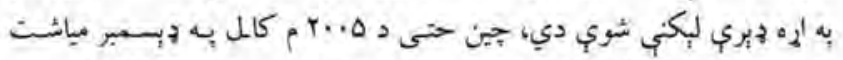

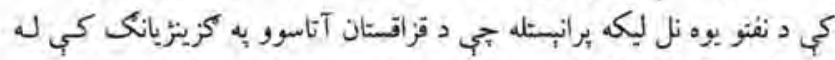

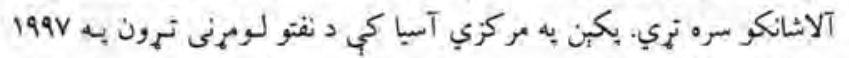

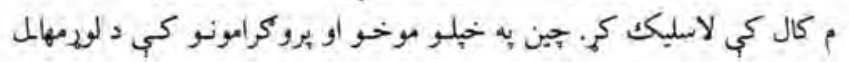

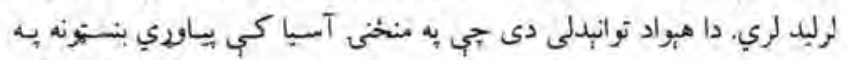

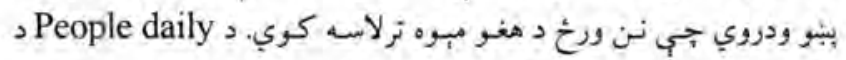

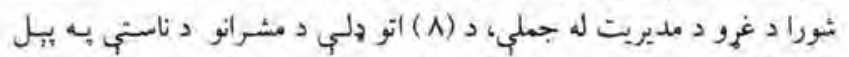

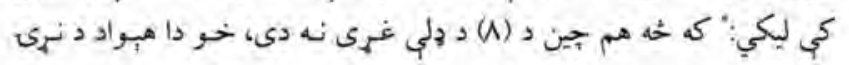

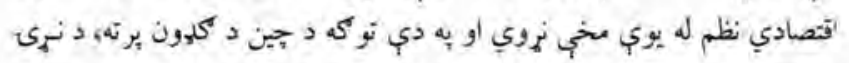

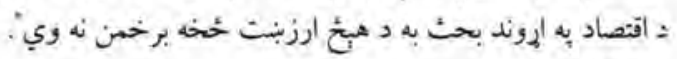

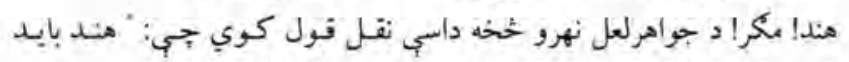

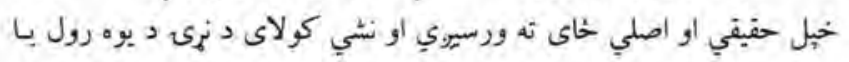

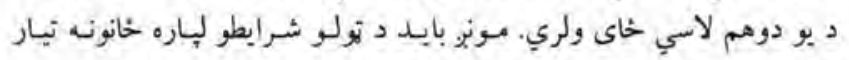

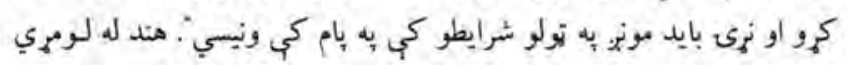

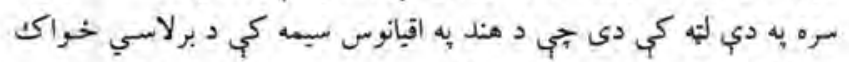

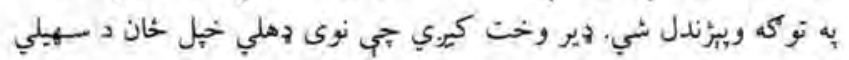

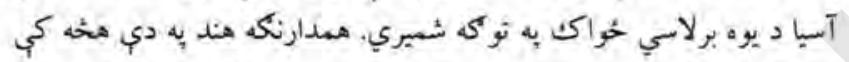

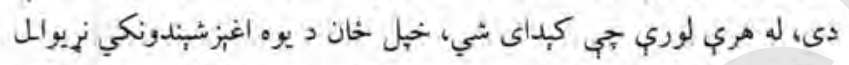

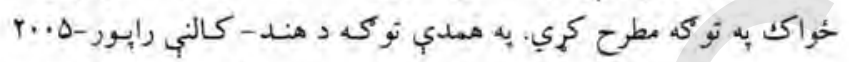

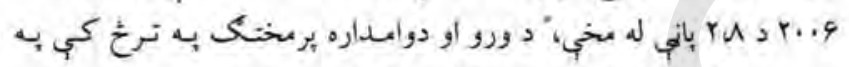

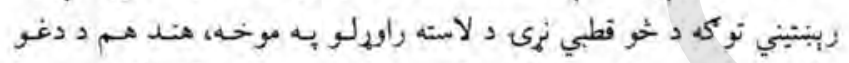

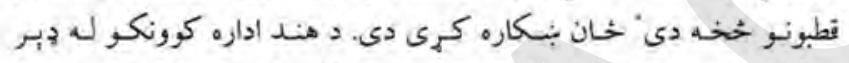

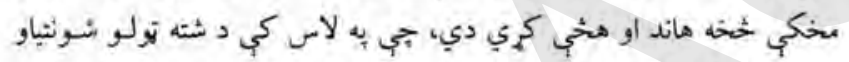

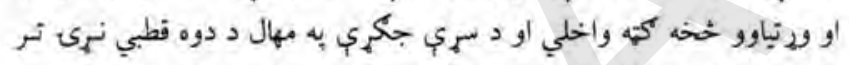

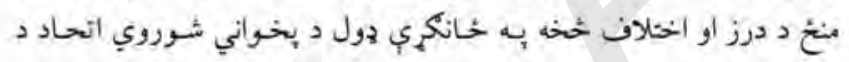

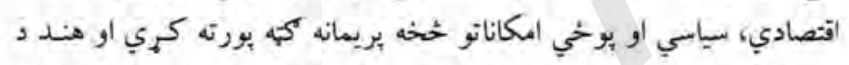

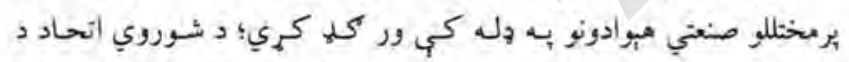

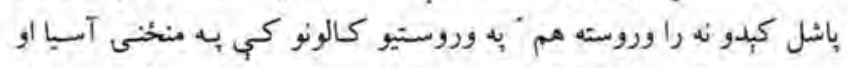

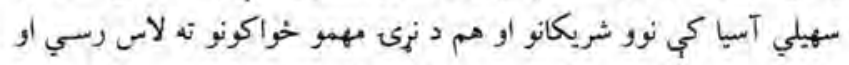

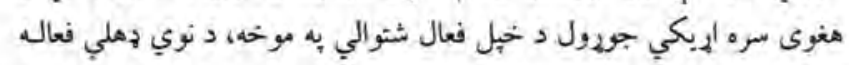

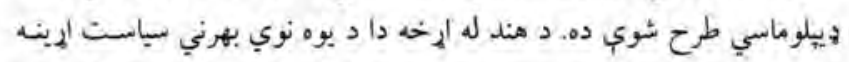

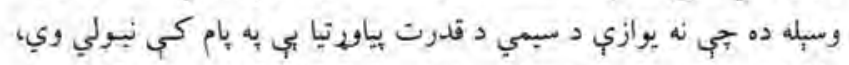

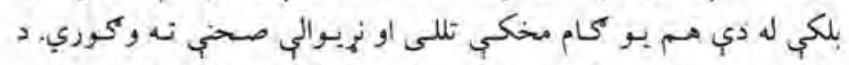

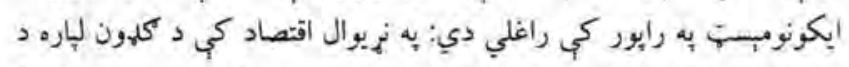

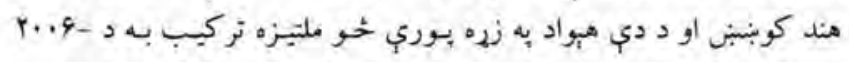

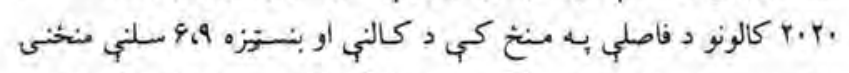

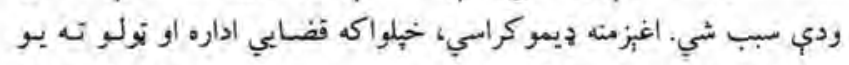

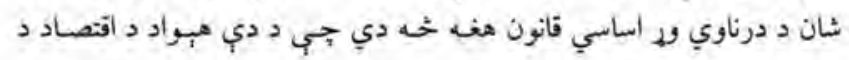

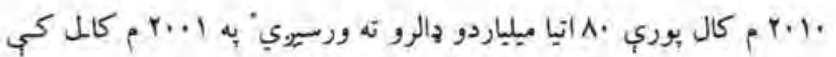

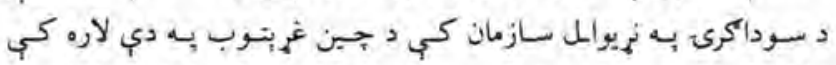

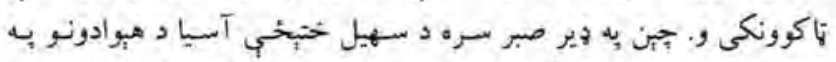

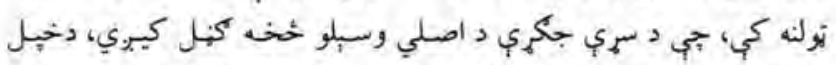

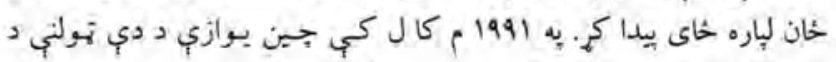

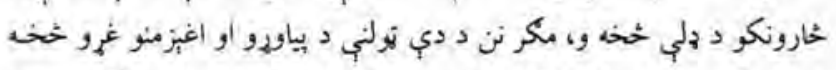

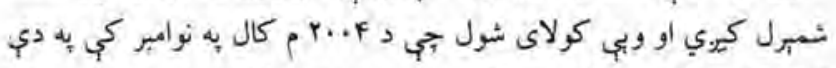

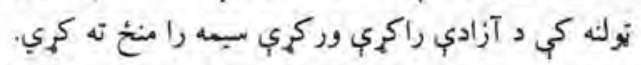

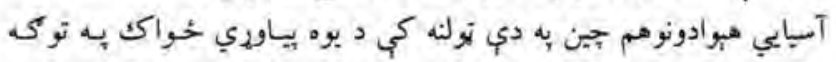

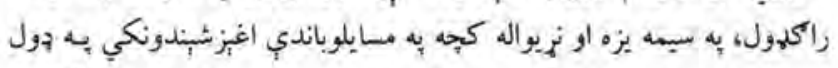

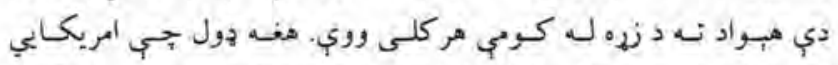

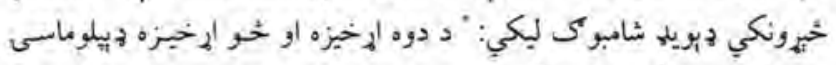

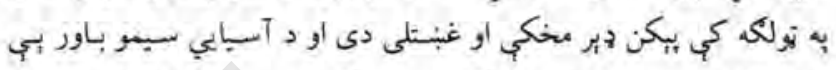

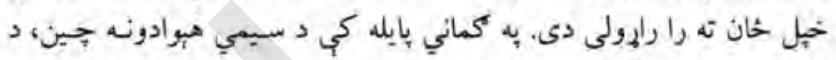

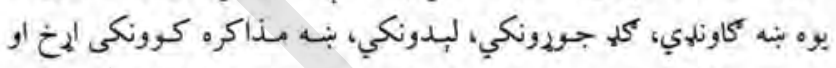

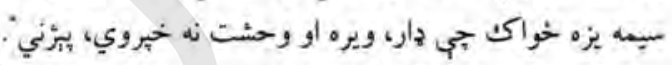

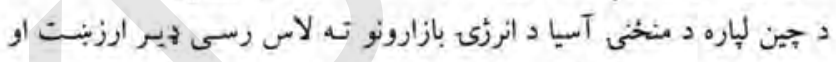

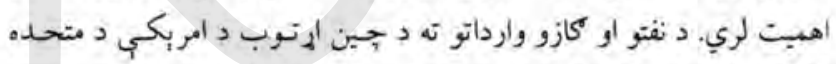

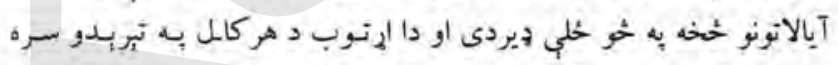

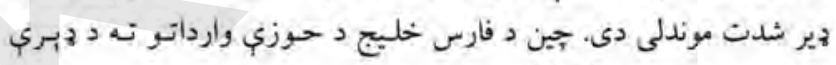

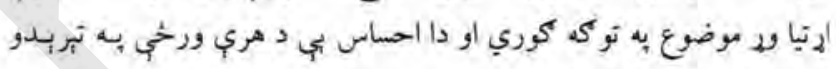

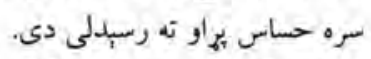

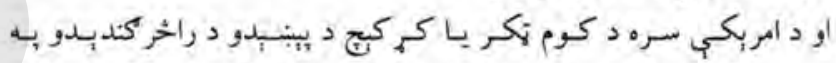

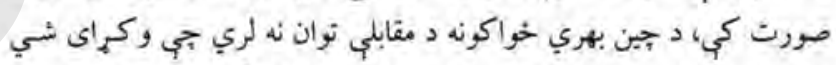

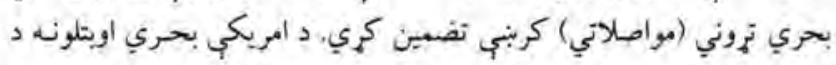

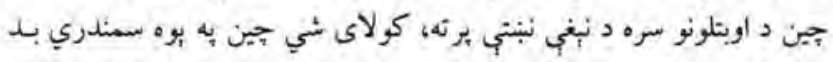

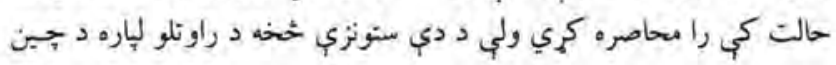

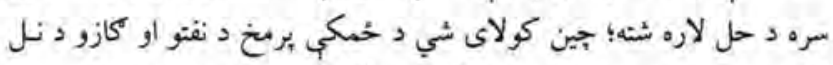

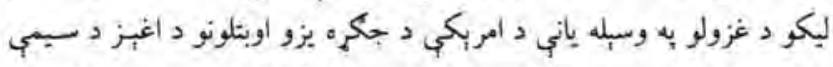

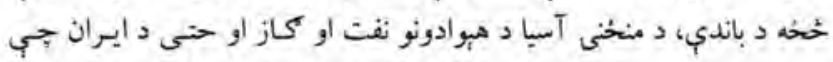

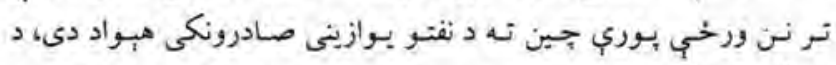

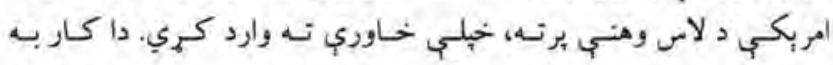

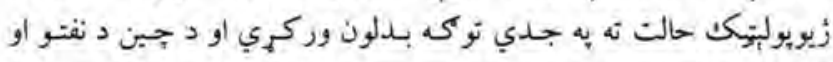

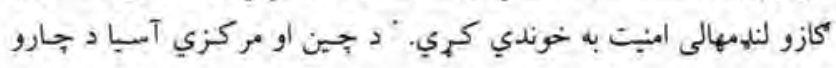

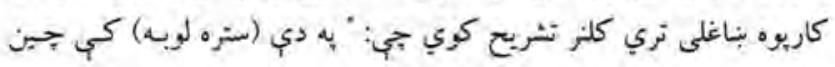
هم دري موخي خحاري.

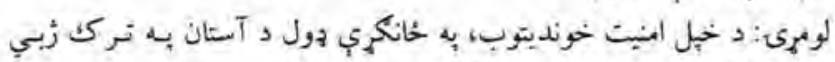

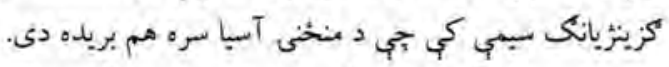

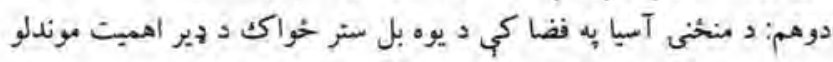

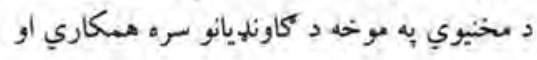




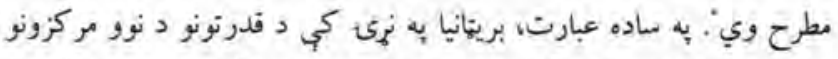

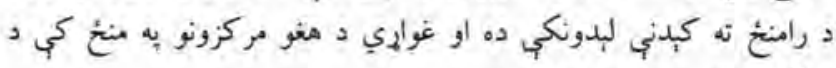

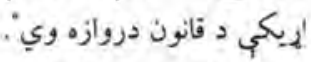

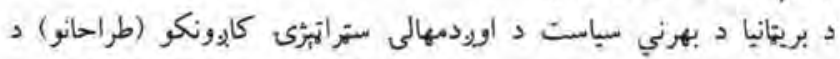

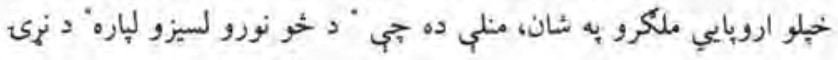

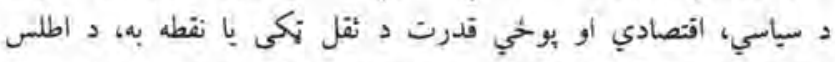

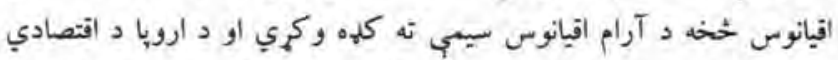

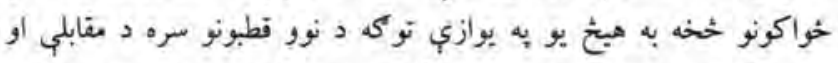

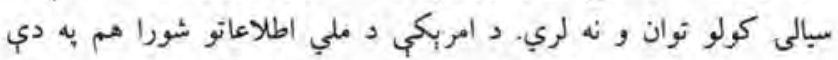

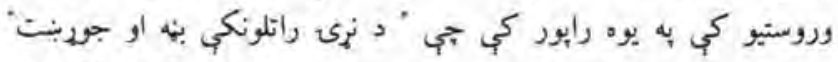

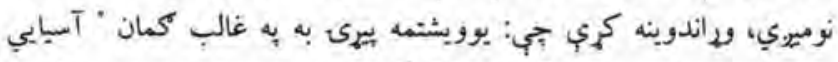

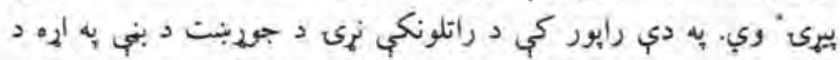

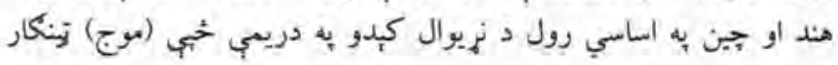

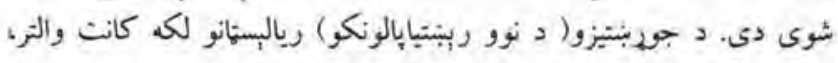

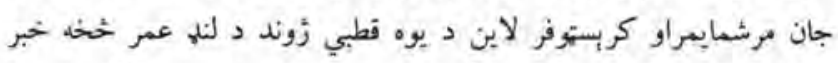

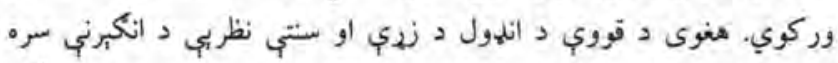

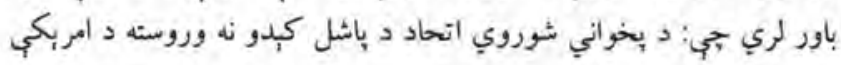

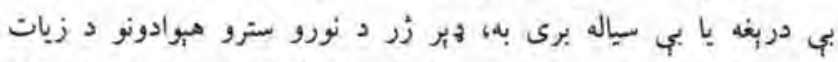

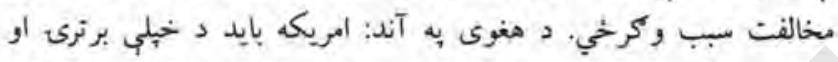

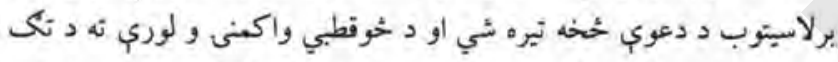

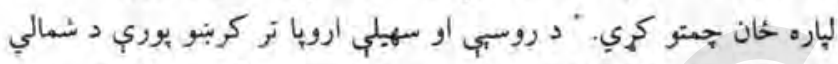

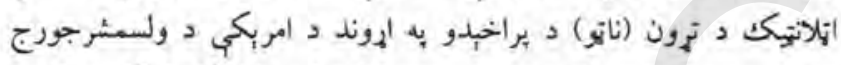

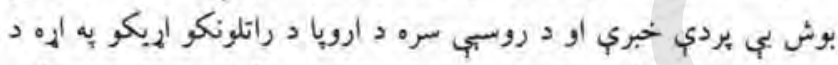

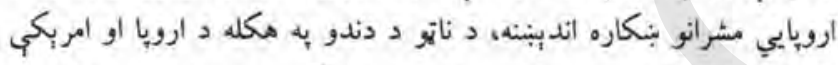

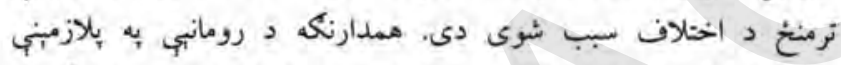

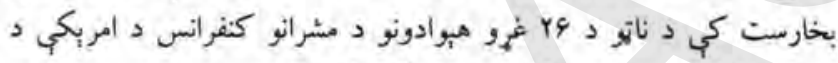

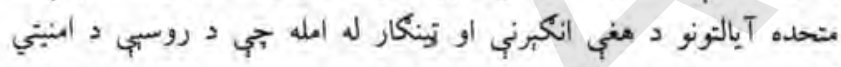

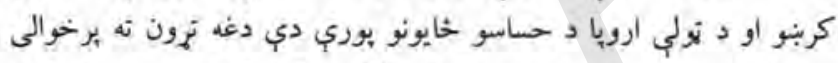

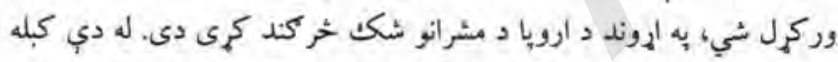

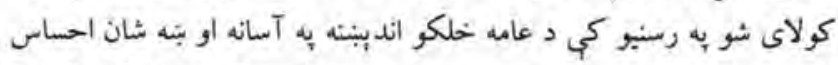

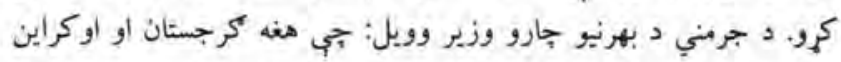

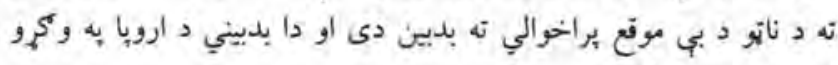

كي هم احساس كوي.

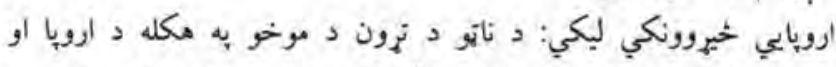

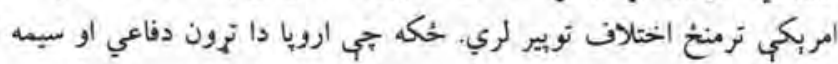

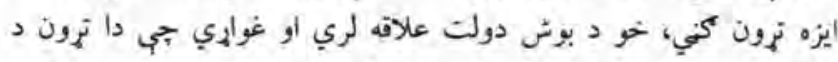

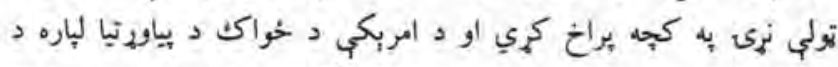

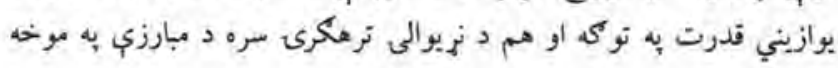
تري كار واخلي.

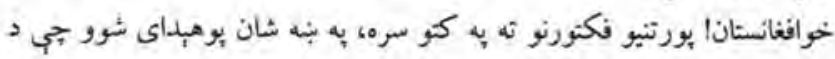

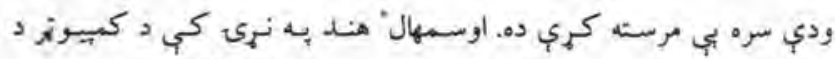

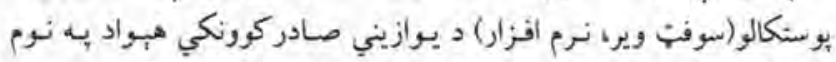

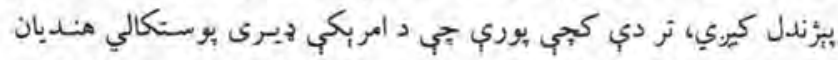

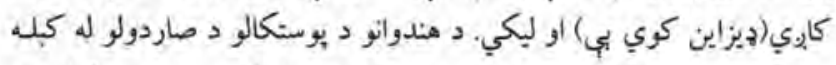

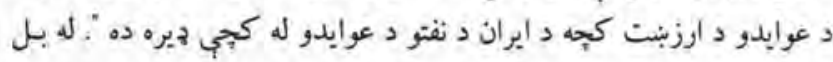

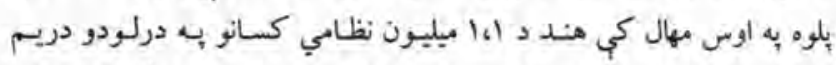

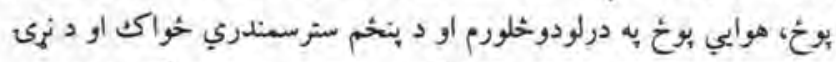

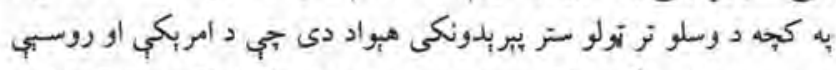

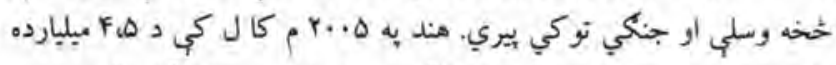

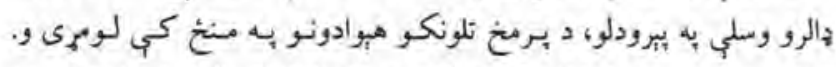

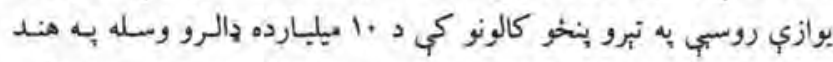

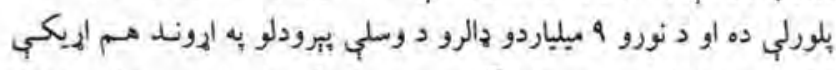

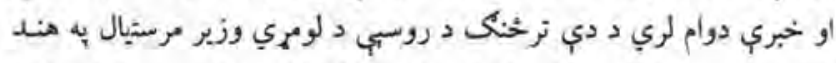

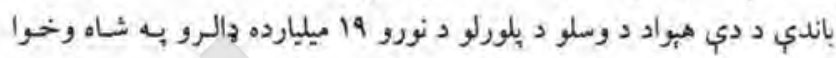
كي خبر وركيى دئ:

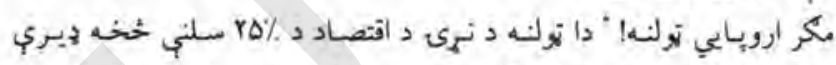

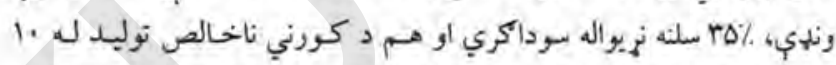

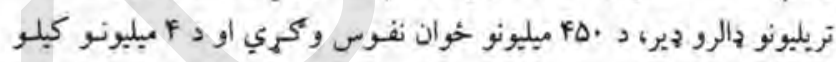
مبترو مربع سره برابرمساحت لري.

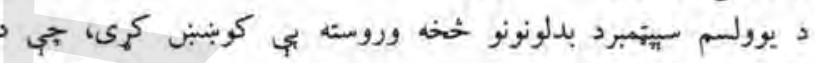

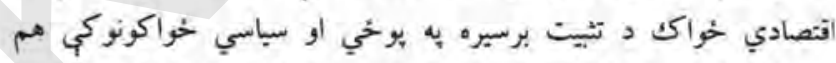

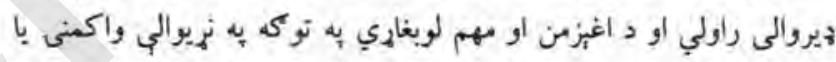

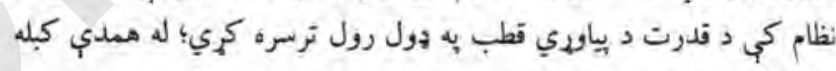

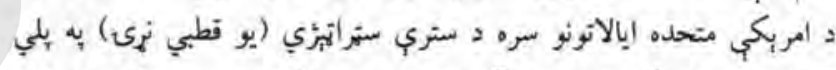

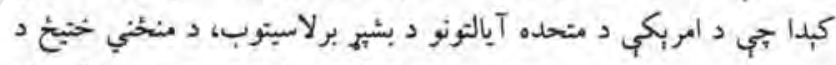

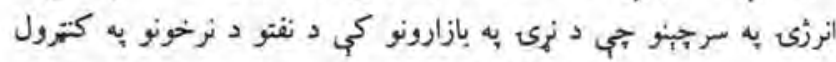

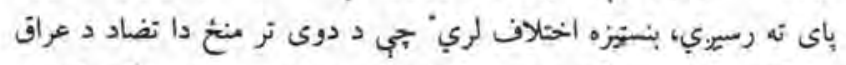

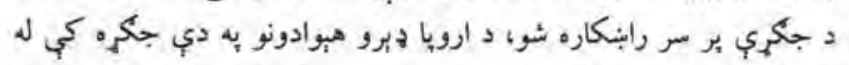

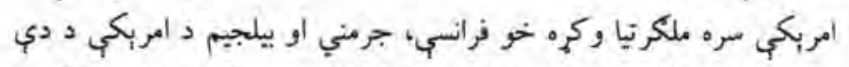

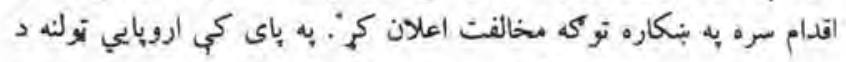

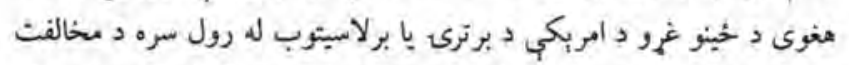

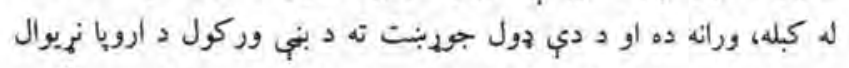

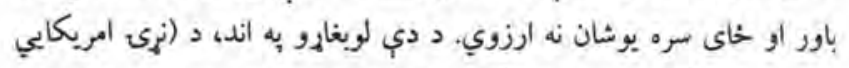

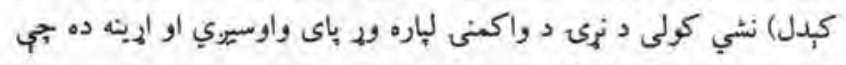

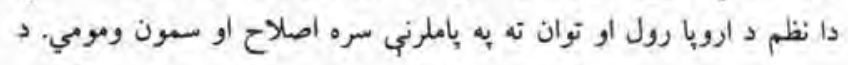

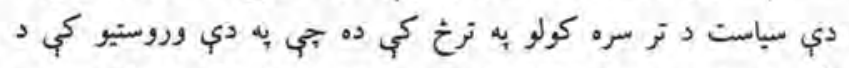

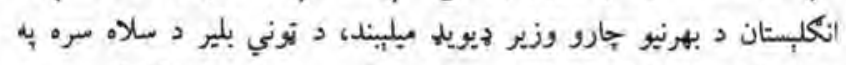

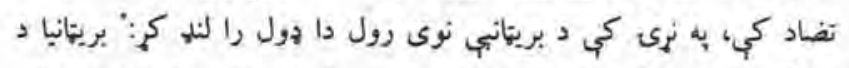

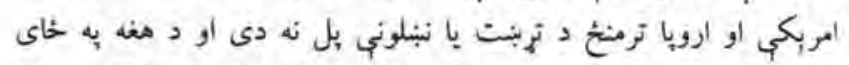

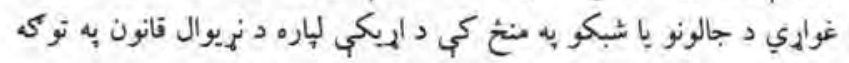


كي به به يو إخخيزه توكه د امربكي به كمهيه د قووي انئول له منخد يوسي.

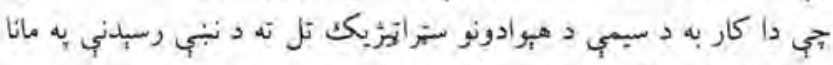

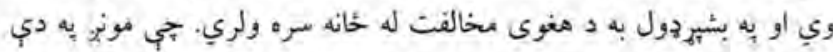

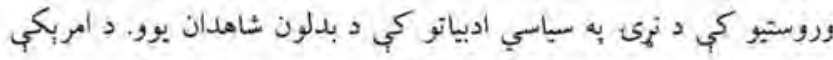

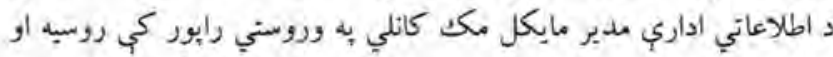

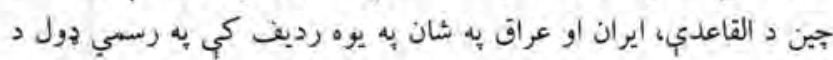

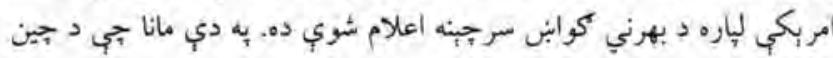

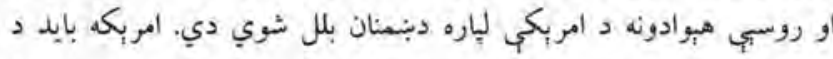

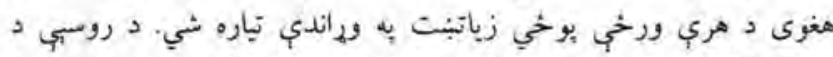

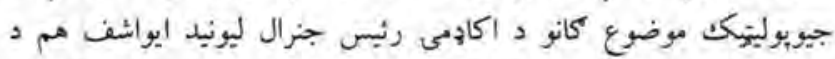

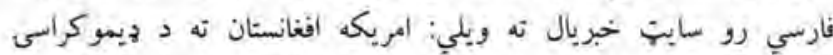

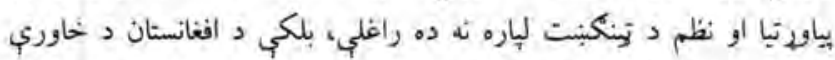

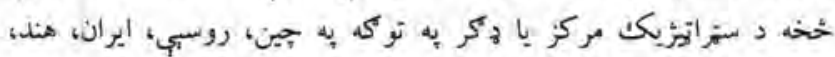

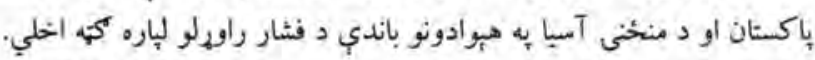

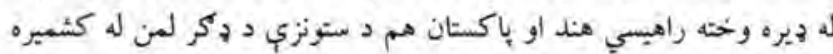

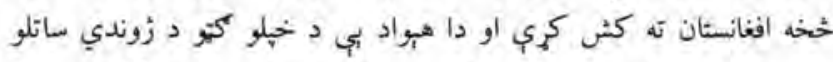

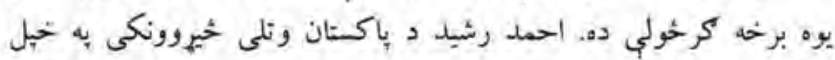

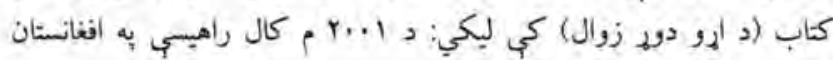

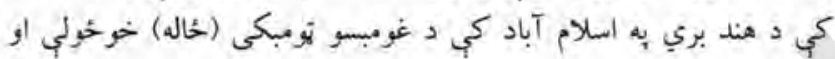

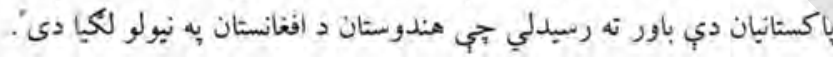

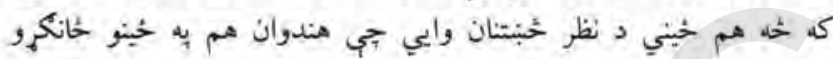

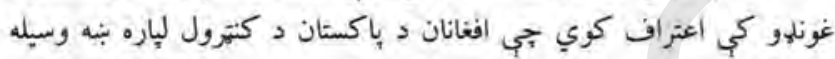

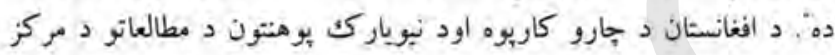

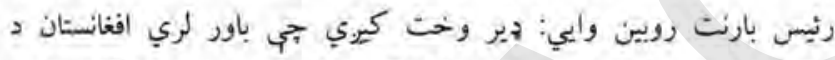

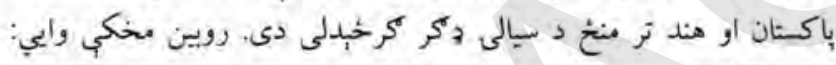

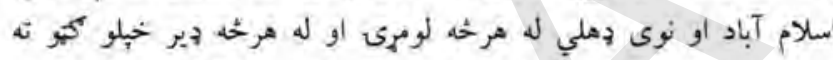

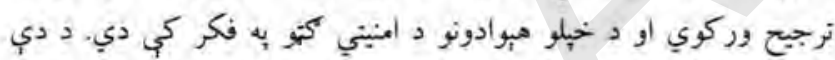

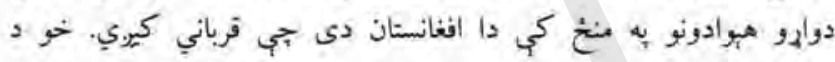

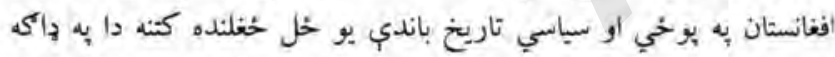

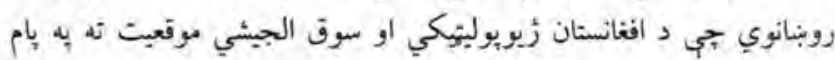

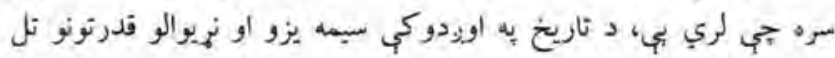

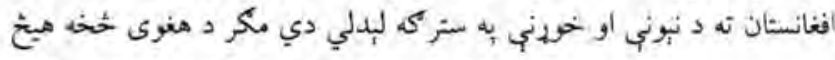

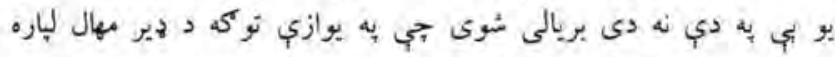

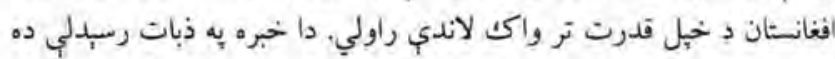

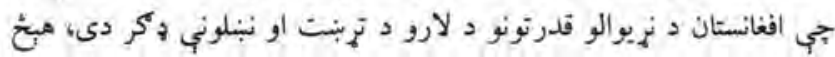

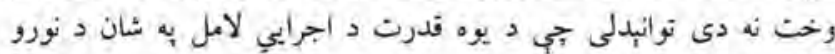

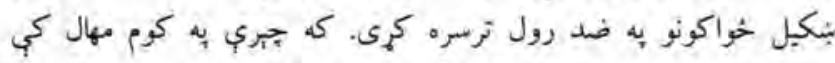

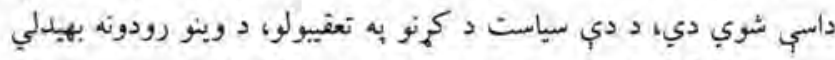

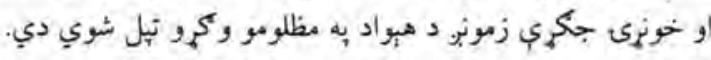
(د افغانستان ورخياني خخخه بيه منتي)

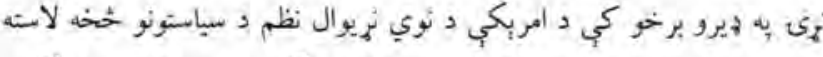

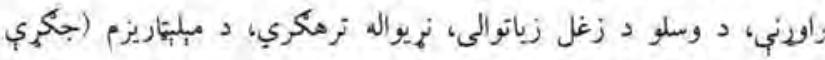

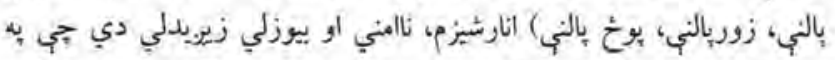

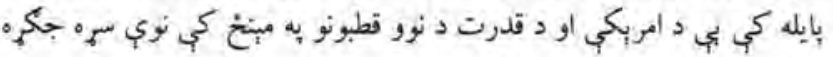

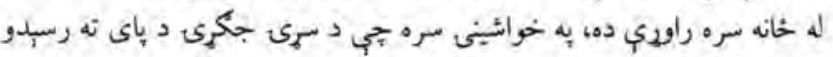

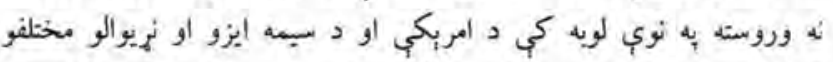

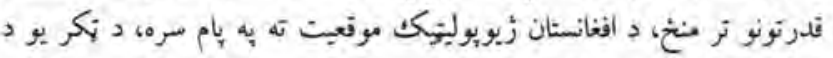

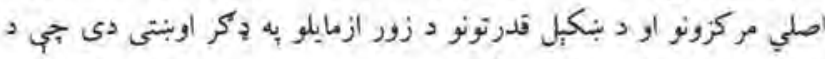

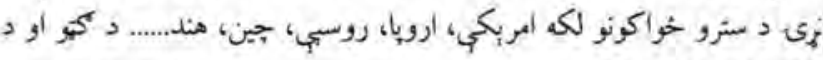

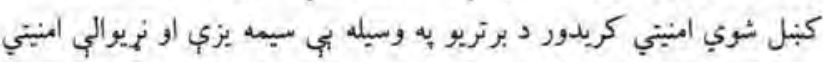

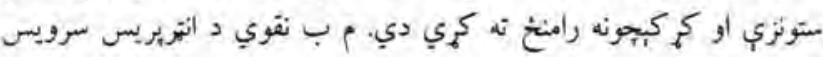

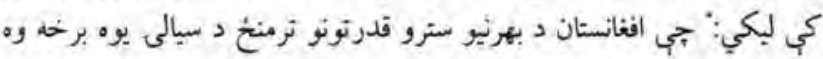

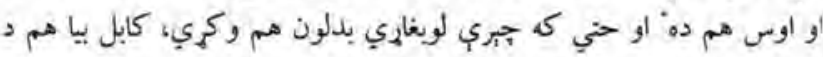

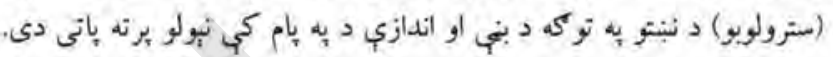

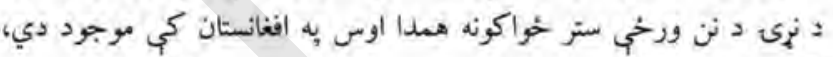

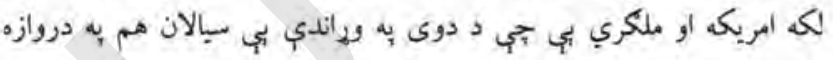

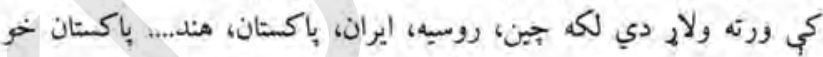

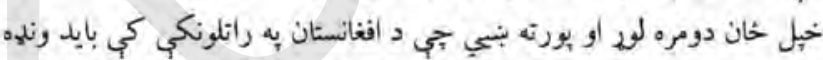

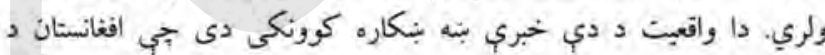

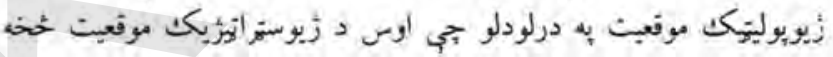

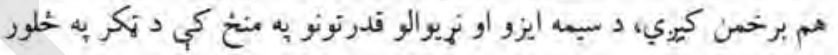

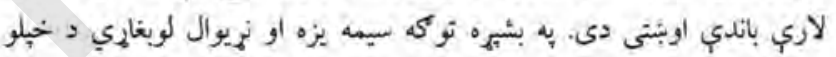

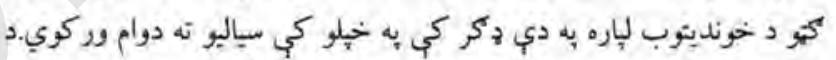

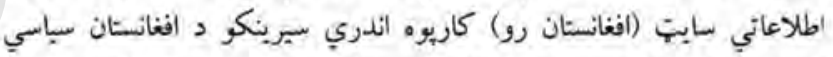

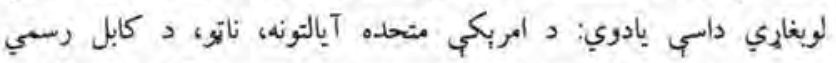

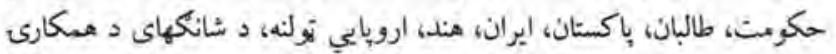

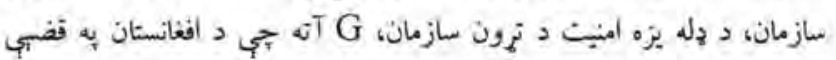

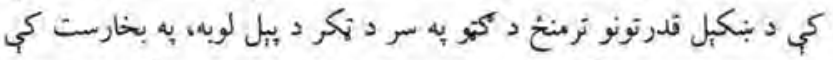

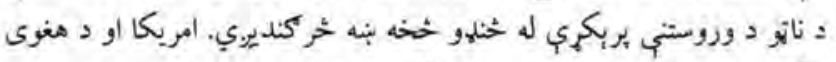

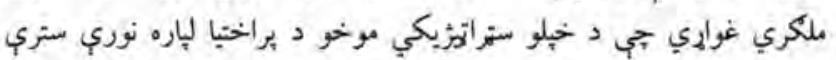

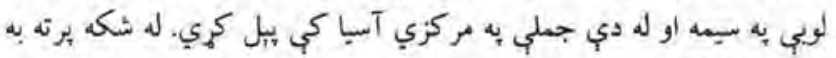

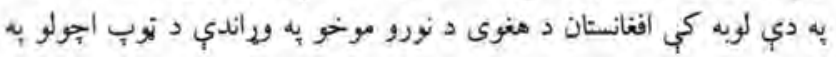
تحتّه بدلئيري.

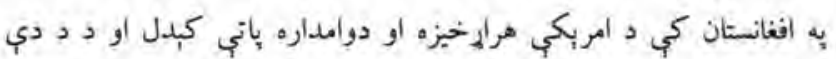

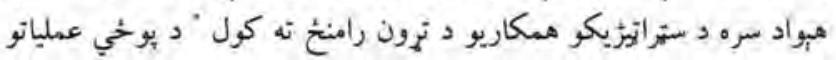

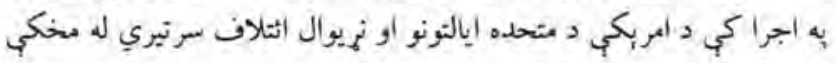

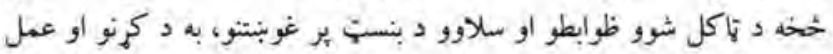

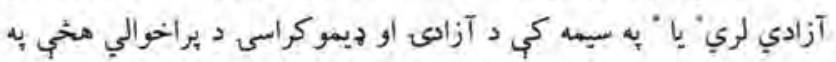

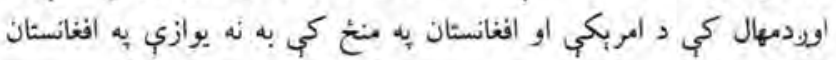

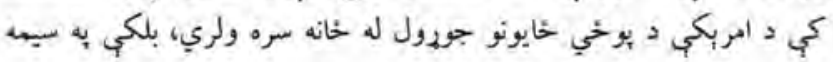




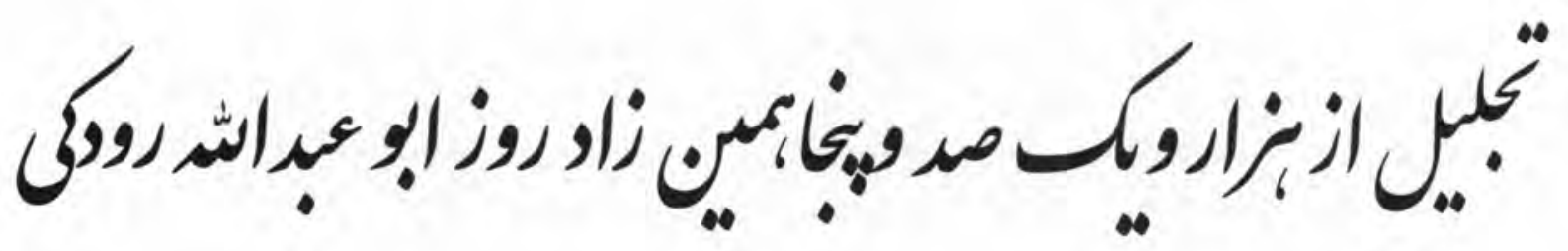

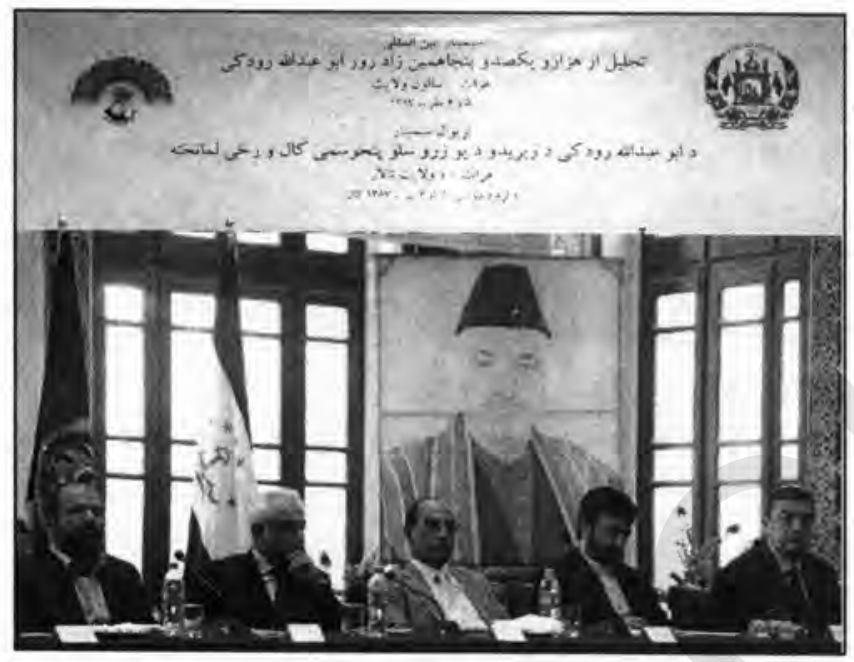

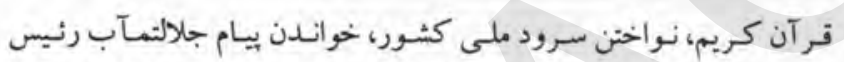

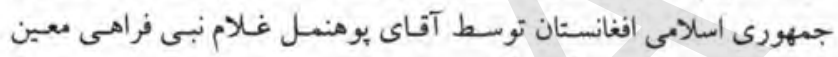
وزارت اطلاعات و فرهيخث بيخيرى شد.

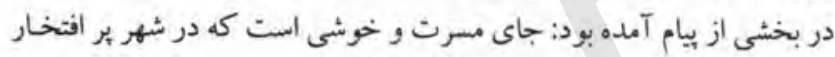

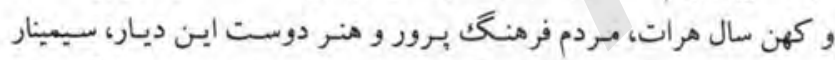

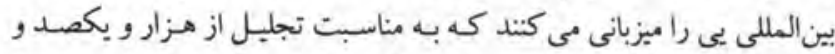

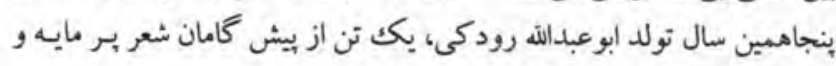

$$
\text { بر بار درى بر خزار شده است. }
$$

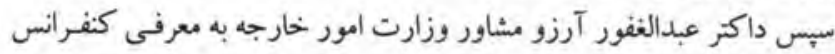

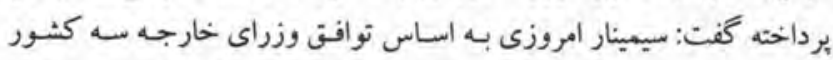

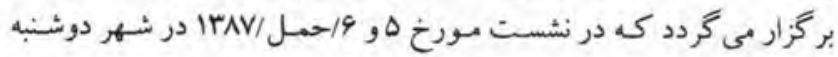
صورت كرفته بود.

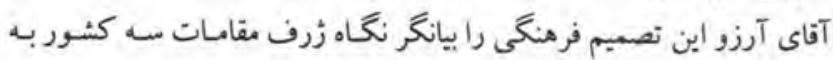

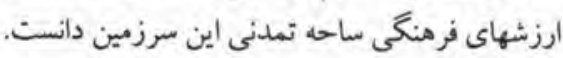

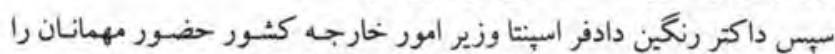

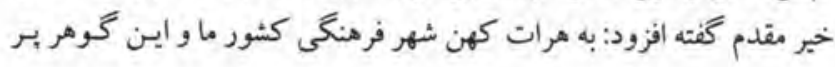

سيمينار بين المللى تجليل ازهزار و يكصــ و بنجاهمين زاد روز ابوعبدالثه

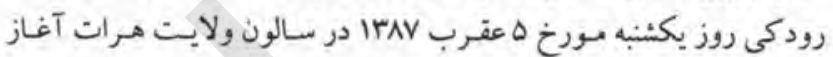
كرديد. ت رودي روز

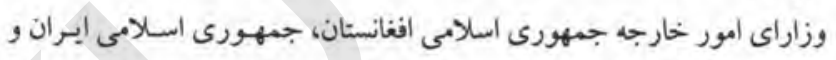

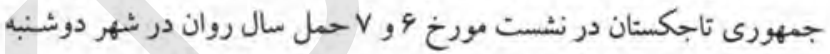

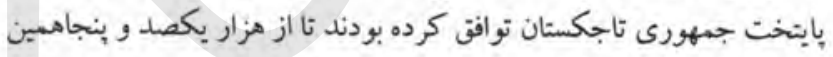

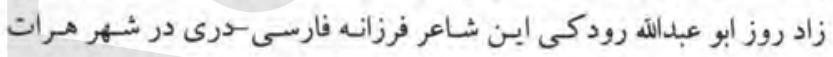
باستان ياد بود به عمل آيد.

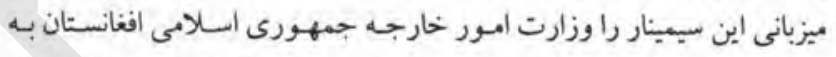

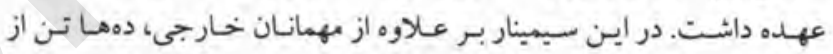

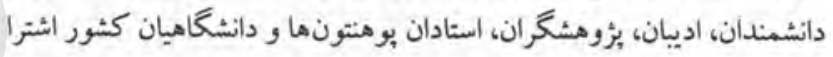

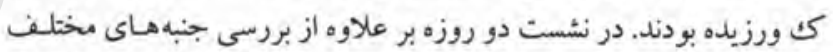

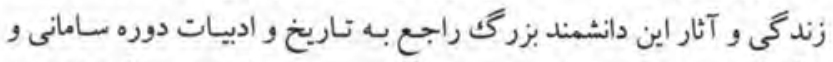

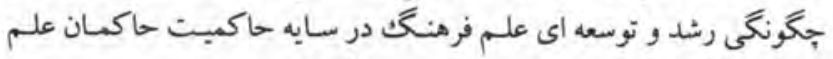

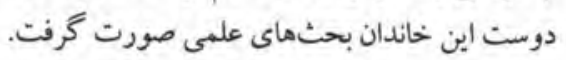

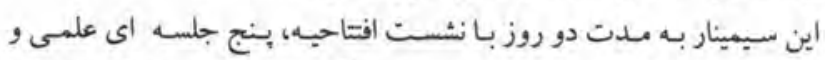

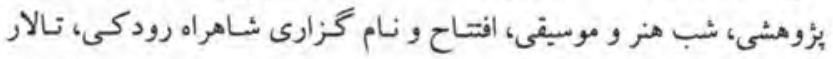

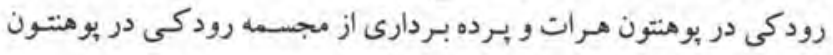

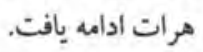
نشست افتتاحيه

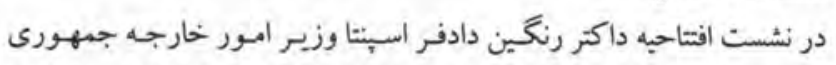

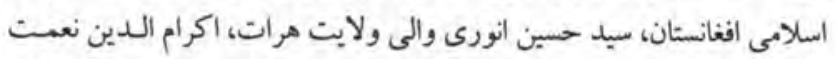

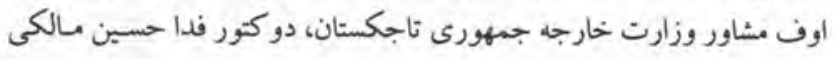

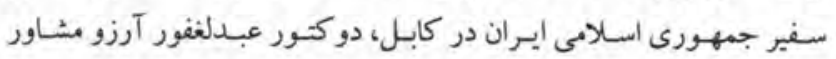

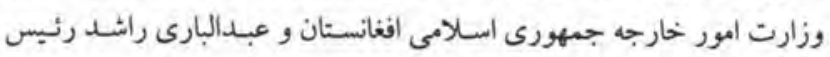

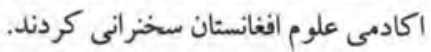

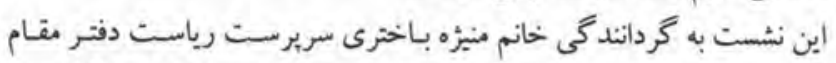

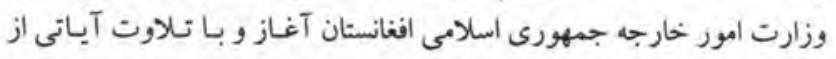




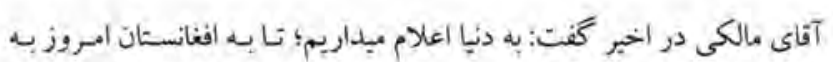

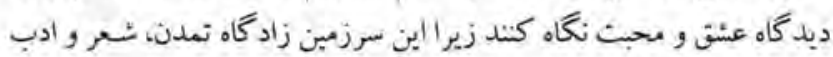
ايران و تاجيكستان نيز ميباشد.

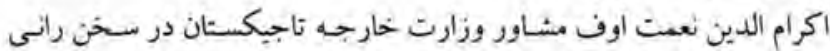

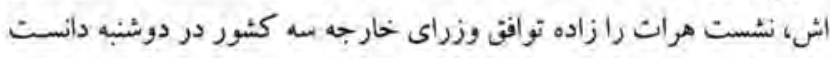

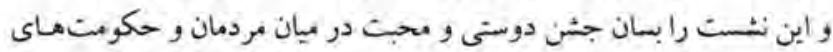
سه كثور توصيف كرد و به شعر رودكى استناد جست كهي:

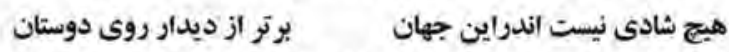

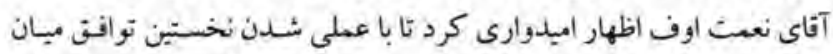

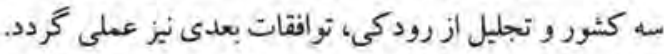

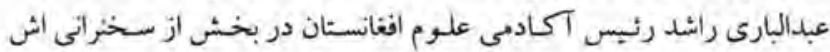

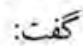

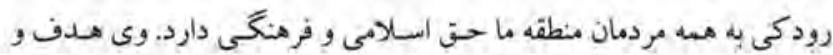

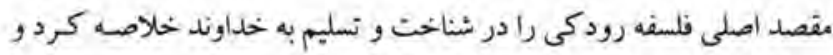

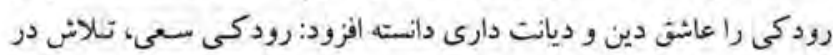

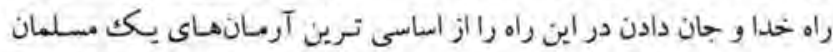

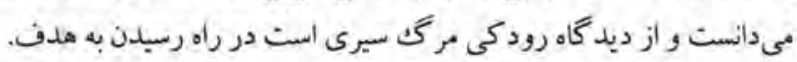

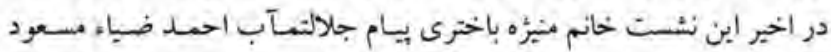

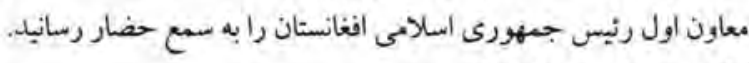

\section{نخستين نشست بؤوهشى ترئ}

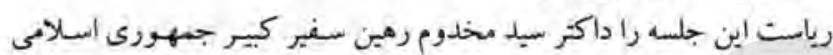

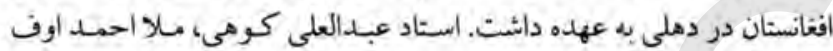

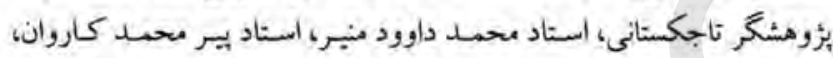

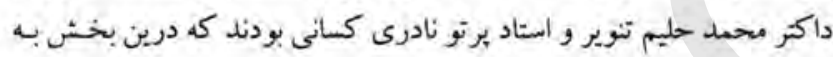

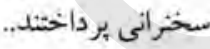

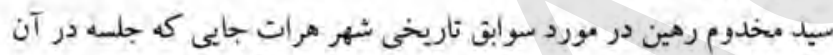

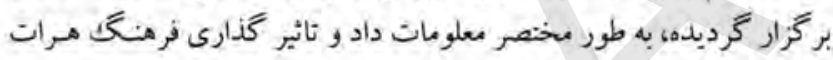

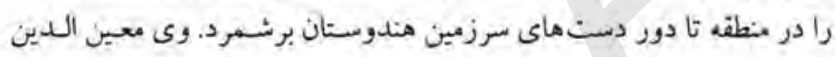

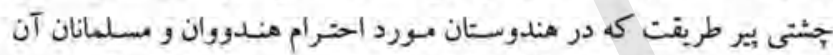

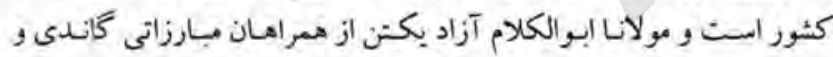

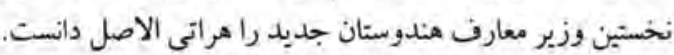

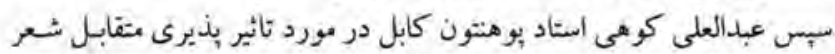

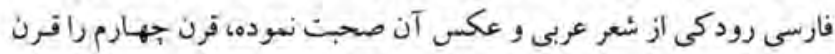

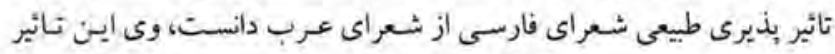

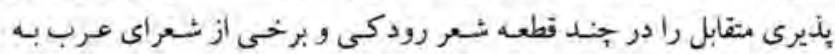

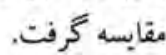
استاد محمد داود منير در سخنر انى اش عصر رودكى راعصر زيبايى شناسيى

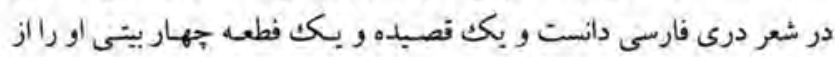

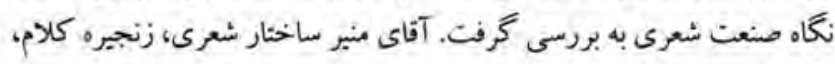

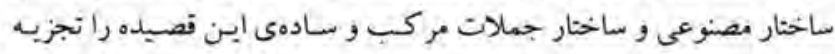

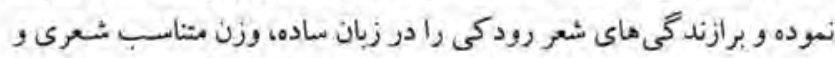

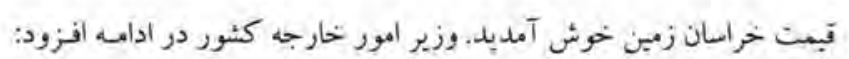

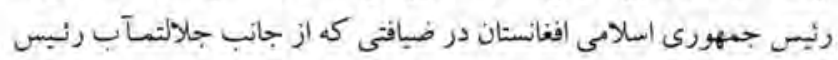

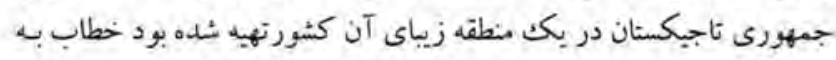

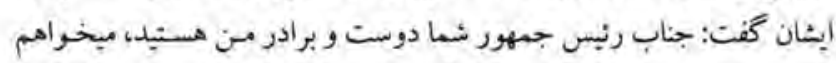

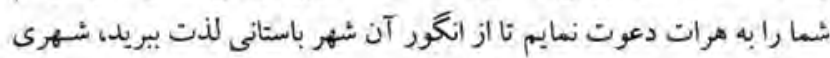

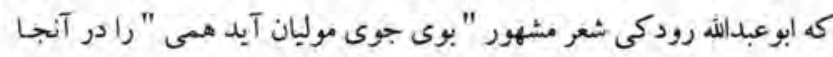

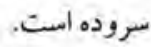

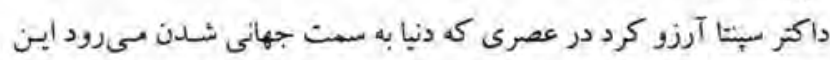

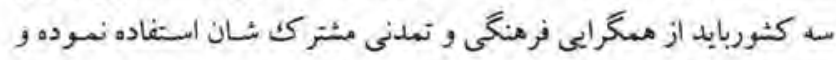

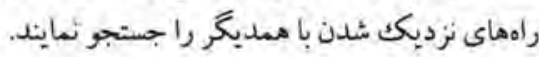

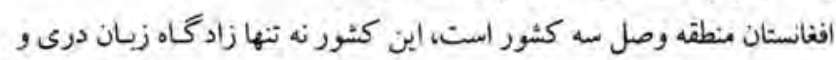

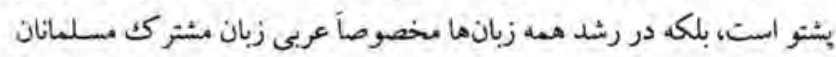
رول مهم و ارزشمندى را البفا تموده است دئ.

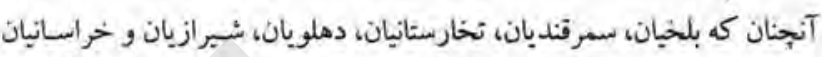

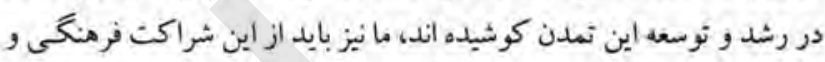

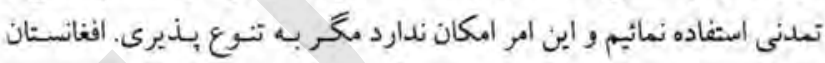

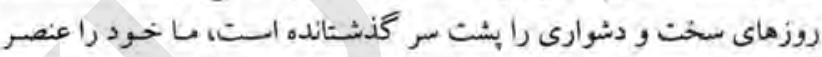

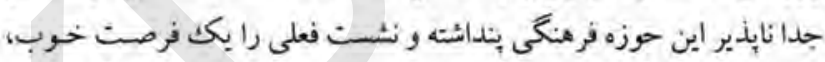

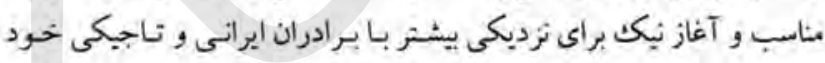

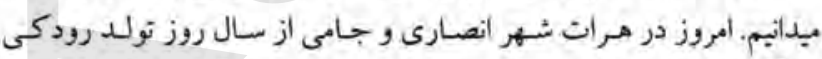

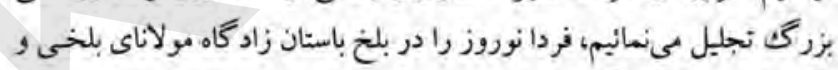
رابعه بلخى جشن ميخيريم.

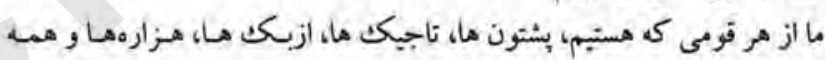

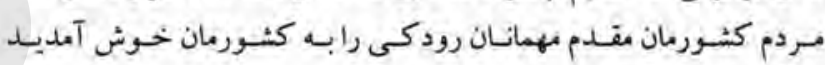
مى مئيم. سيد حسين أورى والى هرات ضمن خير مقدم كفتن به مهمانـان، رودكى را

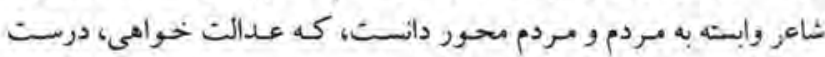

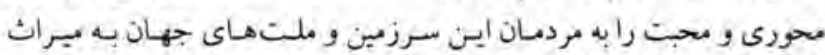

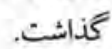
داكتر فذا حسين مالكى سفير جمهورى اسلامى ايران در كابل ضمن ثوصيف

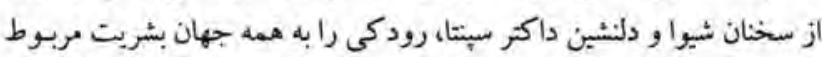

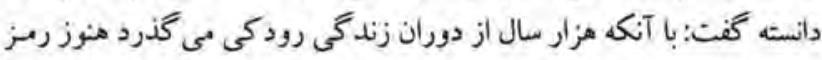

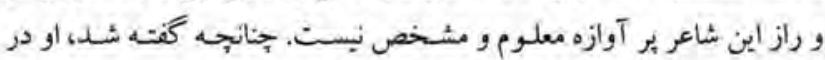

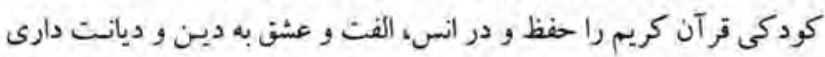

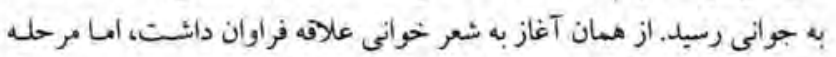

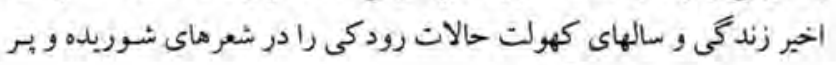
سوزش مشاهده مى اتوان كرد.

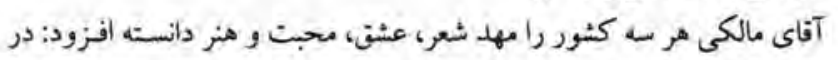

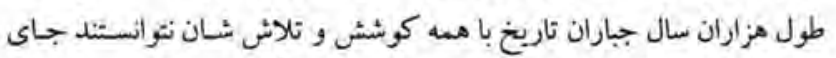

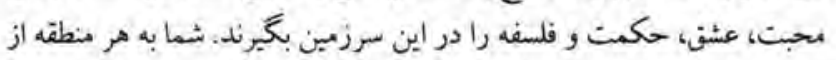

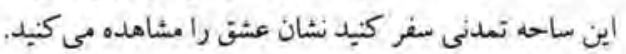


جهال سالخى آغازشده باشد.

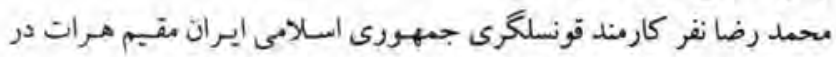

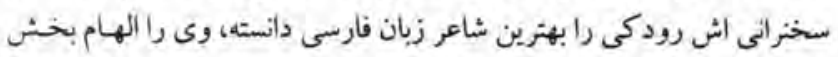

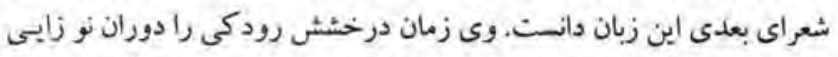

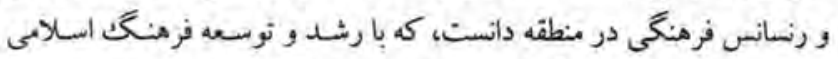

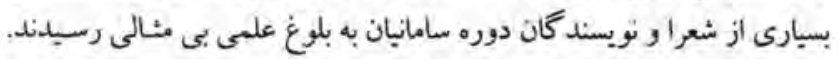

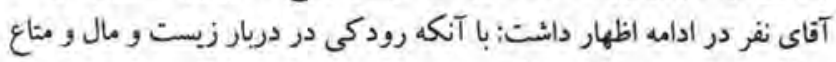

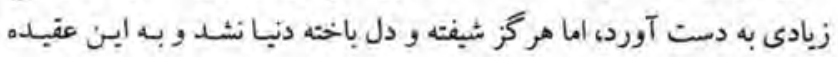

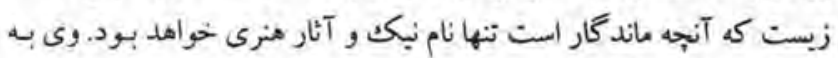

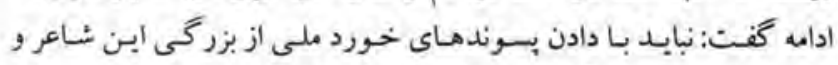

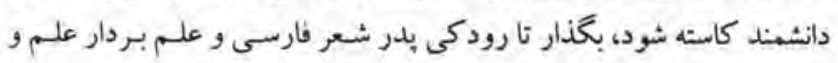
هنر، معرفت و محبت در جهان باشد.

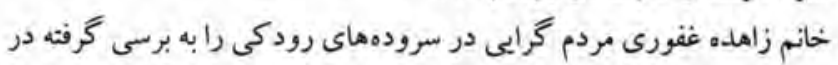

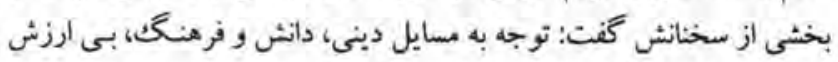

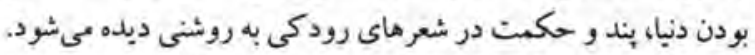

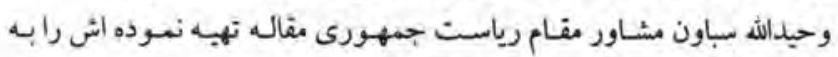

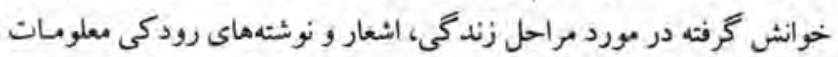

Sוs

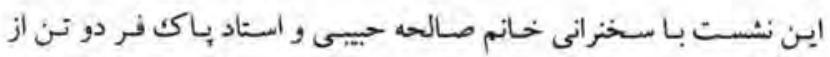

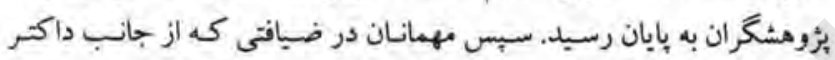

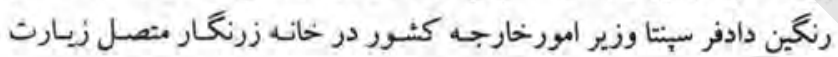

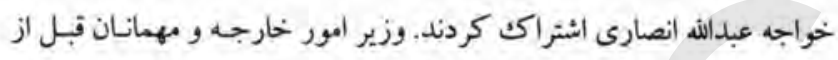

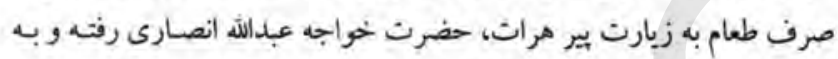

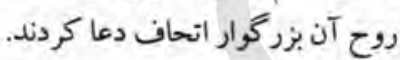

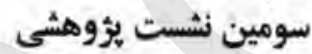

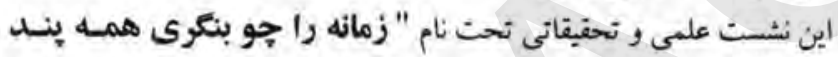

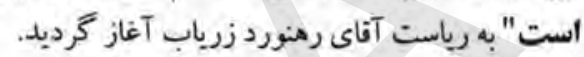

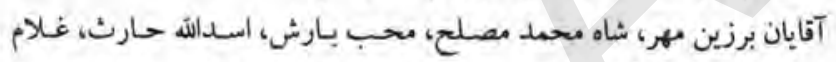

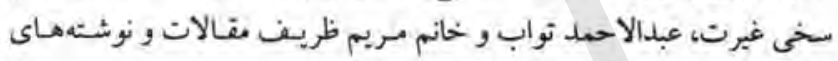

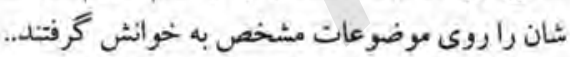

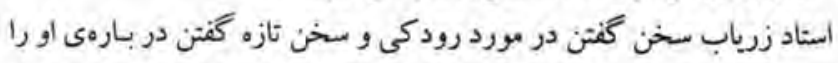

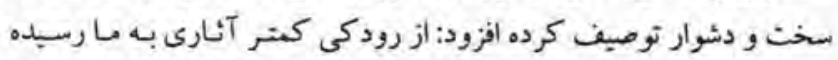

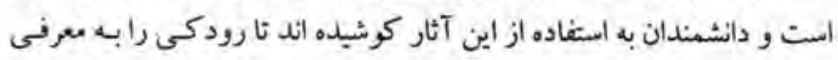
كيرند.

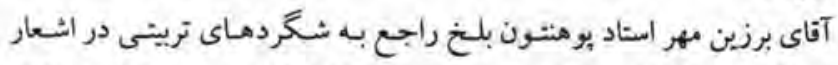

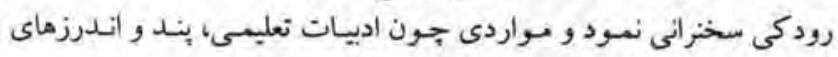

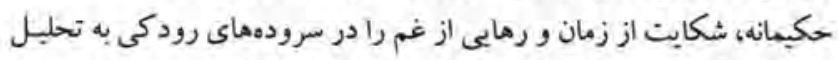

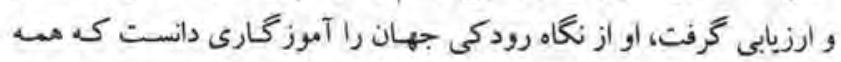

دوره هايش بند است.

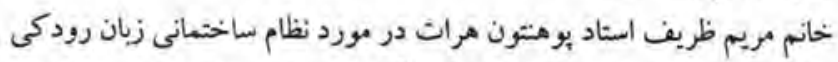

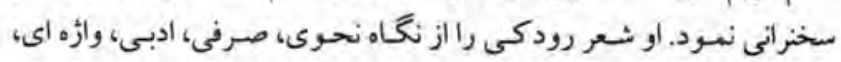

بو جوديت روح حساسى و عبنى كرايى او دانست.

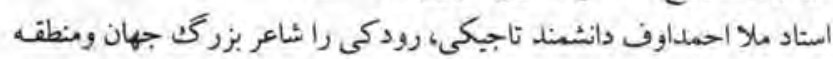

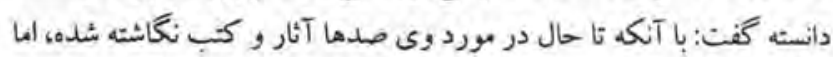

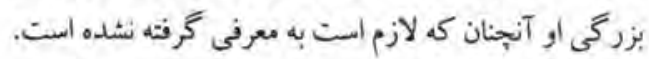

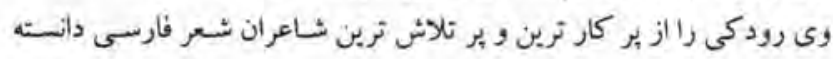

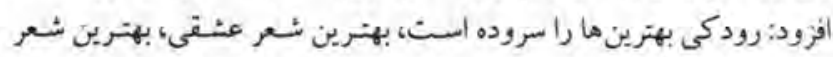

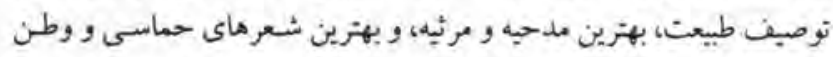

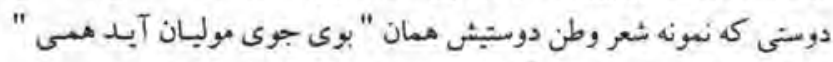

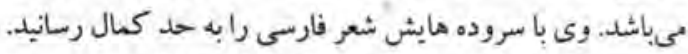

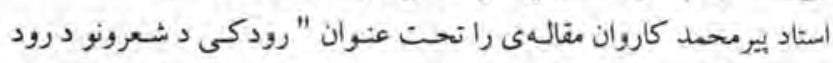

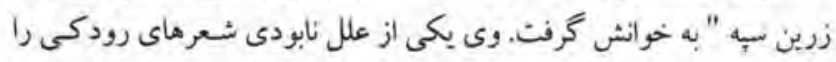

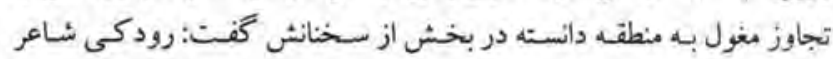

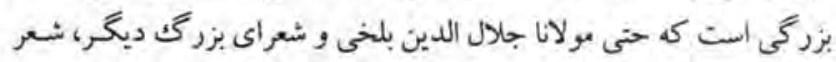

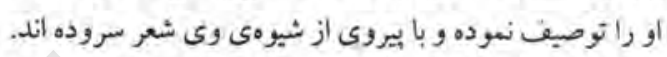

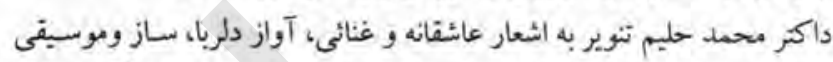

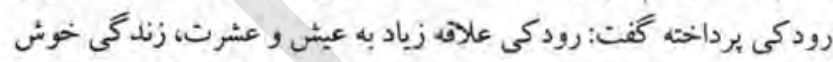

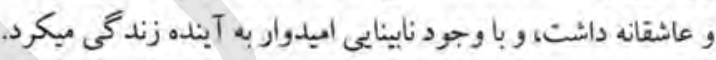

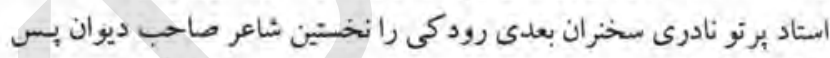

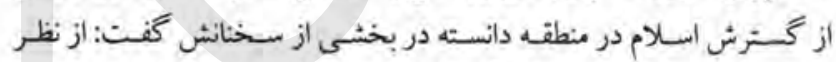

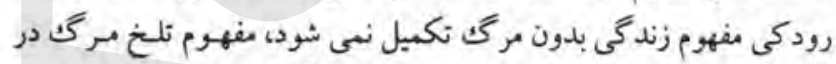

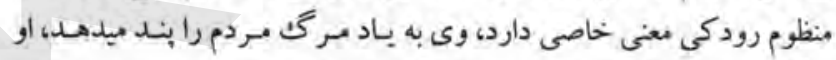

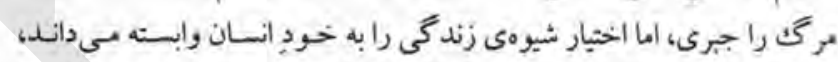

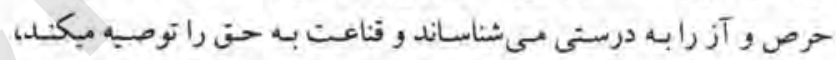

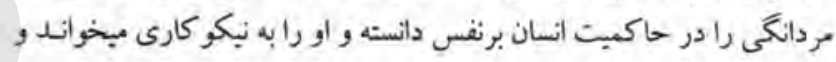

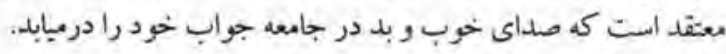
انتشت مكن رنجه به در كوفتن كس تا كس نكند رنجه به در كوفتئت دور مشت كشت

دومين نشست يوزوهشى

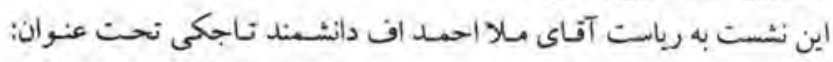

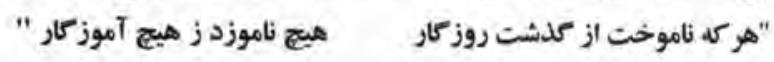

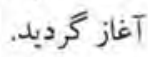

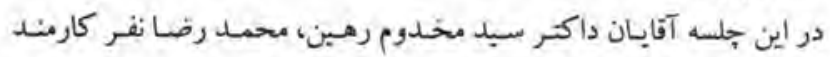

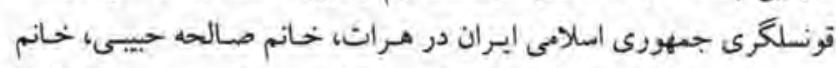

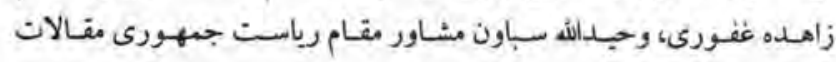

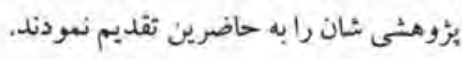

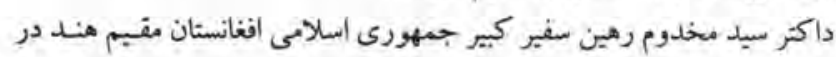

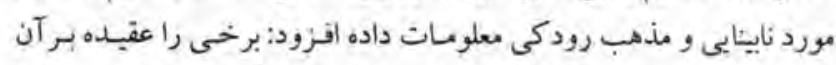

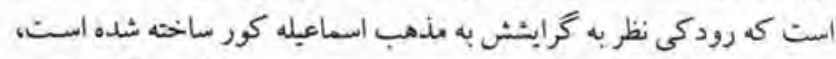

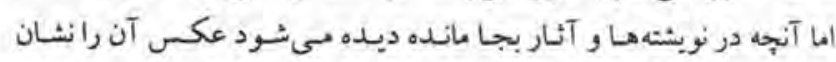

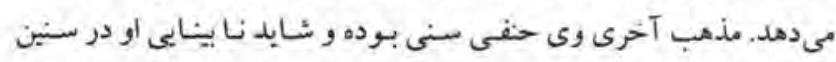




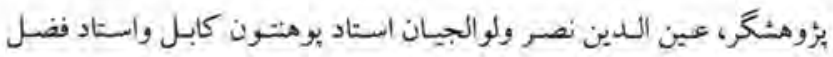

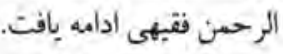

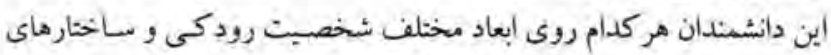

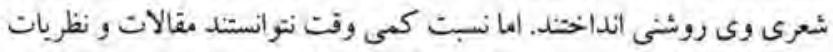

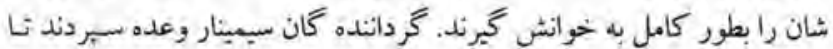

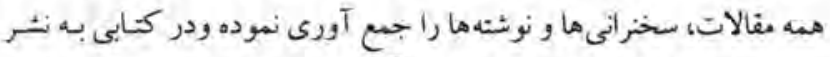

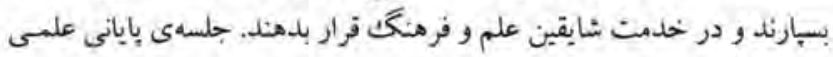

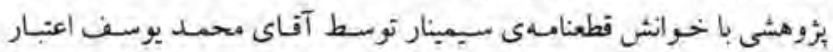
مشاور وزأرت أمور خارجه جمهوري اسلامى افغانستان به بايانان رسيل.

\section{بخش ينجم}

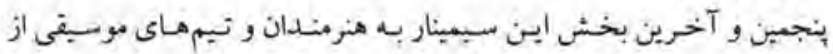

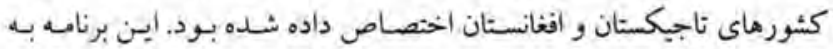

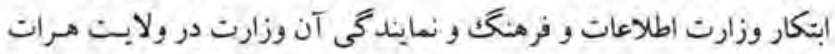

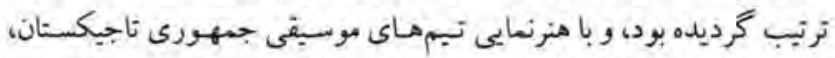

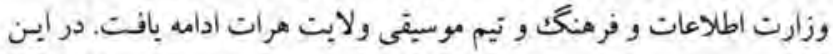

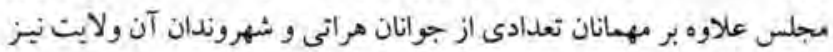
حضور داشتند.

با ختم شب موسيفى، مهمانان در ضيافنى كه از جانسب رياست اتشاقهاى

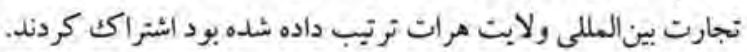

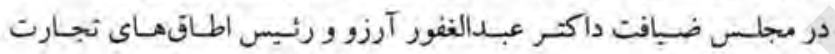

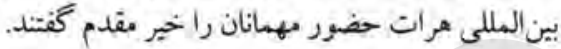

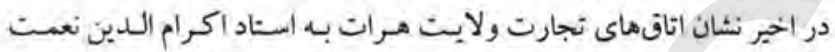

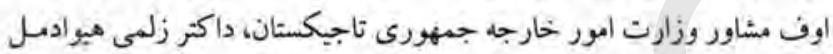

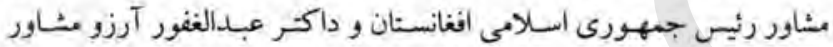
وزارت امور خارجه جمهورى اسلامى افغانستان تقديم گر ديد.

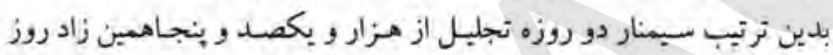

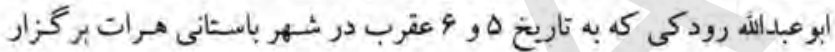

كر ديده بود به بايان رسيد.

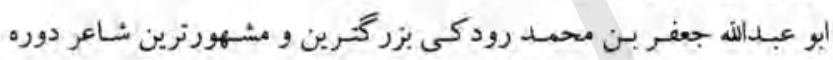

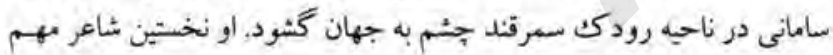
زبان درى بوده و مشهور به بذر شعر فارس مى باشّلد.

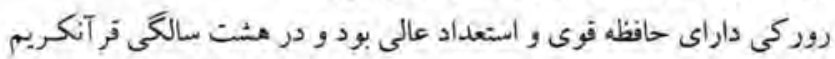
را حفظ نمود و در همين سن كودكى به سرودن شعرى آغاز كرد.

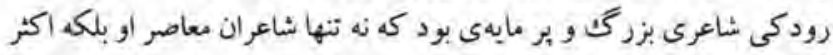

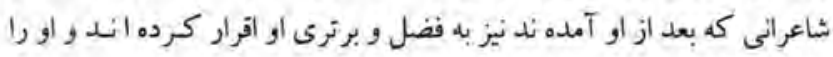
سلطان و استاد شاعران ناميده اند أند

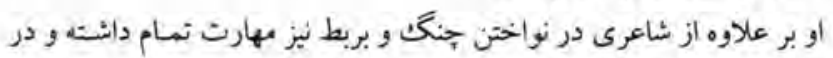

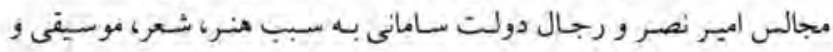

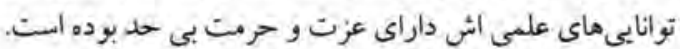

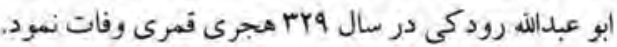

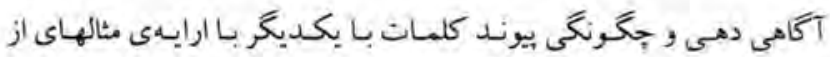

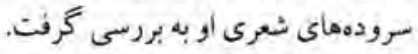

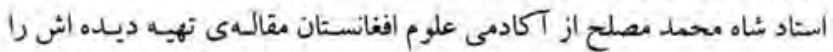

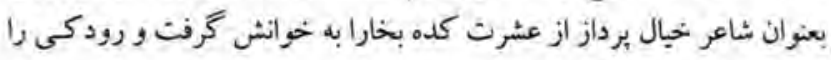

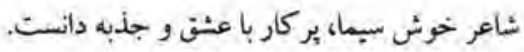

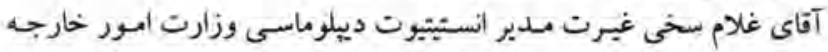

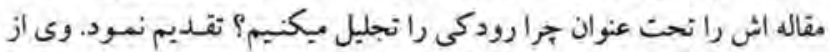

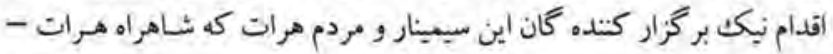

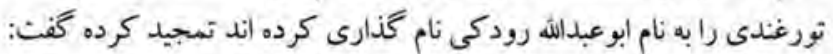

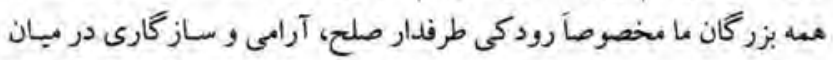

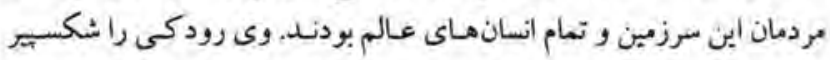

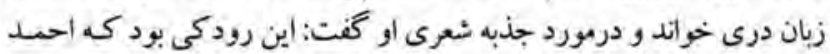

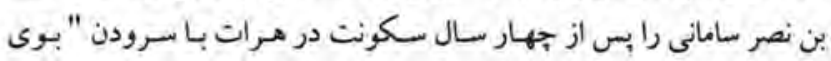

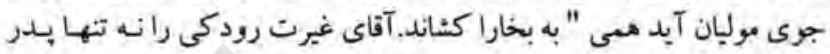

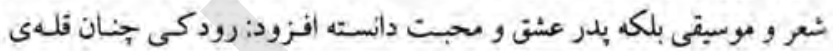

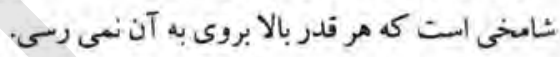

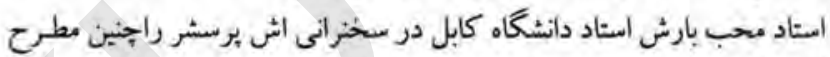

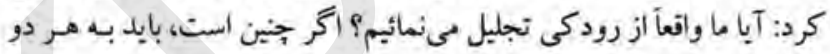

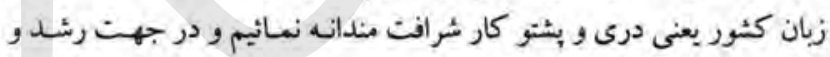

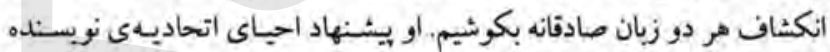

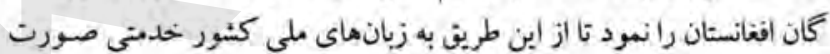
كير

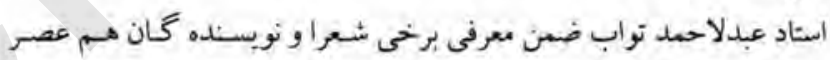
رودكى، رابعه بلخى را نخستين زن سراينده و شاعر زبان فارسيى دانسته و در

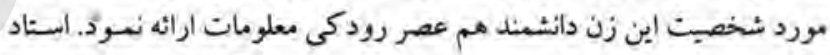

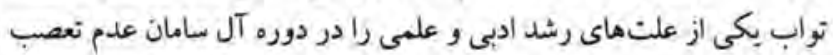

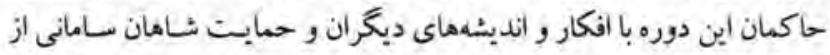

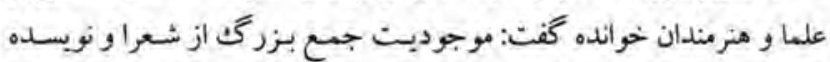

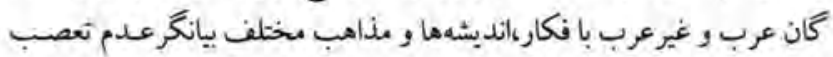
و علم برورى ائن خاندان دانست.

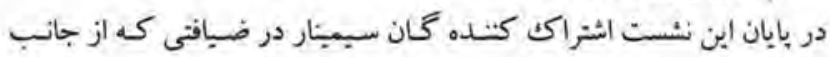

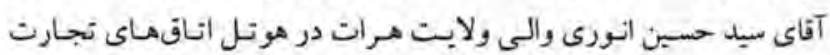
بين المللى هرات ترنيب داده شده بود اشتراكت كردند.

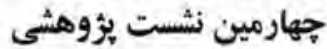

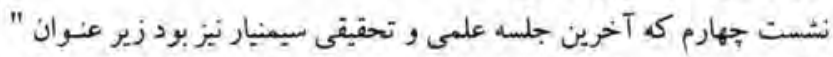

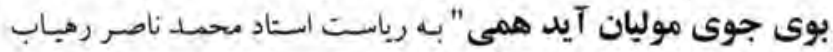

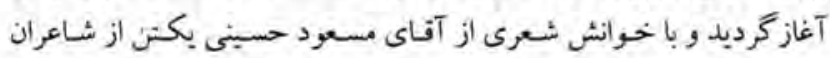

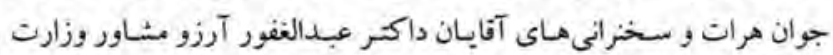

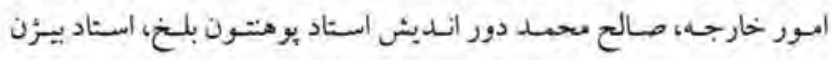
سلجوفى، داكثر زليى هيوادمل وزير مشاور رياست جمهوردى در امور علمى

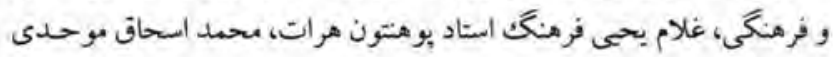




\section{م ارويا د امنيت او ممكارى سازمان

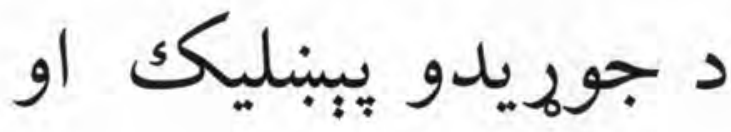

ع/ نجات

\section{ح مغه دندي}

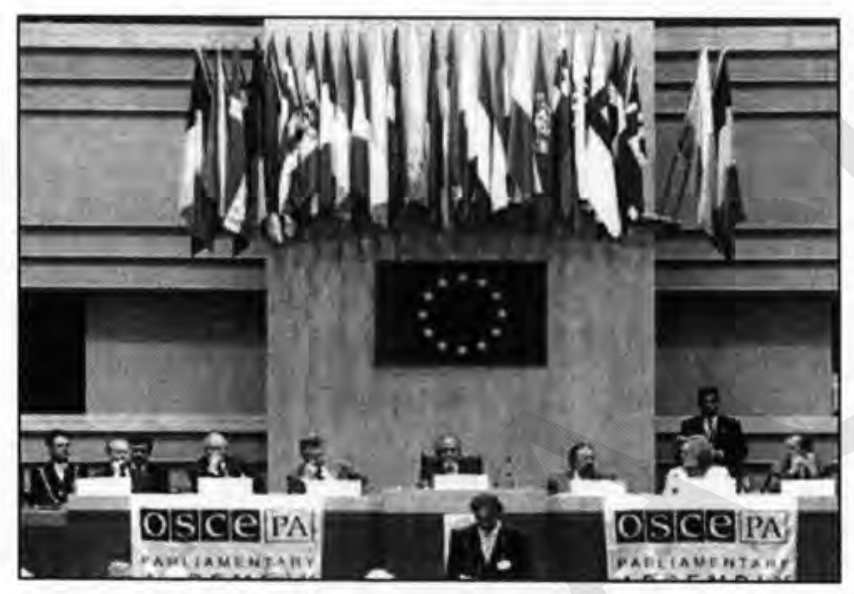

ختيزي او لويلديزي ارويا، قفقاز او د مبنخنى آسـيا بـه سيمو كي د ماموريت نولس د همكارى سيمي لري. د دي سيازمان

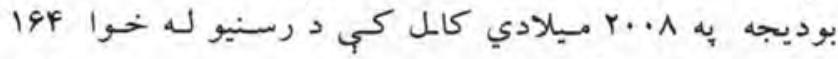

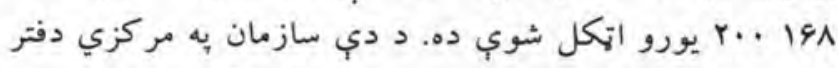

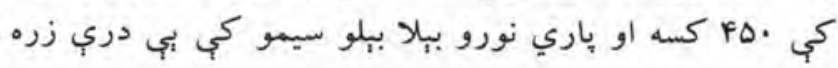
كسان يه جارو بوخت دي. د دي

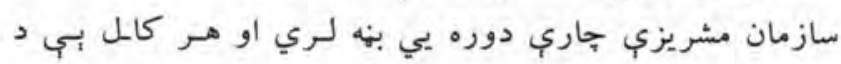
جارو كلنى مسؤليت د غرو هبوادونو د بهرنيو جارو يو بو وزيسر

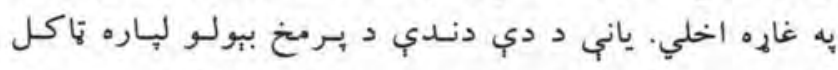

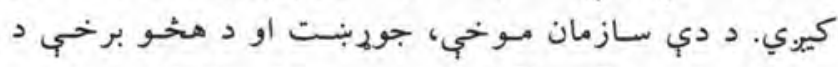
هلسنكي به سند كي تاكل شوي دي . دغه سازمان يو رئسيس او يه كاري ببلاببلو برخو كي تاكلي خحانكي او بنستونه للري
د ارويـا د امنيست او همككارى سـيمه ييتز سـازمان د

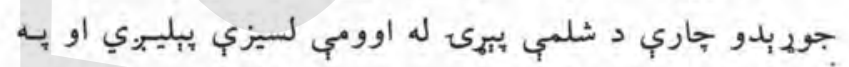
19V. ميلادي كال كي د هغي سيمب له امنيت سره تراو او لري.

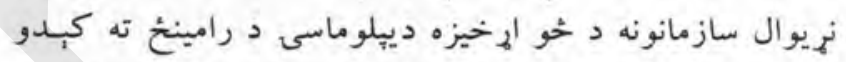

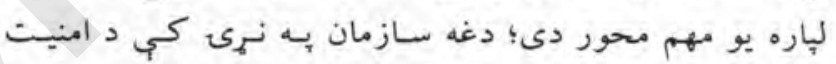
لوى سيمه ييز شميرل كيري. همدا راز دغه سـازمان د وختــ د إفتياو او ضرورت له مخي د لويديزو او ختيزو هيوادونو تر

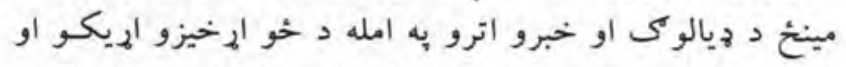
زياتي همكارى د فضا رامينخ ته كبدو به خـاطر بـه بـام كي نبول شوى و.

دغه سازمان د دوو ناستو به ترخ كي د هلسنكي او د رُنيسو د

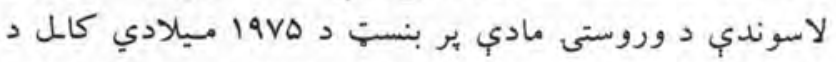

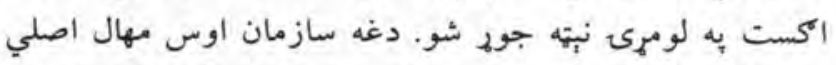

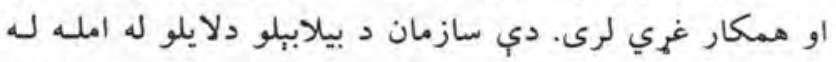

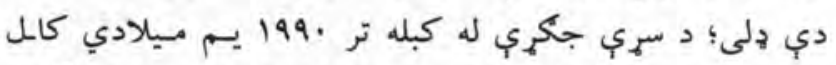

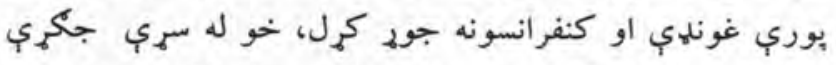

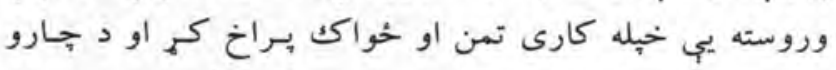

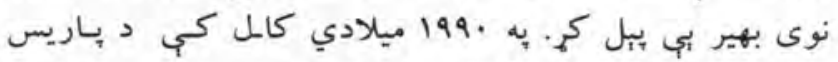
دغه سازمان له سهري جكيكي وروسته مهال سره د سمون لياره

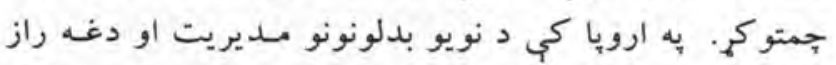

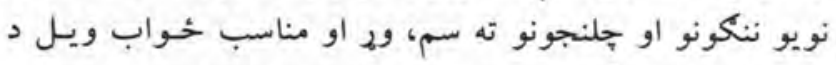
دي سازمان خانكيري دندي وشمبرل شـوي. دغه سـازمان يـه 
ها- له جكيكي وروسته د شخرو رابنكته كـول او له مينخه.

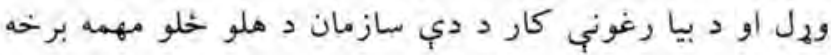

$$
\text { إن }
$$

IV هغه هلي خلحي جي دي سازمان تر دي دمه تر سره كري دي دي دي:

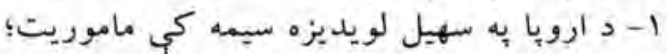

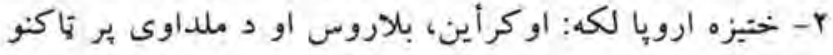

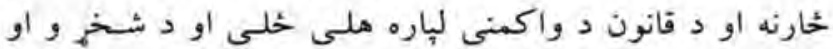

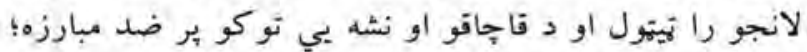

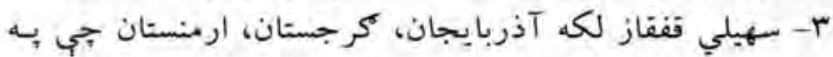

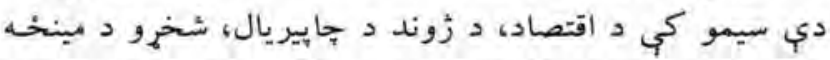

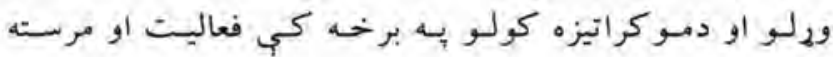
كوي؛

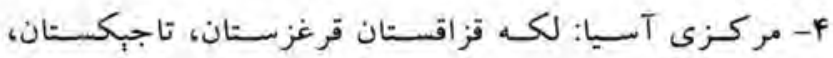
تركسنستان او ازبكستان هخبي او همكاري؛ قرئ ه- لويديزه ارويا او شمالي امريكا.

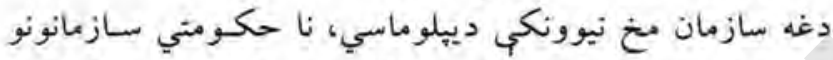

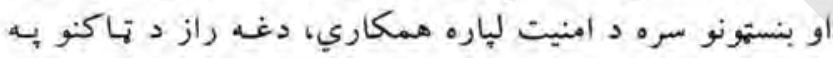

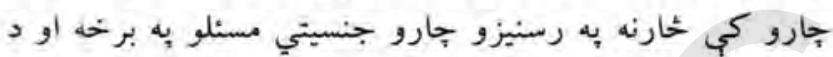

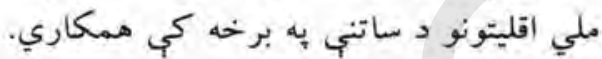

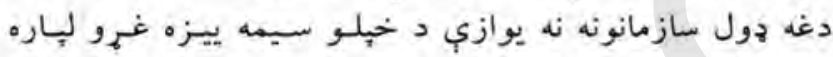

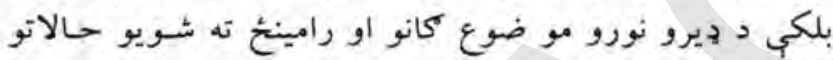

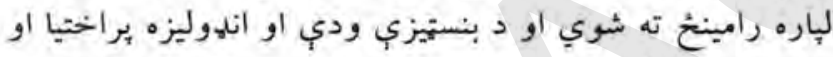

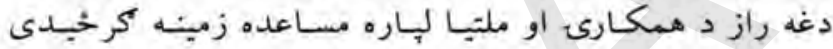

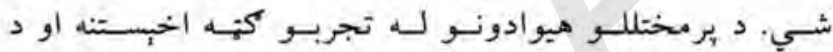

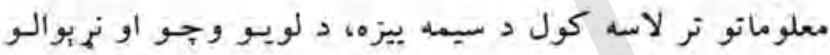

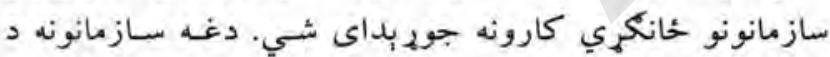

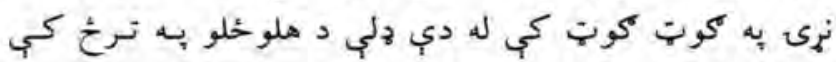

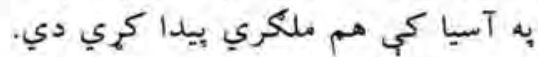

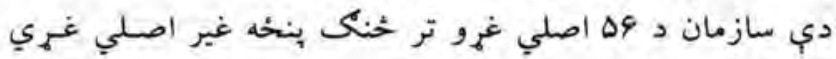

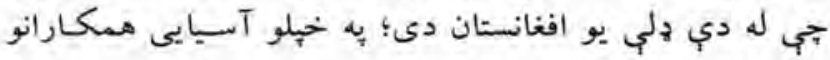
كي خان سره ملكري كري دي دي إني.

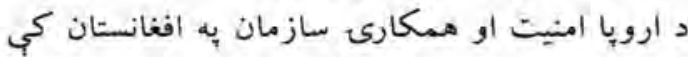

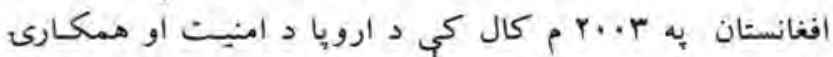

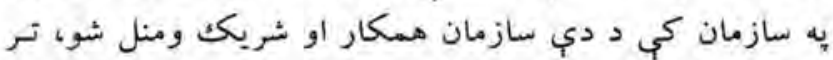

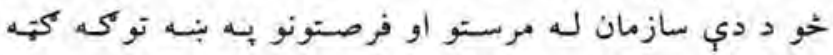

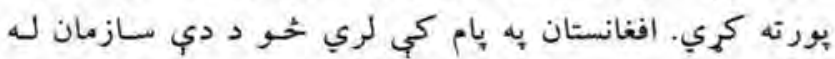

او مونب، بي دلثه لاندي لثنه يادونه كوو:

جوربنتيزه برخه

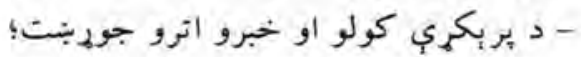

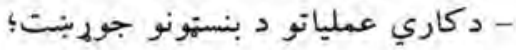

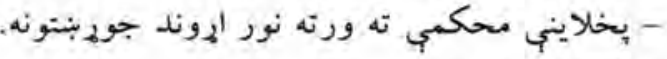
د كار كولو سيمي

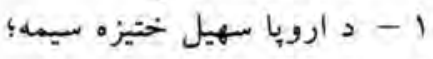

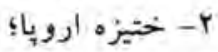

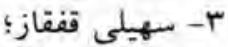

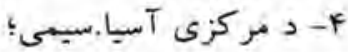

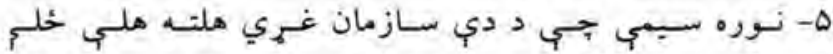

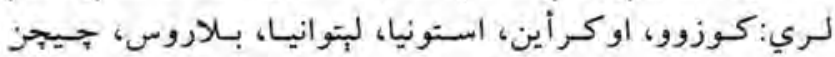
ازبكستان، كروشيا، تاجبكستان او افغانستان.

د فعاليت كاري برخي

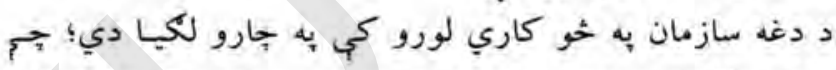

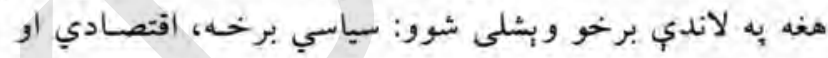

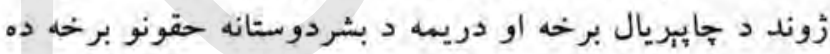

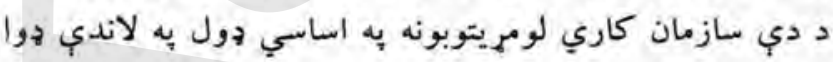
1- د انسانانو قاجاق، نشه يبي توكو يـه ورانسلدي مبـارزه؛ د دئ

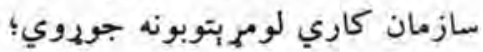

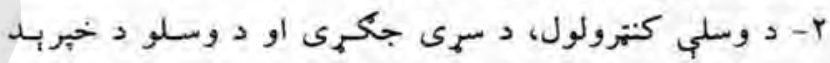
مخنبوى او بندول؛

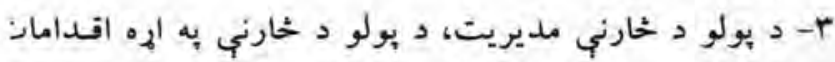

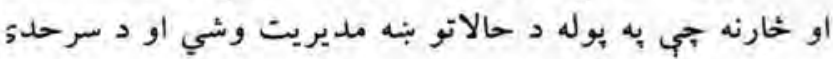
ساتونكو (بنستونو) ورتياوي بياوري شئ شئ ه-

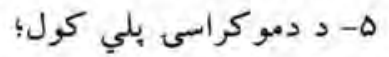

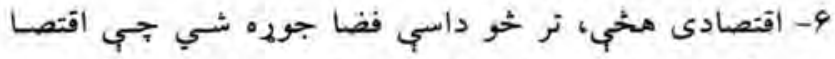
وده وكري أو غُور دولثونو لهاره روغتيايى جايبريال برابر شي؛

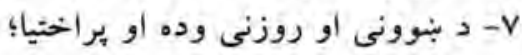

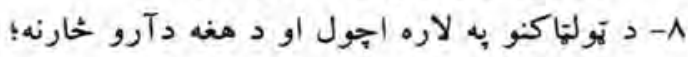

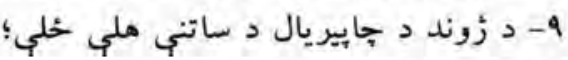
ا - أنسيني برابري؛ | 11 rا- د رسنيو آزادي؛ rا بو بوخي اصلاحات؛ flf 
به برخو كي مرسته وكري.

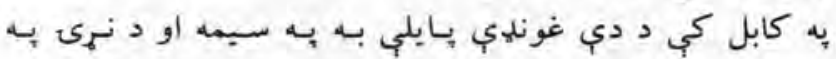

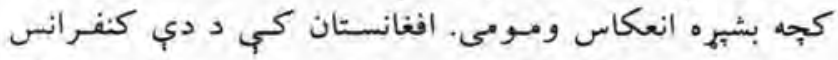

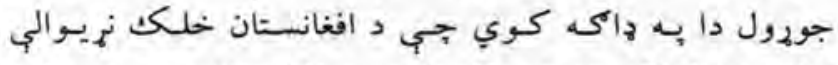

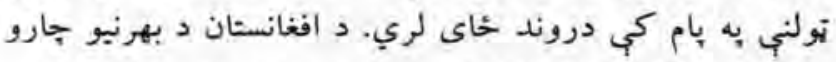

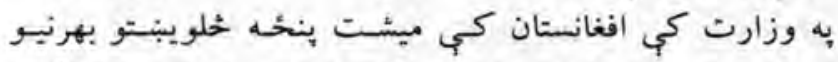

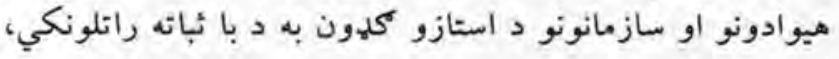

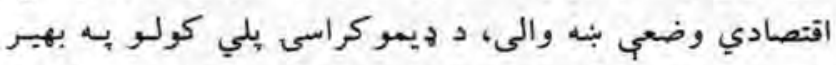

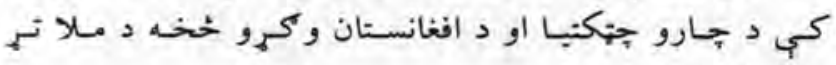

$$
\text { وانكيرل شي }
$$

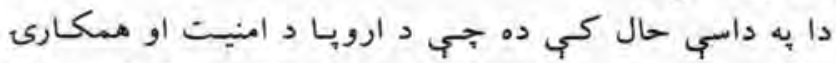

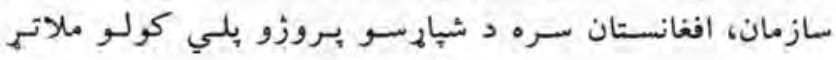

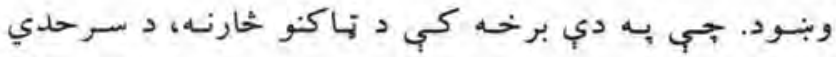

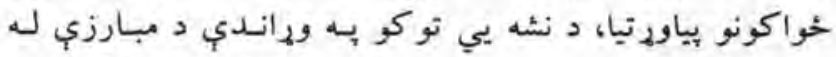

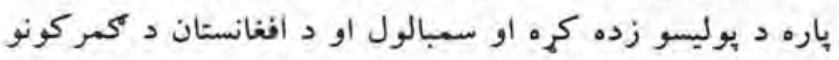

د مامورينو زده كمه شاملي دي.

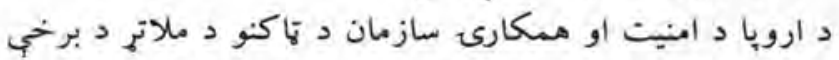

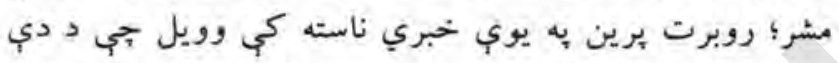

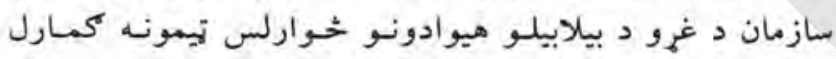

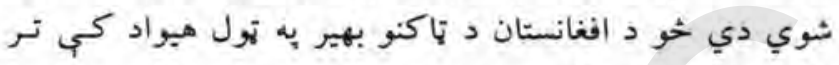

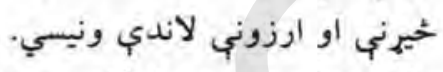

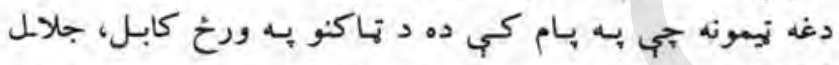

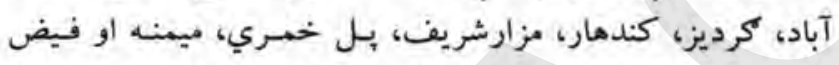

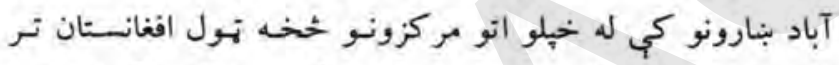

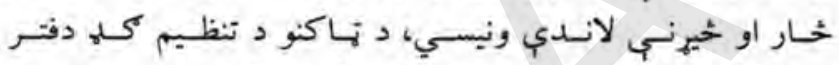

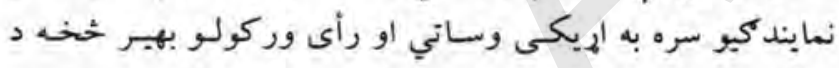

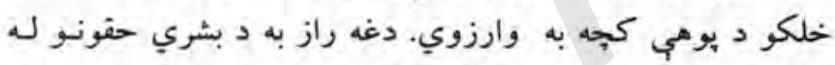

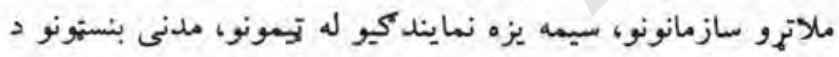

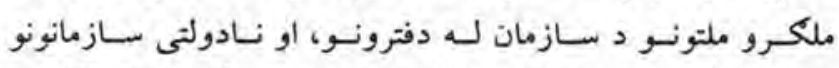

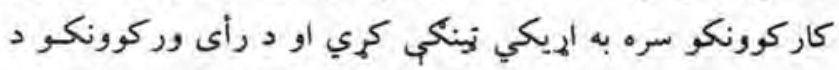

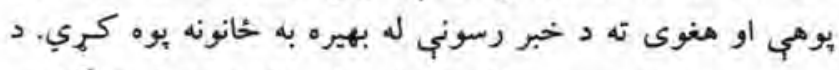

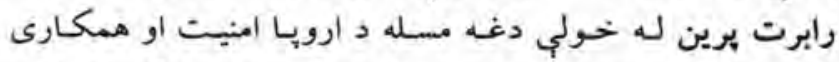

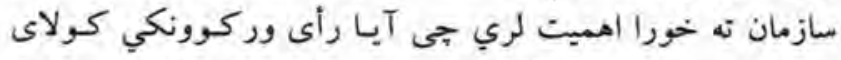

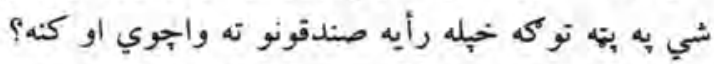

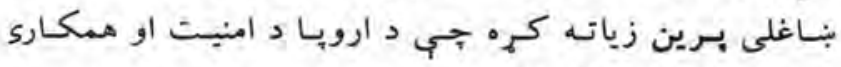

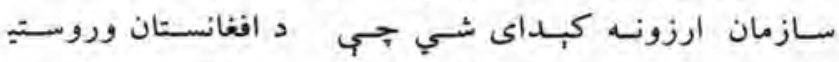

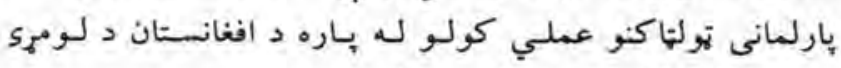

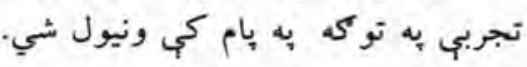

بروكر امونوسره همكاري وكري. د مادريد د ناستو بـه بايلـ

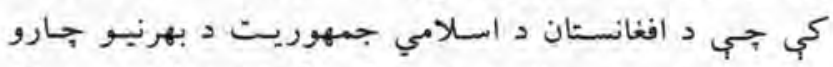

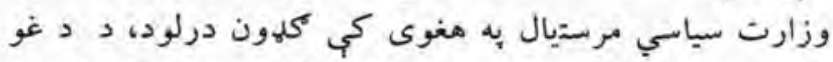

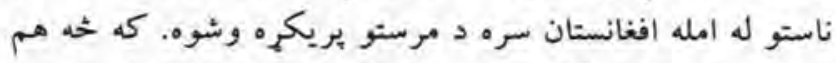

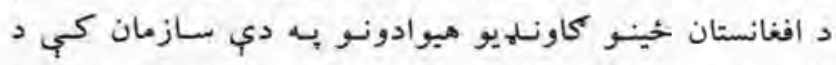

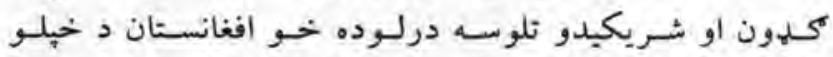

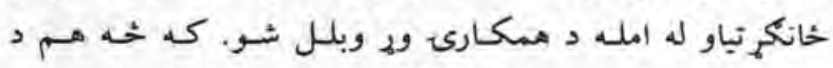

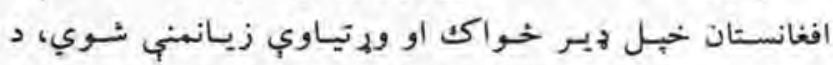

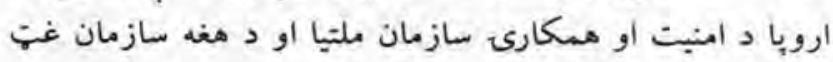

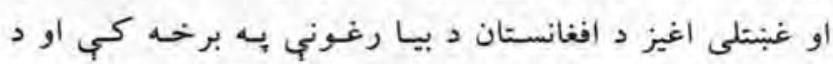

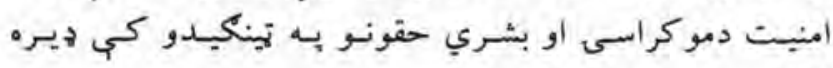

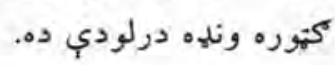

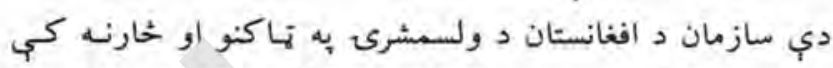

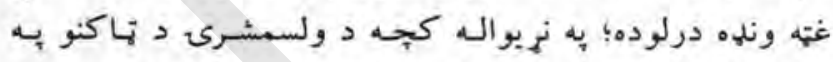

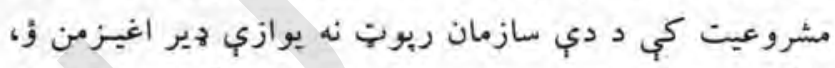

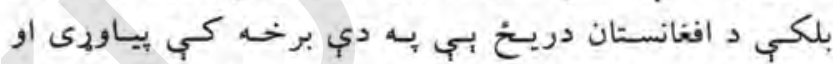

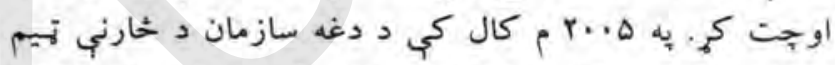

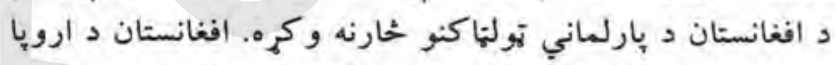

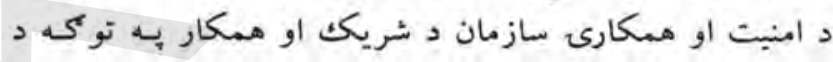

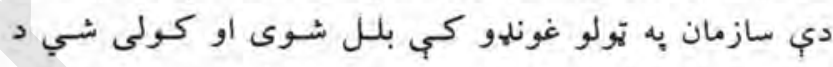

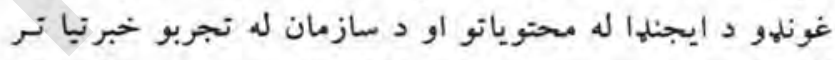

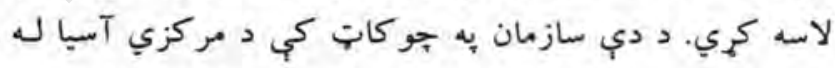

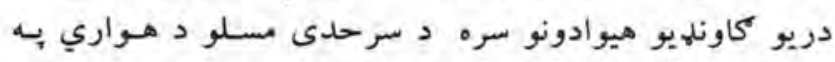

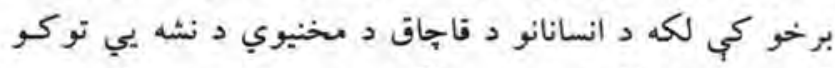

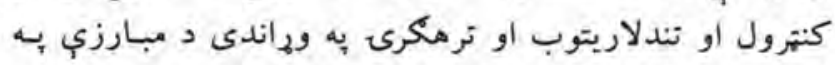

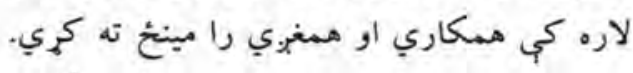

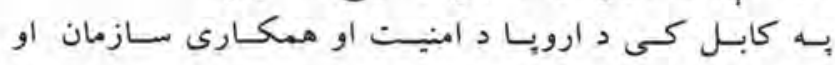
افغانستان مكلي كنفرانس

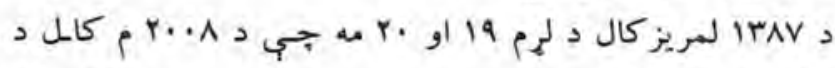

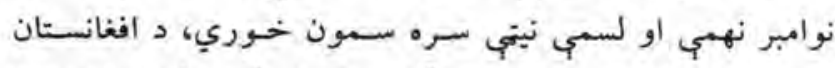

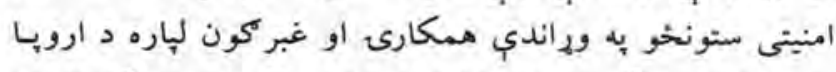

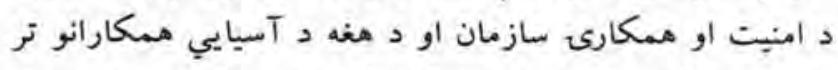

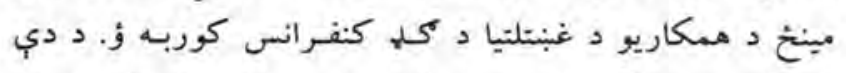

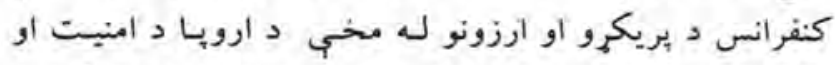

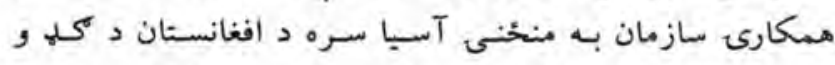

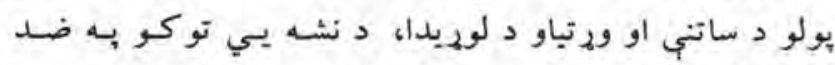

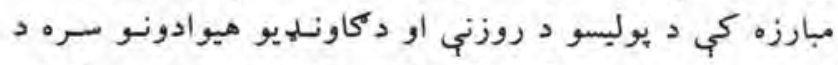

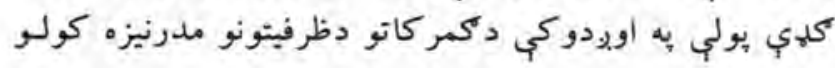




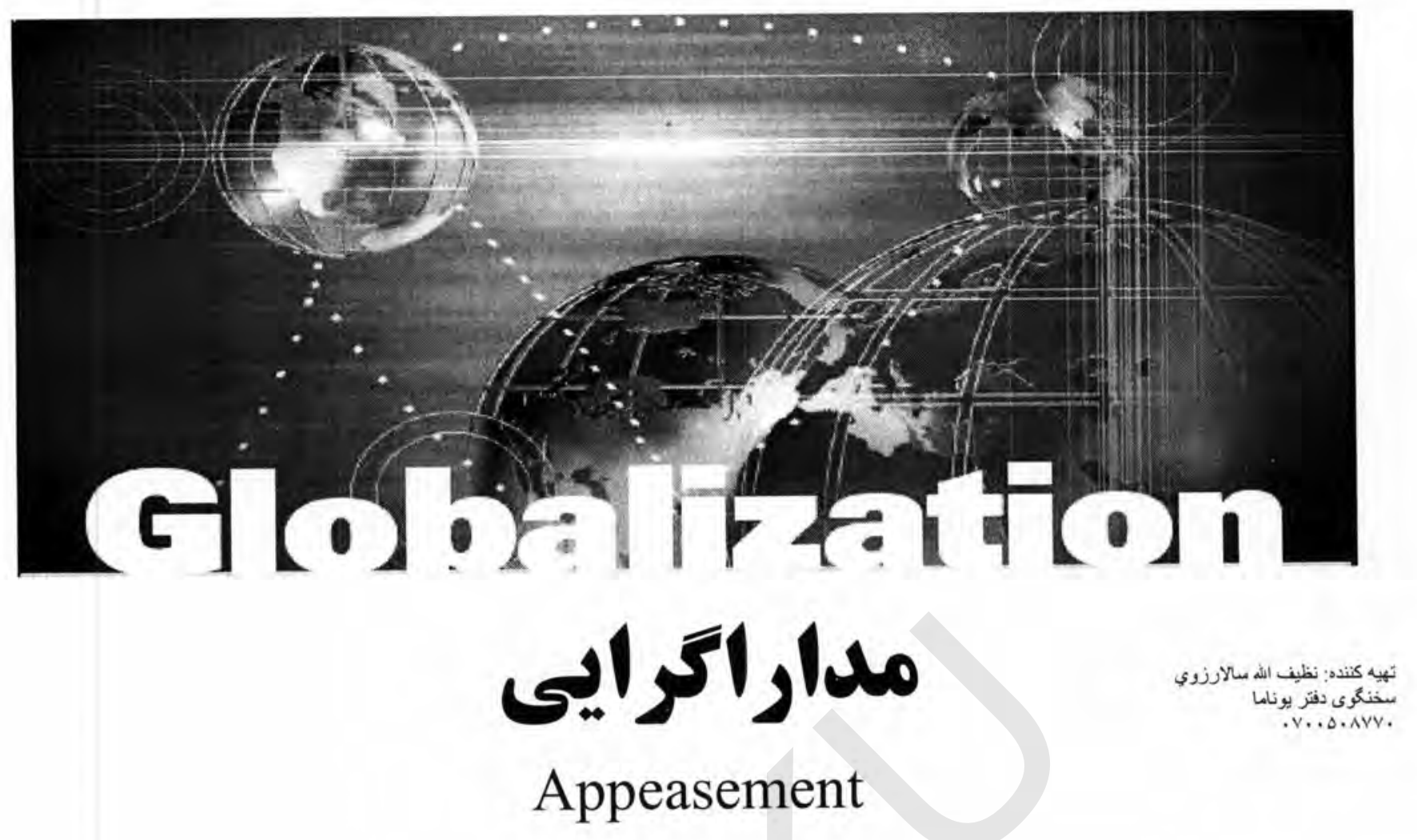

علت ايجاد اين هاليسى

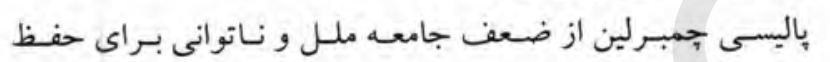

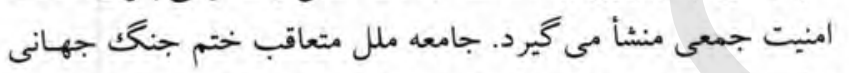

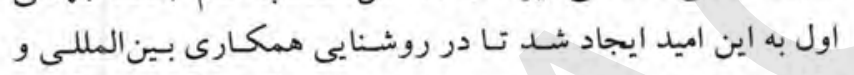

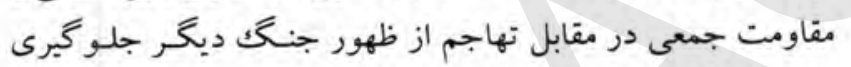

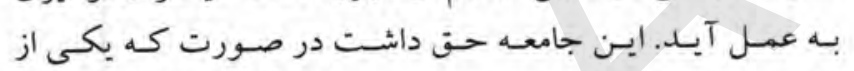

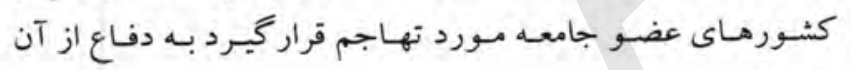

$$
\text { برخيز }
$$

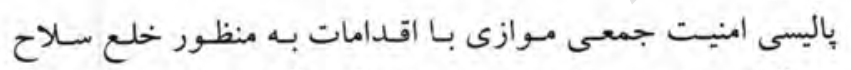

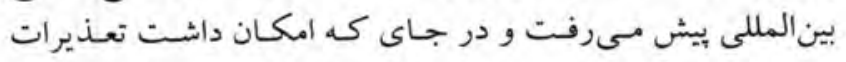

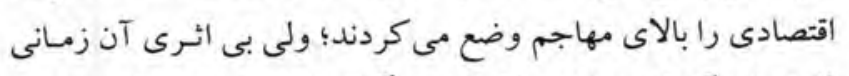

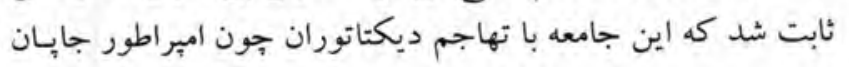

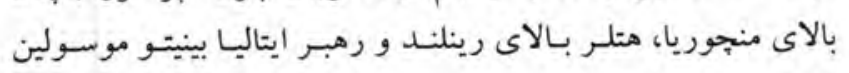

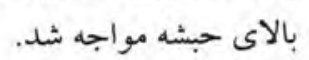

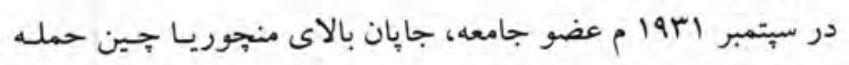
برد.

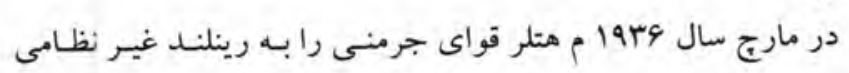
مىفرستد. در دسمبر الم أم بعد از يكك زد وخورد ميان نيروهـاى ايتالوى و
مداراكردن (مداراكرايى) يكك استر اتيزّى دييلوماتيك است كه بــ

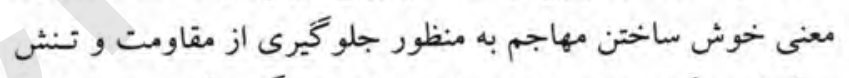

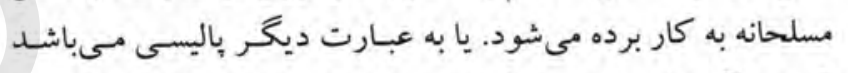

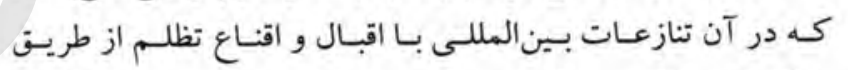

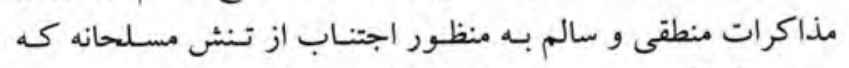

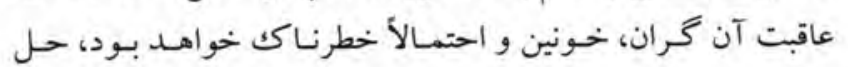

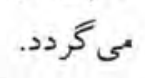
اين اصطلاح اغلباً براى باليسى خارجى نخست وزئ وزير بريتانيا، نيسولى

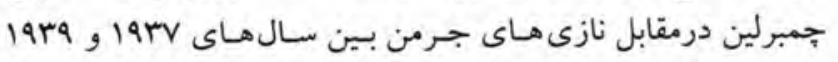
استفاده مىشد.

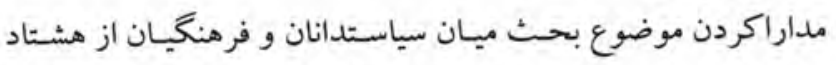

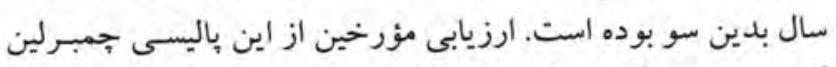

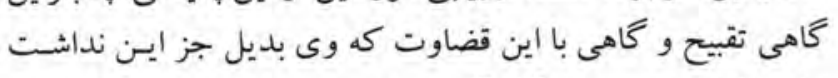

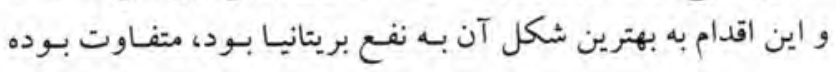
از دهه . بوا1 م بدين سو اين اصطلاح منحيث كلمه مترادف بـراى

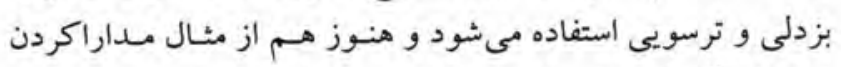

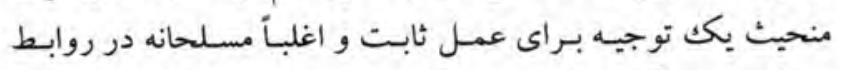
بين المللى جايگاهى دارد. 
نظرداشت شرايط عينى وقت، نهايـت سبعى خسود را كردنـد. ابعاد

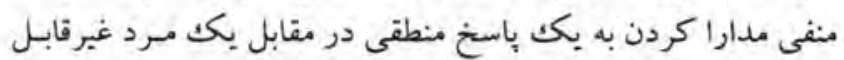

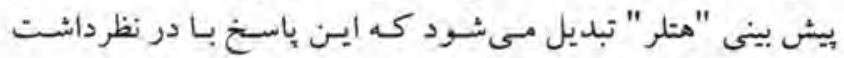

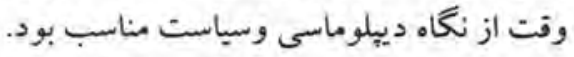

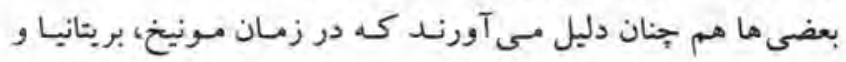

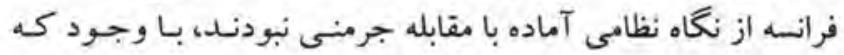

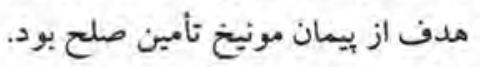

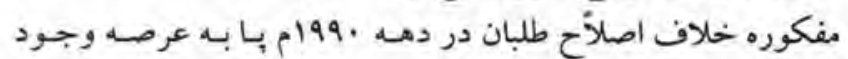

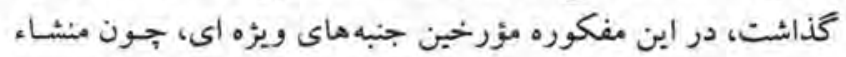

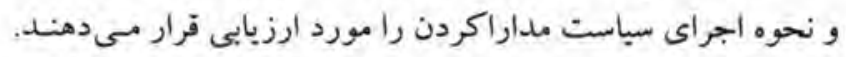

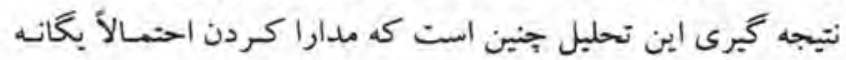

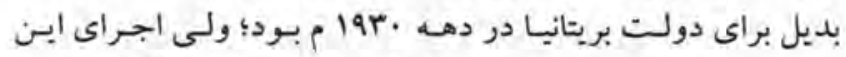

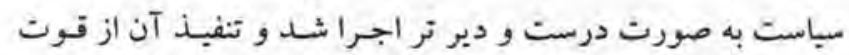

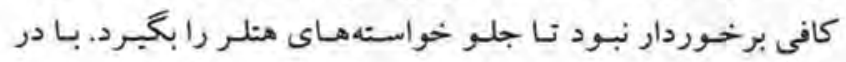

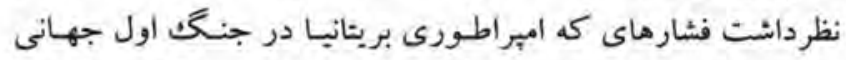

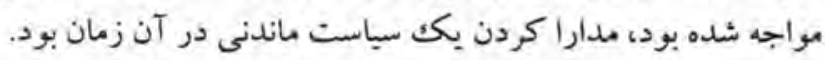

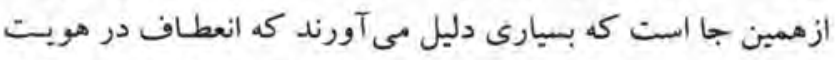

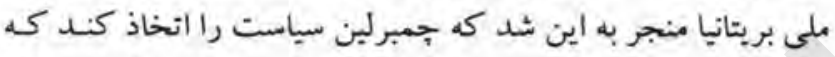

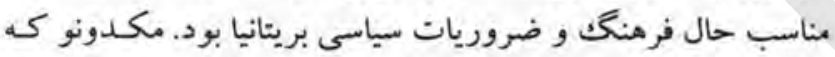

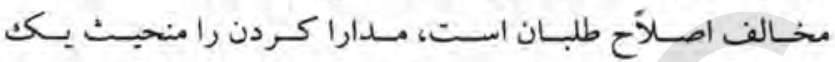

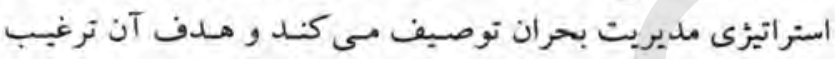

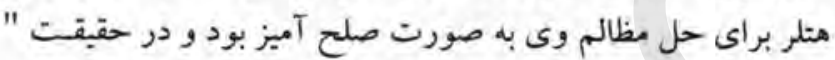

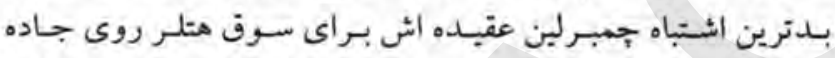

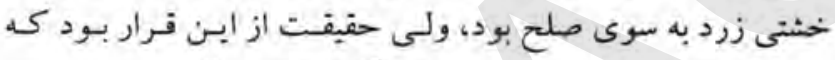

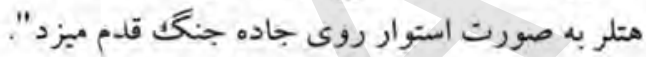
سياستمداران و مدارا كودن

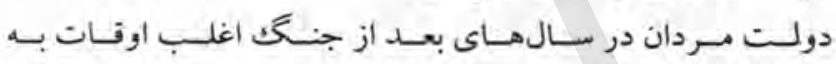

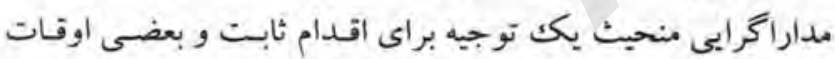
مسلحانه در روابط بين الملل استفاده مى كيند.

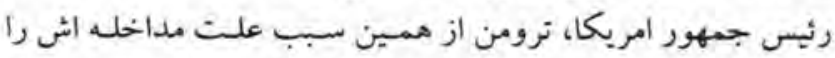

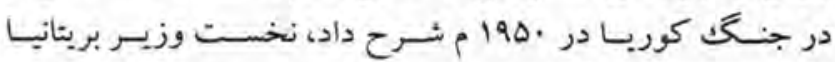

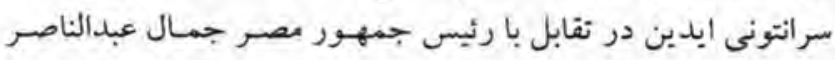

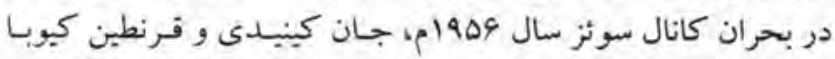

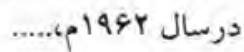

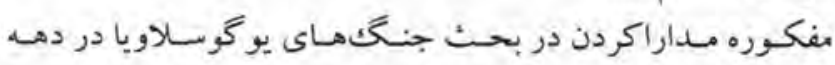

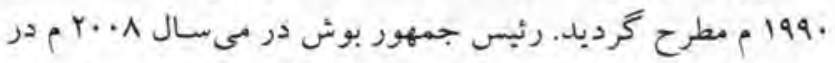

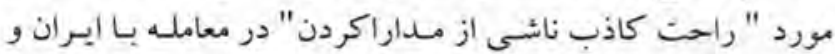
رئيس جمهور اش محمود احمدى نزٔاد هشدار داد.

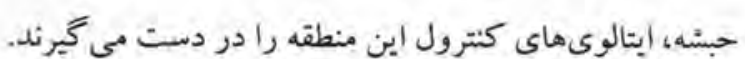

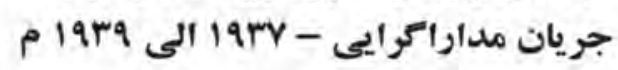

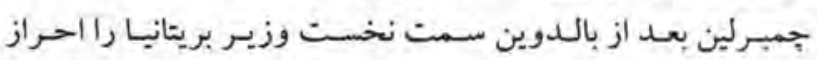

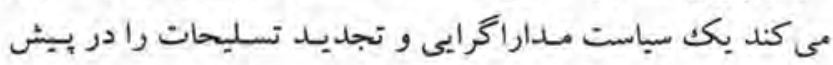

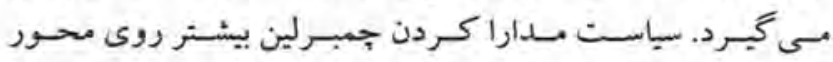

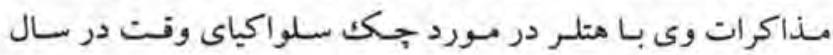

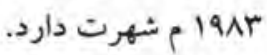
بر اساس توافق ويرسيليس جكسلواكيا ابجـاد شـد، سـوديتبنلند كه.

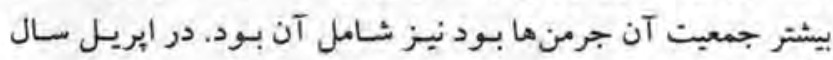

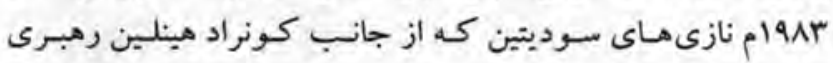

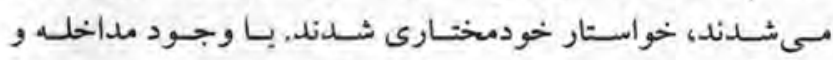

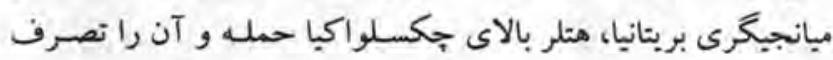

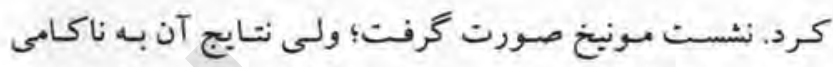

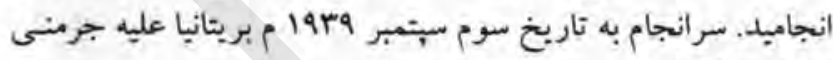
اعلان جنيخ كرد. تغيير كرايش به مداراتكرائ جكرد

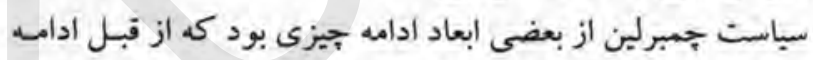

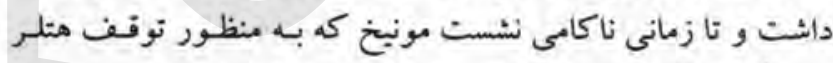

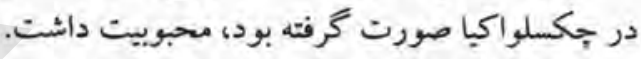

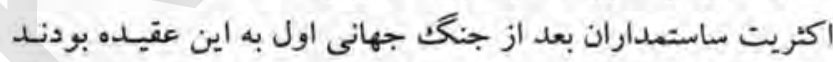

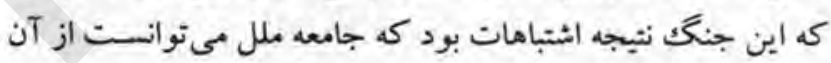

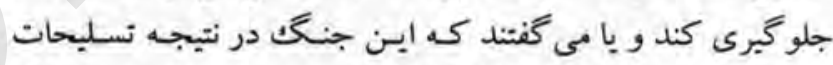

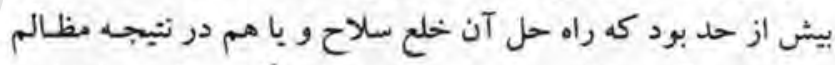

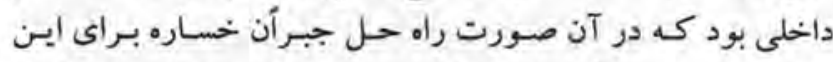

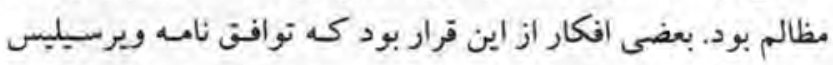

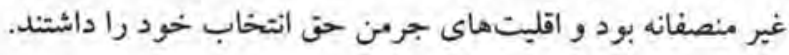

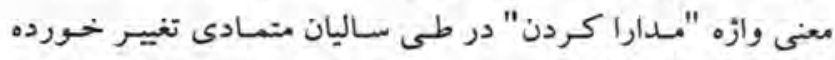
است و هر مكتب فكرى تعريف ويزٔه اي براى اين وازٔه قائل اند.

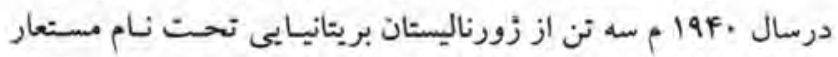

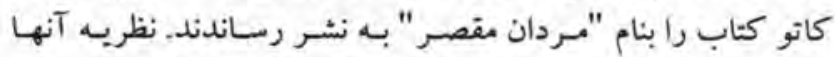

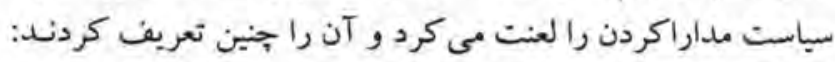

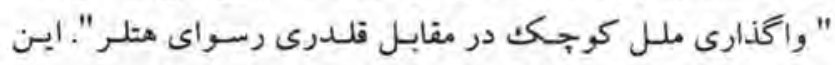

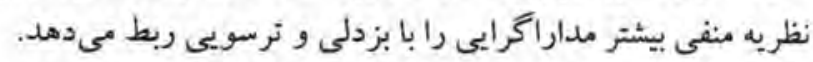

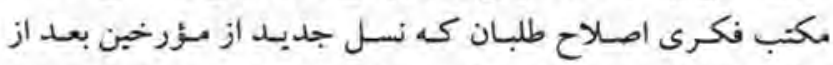

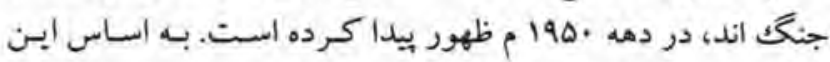

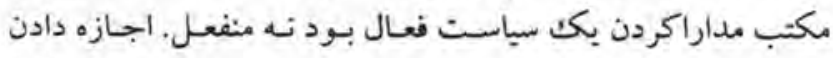

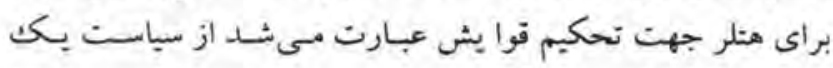

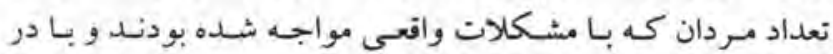




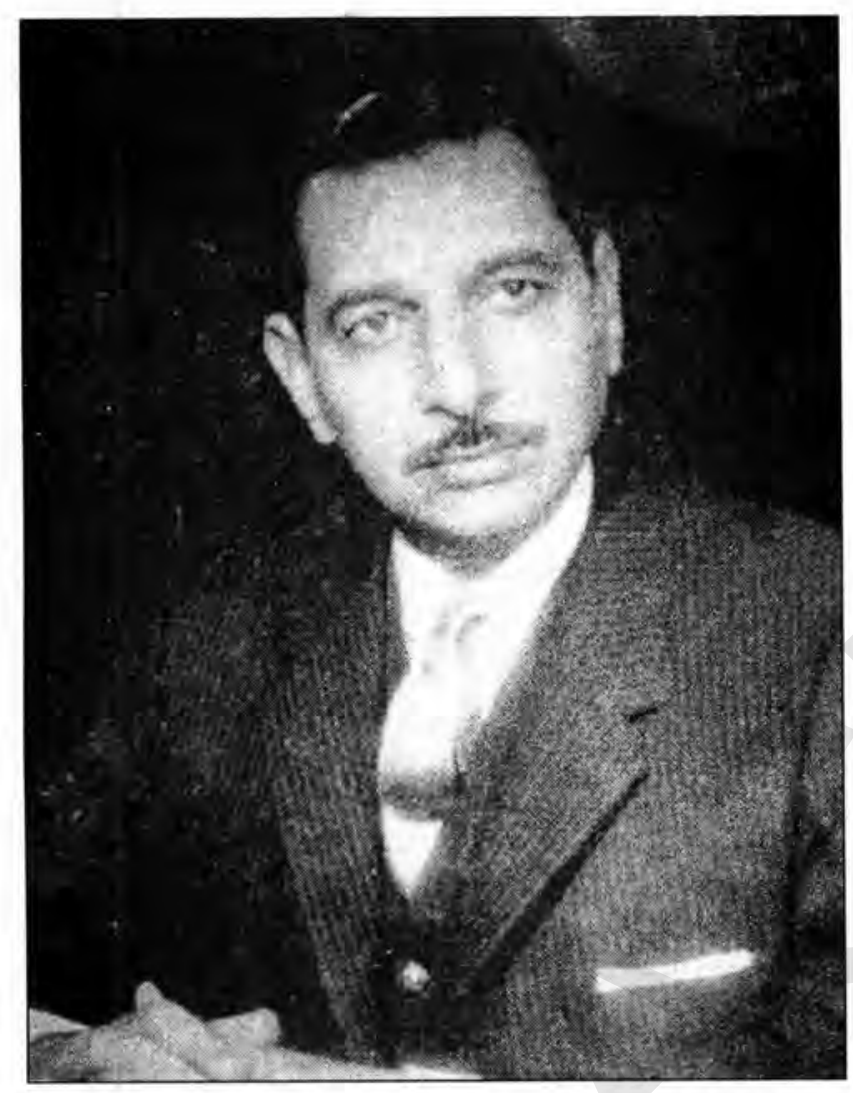

وزير امور خارجه ايفاى وظيفه كرده است. در سال 99Vام در نشست كشورهاى غير متعهد در مجمع عمومى ملل متحد

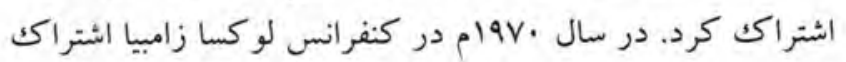

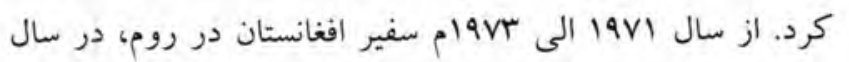
rا9Vام سفير در مسكو و در سال 19V4ام سفير در اسلام آباد بود. در ماه سنبله، سال جهت اشتراكت در سومين كنفرانس سران دول و حكومات كشورهاى بى طرف، منعقده لوساكا.

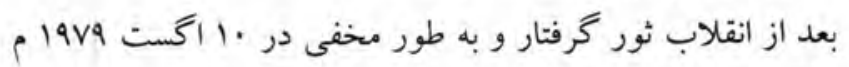
به قتل رسيد،. وى داراى سه بِّر بود.

\section{'ورامحاكمتوكى}

\section{دهمين وزير امور خارجه افغانستان}

(Ird.-IrFG) -(IrFG-IMFF)
نور احمد اعتمادى يُر غلام احمد خان و نواسه سردار عبدالقدوس خان در سال الو الم مدر شهر قندهار ديده به جهان كُود. وى از ليسه استقلال كابل فارغ التحصيل گرديده، بعد از سال

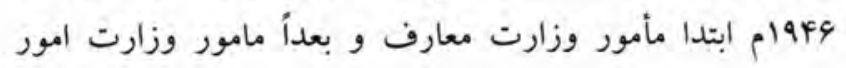
خارجه شد. در سال qFV ام به حيث سكرتر اول سفارت افغانستان در لندن تعيين گرديد، بعداً سكرتر اول در سفارت افغانستان در واشنگتن مقرر شد. در بستهاى معاون رياست تشريفات، مدير روابط اقتصادى، رئيس امور سياسى و سكرتر جنرال وزارت امور

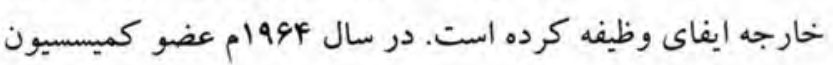
ترتبب قانون اساسى و لويه جرگه بود. در سال ع 1944 به حيث

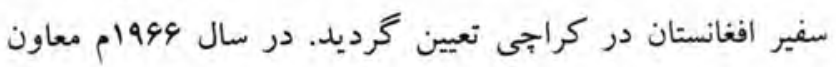

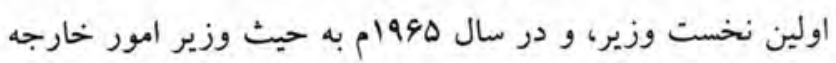
تعيين شد. در جلسههاى هـ و را مجمع عمومى سازمان ملل اشتراكت كرد، از سال 199V الى العام ام به حيث نخست وزئ وزير و 


\section{نُيوالِ إريكب، نن او يرون}

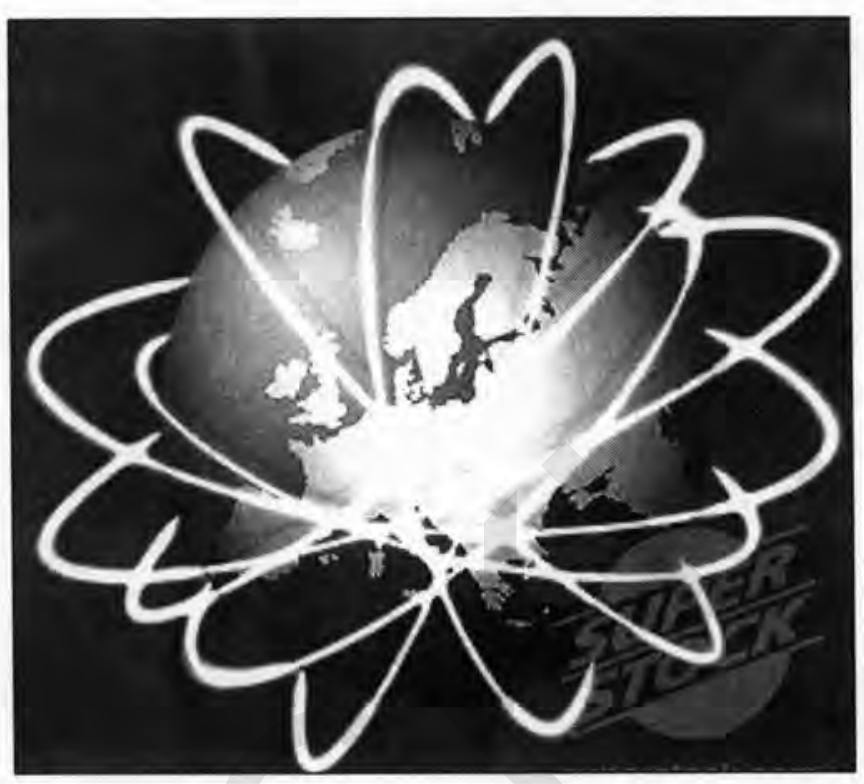

نور ولى خان نور

د ويندوى ريلميت

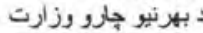
Noor.noor@inbox.com

\section{به تبر يسي} دوهمه برخه

و حالتونو كي خيني خبري، موضوع كاني او مسلي كلهي او شـريكي

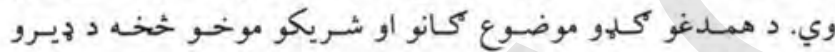

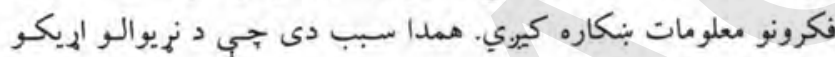

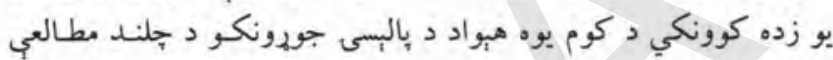

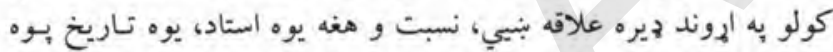

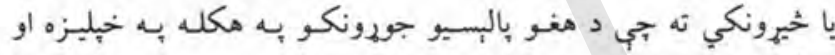

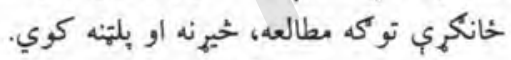

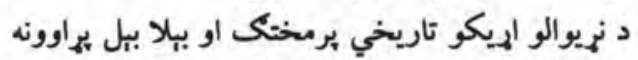

Historical development of IR

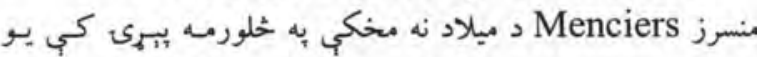

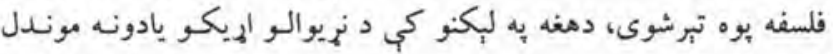

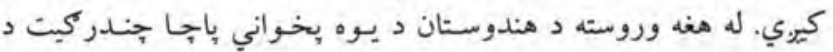

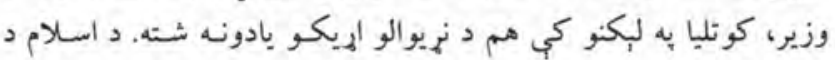

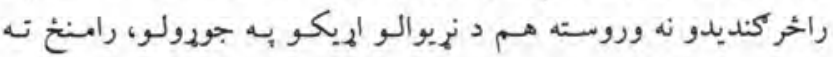

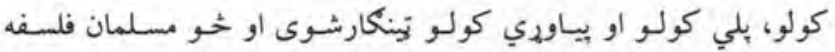

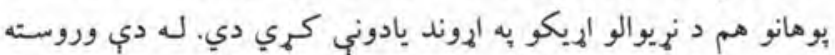

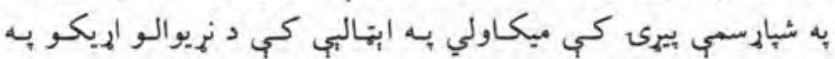

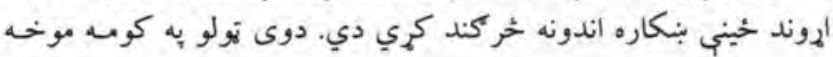

لكه جي به لومهى برخه كي د نئيوالو إريكو به هكله بـه عمومي

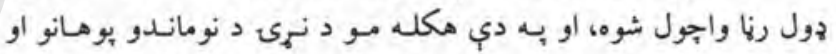

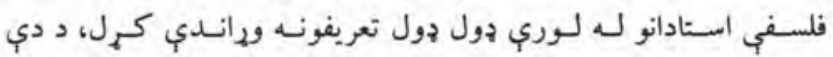

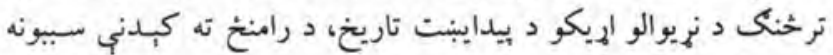

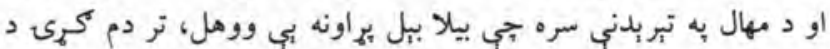

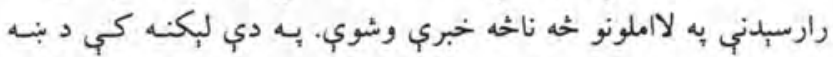

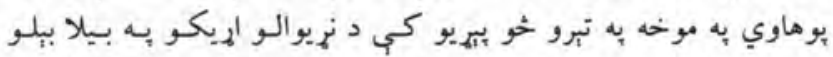

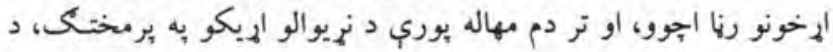

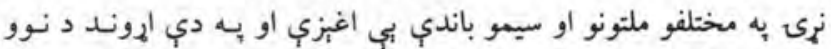

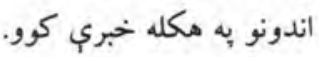

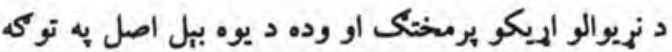
Development of IR as a separate discipline آشن ليك Achan League لومرى كس و، جي دي نهيوالو

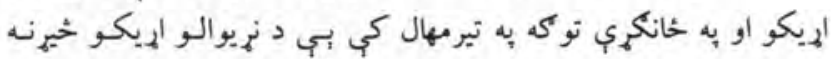

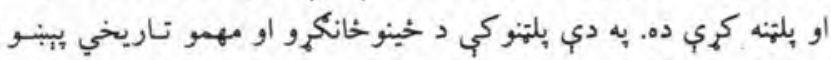

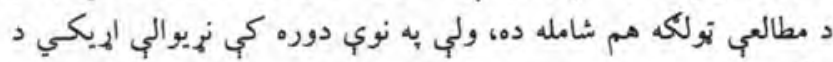

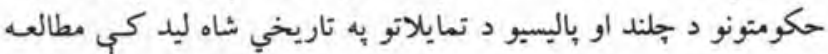

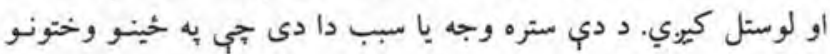




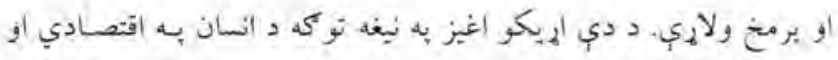

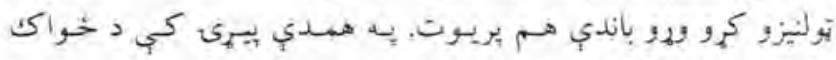

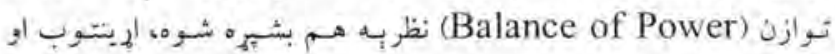

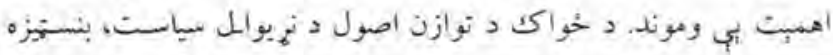

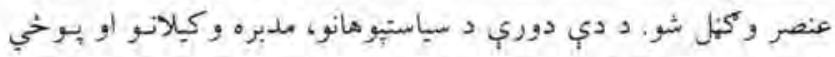

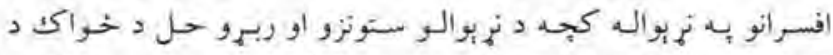

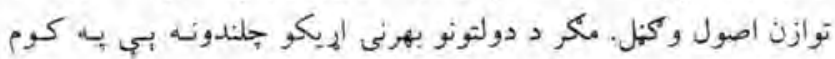

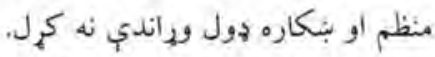

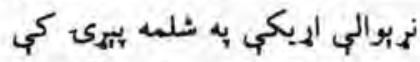

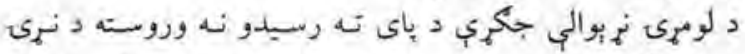

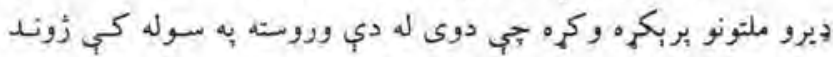

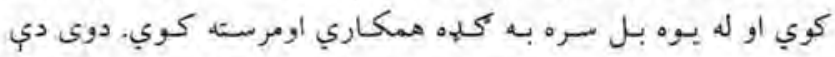

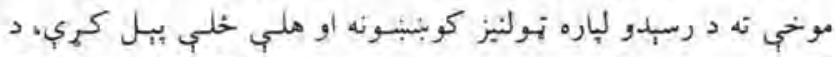

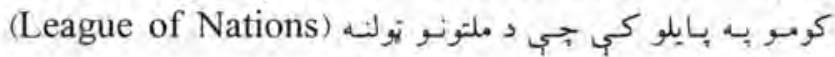

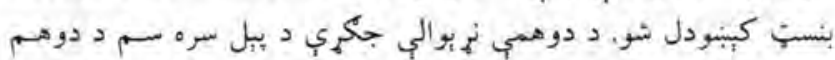

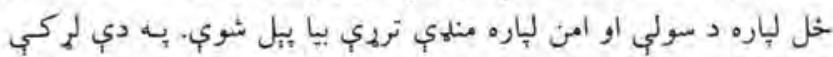

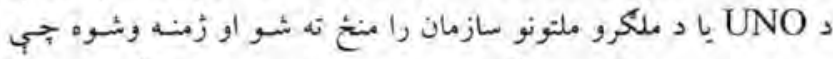

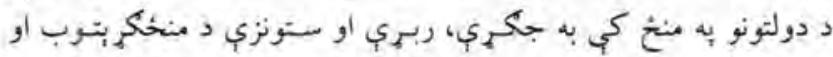

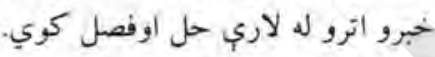

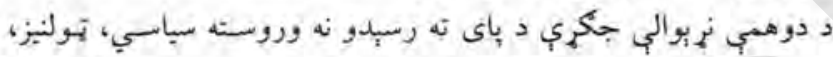

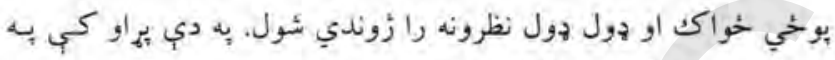

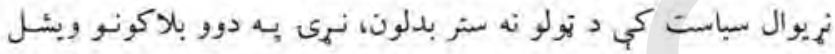

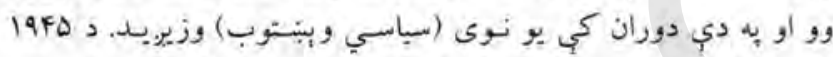

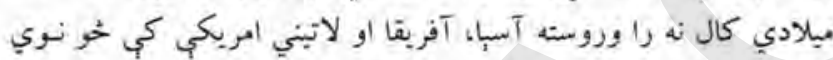

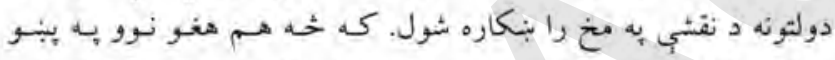

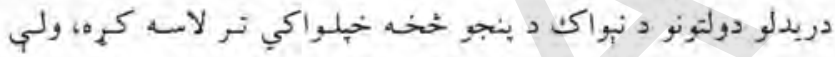

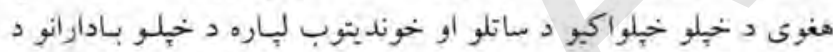

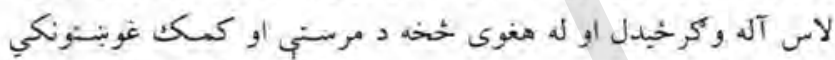

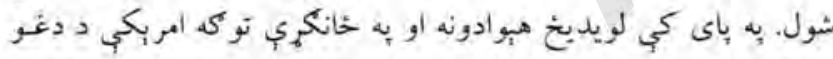

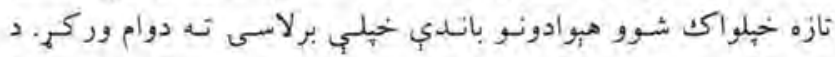

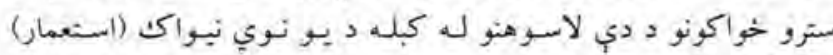

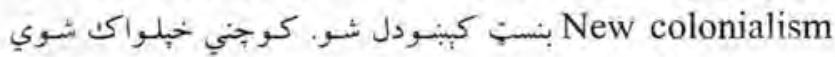

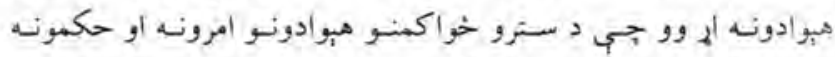

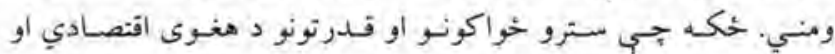

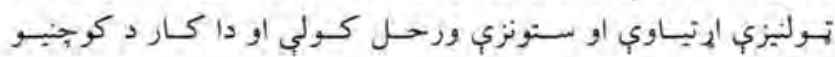

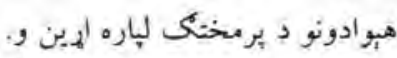

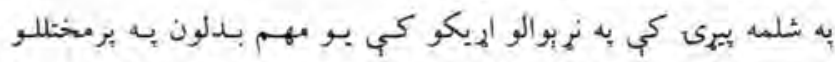

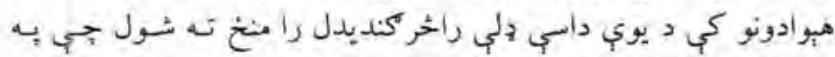

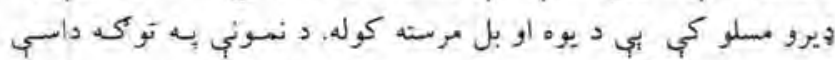

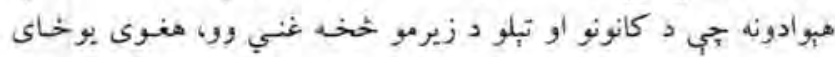

داسي وانكيرل؟

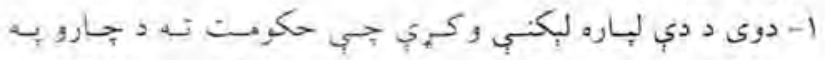

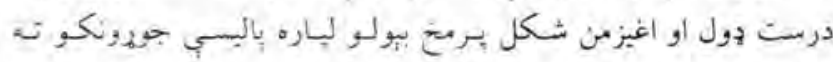

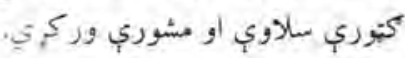

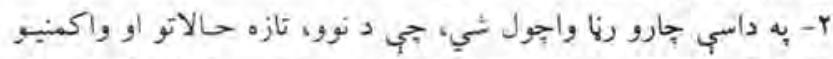

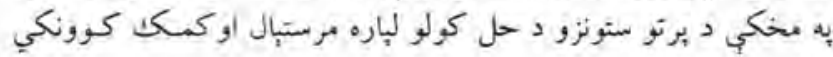

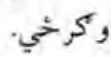
نهيوالي الجيكي به اوولسمي بيرى كي

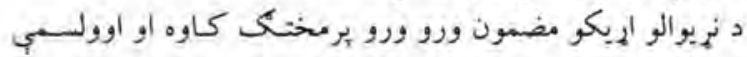

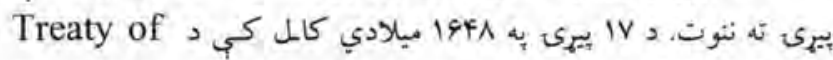
Westphalia

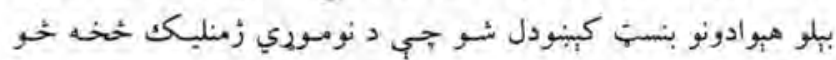

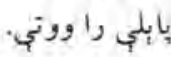

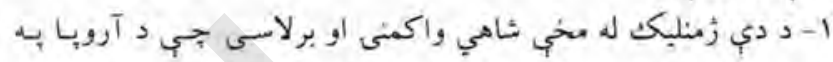

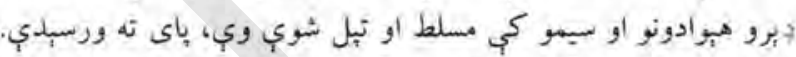

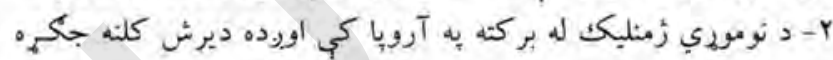

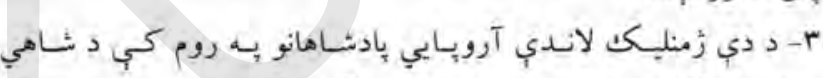

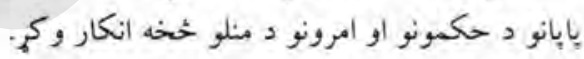

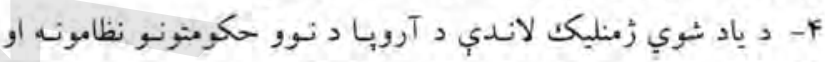

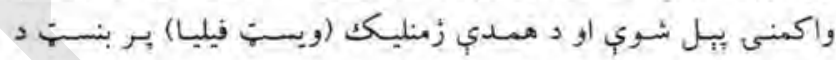

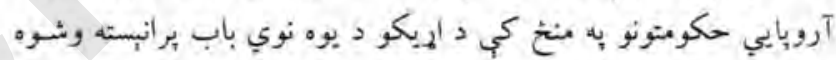
يا بحي هبره كيبنودل شوه.

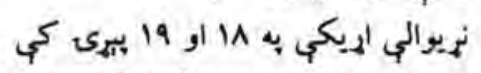

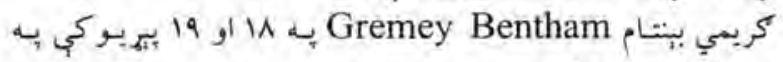

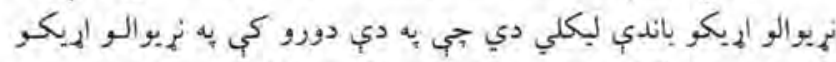

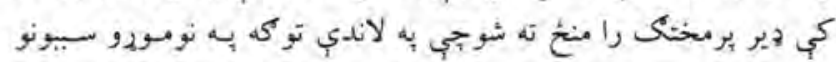

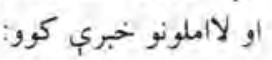

Diplomatic relations سفارتي إيكي كور: Military Strategy بوخي سترانيزي انيخي

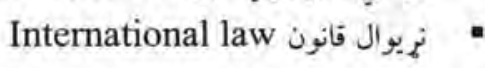

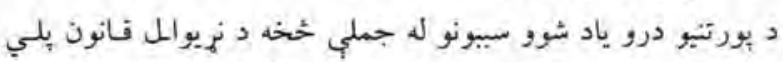

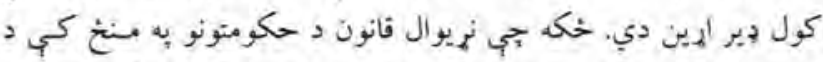

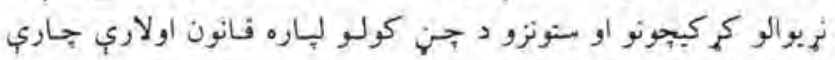

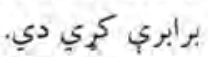

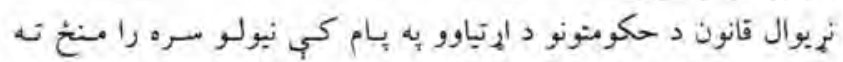

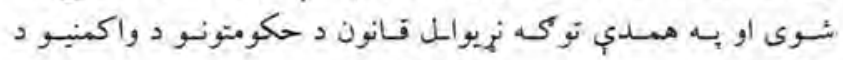

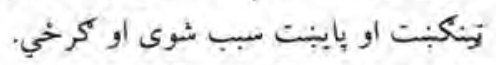

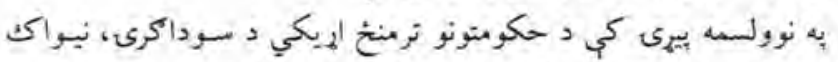

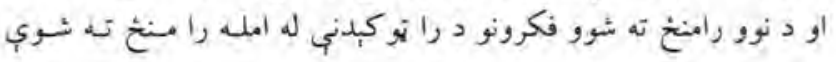


بل به خلاف د ببلا ببلو هبوادونو سره بـ بـوخي، افتصادي او فرهنكي

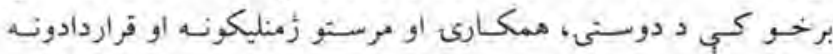

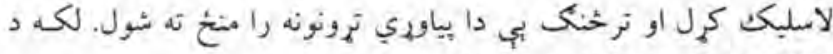

SEALO,CENTO,NATO

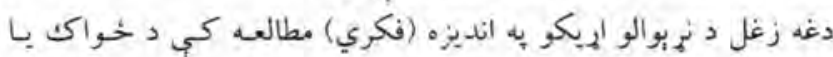

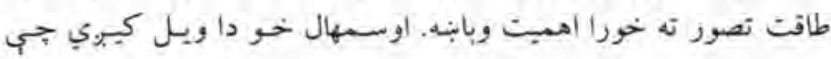

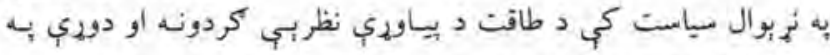

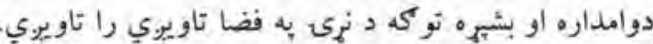

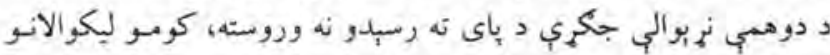

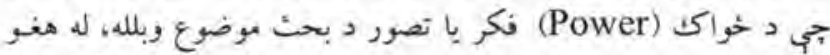

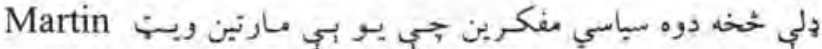

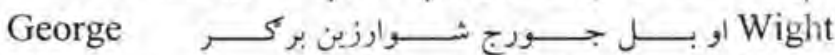
Schwarzenberger

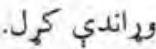

مارتهن به خجل كتاب: Power Politics 194 (د طاقت سياست) او شئوارزين بركمر بـه خهـل كتياب: Valency of power in Global Politics

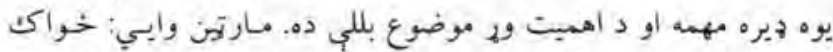

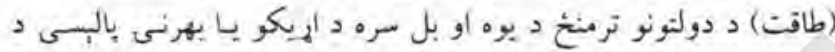
جويوني به مهال مهم رول ترمبره كوي.

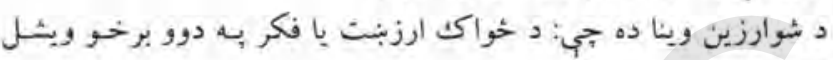

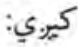

1- د كوابن به جول د خواكت يا طاقت كارونه (استعمال).

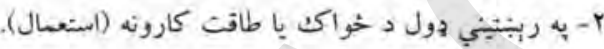

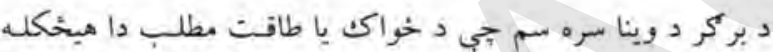

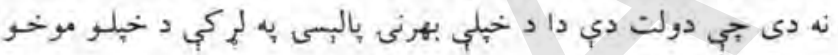

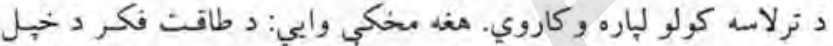

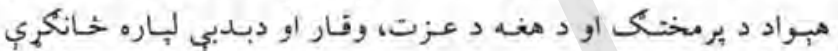

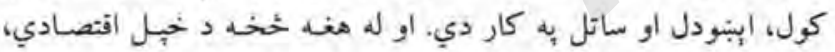

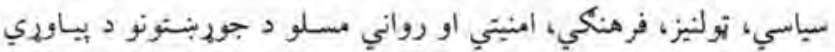

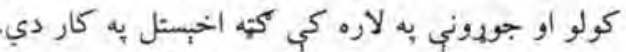

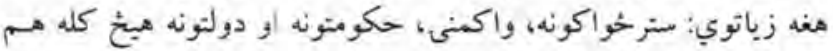

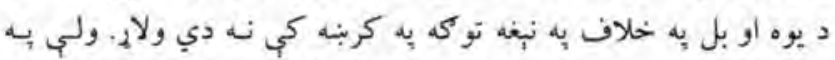

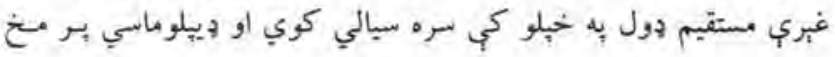
بيائي.

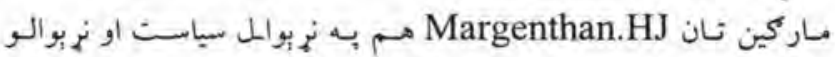

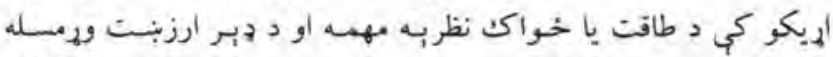

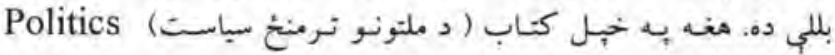

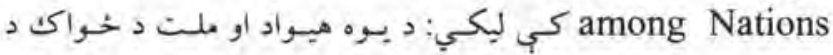

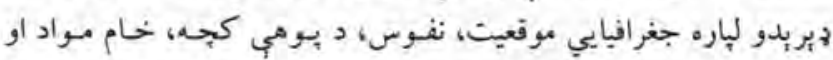

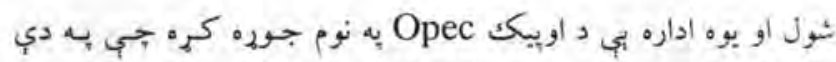

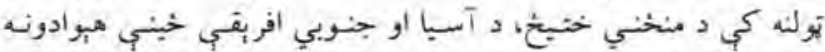

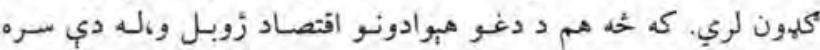

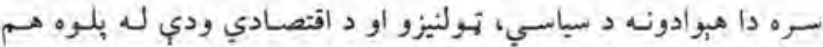

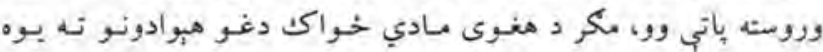

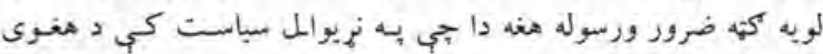

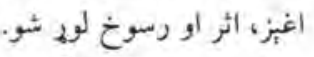

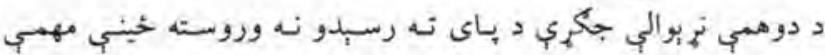

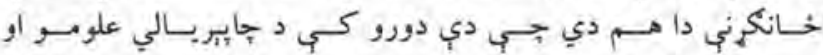

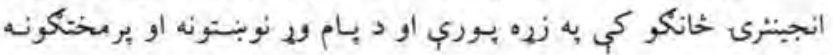

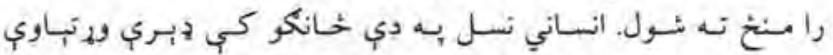

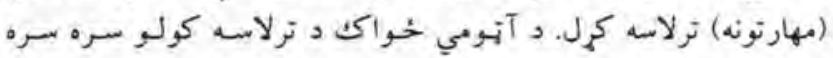

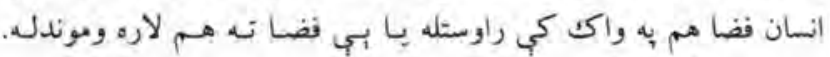

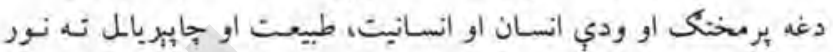

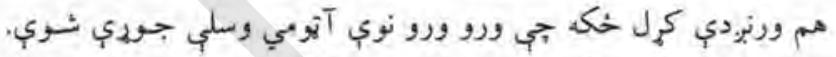

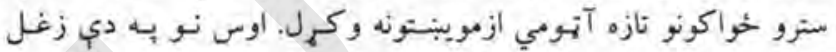

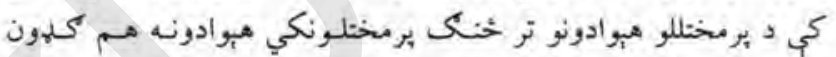

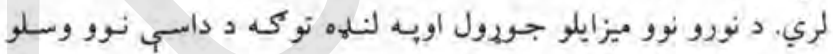

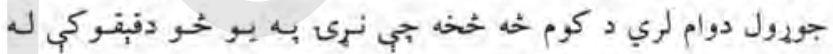
يوي مخي ورانبدلى او رنكيدلى شي.

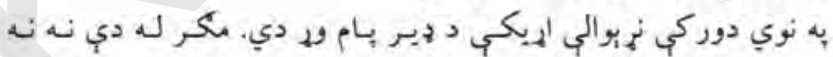

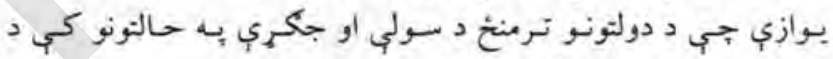

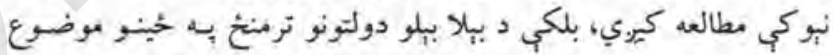

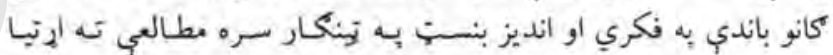

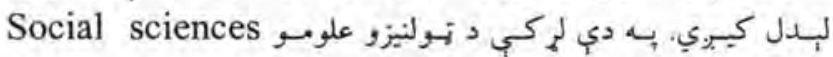

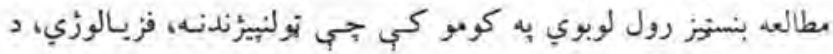

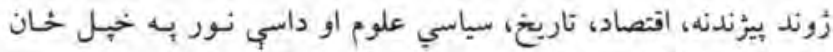

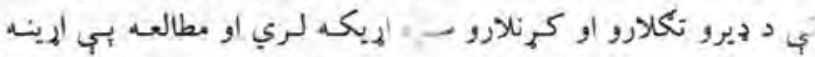

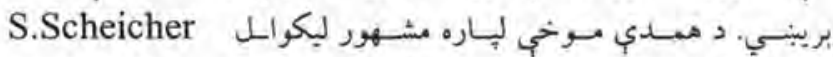

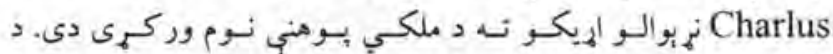

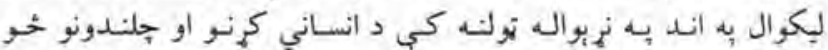

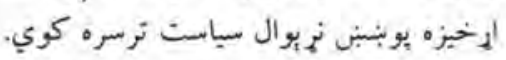
به نـبوالو إيكو كي نوي اندوته New concept in International relation

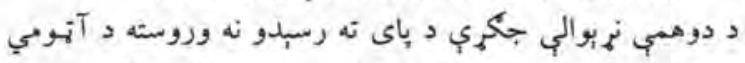

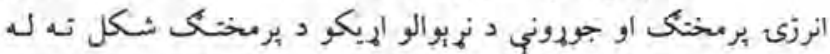

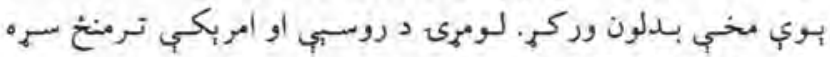

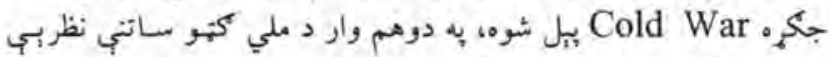

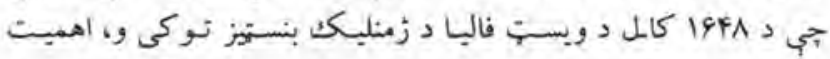

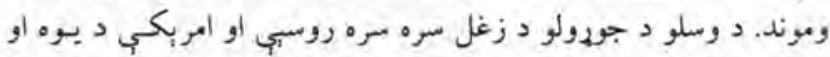




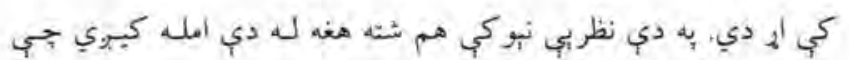

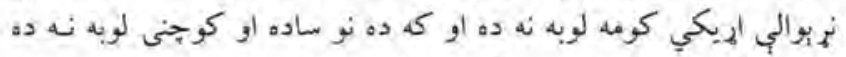

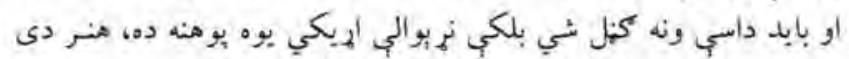

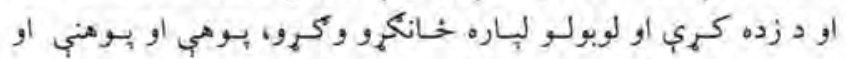
ورتياوو ته أينيا لري. د مخابراتو اند نداند

Communication approach

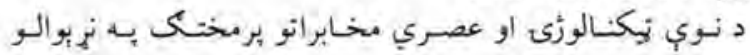

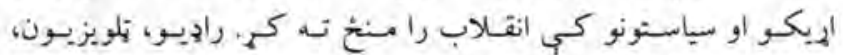

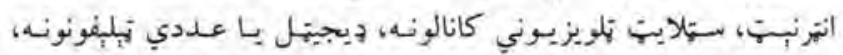

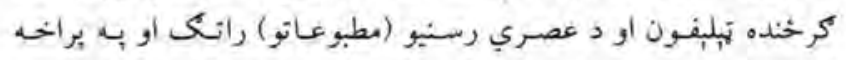

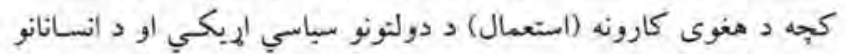

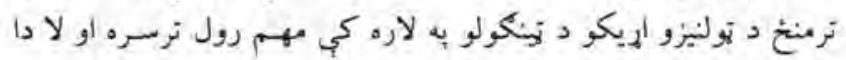

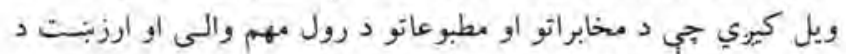

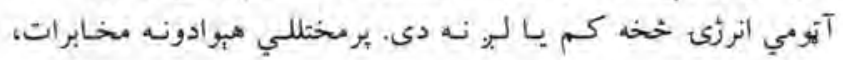

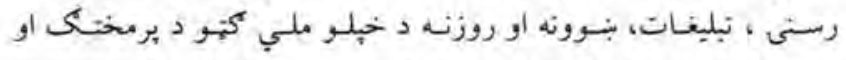

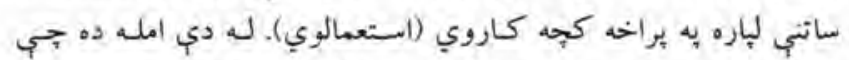

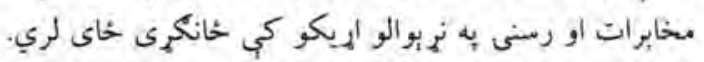
دور، زوراكت يا طاقت نظريه

\section{Theory of the Power}

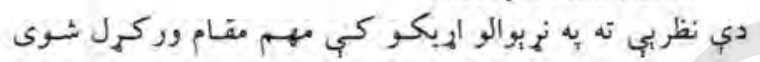

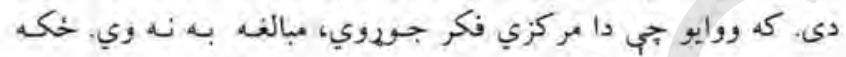

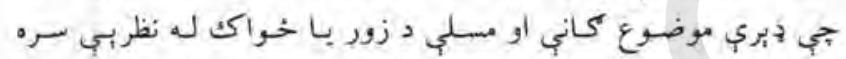

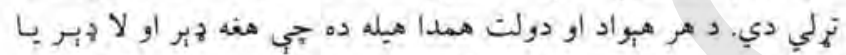

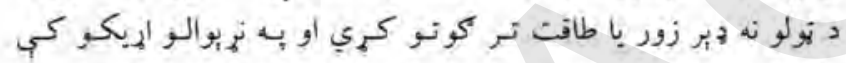

$$
\text { " . بكاره، واضح اثر او اغبز وبنيبي او وساتي. }
$$

Theory of the Intl.Organization

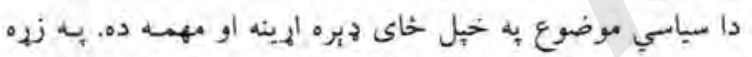

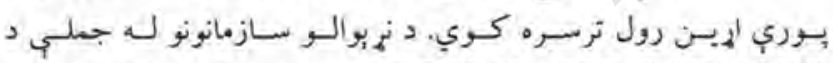
EEG,UNO ,OIC,OAS,NATO

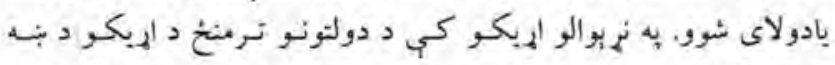

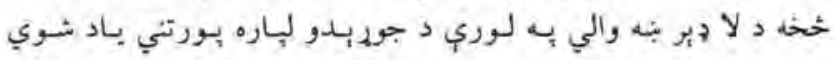

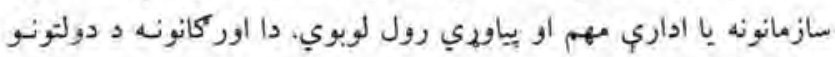

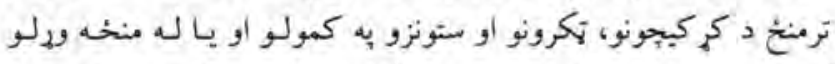

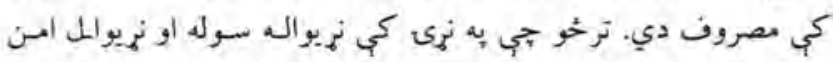

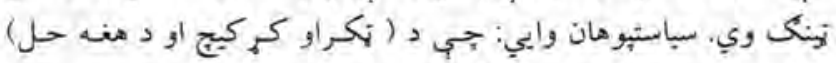

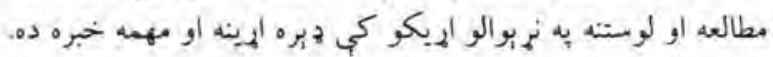

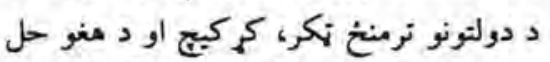
Conflict $\&$ conflict resolution

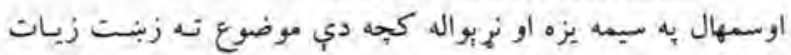

أقتصاد بهم رول لوبوي.

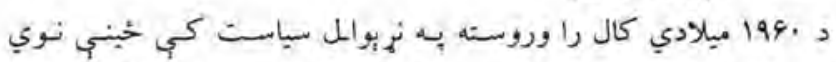

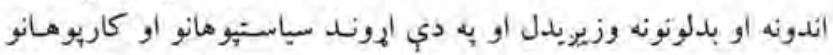

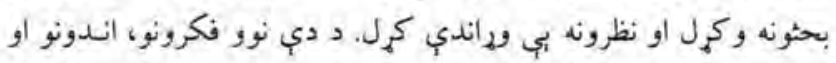

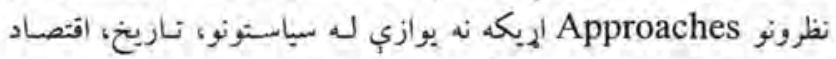

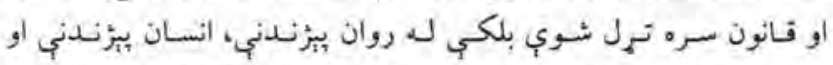

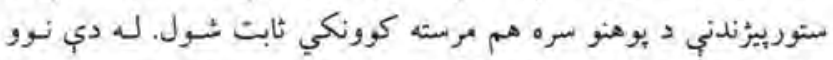

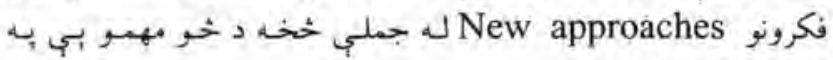
لاندي توكى بادونه كورو: System approaches ن-

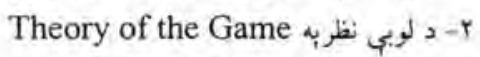
Communication theory

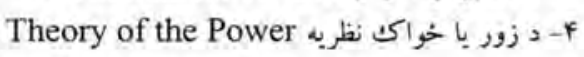
Theory of the Intl.Organization

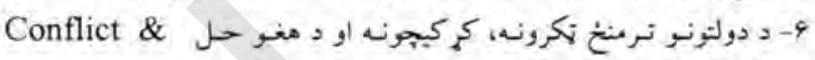
Conflict resolutions

Theory of the War \& Peace د د دكي او سولي نظريه 1- Theories of Ideologies

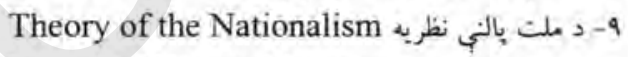

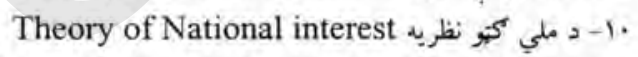

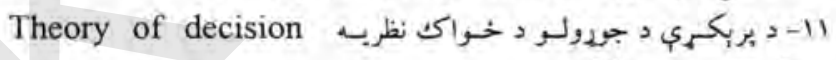
making approaches

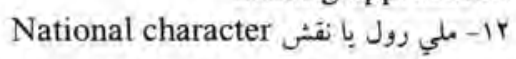

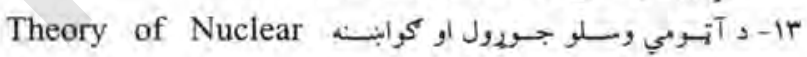
weapons Food Problem if

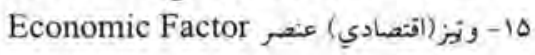

\section{د واكمنى يا بياوري نظام نظريه}

Powerful system approach

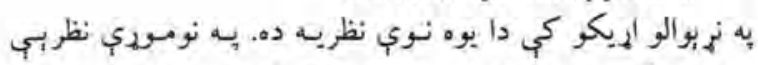

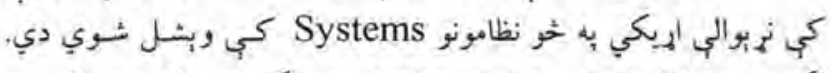

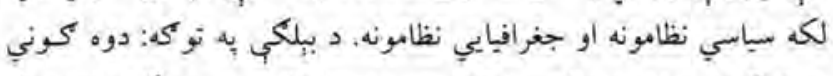

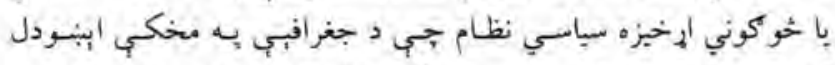

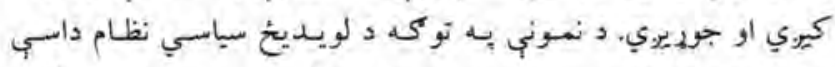

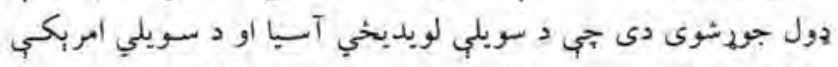

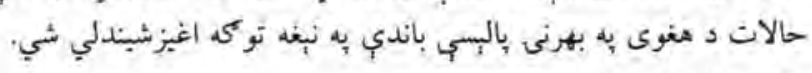

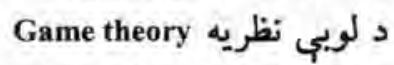

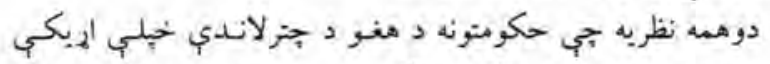

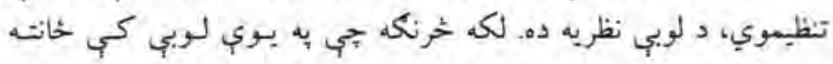

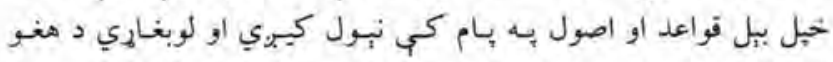

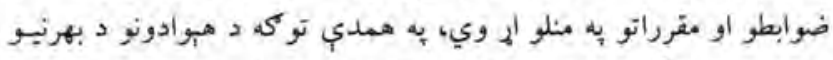

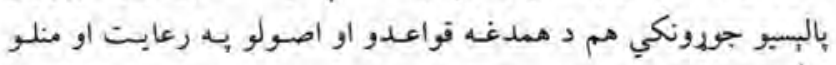


خحه د بنكالي ملت او بنكالي زبي دو رسمبت به نوم د نقشي بـه مـخ را

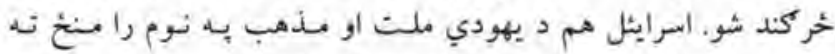

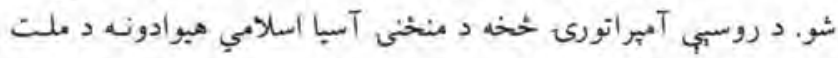

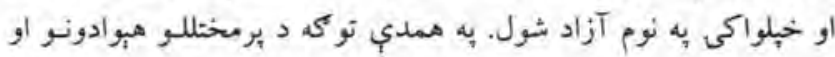

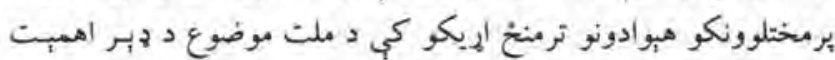

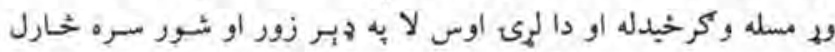

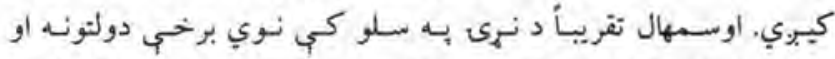

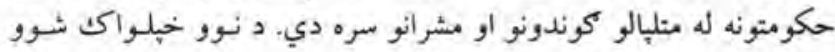

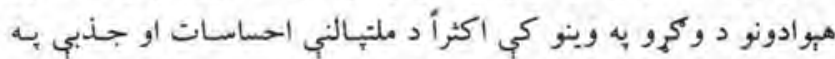

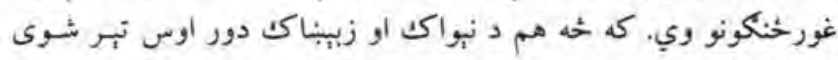

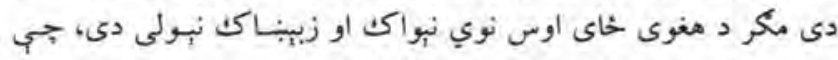

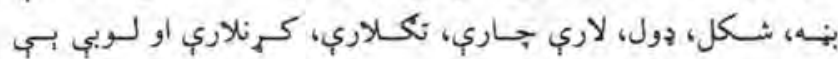
تويير لري او بس.

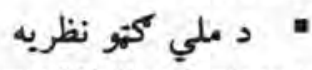

Theory of National interest

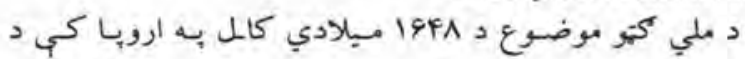

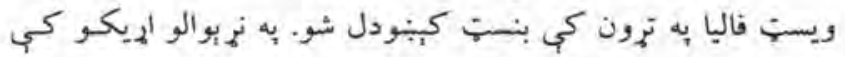

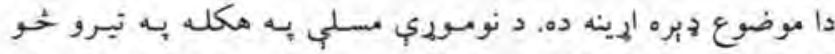

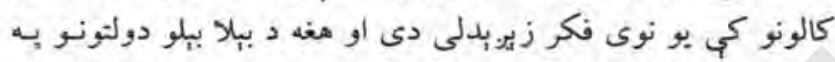

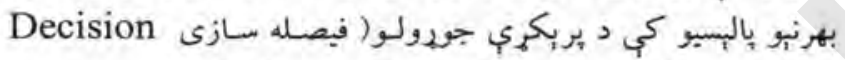

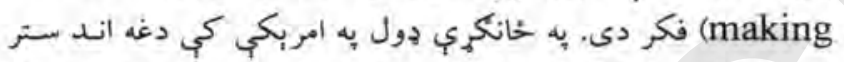

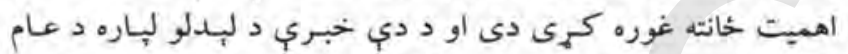

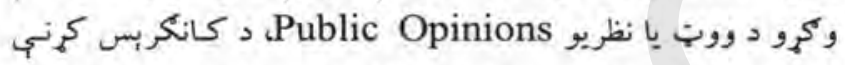

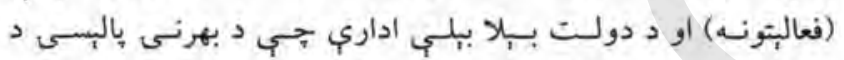

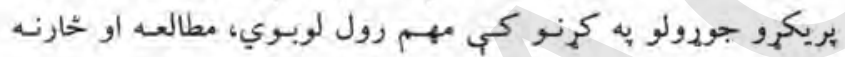
كوي.

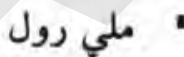

\section{National Character}

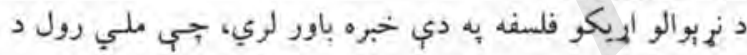

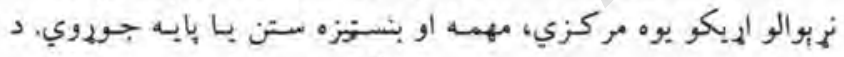

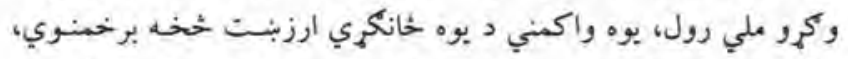

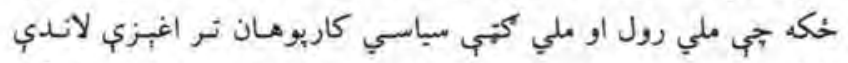

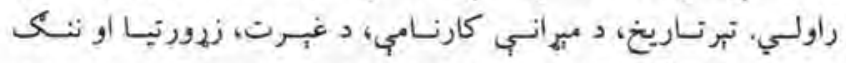

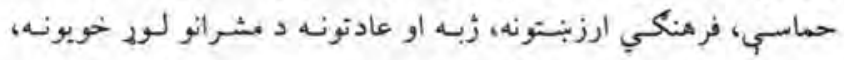

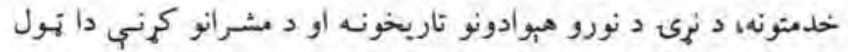

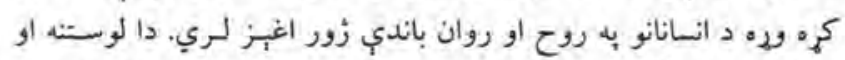

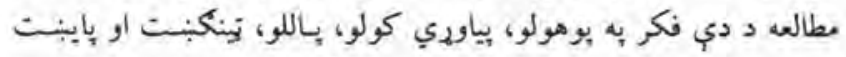

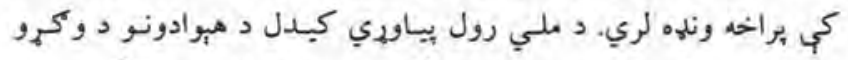

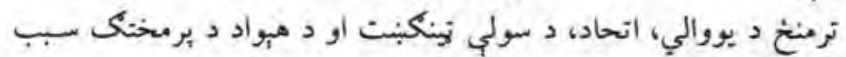
كرخي.

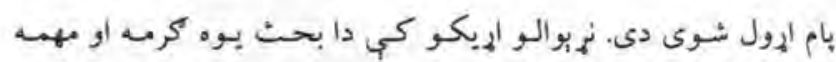

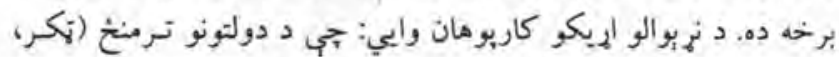

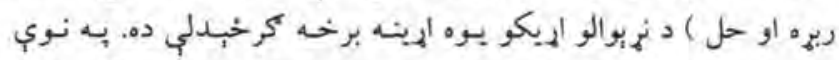

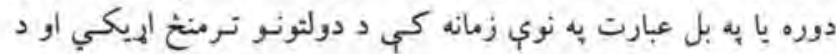

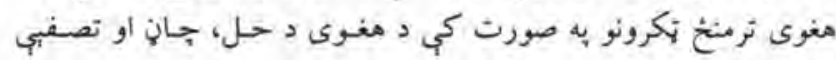

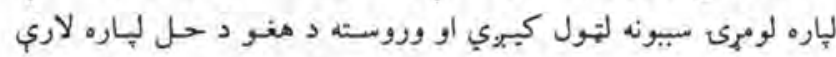

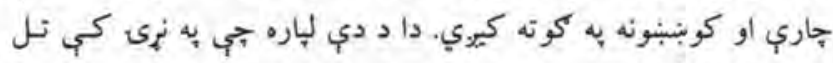
باتي سوله تزبكه وي.

\section{د جيكي او سولي نظرين}

Theory of the War and peace

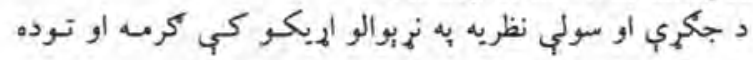

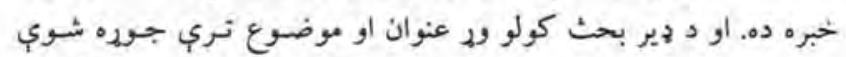

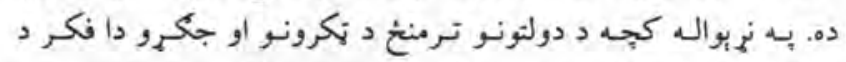

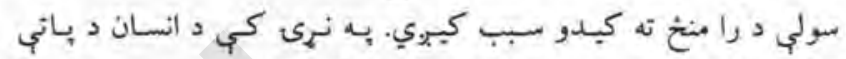

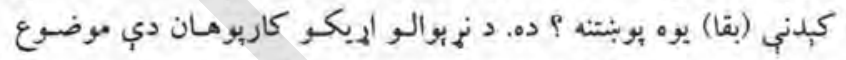

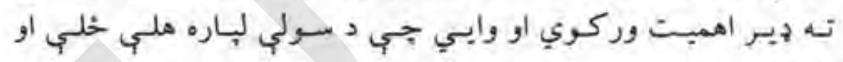

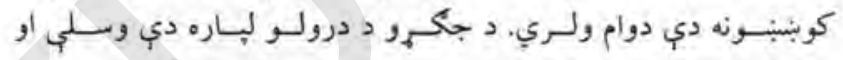

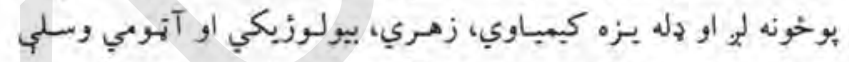

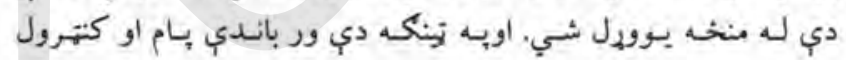
وماتل شي.

\section{د باورونو، عقيدو او ارزبنتونو نظريه}

\section{Theory of ideologies}

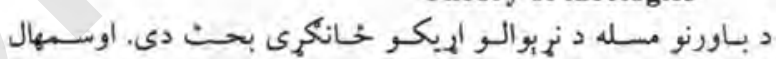

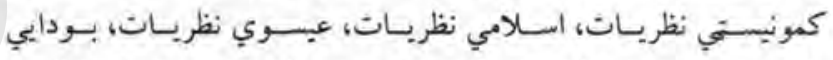

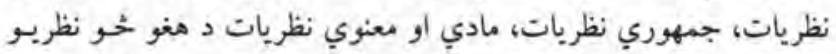

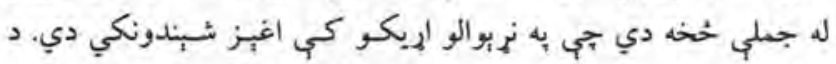

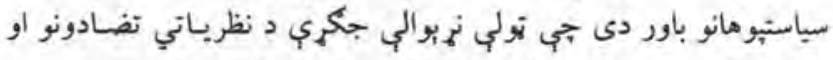

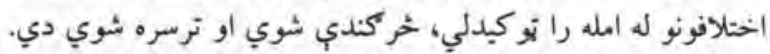

$$
\text { د ملت بالني نظريه }
$$

The theory of Nationalism

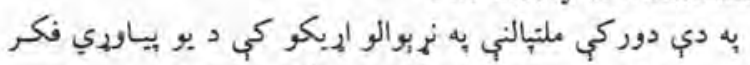

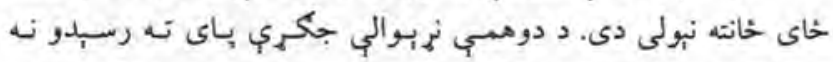

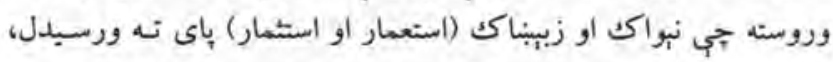

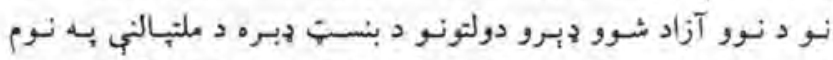

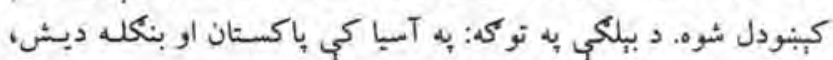

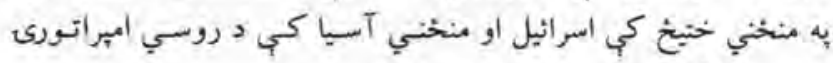

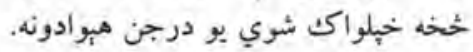

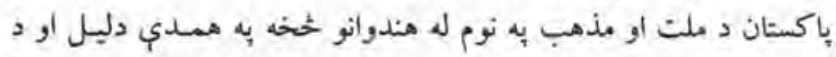

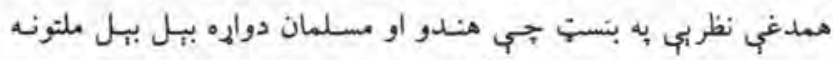

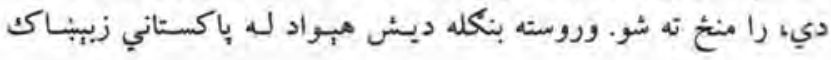




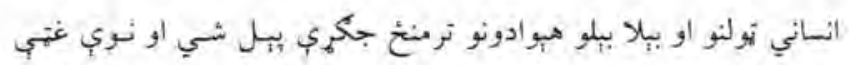

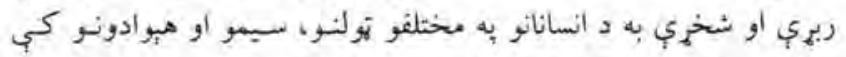

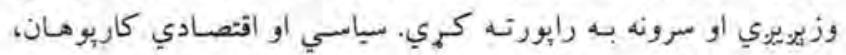

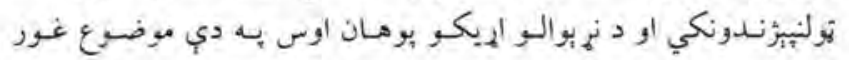

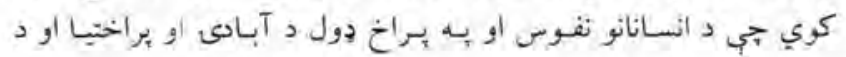

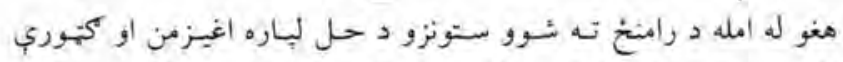

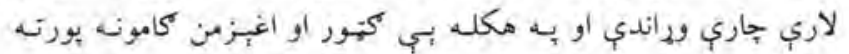

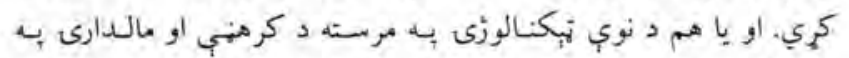

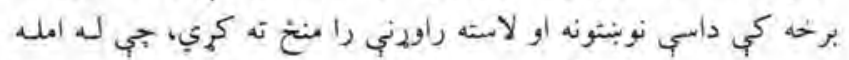

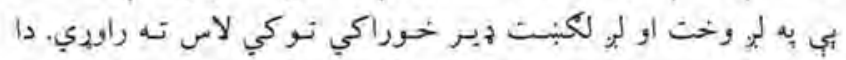

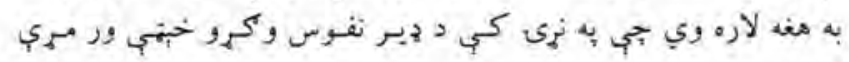

\section{وتيز (اقتصادي) عنصر}

\section{Economic Factor}

د ويلو ده ججي ووايو اقتصاد د سياست بنسيَّ دي، همدا اقتصاد

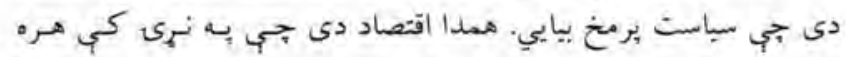

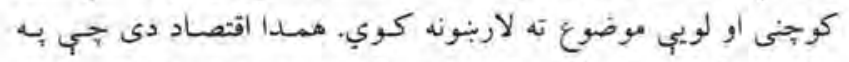

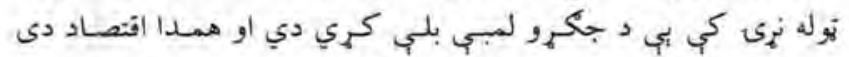

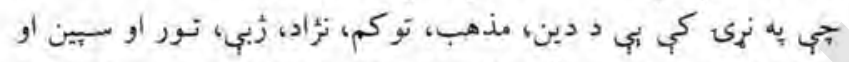

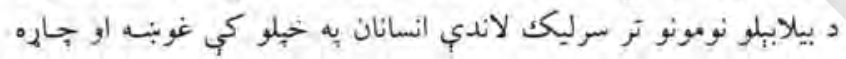

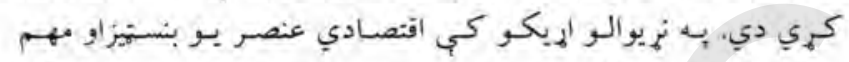

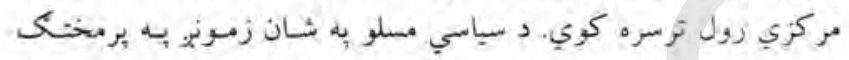

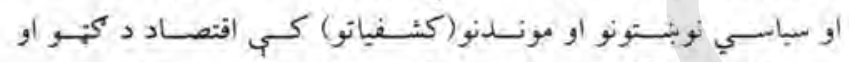

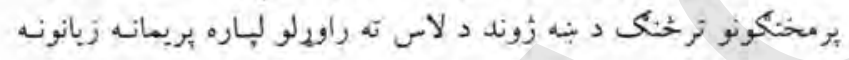

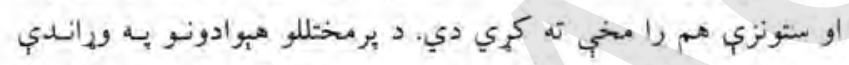

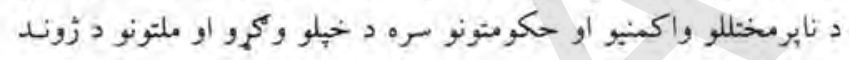

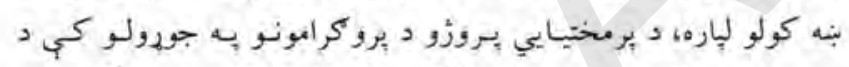

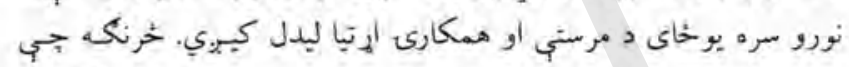

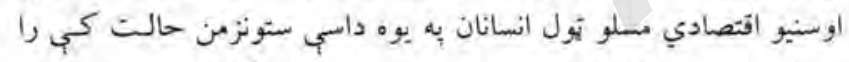

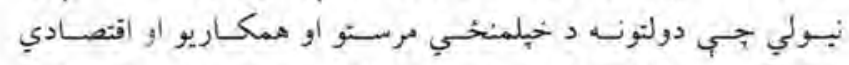

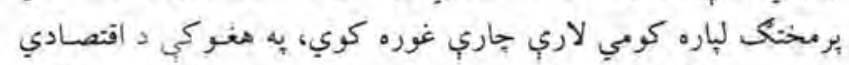

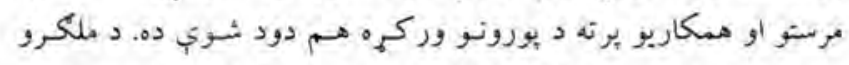

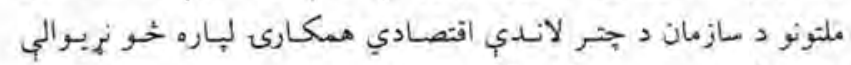

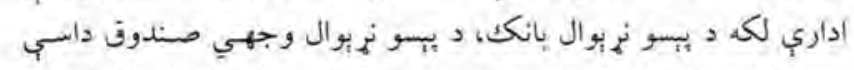

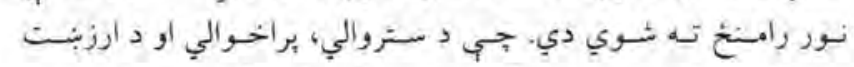

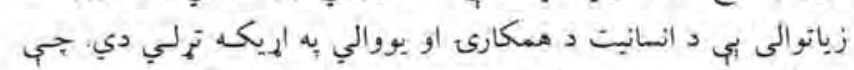

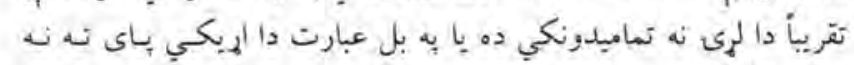

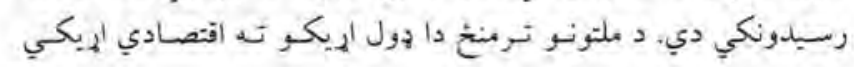

وايبي.

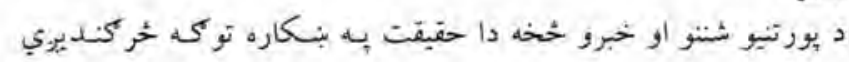

\section{د آتومي وسلو د لاسته راورنو اند \\ Theory of Nuclear Weapons}

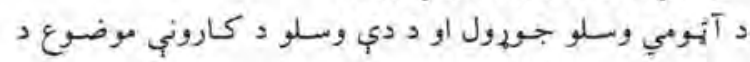

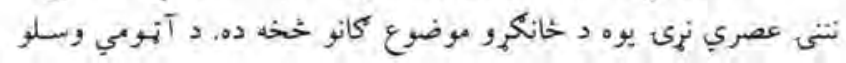

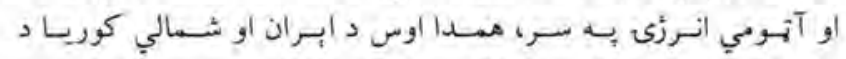

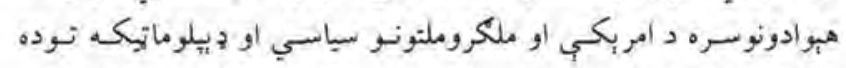

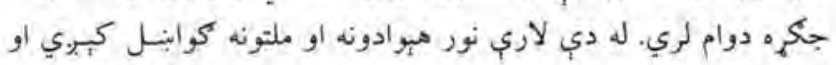

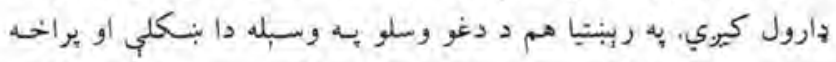

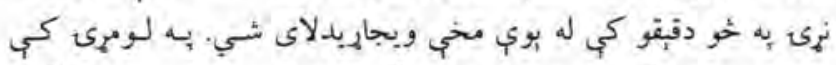

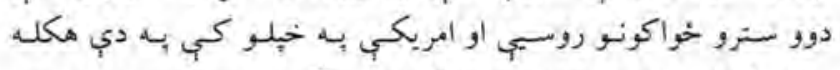

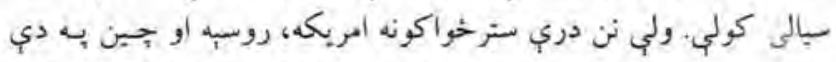

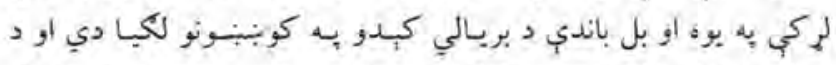

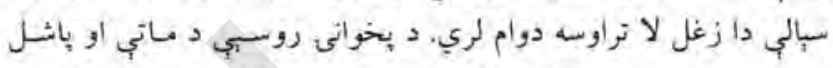

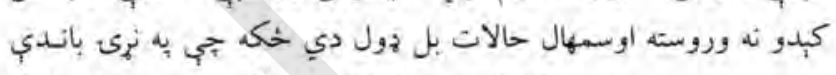

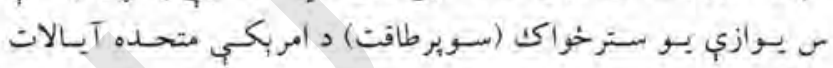

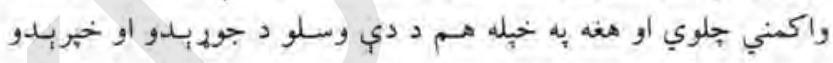

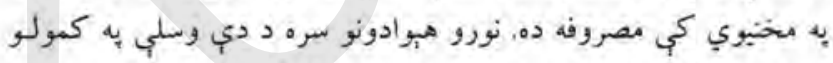

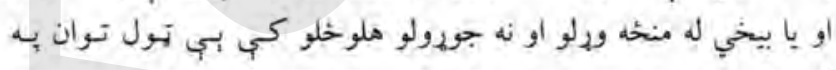

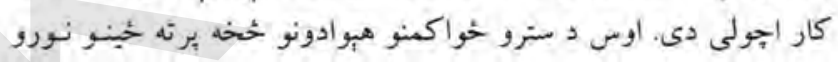

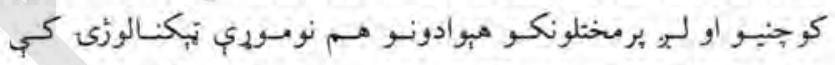

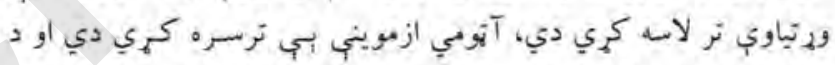

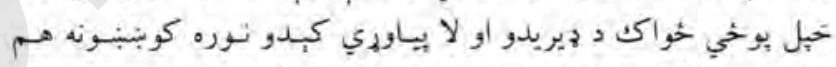

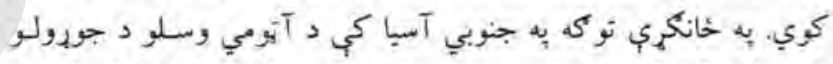

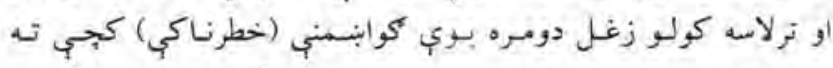

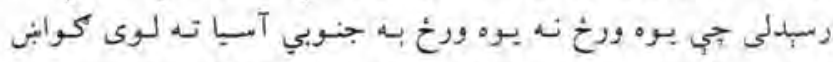

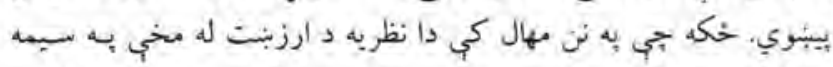

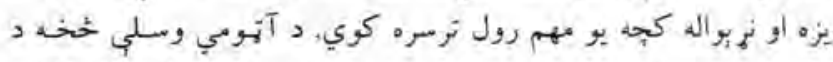

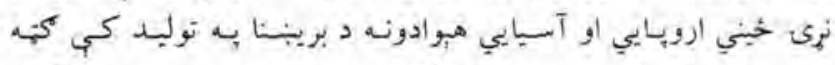

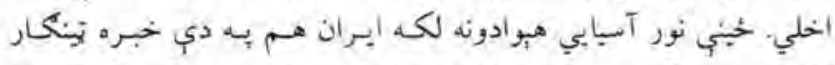

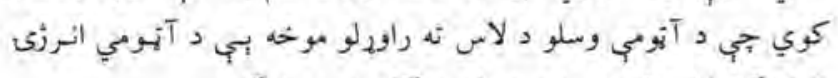

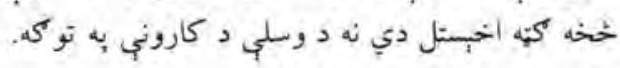

\section{د خوراكك او خبناكت مسله}

The theory of Food problem

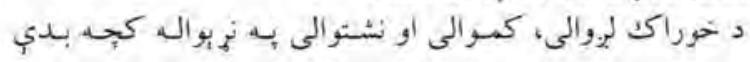

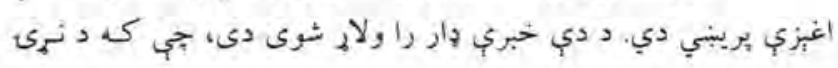

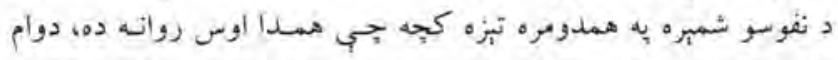

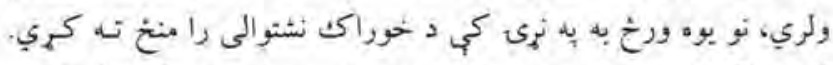

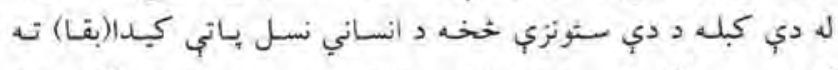

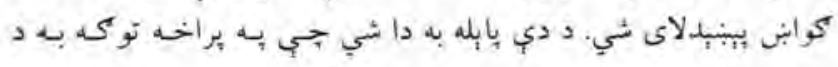


همدا لامل دى جي نهيو اله اداره د جيرو بريمانه ستونزو او كي كيجونو

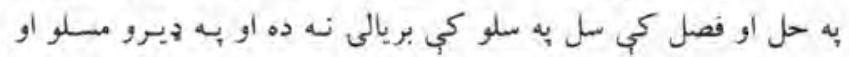

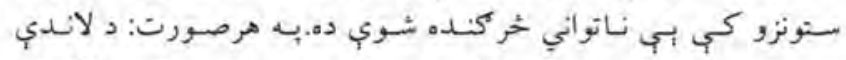

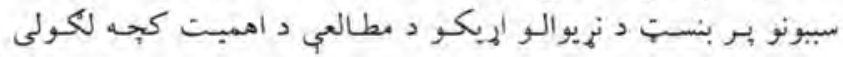

شور:

\section{1-}

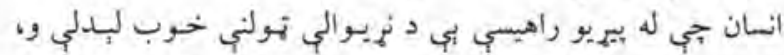

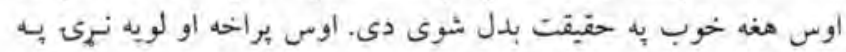

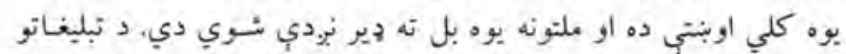

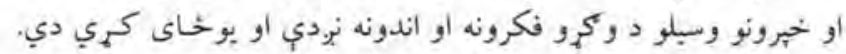

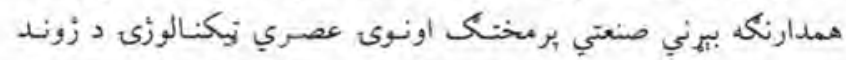

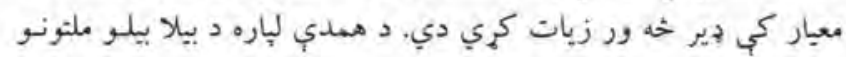

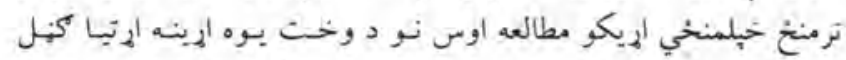

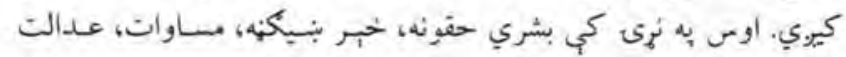

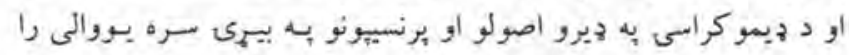

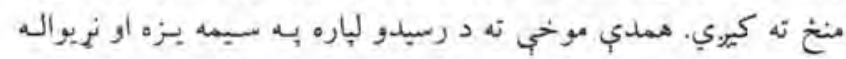

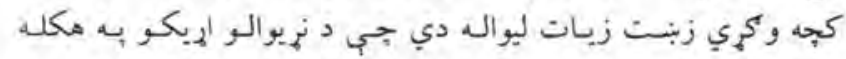

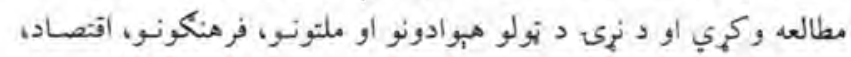

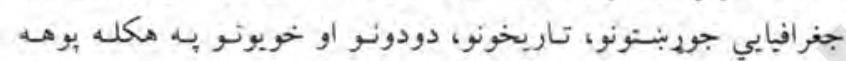

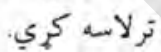

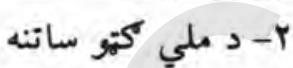

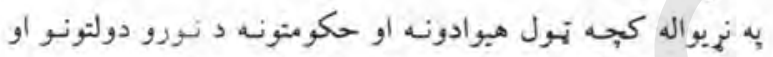

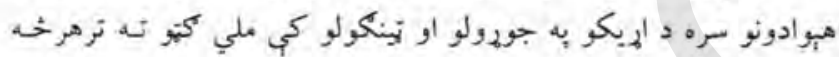

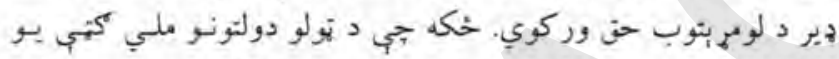

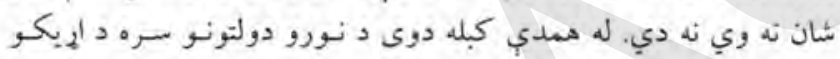

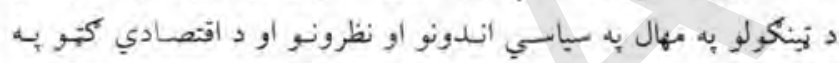

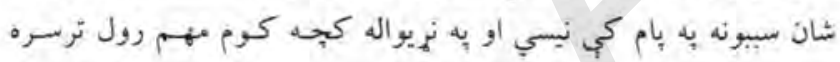

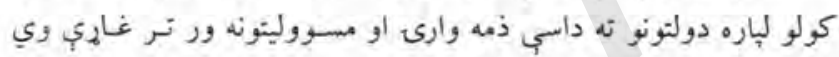

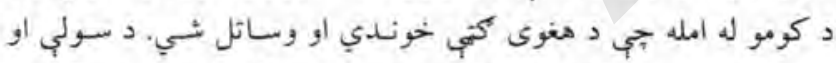

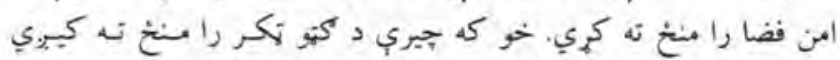

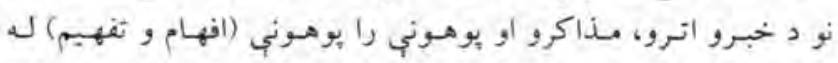

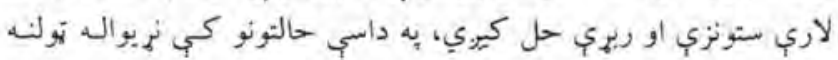

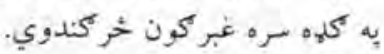
ب- نهيوال سياسي كركيج

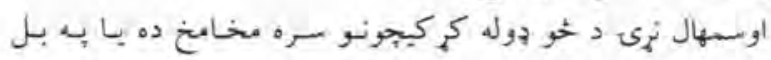

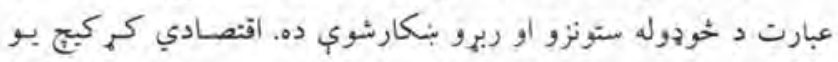

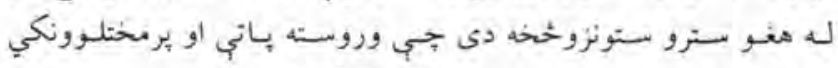

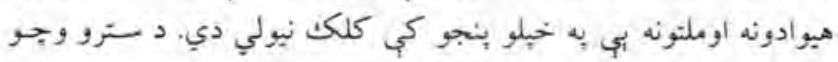

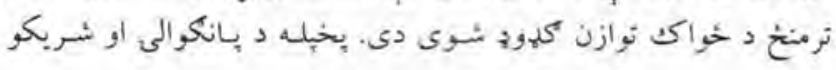

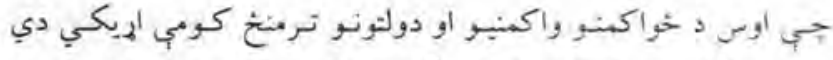

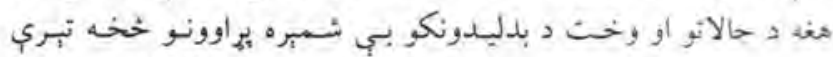

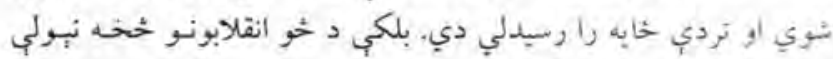

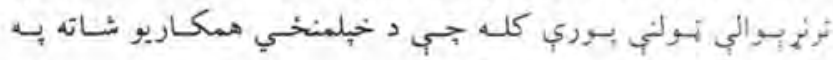

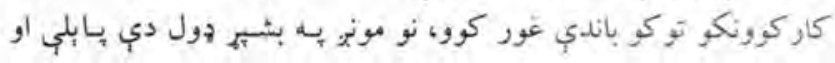

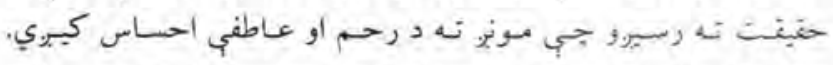

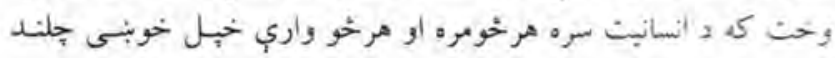

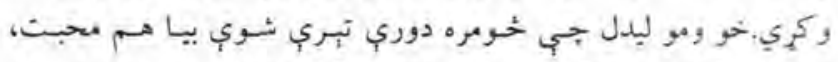

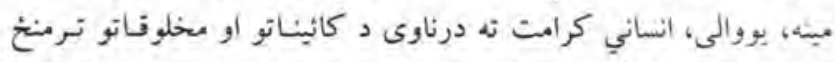

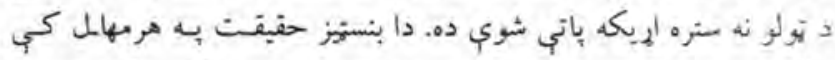

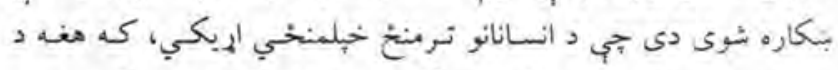

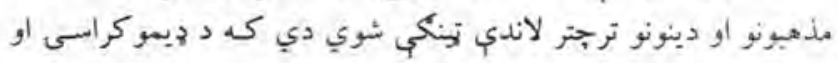

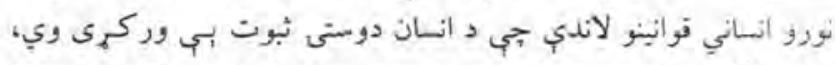

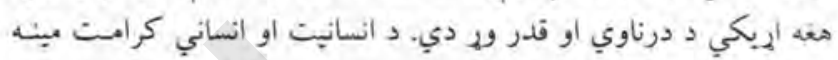

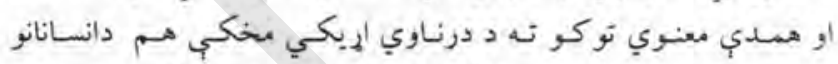

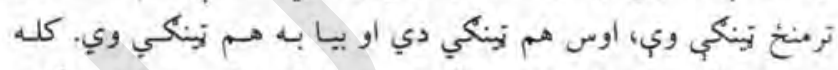

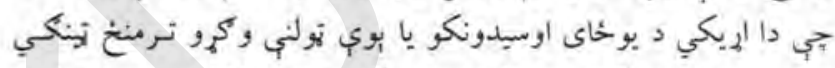

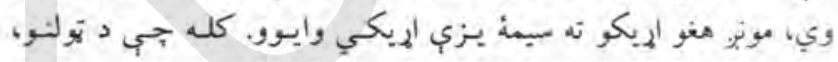

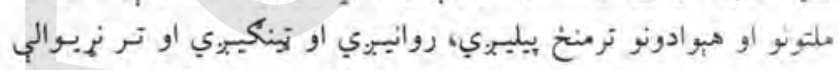

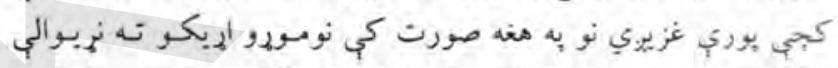

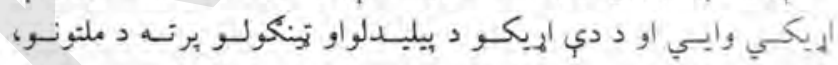

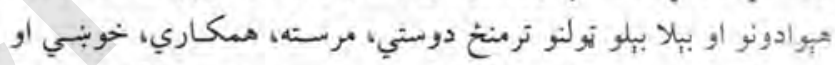

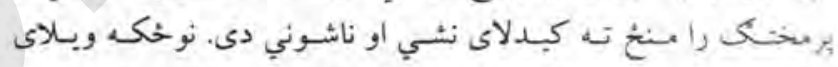

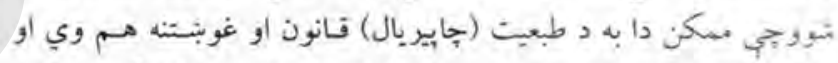

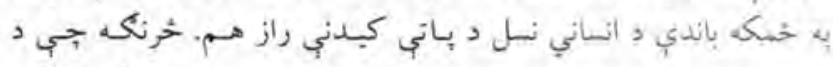

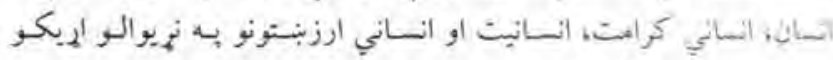

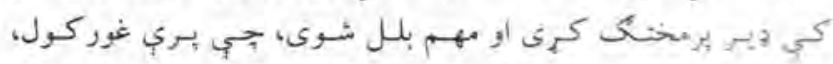

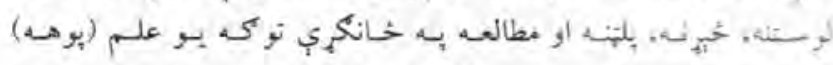

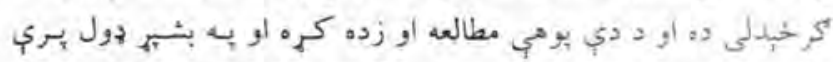

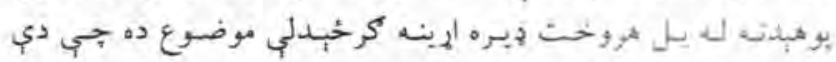

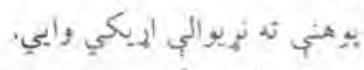

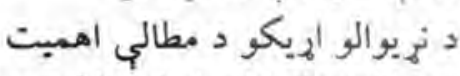
Importance of the study of Intl.relations

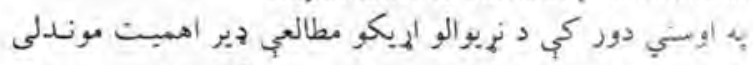

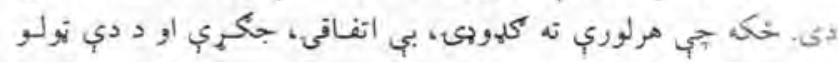

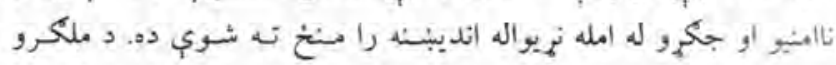

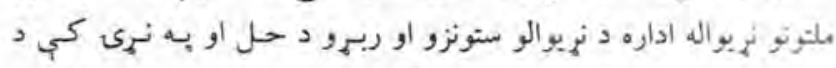

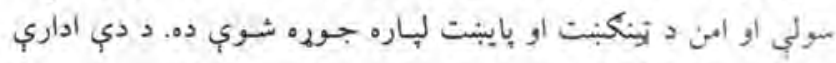

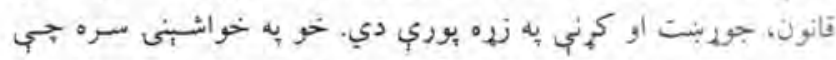

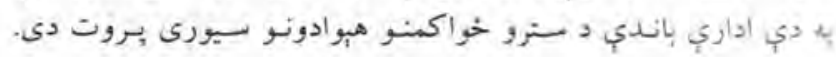




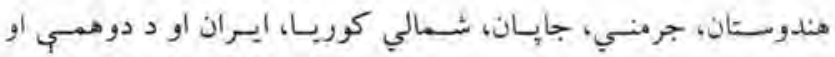

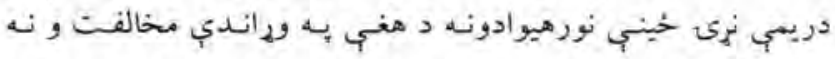

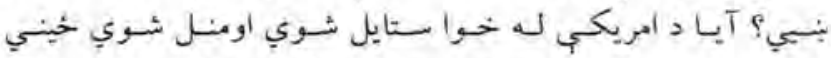

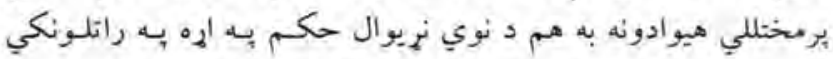

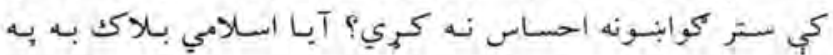

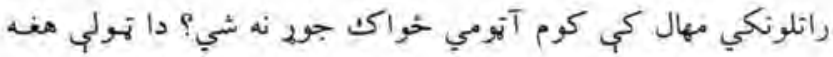

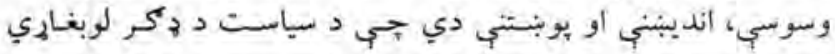

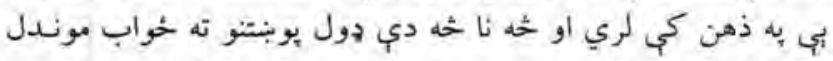

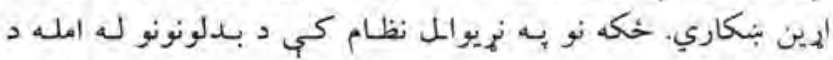

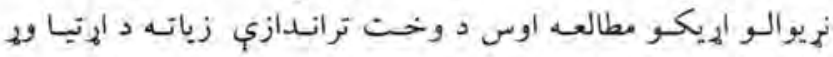

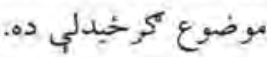

ه- د حكومت او واكينيو د نظامونو بطالعس

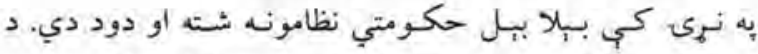

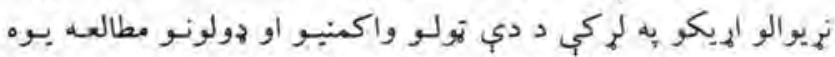

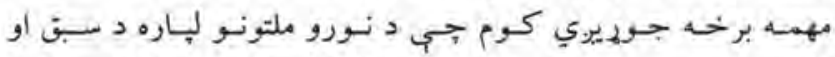

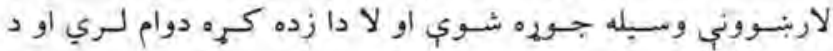

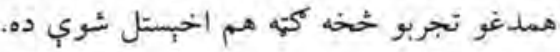

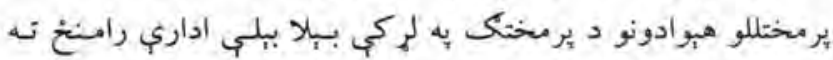

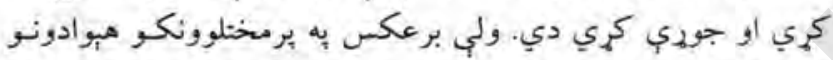

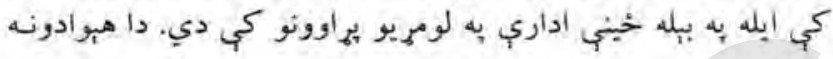

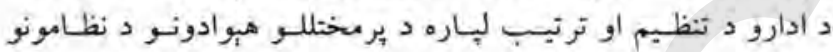

خخه كَّه اخبستلاى شي. 9- د نـيوالو ادارو مطالعه

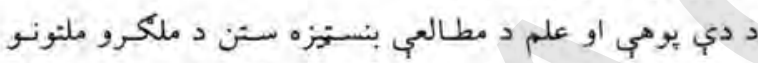

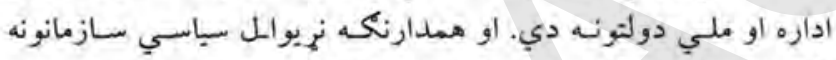

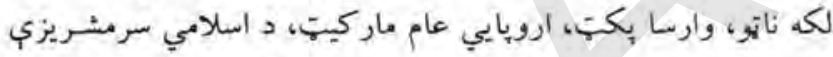

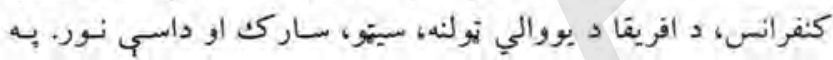

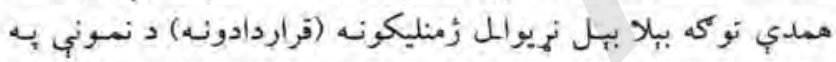

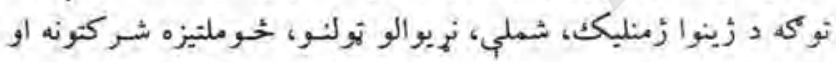

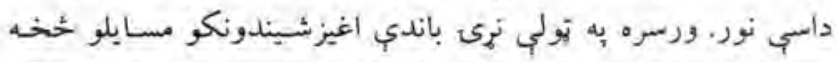

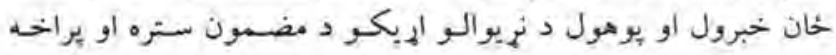

موخه

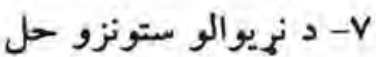

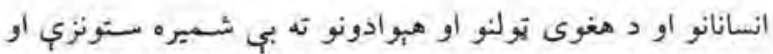

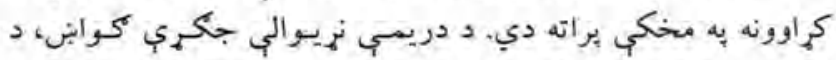

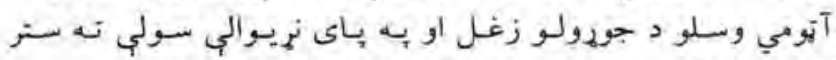

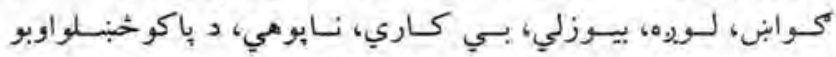

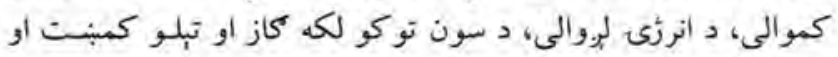

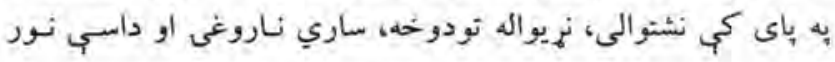

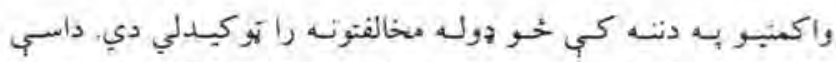

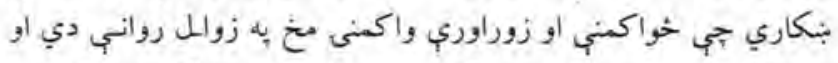

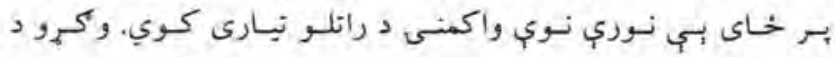

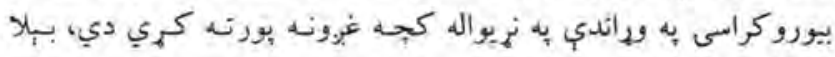

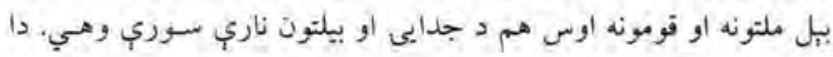

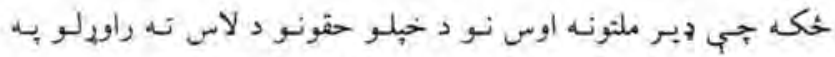

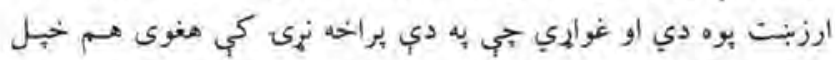

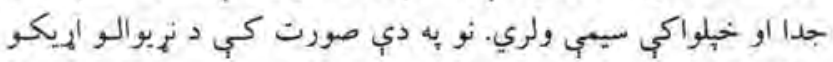

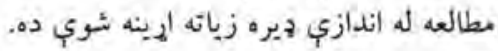
F به سياسي نظامونو كي د بدلونونو مطالعه

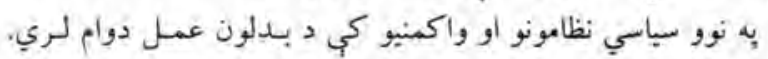

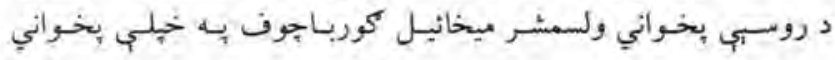

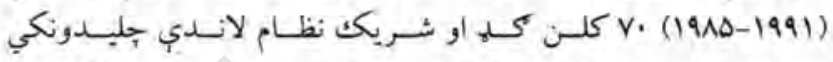

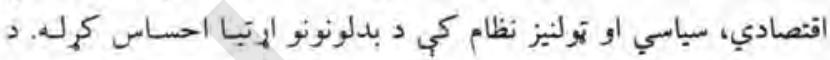

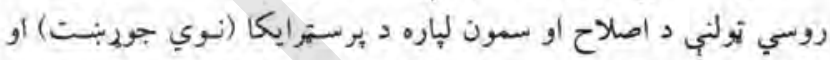

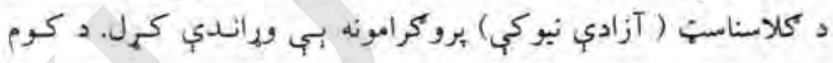

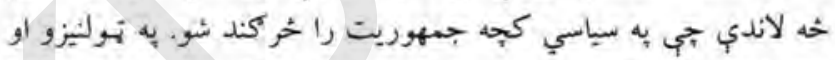

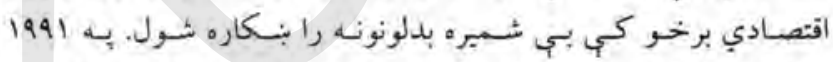

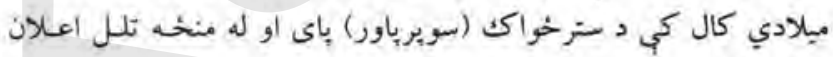

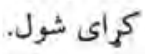

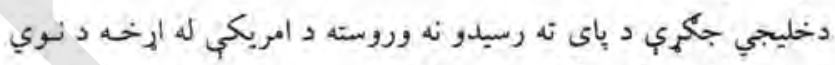

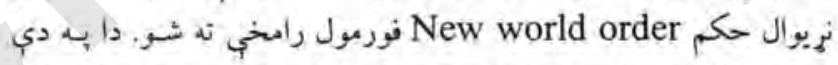

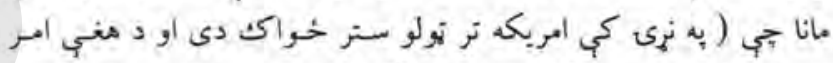

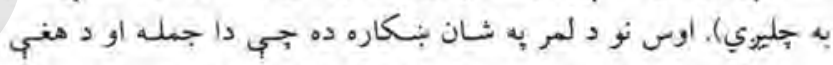

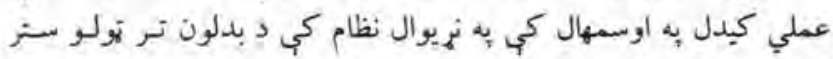

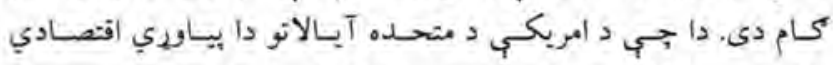

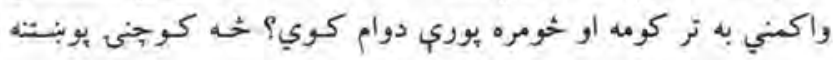

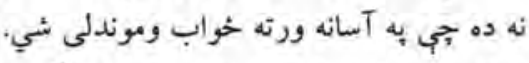

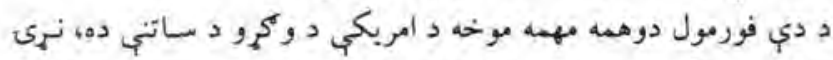

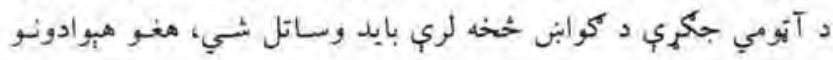

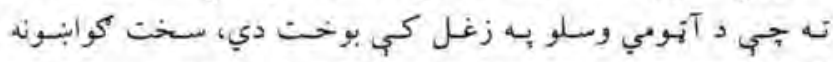

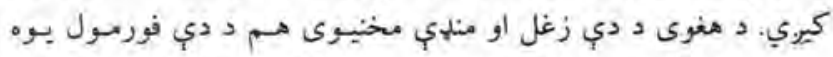

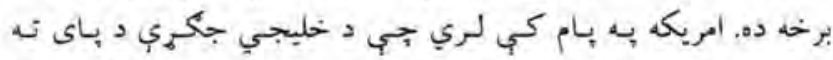

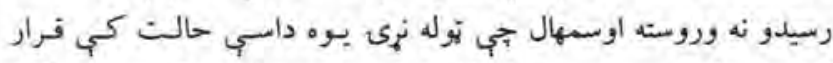

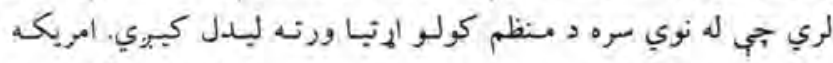

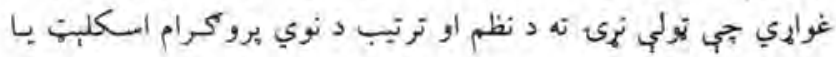

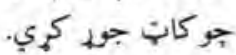

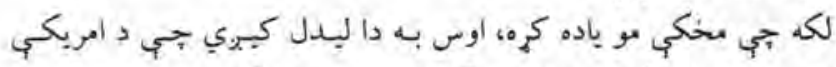

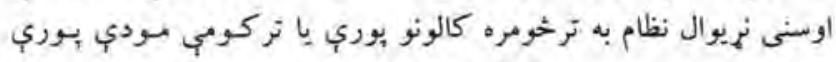

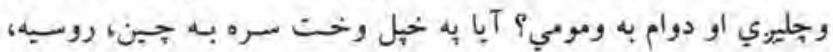




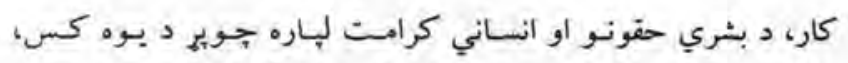

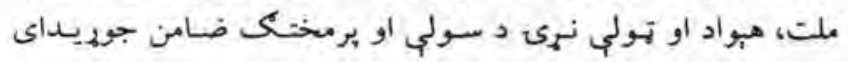

• 1 - د نريوالو سياسي خوخبتونو مطالعه

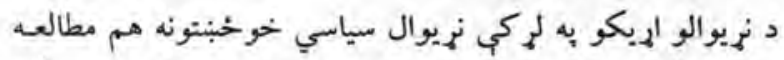

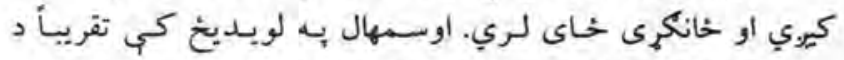

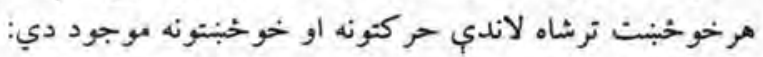

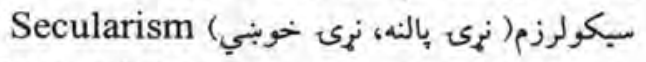

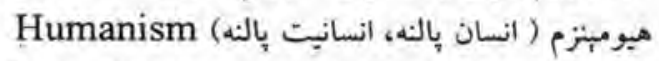

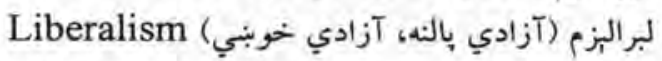

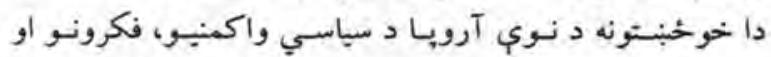

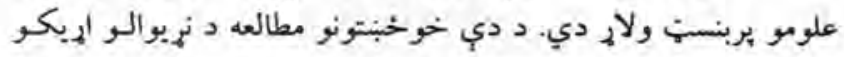

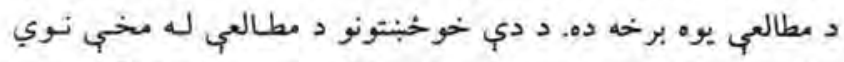

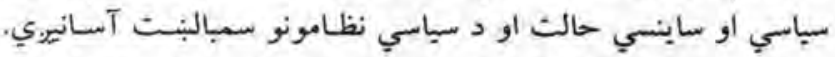

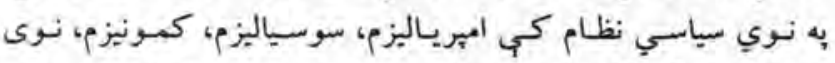

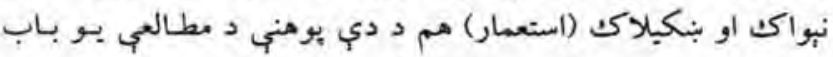

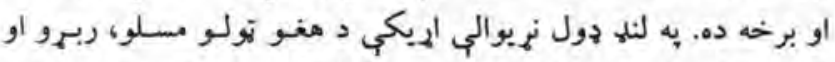

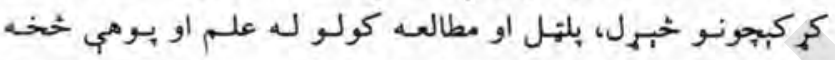

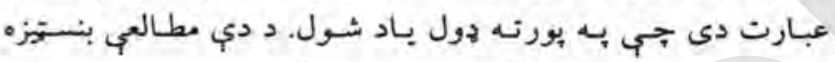

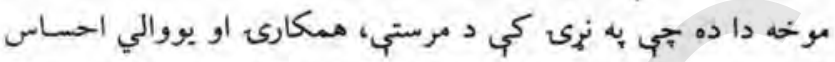

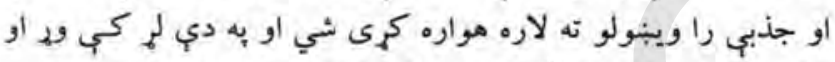

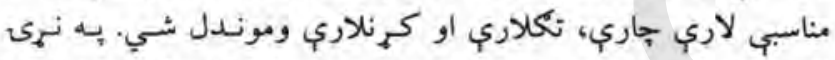

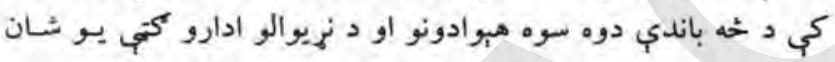

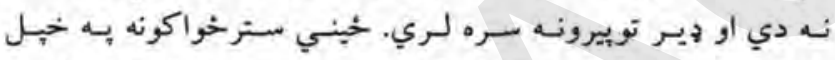

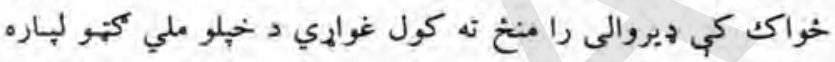

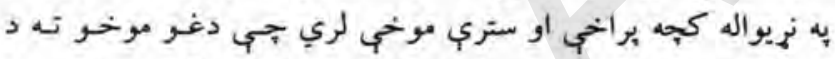

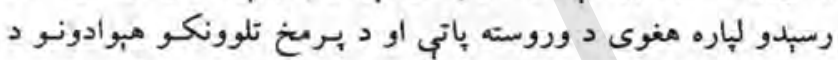

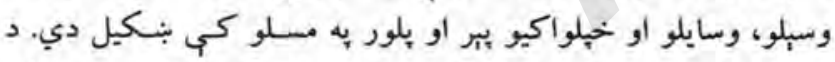

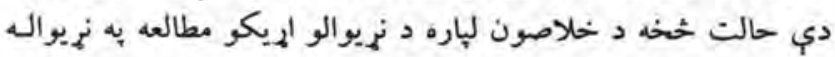

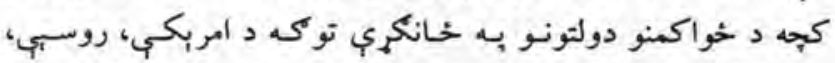

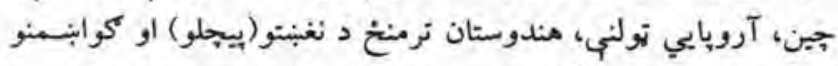

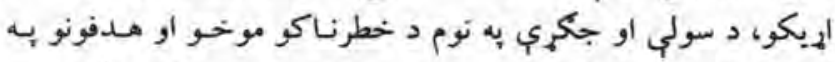

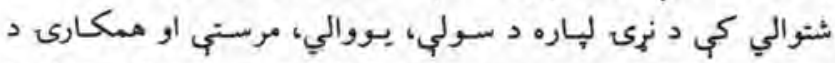

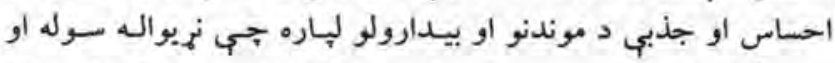

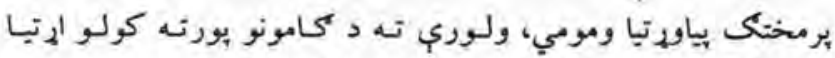

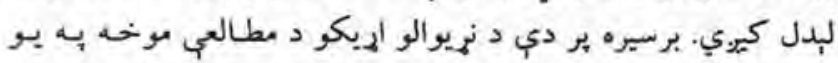

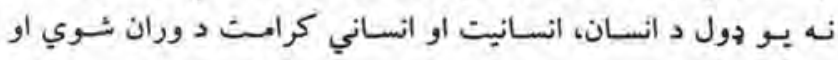

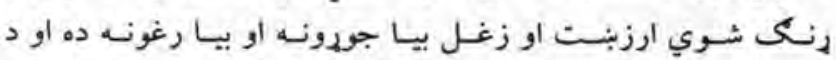

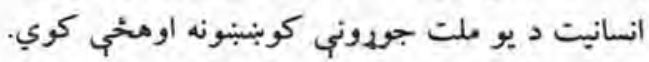

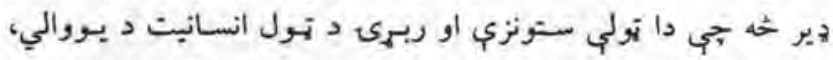

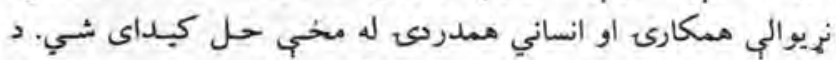

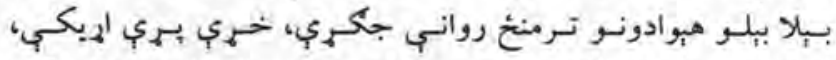

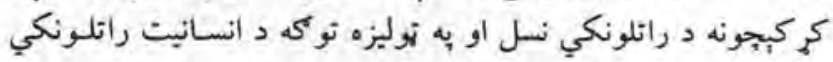

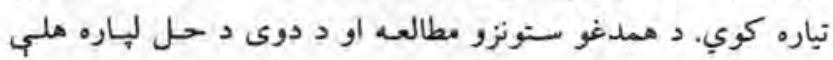

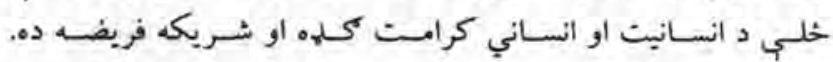

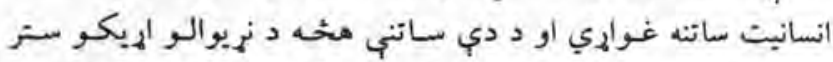

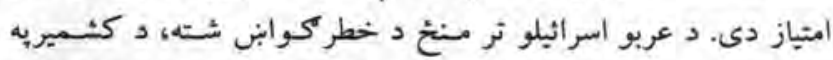

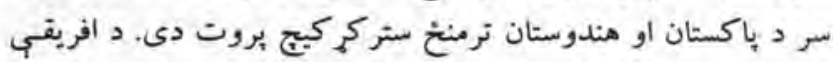

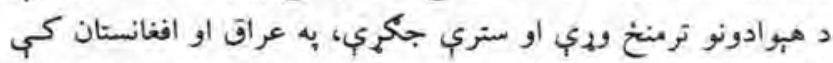

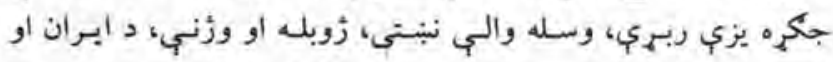

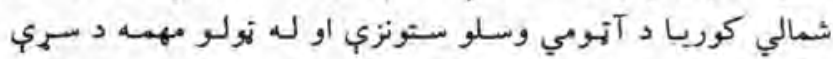

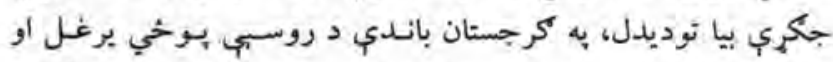

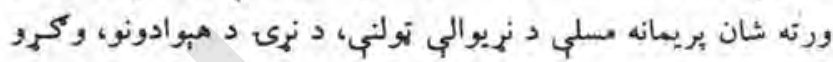

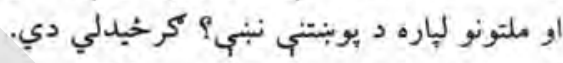

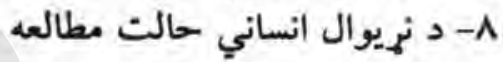

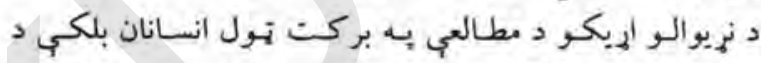

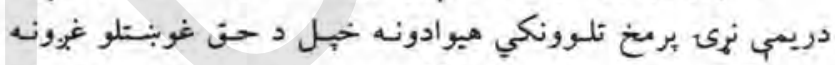

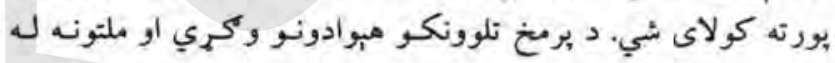

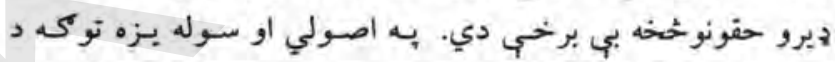

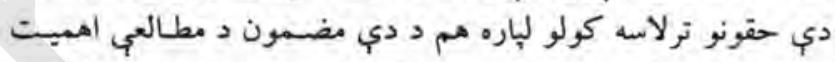

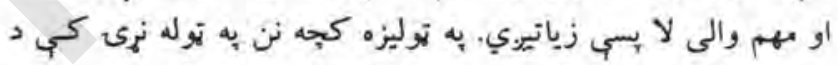

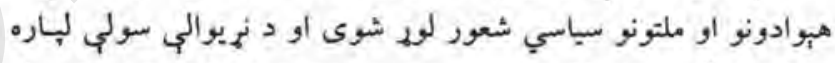

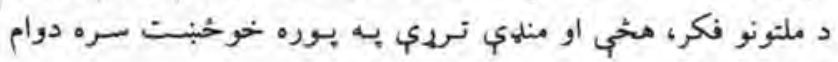

9- د سترو خواكونو د حواكث لاست راونو د زغل مطاله

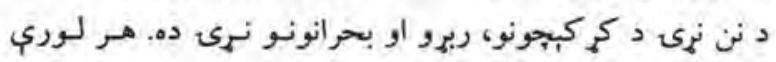

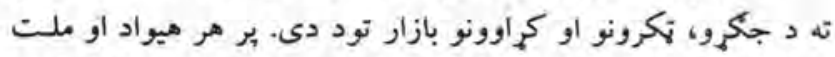

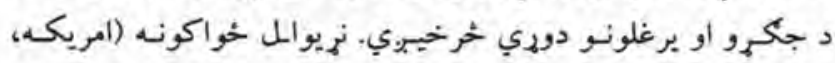

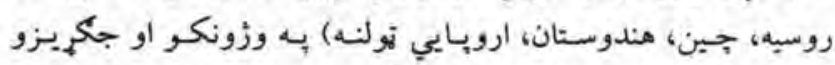

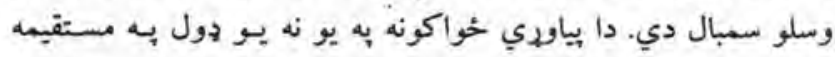

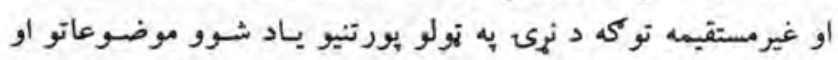

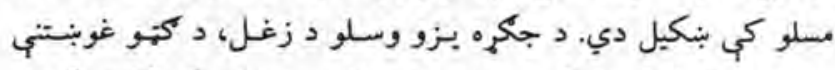

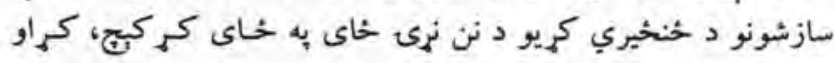

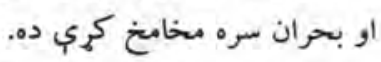

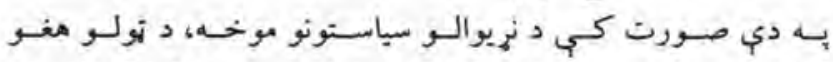

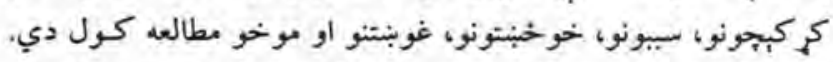

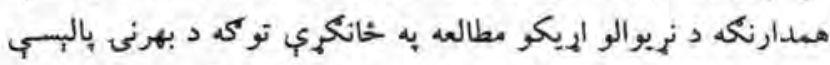

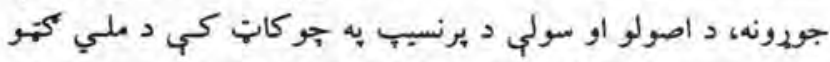

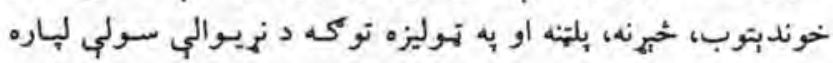




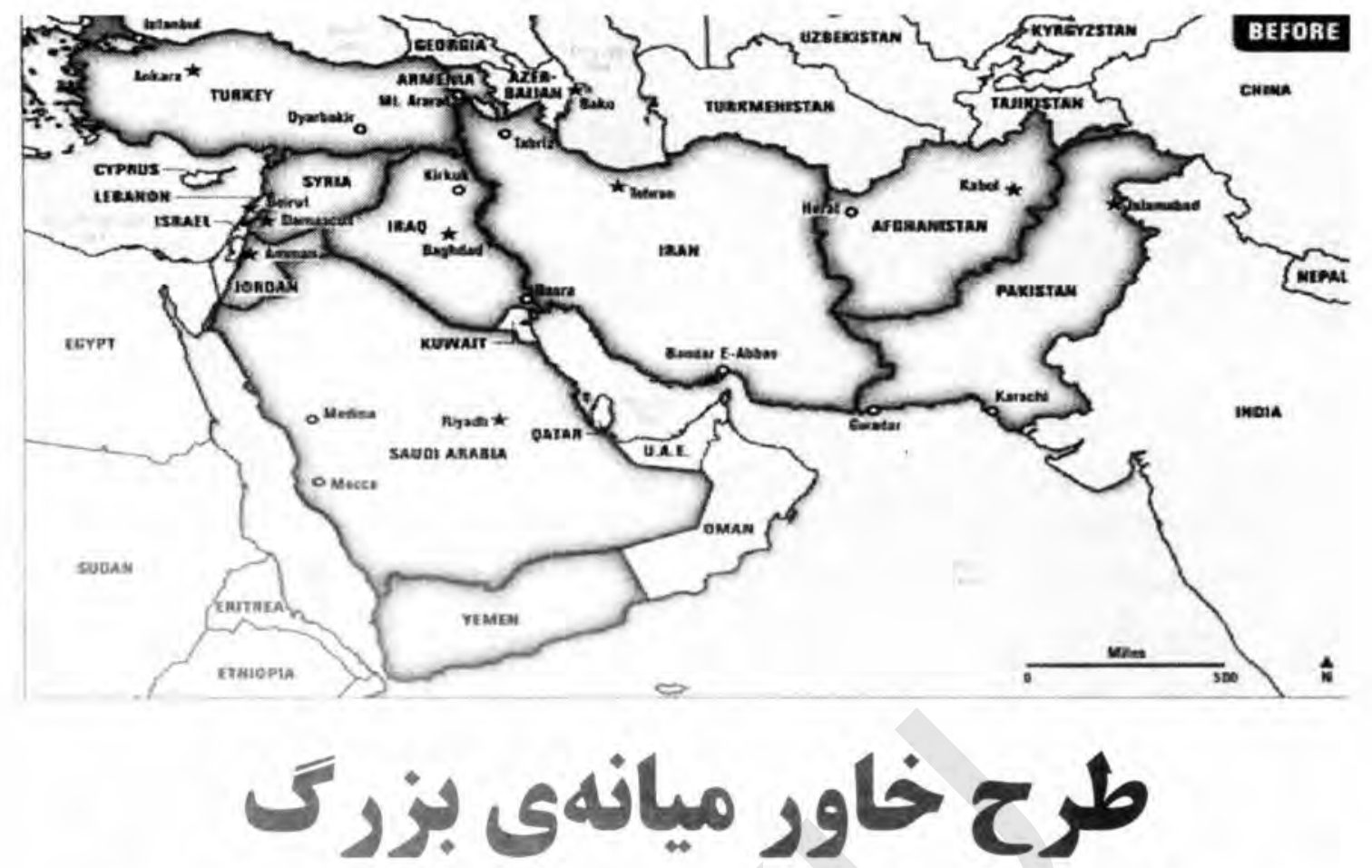

مبناى دكر كونى هاى عظيم جغر افيايى در منطقه و عامل فروريزى مرز هاى بينالمللى كنونى كشوز ها (از مراكش تا باكستان)

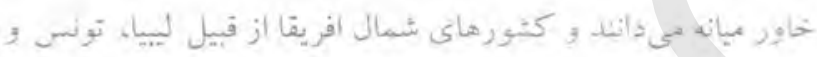

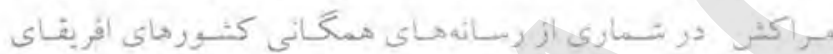

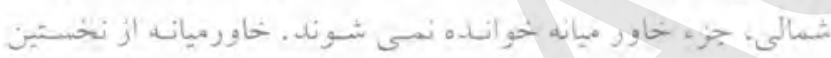

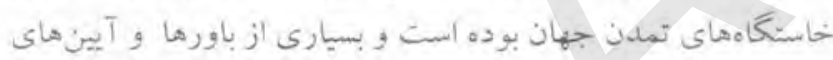

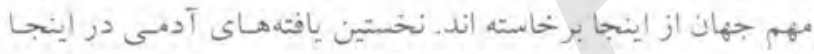

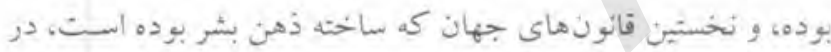

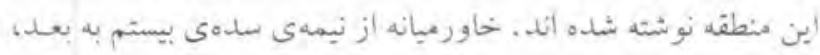

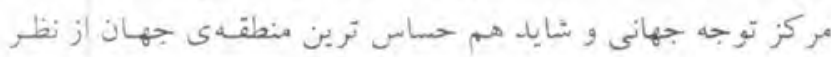

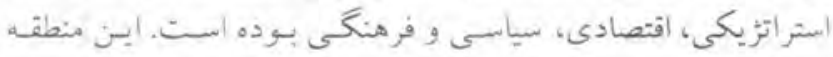

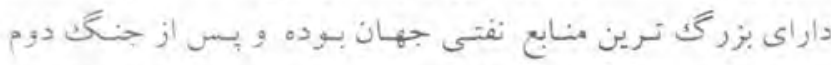

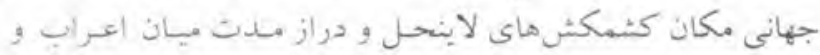

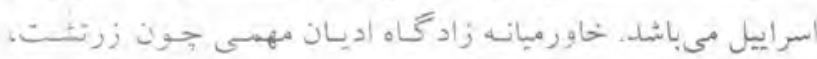

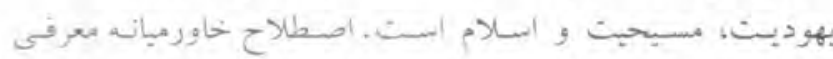

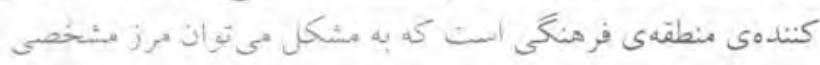

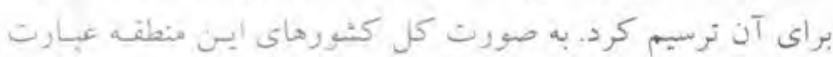

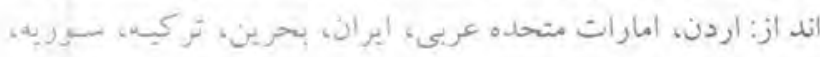

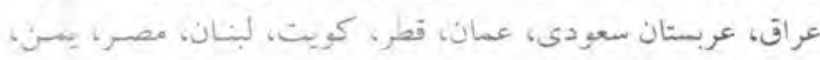

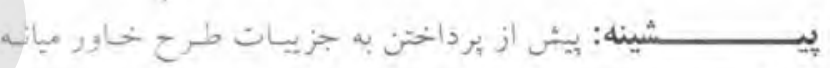

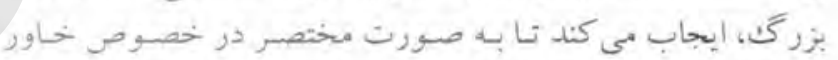

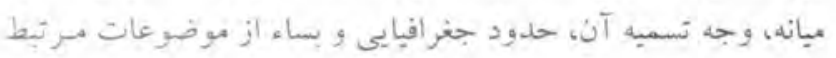

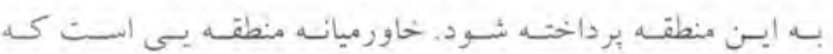
سرزمينهاى ميان بحير مى ملديتر انه و خليج فارس را شامل مي شئرد

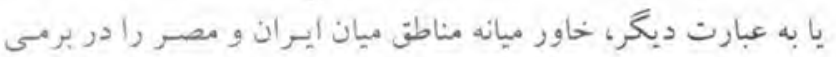

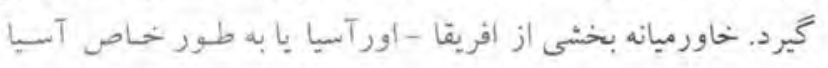

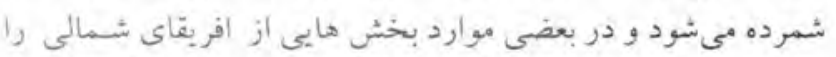

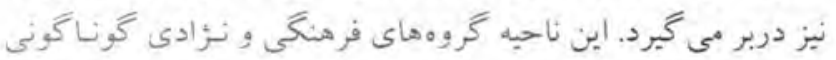

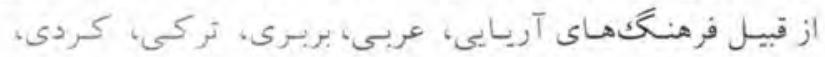

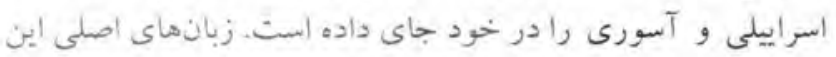

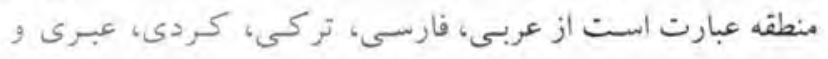

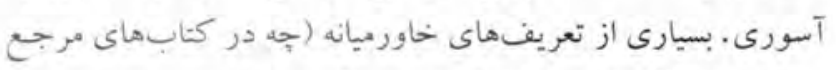

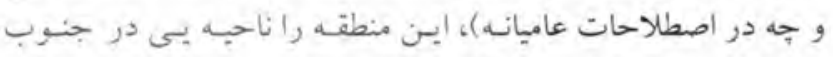

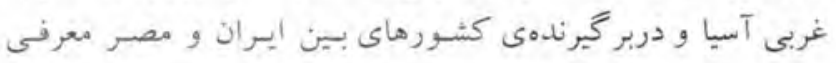
مى كند. با اين كه بخش بيشتر كثور مصر (به جز صحر اي سينا) در

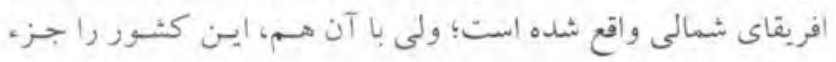


مسايلى نظير منابع انرزيى، سهولتهاى مواصلاتى، توليد سـلاحهـاى

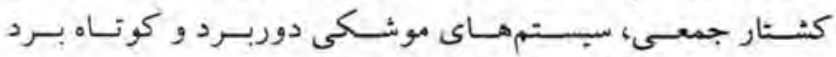

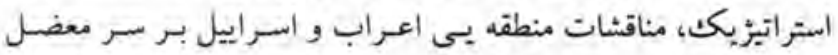

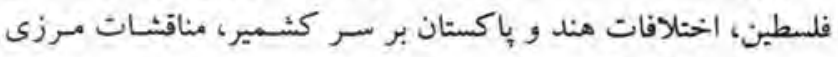

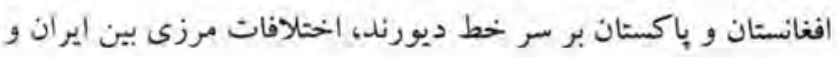

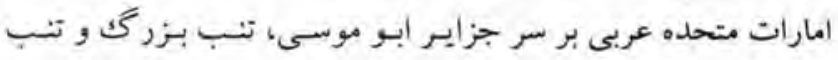

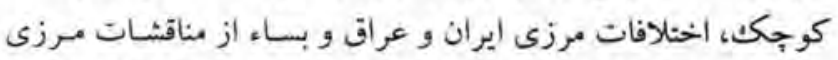

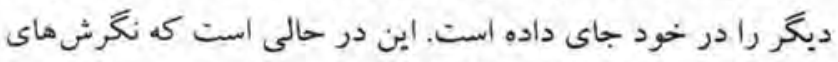

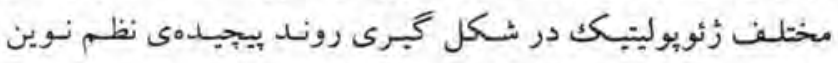

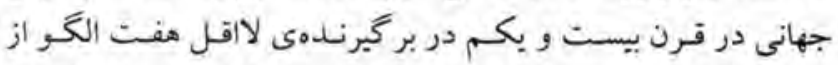

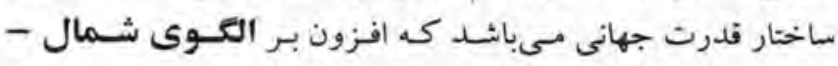

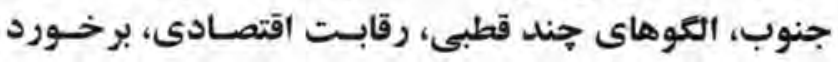

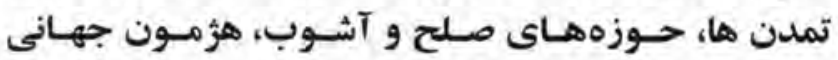

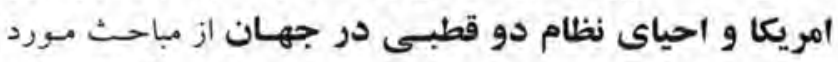

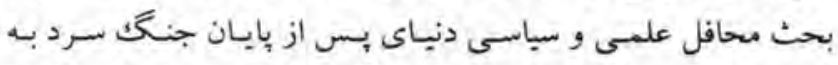

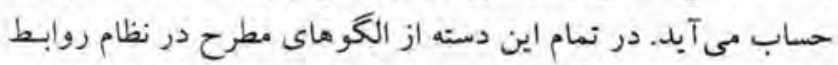

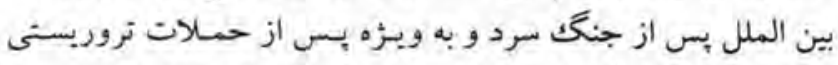

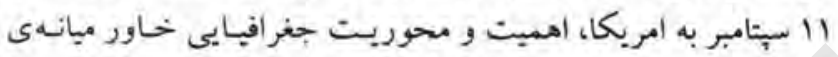

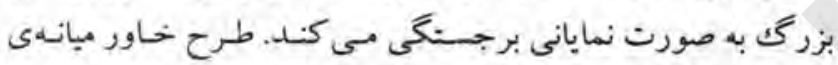

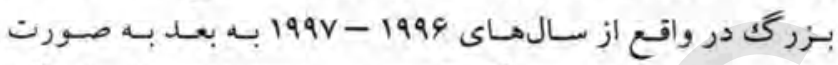

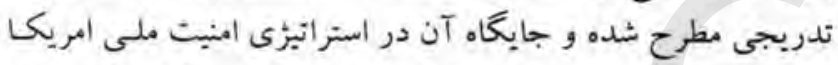

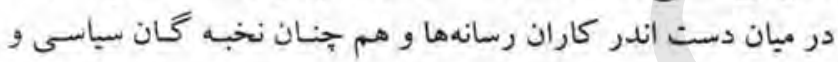

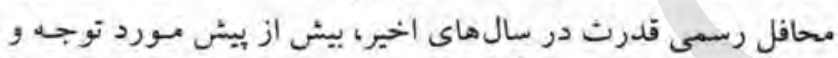

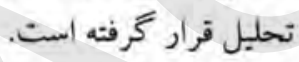
كليات طرح خاور ميانهى بزر كت

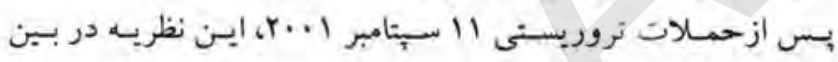

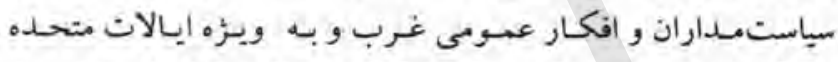

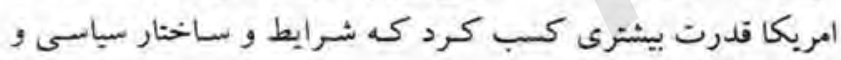

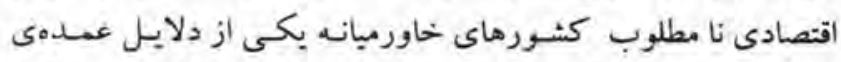

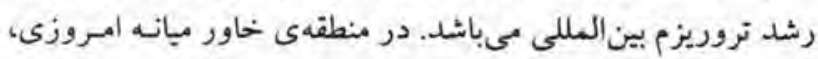

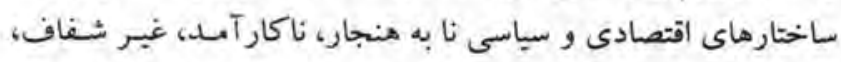

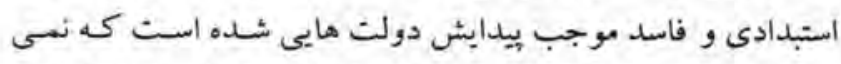

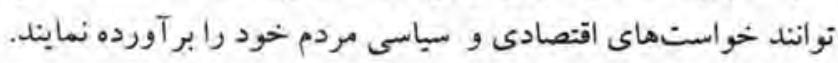

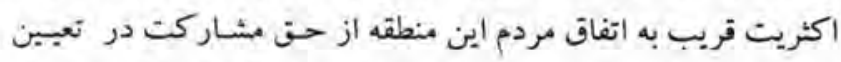

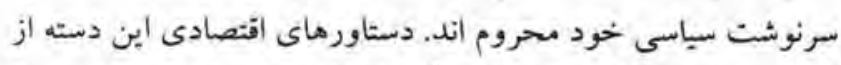

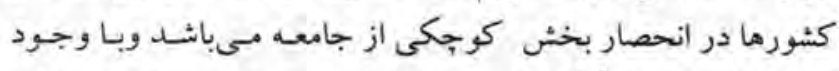

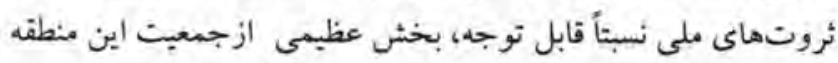

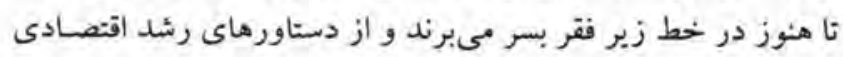

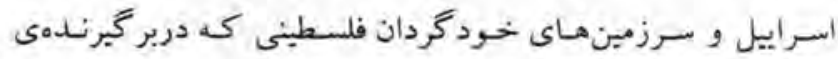
كر انه غربى رود اردن و نوار غزه مى بـاشد.

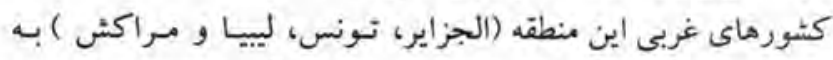

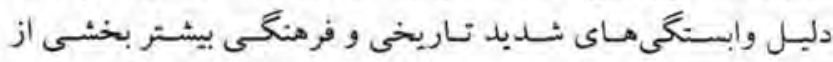

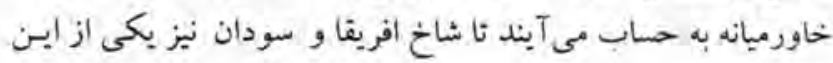

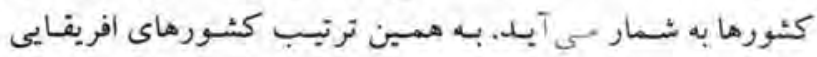

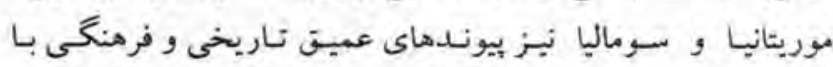

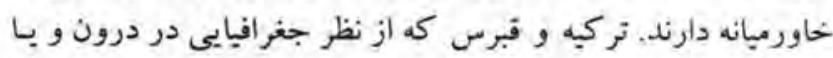

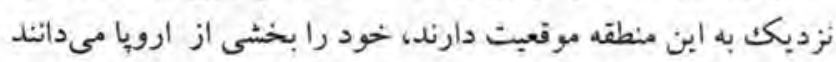

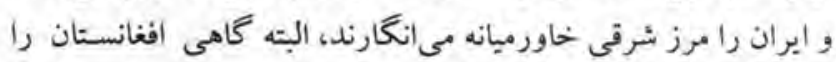
نيز از كئورهاي خاور ميانه به شمار مى آورند.

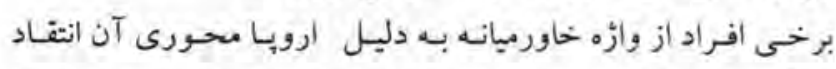

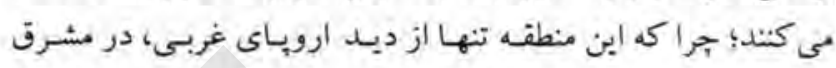

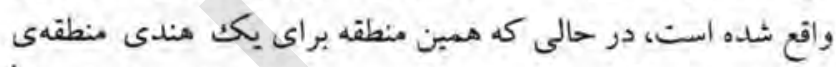

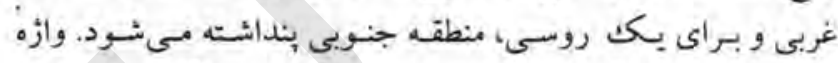

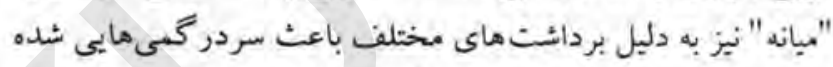

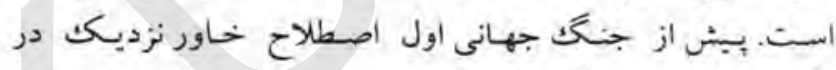

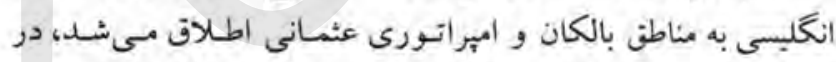

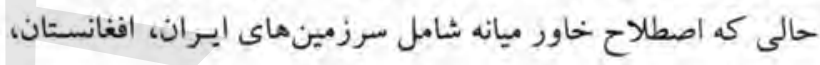

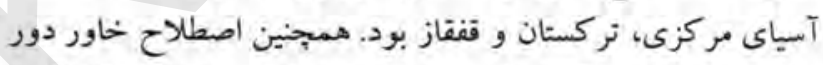

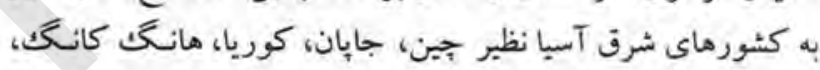
تايوان و غيره اطلاق ميى فيد.

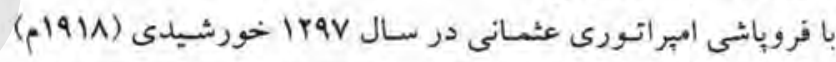

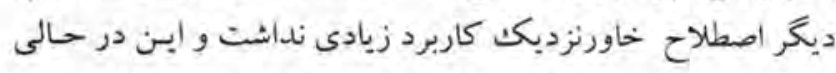

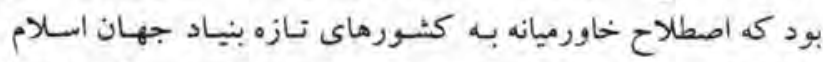

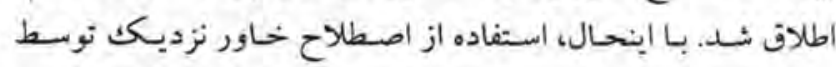

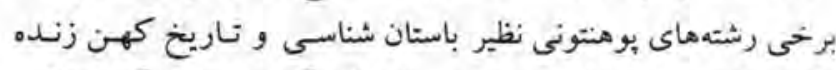

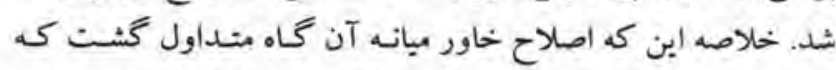

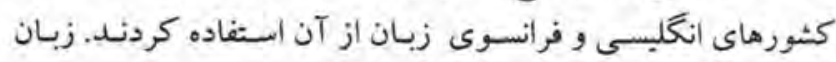

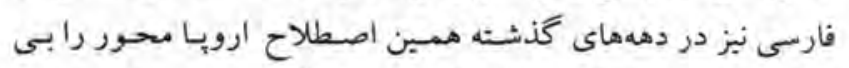

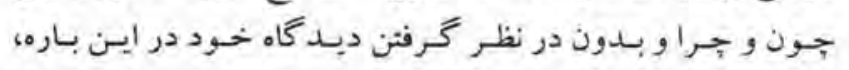

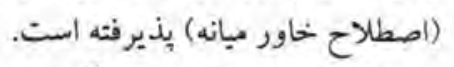

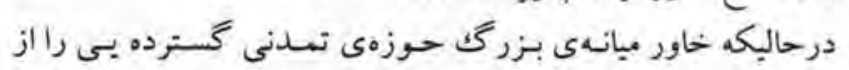

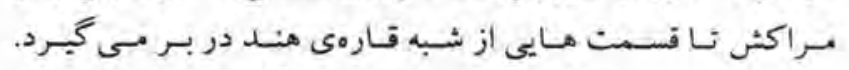

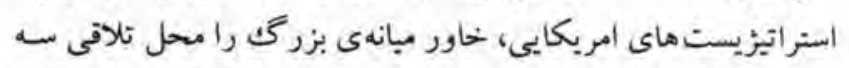

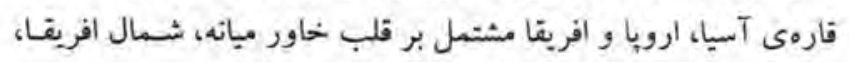

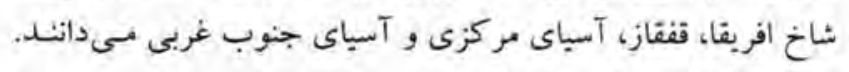

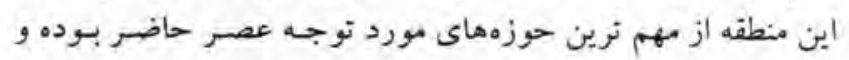




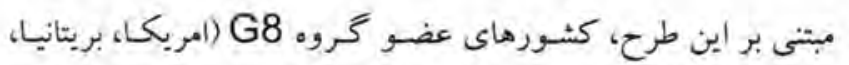

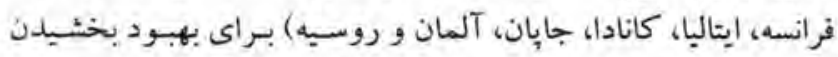

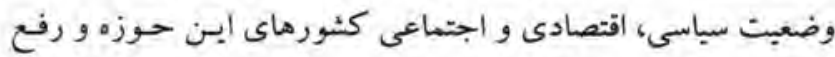

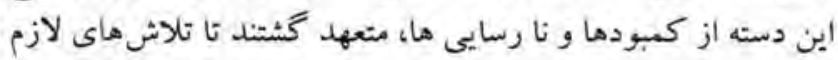

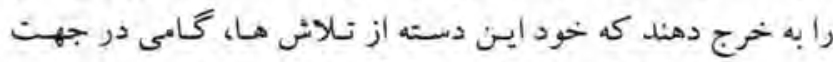

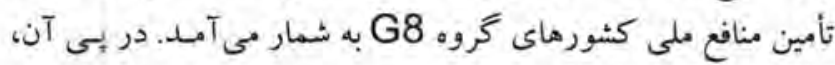

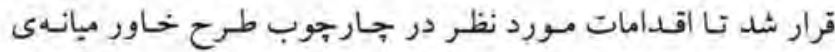

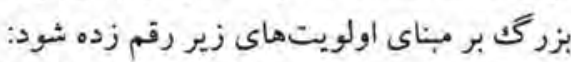

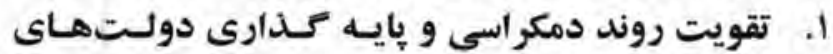
مشروع و قانونى؛

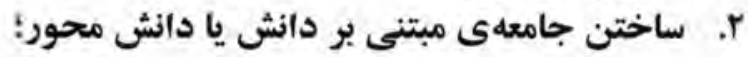
r.

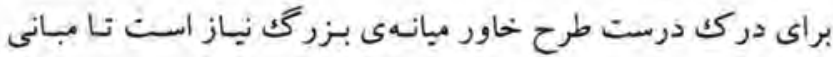

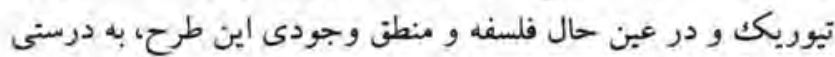
به برونى كر فته شود.

مبانى تيوريكك طرح خاور ميانهى بزركت:

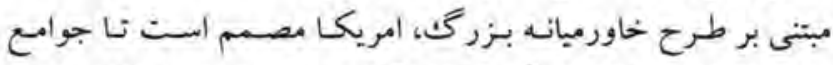

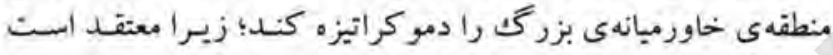

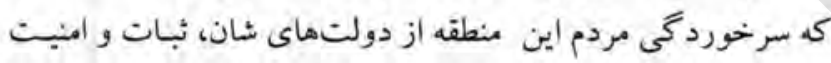

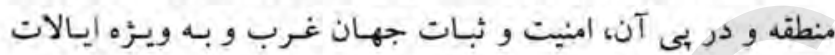

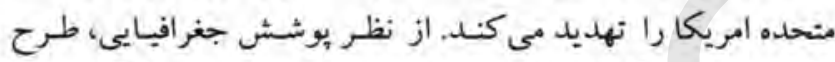

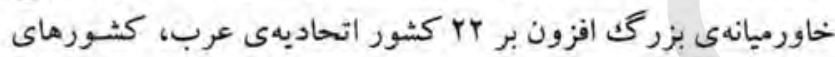

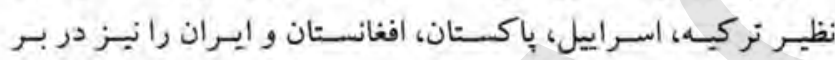

مى گيرد.

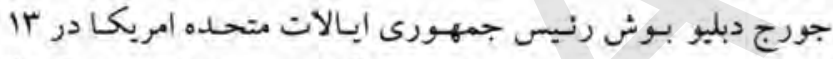

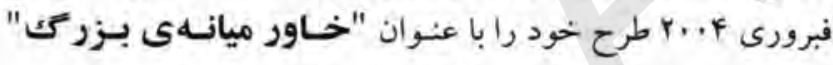

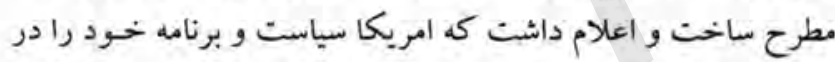

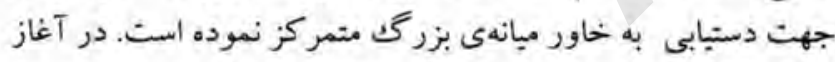

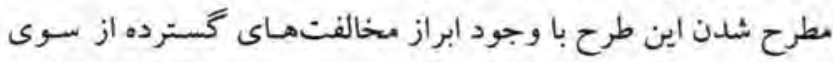

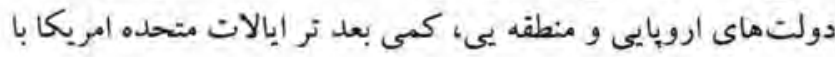

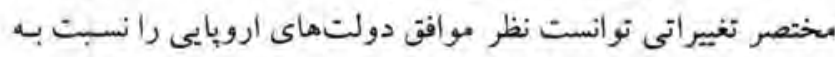

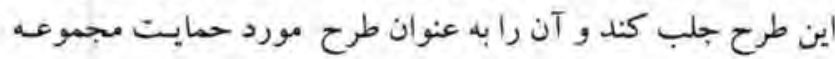

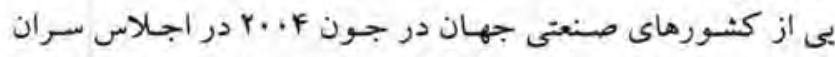

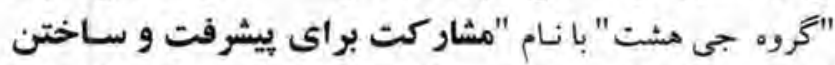

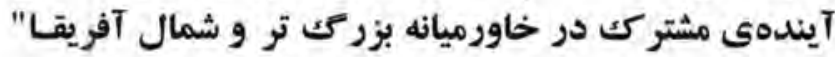

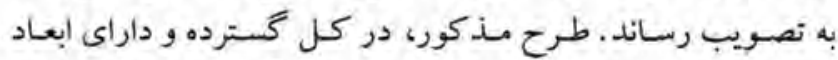

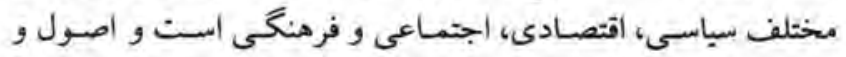

اهداف آن به طور خلاصه عبارت اند ازئ

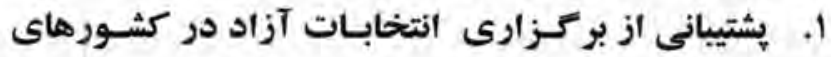

بى بهره اند. نارضايتى در ميان طبقى متوسط، اقشار تحصيلكرده و

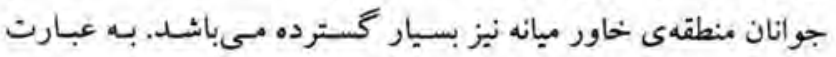

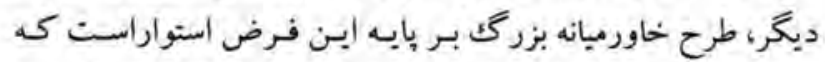

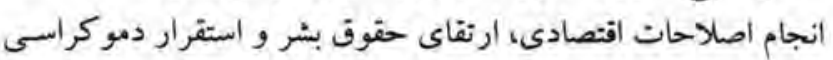

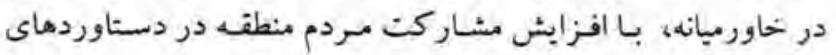
انكثاف اقتصادى و سرنوشت سياسى كشـورهاى شـان، بسى ترديـل

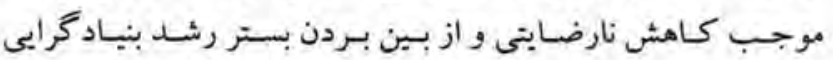

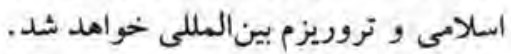

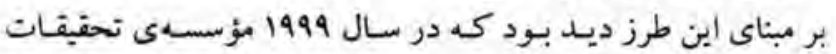

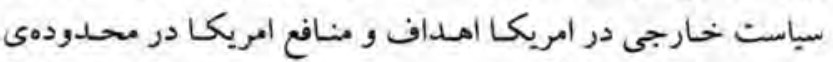

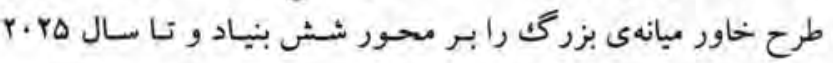
مطرح نمود:

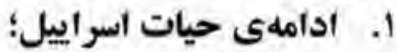

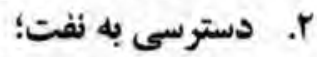

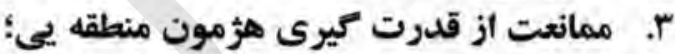

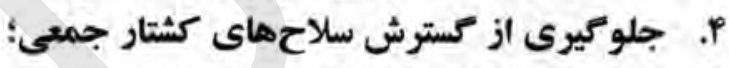

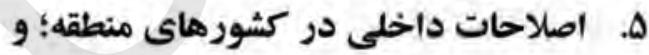

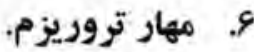

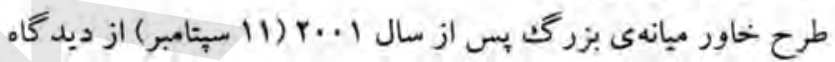

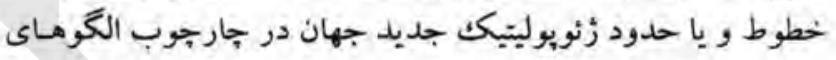

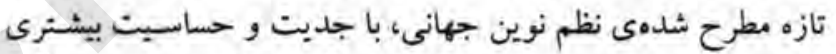

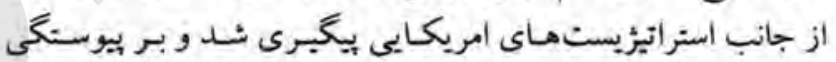

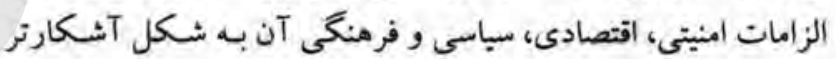

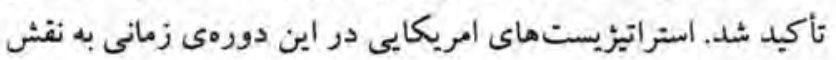

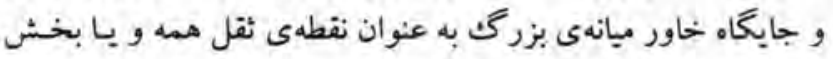

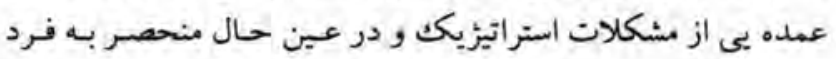

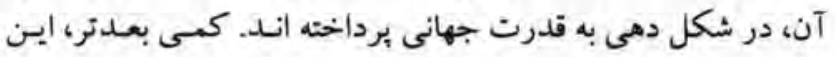

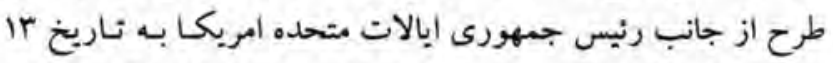

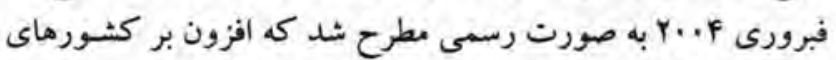

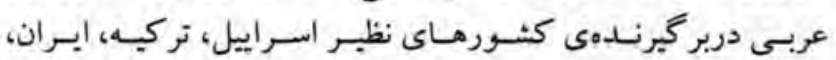

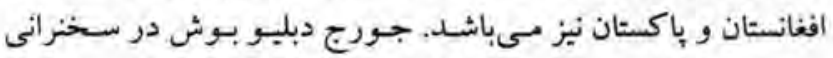

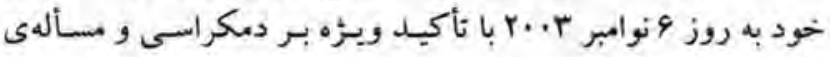

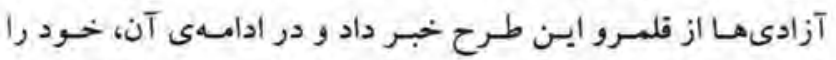

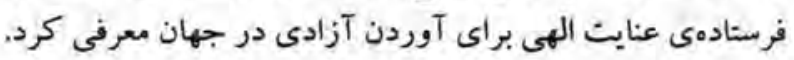

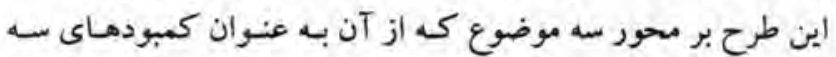

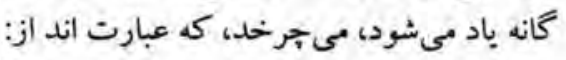

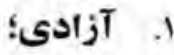
r

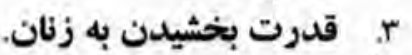




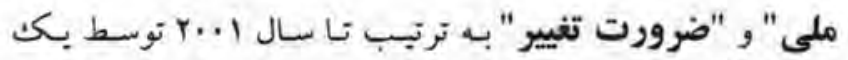

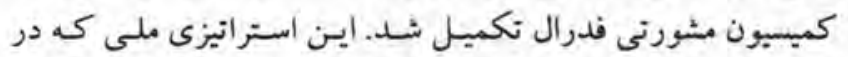

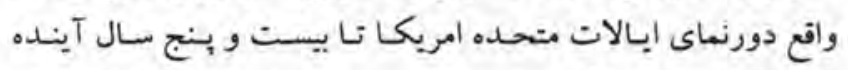

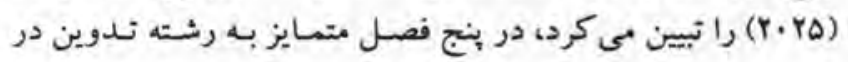

فصل اول - بررسى بويايى جهانى و از آن شــمار آيـلدهى علبم و

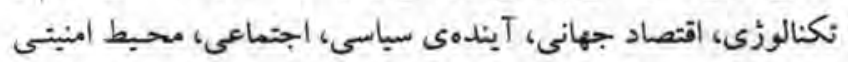

و نظامى.

فصل دوم - حركت جهانى كه به بررسى روندهاى منطفه يى در برتو بويايى جهانى مى بردازد.

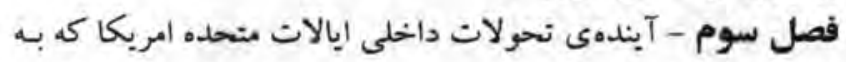

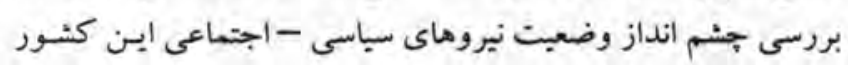
ميردازد. فصل جهارم - جهان بيشرو كه تحليل هاى سـه بخـث يـاد شـدمى بالا را (سه فصل را) در جهار سناريوى جهانى بيان مي كند.

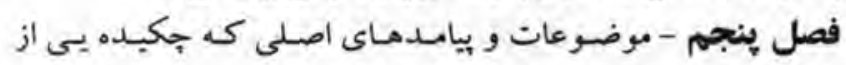
يافتهاى كميسيون مشورتى فدرال مى باشد.

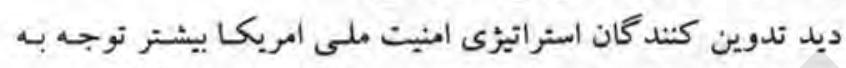

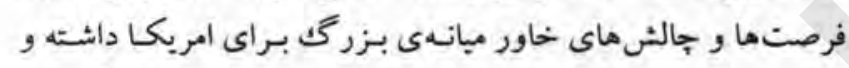

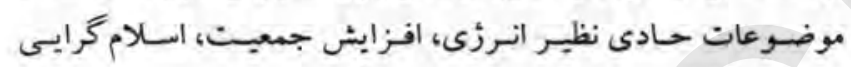

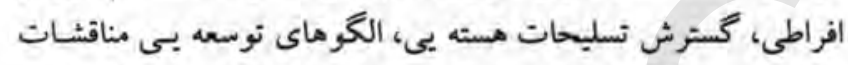

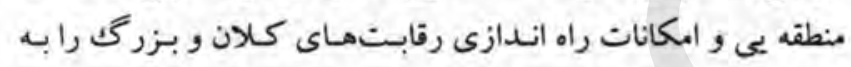

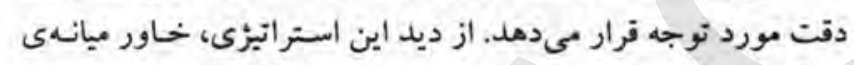

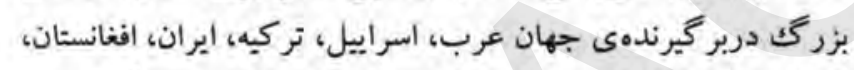

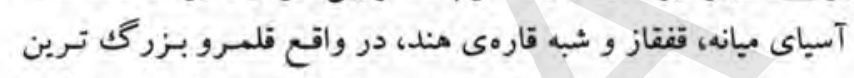

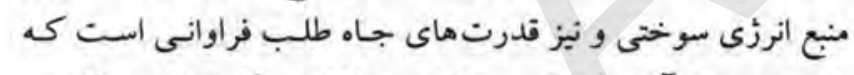

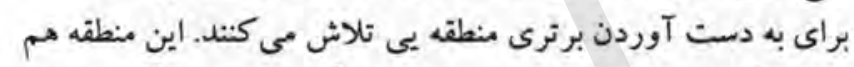

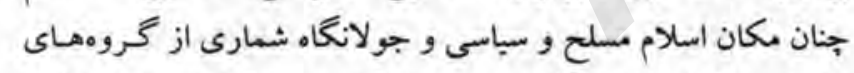

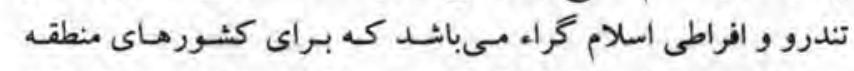

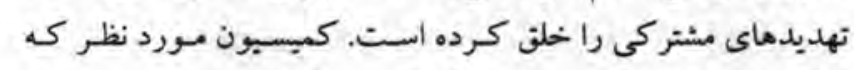

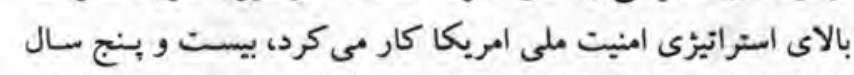

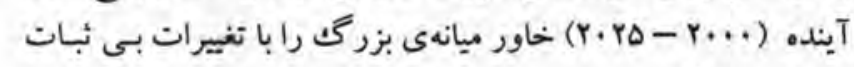

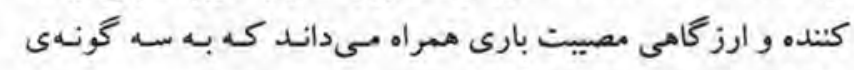

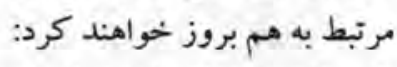

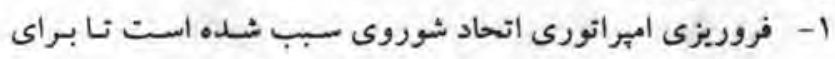

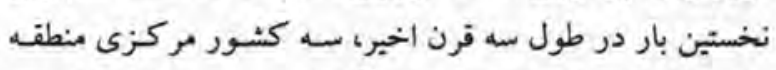

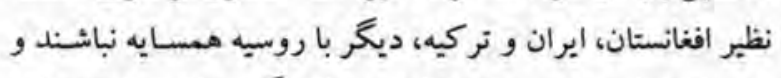

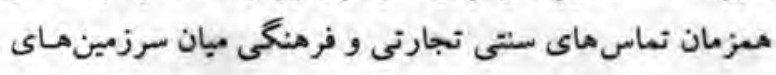

خاورميانهى بزركك؛

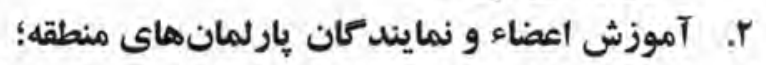

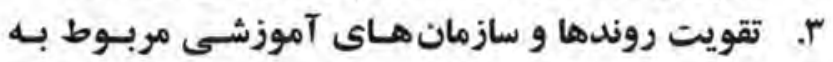
مديريت و رهبرى زنان؛

f.

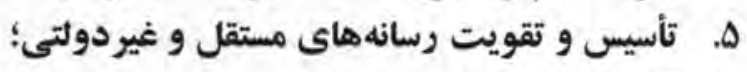

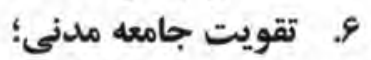

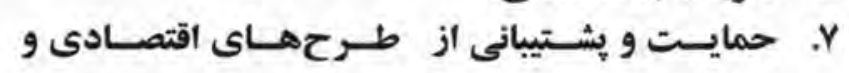
اجتماعى.

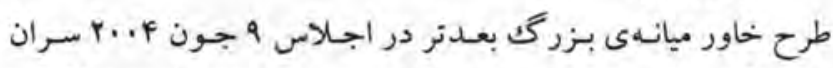

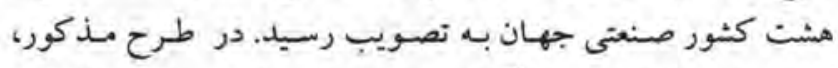

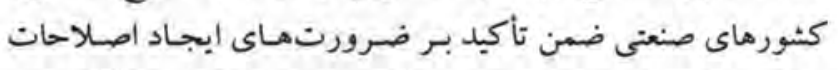

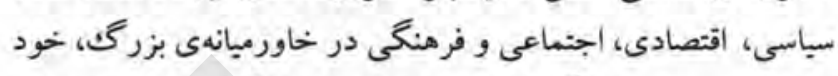

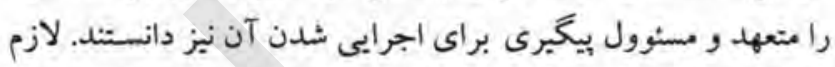

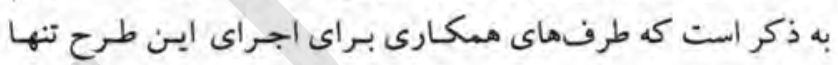

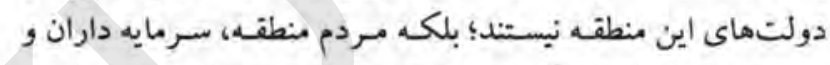

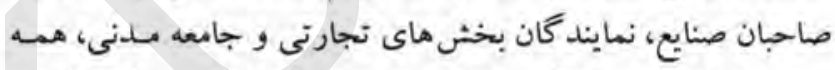

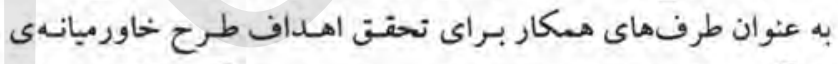

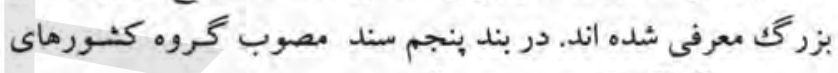

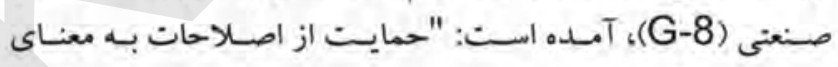

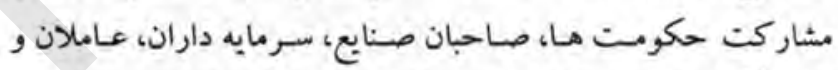

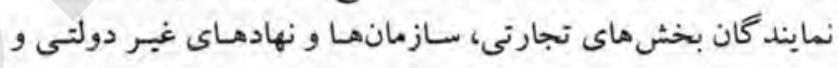

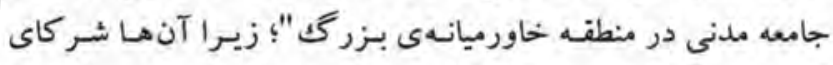
كامل در تلاشهاى مشترك كشورهاى صنعتى به حساب ميى آيند.

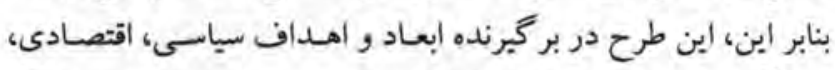

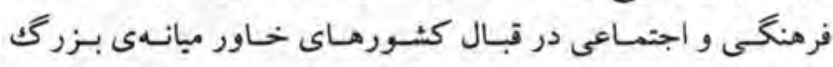

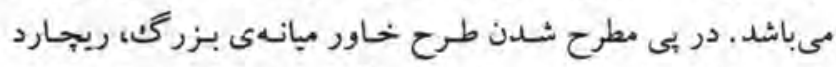

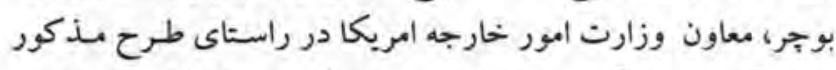

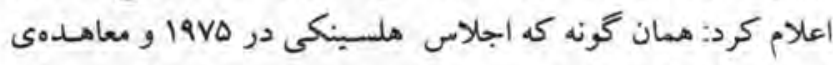

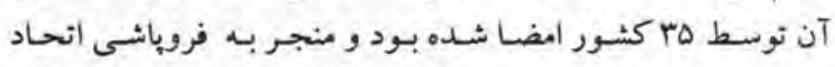

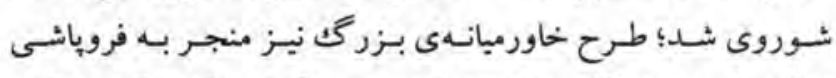

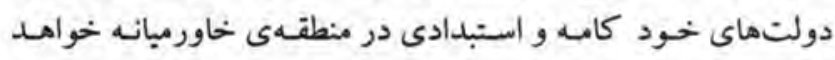

شد.

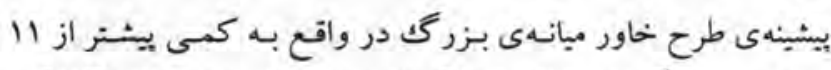

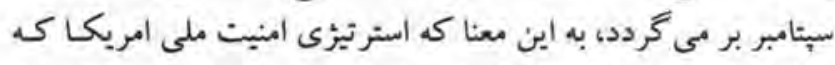

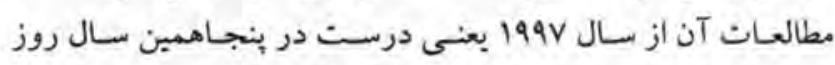

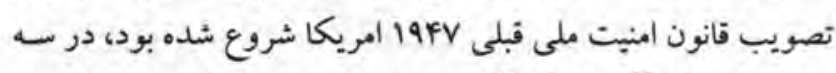

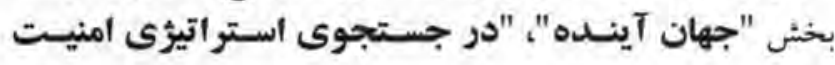




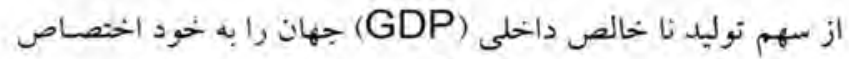

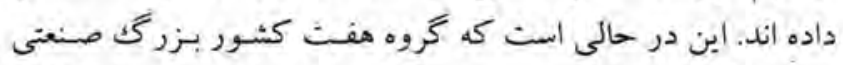

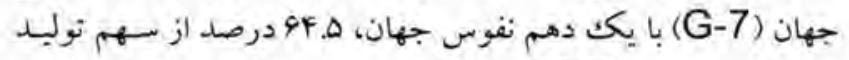

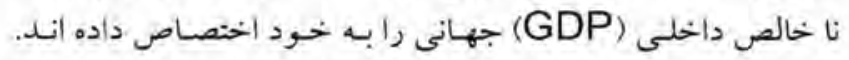

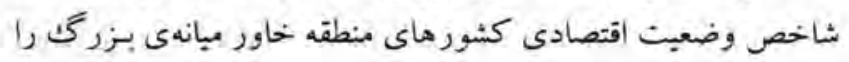

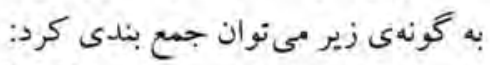

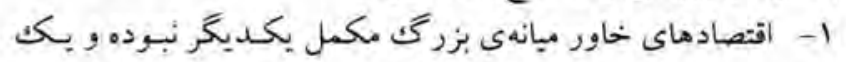

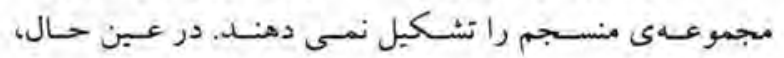

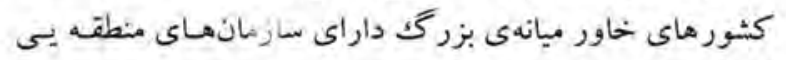

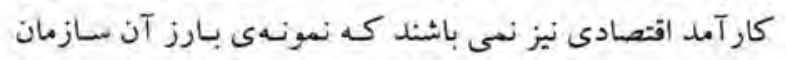

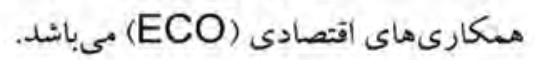

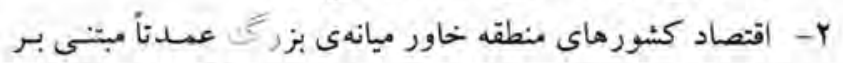

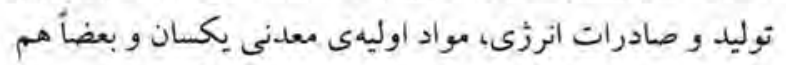

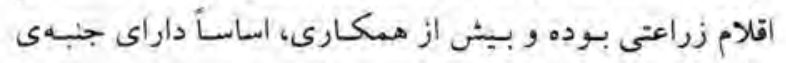

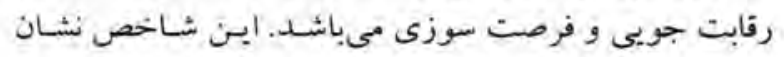

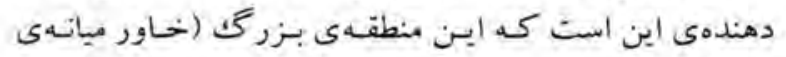

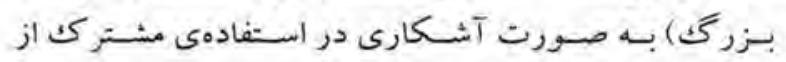

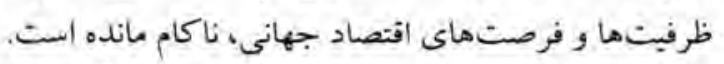

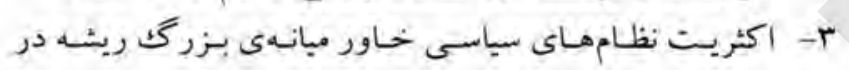

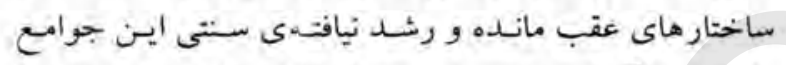

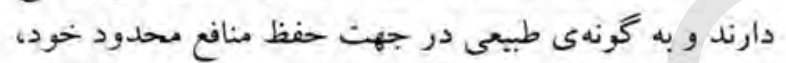

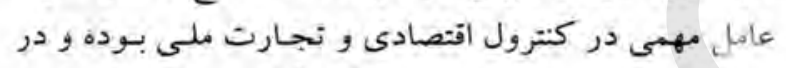

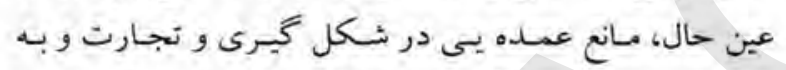

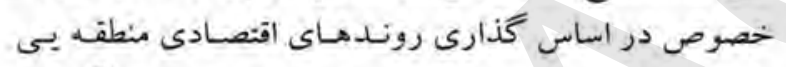

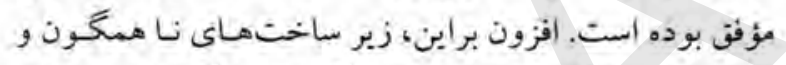

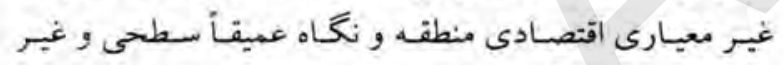

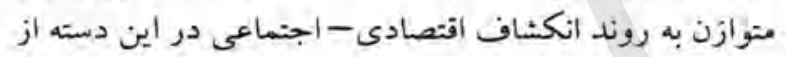

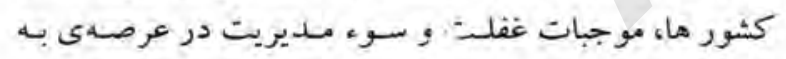

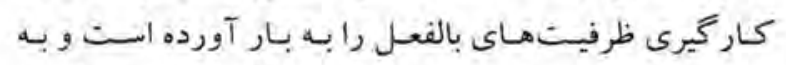

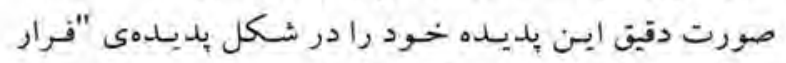
مغزها و سرمايه" نمايان ساخته است.

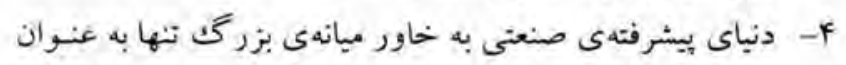

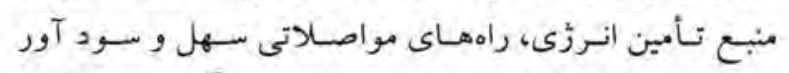

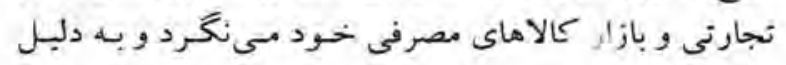

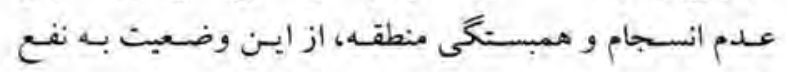
اقتصادهاى خود سود مئبرند.

جهت روشن شدن وضعيت اقتصادى - اجتماعى منطقهى شحاور

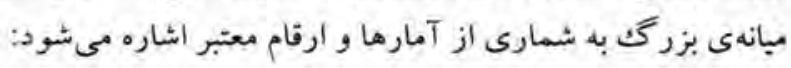
ادامه دارد المباره

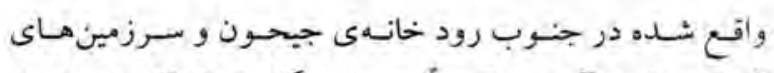

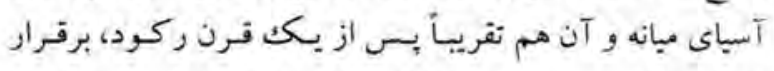

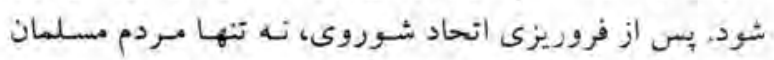

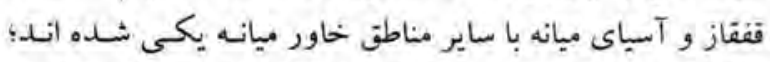

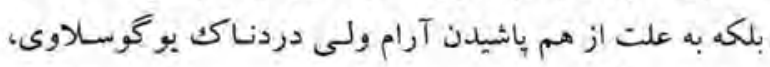

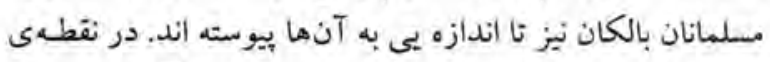

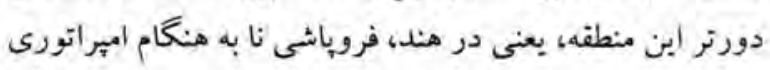

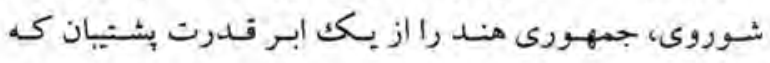

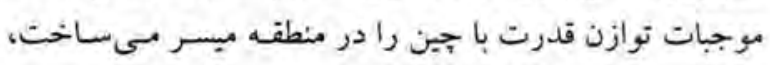

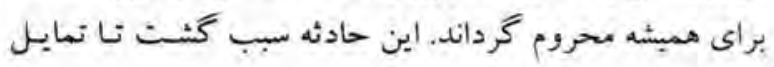

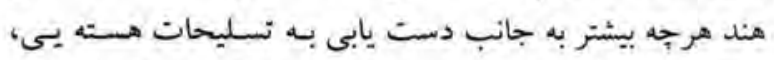

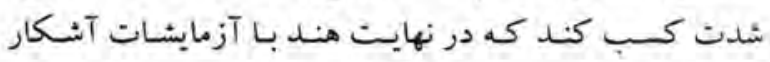

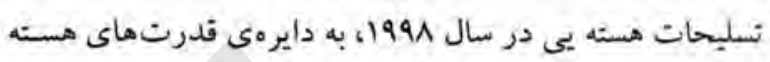

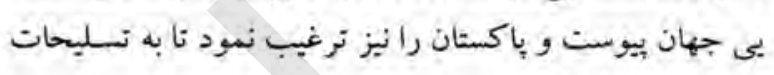
هسته يى دست يابد.

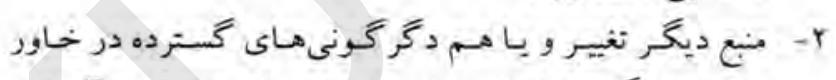

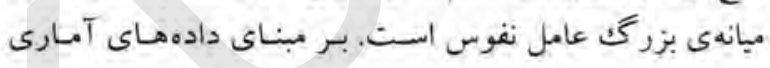

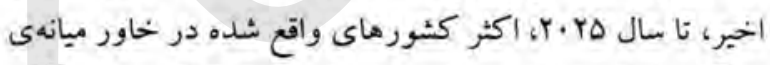

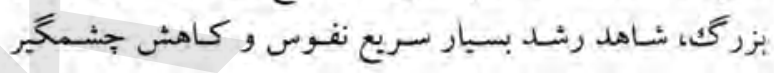

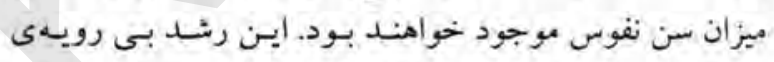

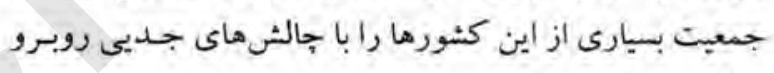
خواهل ساخت.

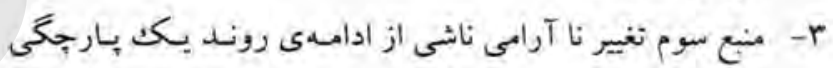

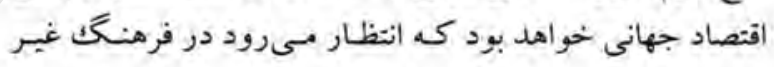
غربى منطقه، موجبات يكت سلسله تنشها ها رابه بار آورد.

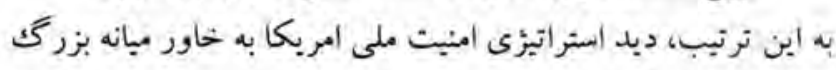

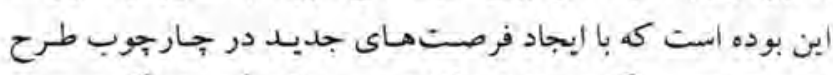

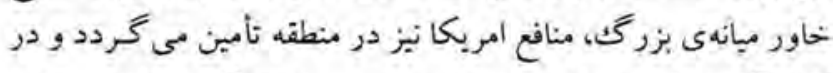

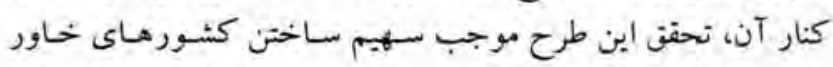

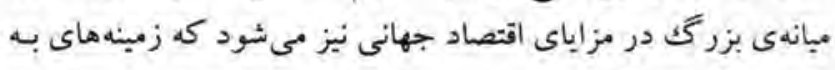

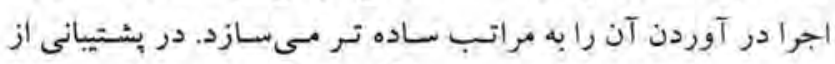

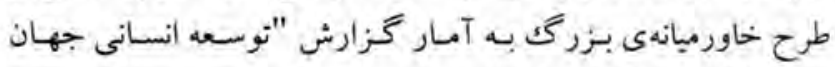

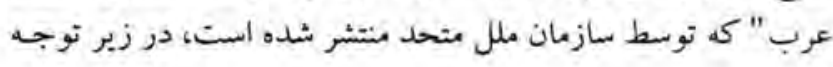

تسوبد.

ساختارهاى موجود اقتصادى - اجتماءيى كشورهاى منطقه

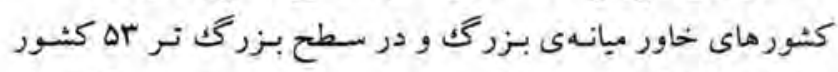

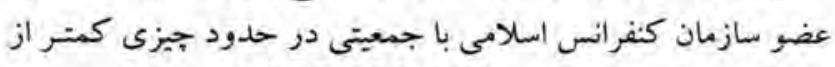

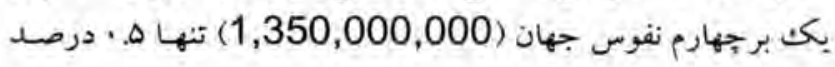




\section{اففانستان و تجربه كار با سازمانهاى منطقهاى}

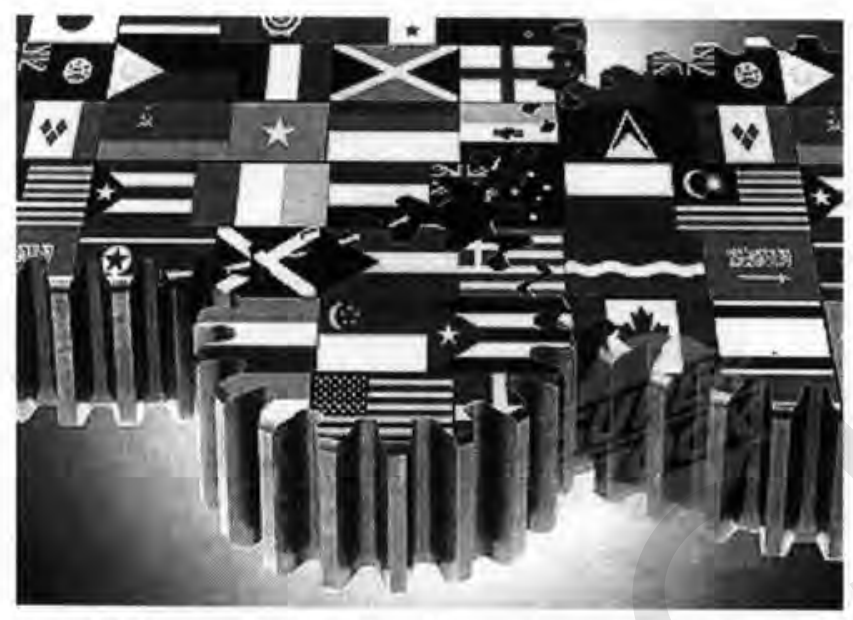

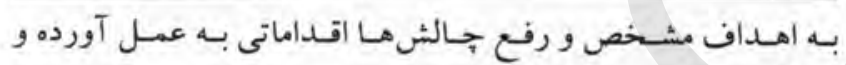

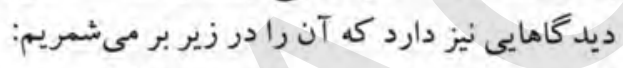

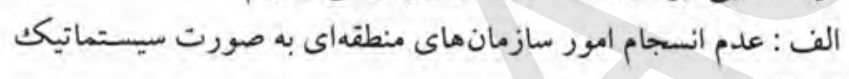

و منطقى نكات عمده مورد بحث جلسات اين سازمانها را موضوعاتى تشكيل

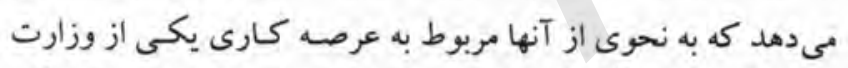

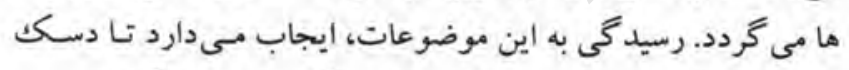

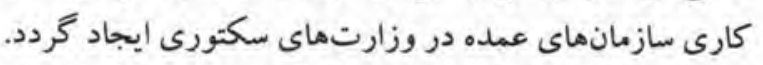

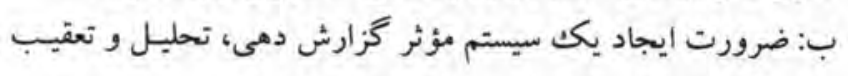
موارد اجرايى ناشى از تصاميم جلسات:

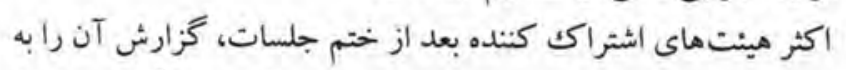

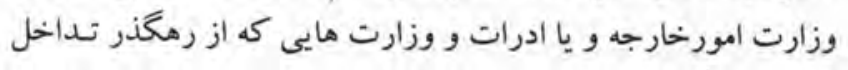

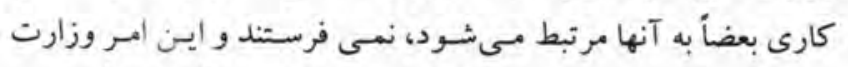

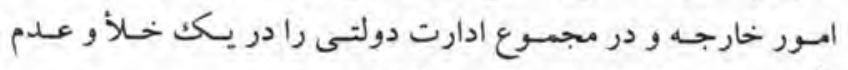
آكاهى از رخدادهاى اقتصادى منطقه قرار مىدهد.

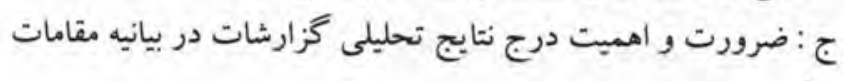
عاليه
بعد از ايجاد ادارة مؤقت، افغانستان به هدف بر آمدن از يكك انزوا و

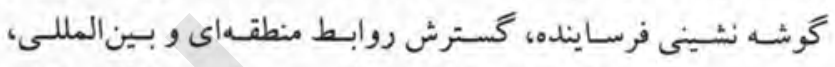
تشخيص و تحقق الويت هاى اقتصادى، كسب تجارب و اطلاعات در

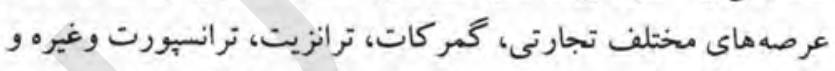

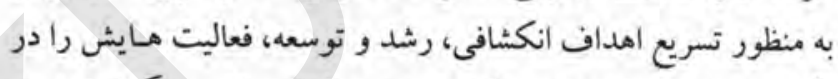

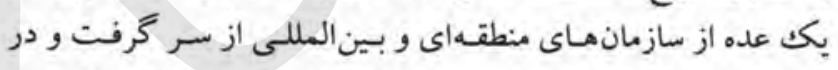
جهت كسب عضويت تعدادى از سازمانهاى عمده، مسـاعى لازم بـهـ

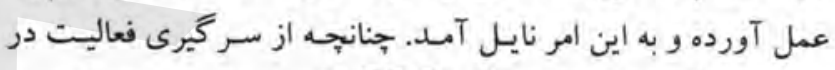

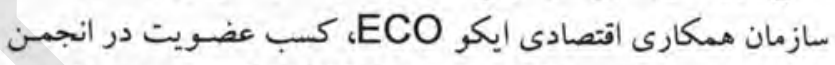

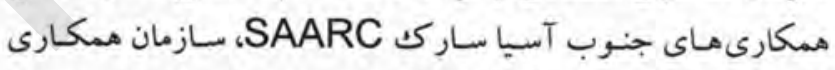

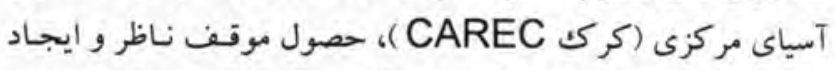

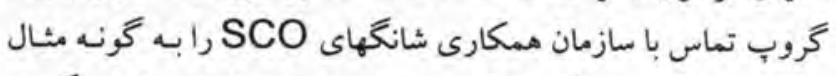

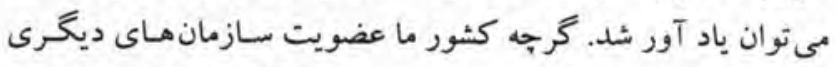

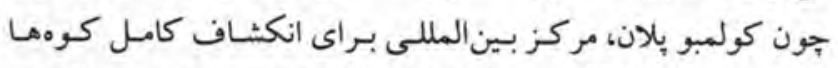

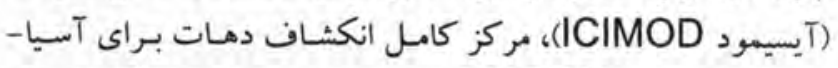

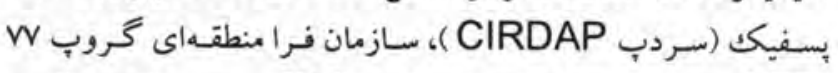

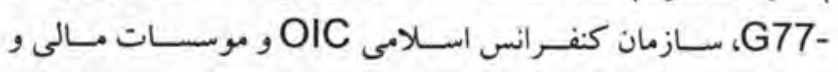

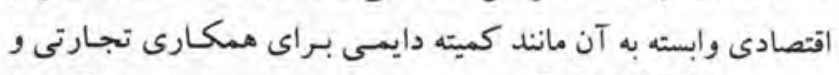

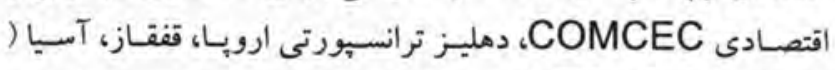

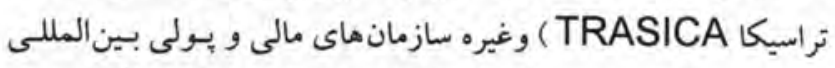

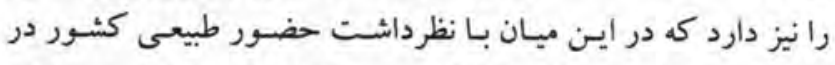

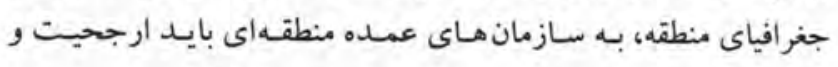
اهميت قايل شد.

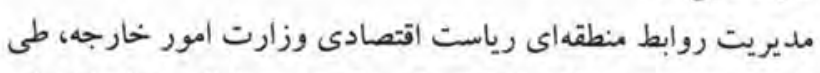

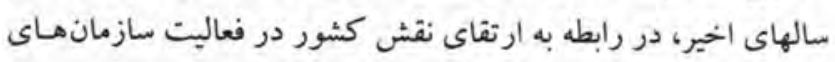

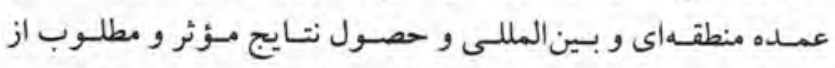

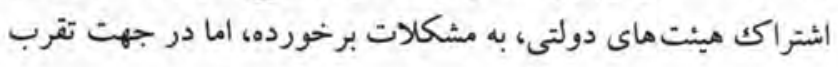


افغانستان و جناب وزير السور خارجه، نكات مـرتبط بـا فعاليـتهـا و موضوعات مطروحه يكك سال قبل، جـالشهـا در راه تطبيق تصاميم

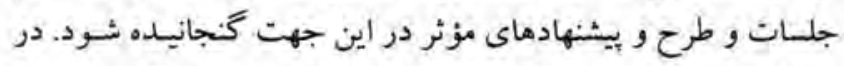

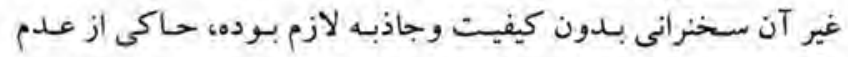

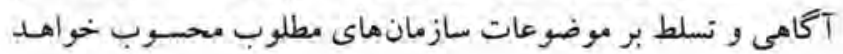

شد.

وزارتهاى نماينده فوكل باينت فوق الذكر، قبل از تـدوير جلسـات

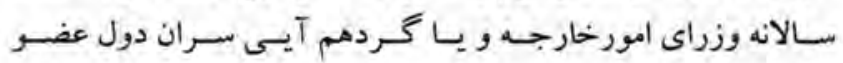

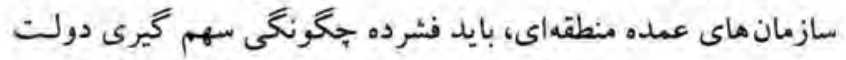

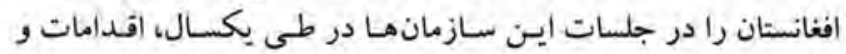

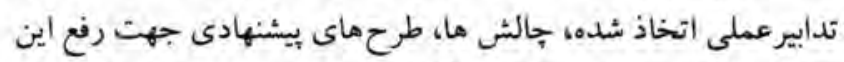

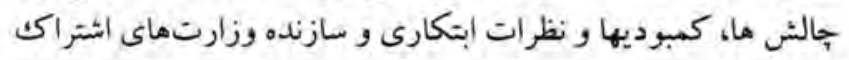

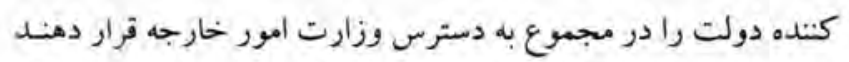

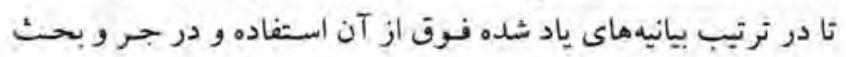

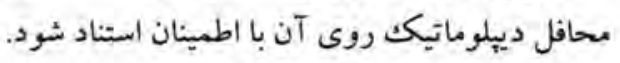

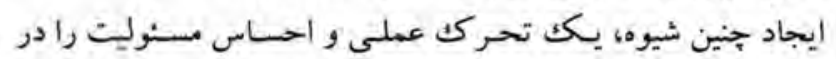

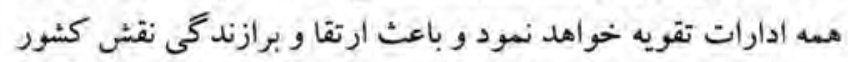

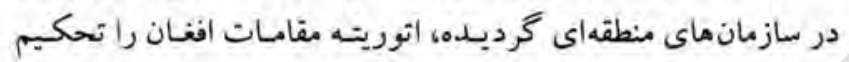
خواهد بختشيد. موارد فوق الذكر كه روى آن در نشست مشتركث مستولين رياست

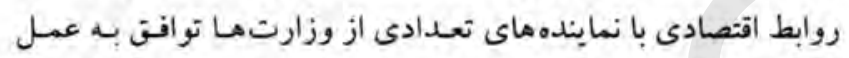

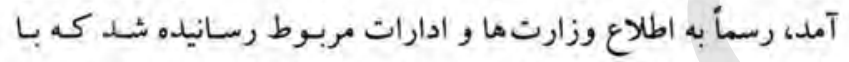

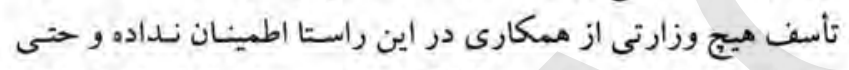

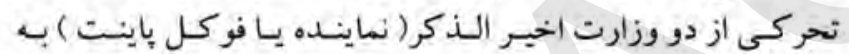

مشاهده نرسيد. جالشهاى كادرى علاوه از مواردى كه قبلأ ذكر شد، از نو اقص و جالشهاى ديخرى نيز مىتوان حسب زير ياد آور شد:

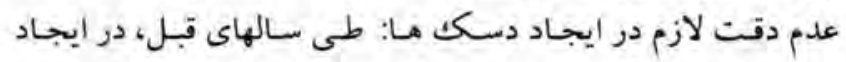

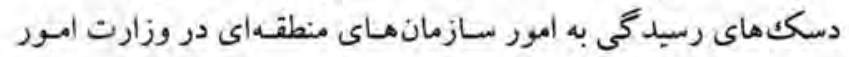

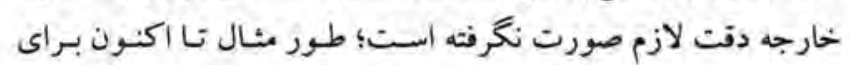

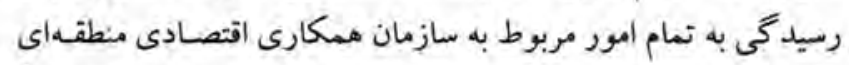

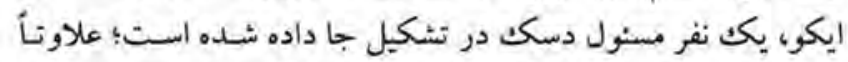

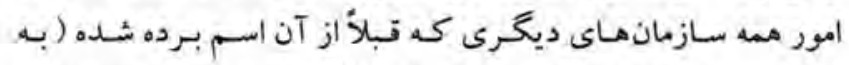

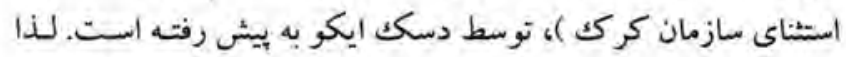

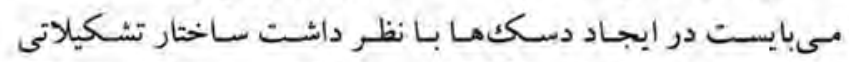

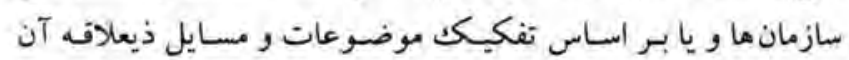

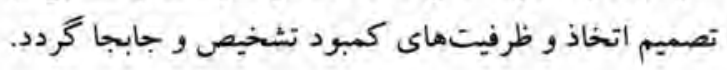

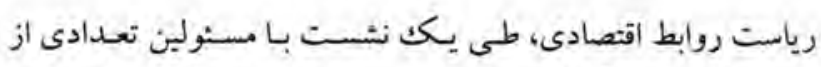

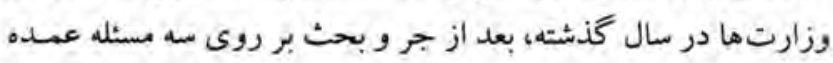
فوق به اين نتيجه رسيدند:

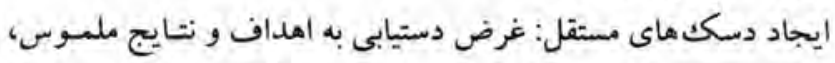

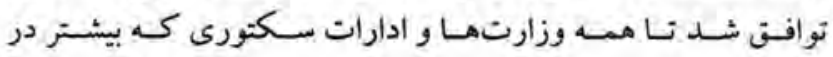

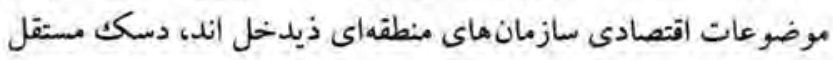

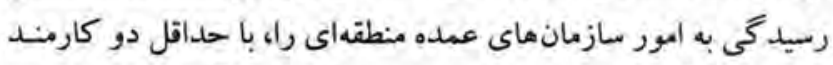

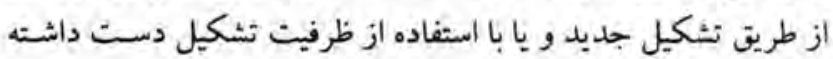

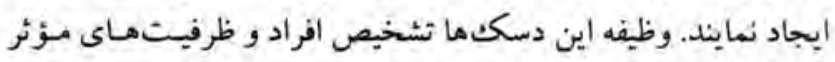

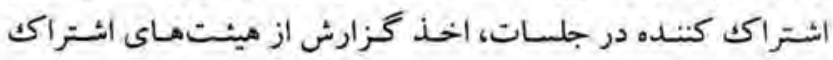

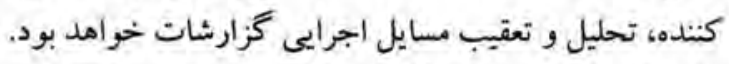

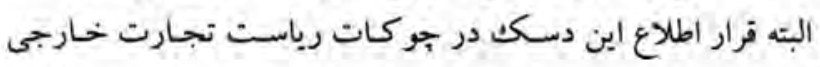

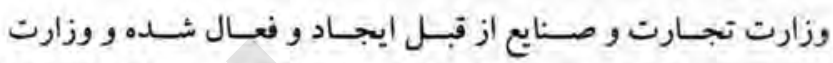

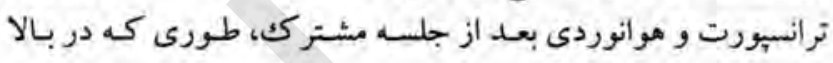

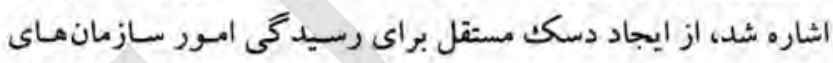

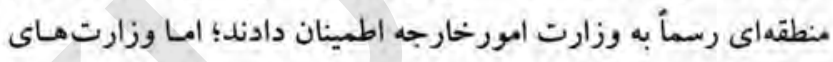

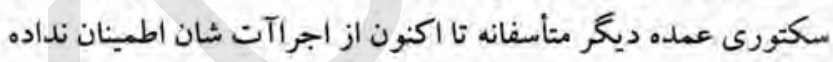

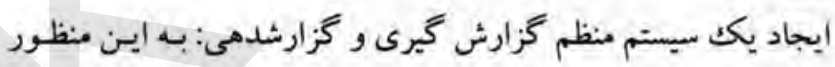

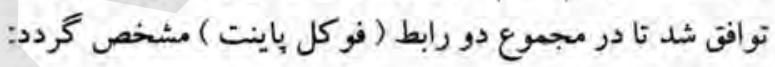
- وزارت اقتصاد، - وزارت كار و امور اجتماعى، شهار و ومعلولين.

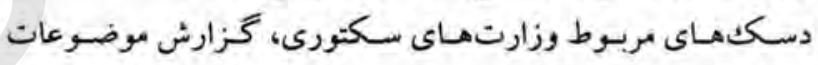

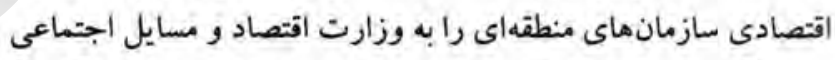

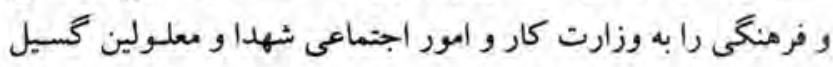

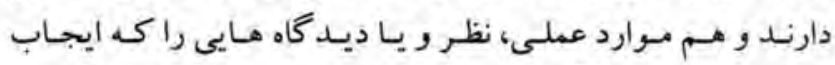

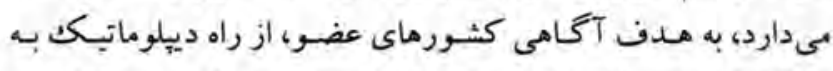

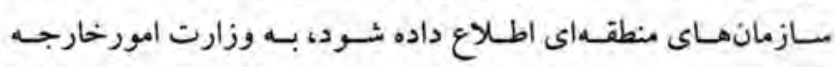

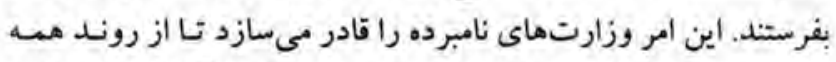

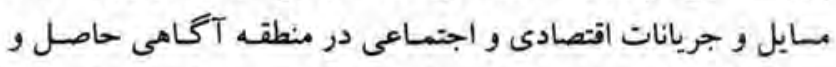

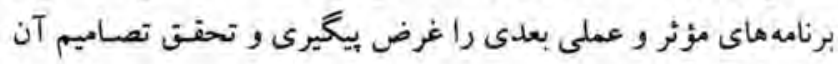
روى دست گيرند.

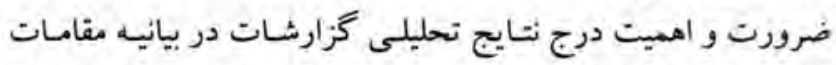

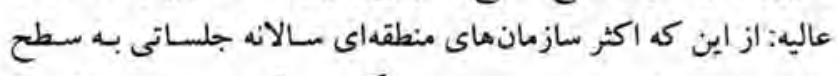

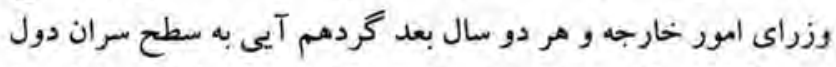

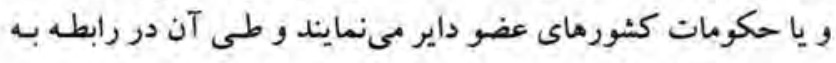

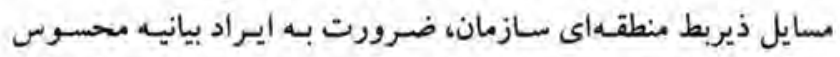

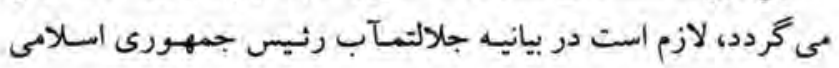




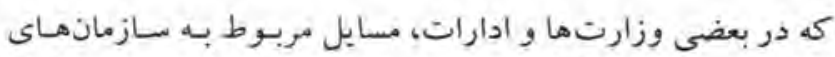

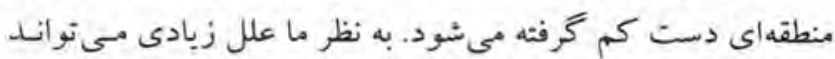
در اين امر دخيل باشد:

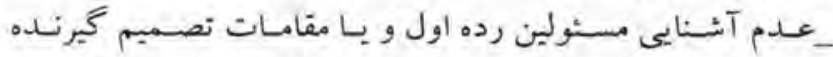

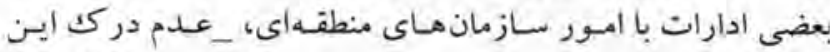
مسئله كه موضوعات مربوط به سازمانهاى منطقهاى بـه شـكلى از

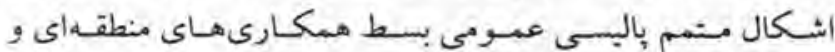

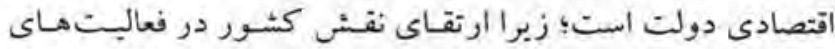

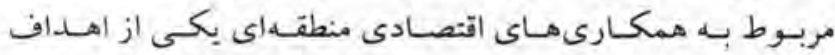

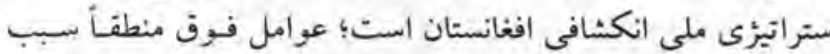

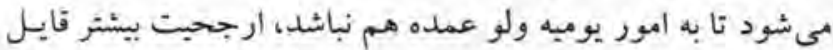

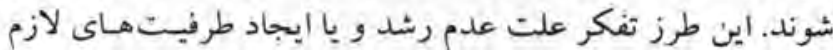

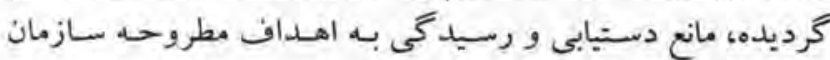

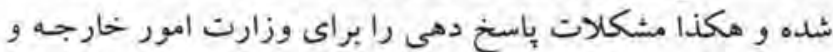

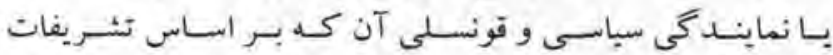

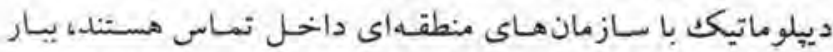

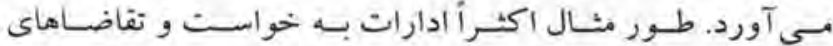

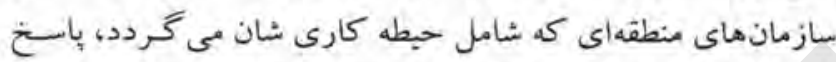
مئبت، منفى و يا نظر بيشنهادى ارايه نمى دارند.

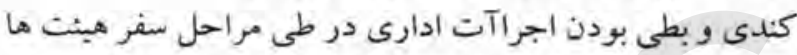

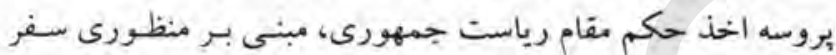

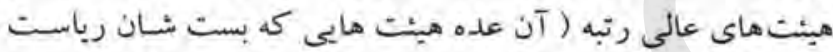

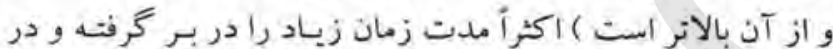

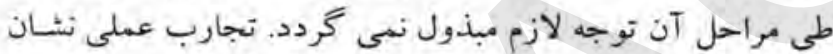

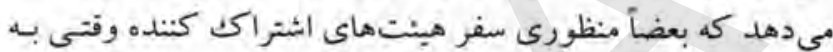

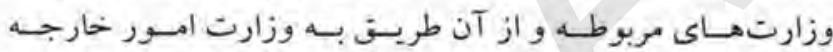

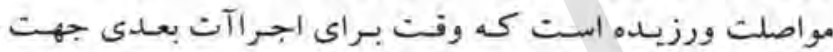

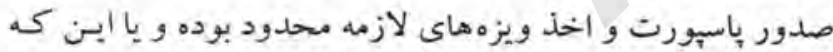
جلسات بهم و عمده خاتمه بافته أست.

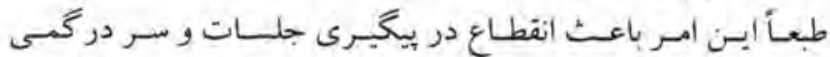

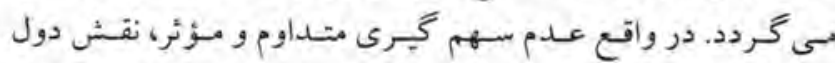

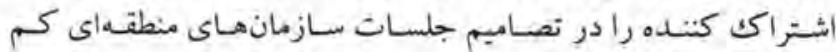

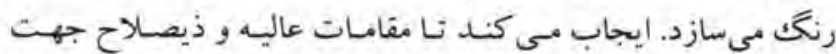

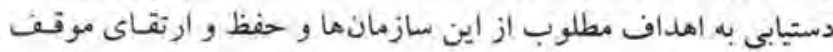

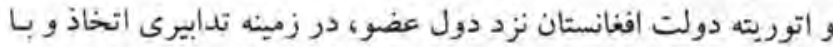
آن به طور جدى برخورد نمايند، در غير آن با موجوديت اين حالك

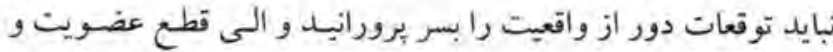

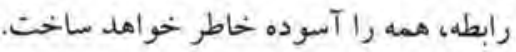

تغيير و تبديل كادرى در داخل ادارات و وزارتخانه ها، بدون در نظر

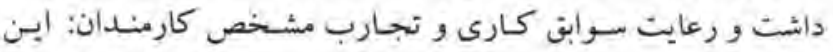

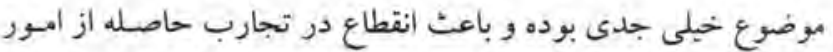

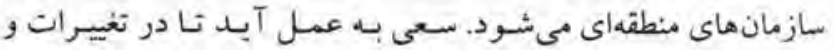

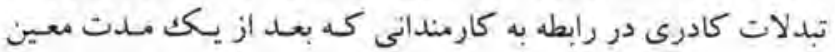

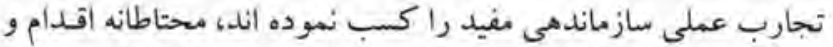

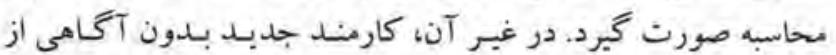

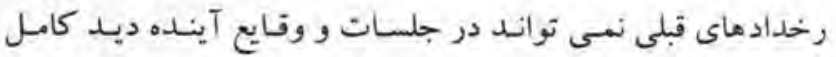
داشته عمل نمايد. جالث هاى أدارى

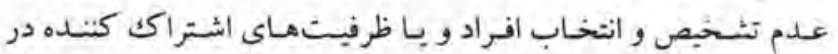

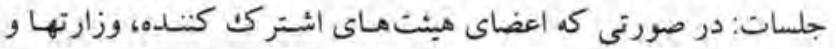

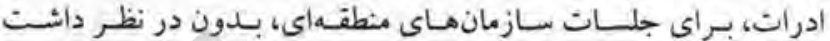

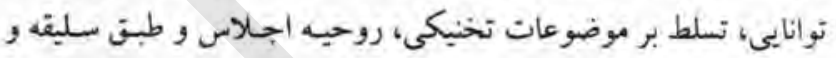

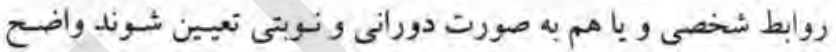

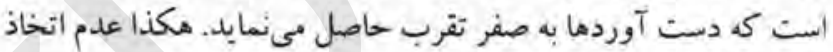

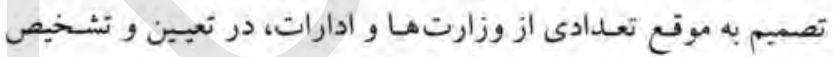

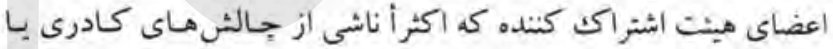

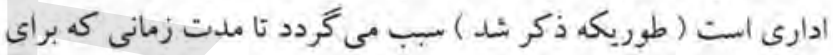

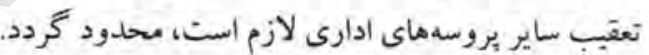

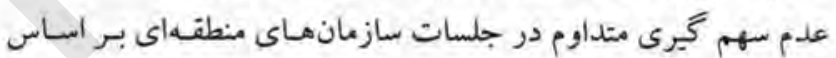

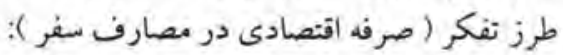

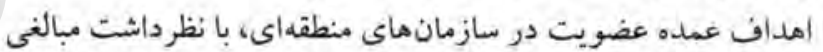
كه سالانه به عنوان حق العضويت برداخت ميشود متقاضى آنست تـا

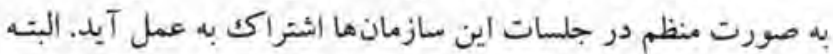

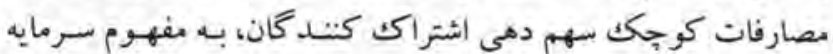

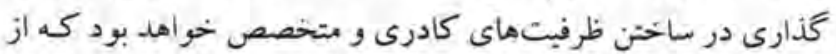

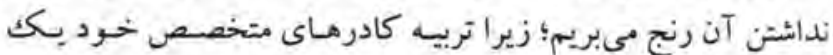

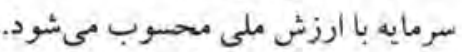

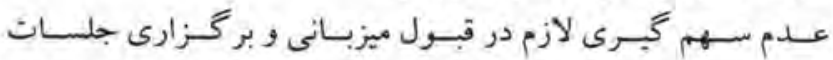

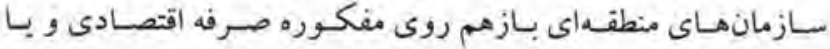
عدوديتهاي بودجوى:

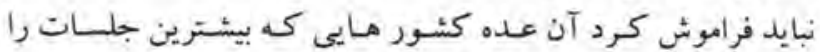

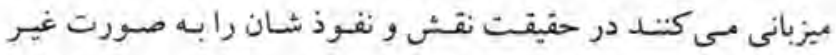

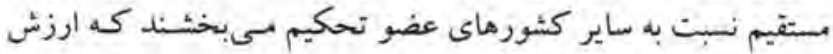
معنوى آن به مراتب بالاتر از دست آورد مادى است.

عدم ارجحيت به مسايل سازمانهاي منطقهاى: جنين استنباط مىشـود 


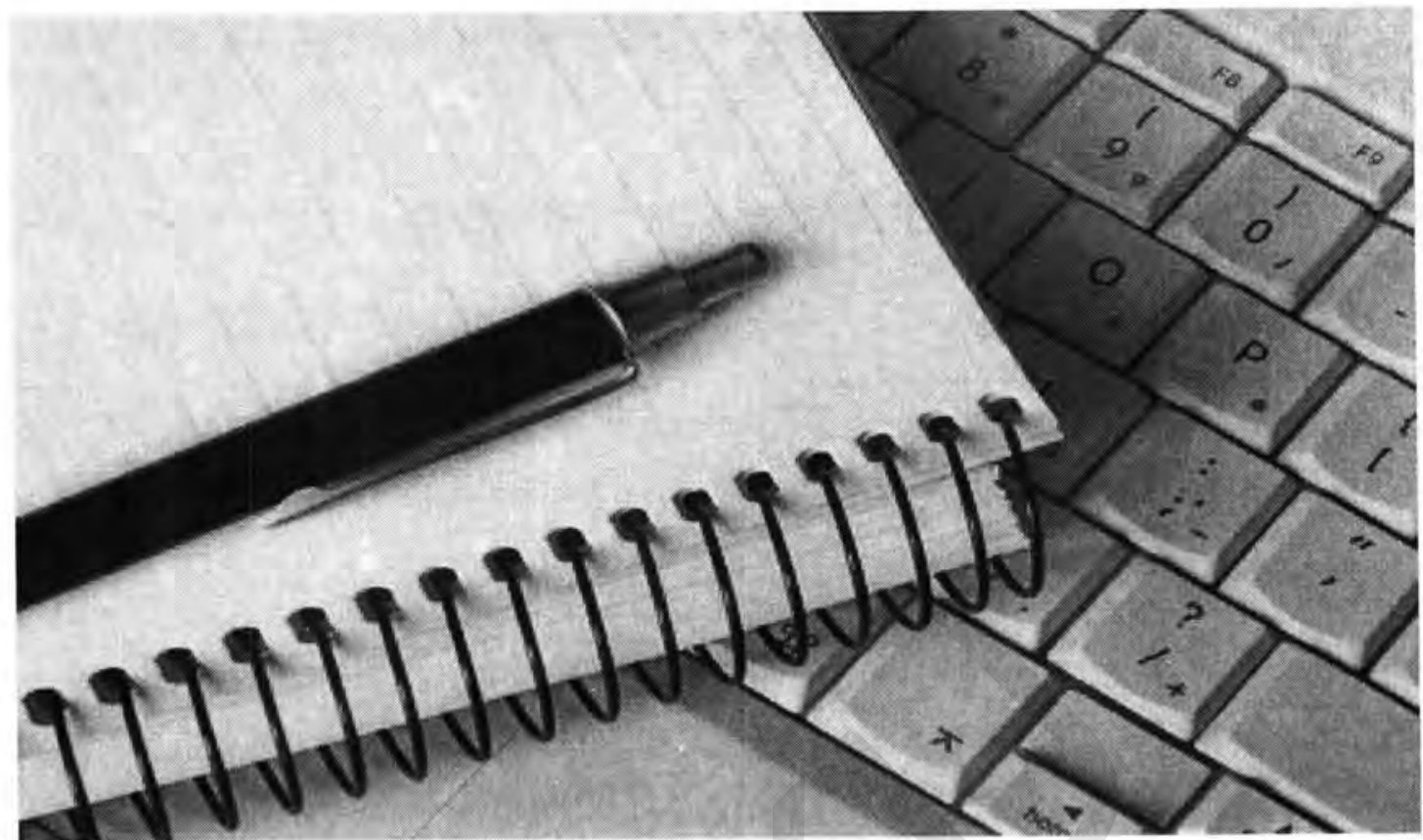

\section{هـ نوي ثورناليزم آرونه}

\section{4}

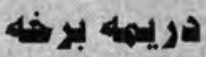

لبكوال: رحيم الله سمندر

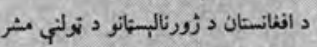

- vast....

samander@3wakht.com samander2003@yahoo.com

د رايور يلتنبي برخه
د رايور موضوع زوندى بنيي، د رابور موضوع نوي او تازه كوي، لوني،

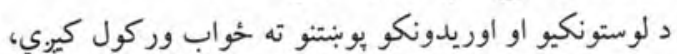

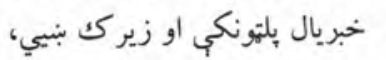

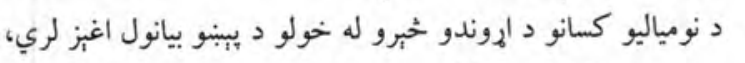

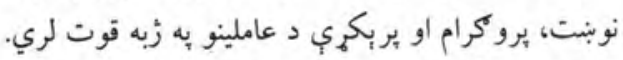

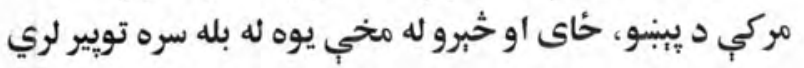

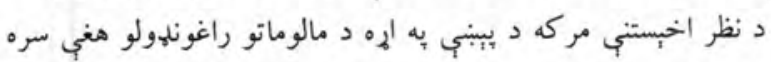
توبير لري،

د يوه لاروي سره لنلهه مر كه د يوه بوهاند هغي سره تويير لري،

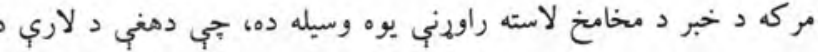

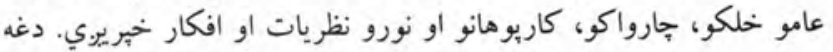

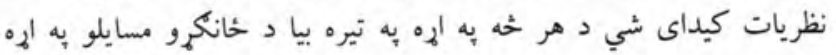

$$
\text { د مركي ارزبنت }
$$

خبري سوزي ته بياور تيا ورببني،

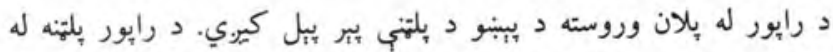

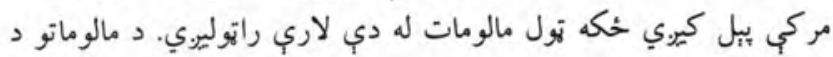

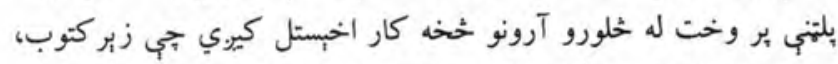

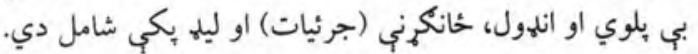
مركه

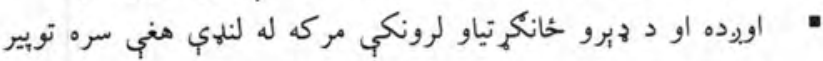

د يوه تي سرتيري مركه د يوه سوبمن جنرال هغي سره تويير لري. 


$$
\begin{aligned}
& \text { مركي د ثبت تر خنيك وليكى، }
\end{aligned}
$$

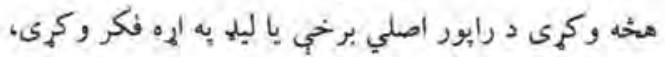

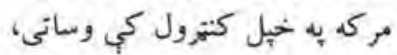

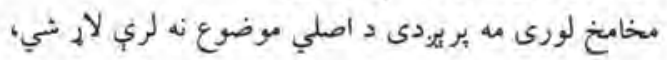

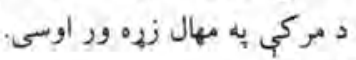

$$
\begin{aligned}
& \text { م مركي اداره }
\end{aligned}
$$

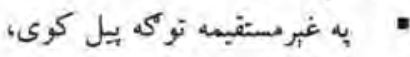

$$
\begin{aligned}
& \text { د تاكتيك لرل، } \\
& \text { د خبرو سبك أو بني (ستيايل) نه زيركيدل، }
\end{aligned}
$$

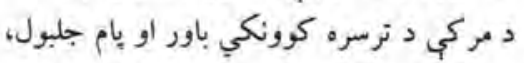

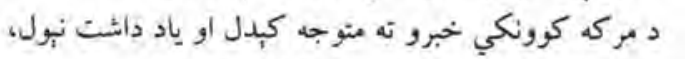

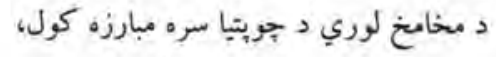

$$
\begin{aligned}
& \text { د مخامخ لوري نه د انخور (عكس) اخبستل. }
\end{aligned}
$$

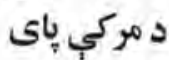

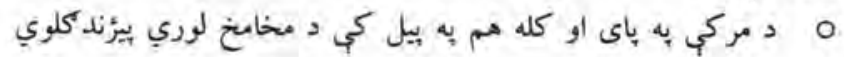

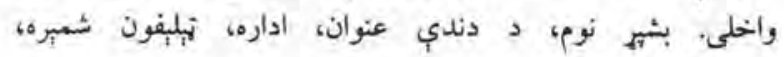

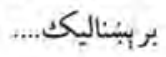

O مدي مالوماتو د الخبستلو او لرلو دلايل ورته بيان كرىى،

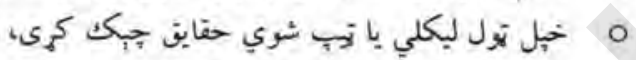

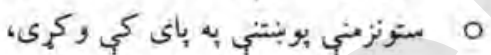

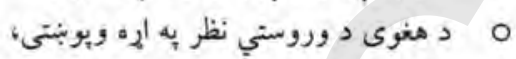

$$
0
$$

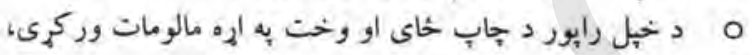

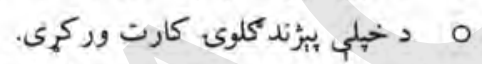

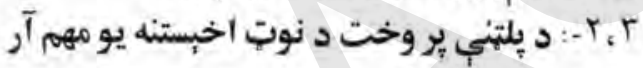

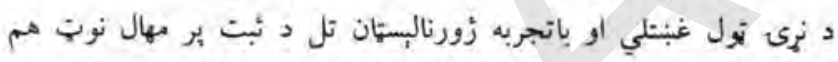

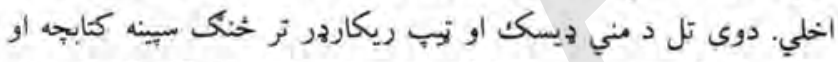

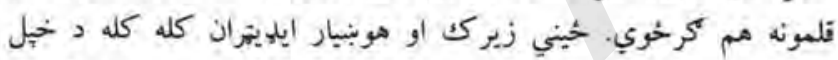

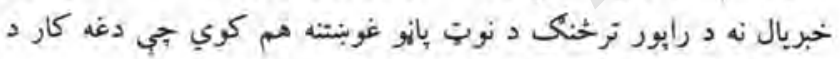

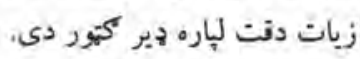

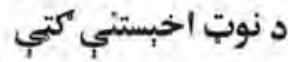

$$
\begin{aligned}
& \text { د تبروتنو مخه نيسي، } \\
& \text { دقت او كره لبكتو كي مرسته كوي، } \\
& \text { ليكلي شبان له ياده نه وخي، }
\end{aligned}
$$

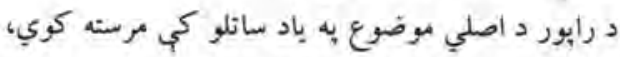

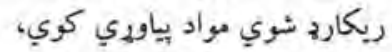

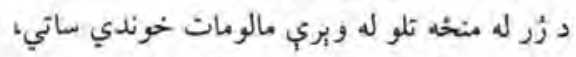

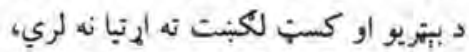

كارونه او جاري بي هي اوير وخت نه نيسي،

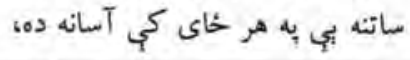

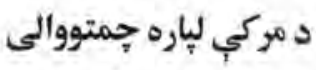

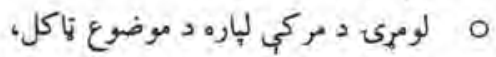

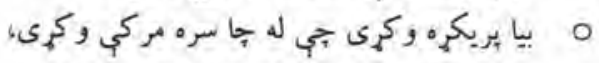

O 20

0

م 2

0

O 2

0

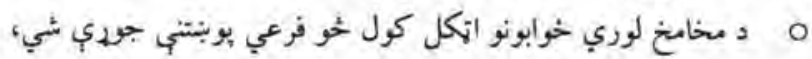
0

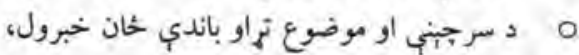

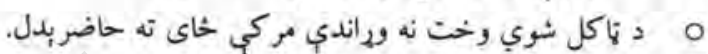

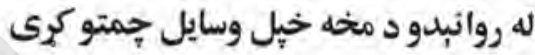

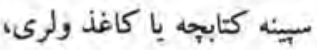

له يوه خخه جير قلمونه له خائه سره وباتى كانى،

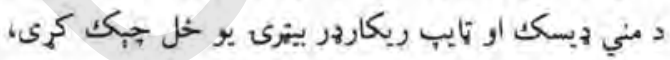
خالي كسيتونه ولرىى، دئن

د كبري بيترى أو فلم جبك كئرى

د موكي بيل كله جي د سرجبني (مركي كوونكي شخص) دفري

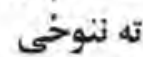

خجل خلور خواوي وكوري، كوم نوي خحه تر ستركي كيري؟ >

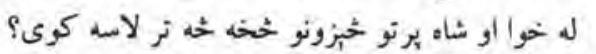

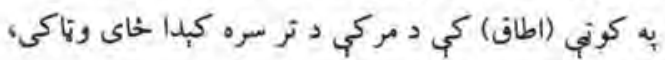

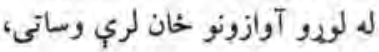

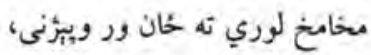

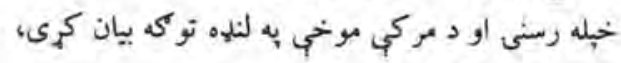

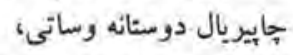

كه له بهرني كس سره مركى كوى او د هغه زبه مو بوره نه وي زده،

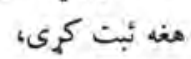

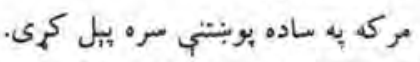

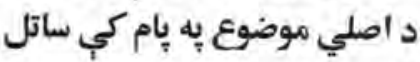

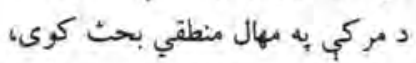

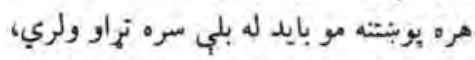

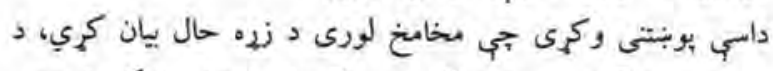

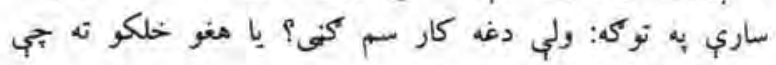

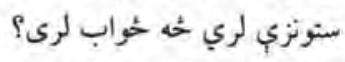

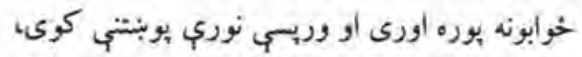


لرونكي كلمب وكاروي او دغه راز حُانته خيني كلمي لندي او آروته

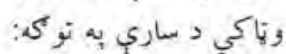

(a.)

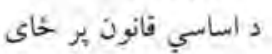

(ج.1.)

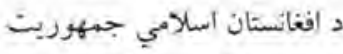

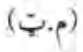

(נ) (ج)

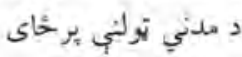

(ج.g)

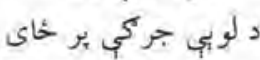

$(\mathrm{e})$

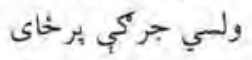

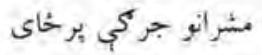

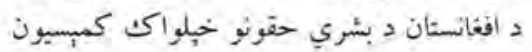
(1)

شمال، جنوب، ختيخ او لويديخ بر خاي راب

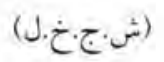

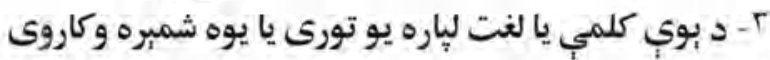

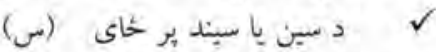

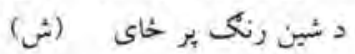

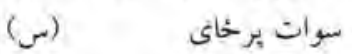

(c) حمزه بر حايى

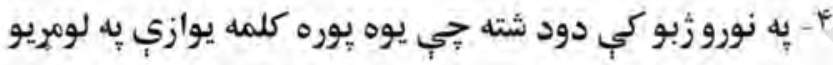
دوه تورو يا يوه توري او يوب شمبري باندي نبيي د ساري بِ يه

توكنه:

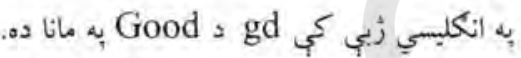

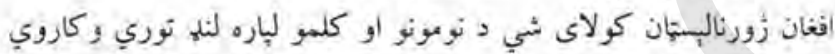

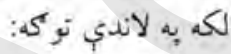

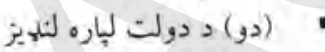

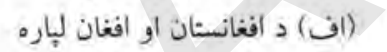

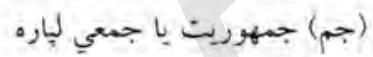
(كا) كابل لِاره

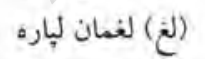

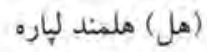
(J) (ل) دوه لسبزو لباره

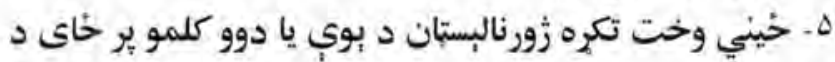
مختارو او وروستارو سره د هنو خيني توري كاروي لكه

$$
\begin{aligned}
& \text { (ب.تون) يو هنتون لِاره } \\
& \text { (كن.تون) ح كتابتون لياره }
\end{aligned}
$$

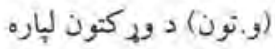

$$
\begin{aligned}
& \text { (ر.تون) د روغتون لياره ليار } \\
& \text { (ن. هار ) د نثكر هار لهار. } \\
& \text { (د.نون) د درملتون لياره }
\end{aligned}
$$

بهة آسانه او بنه شان فايل كيري، نبهَه او ثوم وركول كيري،

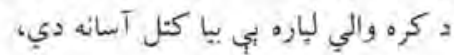

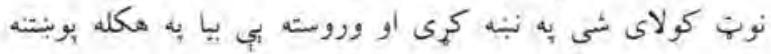
وكرئ.

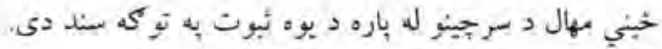

د نوت اخبستني لارنبود

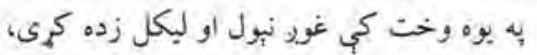

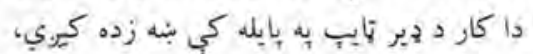

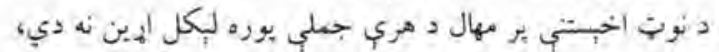

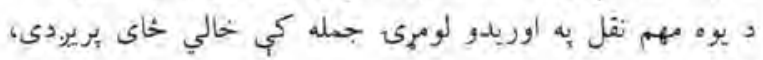
هغه نقل، نقل وليكى،

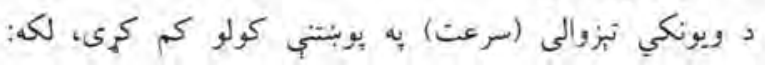

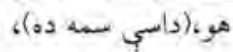

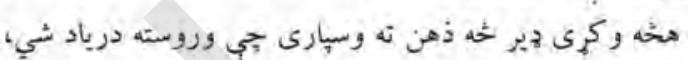

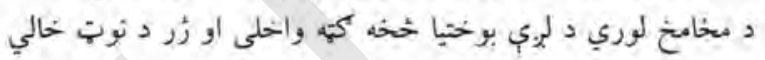

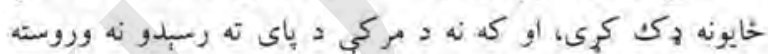

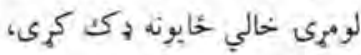

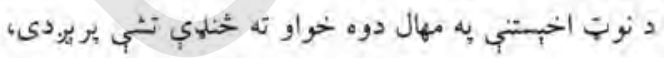

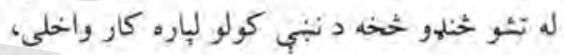

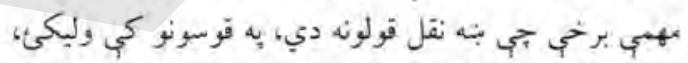

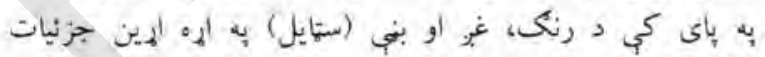
وليكئ وغن رأز له لمه فكر وروسته ذهن ته سيازلي جزئيات كاغذ ته ورسوىن

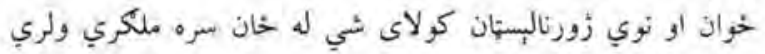

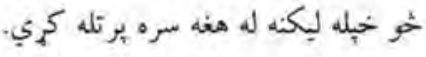

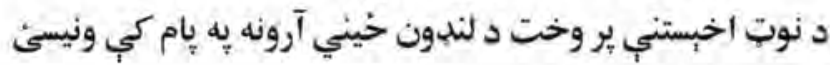
لنيون (Contraction

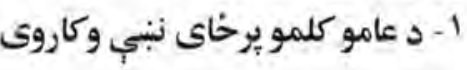

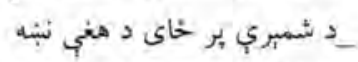

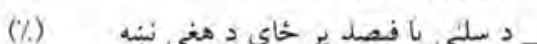

(a) _ ل

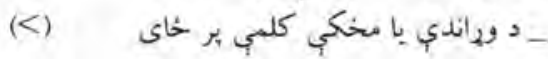
(P) ل

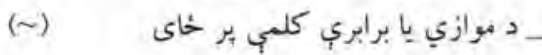

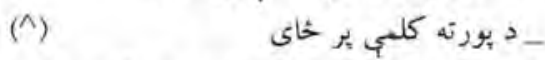

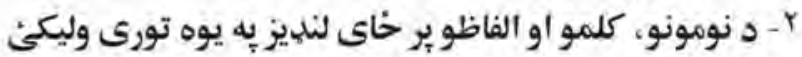

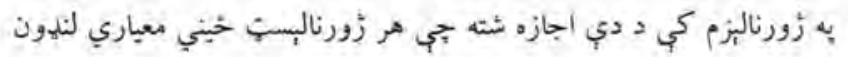




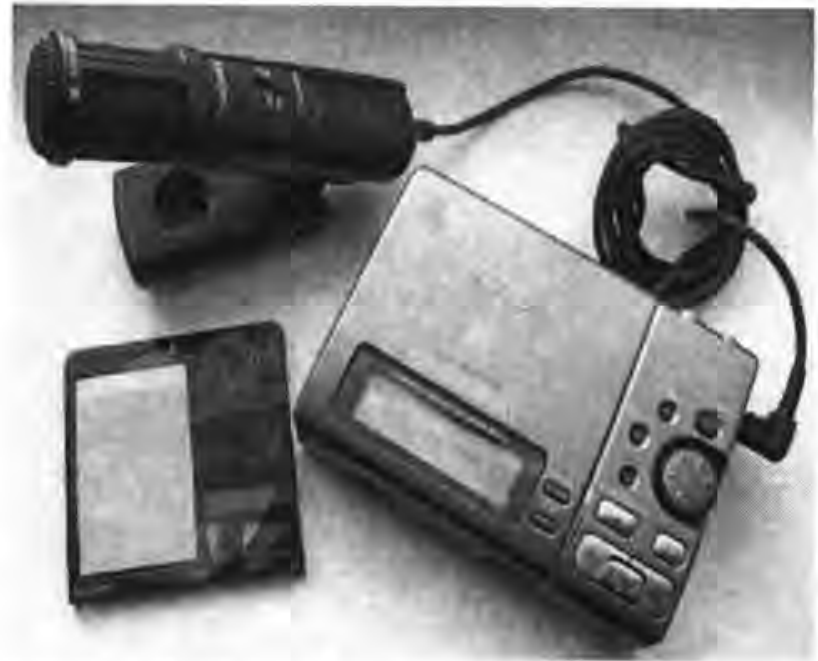

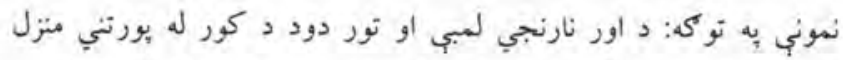

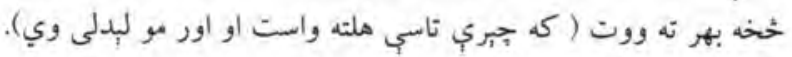

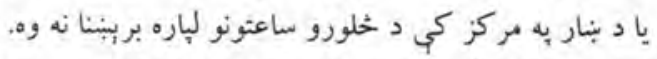

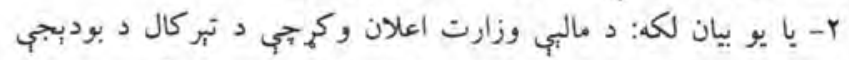

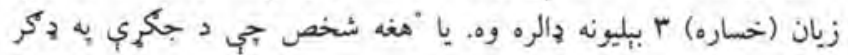

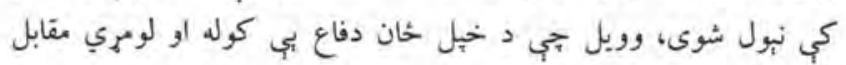

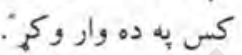

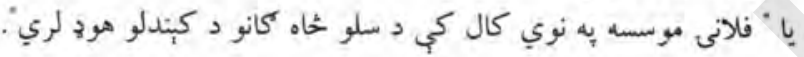

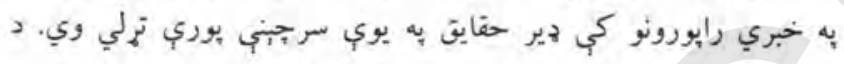

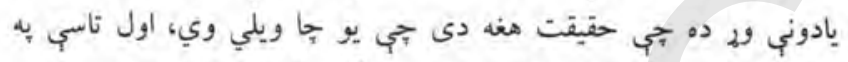

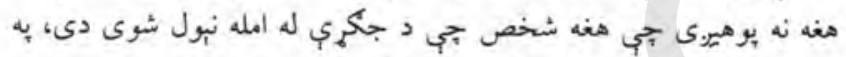

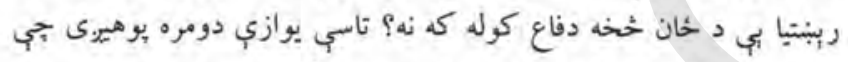

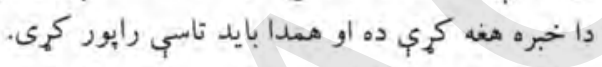

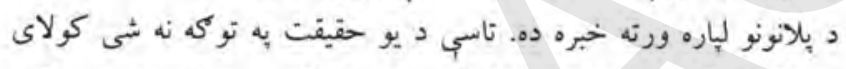

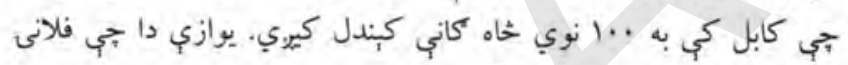
موسسه بلان لري جي داسي وكري بهي.

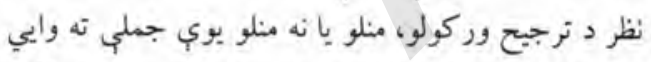

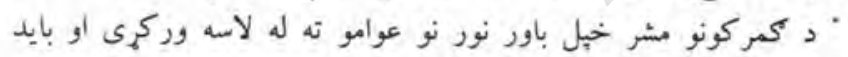
استعفا وركمي".

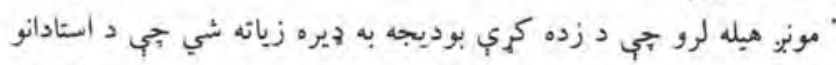

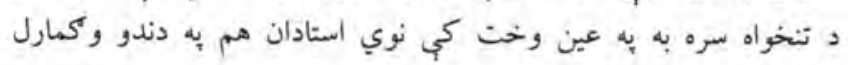
"يوليس بايد هغه صاحب منصبان اصلاح كري، خب د نبوني بر وخت

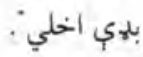

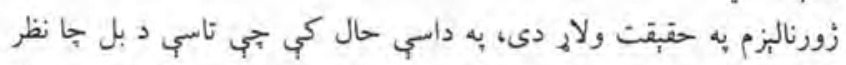

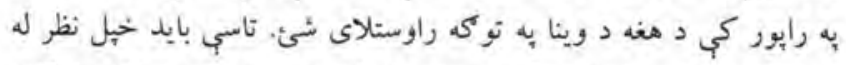

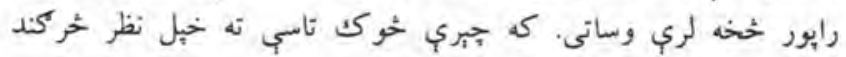

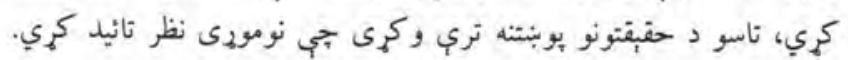

هخه وكرى خُبني نوري كلمب او ببلكي د لنهون او د كار د آساني لباره

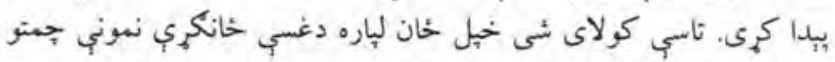

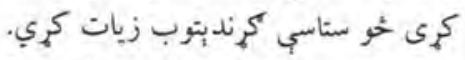

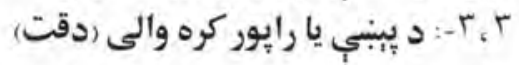

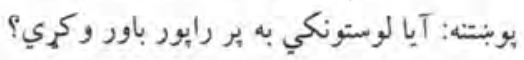

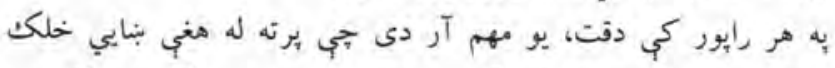

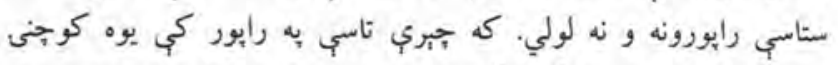

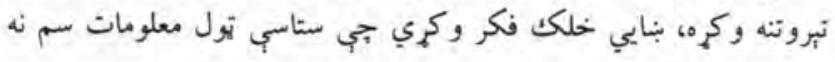

دي.

2 بوي كوجنى تبروتني وروسته خنكه كولاى شى لوستونكو ته قناعت

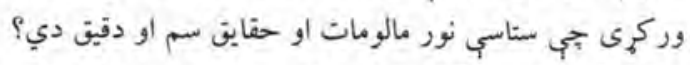

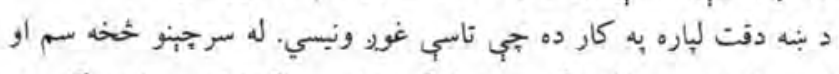

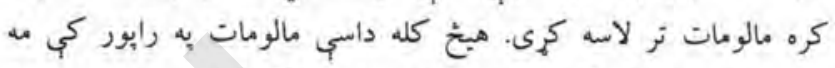

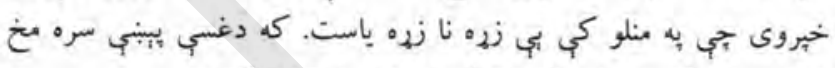

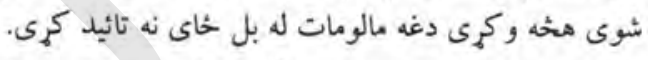

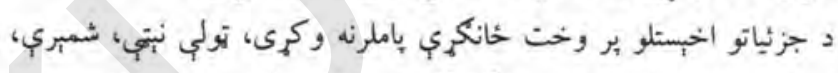

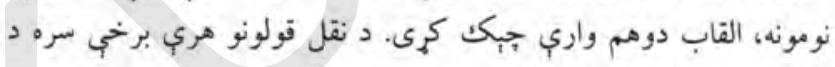
هماغي سرجنبي د أريكي لاري او شمبري وليكئ.

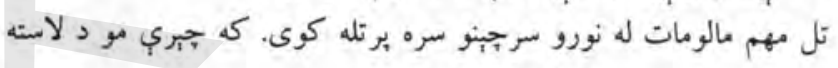

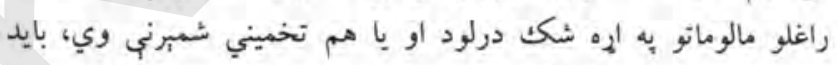

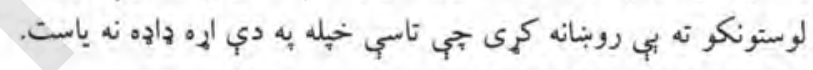

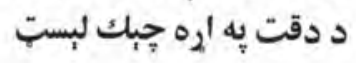
• آيا د هري سرجبني نوم، تخلص، عمر، دنده او اوسبدو شخاى مالوم دى " آيا د هري سرجنبي سره مالومات جبك شوي دي؟

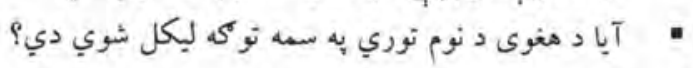

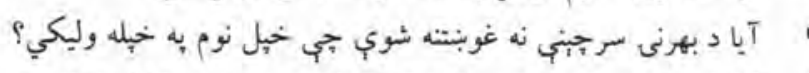

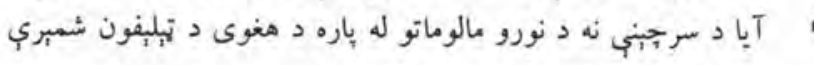

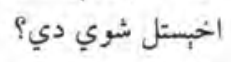

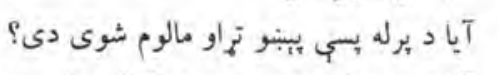

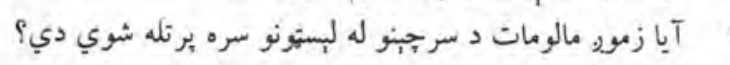

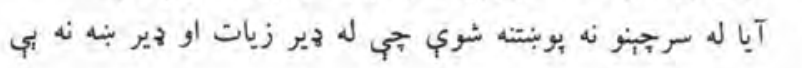

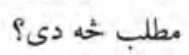

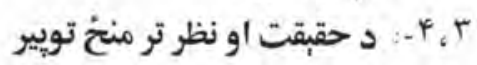

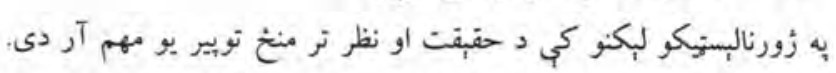

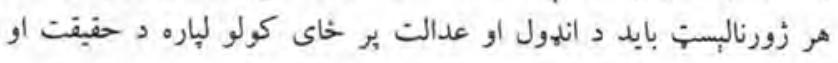
نظر تر منغ توبير ويئني.

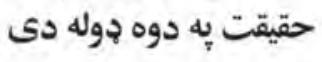

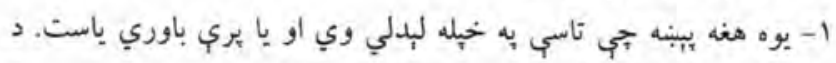


يوه بنه شمبره كولاي شي د رابور لوستونكي خو برابره زيات كري،

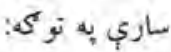

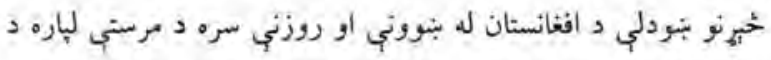

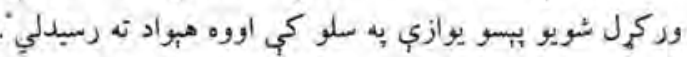

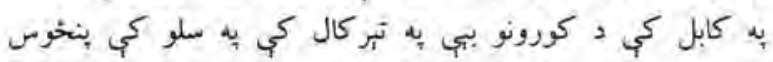

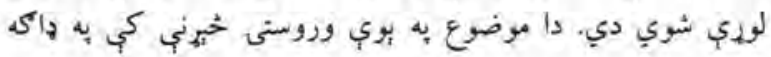
شون.

\section{لويخي شمبري پهِ ساده جول وليكئ}

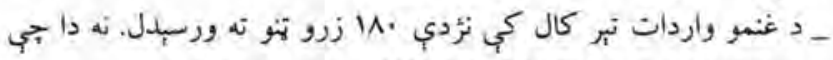

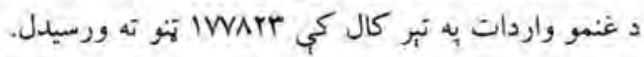

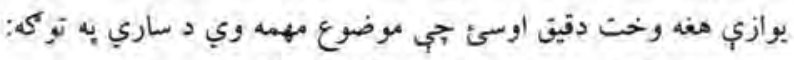

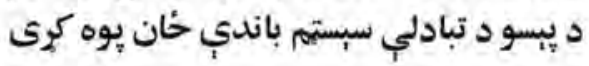

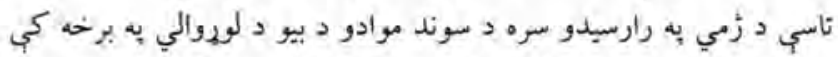

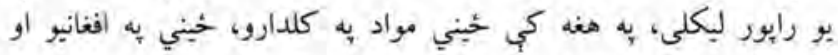

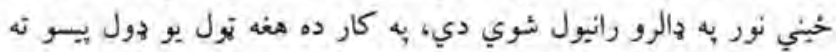

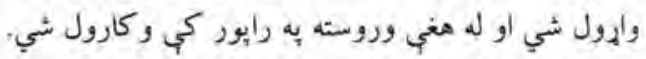

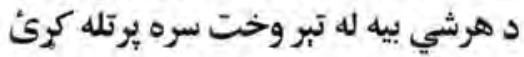

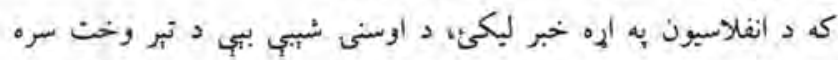

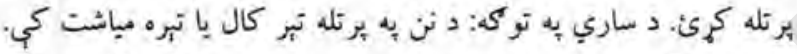

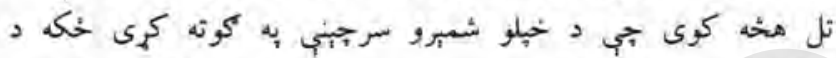

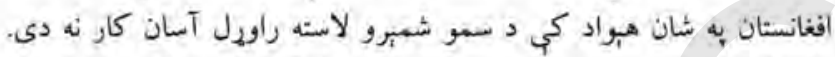

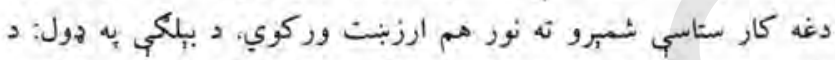

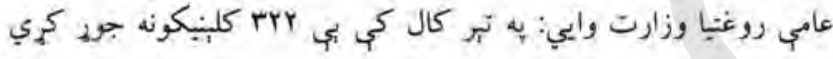
دي

\section{لوستونكي د شمبرو د ناسم والي خُخه خبر كيى}

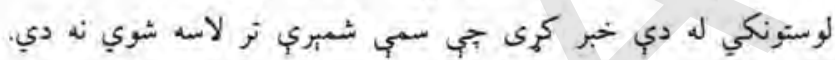

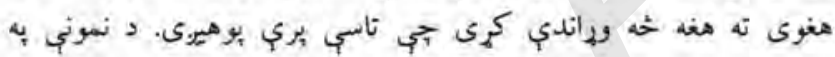

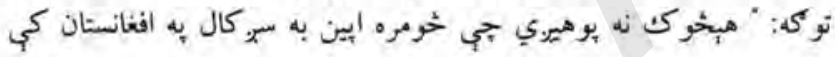

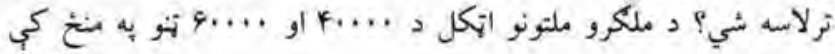

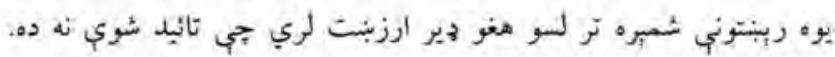

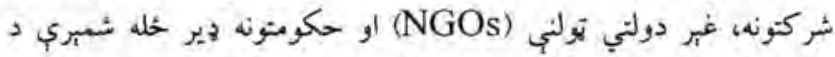

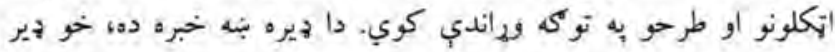

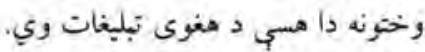

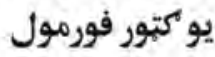
به زورناليزم كمي بايد هئه وشي د شتمبرو تر منغ توييرونه به ساده زبه بيان

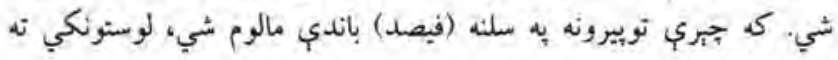

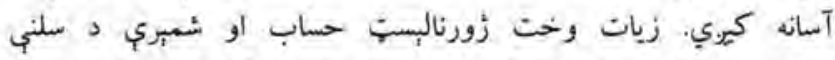

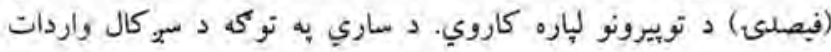

دا 2 لونستونكي لياره جير ثابت او مرسته كورنكى دى.

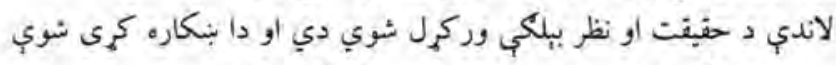

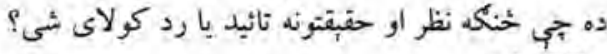
حقبقتونه

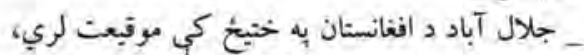

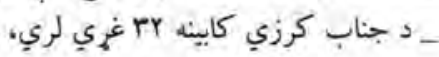

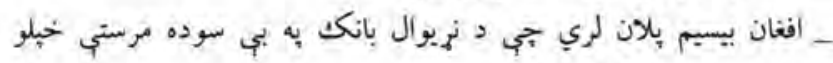
وسيلو ته براختبا وركيري. نظريات

د نوي اساسي قانون ووب أجوني غبري عادلانه وي.

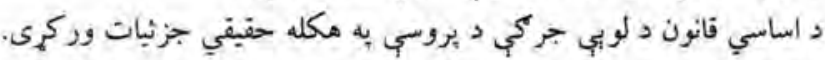

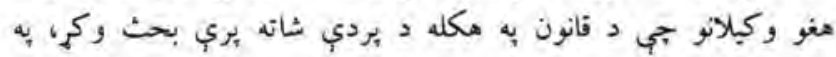

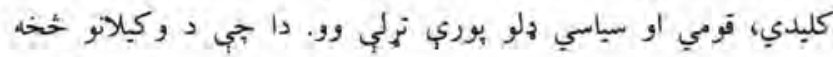

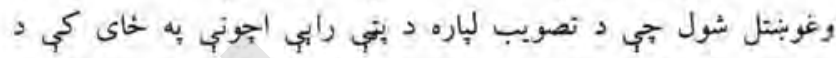

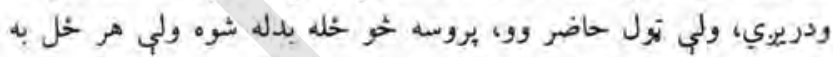

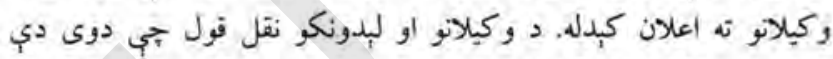

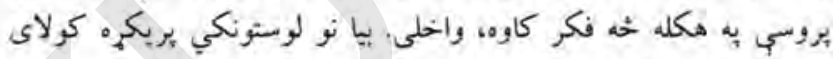

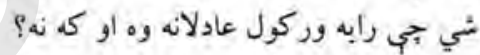

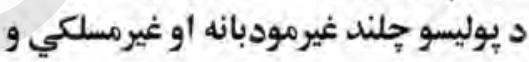

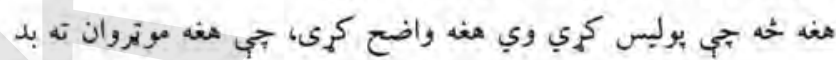

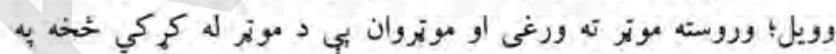

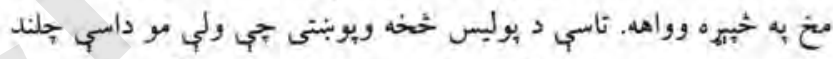

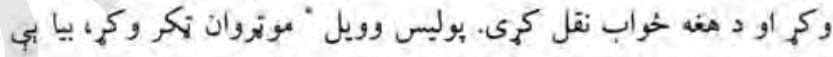

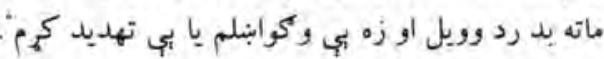

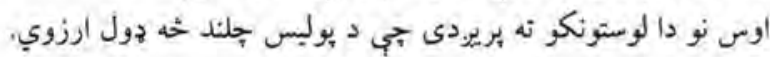

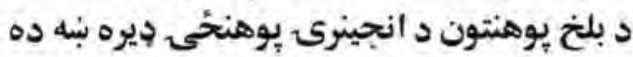

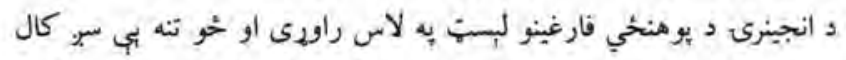

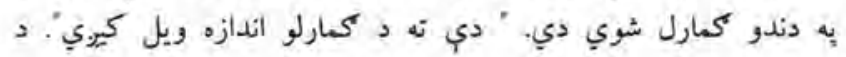

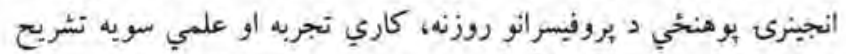

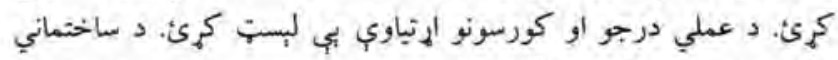

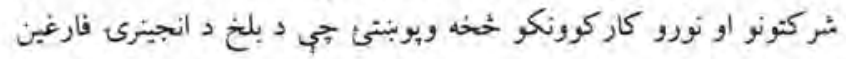

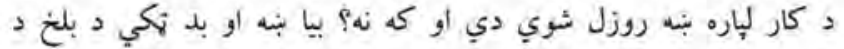

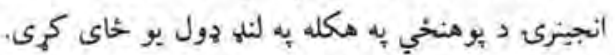

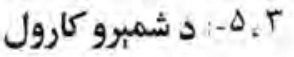

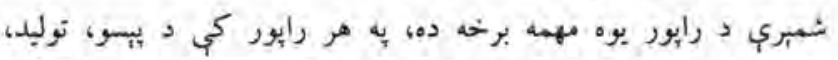

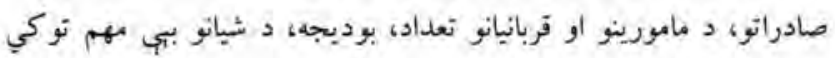
دي، جي د رايور عمومي مالومات حمايه كوي.

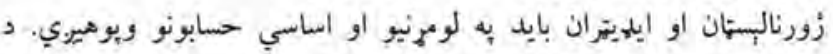

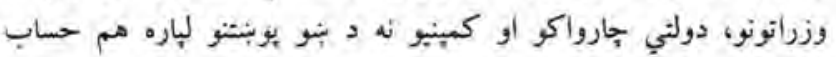
باندي بوهبدل هير أهين دي. 
قانون هادي، نَليفون شعبري، د موترو نومرب، د كتابونو بانهي، د نذكرو،

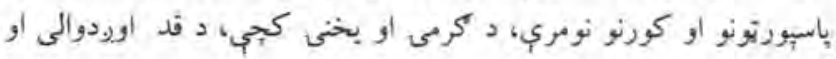
وزن به حسابي شكل لبكل كيري.

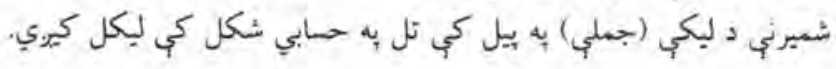

$$
\text { V نخيره مهمات از ولايات شختلف به دست آمد }
$$

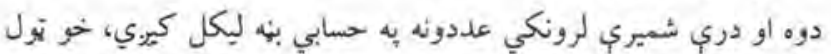

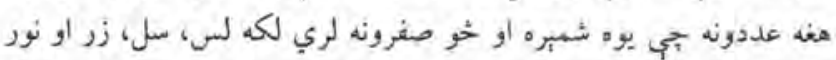

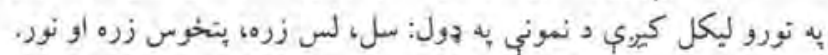

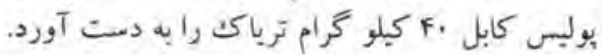

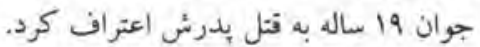

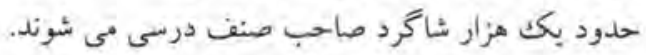
له دري شميرو خخه يورته عددونه

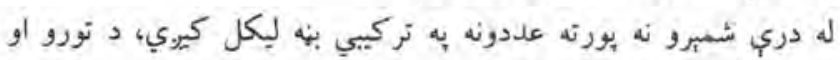

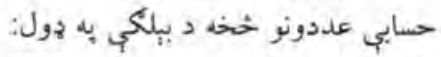

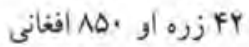

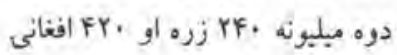

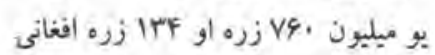

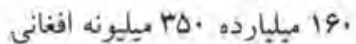

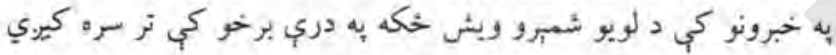

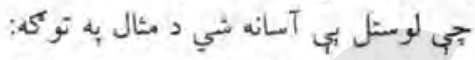

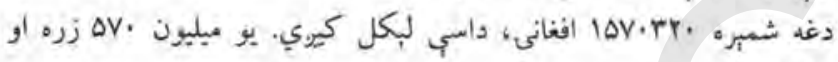
. Tr.

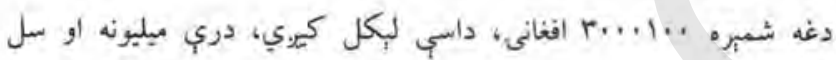
افغانى

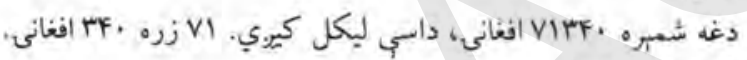
اعشاري شمبري يا عددونه اعشاري شمبري به حسابي بنه ليكل كيري.

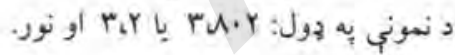

\section{به سلو كي سلنه (فيصدي)}

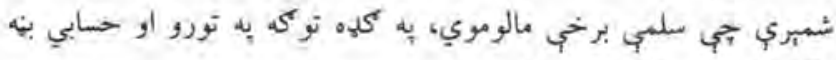

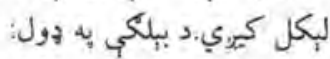

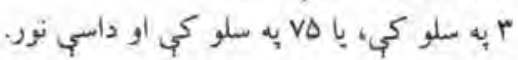
كسري شمبري يا علدورنه

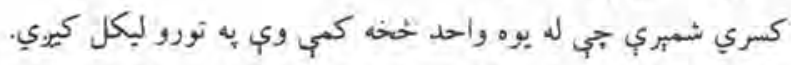

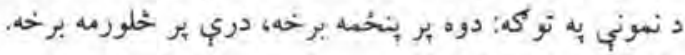
تقيبي او تخميني شمبري

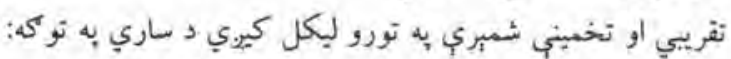

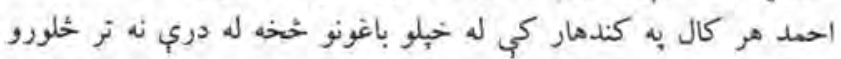

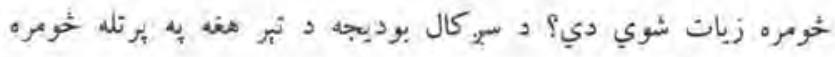

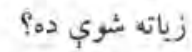

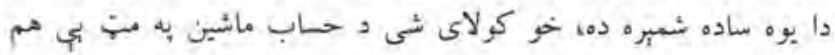
حل كرى في فورمول دا دئى لوميى او دويم رقم تويير،

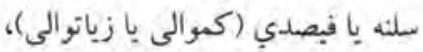
ويئ يا تقسيم به اصلي (اولي ) رقم.

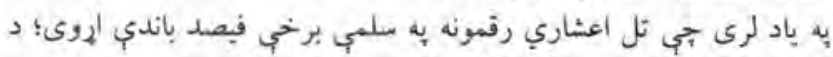

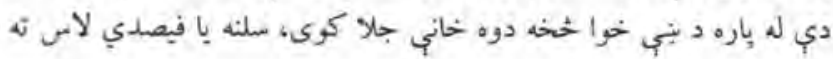

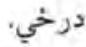

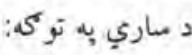

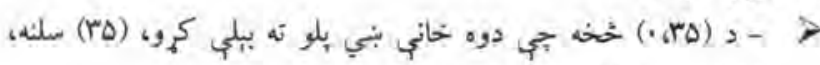
فيصدي با \%الاس ته راخي.

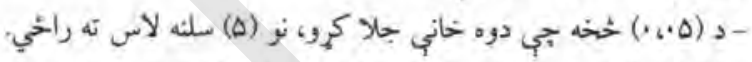

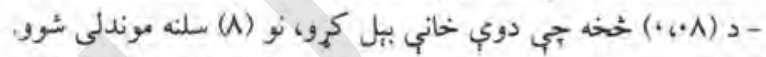

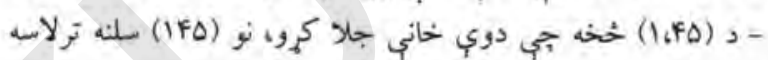

$$
\text { كولاى شبوو, }
$$

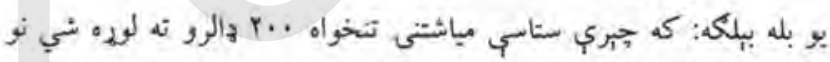

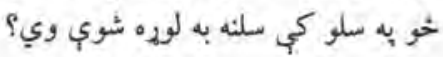

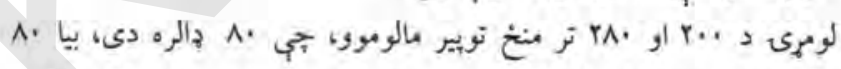

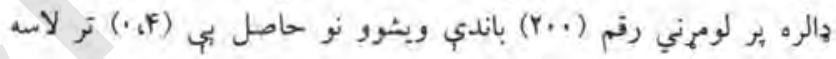

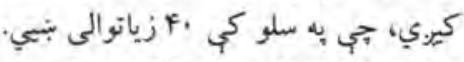
يه خبر كي د شميرو د ليكني لاري لئي

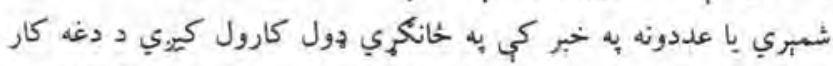

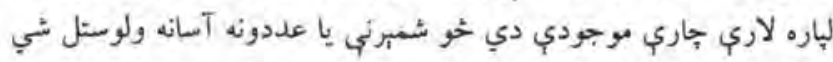
ار كيم خاي ونيسي. د يوي شمبري لورونكي عددونه

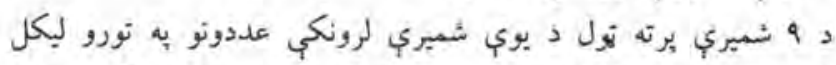

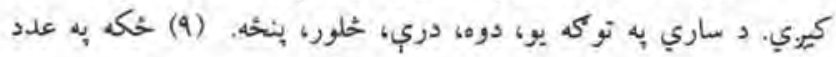
ليكل كيري خو لوستل يب آسانه وي او به ليكلو كي بي بي تبروتنه ونشي.

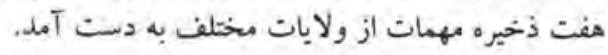

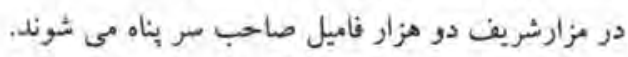

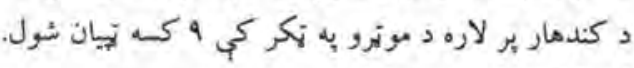

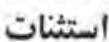

به عنوان كمي كولاى شو شميري به حسابي بنه هم وليكوو، د بيلكي به

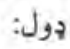
تهها ب تن مى تواند ازَ موترهاى شيشه سياه استفاده كثند.

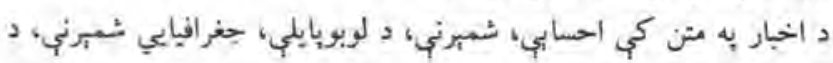


د تور لكيدو بر وخت بايل د مفابل لوري خخخه د هغه مبناوي وبنّين

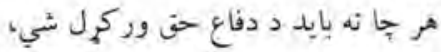

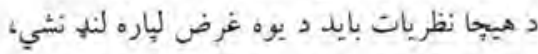
به رابور كي بإيد شخصي نظريات شاهل نه وي،

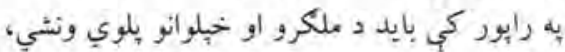
و كومبي سيمب، زبي، توكم، مذهب او سياست بروا ونه ساتل شي،

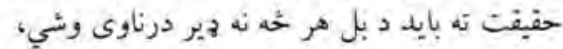

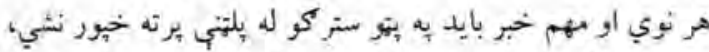

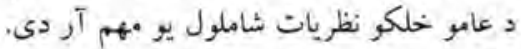

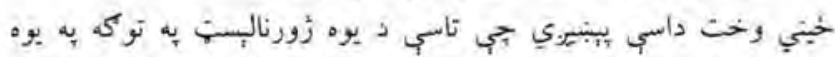

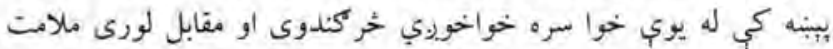

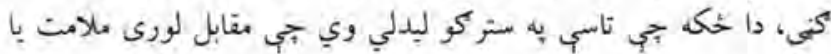

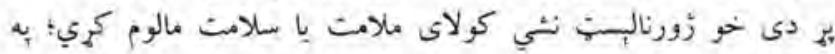

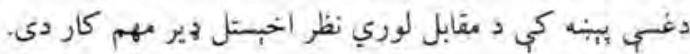

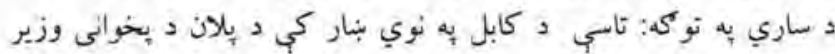

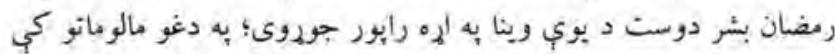

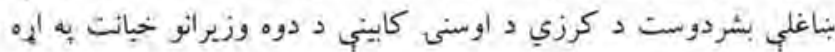
خيني مالومات خحياره كئل

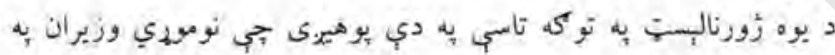

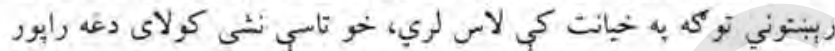

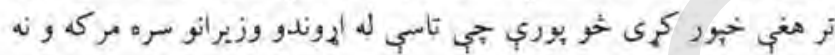

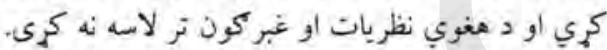

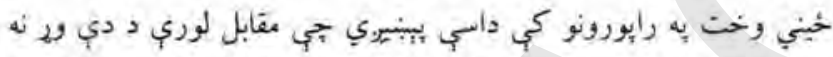

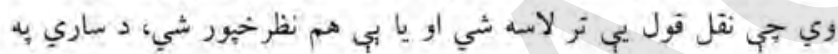

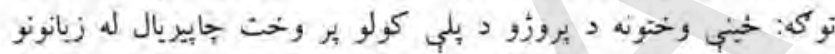

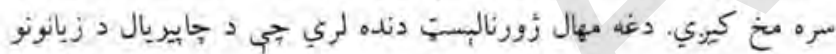

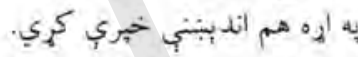

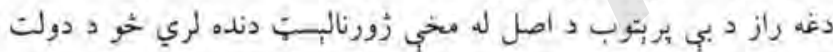

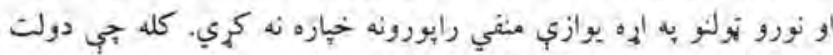

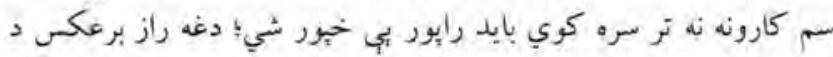

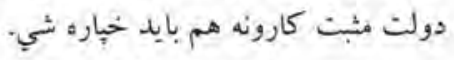

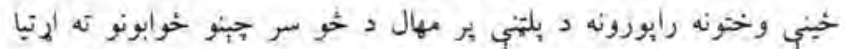
لري. د ساري به تو كنه

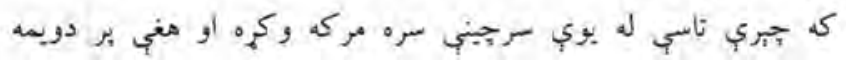

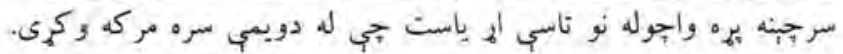

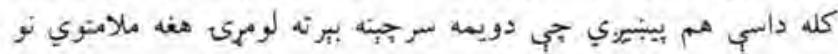

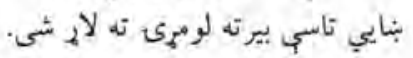

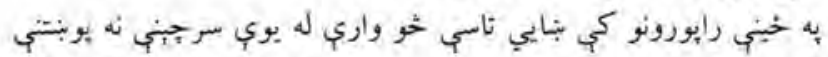

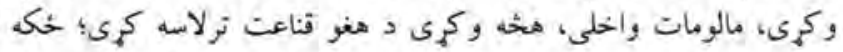

تهو بودي النار بلوري. توتيبي يا برله يسب شمبري

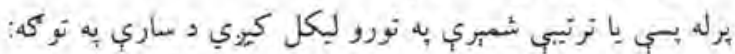

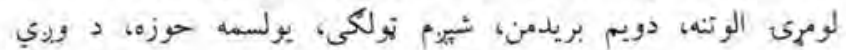

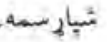

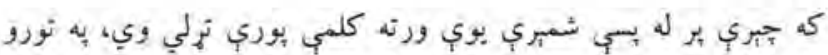

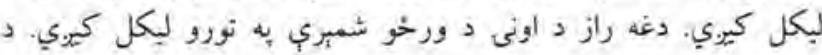

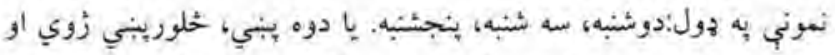

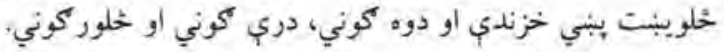
نسبي ستايني (صفات) به تورو ليكل كيري، وني، بايد به حسب حسابي بنه ونه ليكل تُبي.

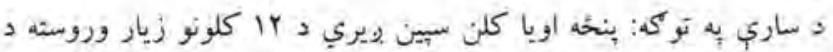

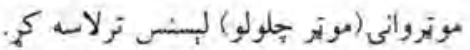

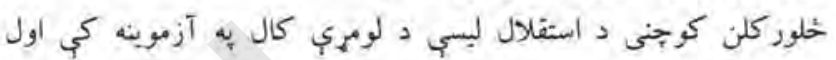
نومره شو. كولاى شو به بورته بلكيك كي جملي د اوسنى (نسبي ستايني) له بني

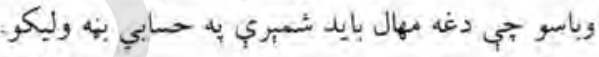

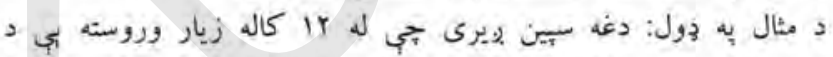

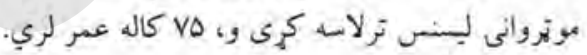

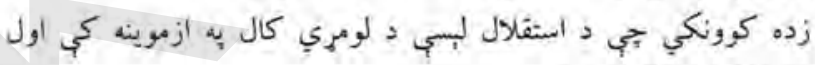
نومره شوى و. f كلن دى.

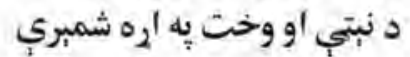

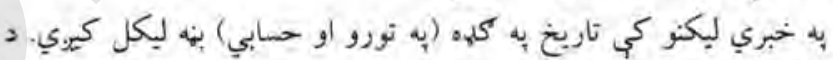

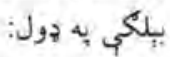

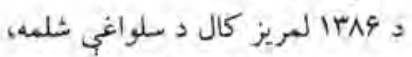
ITAV 2

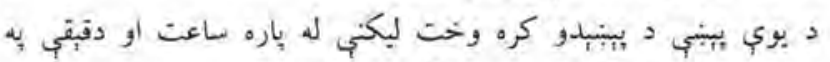

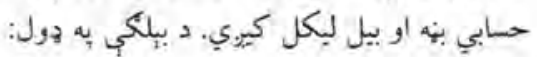

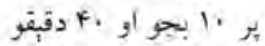

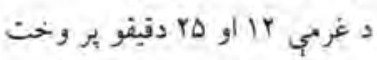

ثبع: جزوه اموزث خبر كزارى ايرنا

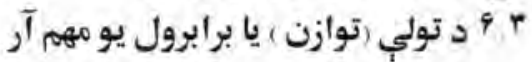

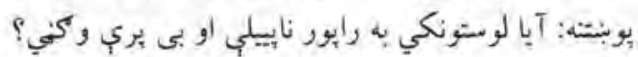

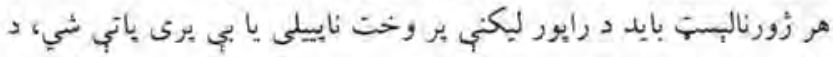

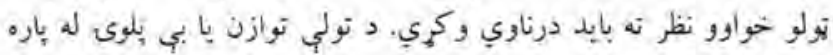

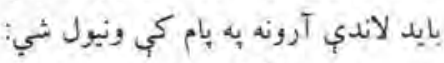

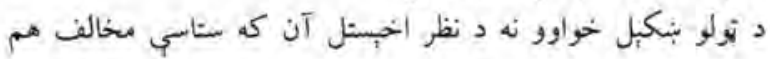

وي، • بر ته له شخصي قضاوت خخه د مالوماتو خهرول، 
د رابور د موضوع به باره كي زما شخصي نظر بإ احساس خخه دئ

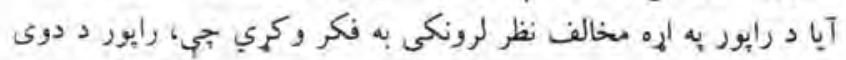

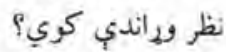

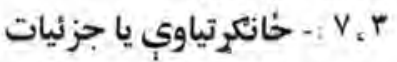

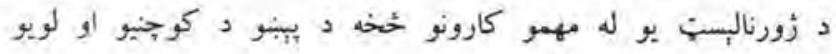

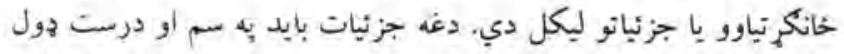

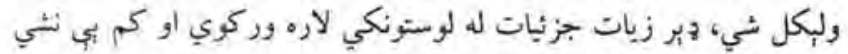
كولاي بينه روبنانه كريكي.

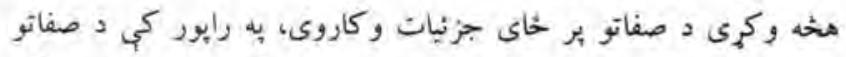

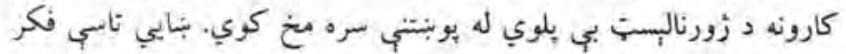

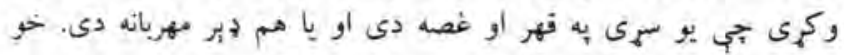

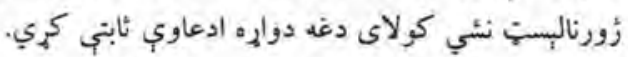

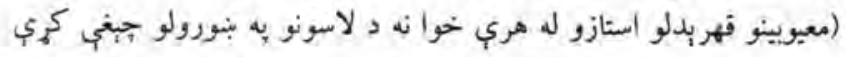

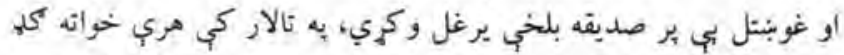

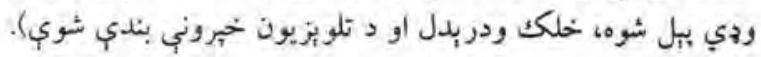

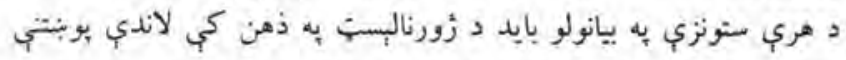

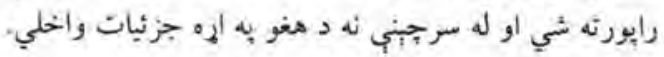

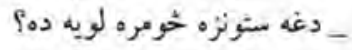

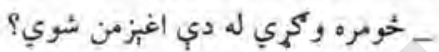

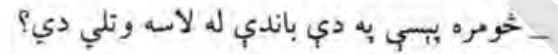

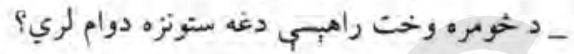

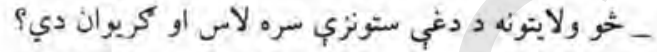

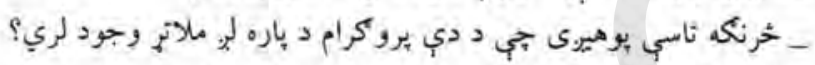

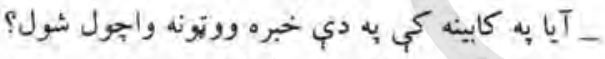

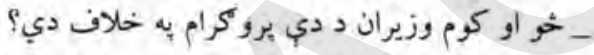

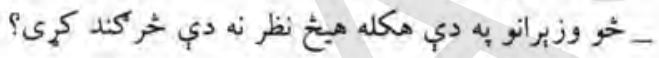

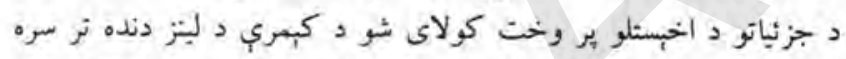

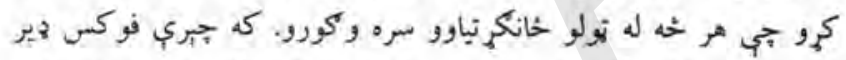

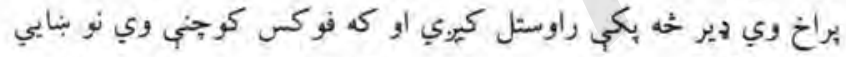

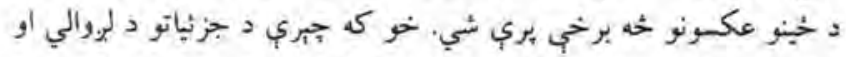

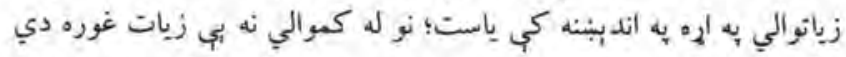

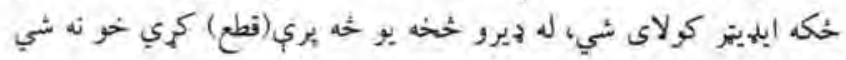

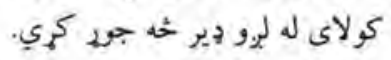

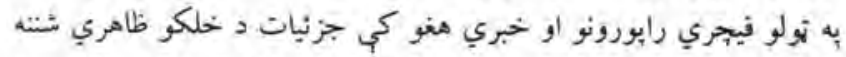

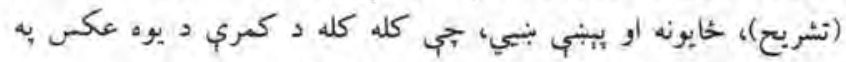

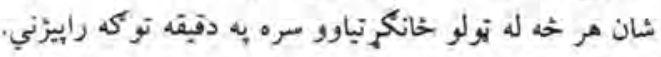

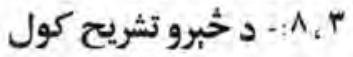
هري سرجني خحخه جي نقل قول ورخيني اخبستل شوى؛ بايد لوستونكي

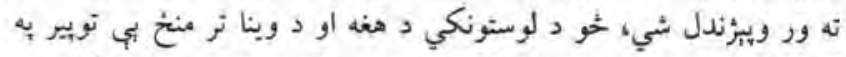

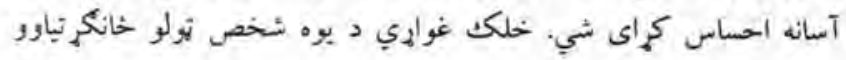

بورء انلهول يا توأزن به بام كي نيول يو هلم آردى.

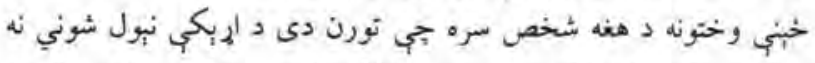

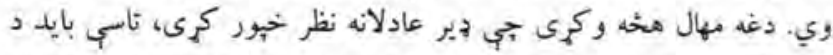

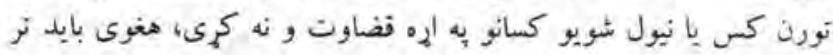

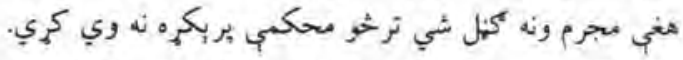

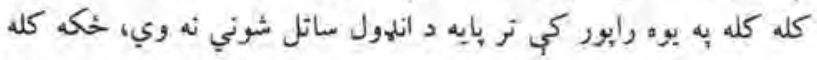

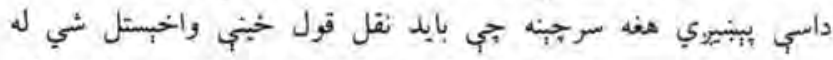

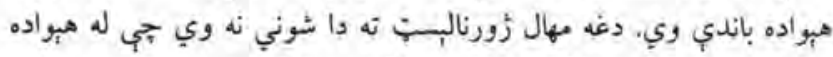

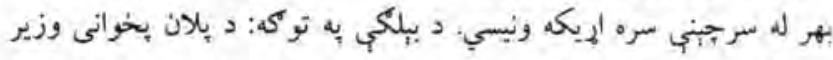

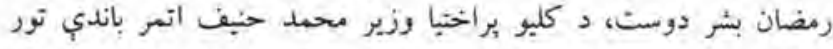

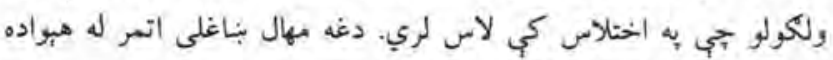

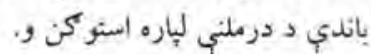

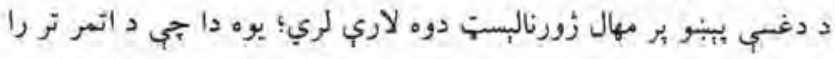

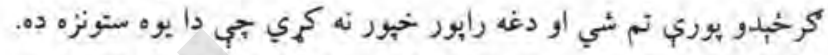

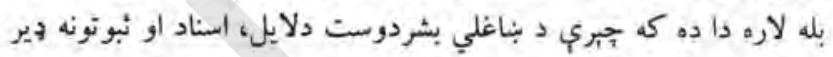

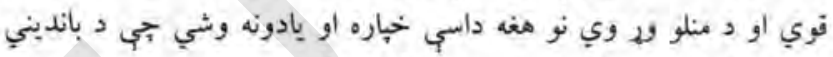

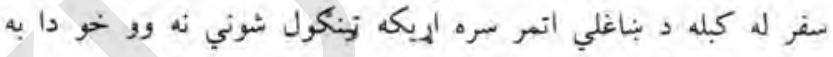
ستاسي بي وسي او كمزوري وبنيهي.

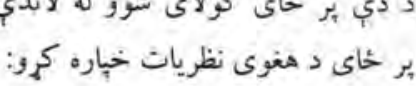

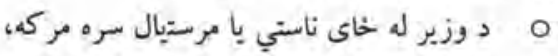
0 0

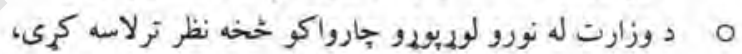

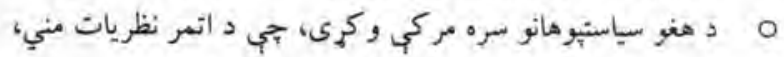

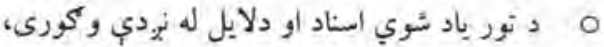
0 0

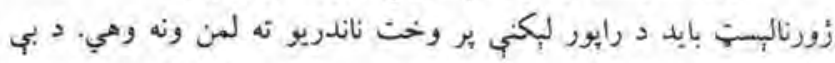

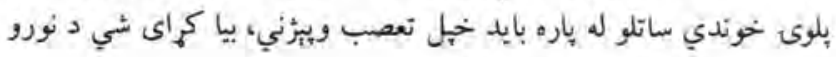
نعصب بر خلاف رايورونه خياره كيري.

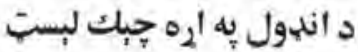

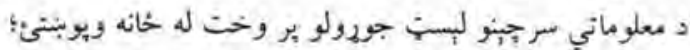

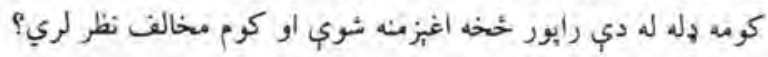

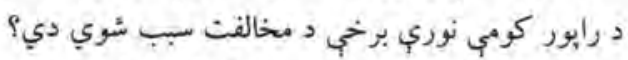

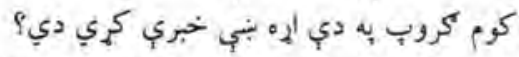

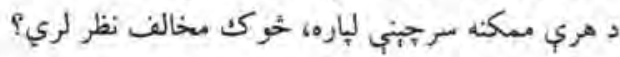

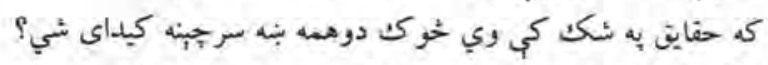

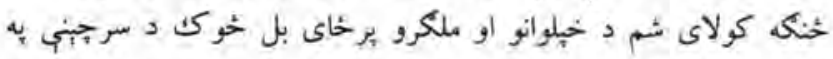

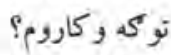

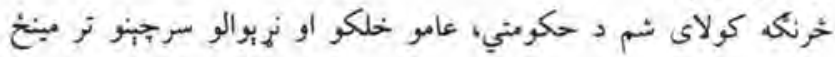

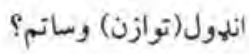


Tبا جزئيات زهره رابنكونكي، د دمنى لرونكي او به موضوع بوري

ترالي دين

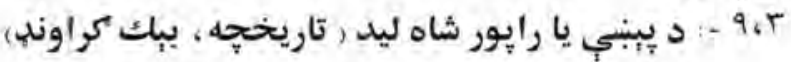
بس منظر (شاليد)

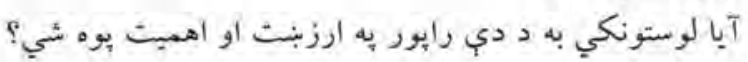

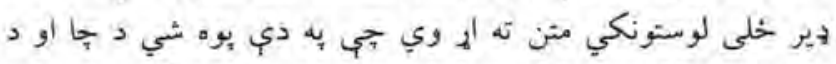

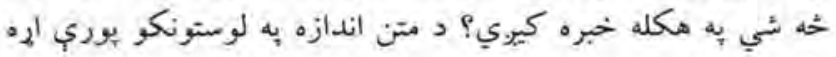

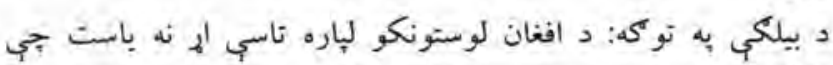

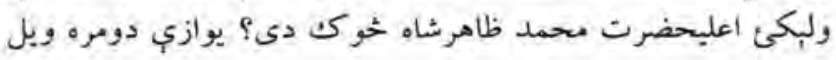

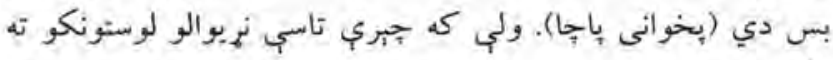

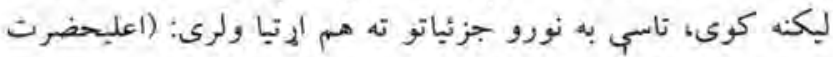

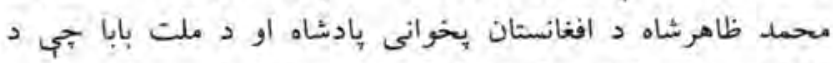

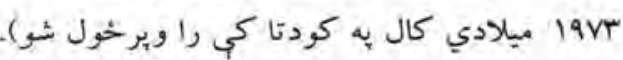

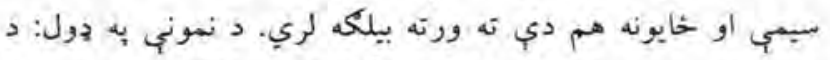

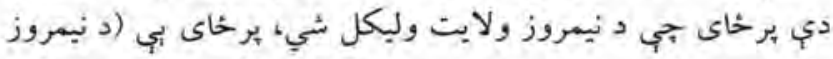

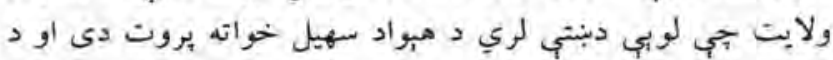

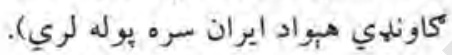

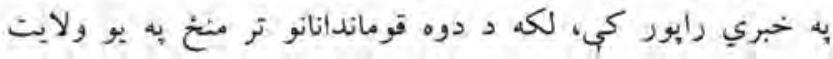

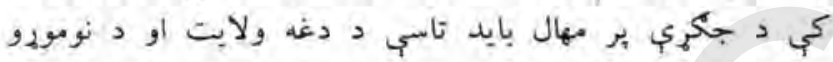

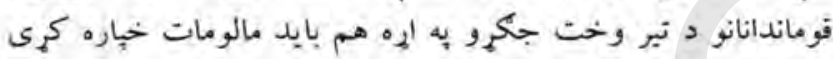

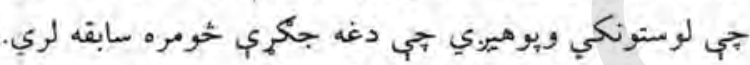

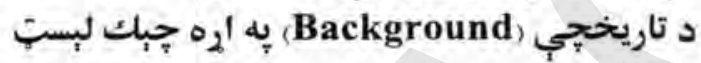
آبا لوستونكي به د رايور بر مانا بوه شي؟

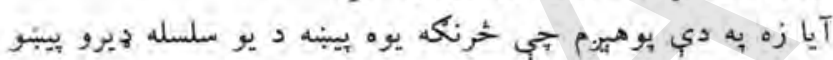
برخه

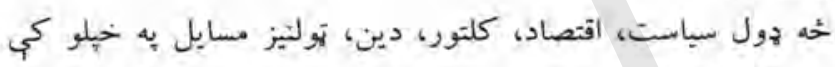

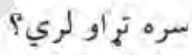

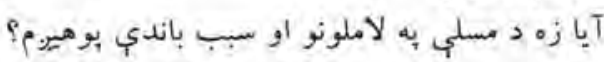

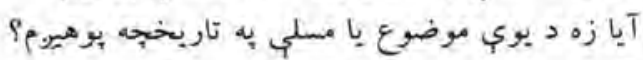

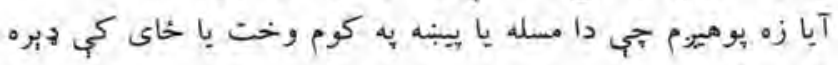
غهَه ون

آيا زه بوهير جي به به دي رايور كي د بردي ترشا خوك دي؟

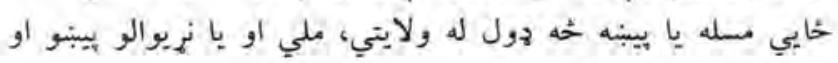
عسايلو سره تراو بيدا كوي؟ بئه

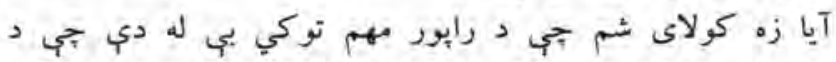

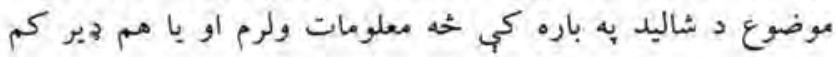

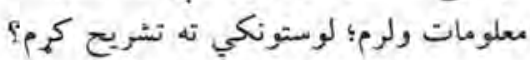

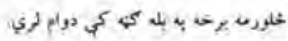

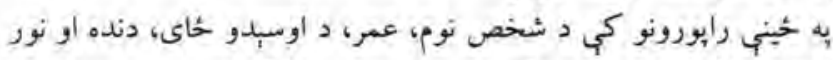

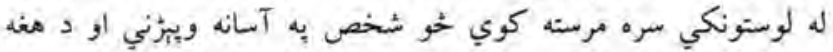

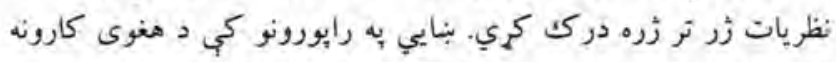

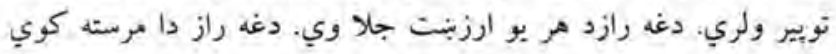

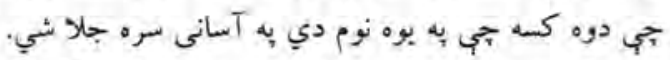

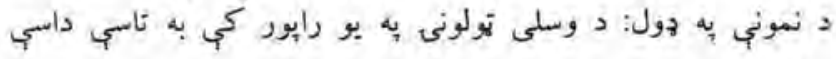
ووائي:

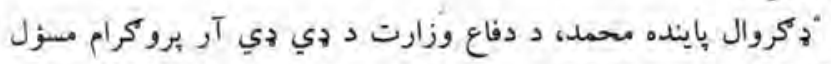

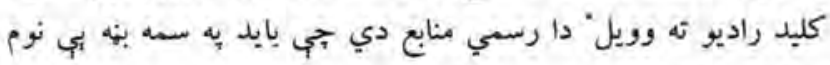
او دندي يادي شي. دغه راز هغه خلكك هم بايذ به بيه شان لوستونيكو ته ور ويثرندل شي

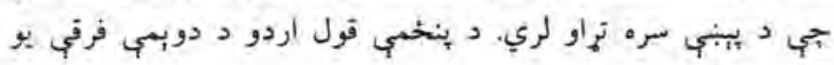
سرتبرى عبدالمجيب وريل:

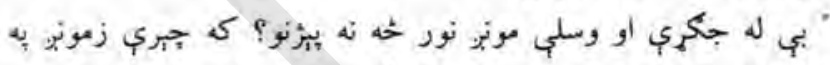

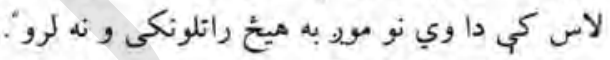

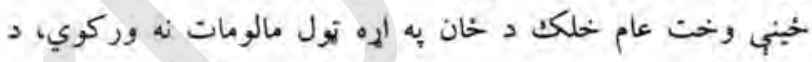

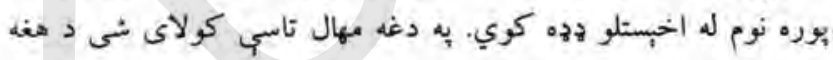

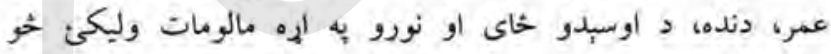

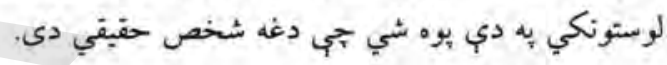

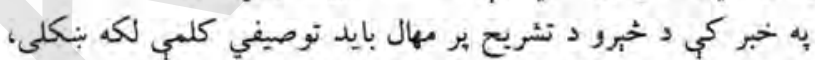

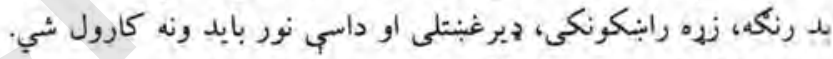

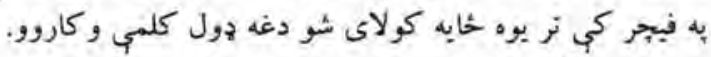

يو جيو مهم آر

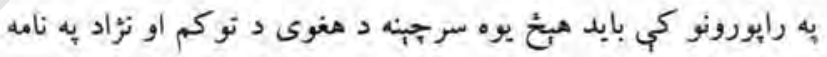

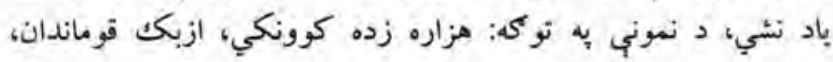

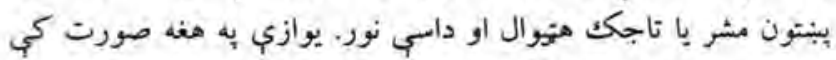

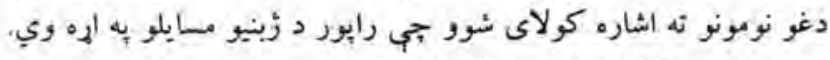

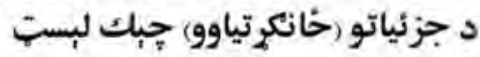

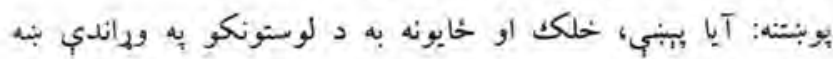

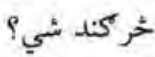

آيا د شخص د جلند او خمبري به إهـ مو جزئيات ليكلي دي؟

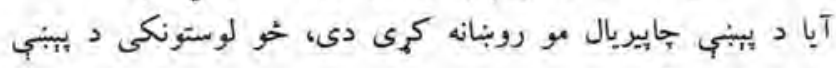

تصوير وويني؟

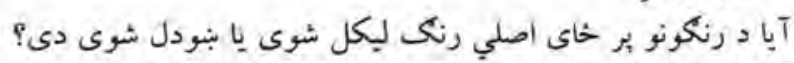

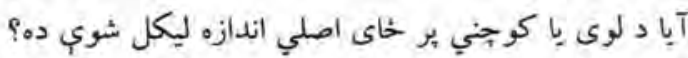

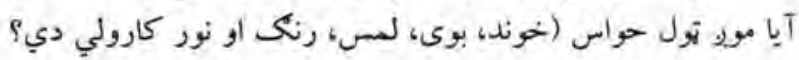

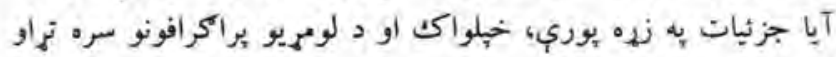
آيا عمومي جملي به حانكيكيو شميرنو، حقايقو او ببلكو حمايه شوي 


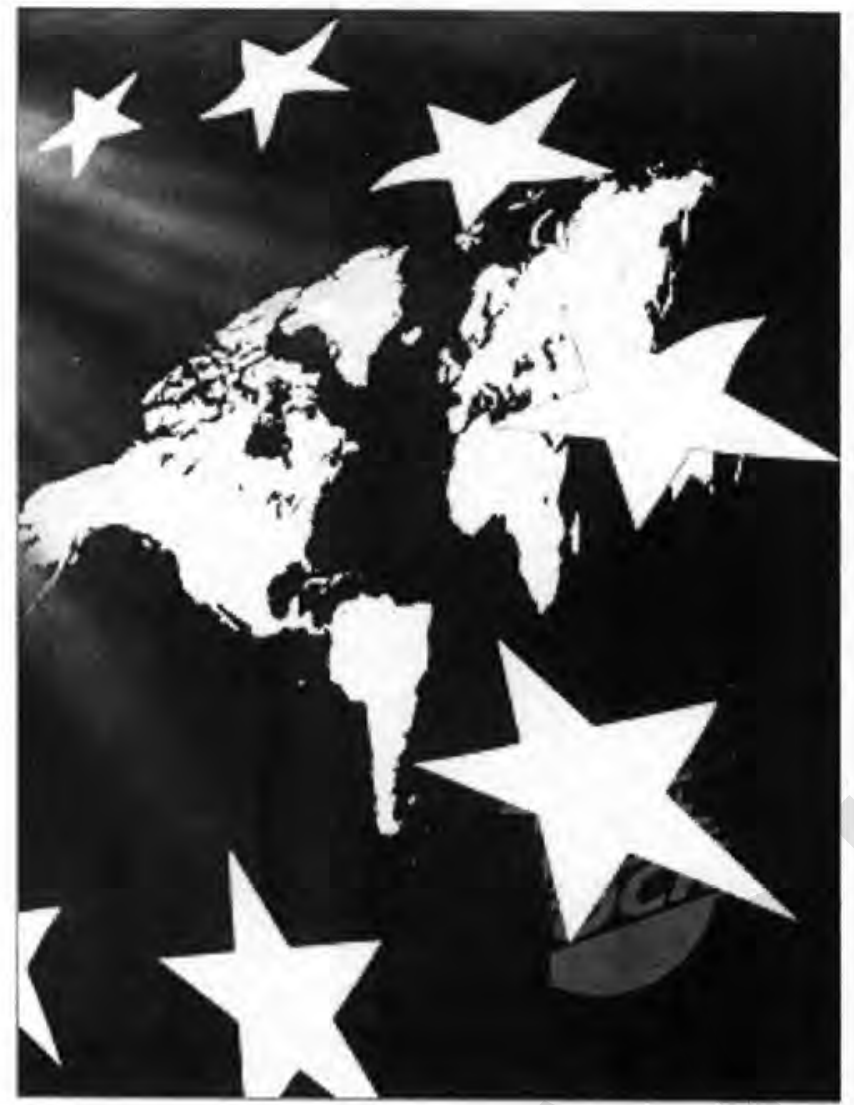

كليساى كاتوليكن، و اميراتور در رأس امير اتورى مقدس روم.

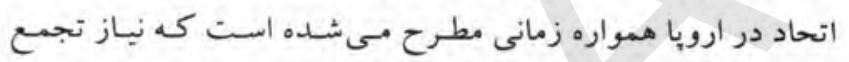

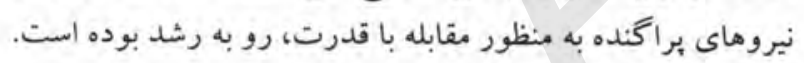

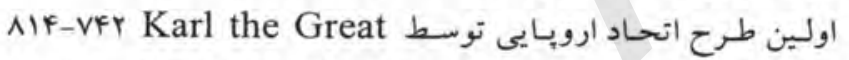

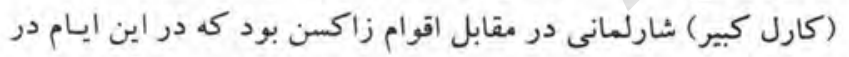

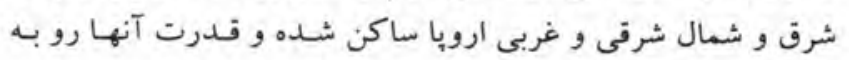
افزايش بود.

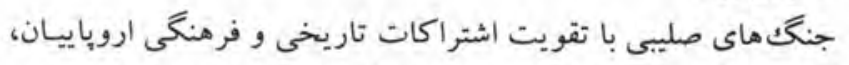

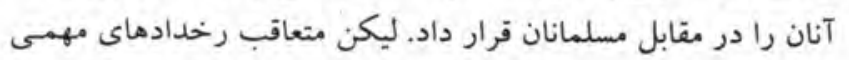

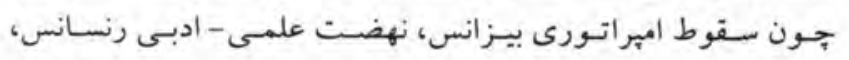

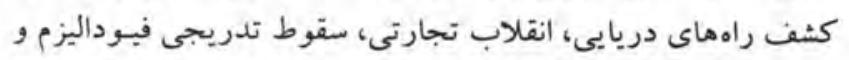

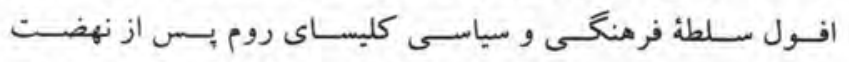

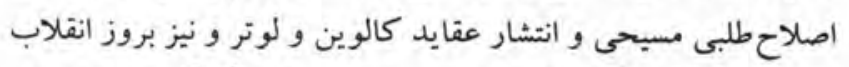

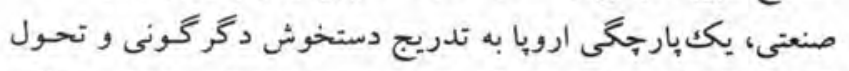

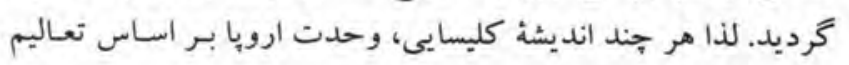


خونين بابان داده بودند، خود را به اتحاديةهاى گمبركى و اقتصادى

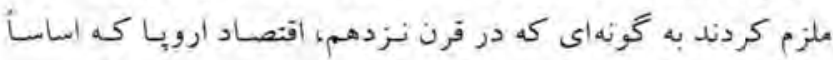

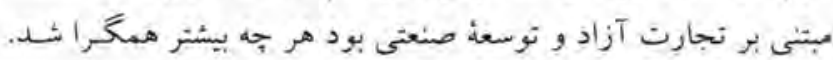

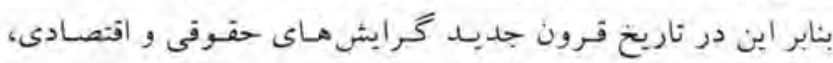

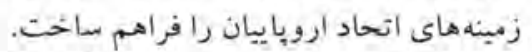

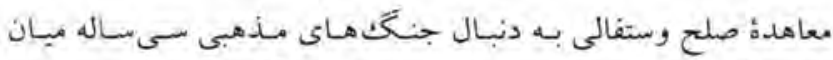

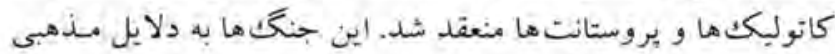

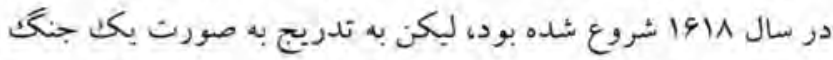

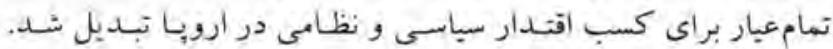

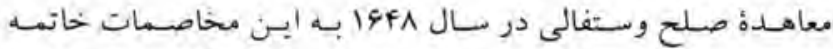

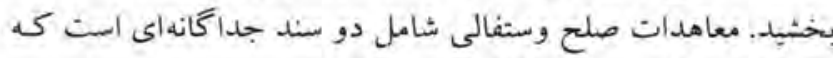

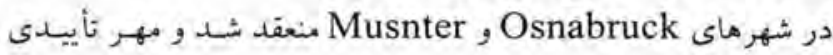

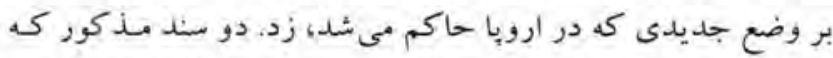

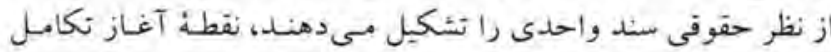

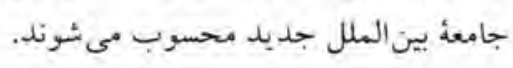

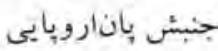

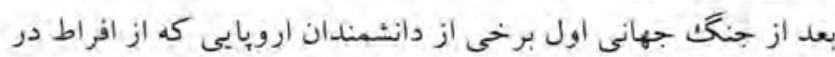

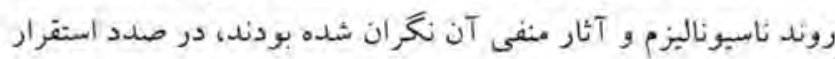

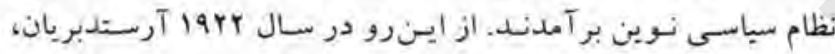

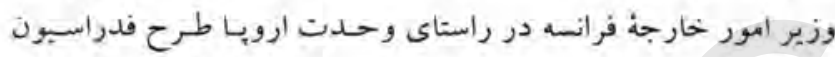

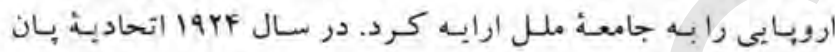

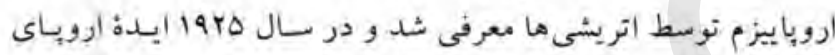

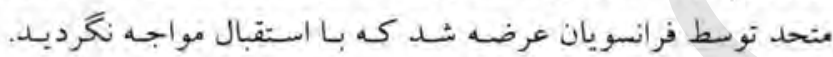

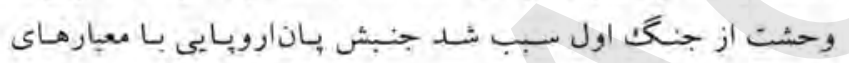

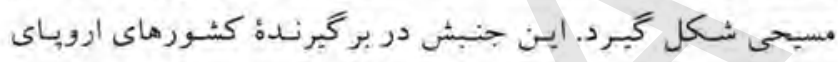

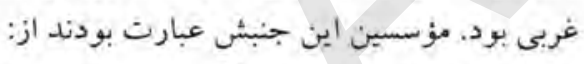

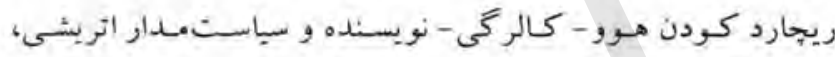

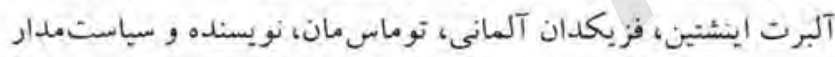

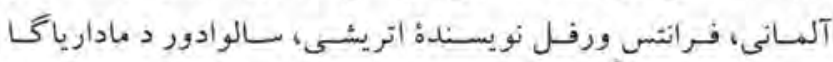

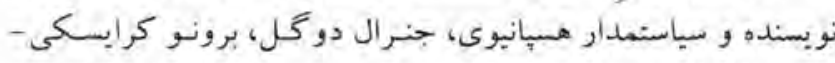

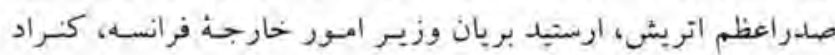

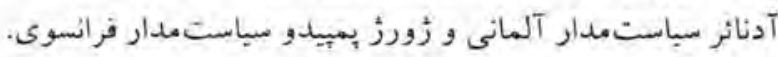

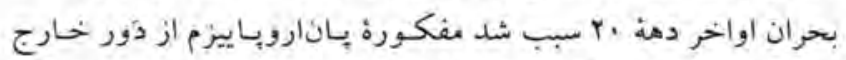

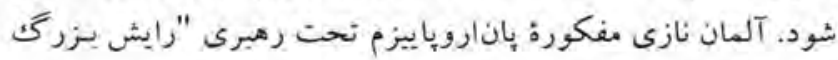

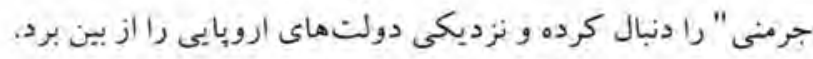

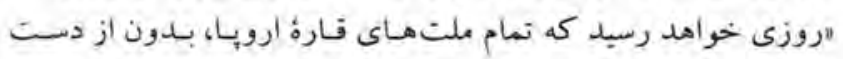

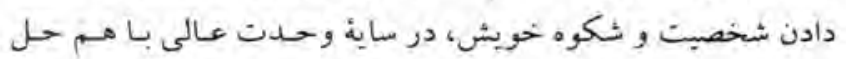

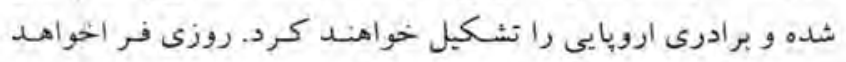

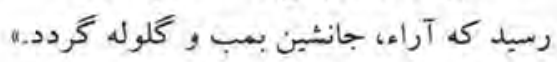

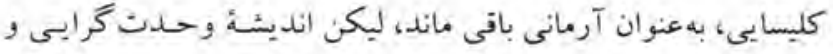

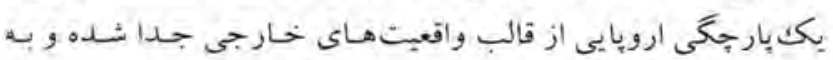

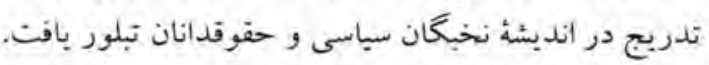

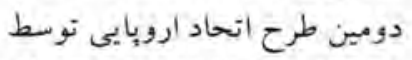
Maximilien de Béthune (1941-1091) ماكسيمبليان بتونه مارشال فرانسوى بود كه طرح خود را براى اروبايـ

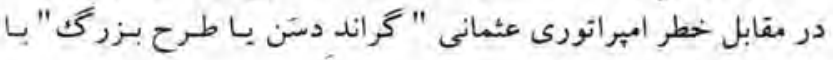
تركيب زير ارايه داد:

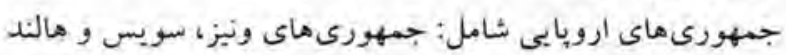
بادشاهى هاى انتخابى: آلمان، بولند، هنگگرى و و واتيكان

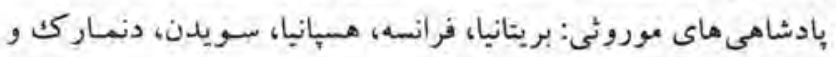

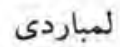

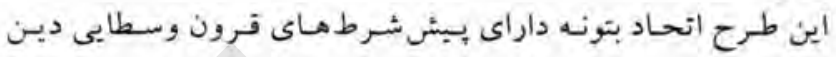

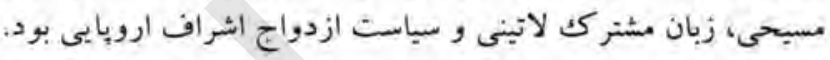

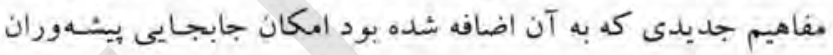

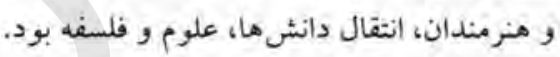

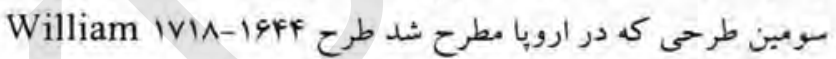

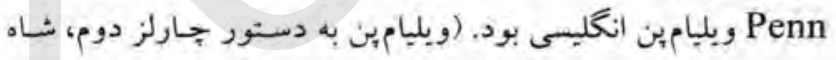

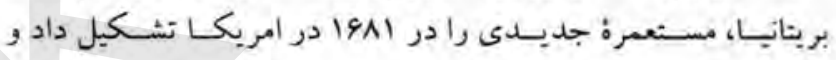

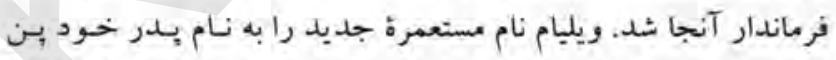

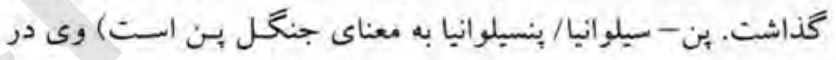

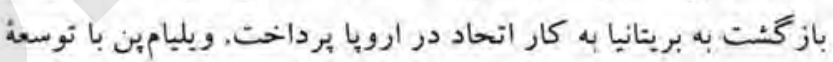

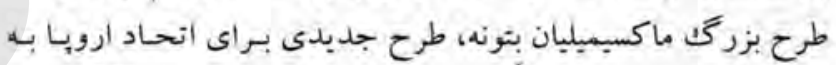
وجود آورد. در اين طرح، بروسبه و امبراتورى غثمانى هم گنجانيبه.

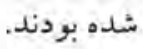

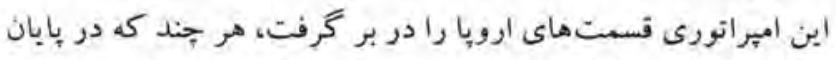

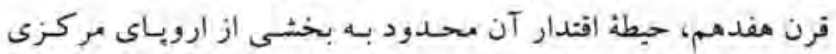

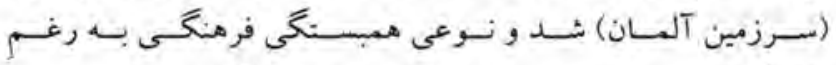

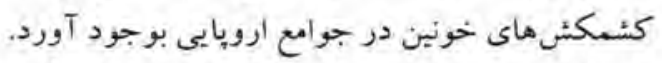

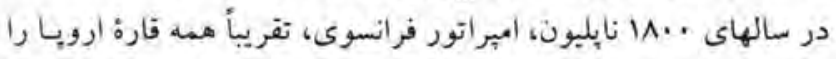

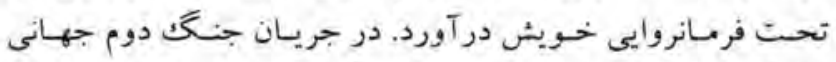

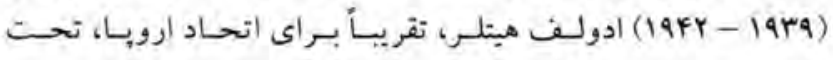

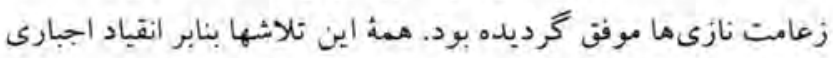
و خشن، ناموفق بدر آند.

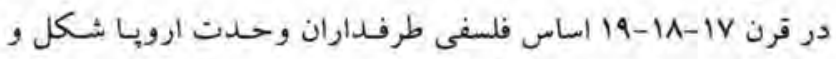

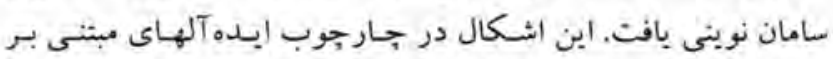

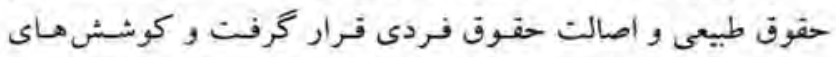

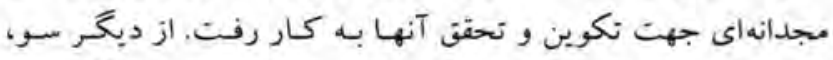

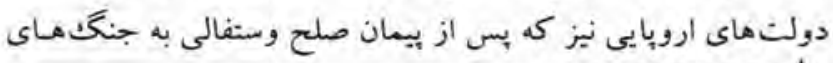


كمثر در اتحاديئ فرانسه، ماوراي بحار را توسعه دهل.

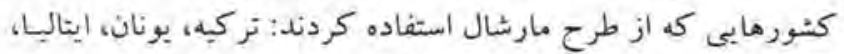

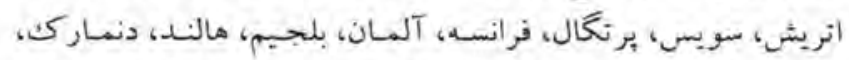

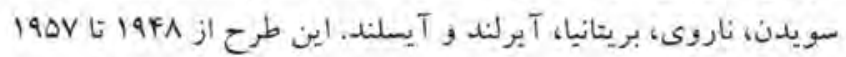

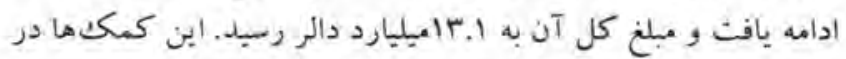

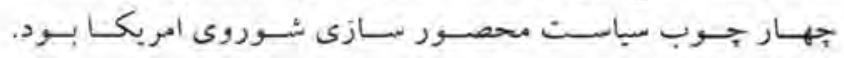

Containment-Politic مفكورة: عالى مد مانى

بعد از جنغك جهانى دوم، سباستمدار فرانسـوى، Jean Monnet

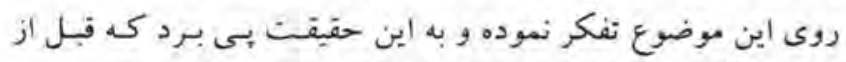

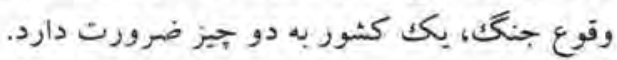

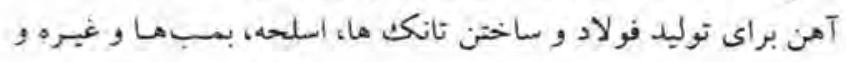

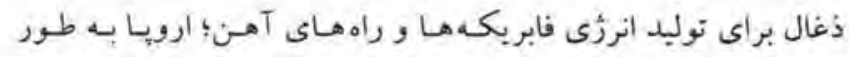

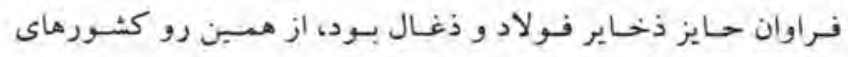

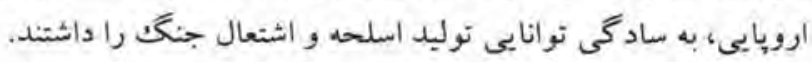

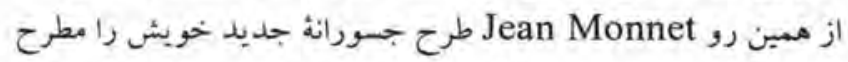

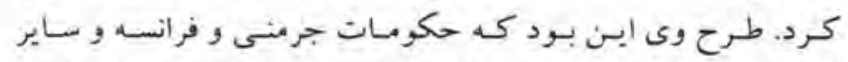

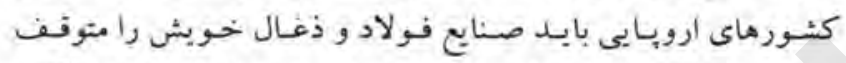

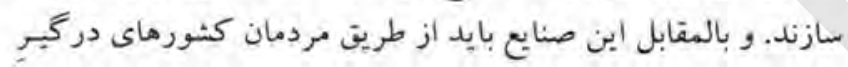

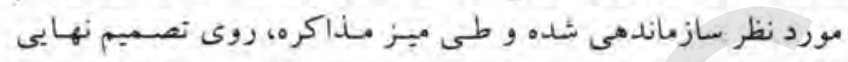

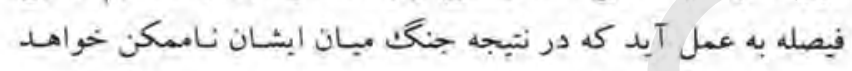

حean Monnet

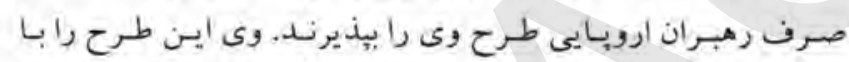

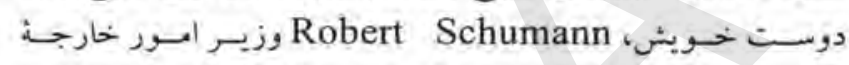

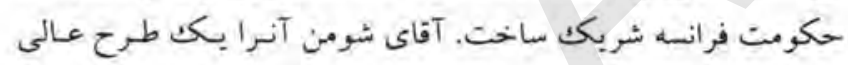

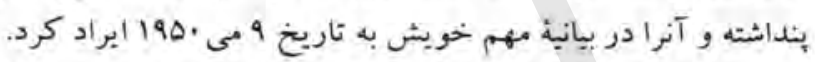

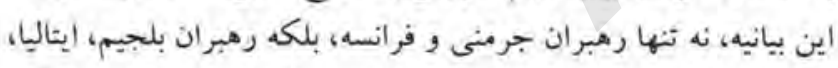

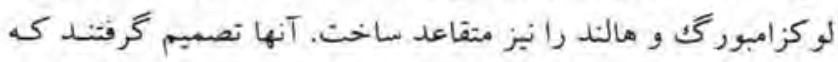

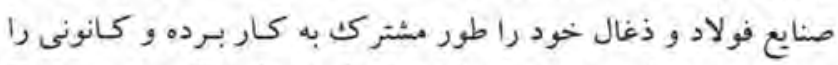
كس بنـام جامعة ذغال و فولاد ارويا مئهور است، تأسبس كردنــ.

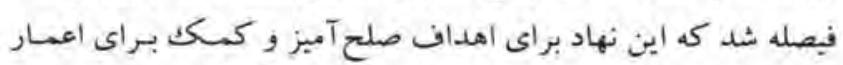

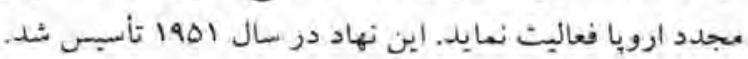
سه ارگان تصمبم گيرنده در اين اتحاديه أينها اندئ

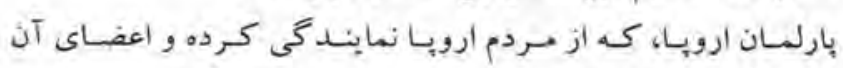

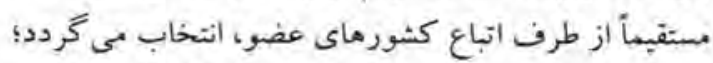

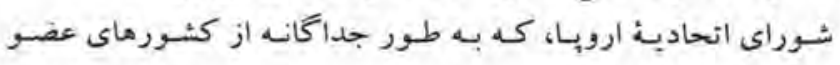

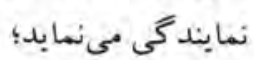

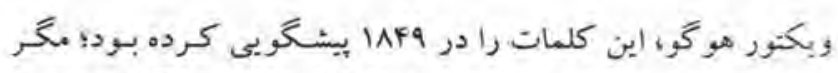

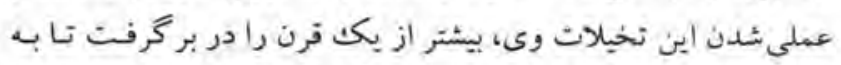

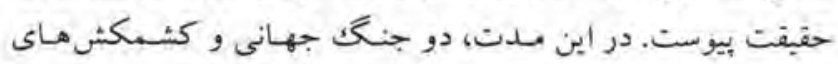

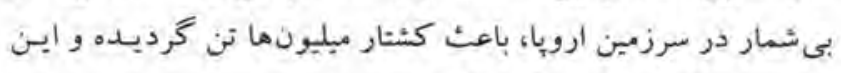

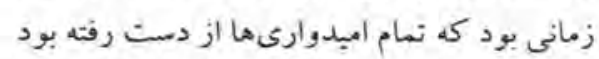

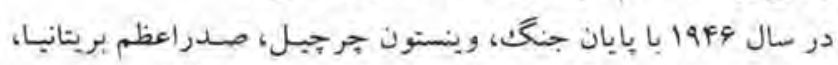

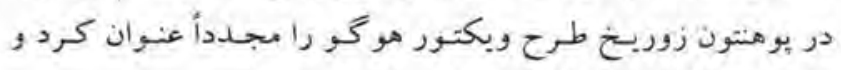
خوأهان تشكيل " ابالات منحدة أرويا" شيد.

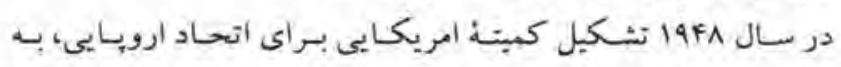

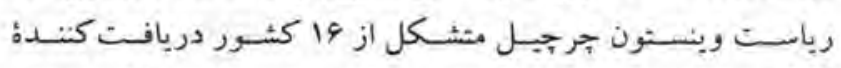
كيككهاى طرح مارشال، كميته بر روى قانون اساسى ايالات متحدة ارويا كار كرد.

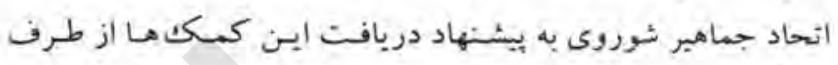

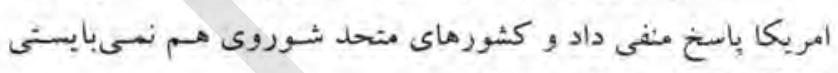

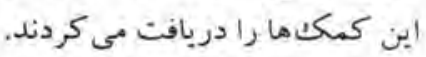

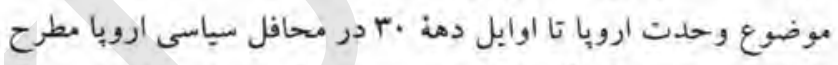

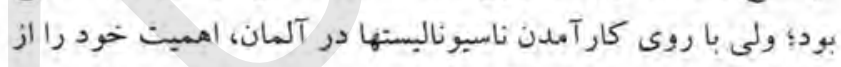

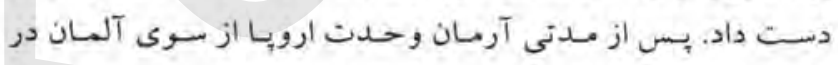

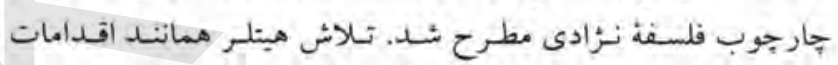

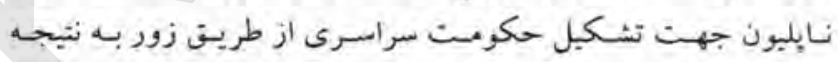

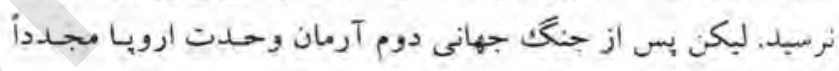

احبا شد.

طرح مارشال و بازنسازى أرويا

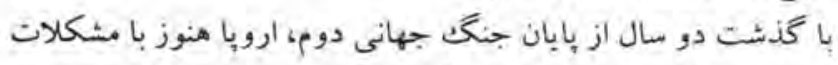

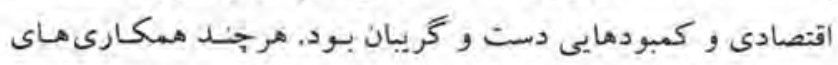

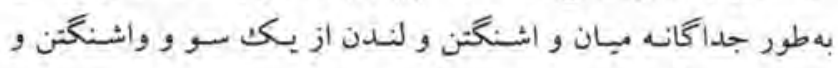

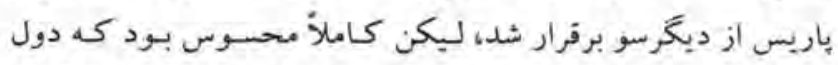

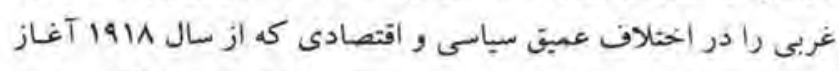

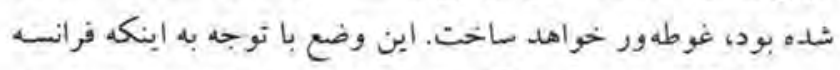

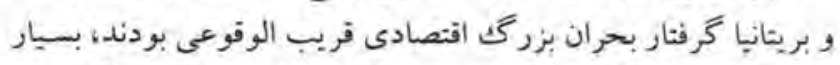

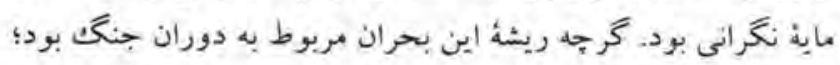

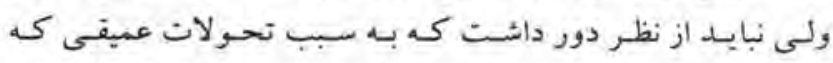

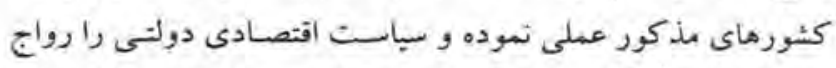

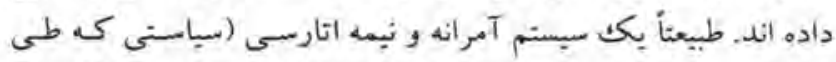

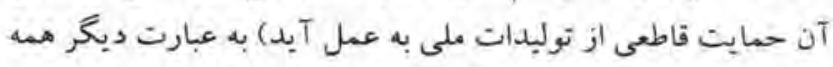

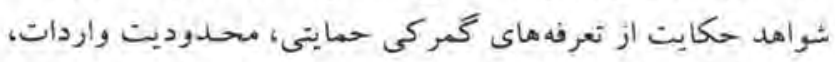

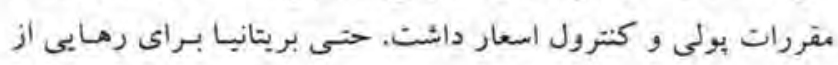

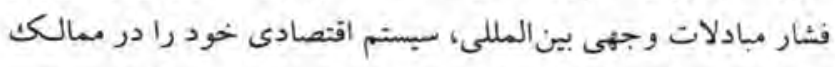

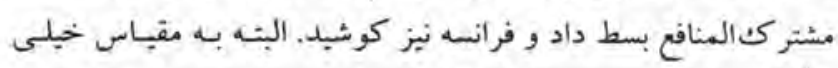


جامعة اقتصادى ارويا، بر علاوةٌ رسبدگى به نقش اقتصادى خويش،

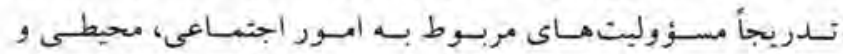

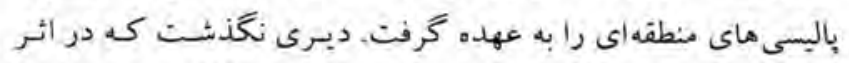

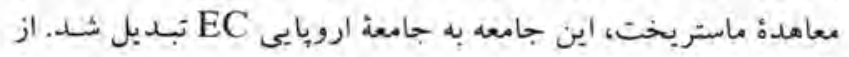

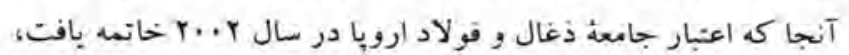

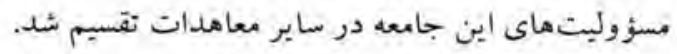

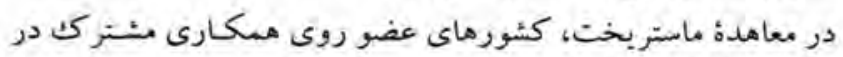

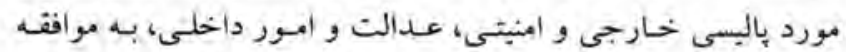

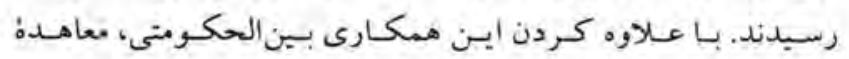

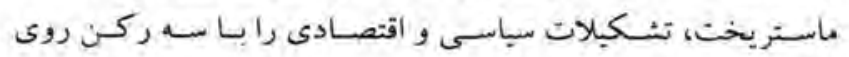

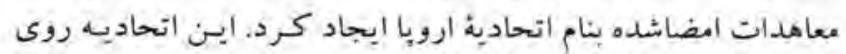

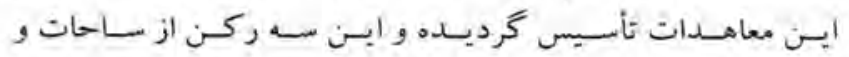

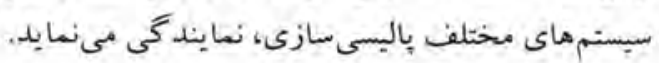

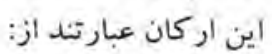

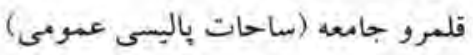
باليسى خارجى و امنيتى

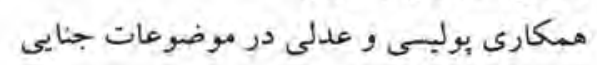

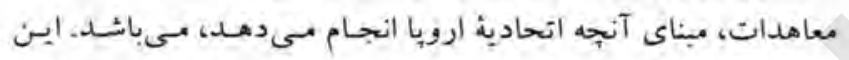

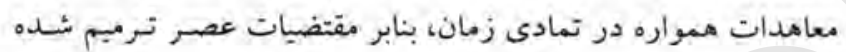

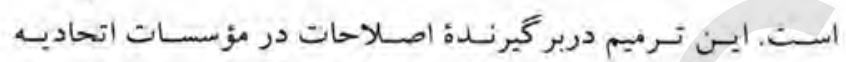

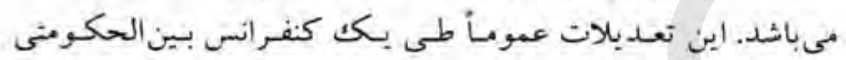

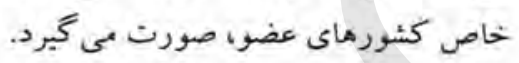

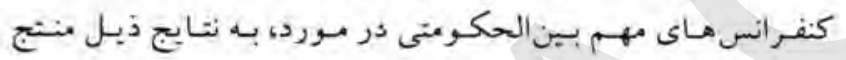
كرديده است: سند واحلد اروبايیى The Single European Act (SEA)

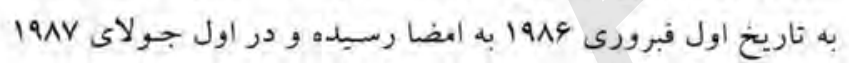

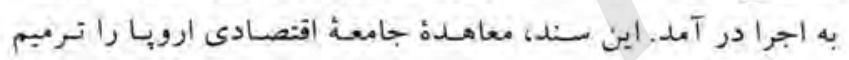
نموده و راه را براي بازار مشتخركث، هموار ساخت.

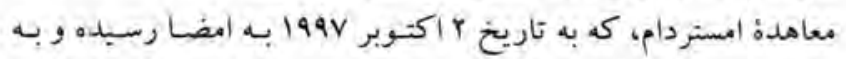

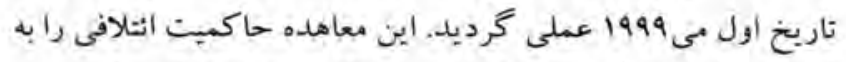

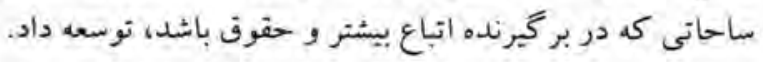

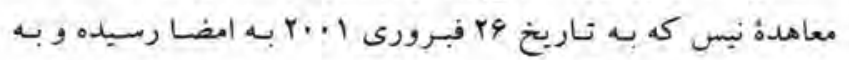

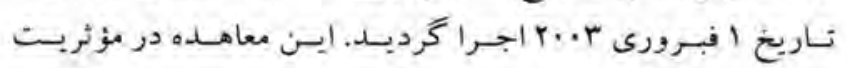
سيستمهاى تصميم كيرى نقش داشته است

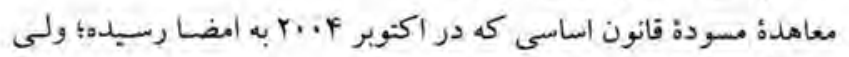

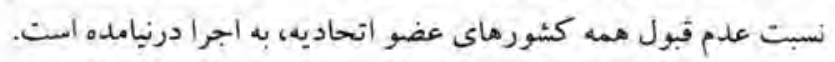

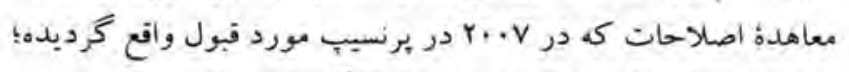

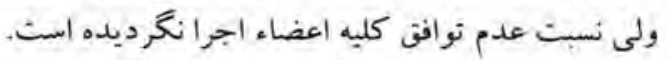
اداهي دارد

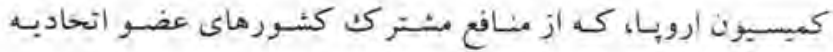

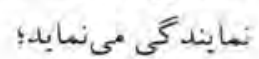

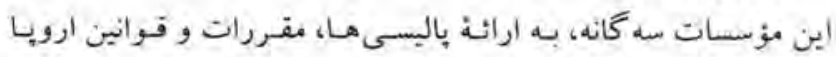

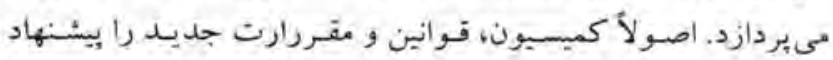

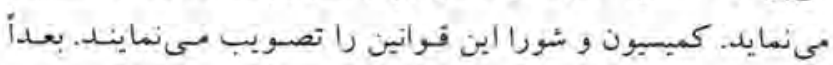

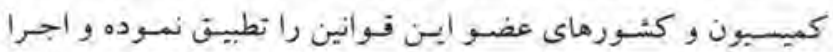
مي تصايند. محكمة عدالت، حكمث نهايى در مباحثات قوانين ارويا بىباشد.

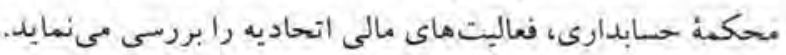

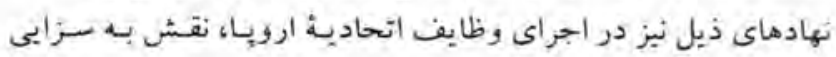
دارد: كمينة اقتصادى و اجتماعى اروبائي كه از مركبهـهـاى اقتصادي و

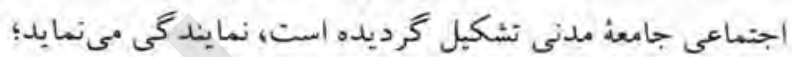

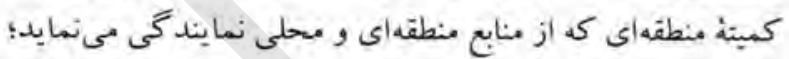

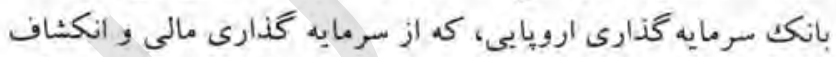

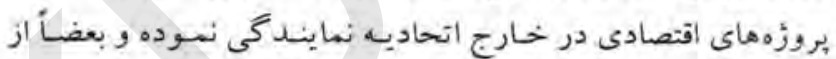

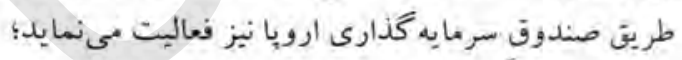

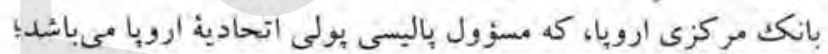

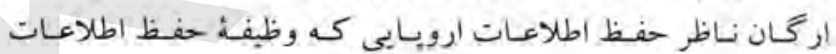

$$
\text { تُخهصى اتباع رادارد؛ }
$$

تlater

اتحادية ارويا به اساس جهار معاهلدة ذيل تأسيس گرديده است:

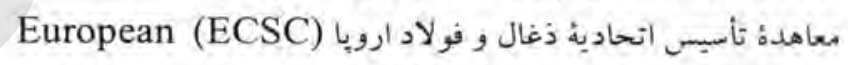
Cool \& Steel Community

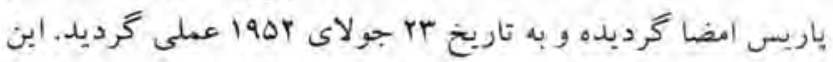

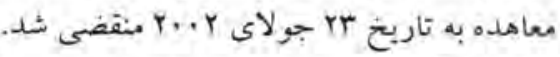

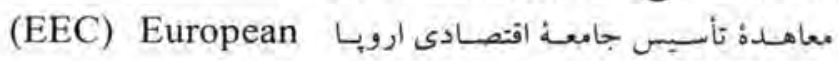
Economic Community

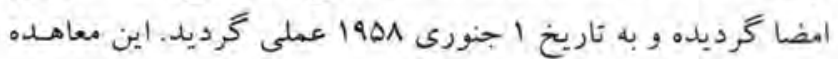

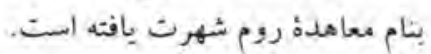

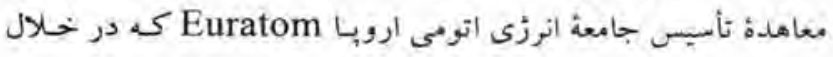
امصاى معاهدة روم در بسال 190V به أمضا رسيد.

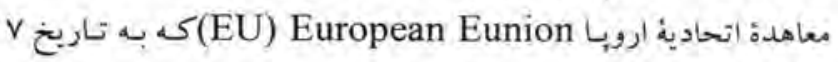

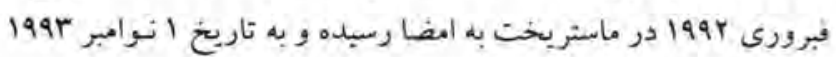

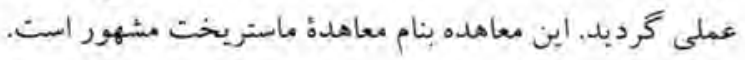

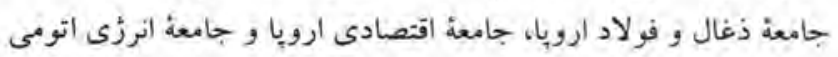

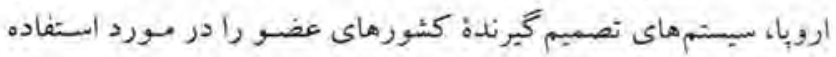

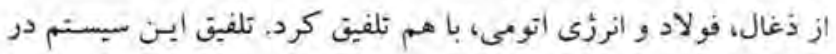

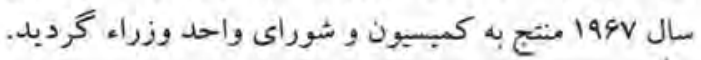




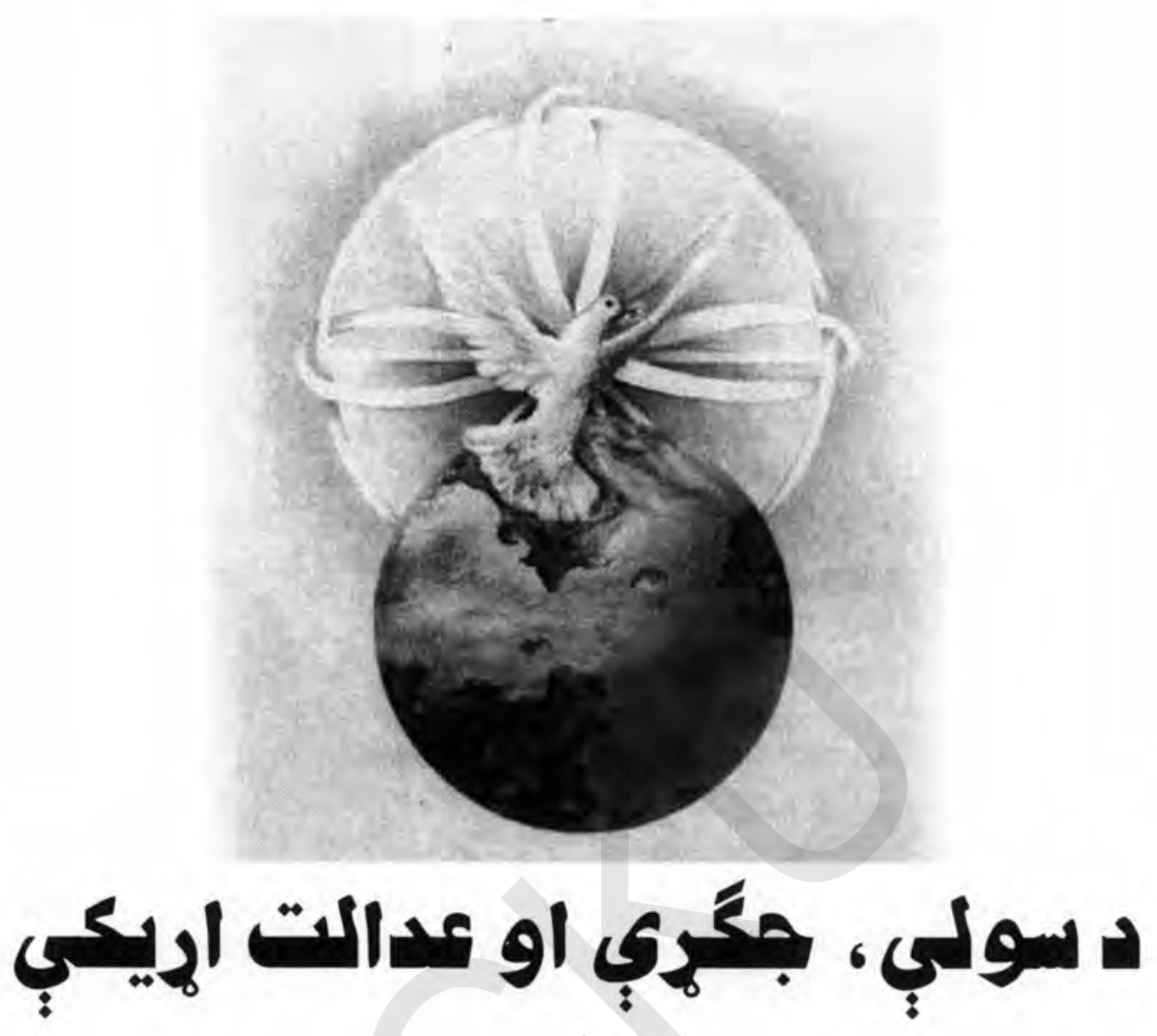

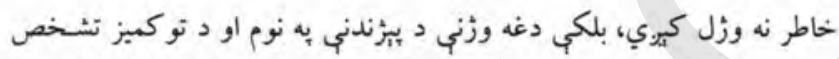

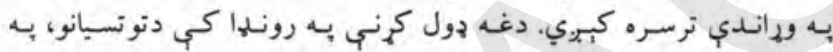

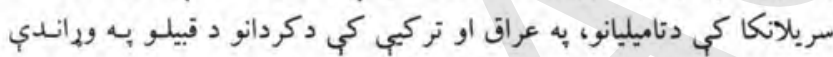

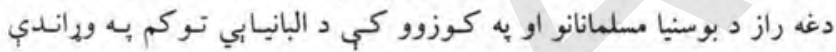

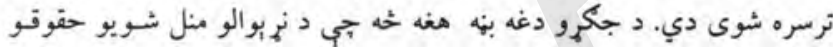

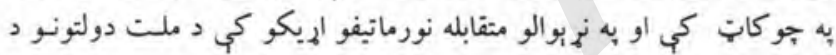

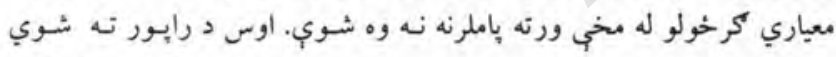

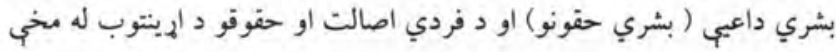

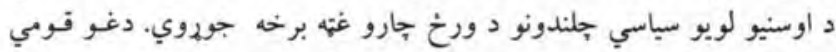

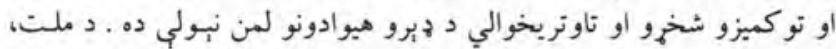

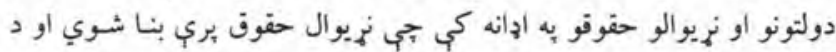

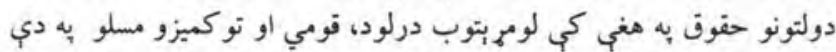

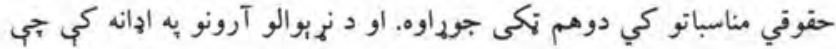

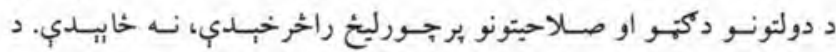

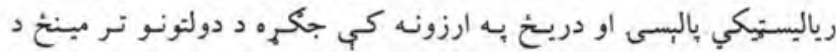

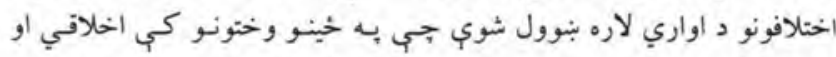

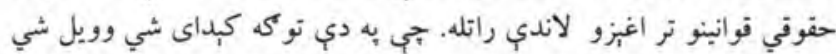

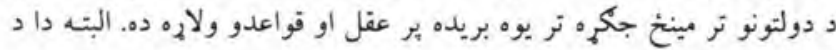

د سولي او جكهي مسله لكه د انسان د انساني برخليك خبره تل

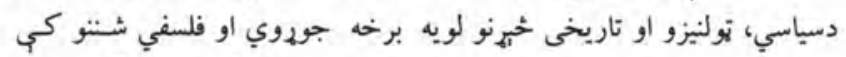

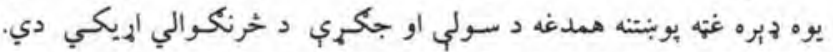

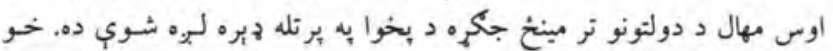

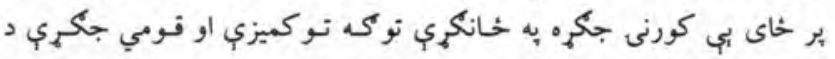

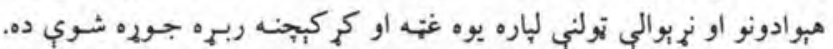

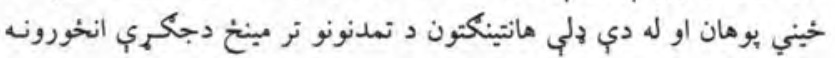

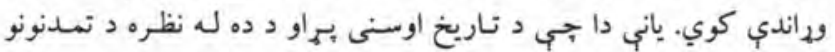

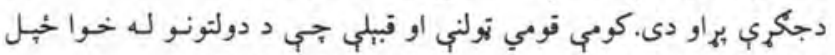

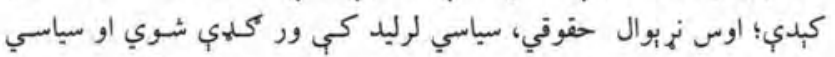

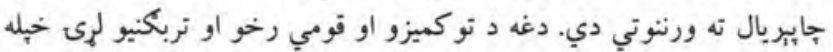

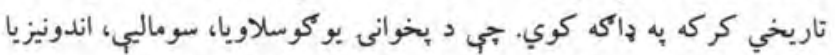

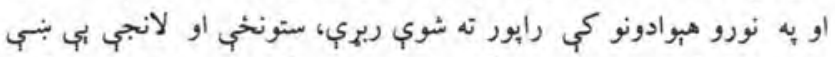

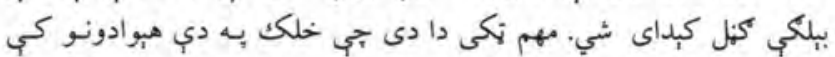

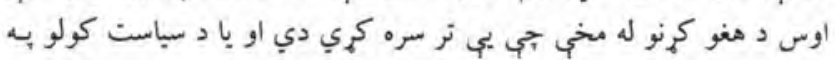




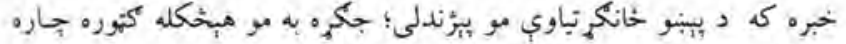

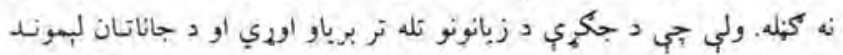

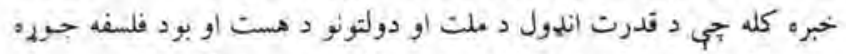

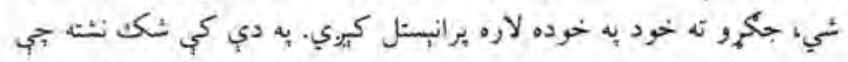

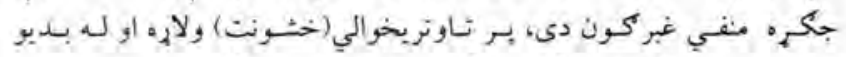

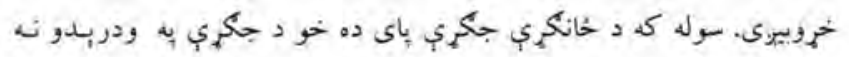

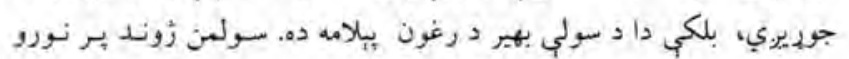

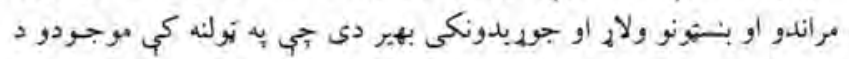

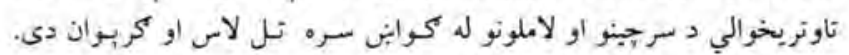

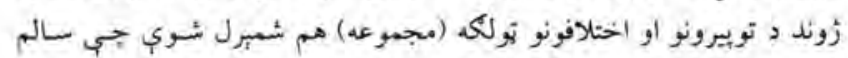

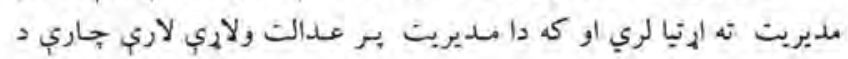

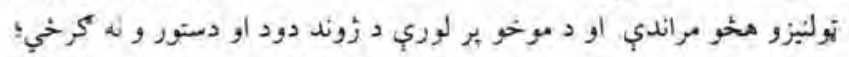

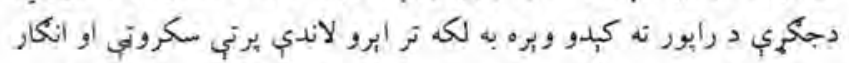

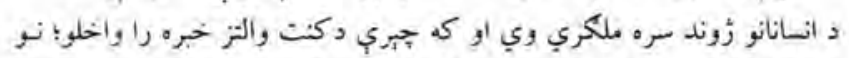

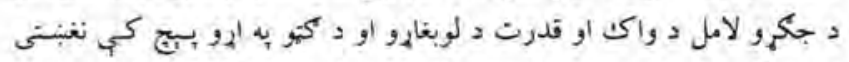

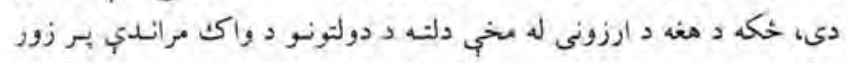

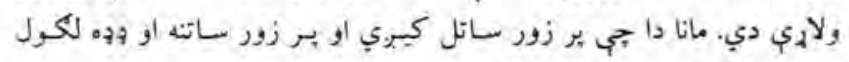

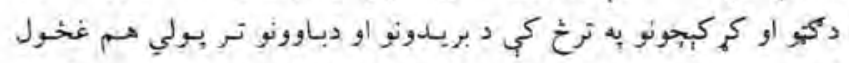

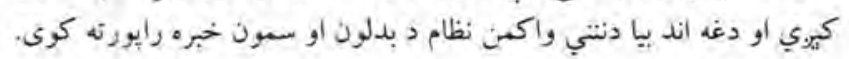

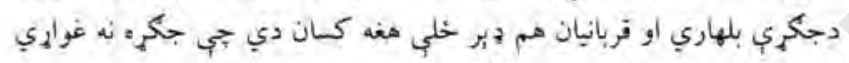

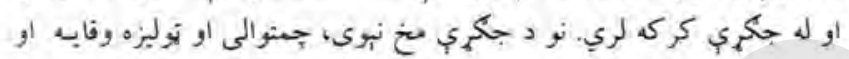

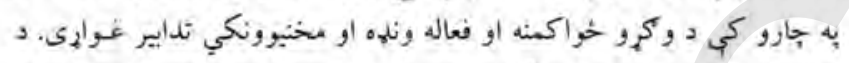

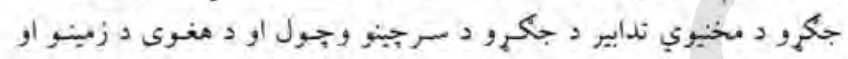

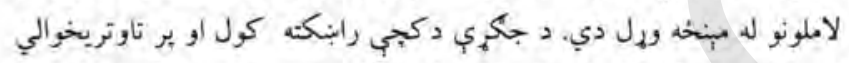

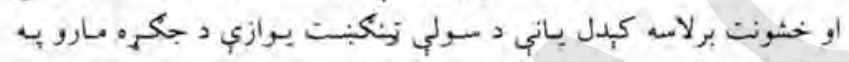

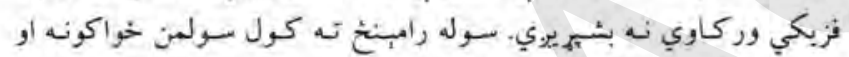

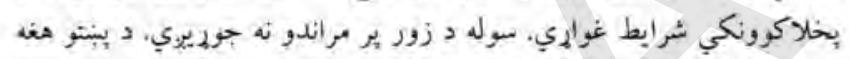

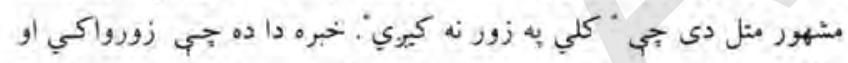

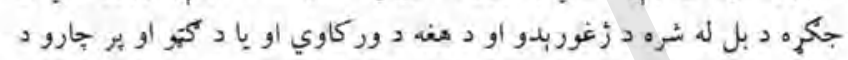

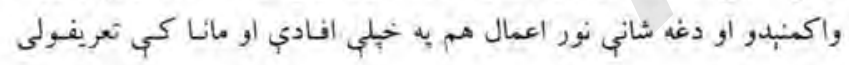

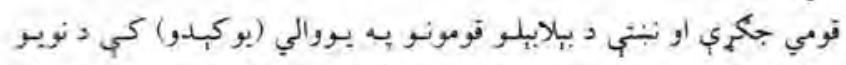

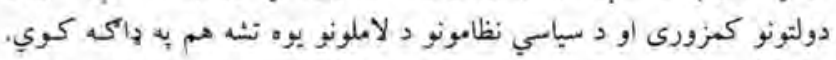

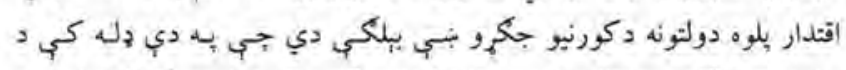

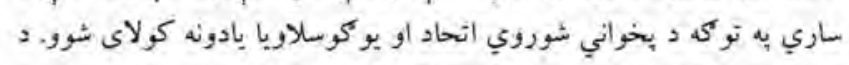

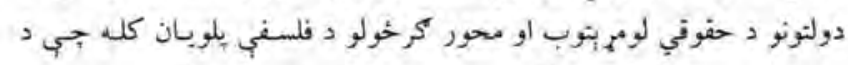

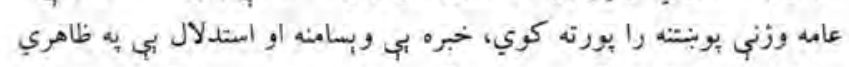

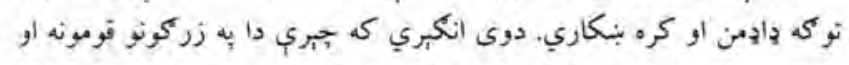

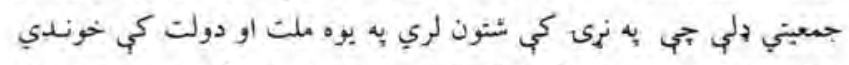

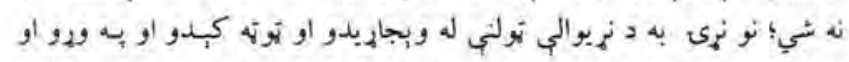

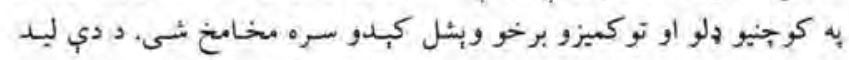

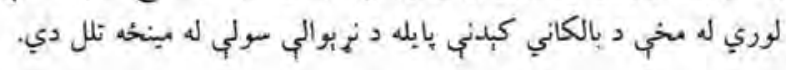

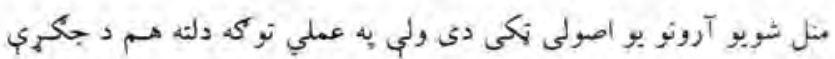

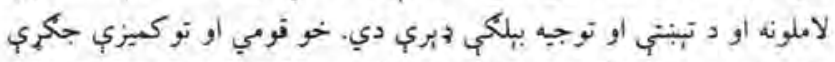

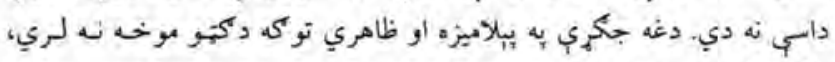

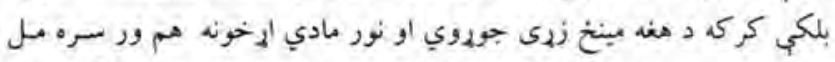

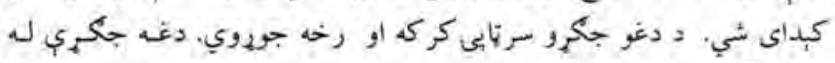

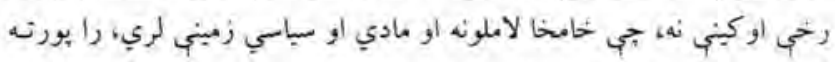

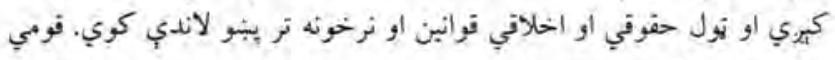

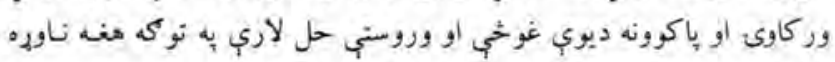

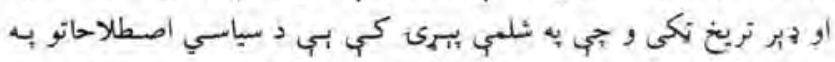

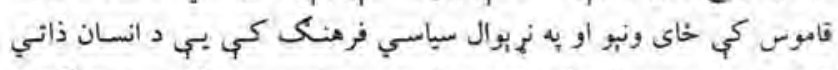

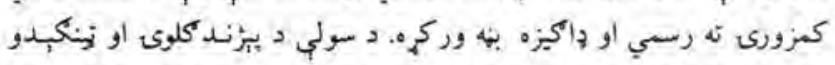

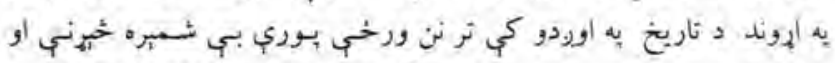

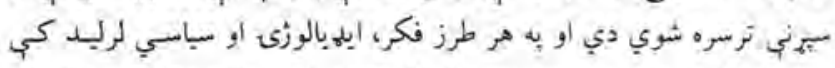

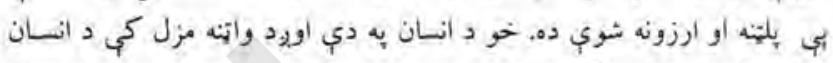

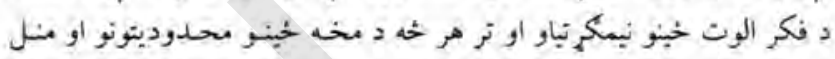

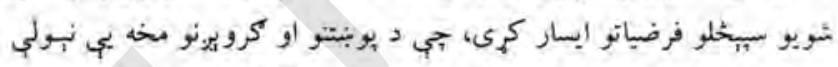

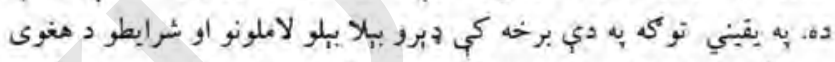

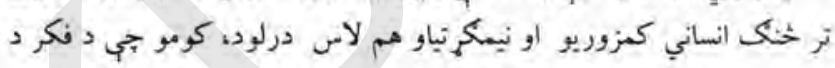

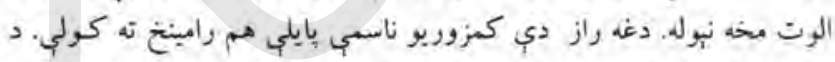

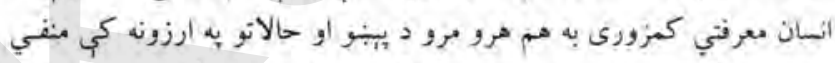

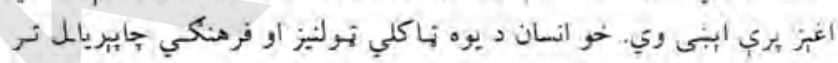

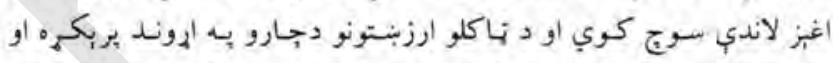

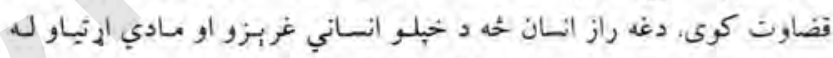

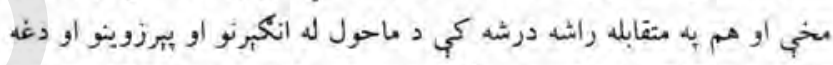

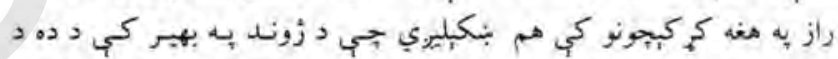

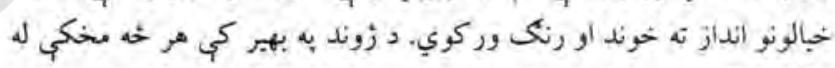

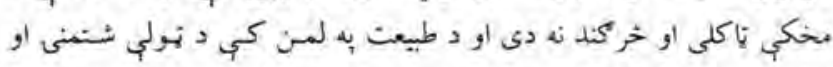

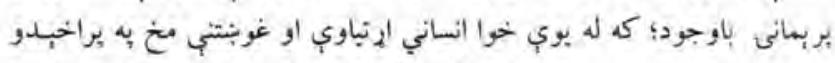

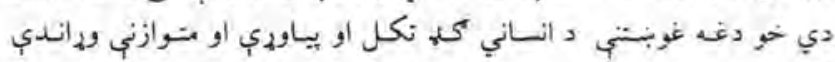

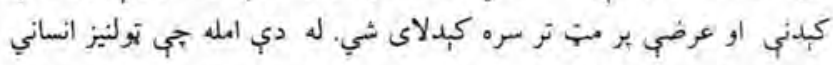

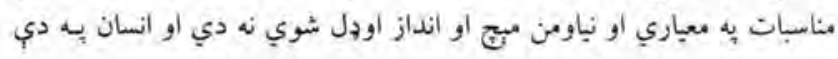

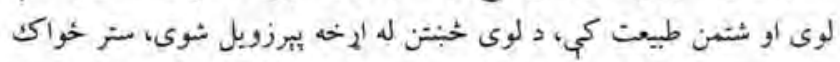

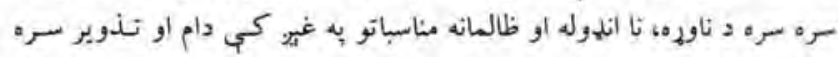

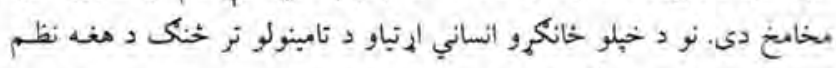

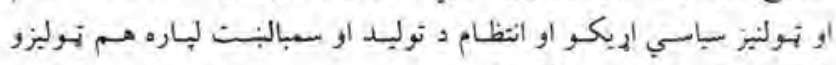

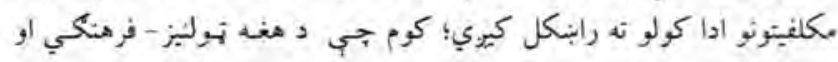

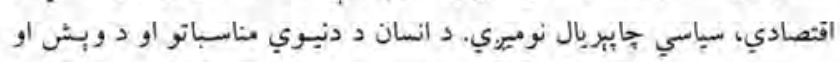

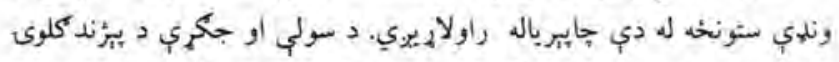

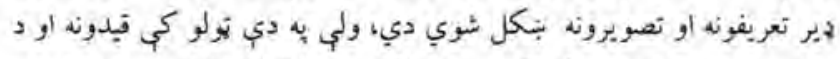

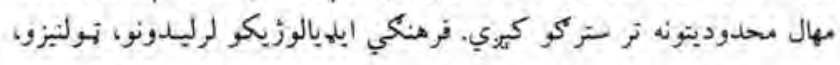

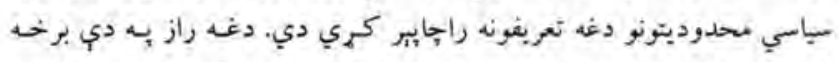

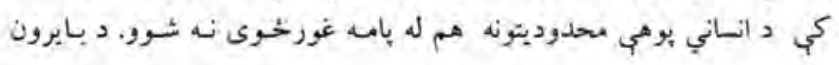




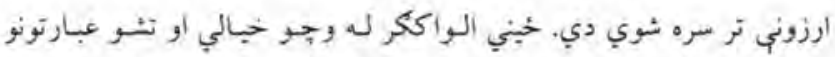

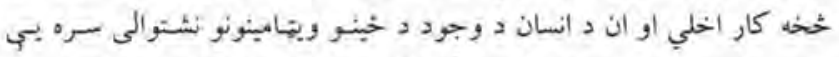

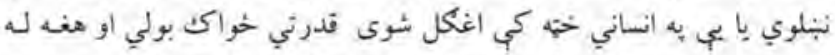

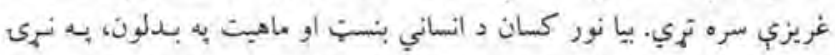

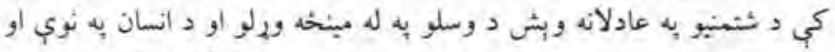

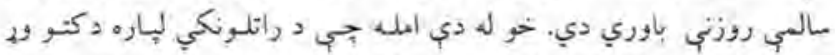

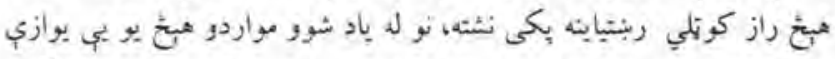

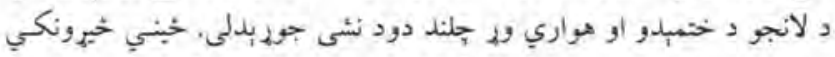

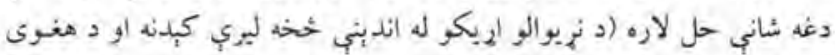

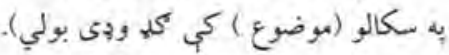

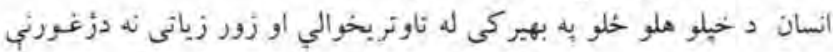

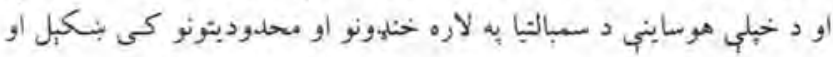

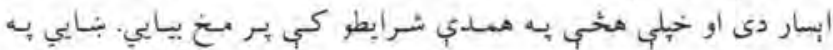

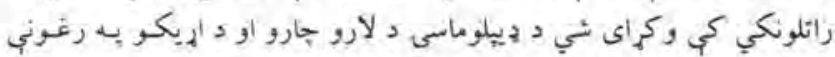

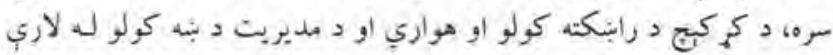

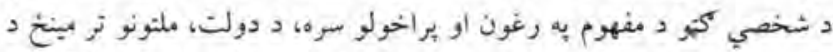

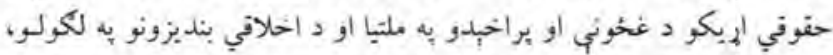

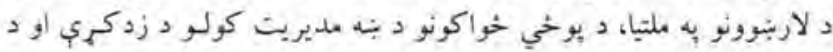

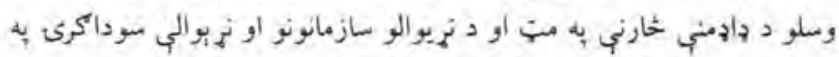

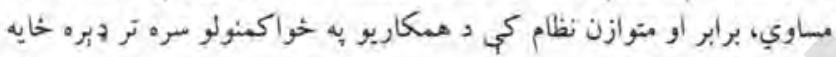

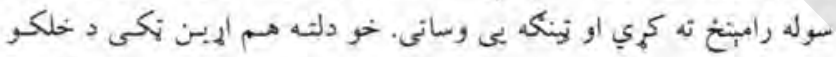

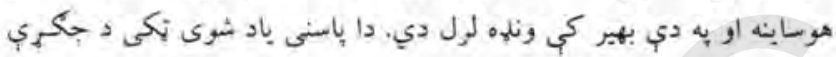

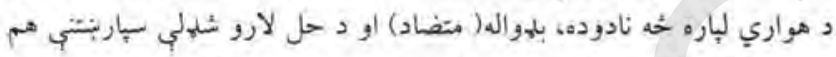

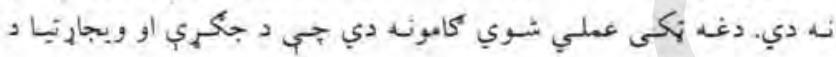

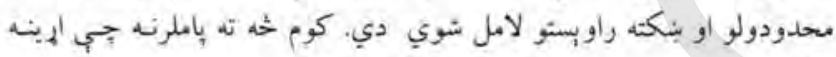

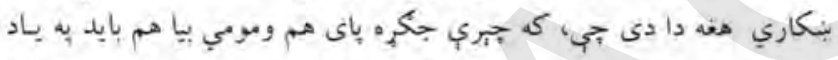

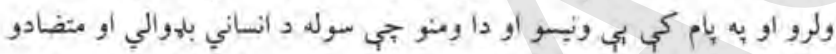

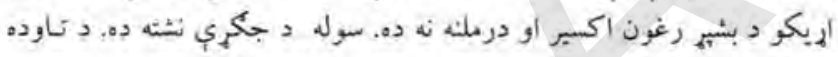

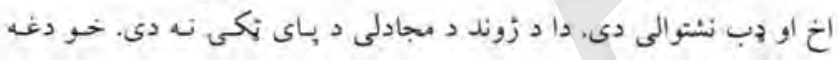

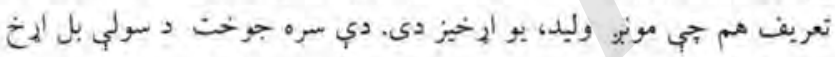

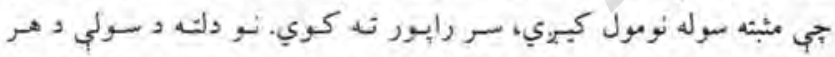

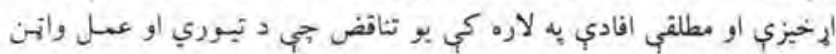

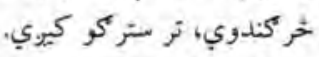

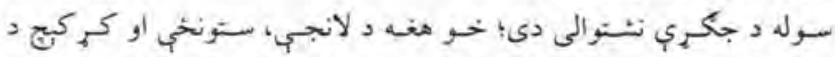

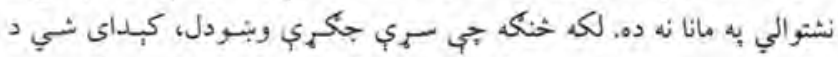

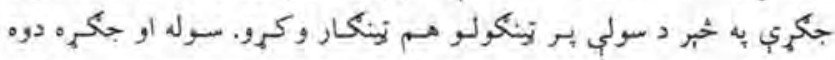

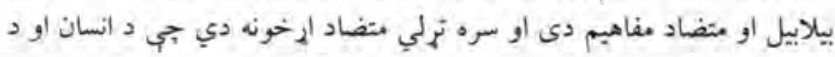

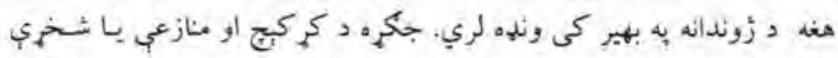

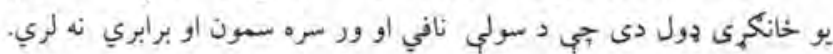

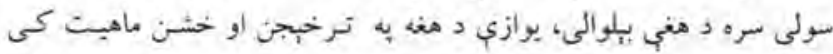

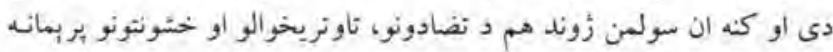

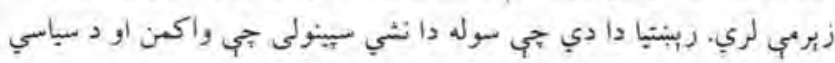

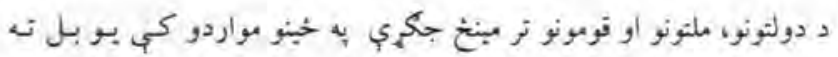

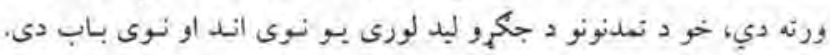

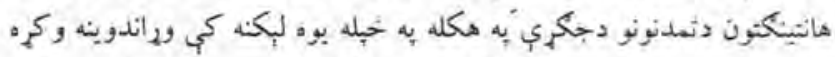

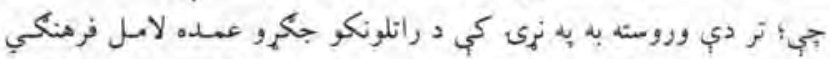

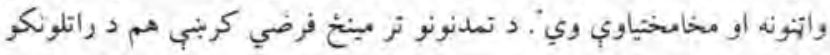

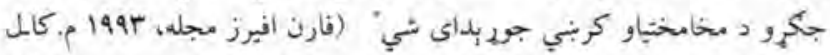

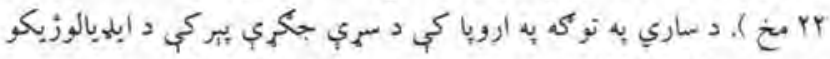

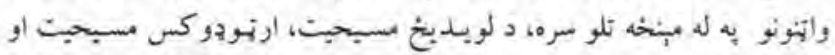

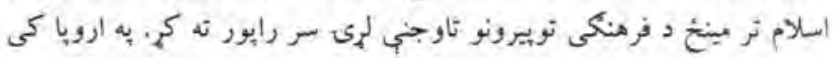

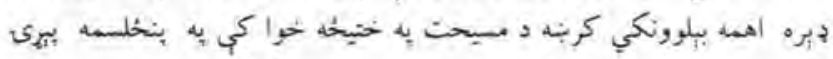

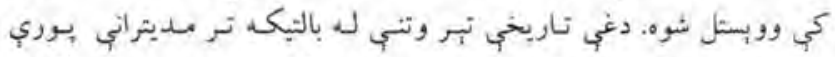

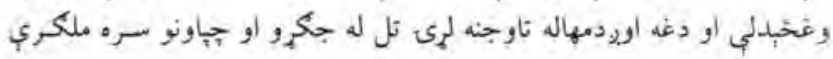

. $\circ$

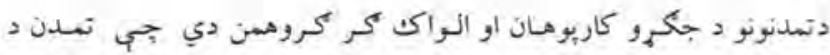

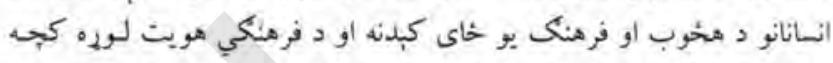

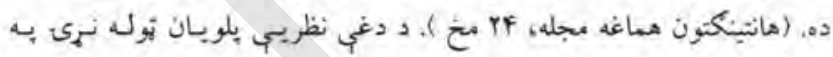

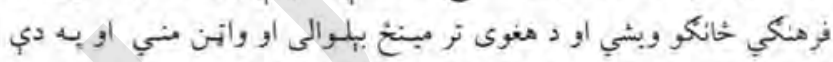

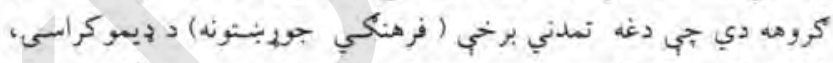

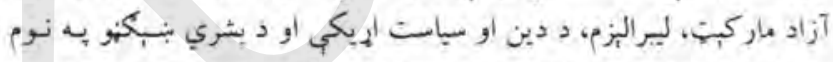

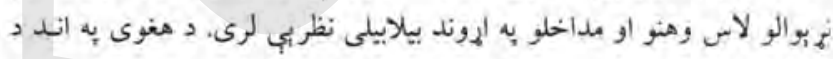

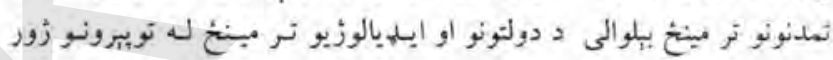

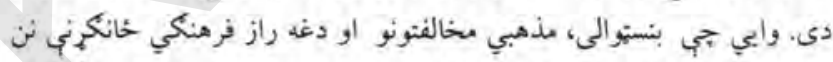

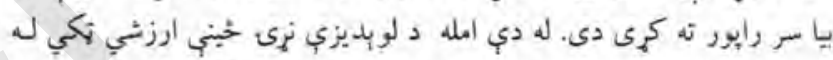

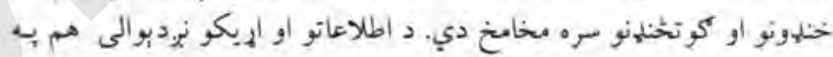

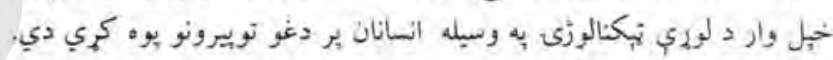

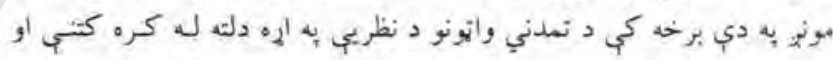

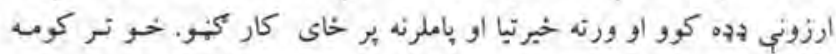

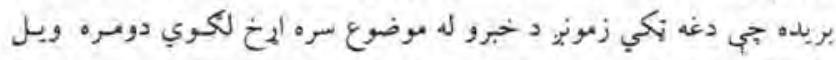

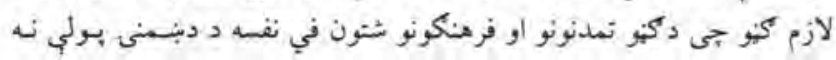

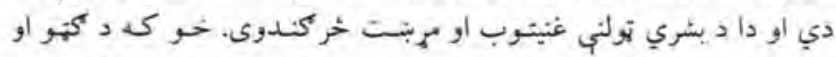

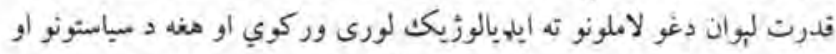

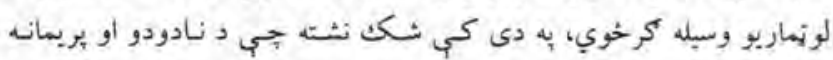

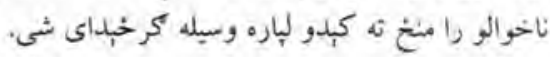

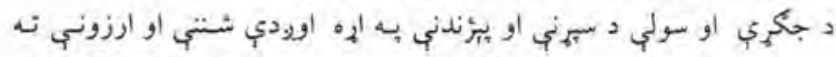

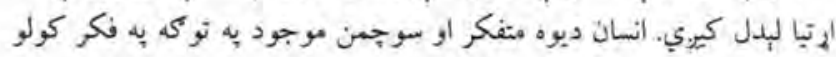

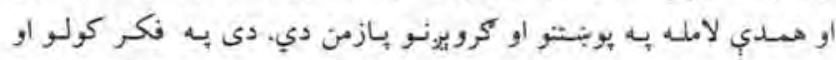

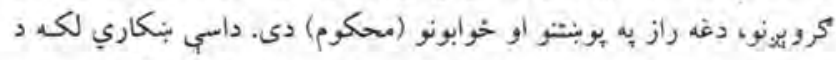

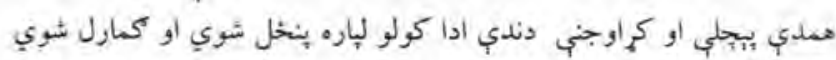

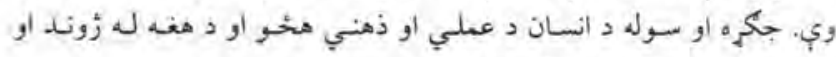

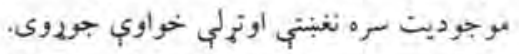

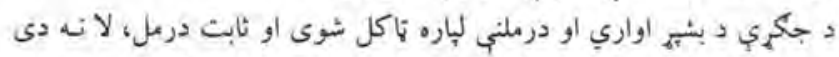

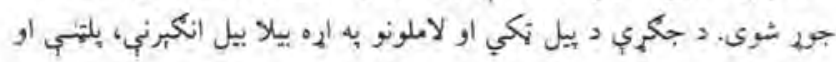




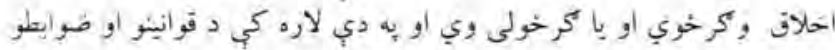

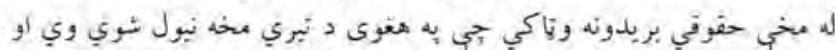

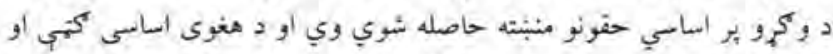

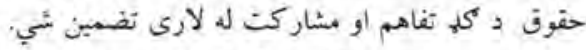

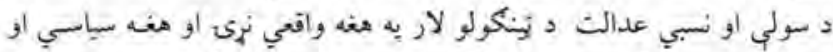

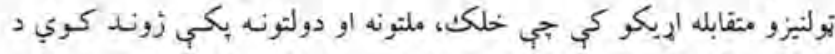

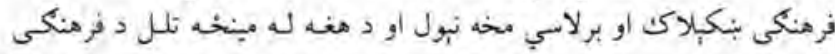

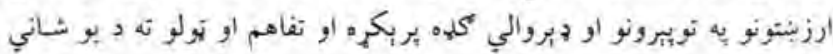
عتبار متنته او هوكيه إبجابوي.

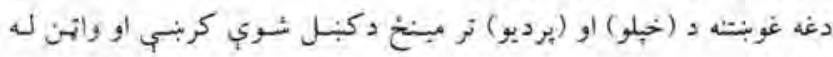

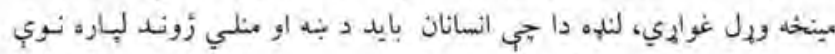

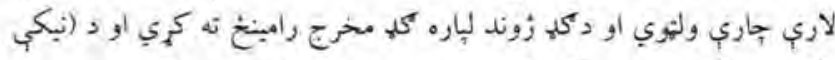

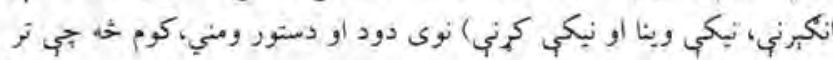

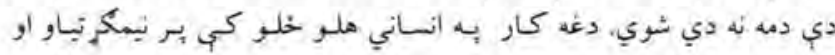

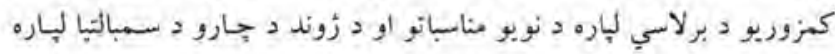

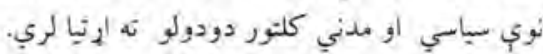

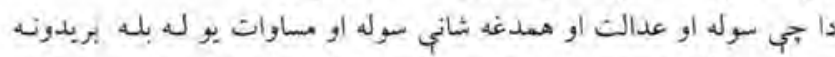

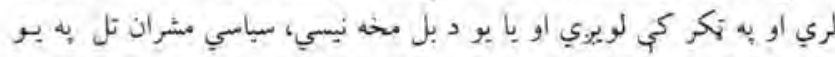

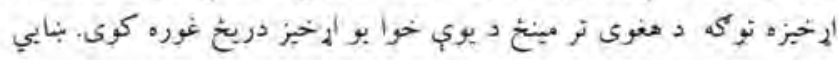

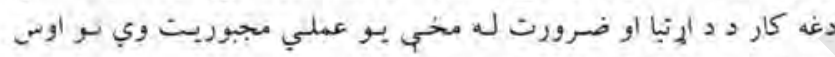

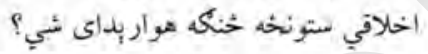

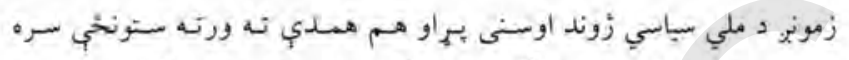

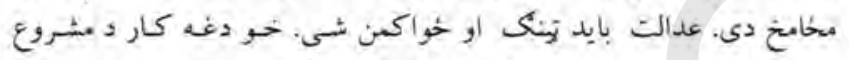

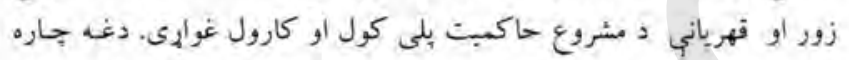

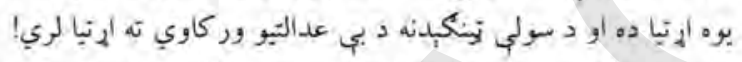

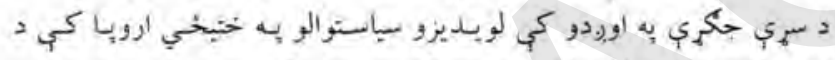

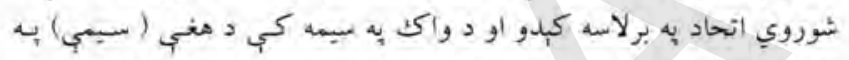

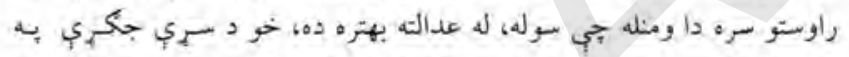

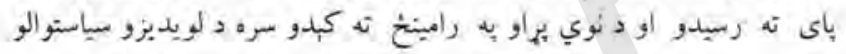

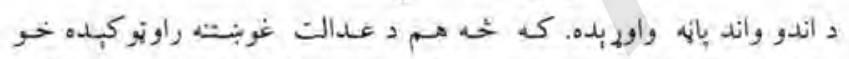

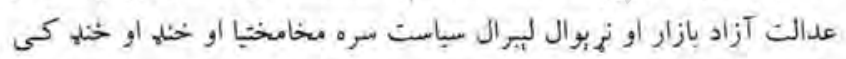

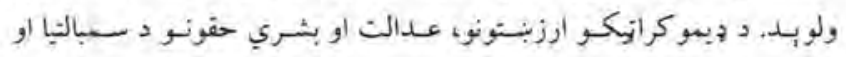

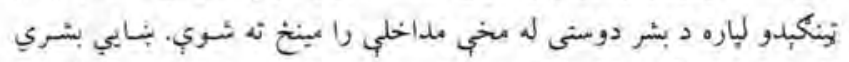

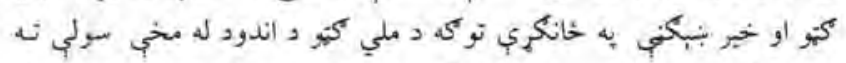

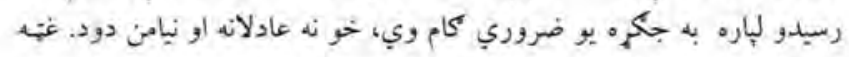

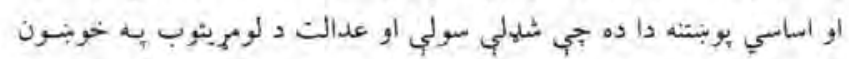

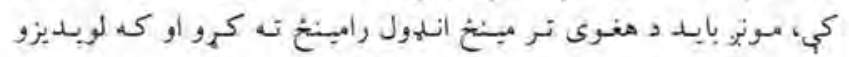

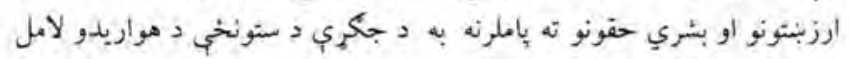

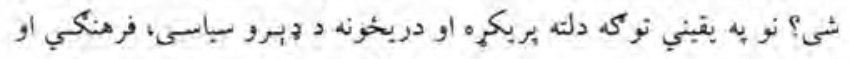

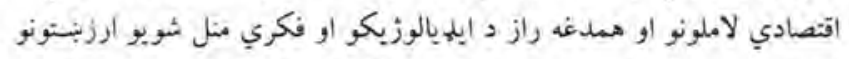

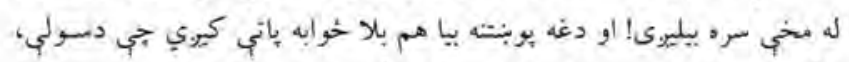

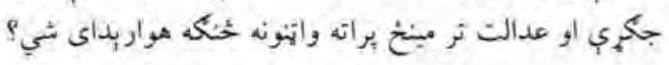

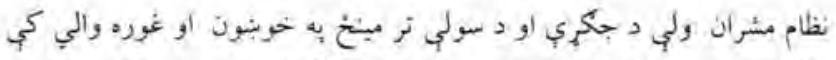

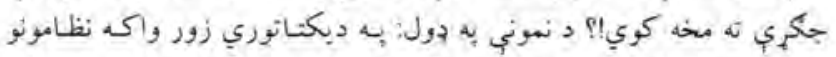

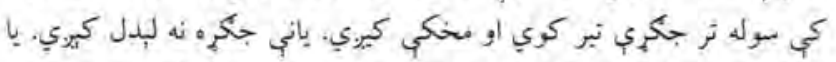

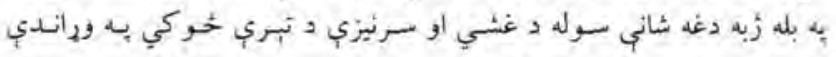

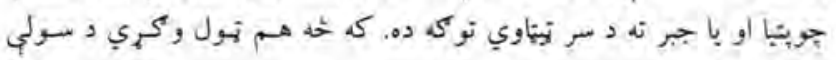

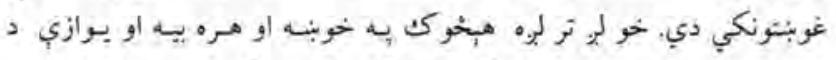

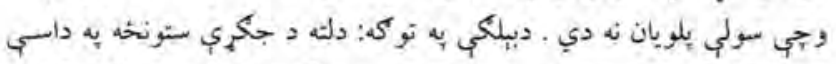

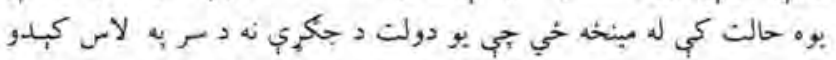

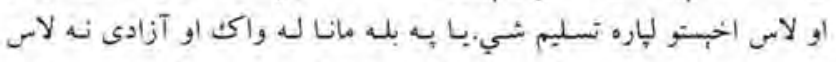

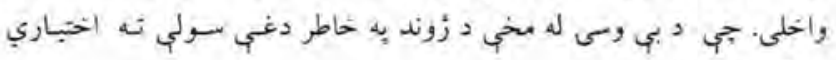
بردكي هم ويل شوبي دهي

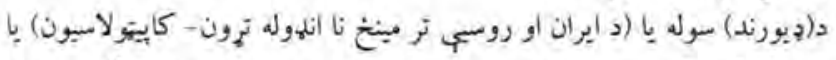

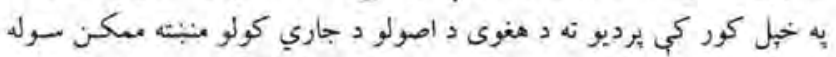

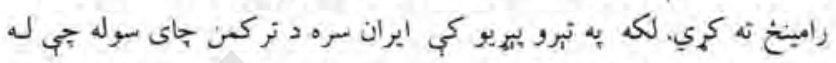

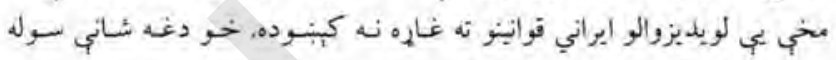

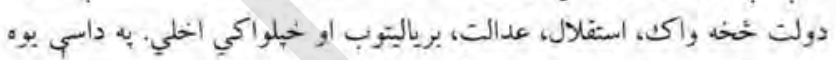

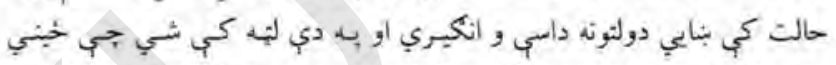

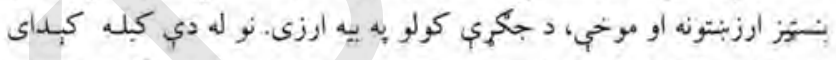

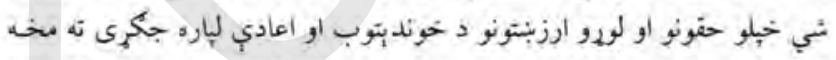

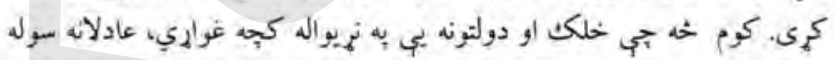

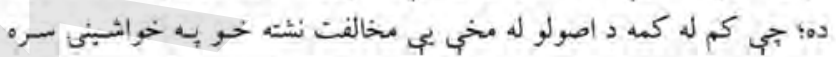

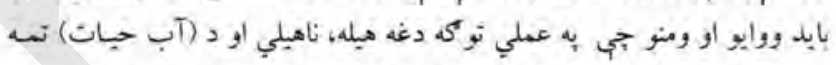

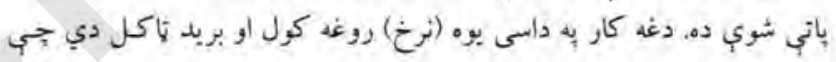

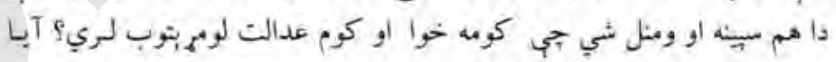

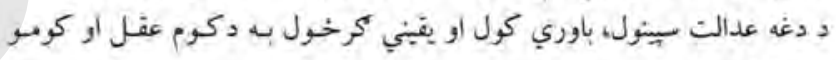

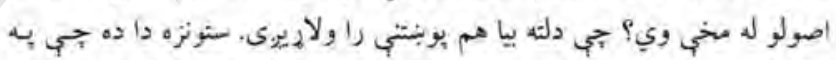

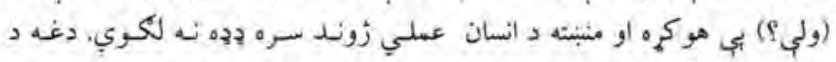

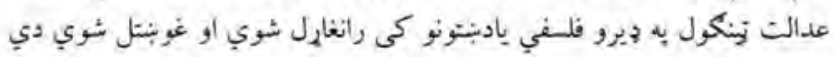

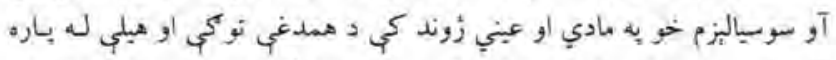

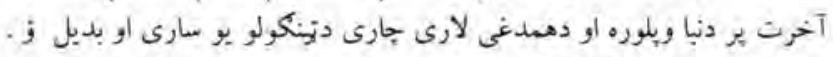

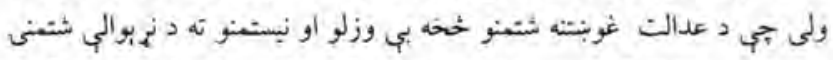

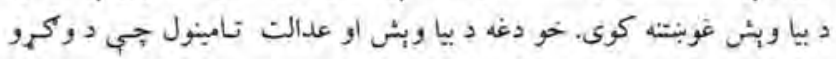

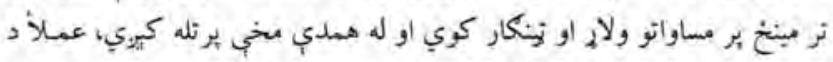

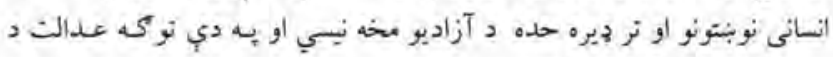

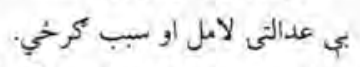

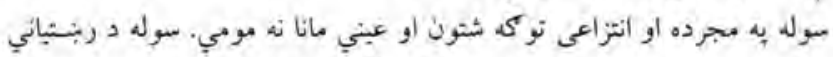

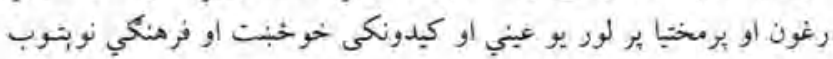

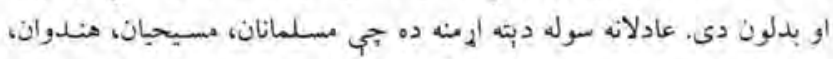

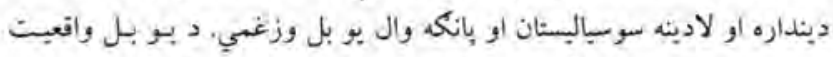

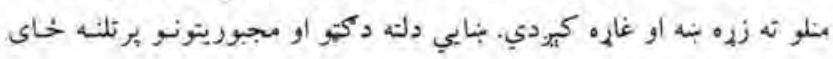

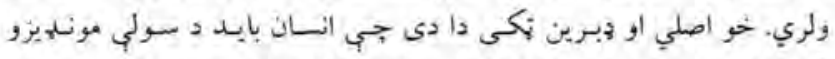

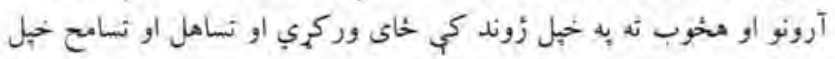




\section{نقش سازنده اصلاحات}

\section{در ايجاد اداره سالم}

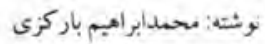

وزارت امور خارجه

Ebrm_brzüyahoo.com

كئسور، طـرح و تنظبم قـوانين مفـر رات، لـوايح و باليسى خـدمات

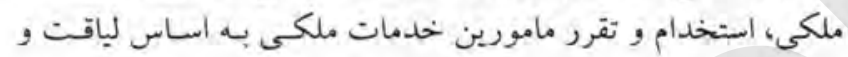

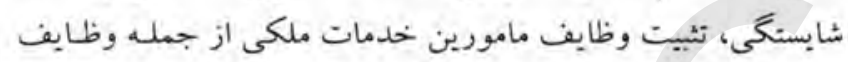
اساسى اين كميسيون محسوب مئى تر دد. قبل از همه اصلاحات ادارى و تطبيق آن رهبـرى و مسئولين اداردات

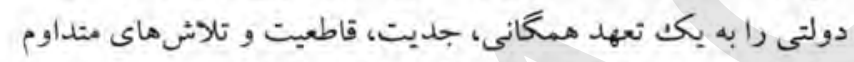

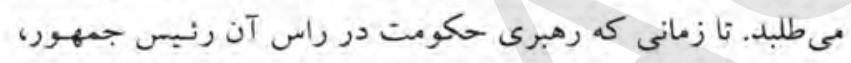

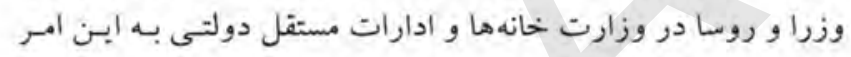

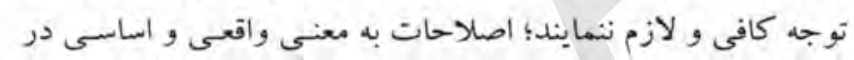

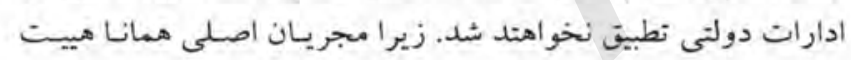

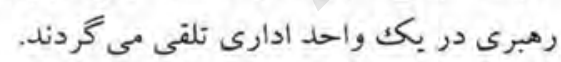

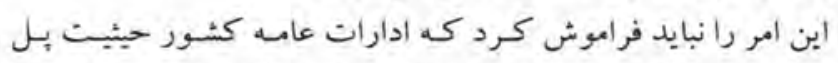

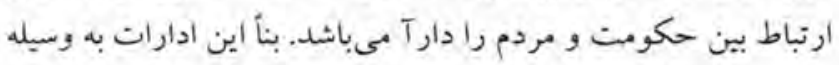

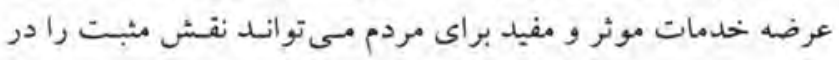

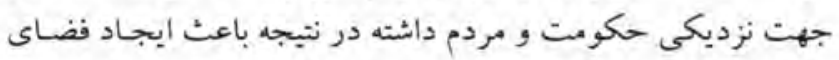

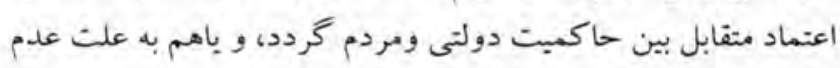

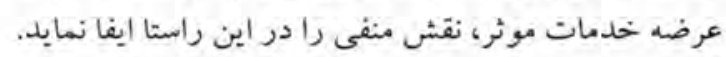

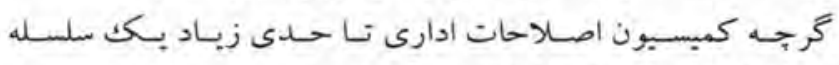

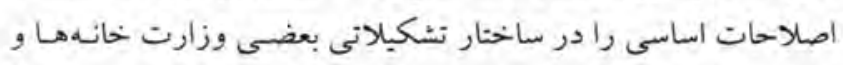

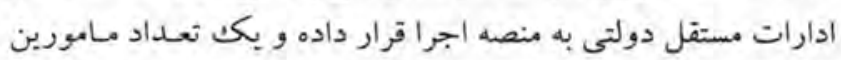

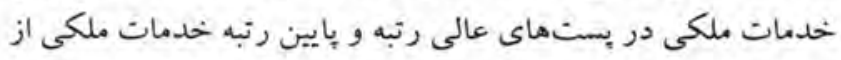

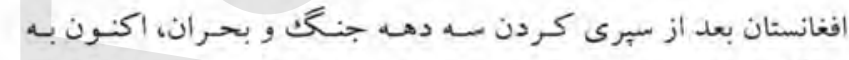

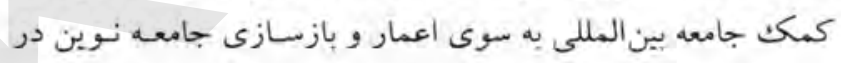

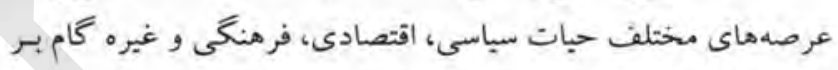

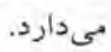
بفيناً كه بحر ان سه دهه اخبر ائرات نـاكوارى و نـامطلوب در كنـار

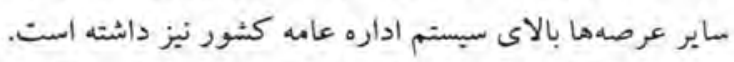

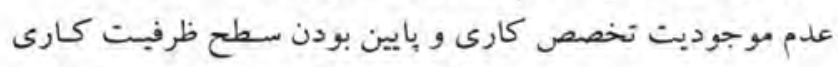

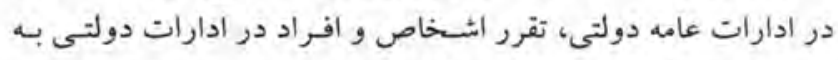

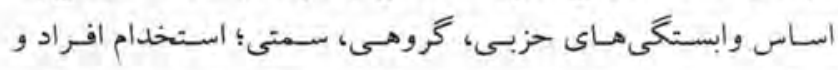

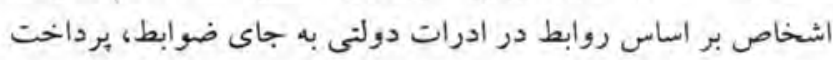

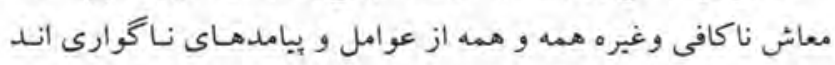

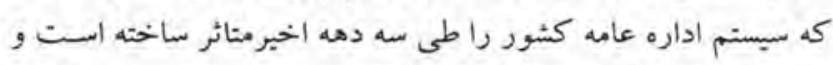

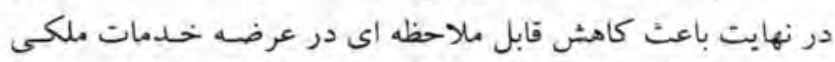

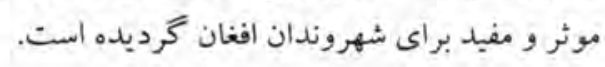

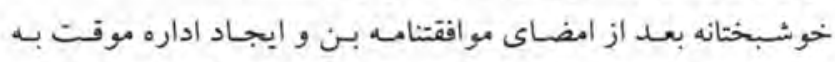

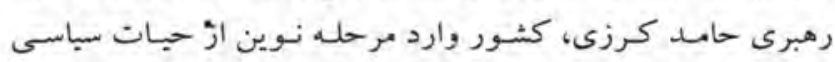
خويش گرمديد.

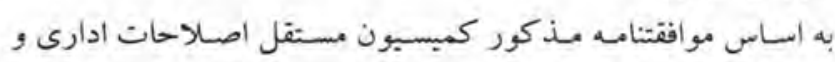

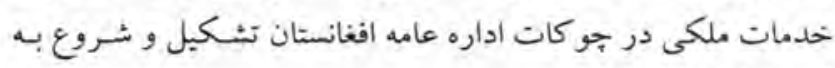
فعاليت كرده است. ابجاد اداره سالم از طريق طرح و تطبيق اصلاحات در سيستم ادارى 
مورد بحث قرار مي گيرد؛ حر اين جا انست كه موضوع مديربت تغير

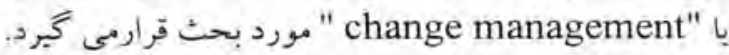

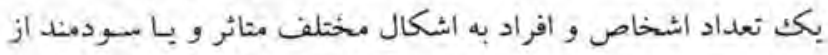

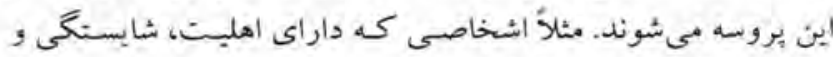

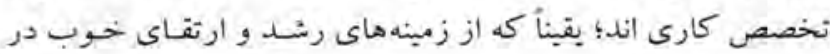

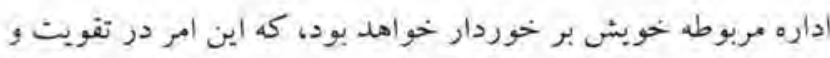

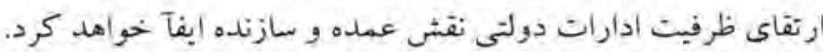

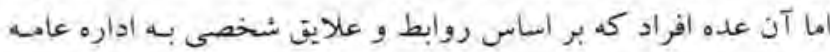

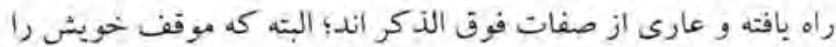
متزلزل مى بيند و حاضر به همكارى در اين راستاى نمى بانشد؛ بعضاً سعى و تلاش در بنى ائر نمودن اصلاحات خواتهد الهرد.

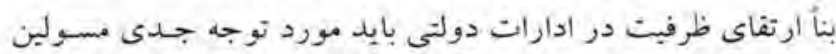

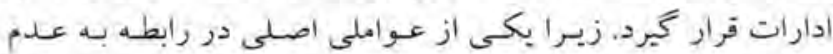

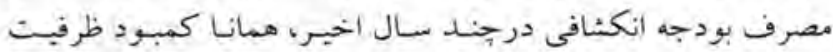

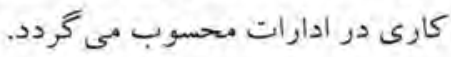

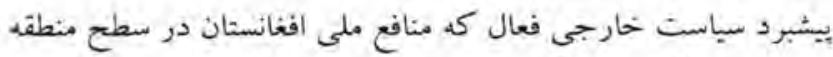

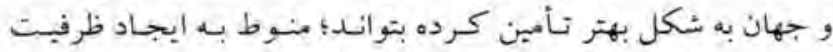

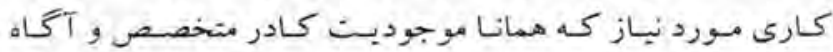
مي اشاشد، أست.

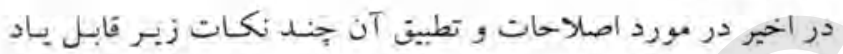
آورى است: تا زمائى كه دولت تعهد خويش را مبنى بر ابجاد اداره سالم، كارا و

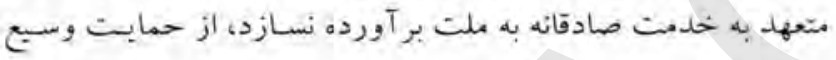

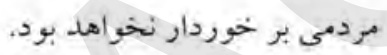

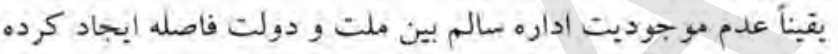

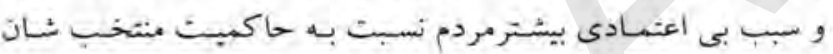

$$
\text { خواهد كردبد. }
$$

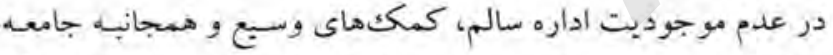
بين المللى در عرصههاى مختلف بدون استفاده موثر و درسيت از آن آن

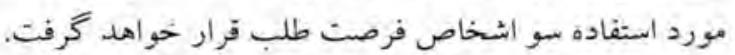

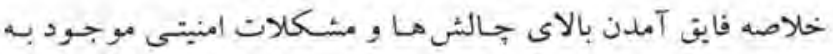

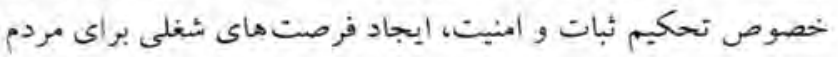

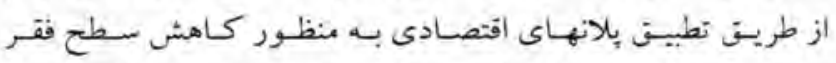

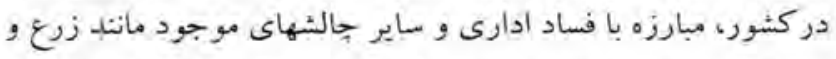

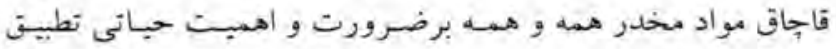
اصلاحات ادارى به هدف ايجاد اداره سالم شفاف وكار آ كه فابلبي

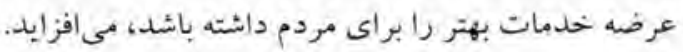

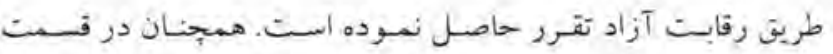

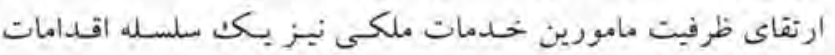

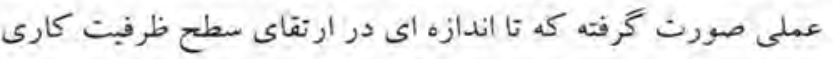

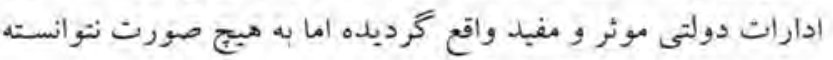

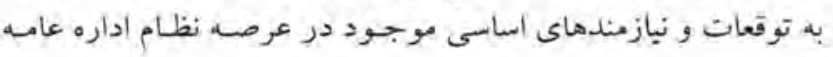

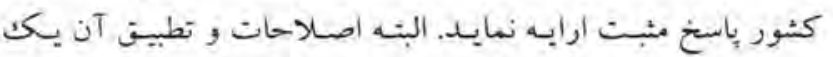

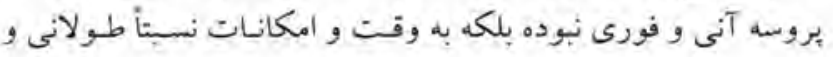

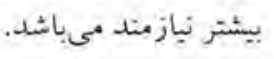

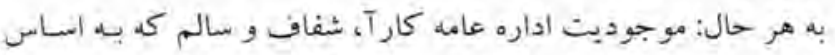

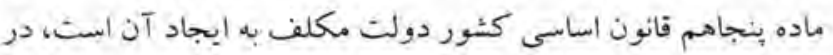

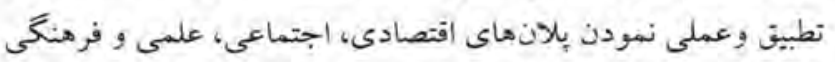

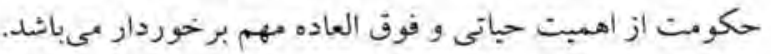

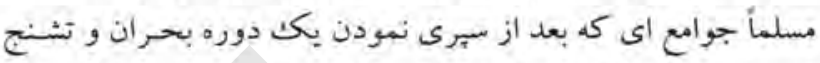

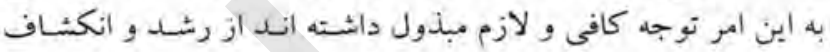

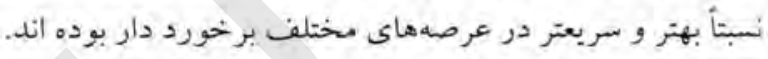

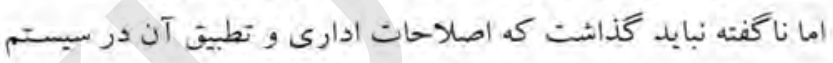

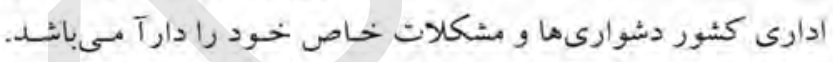

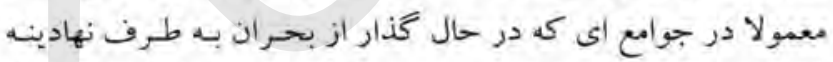

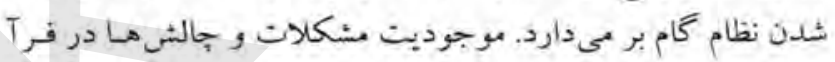

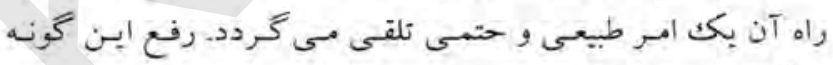

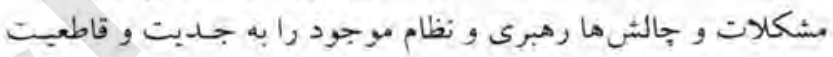
بيثتر مى طلبد.

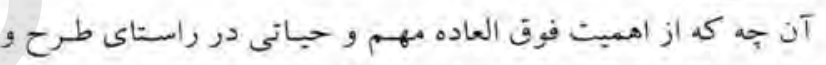

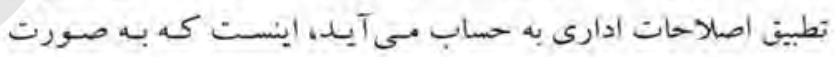

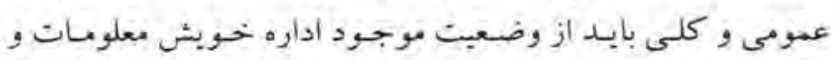

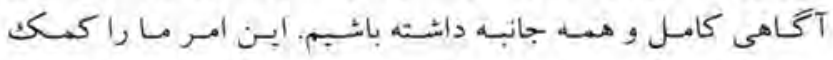

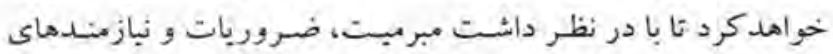

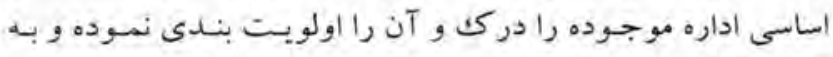

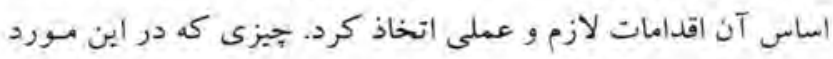

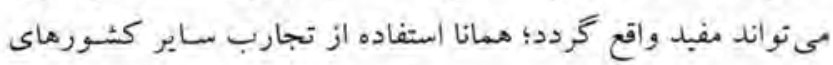

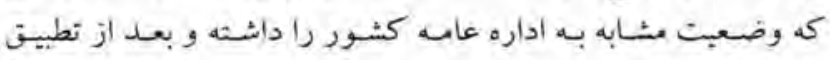

احلاحات، اكنون داراى يكث اداره كارا و سالم هـستند، مىباشند.

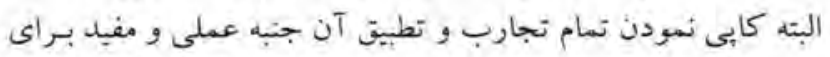

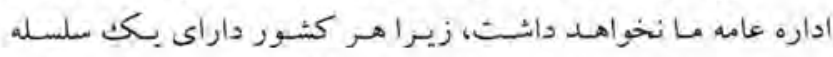

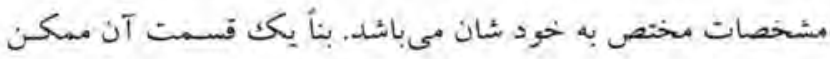
است مفيد و سودمند واقعى سمود نه كل آن.

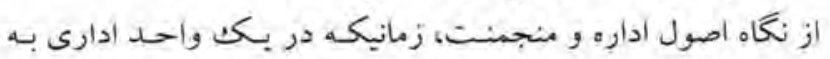

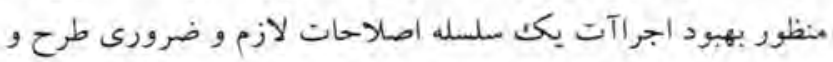




\section{افغانستان، افغاني دودونه}

\section{أو داتلونكِ سو سله \\ خيمينيزه او تحليلي لبكنه}

باسوال حى كل سانليمانخبل

-va9+r.4rA

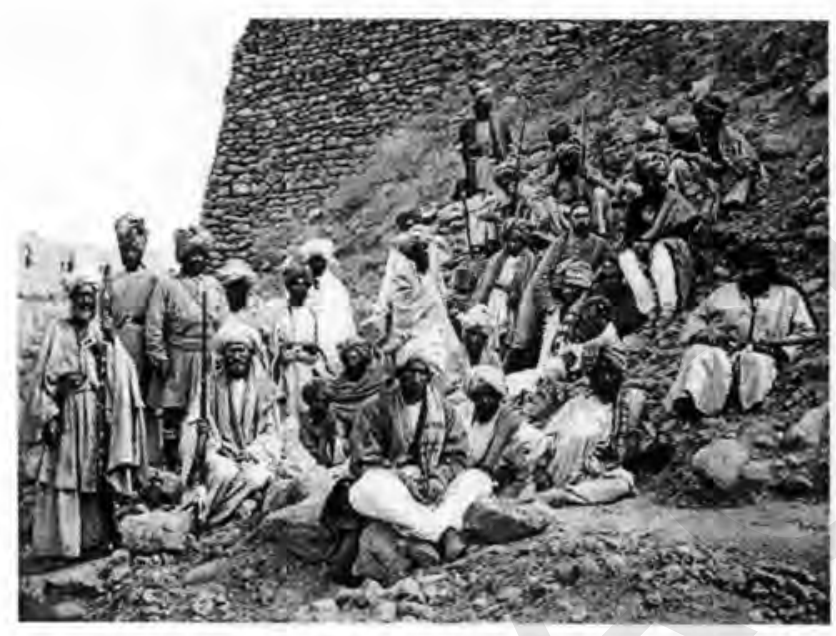

لبنكري به افغانستان را خوري شوي، بريمانه تيري، ظلمونه او ناكي دي بي إبي

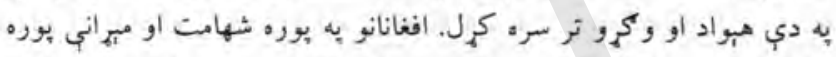

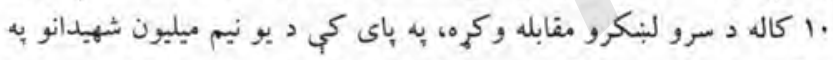

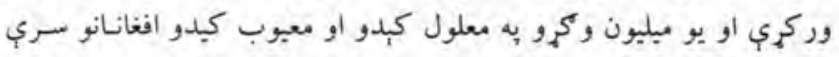

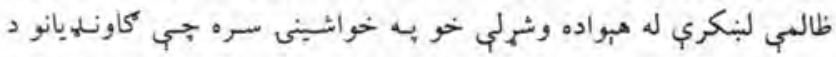

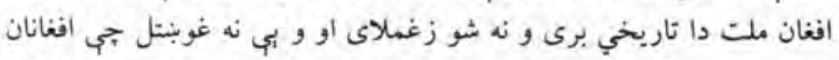

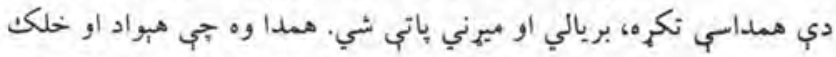

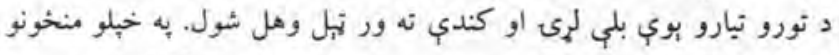

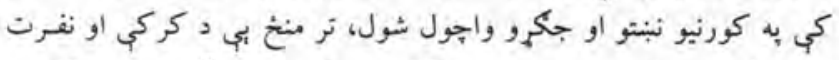

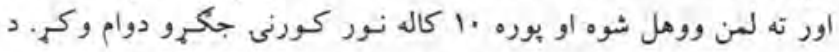

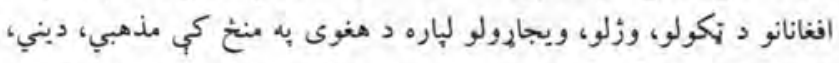

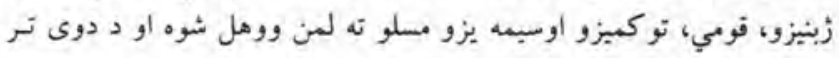

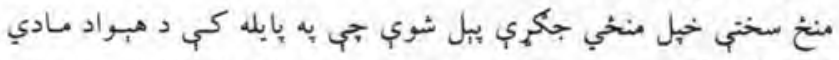

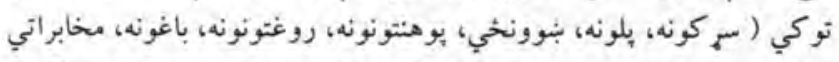

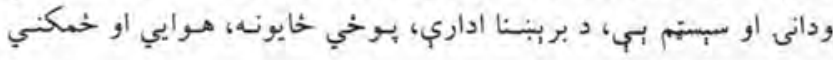

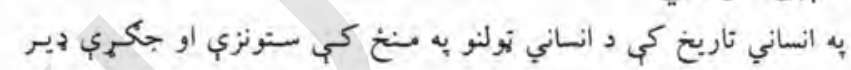

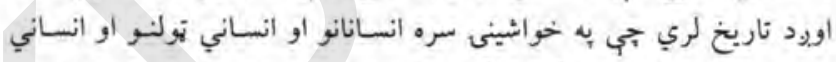

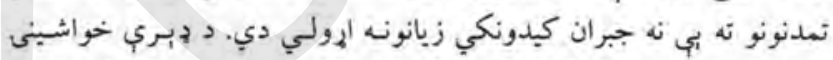

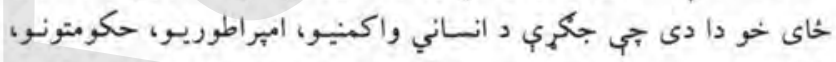

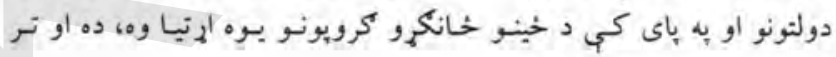
جير مهاله بوري به دا أرتيا وي.

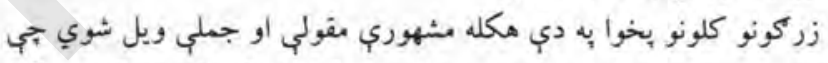
تر اوسه بوري د حقوقو او سياسي علومو به كتابونو كي لوستل كيروي. لكونه

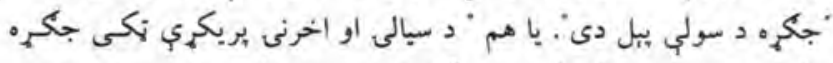

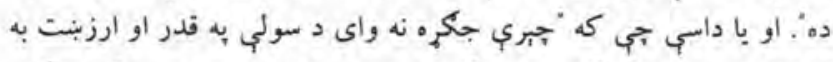

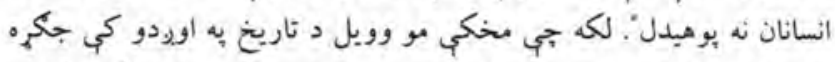

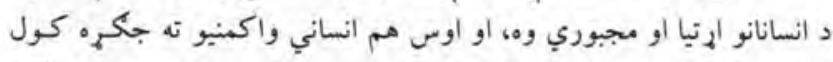

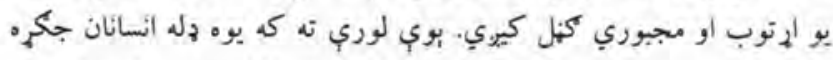

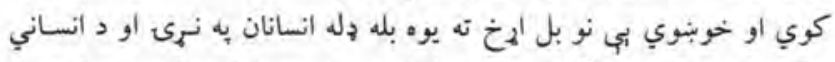

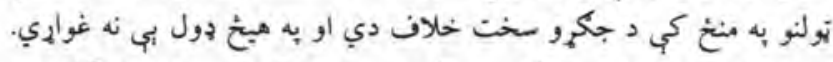

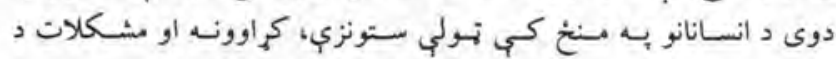

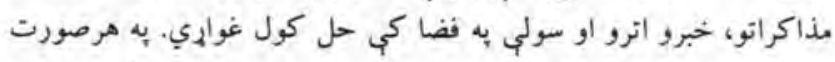

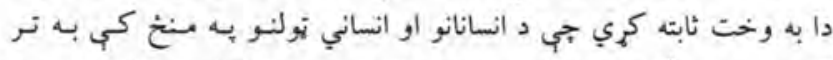

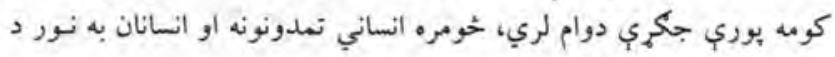

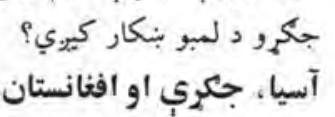
افغانانو كه خه هم د تاريخ به اويودو كي هر يرغلكر ته به بوره مبهاني اني

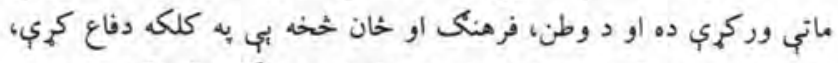

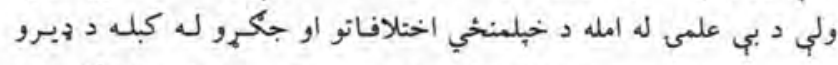

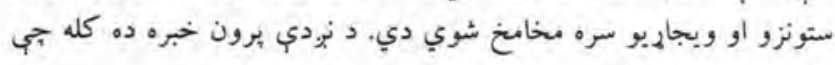
د كيونيزم د امجراطورى سري 
افغانان. سنتي خويونه او اسلام

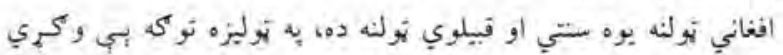

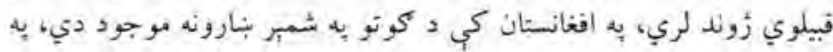

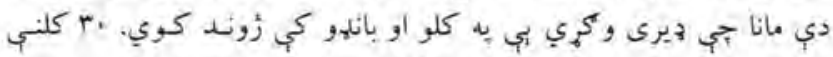

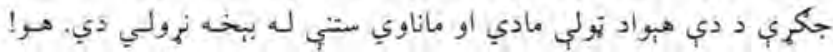

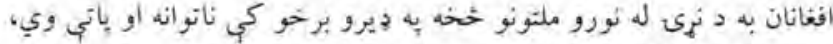

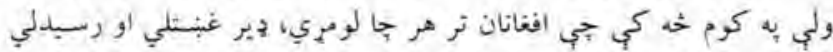

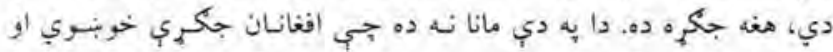

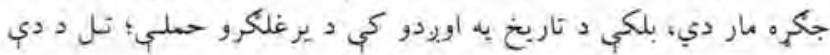

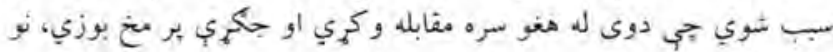

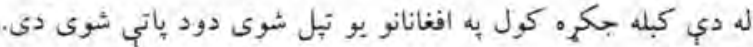

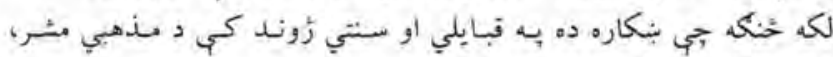

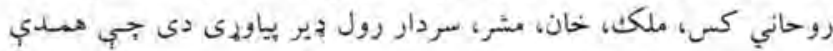

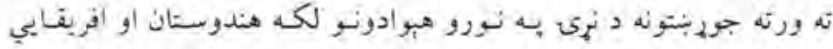

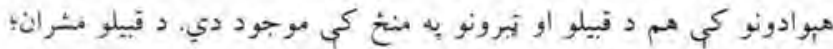

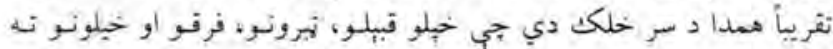

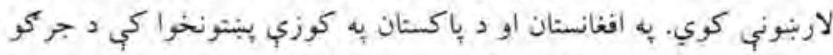

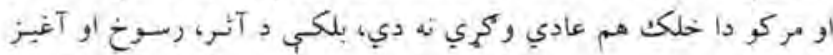

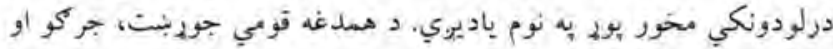

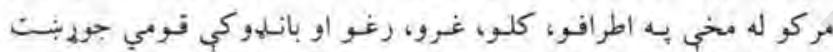

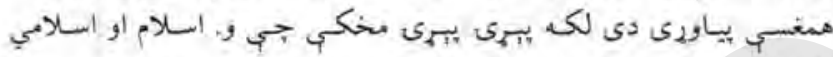

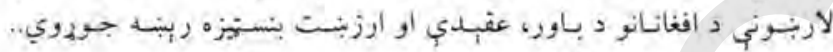

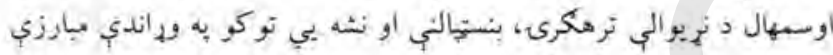

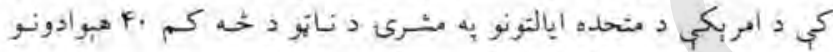

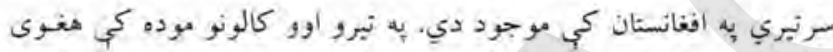

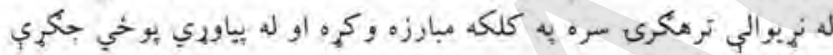

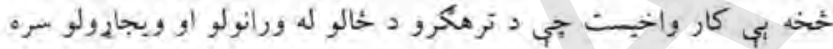

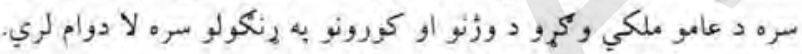

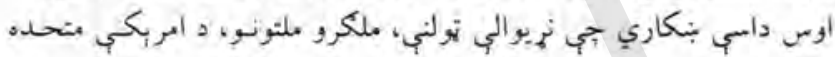

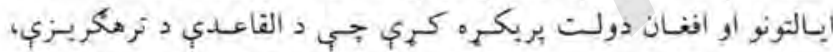

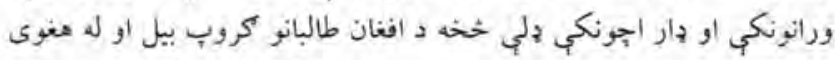

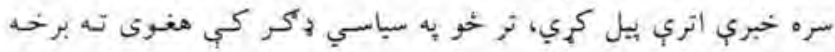

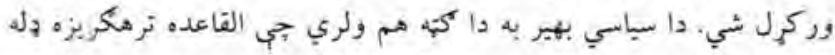

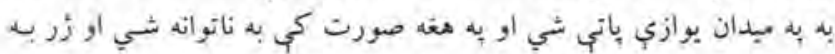

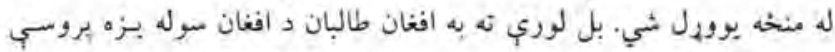

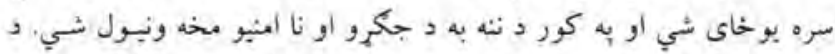

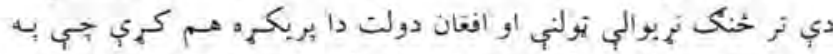

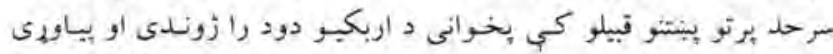

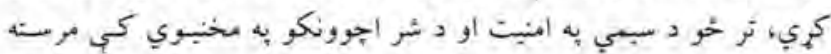

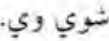

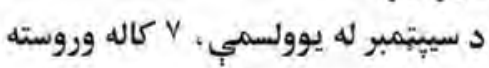

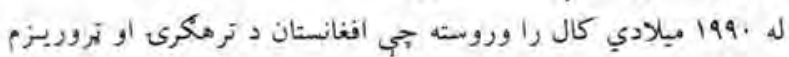

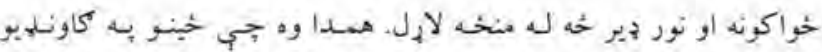

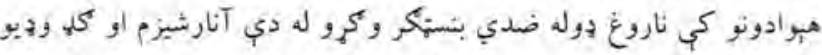

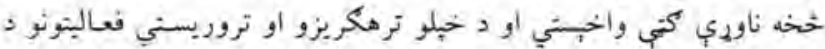

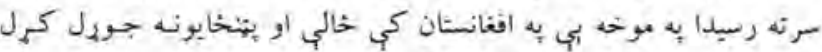

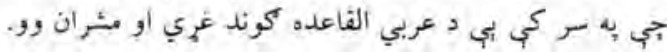

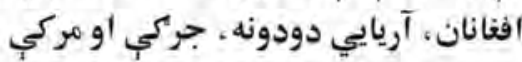

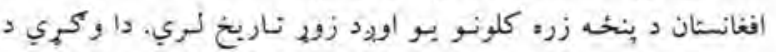

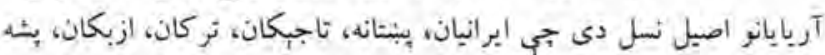

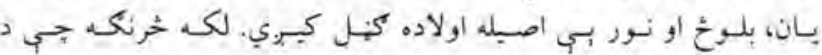

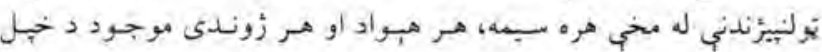

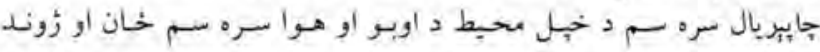

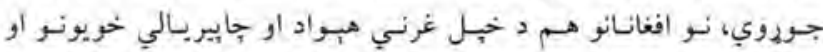

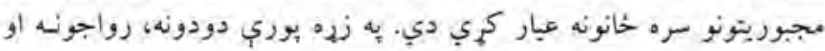

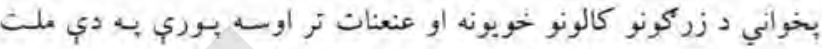

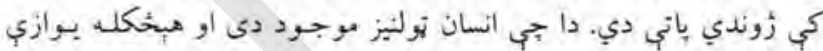

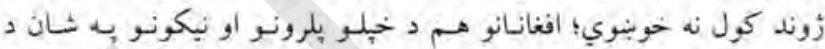

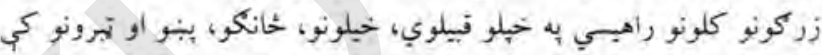

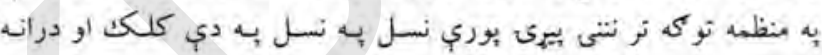

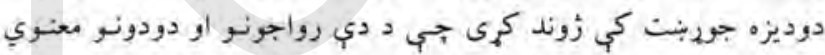

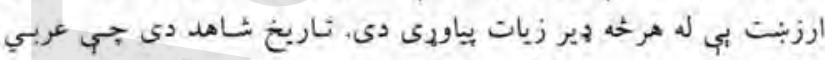

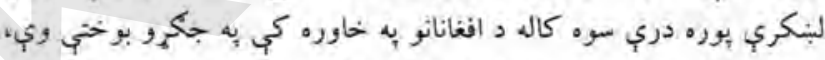

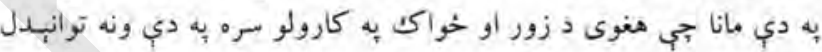

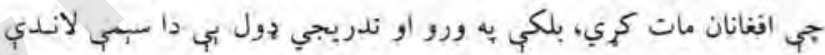

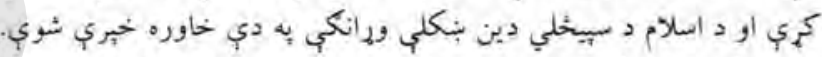

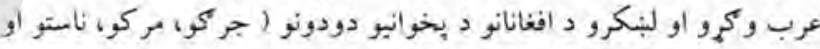

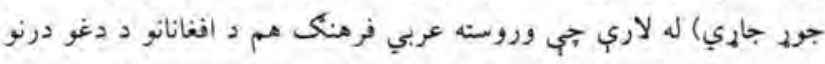

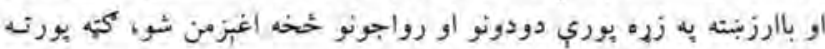

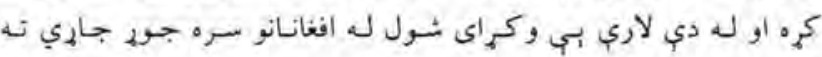

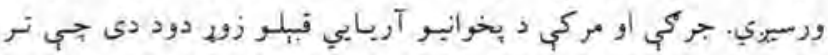

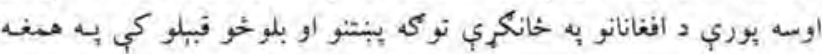

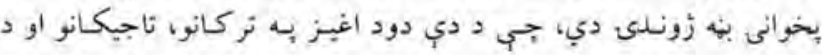

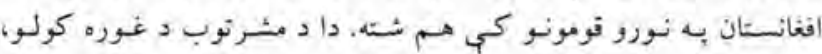

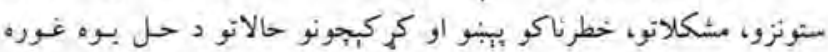

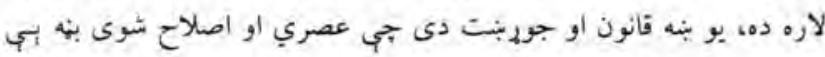

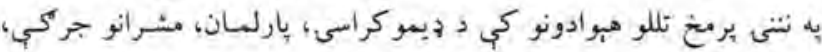

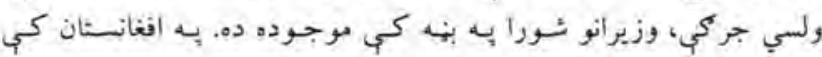

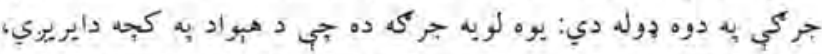

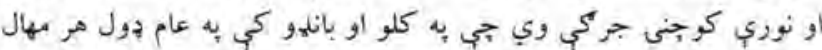

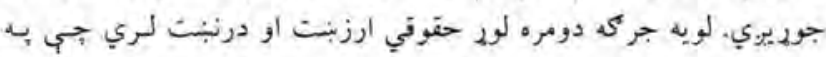

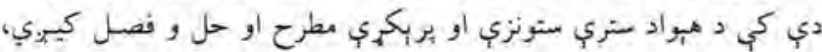

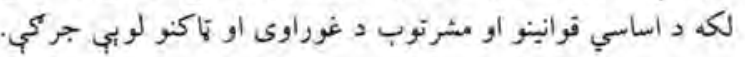




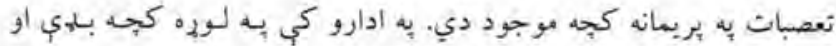

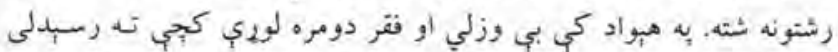

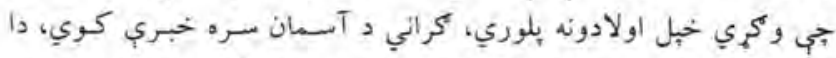

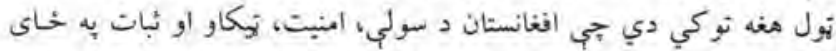

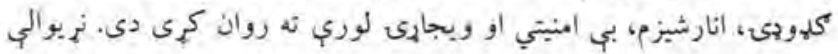

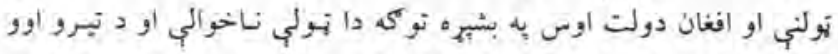

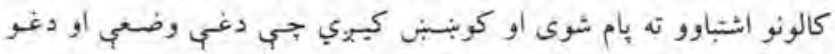

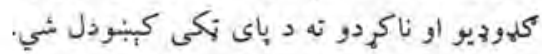

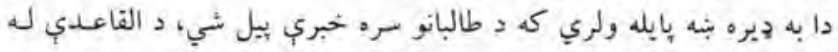

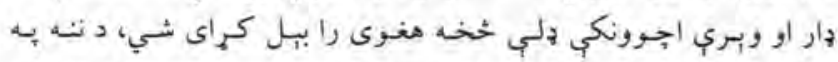

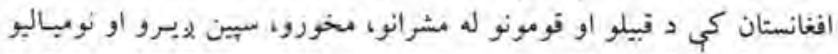

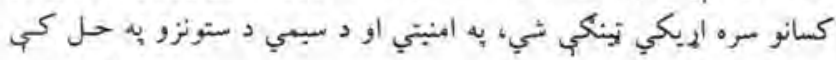

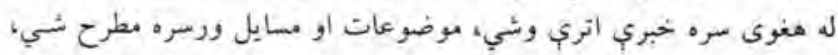

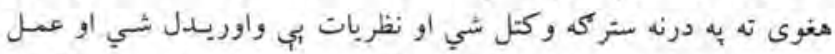

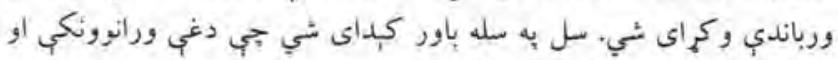

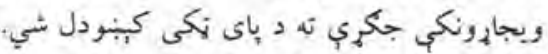

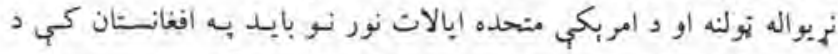

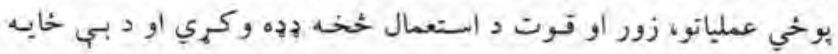

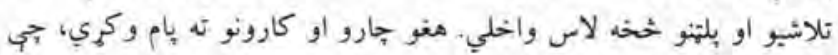

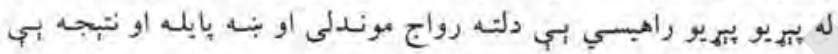

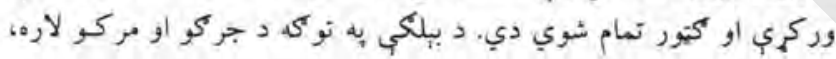

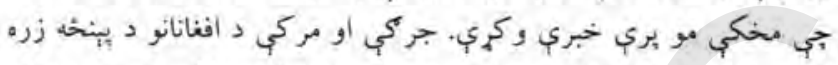

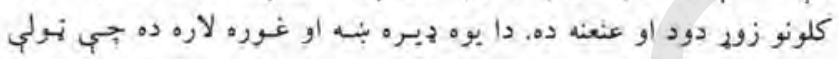

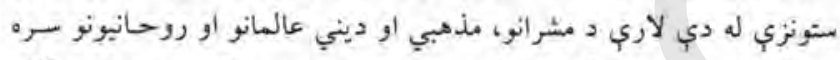

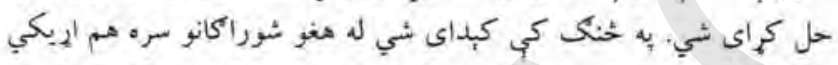

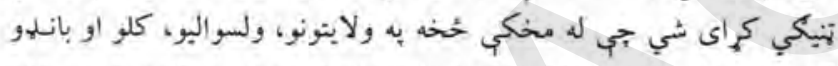

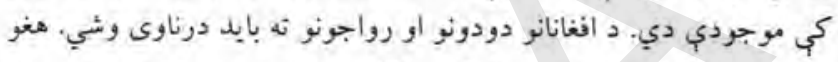

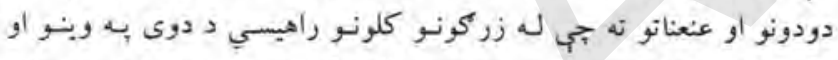

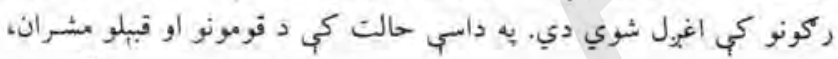

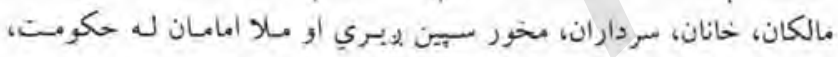

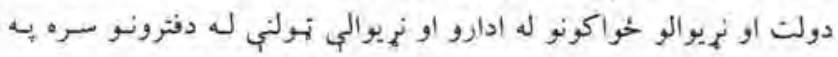

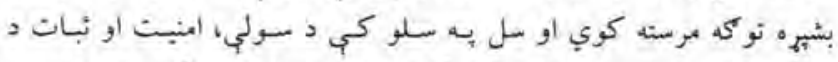

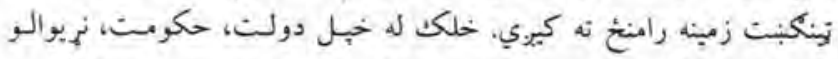

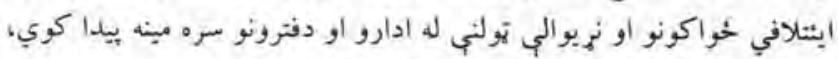

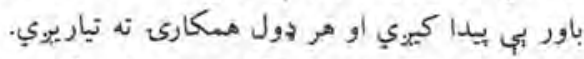

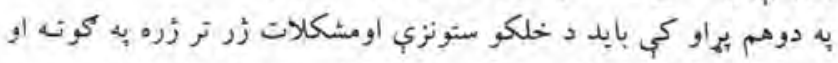

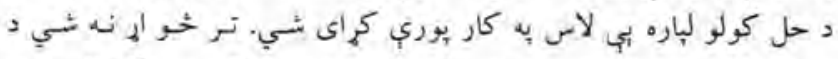

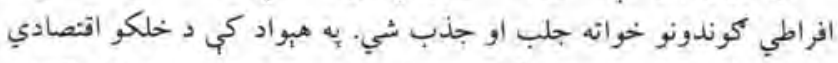

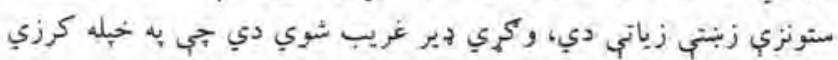

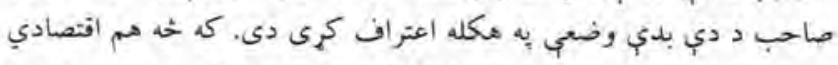

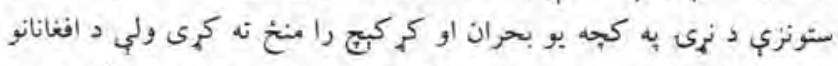

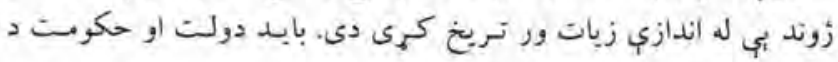

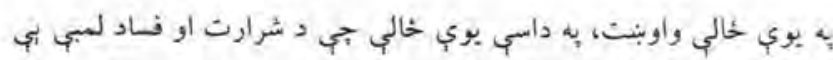

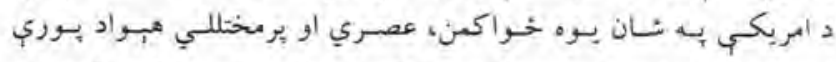

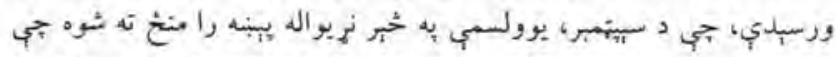

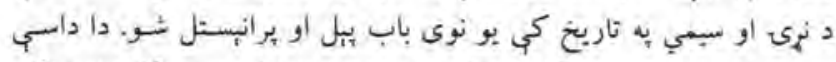

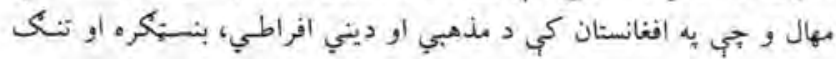

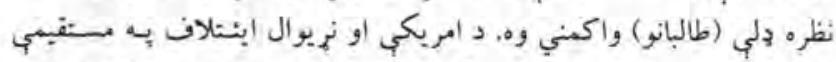

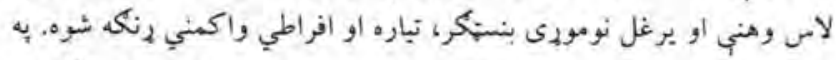

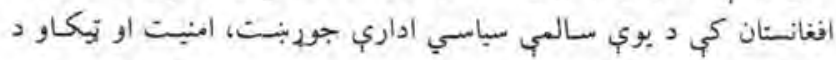

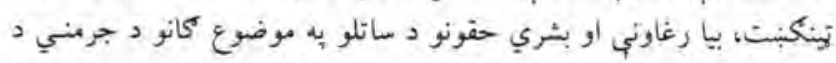

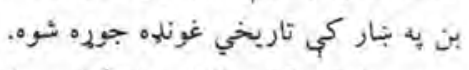

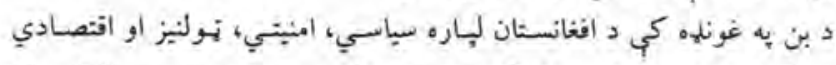

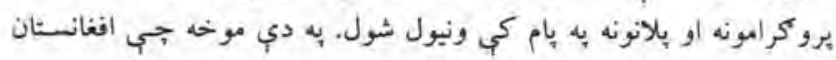

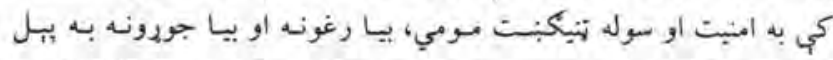

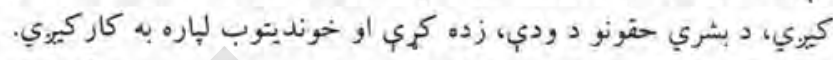

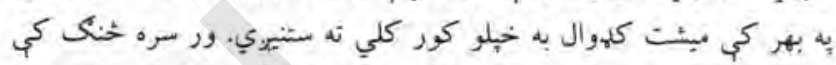

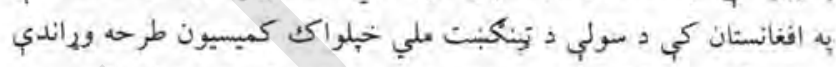

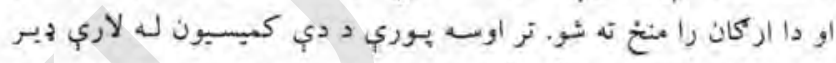

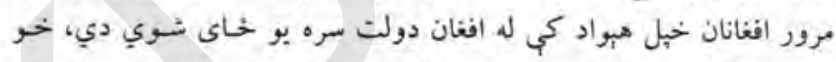

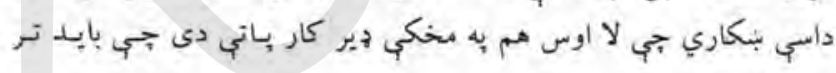

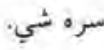

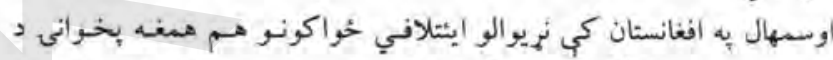

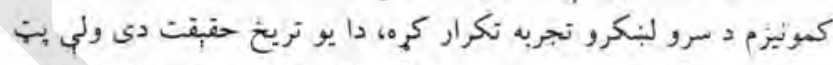

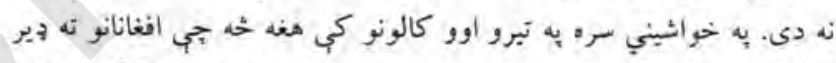

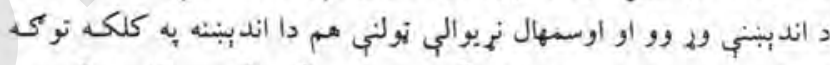

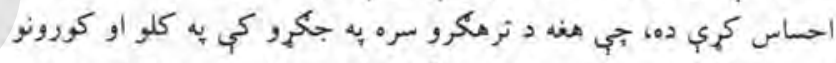

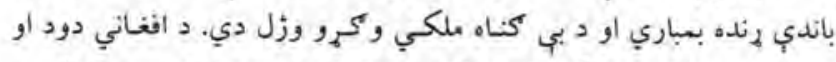

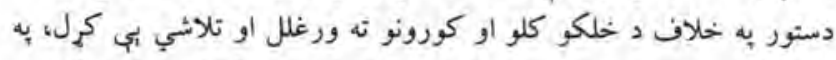

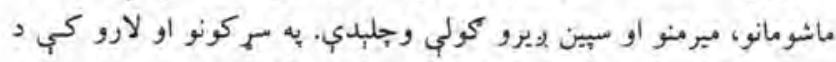

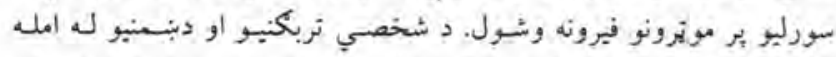

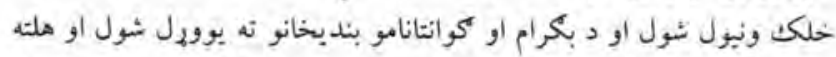

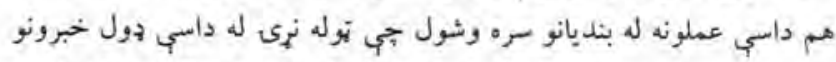

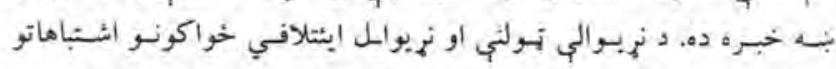

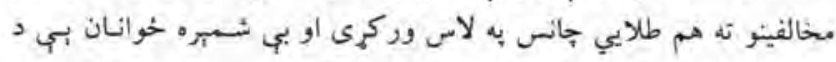

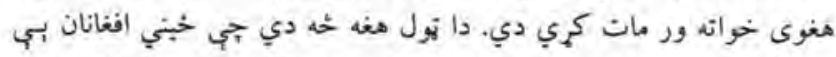

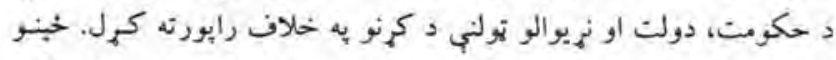

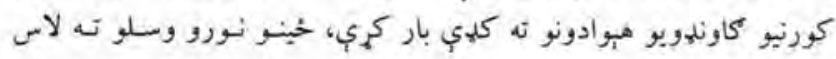

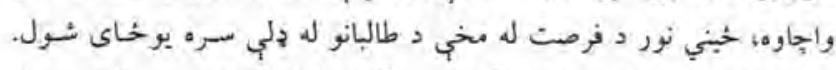

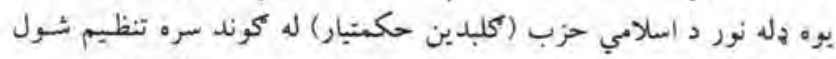

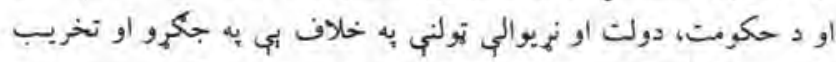

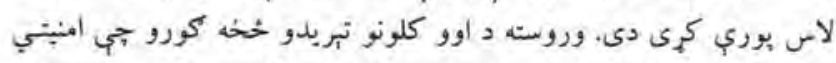

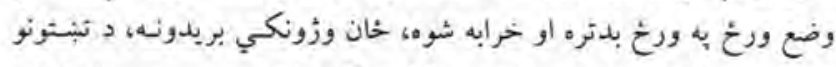

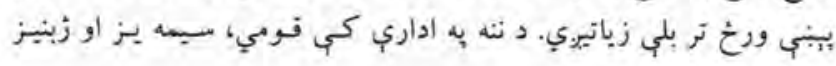




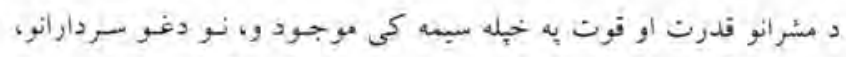

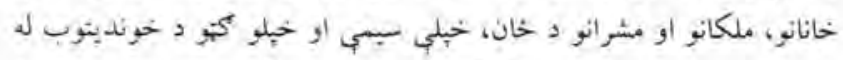

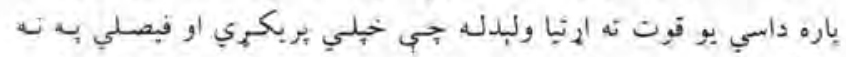

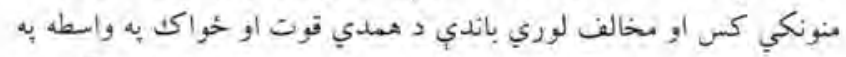

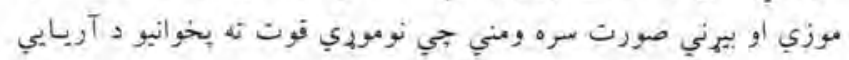

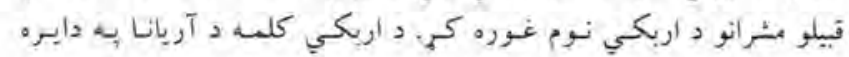

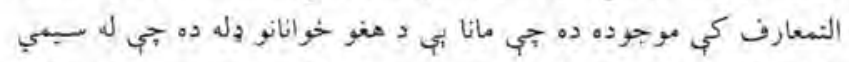

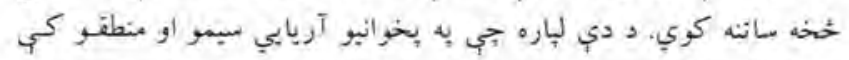

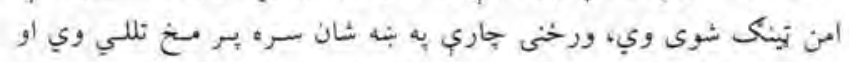

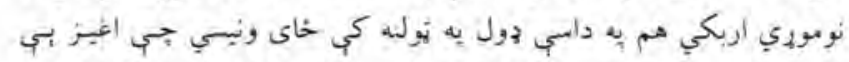

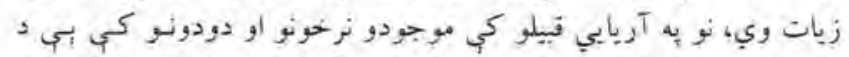

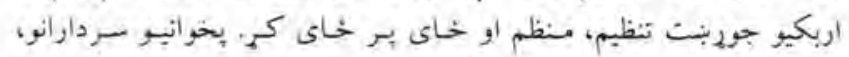

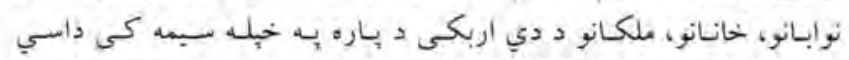

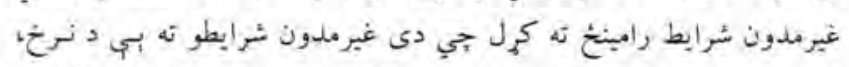

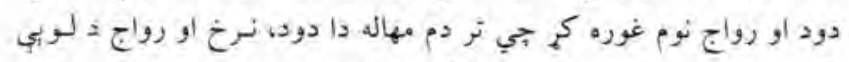

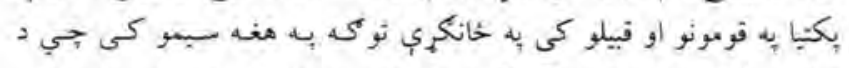

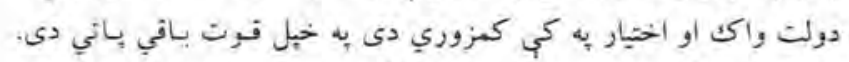

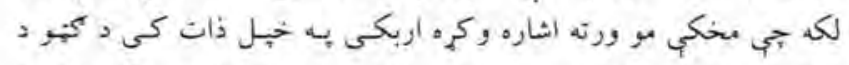

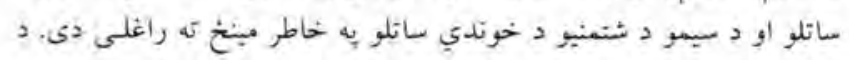

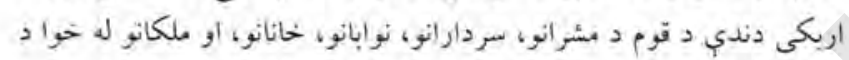

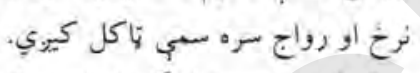

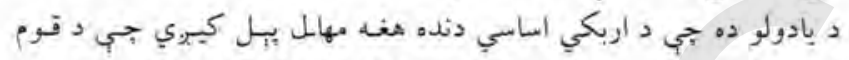

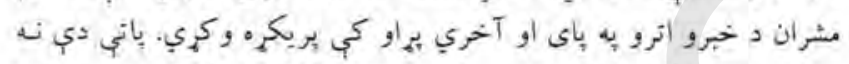

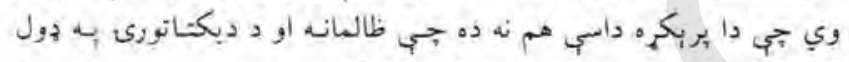

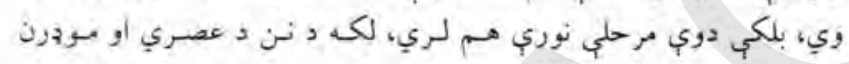

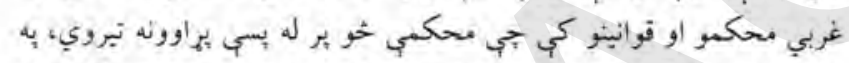

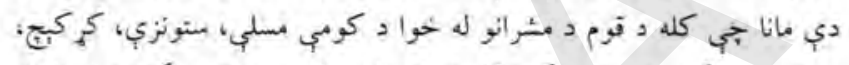

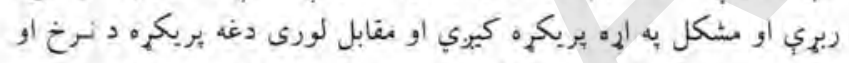

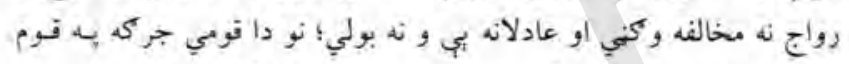

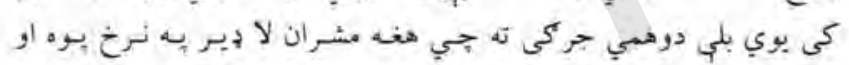

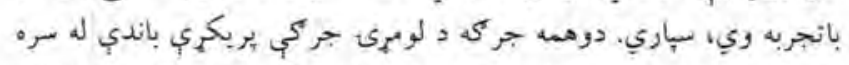

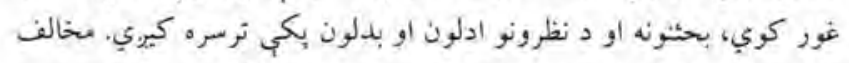

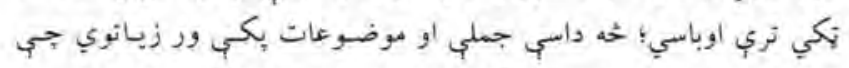

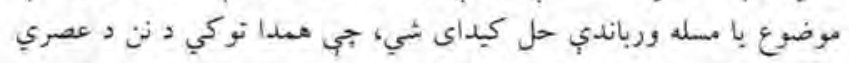

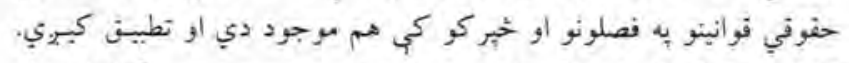

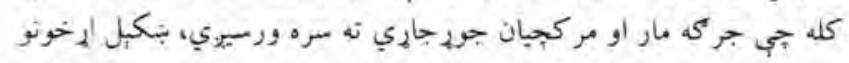

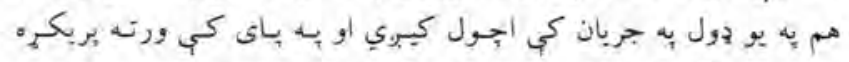

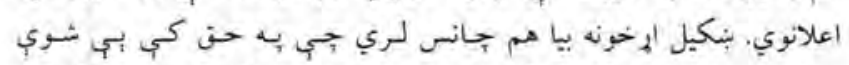

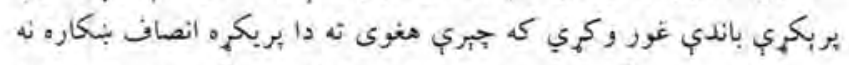

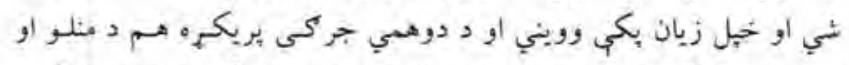

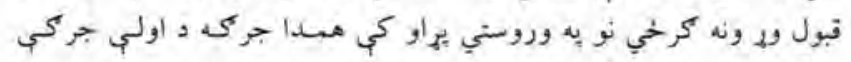

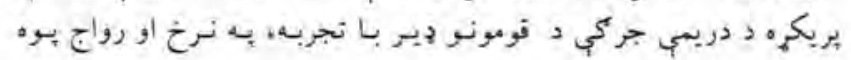

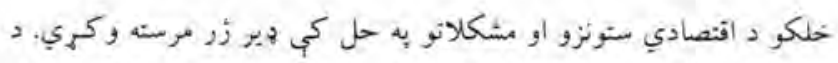

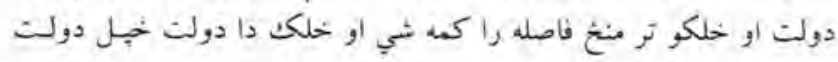

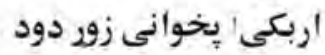

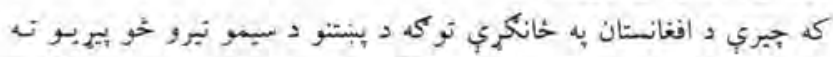

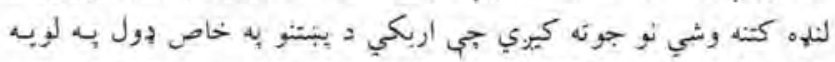

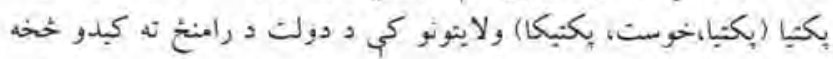

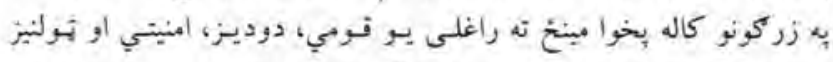

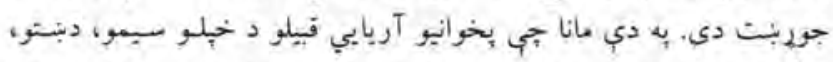

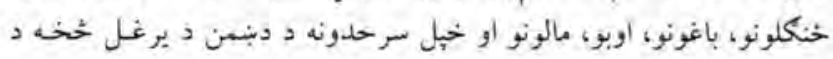

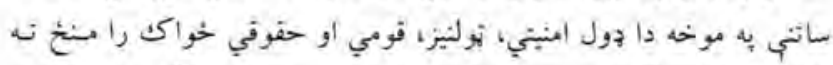

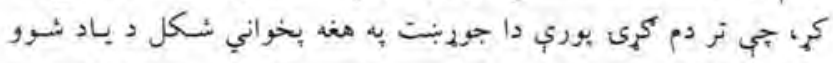

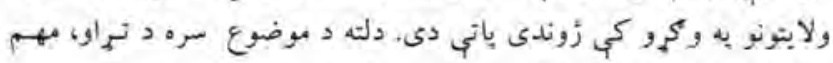

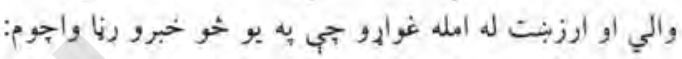

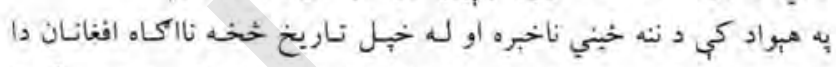

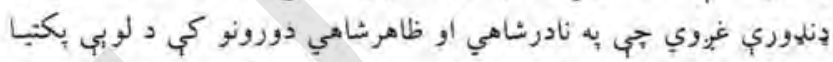

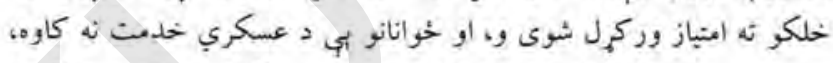

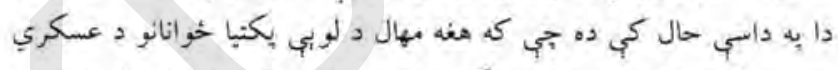

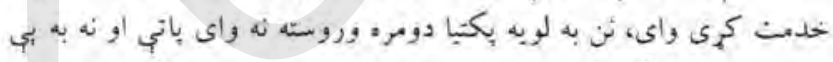

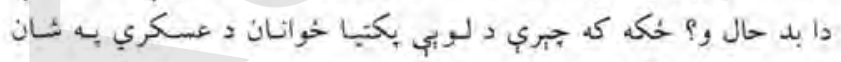

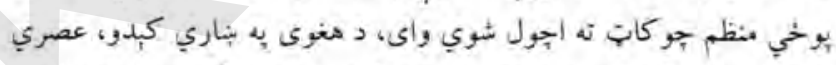

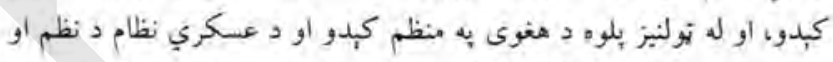

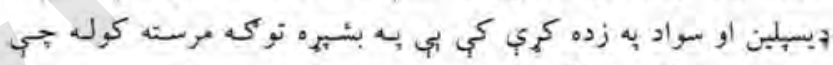

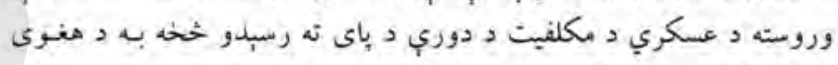

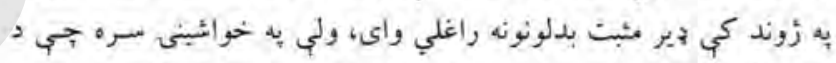

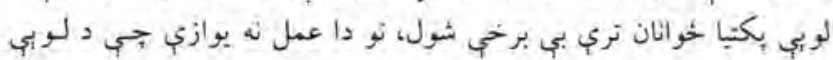

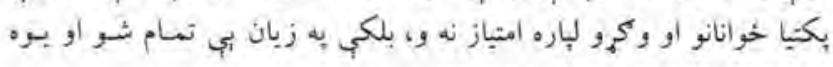

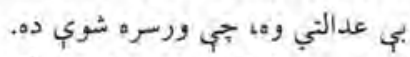

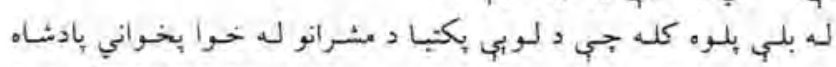

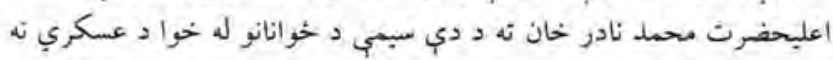

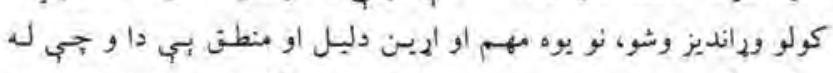

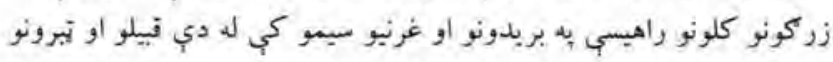

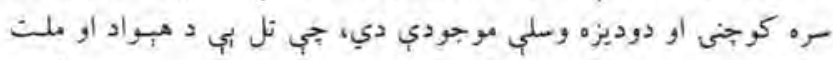

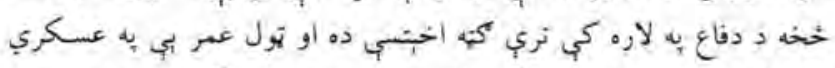

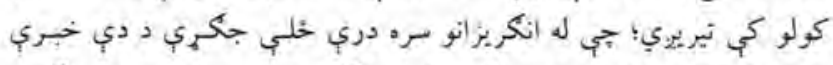

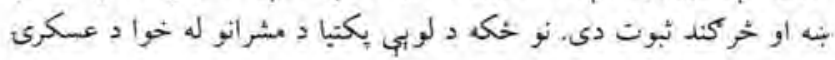

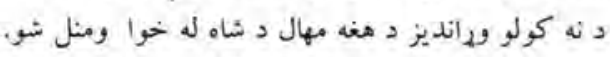

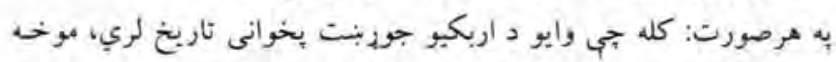

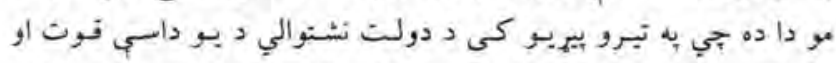

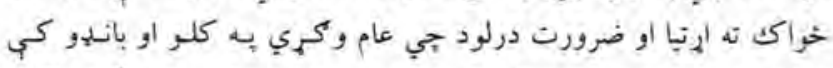

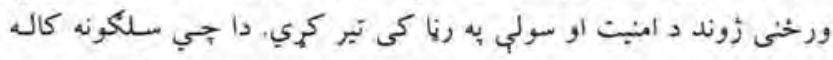

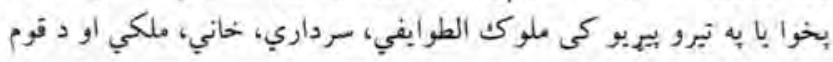


او بكتيكا) فومي شخهو، ستونزو، جكيهو او تربكنيو ته نظر واجبوو، تهولي

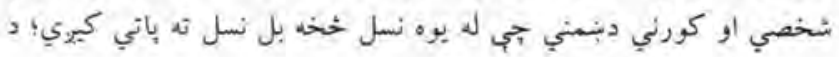

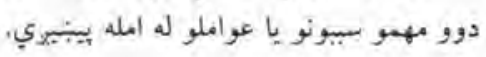
1- ب - حقوفي ستونزي؛

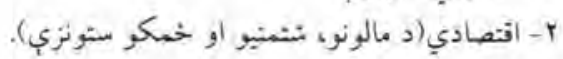

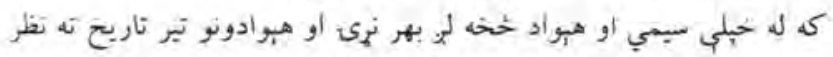

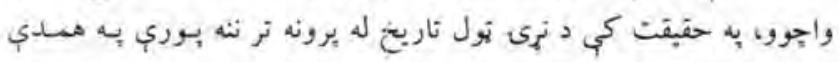

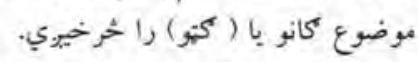

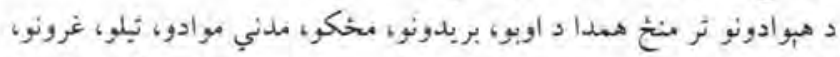

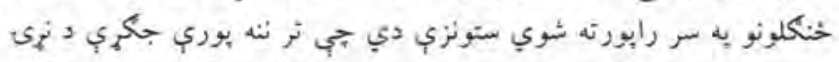

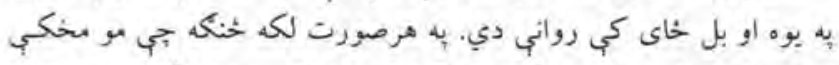

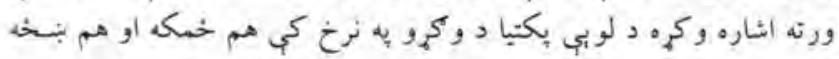

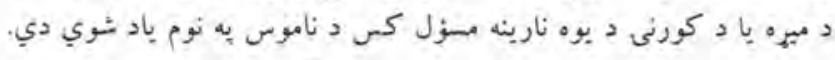

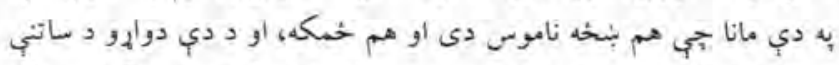

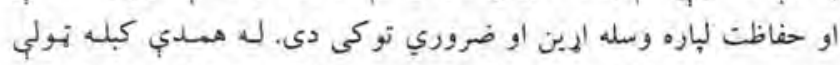

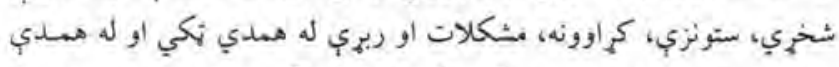

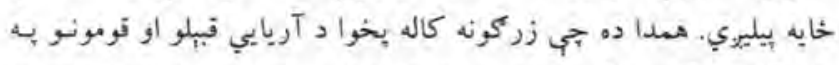

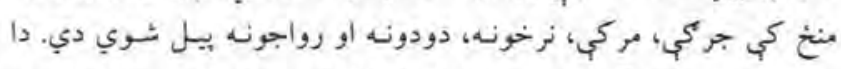

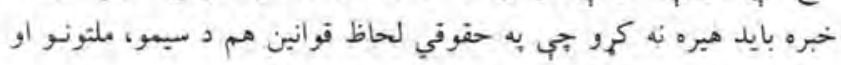

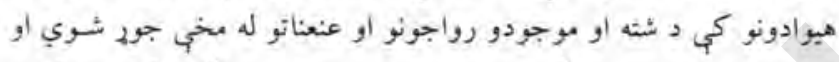

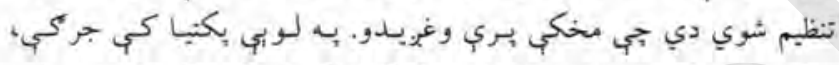

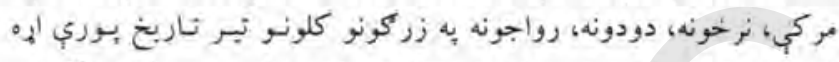

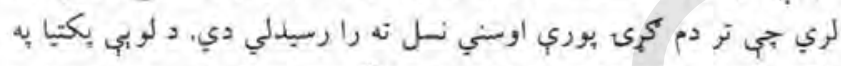

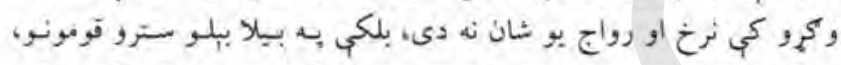

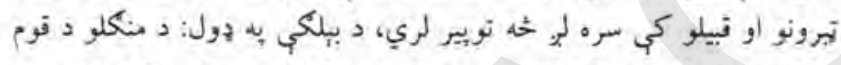

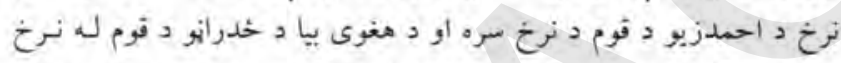

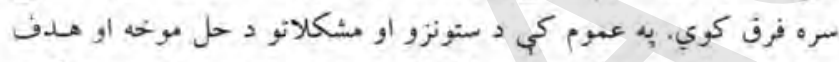

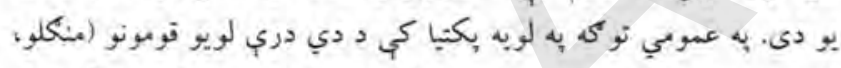

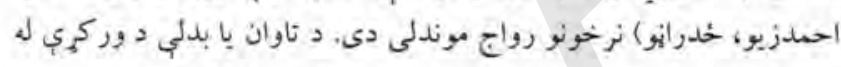

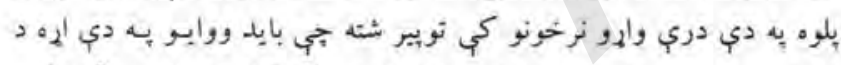

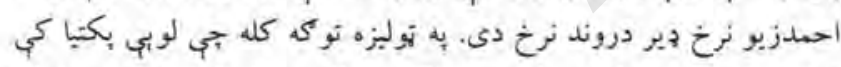

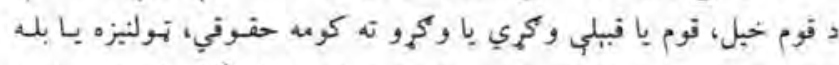

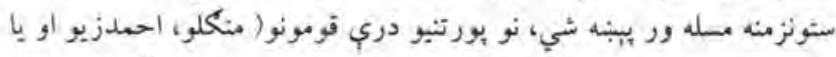

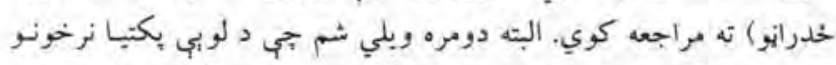

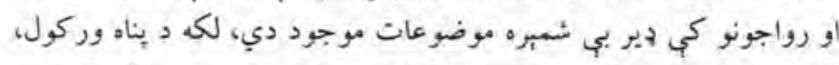

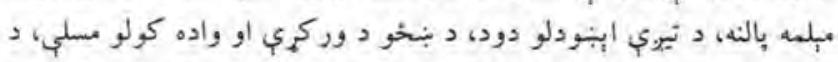

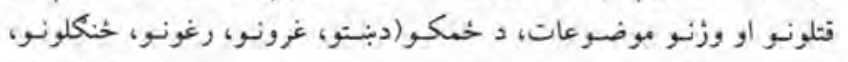

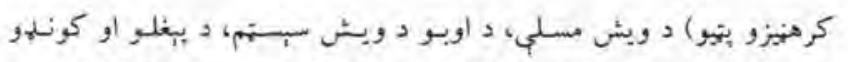

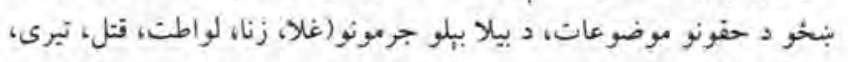

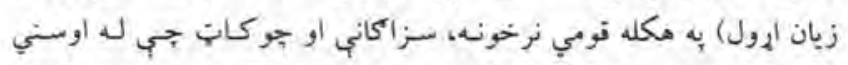

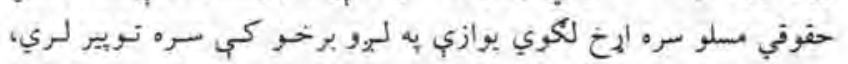

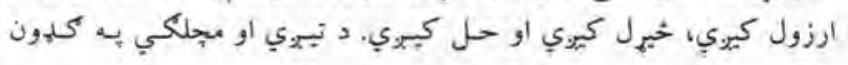

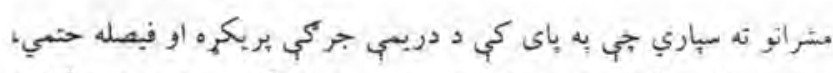

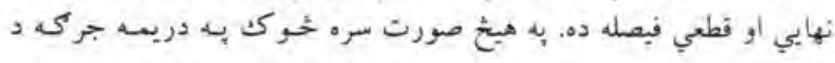

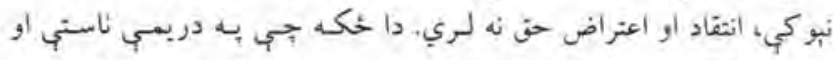

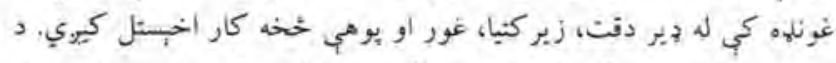

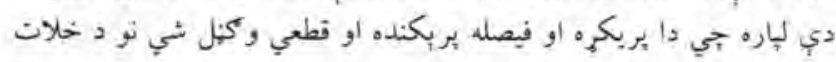

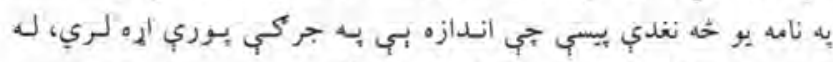

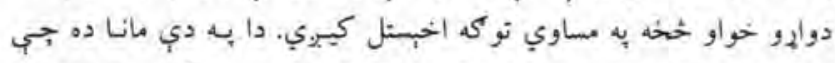

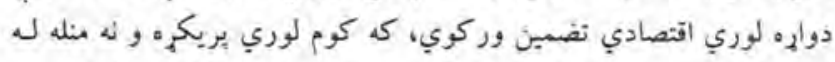

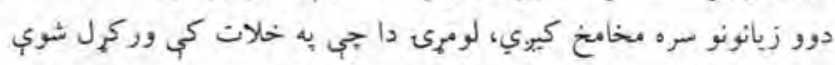

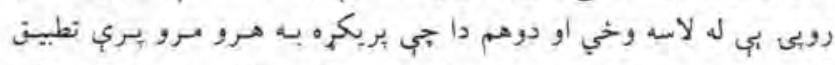

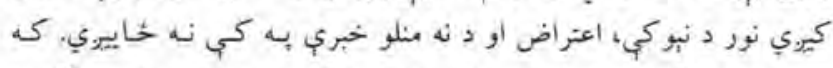

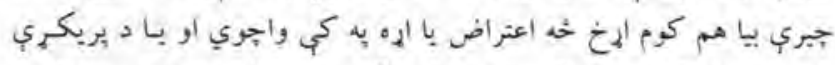

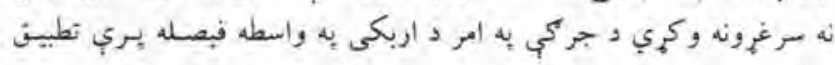

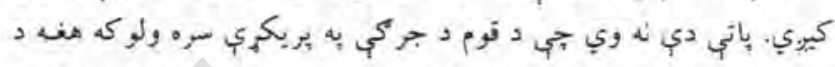

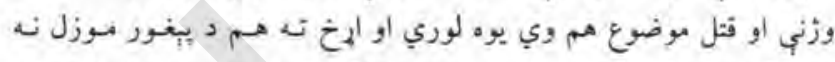

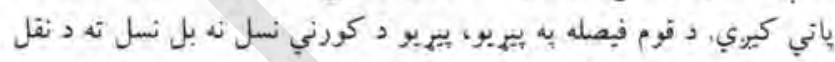

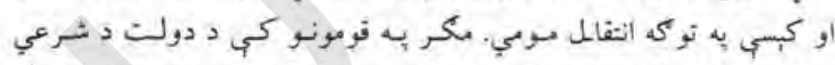

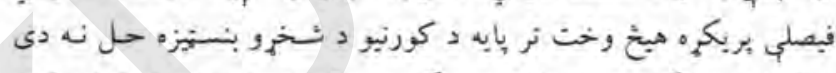

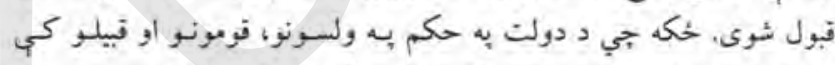

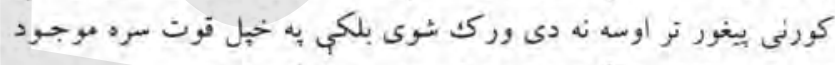

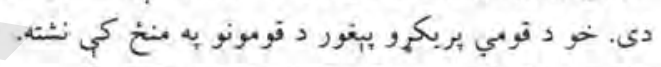

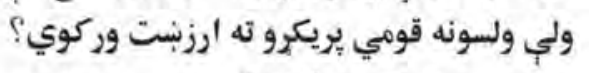

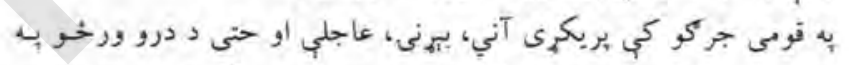

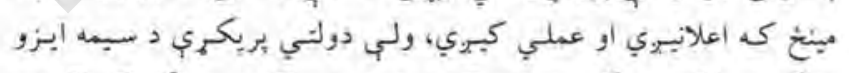

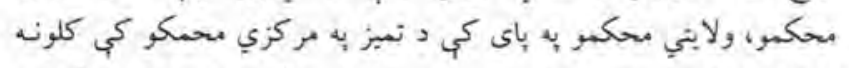

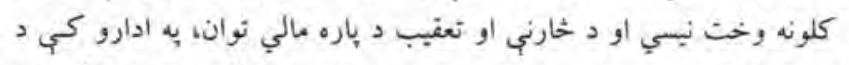

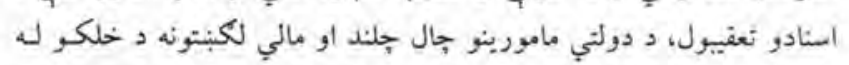

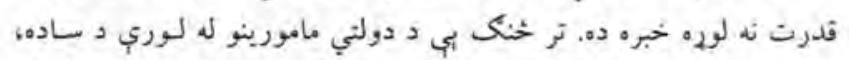

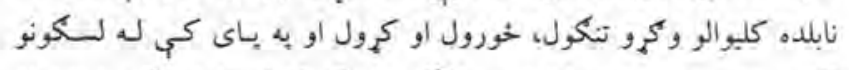

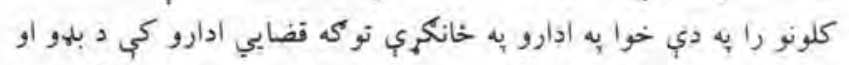

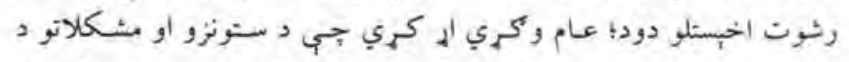

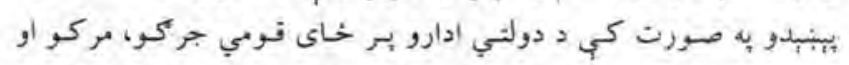

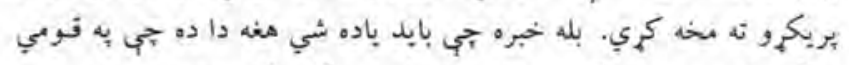

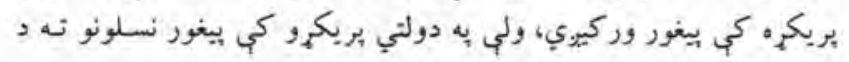

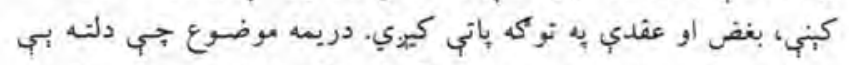

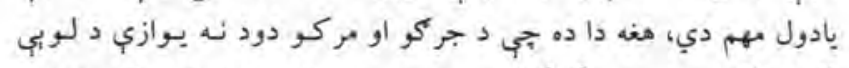

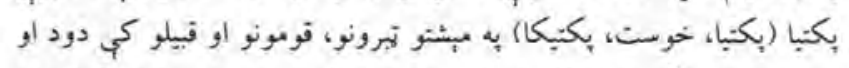

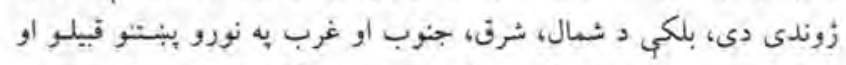

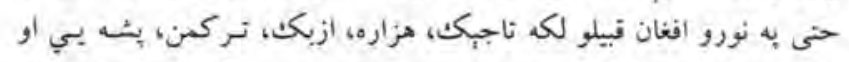

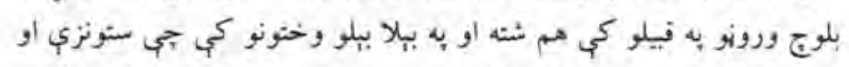

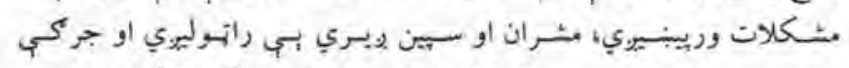

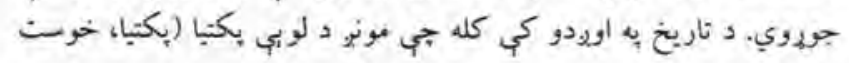




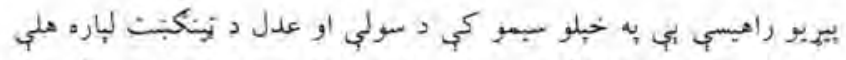

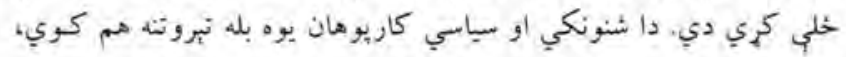

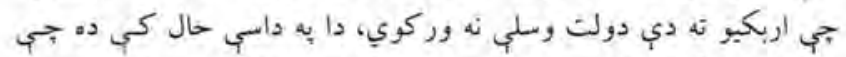

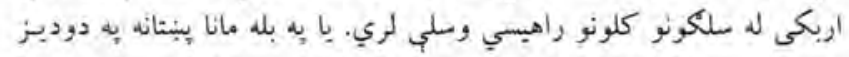

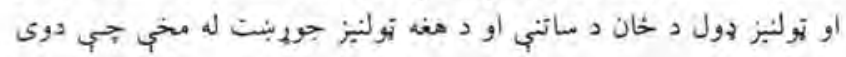

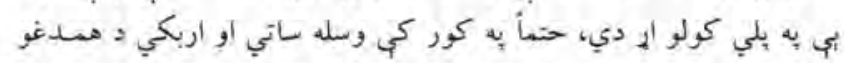

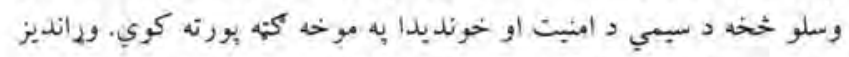

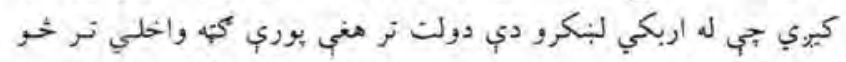

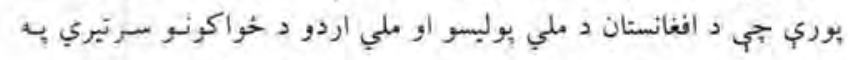

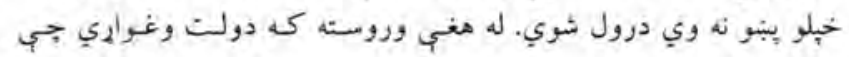

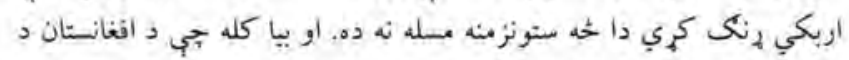

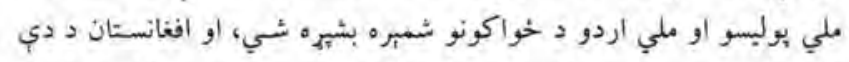

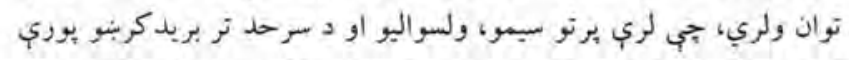

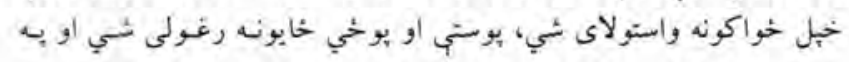

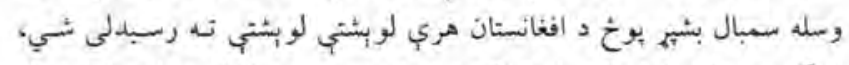

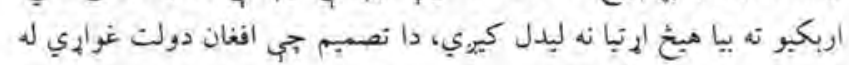

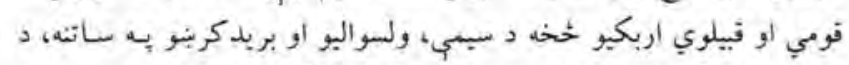

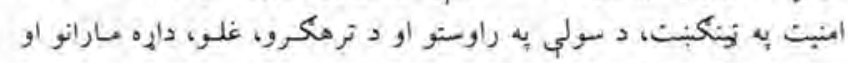

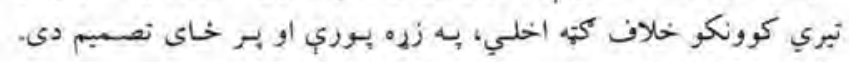

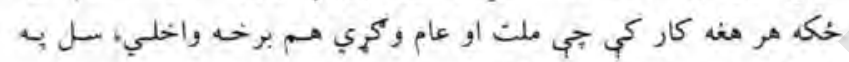
سلو كي بنه بايله او نتيجه وركي كوري.

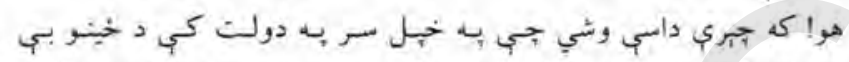

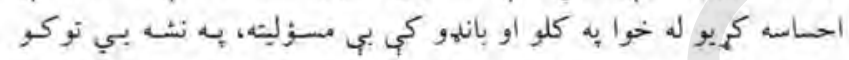

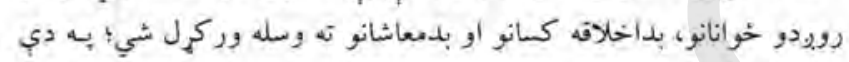

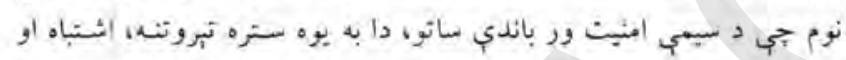

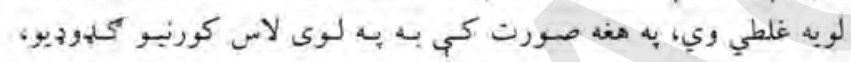

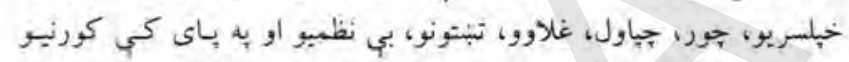

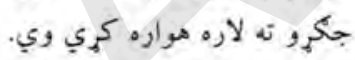
د اربكي جوريست (تشكيل)

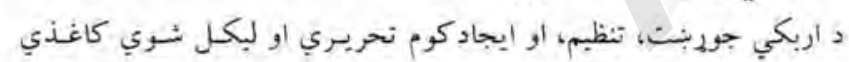

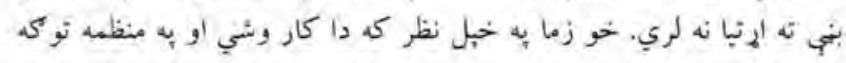

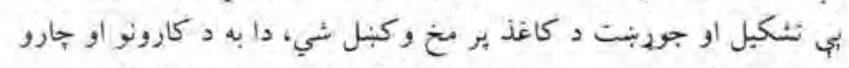

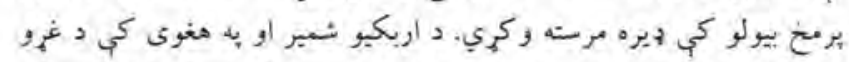

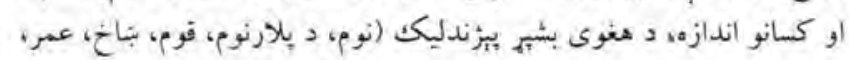

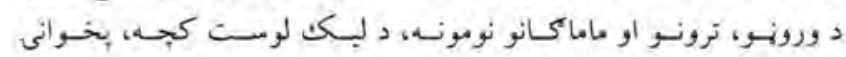

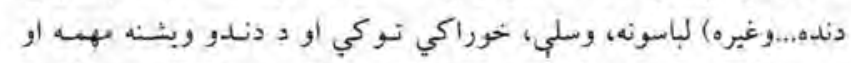

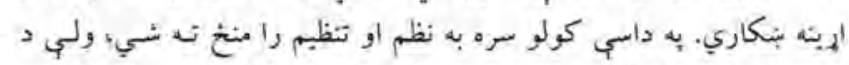

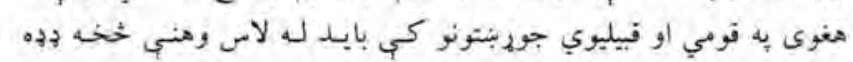

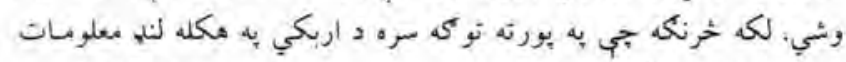

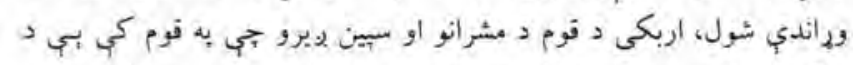

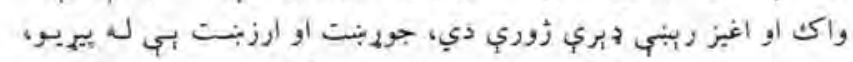

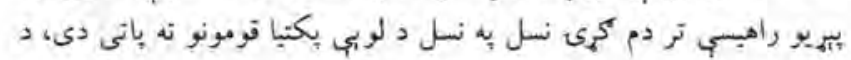

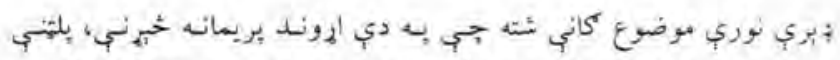

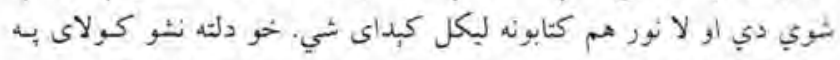

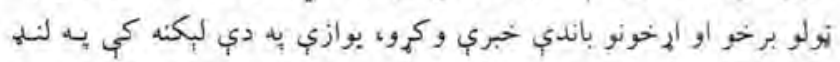

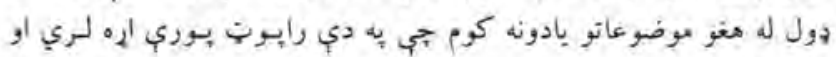

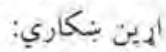

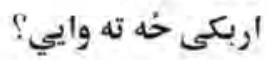

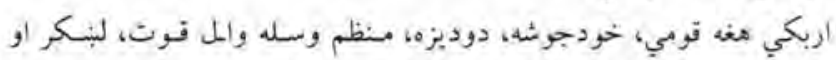

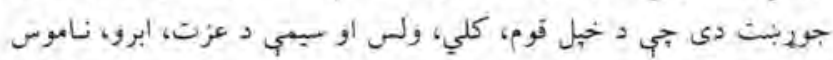

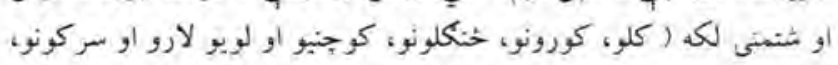

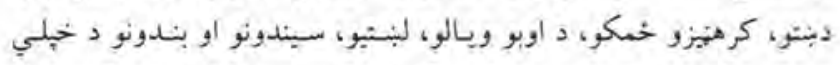

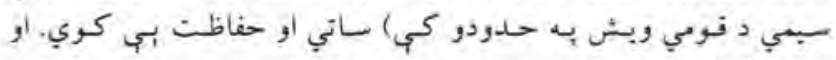

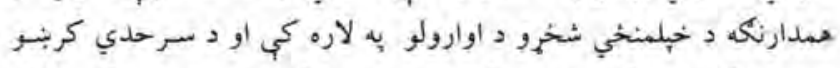

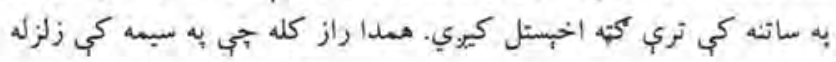

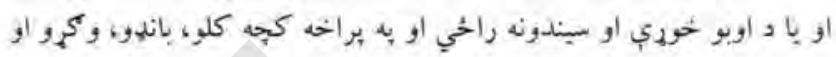

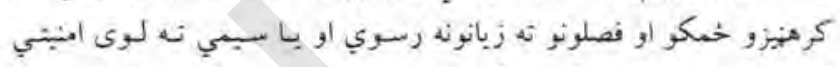

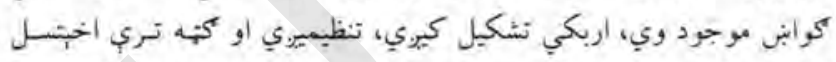

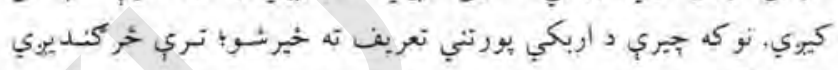

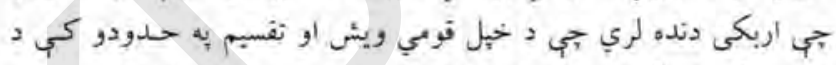

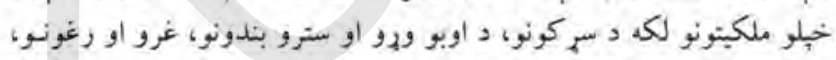

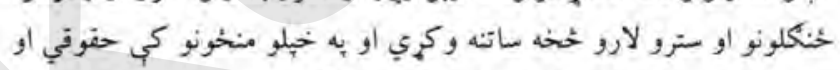

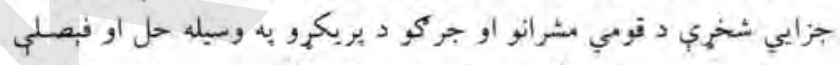

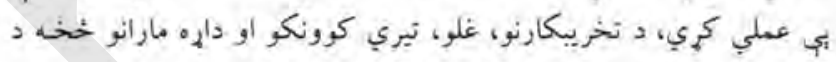

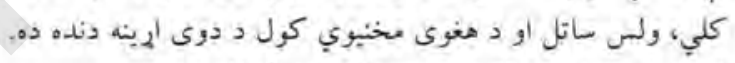

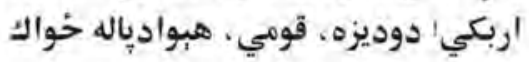

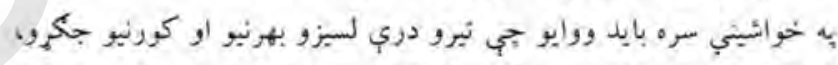

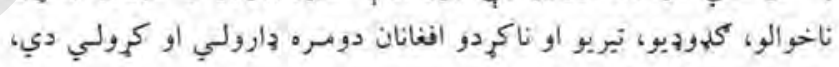

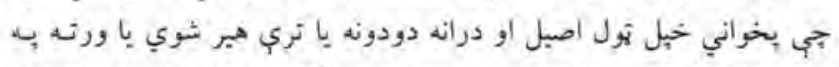

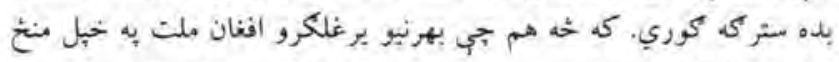

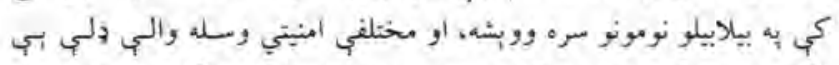

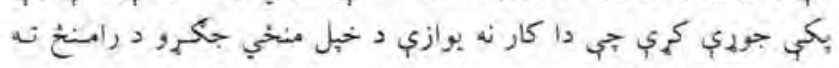

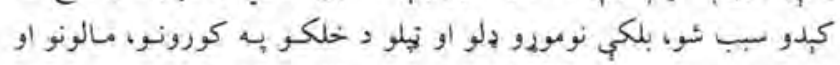

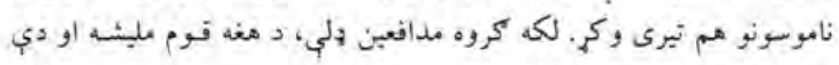
قوم مليثة.

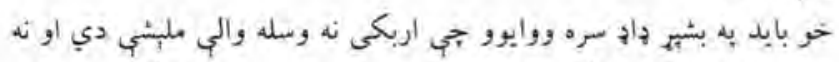

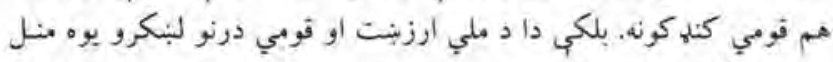

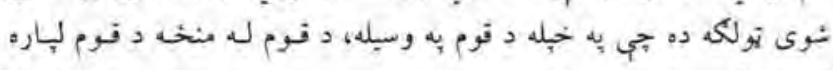

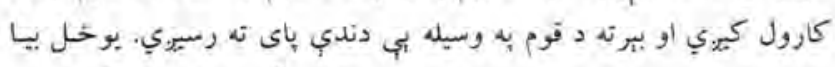

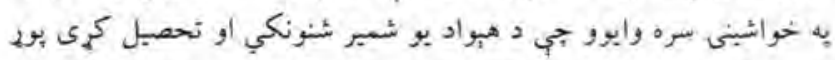

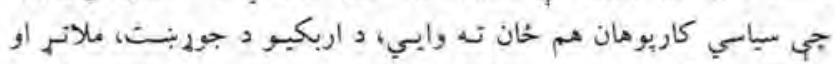

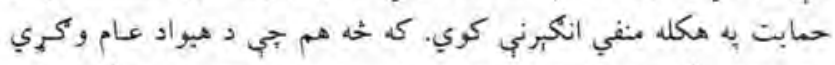

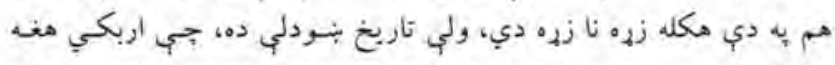

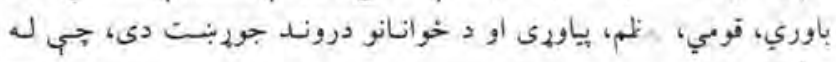




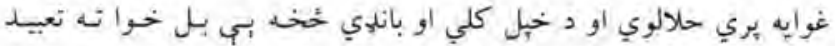

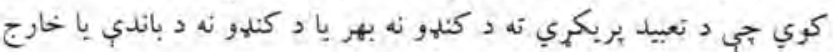
كول ويل كيري.

د اربكي دندي 1ـ اربكي دنده لري جي د د خبلي سيبي امنيث د مشرانو به دستور، هبابت

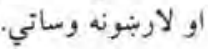

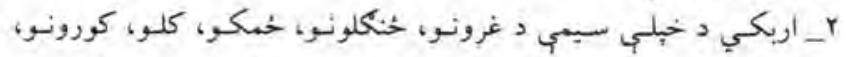

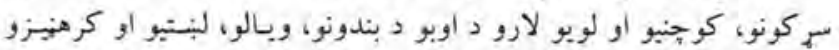
خمكو ساتل به غائه لري.

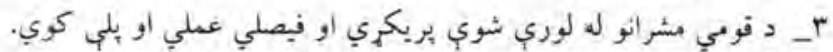

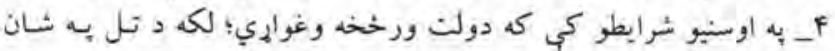

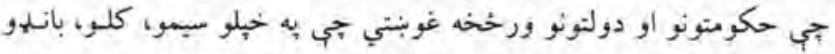

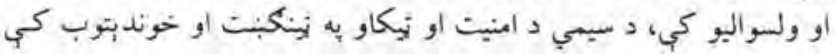

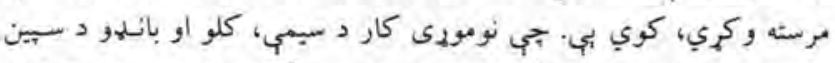
لايرو، مشر انو او مخورو ملكانو سره همغريى، همكاريى او خبرو اترو ته إئنيا

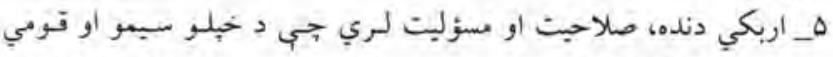

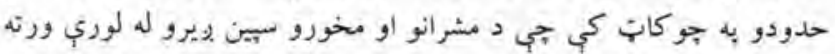
هدابت كيري، دنده تر سرة كمئي.

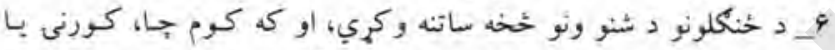

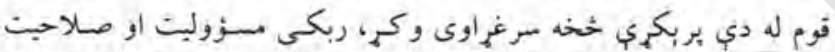

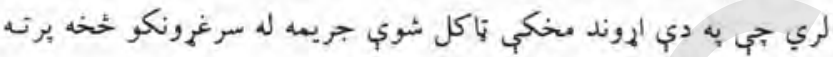

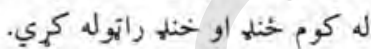

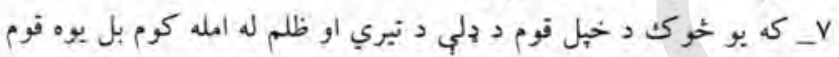

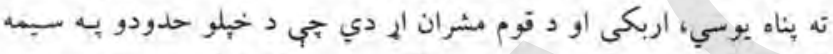

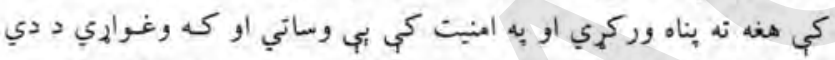

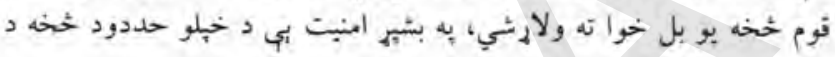

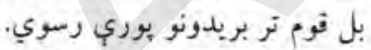

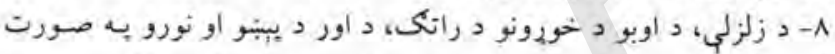

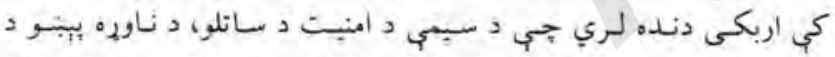

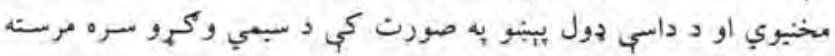
وكري.

\section{خنكه كولاى شو جي اربكي وكمارو؟}

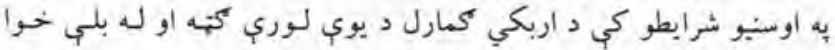

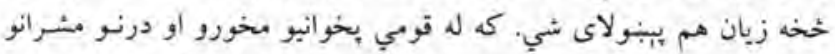

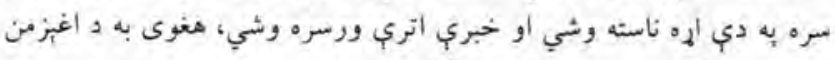

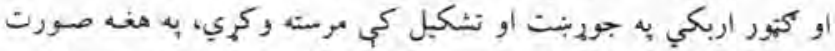

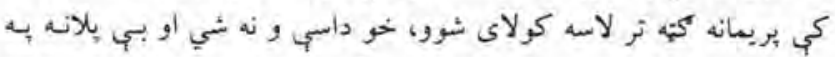

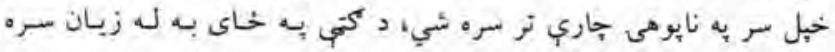
مخانغ شور.

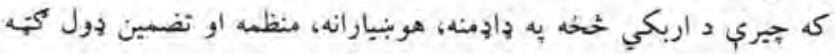

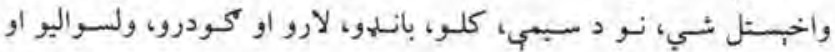

يورتنيو باد سوو إيتياوو او ضرورنونو ته به لبدو سره، اربكي تشكيل، جودل

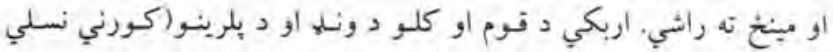

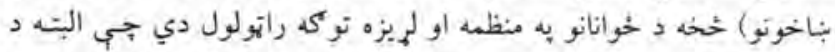

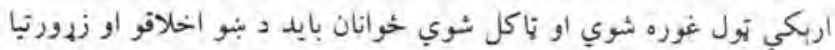

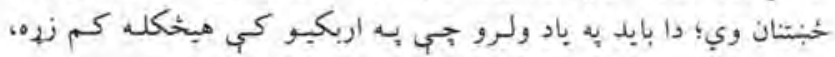

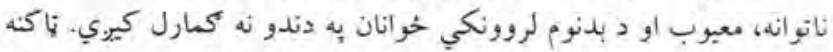

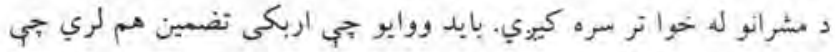

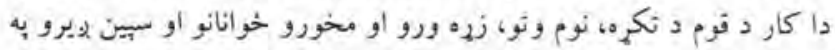

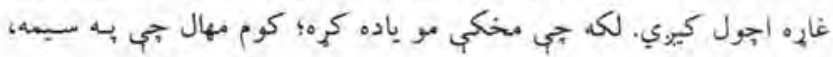

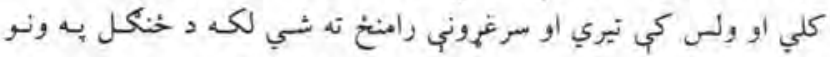

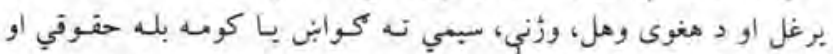

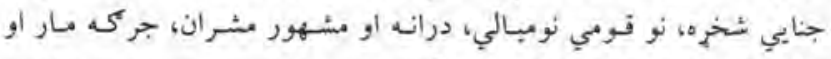

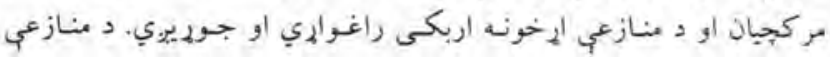

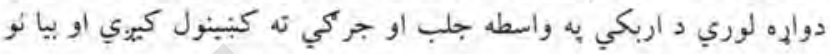

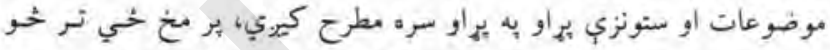

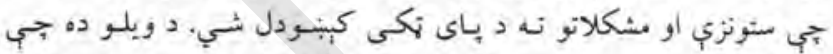

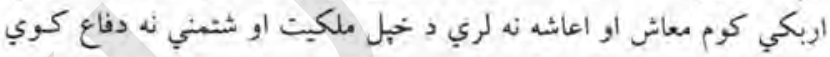

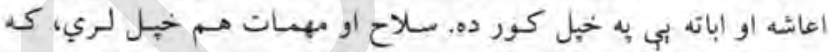

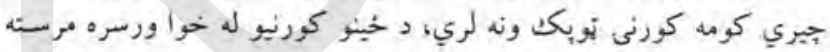

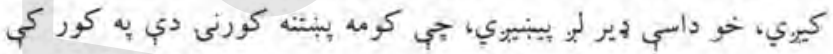

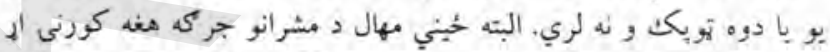

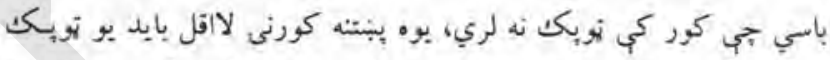

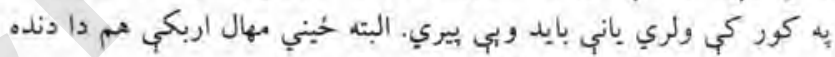

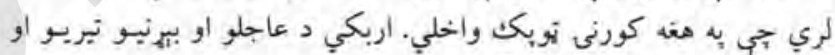

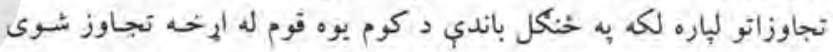

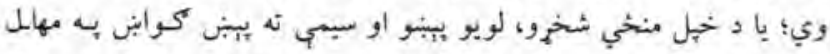

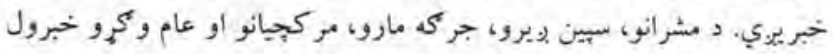

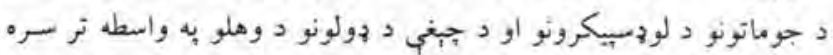

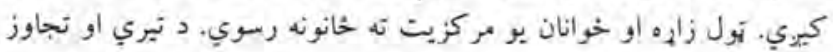

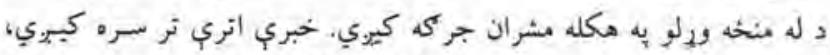

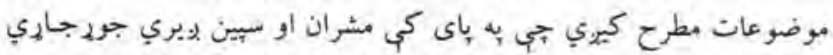

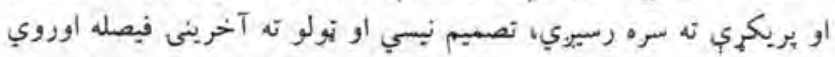

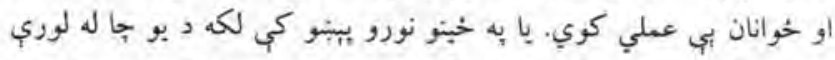

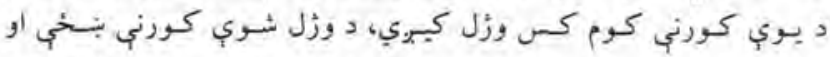

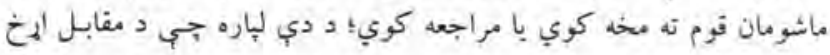

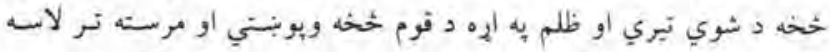

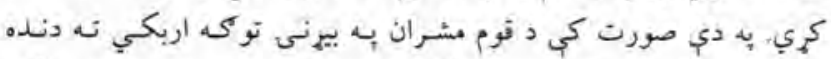

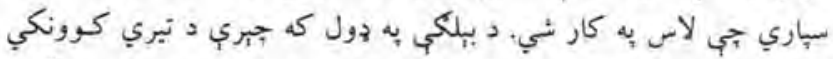

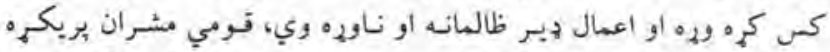

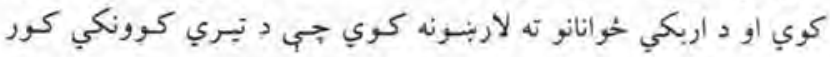

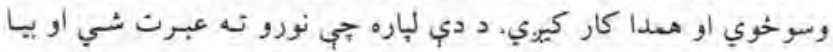

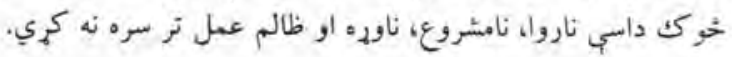




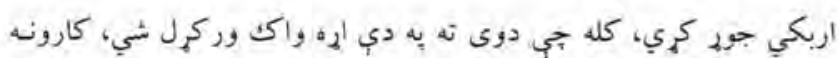

به خجله سمون مومي.

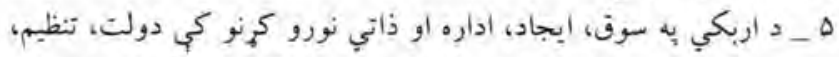

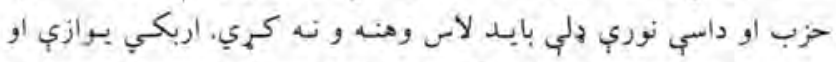

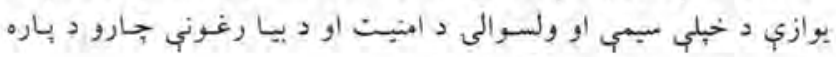

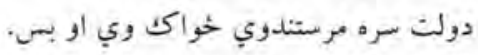

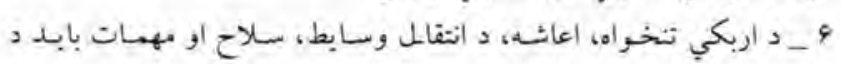

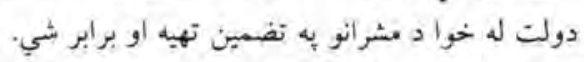

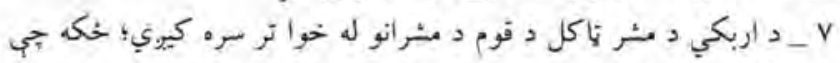

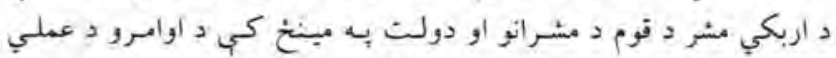

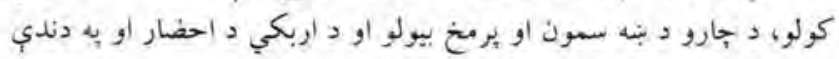

$$
\text { د مكارلو مسوليث لمري. }
$$

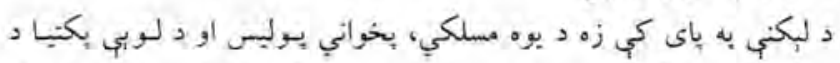

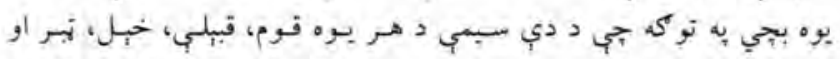

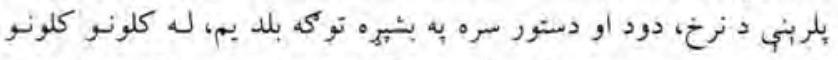

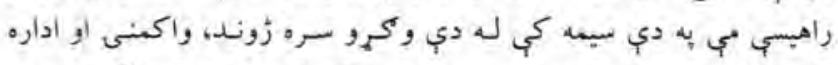

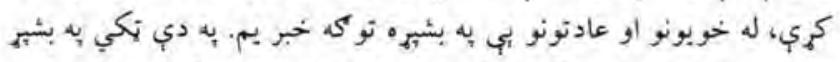

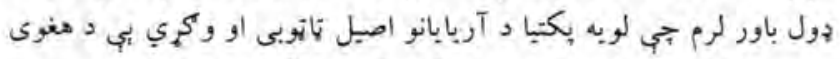

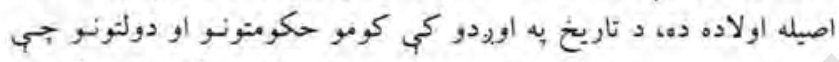

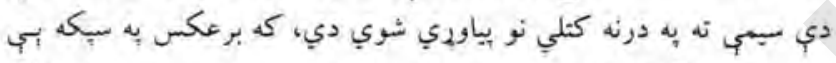

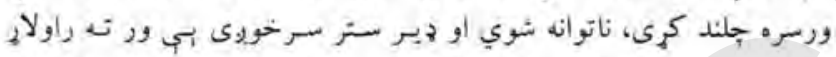

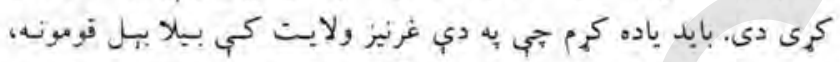

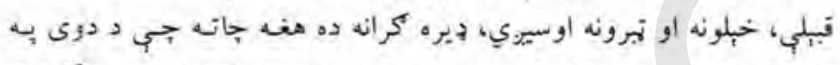

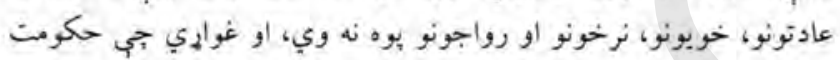
إبري وكري.

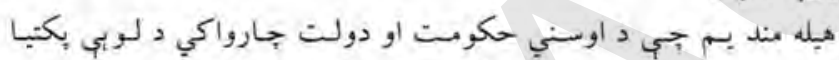

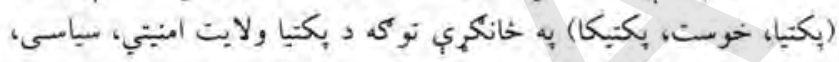

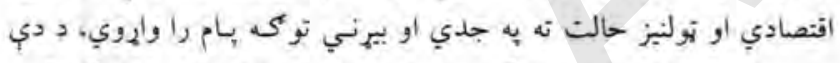

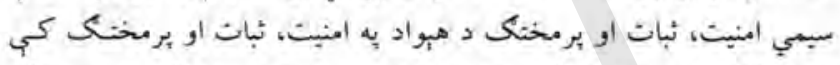

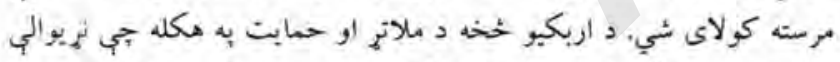

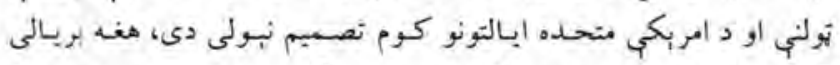

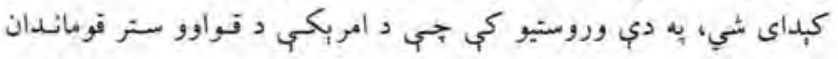

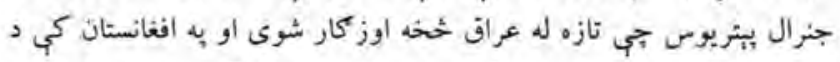

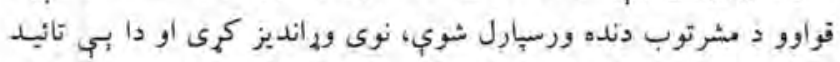

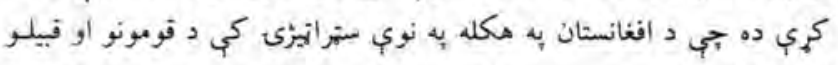

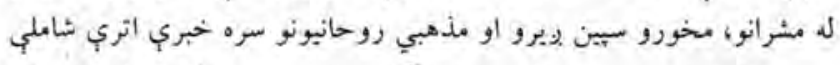

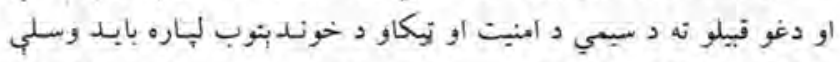

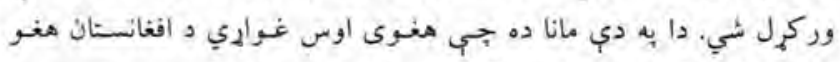

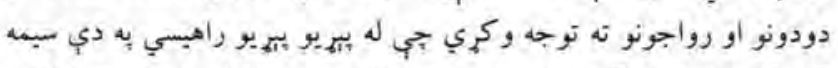

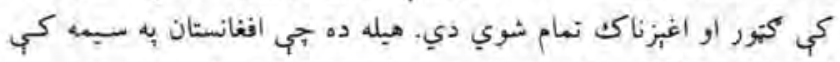

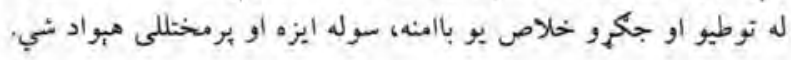

$$
\text { سر حدي بريد كربنو به امنيت كي اغبرُ شبندلى شي. }
$$

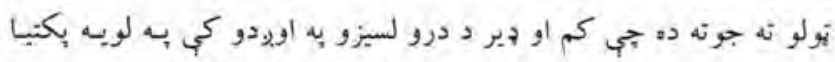

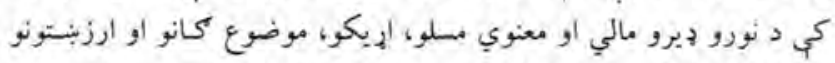

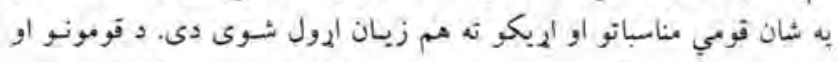

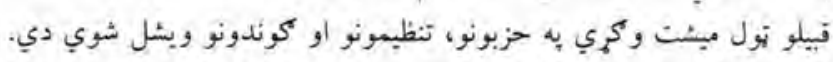

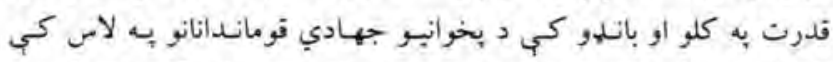

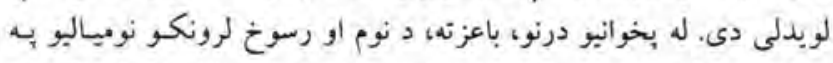

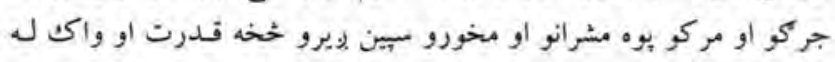

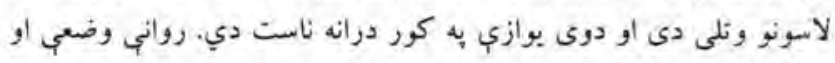

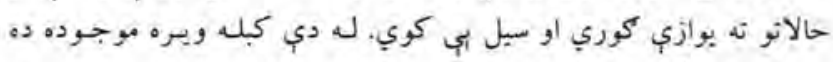

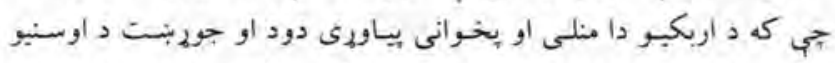

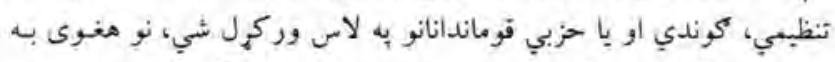

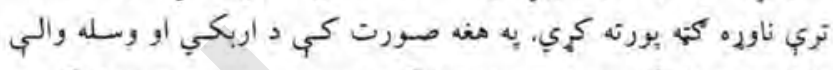

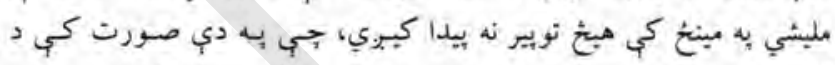

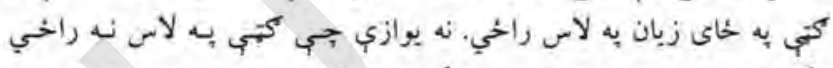

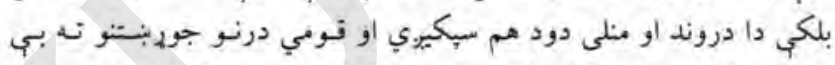

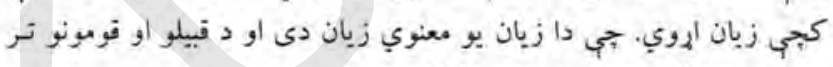

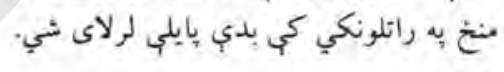

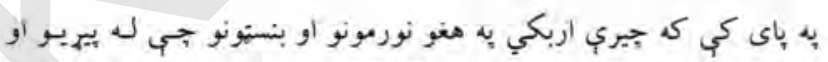

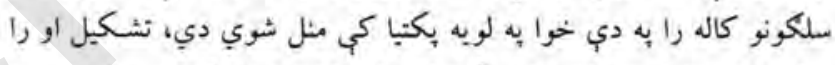

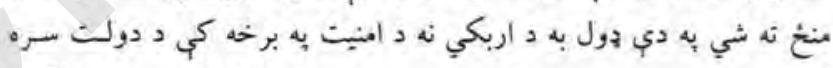

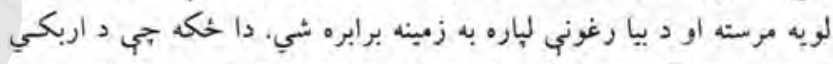

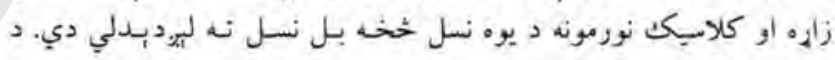

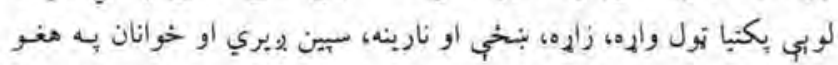

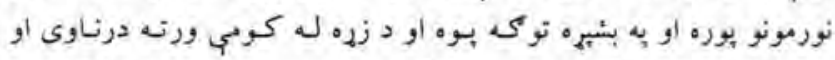

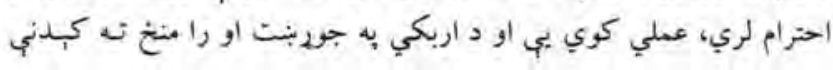

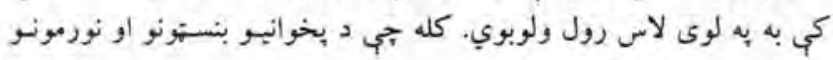

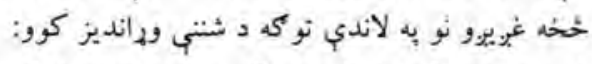

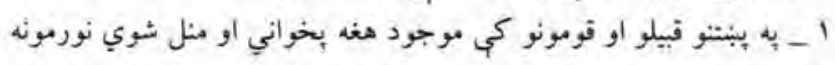

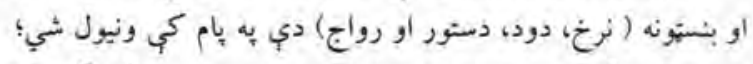

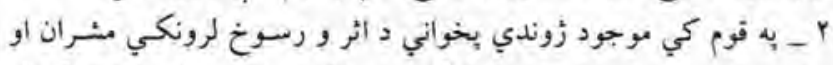

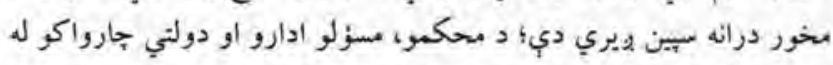

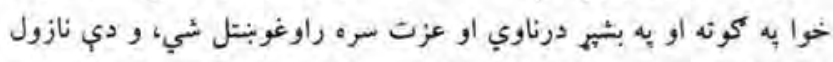

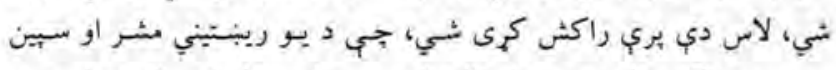

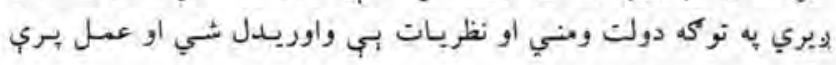
وكراي شي.

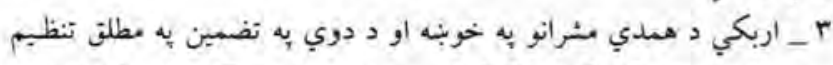

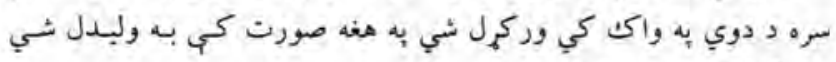

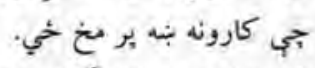

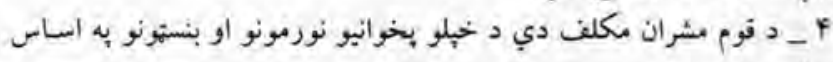




\section{مشر انو جر كَه، شوراى ملى افغانستان و}

\section{وزارت دولت در امور خارلمانى}

از فعاليت ها و دست آوردهاى وزارت امور خارجه اظهار سِاس و قدردانى كرد

بين المللى آن مجلس بعـــ از ارزيسابى نشسـت روز

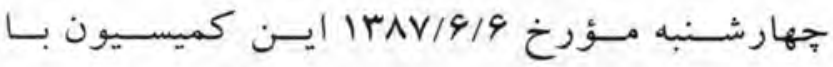

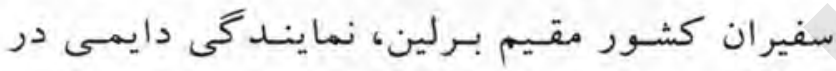

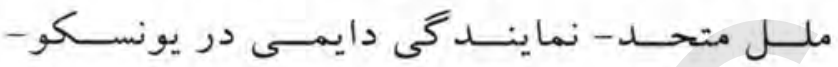

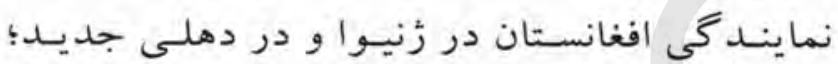

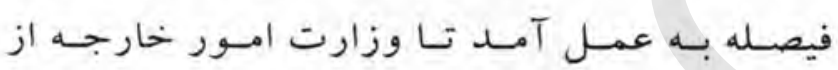

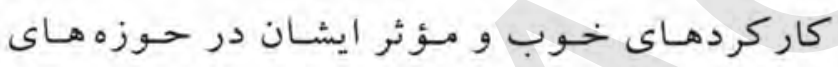
كارى مربوط، تحسين و تقدير نمايند.

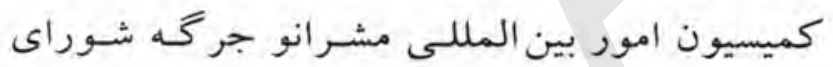

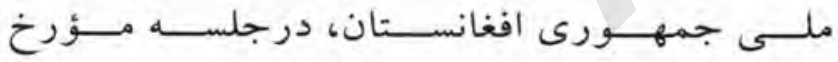

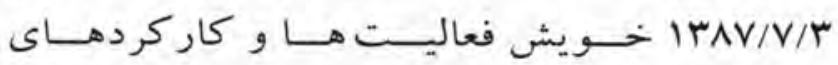
مديريت امور يارلمانى، وزارت امور خارجه را كه

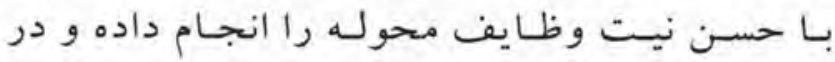

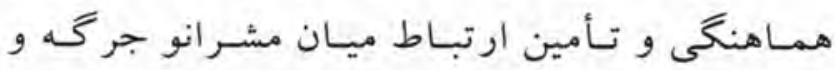

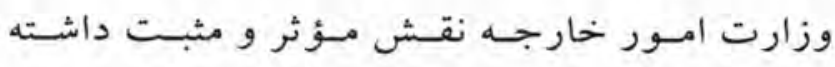

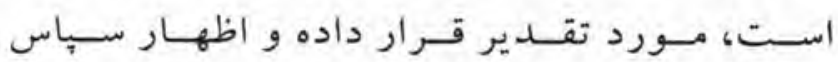
مى منمايد.
وزارت دولـت در امــور هارلمــانى، نائسبـ اول و سريرست مشرانو جرگه از دست آوردههاى وزارت امور خارجه درعرصه هاى مختلف اظهار سـياس و و

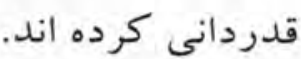

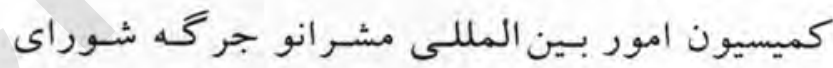
ملى جمهورى اسـلامى افغانستان در جلسـه مـؤرخ IrAV/V/T جلد ياسيورت و در اختيار قرار دادن آن به ادارات

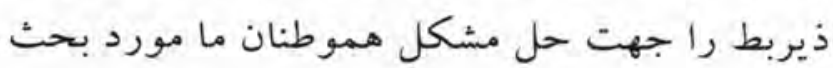
قـرار داد، و ايسن كـه سـفارت افغانسـتان در لنـدن فرن تو انسته است در مدت كم تعداد زيـادى باسـيورت

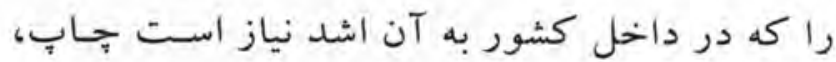

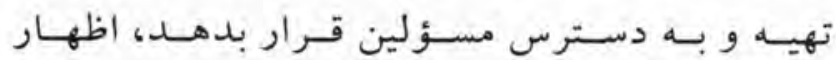

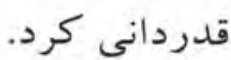

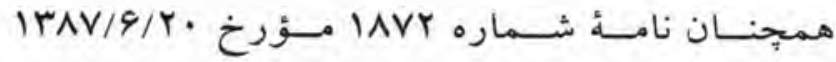

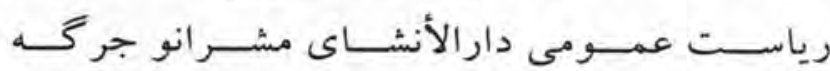
مي نمارد:

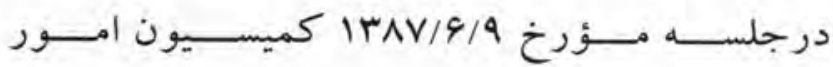




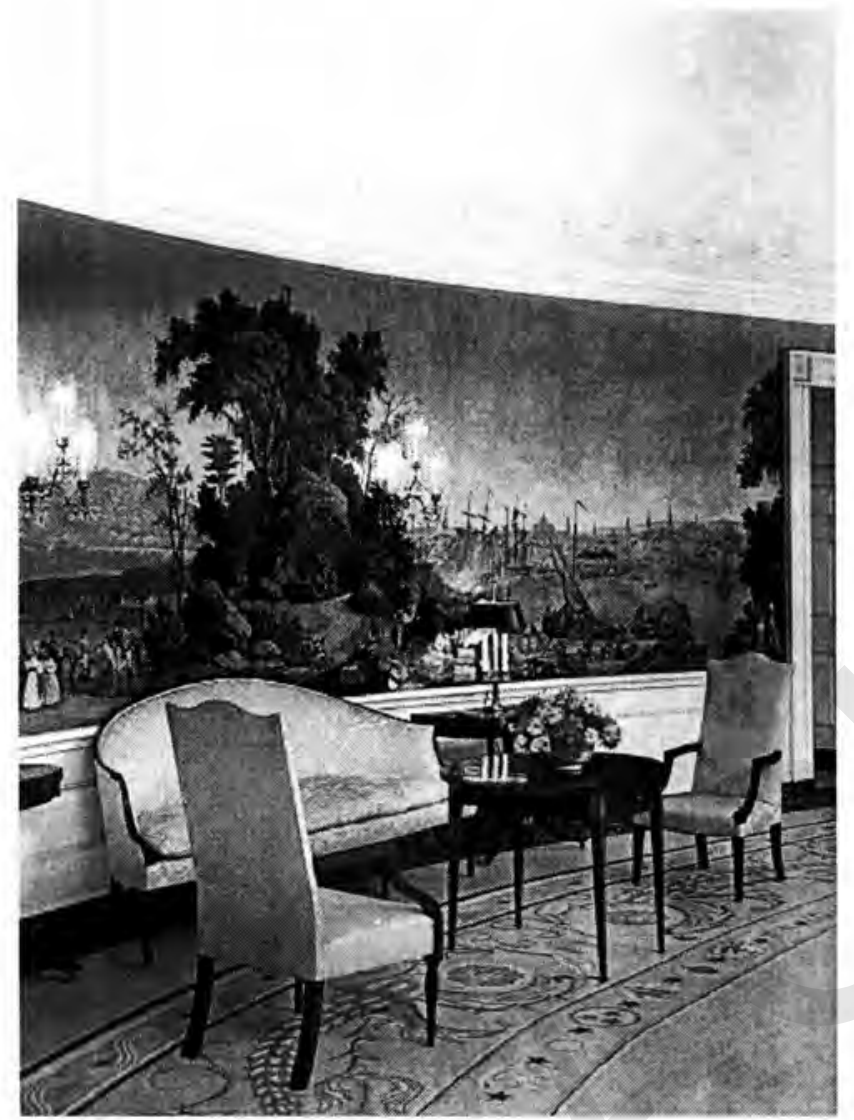

ملاقات ها حتى ميان همسايه كان هم بسيار كـم انجـام مس يـذيرد.

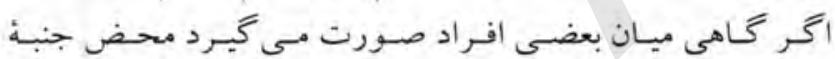

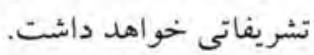

Appointments ملاقات به اساس موعد قبلى

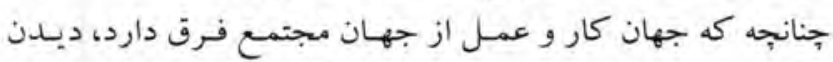
يكك نفر در منزل از ديدن وى در محل كار فـرق دارد. البته هيبج

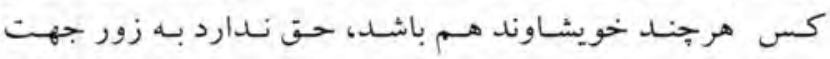

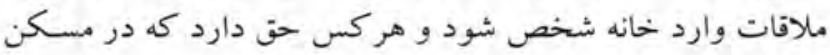

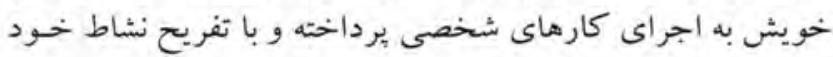
را تجديد نمايد.

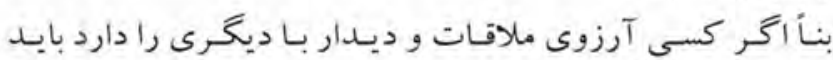

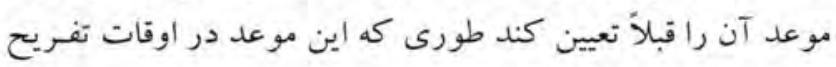
و استراحت تصادف نكند.

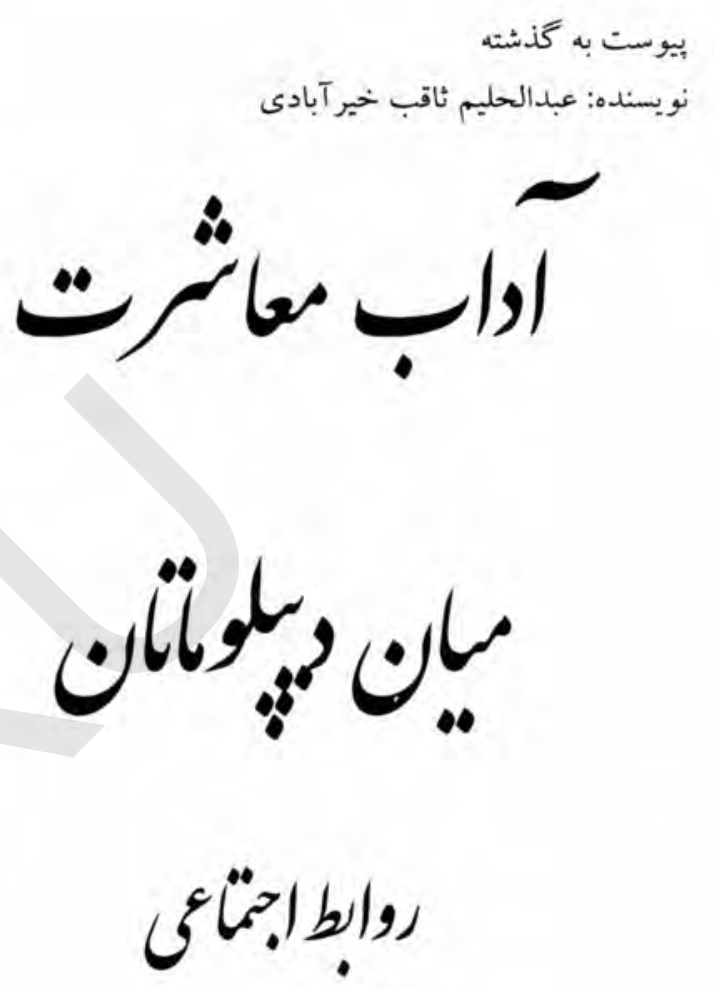


صاحب خانه يا ميزبان نبايد مهمان را در سالون استفبال مدت زياد

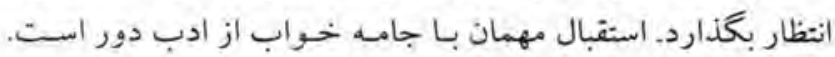

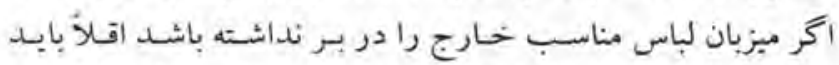

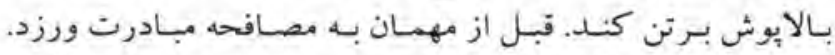

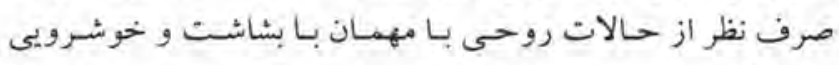

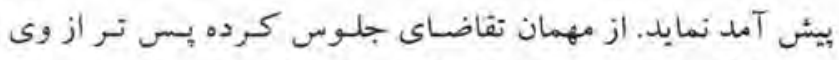

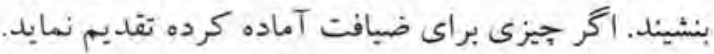

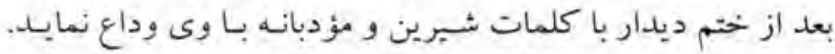

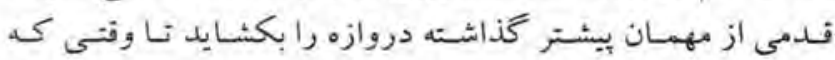

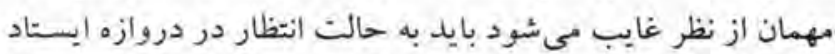

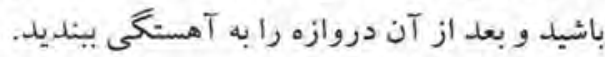

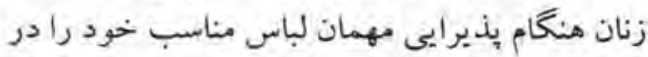

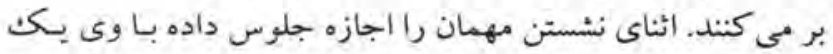

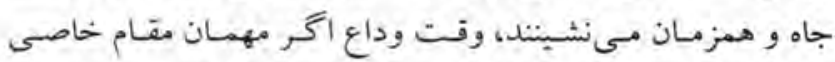

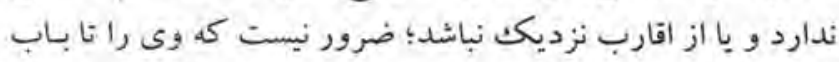
خروج بدرقه نمايند. ملاقات در روز استقبال

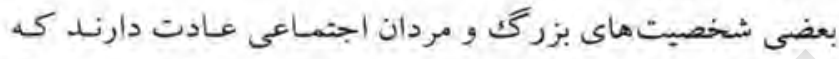

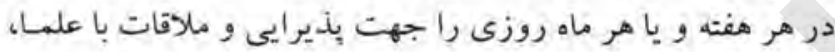

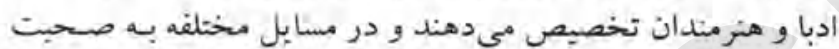
مي يردازند.

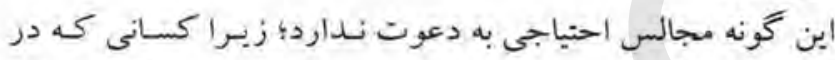

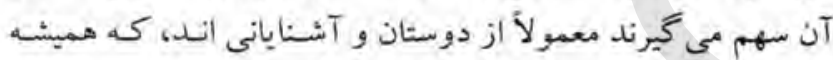

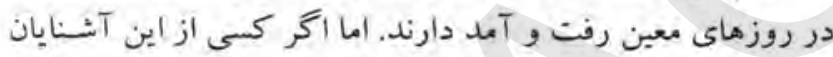

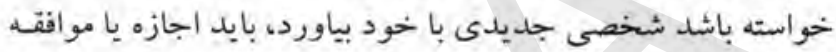
ميزبان راقبلاً كسب نمايلد.

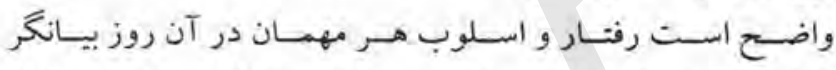

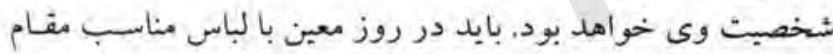

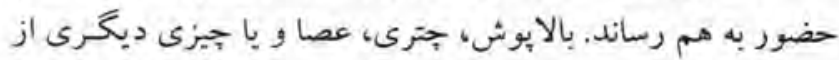

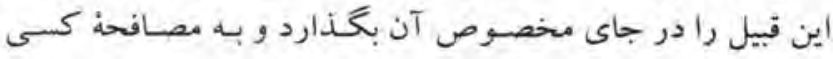
كه در استقبالش هست ورل، بشتابد.

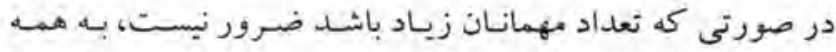

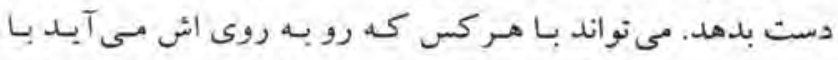

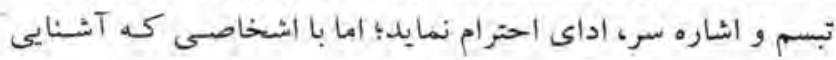

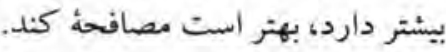

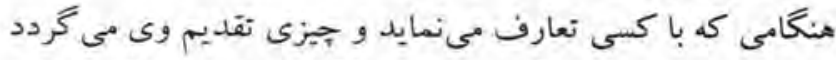

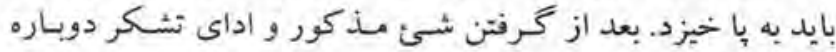

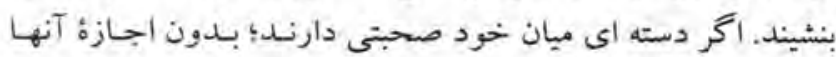

در صورت كه تعيين وفت و موعد ديدار نبايسـ دروازه مـورد نظـر

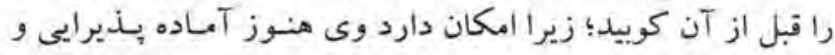

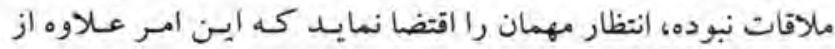

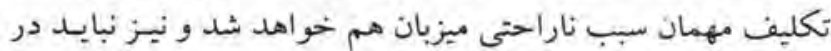

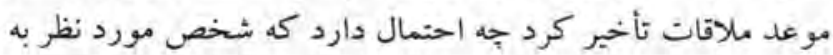

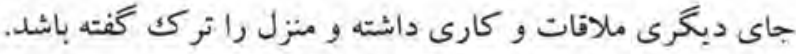

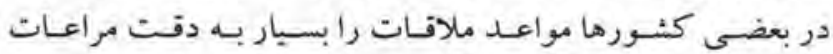

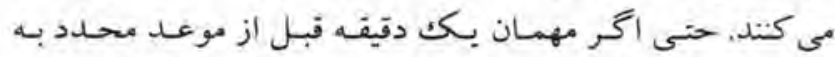

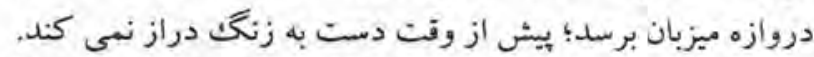

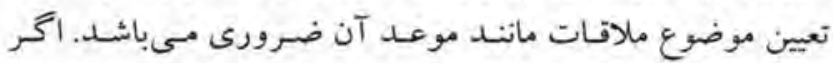

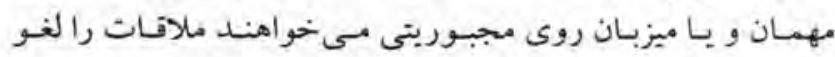

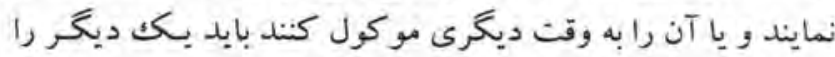

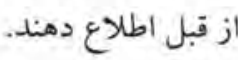

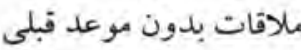

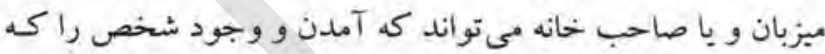

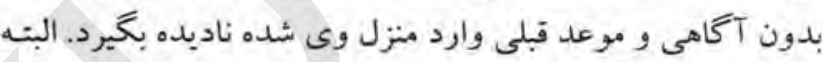

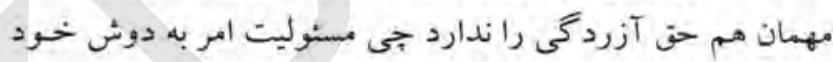

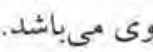

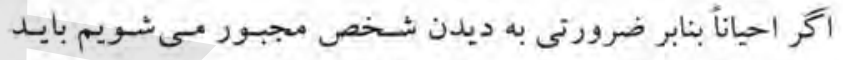

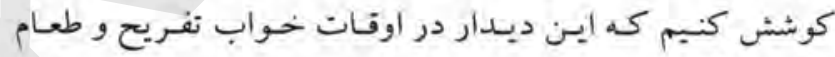
صورت نظيرد.

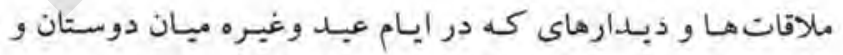

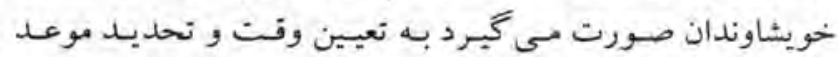

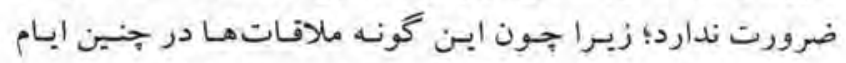

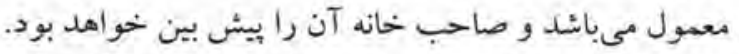

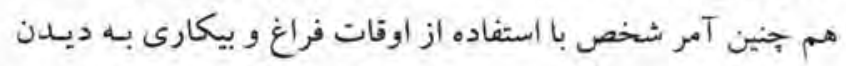

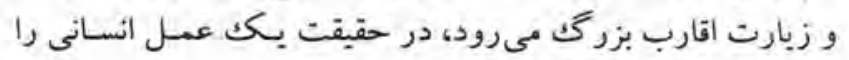
انجام و احتياجى به آكاهى و موعد قبلى ندارد.

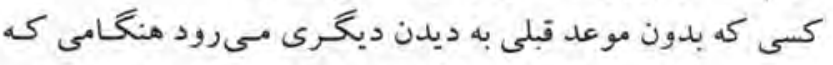

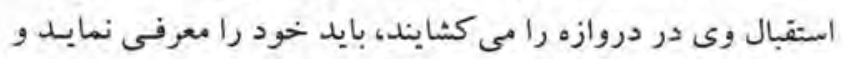

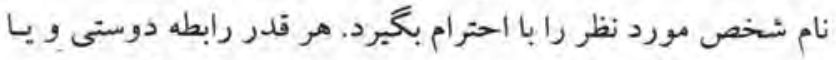

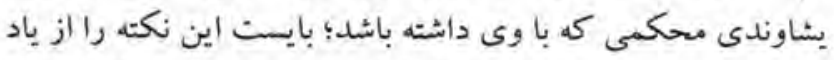

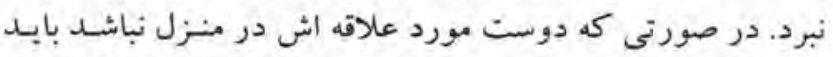

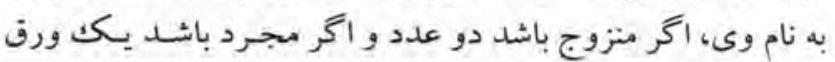

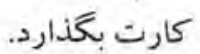
البته اكر وى در خانه باشـــ مهمـان را بـه سـالون ابستقبال هـدايت

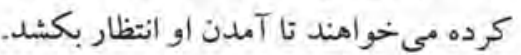
استقبال از مهمان 
داشت. بهتر است كه به واسطه ملاقات و ديدارها آنها را مسرور و

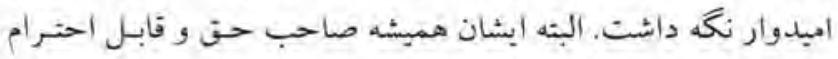

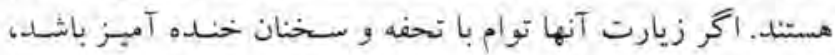
تأثير بهنرى خواهد واشت أهن.

عيادت اقارب و دوستان مريض و معسيبت رسيده از وجايبي هـر

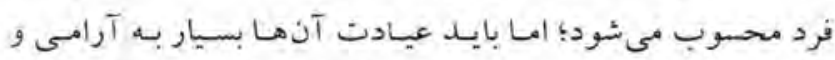

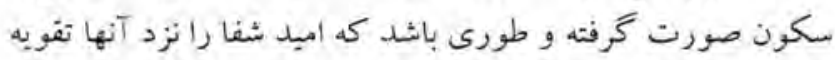

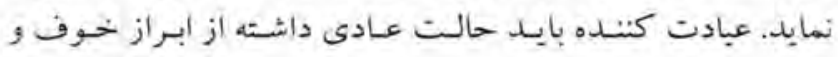

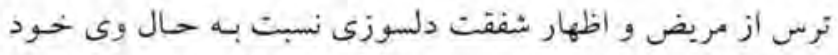

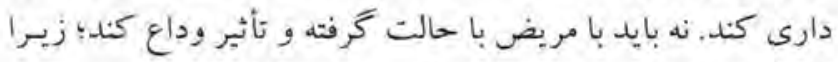

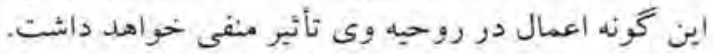

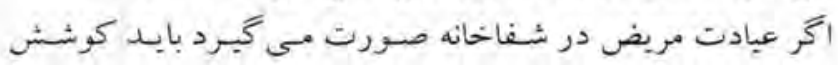

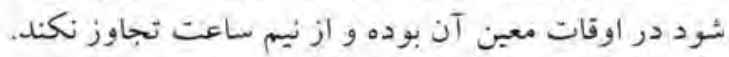

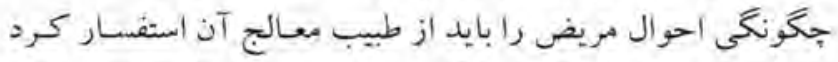

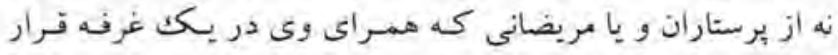

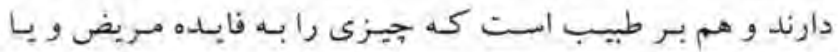

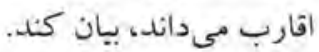

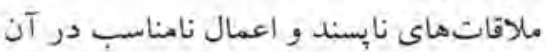

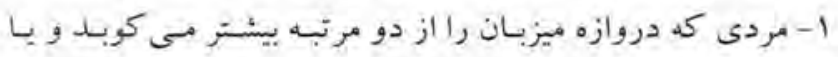

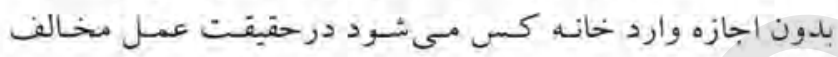

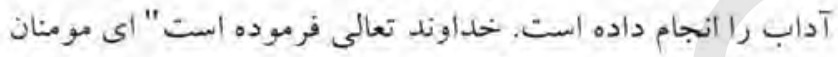

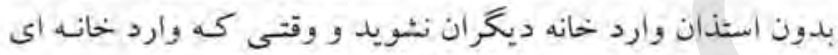
ميشويد، بر اهل آن سلام كنيد".

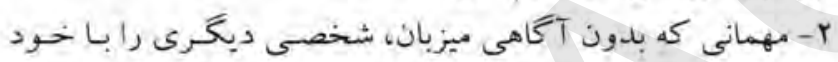

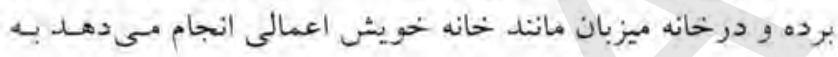

حيثيت و مقام ميزبان لطسه مى زئن.

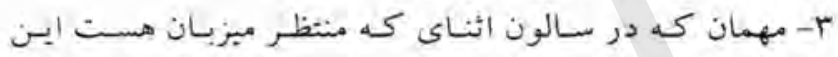

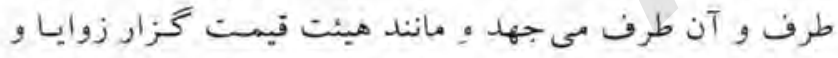

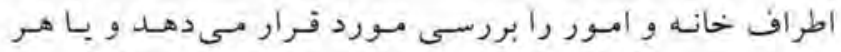

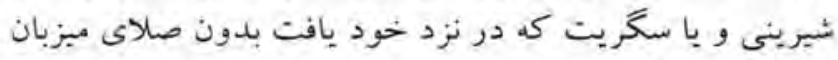

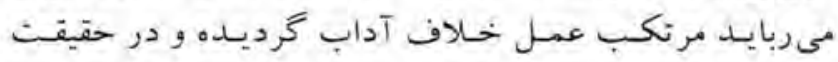

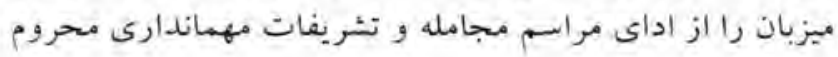

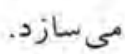

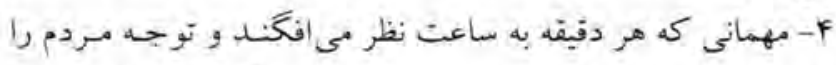

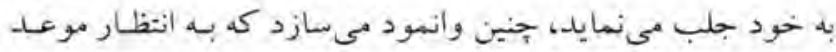

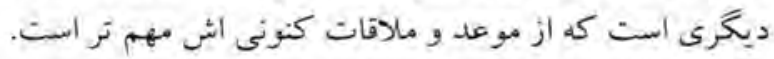

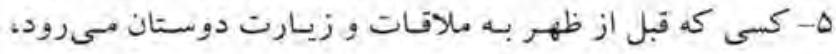

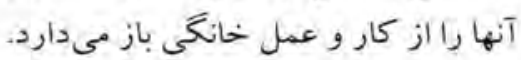
ادامه دازد

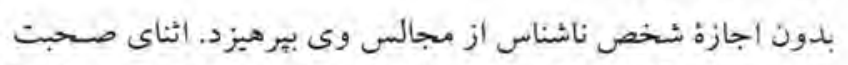

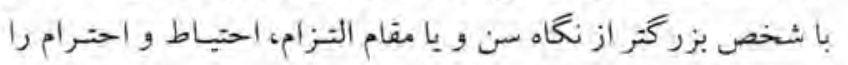
مراعات كند. ميادرت به برخى از ملاقات هـات

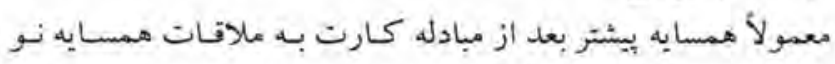

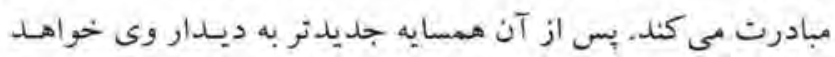

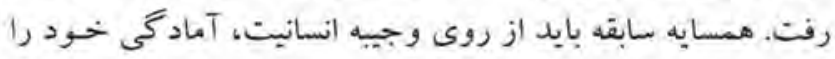
جهت مساعدت و همكارى با همسايه نو ابراز دارد.

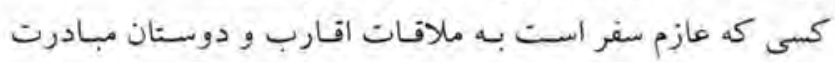

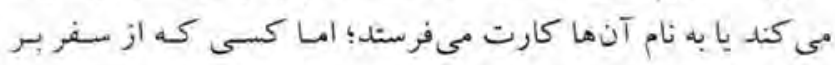

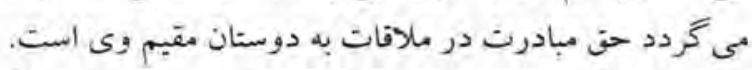

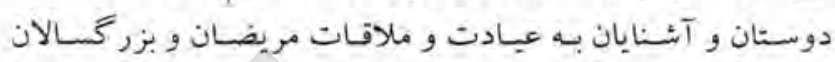
اقدام و مبادرت مىنمايند. در مورد مبـادرت حر ملافـات هـاى ديبلوماتبكث در فصل بـ بـنجم

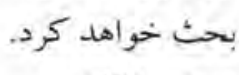
مدت ملاقات در صورتى كه مدت ملاقات فبلأ تحديد نشده باشد بايد، كونـيد

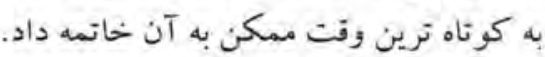

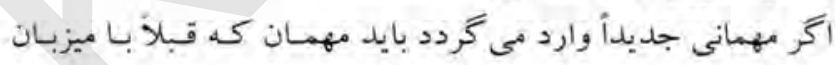

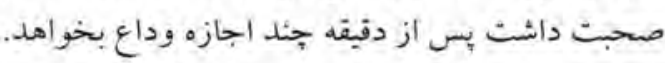

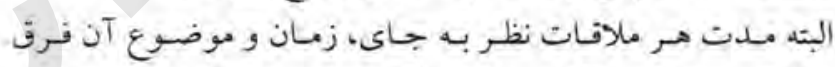

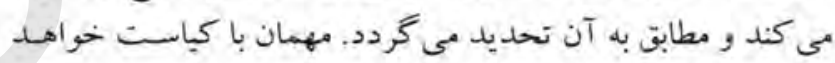

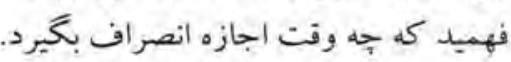

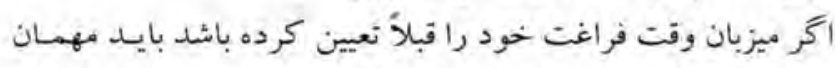

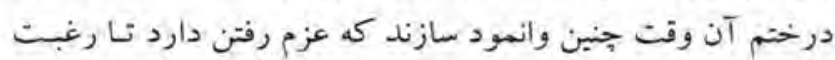

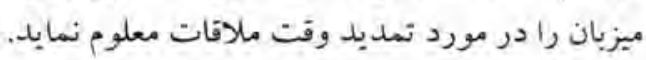

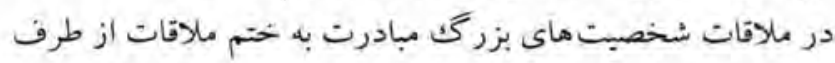

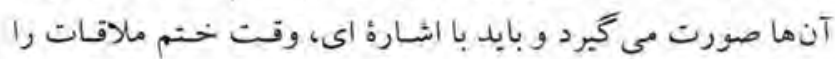

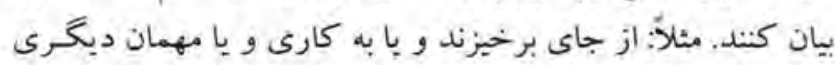
خود را مصروف نشان دهند.

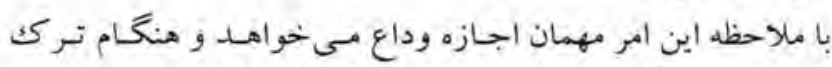

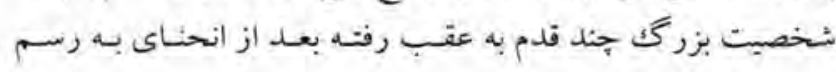

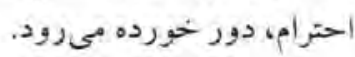

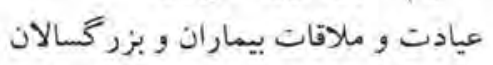

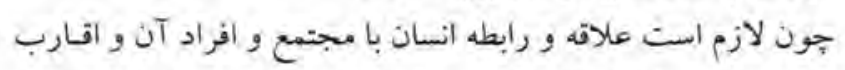

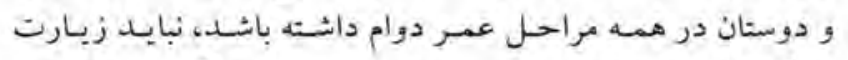

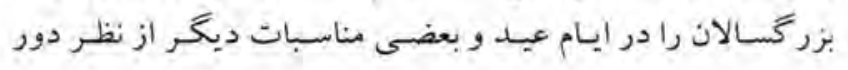


Narcotics remain a key threat not only to Afghanistan's national security, but also the regional and global stability. The magnitude of the narcotics challenge requires a comprehensive strategy, one which should include enhanced regional and global efforts. The challenge of addressing the narcotics threat is compounded by activities of elaborate and wellorganized trafficking groups who seek to reap benefits from the drug-trade. Accordingly, a successful fight against this scourge will require increased efforts to reduce demand and consumption. It is worth mentioning: trafficking of narcotics goes two ways: Drugs are transported from Afghanistan to consumers abroad, but the precursors are entered to Afghanistan from abroad. Consequently, regional and international cooperation on the basis of shared responsibility is essential and critical.

In our part, we will continue to work towards the implementation of our National Drug Control Strategy. Our efforts have thus far resulted in increasing the number of poppy free provinces from 13-18. We will strive to consolidate those gains.

Our counter-narcotics efforts are inextricably linked to our anti-corruption efforts. Afghanistan will spare no effort to address corruption wherever and whenever it occurs. In that spirit, the establishment of the Independent AntiCorruption Administration is among the most recent of our efforts to address corruption and improve goodgovernance at the national level.

\section{Dear Colleagues,}

Afghanistan cherishes its partnership with the OSCE, and appreciates the Madrid Ministerial Council decision on OSCE engagement with Afghanistan. We applaud the OSCE secretariat initiatives that strengthen border security and management, foster cross border co-operation between the Central Asian participating States and Afghanistan, and enhance national law enforcement capacities in accordance with the $\mathrm{MC}$ decision.

In addition, as you all witnessed in 2004 and 2005, the elections encouraged the participation of all Afghans in the democratic process after four long decades. As the calendar nears the 2009 Presidential election in Afghanistan, we welcome and invite the observation of ODHIR in our general election to contribute in the legitimacy of the election outcome.

Finally, let me say that we are grateful to the Finnish Chairmanship of the OSCE, the Spanish Chairmanship of the Asian Contact Group, as well as the Secretary General for their tireless efforts and dedication to Afghanistan. Without you, this conference in Kabul would not have materialized.

I am fully confident that the 2008 OSCE- Afghanistan Conference and the discourse among participants will be critical in further strengthening cooperation between the OSCE and its Asian Partners.

Once again, I am honored to be here, and encourage you to engage fully and openly in this agenda. On behalf of my country, I thank you for being here, and I wish you all a successful conference! I thank you! 
regained their status as an active member of society, demonstrating their competence and commitment to democracy. The significant number of women in our National Assembly is one example. Just this month, President Karzai gathered hundreds of women from across Afghanistan to engage openly and honestly in a discussion on security and human rights. We will continue to work diligently to achieve our human rights objectives by increasing capacity to report on our human rights treaty obligations by the end of 2010. Our liberal media policy has enabled the presence of 20 independent and privately owned TV stations across the country. This is in addition to the more than 40 Radio stations and around 400 periodicals published without governmental influence.

Despite the incredible progress Afghanistan has made, we acknowledge the many challenges that lie ahead. To address those challenges, we have embarked on a comprehensive strategy which focuses on three key pillars: security, social and economic development and good governance. Our efforts will be conducted within the framework of the Afghanistan Compact and our national development strategy.

Terrorism continues to be our number one challenge. Over recent months, we have witnessed a substantial increase in the number of terrorist attacks. While Afghanistan has borne the brunt of terrorist violence, the scourge has now spread across the wider region like a wild-fire. Until recently, extremist circles in the region remained mainly focused on destabilizing Afghanistan. However, now terrorist violence is also directed within the territory of Pakistan. Let us be clear in stating that terrorism will not go away until we deal with this manes as an international serious challenge with regional bases and sources. To achieve success in the fight against terrorism, we must eliminate secure sanctuaries which train, harbor and equip terrorists.

Afghanistan attaches great importance to its relations with the brotherly government of Pakistan. We remain committed to enhanced cooperation to address our common threat and utilize the enormous potential in the region for becoming the anchor of peace, moderation and prosperity for the entire region. Enhanced collaboration and cooperation will be utmost importance to eliminate the scourge of extremism, militancy and terrorism.

\section{Ladies and Gentlemen,}

As a measure to assume a greater responsibility in addressing our security challenges, we have prioritized Afghani-zation of the security sector among our top priorities. Investing in Afghanistan's security sector is a longterm and sustainable solution to maintaining democracy and confronting terrorism. To enable us to succeed as an independent and secure nation, we urge our international partners to redouble efforts to increase the operational capacity of our security forces by accelerating the training and equipping of the Afghan national army and police. 


\section{HE. Dr. Spanta speech at the OSCE Conference in Kabul 9-10 November 2008}

\section{Mr. Secretary General,}

\section{Excellencies,}

\section{Ladies and gentlemen,}

Hosting the 2008 OSCE-Afghanistan Conference in Kabul is a great honor for us. On behalf of the people and government of the Islamic Republic of Afghanistan, I would like to welcome you all to this significant and important event. Let me also convey the best wishes of President Karzai for a successful conference.

This conference is a clear example of the mutual cooperation between our countries. Our gathering here today evidences our commitment to implement the principles, values, and goals of the OSCE. Individually and collectively, the OSCE Asian Partners for Co-operation have the potential to contribute to securing the environment within the OSCE area and beyond. This potential can only be realized, though, if cooperation between the OSCE and its Asian Partners strengthens.

None among us today is stranger to the hardships endured by Afghanistan over the past three decades. Afghanistan has paid a great price in its struggle against foreign occupation, terrorism, and imposed conflicts. Seven years ago, this city, and the rest of the country was besieged by an oppressive

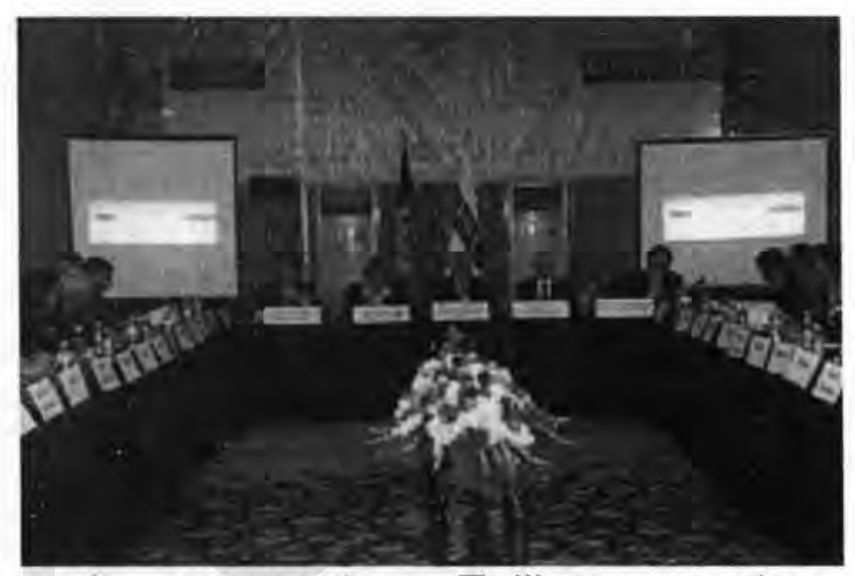

and surrogate Taliban regime. Afghanistan was a safe haven for terrorists and territory without state institutions. However, with the sacrifices of our people, and the support of our international partners, many of whom are present here today, we have opened a new chapter in our modern history.

Today, we continue to march slowly, but tenaciously in our journey towards a stable and prosperous Afghanistan. During recent years, Afghanistan has taken great strides in that path. We have transitioned to electoral democracy. We now have a modern and progressive constitution. Thousands of schools have been built across the country, where children are investing in their future. Afghans today enjoy more political, social and economic rights that any time in the country's history. Afghan women have 
Reconstruction Opportunity Zones will be discussed in more detail in the October 8 , 2008, U.S.-Afghanistan Trade and Investment Framework Agreement talks in Kabul.

The two delegations discussed the importance of strengthening fiscal sustainability, including the challenge of increasing domestic revenue. The Afghan side is considering a number of steps to ensure that all revenues are duly collected and properly transferred to the Ministry of Finance for recording and allocation. The United States delegation welcomes recent steps taken by the Government of Afghanistan to place operations and maintenance of public infrastructure on a sound cost-recovery basis. These include commercializing the management of key public services such as electrical power in Kabul and the provision of urban water to several major municipalities, as well as the establishment of a Road Maintenance Unit within the Ministry of Public Works. The United States pledges to support both of these efforts by sharing high quality technical expertise.

Both sides recognize the importance of the Afghanistan Compact and the Afghanistan National Development Strategy as useful frameworks to foster Afghanistan's reconstruction and revitalization.

Both delegations in the Counter-Narcotics Working Group welcomed the success achieved this year in reducing poppy cultivation by 19 percent from 2007 . This reversed the trend of record poppy growth over the past two years and expanded the number of poppy-free provinces from 13 to 18 of Afghanistan's 34 provinces. During the same period. Nangarhar province went from being Afghanistan's number two poppy-producing province to achieving poppy-free status. These developments are inspiring confidence that the Government of Afghanistan's broad-based counternarcotics strategy of incentives and disincentives, with the support of the United States and the international community, is working in areas that enjoy relative security and stability. However, connections among narcotics, terrorism, organized crime and corruption are undeniable and the drug problem remains a pressing concern, particularly in the insecure south and southwest regions where seven provinces accounted for 98 percent of total opium production this year. The Government of Afghanistan and its international partners are collaborating on an effort to target more intensively these areas to reduce opium production.

The two delegations endorsed the Afghan Government's plan for Helmand province to further improve security and governance in that province, and consequently make sustainable progress in eliminating poppy cultivation. The United States will expand the Drug Enforcement Administration's operations in Afghanistan and continue to build the Afghan Counter Narcotics Police's capacity. The two sides will work together and will focus on creating an intensified mix of disincentives and incentives for further reductions in opium poppy cultivation and trafficking, including expanded alternative development programs and improving market access infrastructure to support the growing of alternative crops. The Afghan side also spoke of the importance of U.S. support toward the restructured and reformed Counter Narcotics Trust Fund (CNTF). The Government of Afghanistan is committed to carrying out a more robust counter-narcotics campaign for the coming year, including poppy elimination and eradication; strengthening the justice sector; enhancing public information and education; taking vigorous anti-corruption measures, and arresting and prosecuting high-value drug kingpin targets.

Based on this Strategic Partnership Joint Statement, the United States and Afghanistan hereby recommit themselves to shared efforts towards Afghanistan's commitment to join the family of nations as a secure, prosperous, progressive and democratic nation. 
and continue to look for ways to expand cooperation in these areas.

Both sides emphasized the important roles of regional countries, particularly in confronting transnational terrorism, extremism, organized crime and narcotics trafficking.

In the Governance Working Group, both sides emphasized the fundamental role of respecting and institutionalizing principles of good governance and human rights. The Independent Election Commission of Afghanistan briefed the Governance Working Group in detail on Afghanistan's preparations for the 2009 Presidential and Provincial Council elections. The Afghan side expressed its gratitude for the significant funding and expertise provided by the United States to support this process, including assistance to the Independent Electoral Commission and a number of nongovernmental organizations helping Afghan citizens to prepare for this upcoming election. The delegation of the Government of Afghanistan emphasized the transformation in sub-national governance, built around the Independent Directorate of Local Governance (IDLG). The two parties agreed on the importance of improving the ability of governors to connect to and serve their constituents. The United States, noting the milestone represented by this second round of democratic elections, pledged funding and technical expertise to support this outreach program.

The Governance Working Group welcomed Afghanistan's recent legal and institutional measures to establish the High Office of Oversight and Anti-Corruption, including special units in the Office of the Attorney General and in the Supreme Court, to intensify and oversee efforts aimed at eliminating corruption through preventative, educational and enforcement measures. Both sides committed themselves to seek more progress on corruption over the next year, and to help ensure concrete results including successful prosecutions where appropriate - the U.S. side agreed to assist the above-mentioned entities in their efforts to secure the necessary resources and means to carry out their respective mandates. We look forward to Afghanistan's next step in establishing anticorruption tribunals in the Supreme Court. In the Prosperity Working Group, both sides expressed concern over increased food insecurity in Afghanistan and pledged to take appropriate actions to resolve this problem. They also acknowledged the enormous needs facing victims of drought, returnees, and internally displaced persons.

Private sector-led economic growth as a stability and confidence-building measure, beginning with passage and implementation of a package of pro-competitive, transparent commercial and investment laws and regulations designed to attract investors and to create new jobs was deemed essential for Afghanistan. The two delegations highlighted the importance of promoting a number of key infrastructure projects as prioritized by the Afghanistan National Development Strategy (ANDS), such as irrigation, agriculture, roads, and power. The delegations noted positively the progress toward electricity sector agreements between Afghanistan and its neighbors. The United States pledged to continue to support efforts to build both bilateral and regional linkages in electricity, and to explore such linkages in transportation and communications.

Both sides also supported concrete steps to expedite and increase Afghanistan's trade with neighbors in the region, eliminate obstacles to commerce, and focus on preparations to implement the Reconstruction Opportunity Zone (ROZ) legislation now under consideration by the U.S. Congress. This type of economic strategy is key to fighting terror and narcotrafficking by creating jobs, promoting sustainable development, and drawing investment to targeted areas and the border regions of Afghanistan. Transit trade and 


\section{Text of Afghanistan-United States Strategic Partnership Dialogue Joint Statement}

Following is the text of the joint press statement of the US-Afghanistan Strategic Partnership, which was released at the end of the third round of the Strategic Partnership Dialogue.

\section{September 25th}

Senior representatives of the Governments of the United States of America and the Islamic Republic of Afghanistan met in Washington DC today for the third round of the United States-Afghanistan Strategic Partnership dialogue. President Bush and President Karzai created and signed into effect the Strategic Partnership in May 2005 to enhance the long-term security, democracy and prosperity of Afghanistan, as well as to support U.S. national interests. Today's meeting again underscores the commitment of the United States and Afghanistan to carrying forward a shared vision through senior-level dialogue to further improve bilateral coordination and cooperation to address near- and long-term challenges.

The United States delegation expressed regret over the loss of any innocent civilian lives incurred during security operations. In response to concerns expressed by the Government of Afghanistan, the United States is conducting a senior level review and assessment of the August 22 Shindand operation. In addition, both sides recognize the need for establishing a mutually agreedupon a framework and mechanism to minimize civilian casualties and to maintain the strong support of the Afghan people in fighting terrorism. The United States reiterated during discussions that it takes every precaution to avoid harming any Afghan civilian during military operations and drew a sharp contrast to the Taliban and $\mathrm{Al}$ Qaida and their deliberate campaigns of intimidation and terror on the Afghan populace. The United States especially condemned, along with the UN Secretary General, the recent murder of two UN doctors and multiple Afghan civilians during the UN's humanitarian efforts to vaccinate Afghan children in southern Afghanistan.

In the Security Working Group, the two sides reaffirmed their commitment to pursue a comprehensive security strategy to address Afghanistan's security challenges and threats. By commending the growing professionalism and sacrifices of the Afghan National Security Forces, they reiterated their determination for the Afghan National Security Forces to progressively assume the leading role in defending the sovereignty and territorial integrity of Afghanistan and protecting the lives of Afghan citizens. The U.S. side welcomed the recent agreement to expand the Afghan National Army (ANA) to 134,000 personnel. This agreement will allow the ANA to move closer to our shared goal of a well equipped and fully capable force. The Afghan National Police (ANP) also continues to strengthen its capabilities, with the Focused District Development Program serving as the cornerstone of these efforts. Hence, in order to support Afghanistan's Ministry of Defense and Ministry of Interior visions, both sides agreed that the assistance of the international community is essential to realizing the improving capabilities of both ANA and ANP. The ANA, ANP and the International Security Assistance Force (ISAF) are playing central roles in voter registration security and are working to ensure that Afghan voters are able to exercise their rights fully, freely and in a secure environment. The two sides recognized the successes of the United States-Afghan Defense Parliamentary Exchange Program and the Agri-Business Development Teams 


\section{به مناسبت تجليل از •ه|| مين زاد روز رودكى}

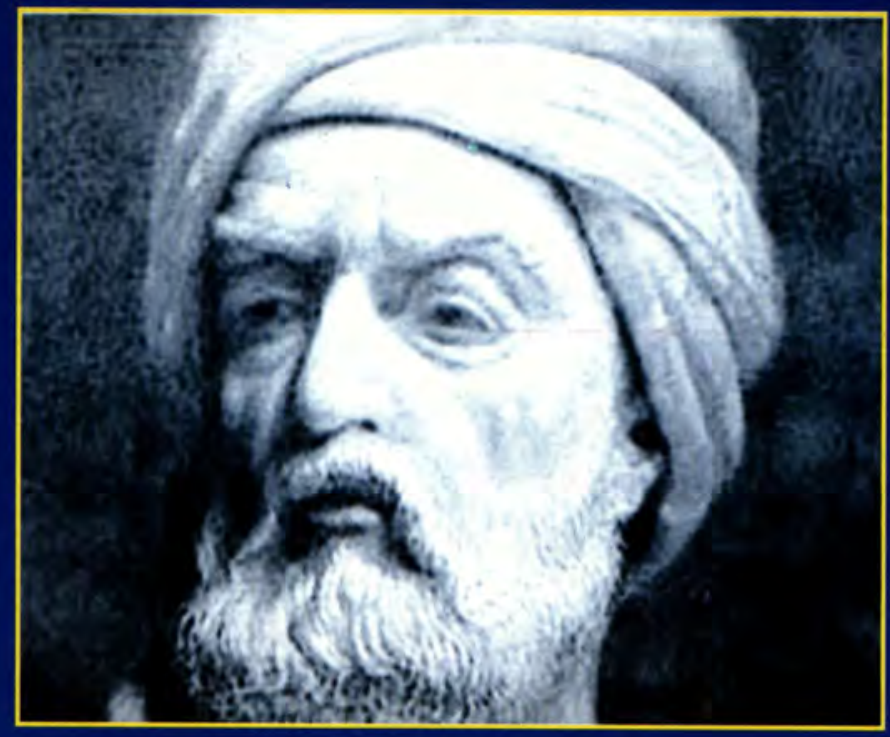

بزرتترين و مشهـورتوين شـاعر دوره سـامانى، ابـو عبـداله

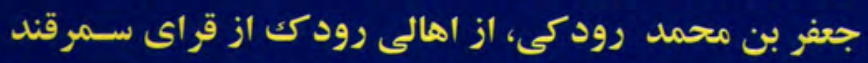
بود. وى نخستين شاعر مهم زبان درى و در حقيقت پيدر شعر

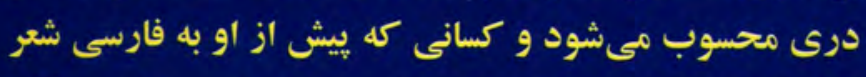

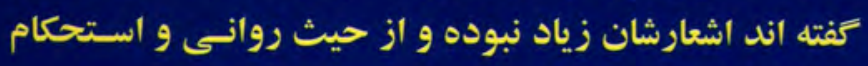
نيز به ياى اشعار رودكى نمىرسيده است.

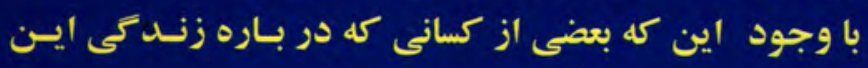

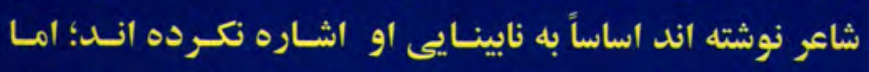

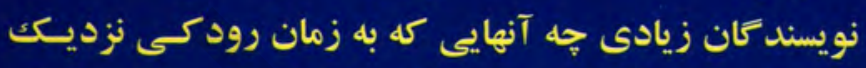

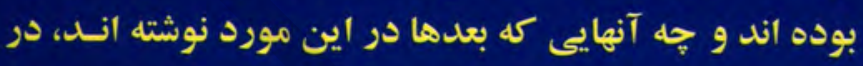
اين مورد صراحت دارند. هـر جنــ تشـبيهات و توصـيفات

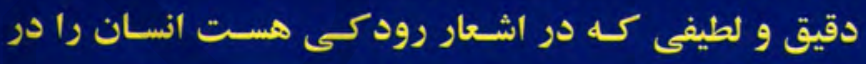
كورى او دجار ترديد مي كند، ليكن در ناينايى او نبايد مردد بود. حتى بنابر نظر محققان، اين كسه ورى كـور مـادرزاد بـوده مسلم شده است. در مورد قدرت حافظه او كفته اند كه در هشت سالكى تمام قر آن را از بر داشت و در اين سن به شعر كفتن يرداخت و معانى دقيق مى كفت. آوازى خوش و دلكش داشت و به سبب داشتن صداى خوب به نوازندئى يوداخت و از شخصى به نام بختيار

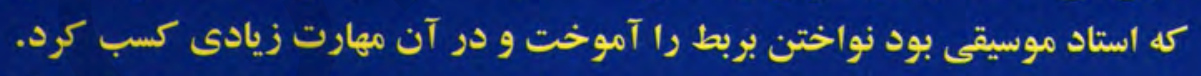

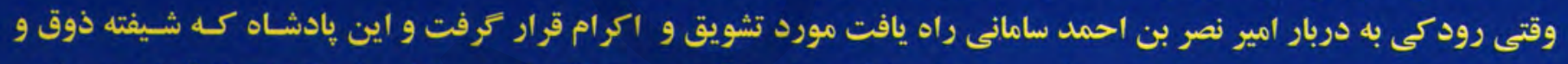

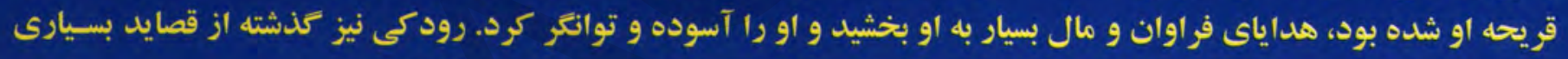

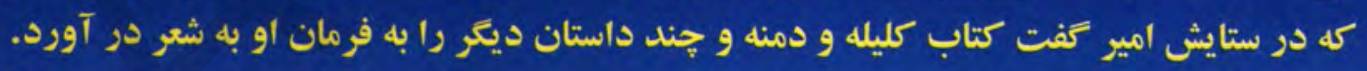

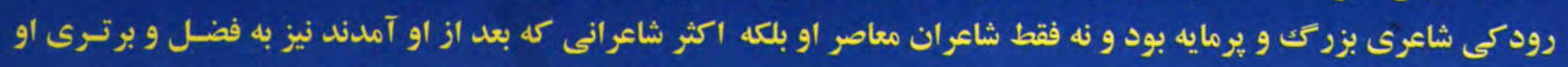

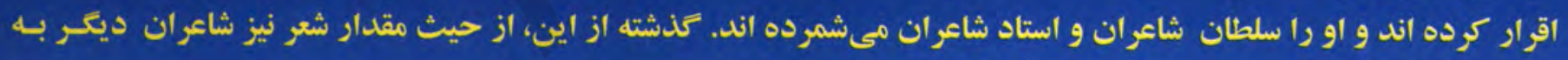
هإى او نمى آنسيدن.

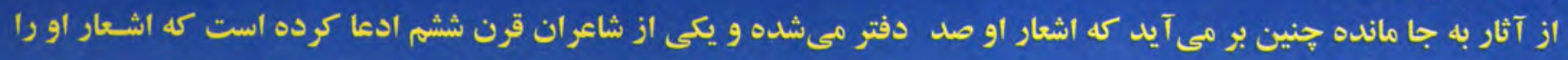

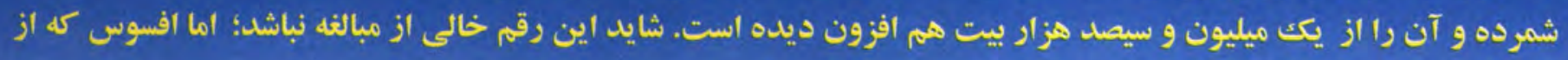

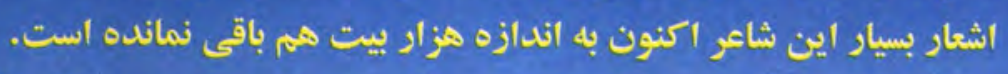

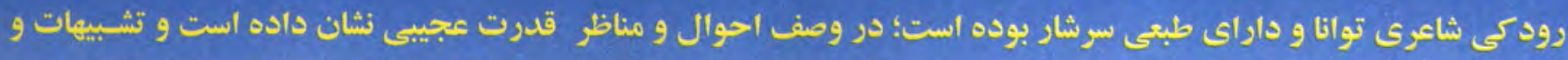

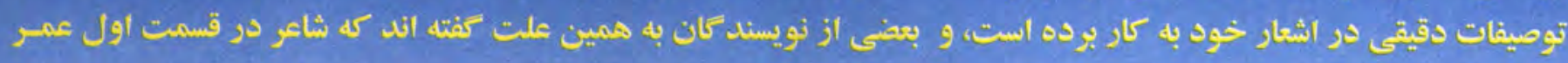

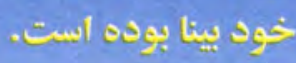

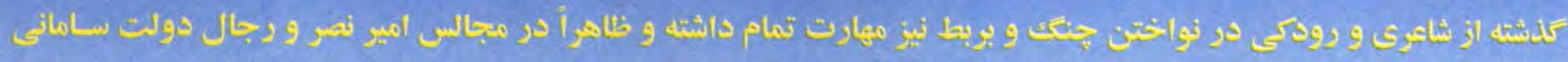

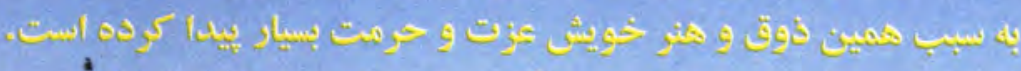

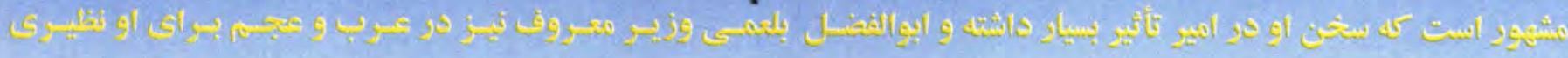




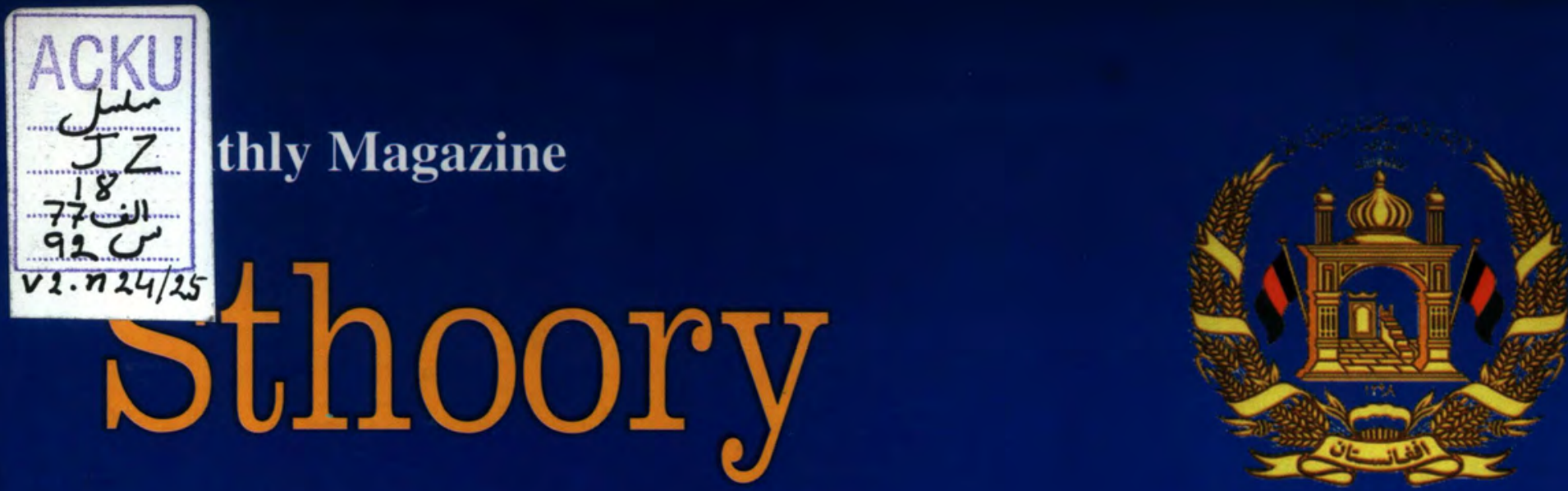

Publication of the Ministry of Foreign Affairs

Twentyforth and Twentyfifth Volumes, Second Round -October and November 2008

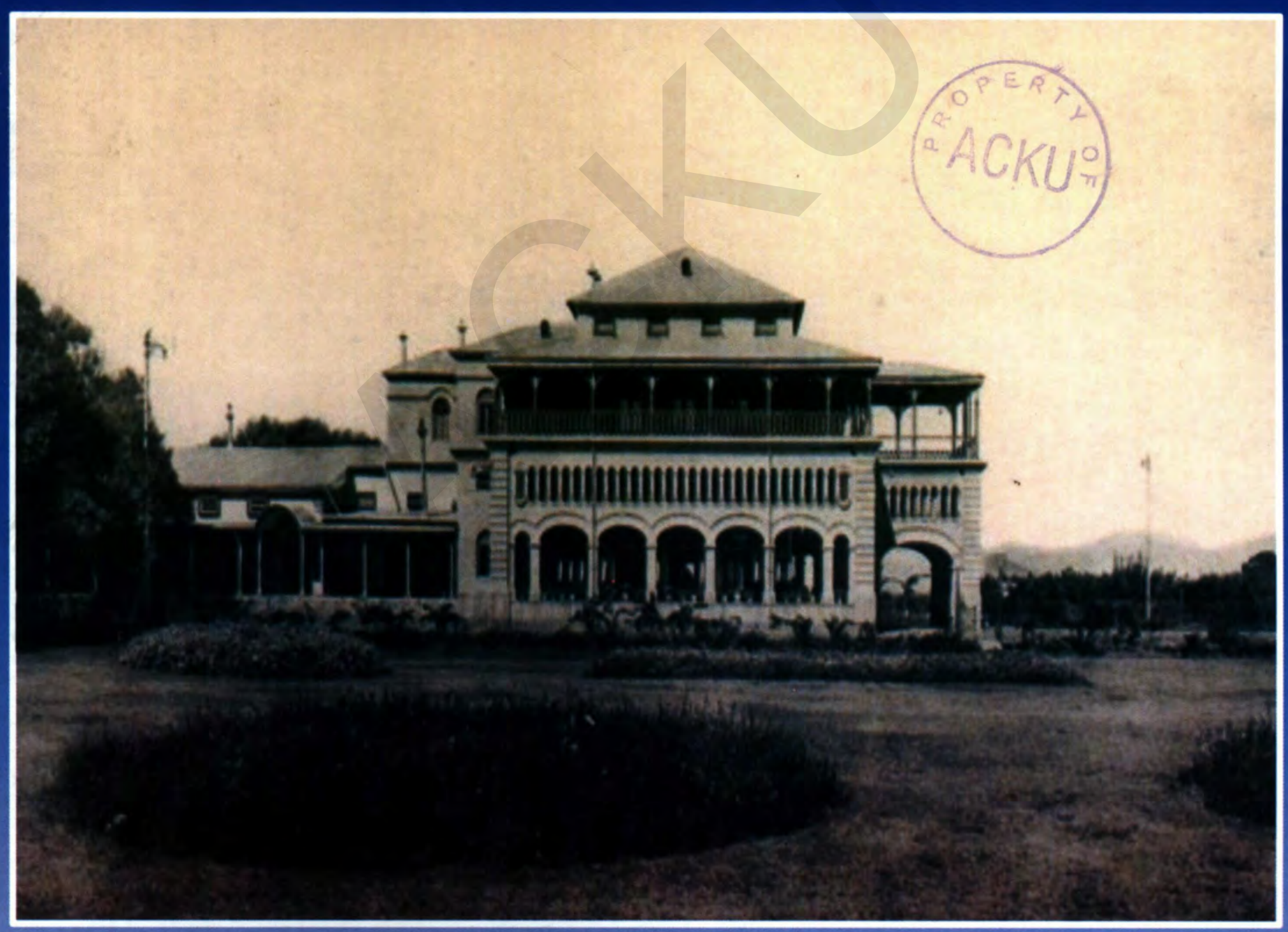

$$
\begin{aligned}
& \text { د بهرنيو جارو به وزارت كي د ستوري مانئ بخخوانى تاريخي عكس }
\end{aligned}
$$

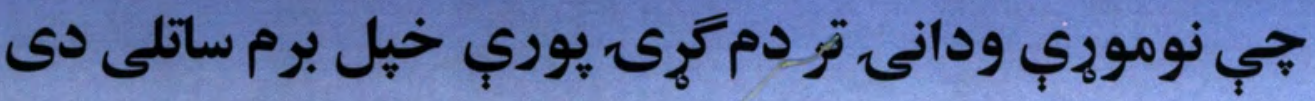

